\title{
De oorlog van Bastiaans : de LSD-behandeling van het KZ-syndroom
}

Citation for published version (APA):

Enning, B. (2009). De oorlog van Bastiaans : de LSD-behandeling van het KZ-syndroom. [, Maastricht University]. Uitgeverij Augustus. https://doi.org/10.26481/dis.20090325be

Document status and date:

Published: 01/01/2009

DOI:

10.26481/dis.20090325be

Document Version:

Publisher's PDF, also known as Version of record

\section{Please check the document version of this publication:}

- A submitted manuscript is the version of the article upon submission and before peer-review. There can be important differences between the submitted version and the official published version of record.

People interested in the research are advised to contact the author for the final version of the publication, or visit the DOI to the publisher's website.

- The final author version and the galley proof are versions of the publication after peer review.

- The final published version features the final layout of the paper including the volume, issue and page numbers.

Link to publication

\footnotetext{
General rights rights.

- You may freely distribute the URL identifying the publication in the public portal. please follow below link for the End User Agreement:

www.umlib.nl/taverne-license

Take down policy

If you believe that this document breaches copyright please contact us at:

repository@maastrichtuniversity.nl

providing details and we will investigate your claim.
}

Copyright and moral rights for the publications made accessible in the public portal are retained by the authors and/or other copyright owners and it is a condition of accessing publications that users recognise and abide by the legal requirements associated with these

- Users may download and print one copy of any publication from the public portal for the purpose of private study or research.

- You may not further distribute the material or use it for any profit-making activity or commercial gain

If the publication is distributed under the terms of Article $25 \mathrm{fa}$ of the Dutch Copyright Act, indicated by the "Taverne" license above, 


\section{De oorlog van Bastiaans}

De LSD-behandeling van het $\mathrm{Kz}$-syndroom

\section{P R O E F S C H R IF T}
Ter verkrijging van de graad van doctor aan de Universiteit Maastricht, op gezag van de Rector Magnificus, prof.mr. G.P.M.F. Mols volgens het besluit van het College van Decanen, in het openbaar te verdedigen

op woensdag 25 maart 2009 om 16.00 uur

$$
\text { door }
$$

Bram Enning 
Promotor

Prof.dr. J. van Heerden

\section{Copromotor}

Dr. J. Withuis (NIOD)

\section{Beoordelingscommissie}

Prof.dr. C. de Ruiter (voorzitter)

Dr. H. Israëls

Prof.dr. G. Kok

Dr. H. Piersma (NIOD)

Prof.dr. M.Schwegman (NIOD) 


\section{Inhoud}

Voorwoord

1 Inleiding

11

Vraagstelling en benadering

12

Autobiografische reconstructie

17

Geraadpleegde bronnen

18

Opbouw van dit boek

I

Aanloop

21

2 Vormingsjaren

23

Inleiding

23

Oorlogsjaren

24

De Psychosomatische Werkgroep

32

Prognose en effect van psychotherapie en psychoanalyse

$3 \quad$ Het proefschrift-psychosomatische gevolgen

van onderdrukking en verzet

Inleiding

Oordelen en causale verbanden

Stress en spanningen

Portret: Nico Mourer

Psychosomatische reconstructie van Mourers geschiedenis

Bij specifieke klachten horen specifieke gebeurtenissen Reacties op het proefschrift 
4 De methode-Bastiaans 66

Inleiding $\quad 66$

Ontdekken en herbeleven $\quad 67$

Narcoanalyse en psycholyse $\quad 68$

Authenticiteit en effectiviteit $\quad 74$

Portret: Gerhard Durlacher $\quad 77$

Medisch en recreatief gebruik $\quad 82$

Omstreden maar mediageniek $\quad 84$

$\begin{array}{ll}\text { Conclusies } & 88\end{array}$

I I Doorbraak $\quad 89$

5 De paradox van het $\mathrm{kz}$-syndroom 91

Inleiding 91

De Wind en de Spätfolge-groep 93

Het ontstaan van de paradox $\quad 96$

Het KZ-syndroom volgens Bastiaans 100

De maatschappelijke functie van het kz-syndroom $\quad 104$

$\begin{array}{ll}\text { Conclusies } & 107\end{array}$

6 Begrijpt u nuwaarom ik huil... 110

Inleiding 110

Hernieuwde aandacht voor de oorlog 111

De politieke strijd van de Vriendenkring Sachsenhausen $\quad 113$

'Schutzhäftling 42.392, meldet sich' 116

Een besloten maar koninklijke première $\quad 121$

Propagandistische effecten $\quad 124$

Hofman en het slachtofferschap $\quad 127$

Conclusies 130

7 Dedrievan Breda 132

Inleiding $\quad 132$

Aanloop: Van Agt is voor vrijlating $\quad 133$

De openbare hoorzitting $\quad 136$

De film wordt in de strijd geworpen $\quad 139$

Onduidelijkheid over het aantal slachtoffers $\quad 142$

Conclusies $\quad 145$ 
I I I Bestendiging

8 De strijd om Centrum ' 45

Inleiding

Directeur of consulent-adviseur? 150

Groeiende moeilijkheden $\quad 154$

Bastiaans buitenspel $\quad 156$

Hart en levensdoel $\quad 158$

De mythe van de methode-Bastiaans $\quad 161$

Het gesprek op Soestdijk $\quad 165$

$\begin{array}{ll}\text { Conclusies } & 167\end{array}$

9 De reconstructie van oorlogsverledens $\quad 169$

Inleiding $\quad 169$

Portret: Eibert Meester $\quad 170$

De sociale fuik $\quad 175$

'Bij Bastiaans is iedereen een oorlogsslachtoffer' $\quad 182$

Portret: Jacques Kopinsky $\quad 186$

Het belang van oorlogsverledens $\quad 189$

Conclusies 195

10 Een voordelig bondgenootschap 197

Inleiding 197

Een begripvol klimaat $\quad 198$

Sluiting Wet Buitengewoon Pensioen 200

Oprichting van het Comité Vervolging en Verzet $\quad 201$

Opnieuw de psychosomatiek 203

Onaantastbare positie 210

$\begin{array}{ll}\text { Conclusies } & 216\end{array}$

IV ……........... Neergang

11 'Ik heb een symbolische functie' 219

Inleiding 221

Van kz-syndroom naar pTss 221

Problemen op de universiteit

Meer dan een psychiater

Portret: Trix Terwindt

Werkgroep Dependance Jelgersmakliniek

Geen uitzonderingspositie voor oorlogsslachtoffers

Een politieke oplossing $\quad 242$

Conclusies 
12 Het einde van de methode-Bastiaans

Doorstart met overheidssteun

Bemoeienis met de methode

Wetenschappelijke bewijzen

Het onderzoek naar Bastiaans' LSD-therapie

Near accidents

262

De val van Bastiaans

266

Conclusies

Epiloog

Noten

286

Gebruikte afkortingen

Geraadpleegde archieven en personen

Geraadpleegde literatuur

Bibliografie prof.dr. J. Bastiaans

Bijlagen

337

Register

341

Summary

349

Over de auteur 


\section{Voorwoord}

Tien jaar geleden stapte ik binnen bij Han Israëls, destijds docent Geschiedenis van de Psychologie aan de Universiteit van Amsterdam, om te spreken over mijn afstuderen. Hij zou me begeleiden bij mijn scriptie over Eibert Meester, Bastiaans' patiënt die midden jaren zeventig werd 'ontmaskerd' als een pathologische leugenaar. Het werd mijn eerste kennismaking met zowel Bastiaans en zijn methode als de problematiek van oorlogsslachtoffers in Nederland.

De gordiaanse knoop waarin de onwaarschijnlijk hard getroffen overlevenden van de kampen en Bastiaans' omstreden LSD-behandeling zich bevonden, bleef me fascineren. Voor de betrokkenen zelf leek het vanzelfsprekend, maar voor iemand die bijna dertig jaar na de oorlog werd geboren, was het dat niet. De vraag hoe het toch kon dat een psychiater zo lang doorging met een zo achterhaalde behandeling bij een zo kwetsbare groep bleef knagen.

Na mijn afstuderen in 2001 bleek het niet mogelijk om financiering te vinden voor een promotieonderzoek. Ik had dat plan al bijna laten varen, toen Han mij - enkele jaren later - tipte over een mogelijke promotieplek bij de Universiteit Maastricht. Zonder Han was dit boek er dus niet of pas veel later geweest.

Zijn tip bracht me bij Jaap van Heerden, net hoogleraar geworden in Maastricht bij de Faculteit der Psychologie. Hij was degene die vertrouwen had in mijn plan en me de kans gaf te doen wat ik wilde doen, op de manier waarop ik dat wilde. We werkten beiden grotendeels vanuit Amsterdam, zodat ik af en toe plaats kon nemen bij hem thuis, in de 'stoel voor de promovendus'; een ideale plek om gedachten de vrije loop te laten. Jaap is daar beter in dan ik, en ik heb er veel van geleerd.

Een nadeel van werken vanuit Amsterdam was dat het mij ontbrak aan een 'omgeving van gelijkgestemden'. Die vond ik gelukkig al snel op het NIOD. Tijdens de tochten van mijn huis - via de Kinkerstraat, over de grachten - naar dat 
indrukwekkende gebouw aan de Herengracht, kreeg mijn proefschrift in gedachten vorm. Om vervolgens daar te worden uitgeschreven, in de studiezaal met in het midden de boom die maar niet lijkt te groeien. Met Hans de Vries, Hinke Piersma, Sytze van der Zee, Onno Sinke, Arno Bornebroek en Hubert Berkhout sprak ik daar zacht (en soms iets minder zacht) tussen de boeken. Dank daarvoor!

Op het NIOD werd Jolande Withuis, die ik nog kende van mijn afstuderen, langzaam maar zeker mijn copromotor. Niet alleen wist zij me intellectueel steeds te prikkelen, ook verliet ik haar kamer altijd met meer enthousiasme en vertrouwen dan waarmee $\mathrm{ik}$ binnen was gekomen. Dat nam niet weg dat ze kritisch was én bleef, ook toen dat me eigenlijk slecht uitkwam omdat de geboorte van mijn dochter Lies zich aankondigde. Gelukkig maar.

Veel dank gaat uit naar al degenen die me ontvingen voor een gesprek en me toegang gaven tot hun vaak bijzondere materiaal. Zonder die gesprekken en dat materiaal was dit onderzoek er niet geweest. In het bijzonder wil ik Nico Mourer jr., Sandor Kopinsky, Freek Polak en Harrie Rooijmans noemen. Ook de instituten die hun archieven openstelden ook al behoorde dat niet direct tot hun taak, zoals Centrum '45, de Universiteit Leiden en de Universiteit van Amsterdam wil ik graag hartelijk danken voor hun medewerking. Dat geldt ookvoor Arjan Post en Nanne Vervoordeldonk van uitgeverij Augustus, dieme in het laatste jaar het laatste zetje in de rug gaven om het manuscript gereed te krijgen.

Promoveren vergt veel van de promovendus. Daar moet je niet over klagen, dat hoort erbij. Maar het vergt ook veel van degene die het dichtst bij de promovendus staat, en dat hoort er niet bij. Toch klaagde Irene nooit. Ze gaf me nietalleen de kans om dit boek te schrijven, ze luisterde ook steeds opnieuw naar mijn enthousiaste verhalen, nieuwe vondsten of lastige vragen. Lieve Irene, dank je wel. 


\section{Inleiding}

Het leven en werk van de hoogleraar psychiatrie dr. Jan Bastiaans (1917-1997) stond in het teken van de oorlog. Meer dan veertig jaar lang konden slachtoffers van de oorlog op hem rekenen; niet alleen van negen tot vijf, maar van vroeg in de ochtend tot diep in de nacht; niet alleen op doordeweekse dagen, maar ook en bij voorkeur in het weekend. Bastiaans was niet alleen behandelaar, hij verleende ook steun in juridische kwesties en trad op als belangenbehartiger in de media en de politiek.

Begin 1972 speelden Bastiaans en zijn patiënten een beslissende rol in een van de meest beladen politieke discussies van de vorige eeuw: de discussie over de mogelijke vrijlating van de laatste drie Duitse oorlogsmisdadigers die hun straf uitzaten in de gevangenis van Breda. De mogelijke vrijlating leidde tot grote beroering onder voormalig verzetsstrijders en overlevenden van de Duitse concentratiekampen. Voor de eerste keer in de Nederlandse geschiedenis werd een Kamerdebat live uitgezonden op televisie. Bastiaans gaf op de voorafgaande, eveneens live uitgezonden, openbare hoorzitting zijn visie op de gevolgen van vrijlating. De avond voor het beslissende Kamerdebat werd de film van Louis van Gasteren Begrijpt u nu waarom ik huil... op de televisie uitgezonden. Daarin was te zien hoe Bastiaans door middel van een omstreden behandeling met het hallucinogeen LSD een patiënt bevrijdde van zijn oorlogstrauma.

Vanaf die dag stond Bastiaans bij het grote publiek bekend als dé nationale expert op het gebied van de behandeling van oorlogstrauma's. Niet lang na het debat rond de vrijlating van de drie van Breda kwam er een speciale kliniek voor oorlogsslachtoffers gereed. Bastiaans was hier altijd een warm voorstander van geweest, en bij de voorbereidingen was hij dan ook nauw betrokken. Het gebouw kwam te staan op het voetbalveld van zijn Jelgersmakliniek, en Bastiaans was de beoogde directeur. Het jaar 1972 vormde het hoogtepunt in zijn carrière.

Vijftien jaar later was de situatie drastisch veranderd. Bastiaans moest met 
emeritaat, waardoor er een einde aan zijn behandelingen zou komen. Zijn patiënten vonden het afschaffen van zijn behandelmethode 'even absurd als het verbieden van penicilline'. Bastiaans verdiende in hun ogen de Nobelprijs voor zijn methode. Collega's daarentegen zagen zijn behandelingen als spelen met vuur en drongen aan op ingrijpen.

Na zijn afscheid van de Rijksuniversiteit Leiden werkte hij nog enige tijd als behandelaar bij Centrum ' 45. Daarna ging Bastiaans thuis en in hotelkamers door met zijn behandelingen. Hij raakte verzeild in een schimmig experiment met een nieuwe afkickmethode voor drugsverslaafden, waarbij een Duitse verslaafde in $1994 \mathrm{kwam}$ te overlijden. De nachtelijke behandeling in een hotelkamer tegenover de oude Jelgersmakliniek werd geleid door Bastiaans. Onder dreiging van een procedure bij de tuchtraad staakte hij zijn werkzaamheden.

Bastiaans overleed in 1997.

\section{Vraagstelling en benadering}

Bastiaans was vanaf 1964 hoogleraar psychiatrie aan de Rijksuniversiteit Leiden en directeur van de universitaire psychiatrische Jelgersmakliniek. Hij kreeg lange tijd als enige toestemming voor het gebruik van een omstreden middel, en claimde grote therapeutische successen bij een uiterst lastig te behandelen groep patiënten: overlevenden van de Duitse concentratiekampen. Zijn patiënten droegen hem op handen en bewierookten hem en zijn behandeling in boeken, films en interviews. Tegelijkertijd was Bastiaans' werkwijze omstreden bij collega's: zijn methode werd als onbewezen en zelfs gevaarlijk gezien en zijn omgang met patiënten riep vragen opvan medisch-ethische aard. Ondanks deze omstredenheid was Bastiaans in een aantal maatschappelijke kwesties waarin de oorlog en de gevolgen daarvan een belangrijke rol speelden een richtingbepalende factor. Uit hoofde van zijn positie als hoogleraar en zijn expertise als behandelaar bracht hij zijn visie over het voetlicht en was daarin succesvol: zijn visie werd overgenomen. Hoe is dat succes te verklaren?

Voor een verklaring daarvan is het belangrijk om te weten wat er in de behandelkamer gebeurde, maar nog belangrijker is het te weten wat daarbuiten gebeurde. Dat blijkt ook uit de drie onderwerpen die onlosmakelijk, hoewel niet exclusief, met dat succes verbonden waren.

Dat was ten eerste het ' $\mathrm{Kz}$-syndroom', een psychiatrische diagnose die ook wel bekend werd als het 'postconcentratiekampsyndroom' en het 'kampsyndroom'. Daarmee werd gedoeld op de klachten van overlevenden van de Duitse concentratiekampen (later ook die van andere groepen patiënten). Het aantal personen dat in de jaren zestig en zeventig leed aan die klachten leek te groeien.

Ten tweede was dat de 'methode-Bastiaans', een exclusieve behandelmethode waarmee Bastiaans het $\mathrm{kZ}$-syndroom (en later ook andere aandoeningen) succesvol zou kunnen behandelen. De behandeling was, vooral door het ge- 
bruik van LSD, omstreden en werd onderwerp van politieke discussie; verschillende Kamerdebatten en overheidsrapporten werden eraan gewijd.

De derde factor was zijn aanhang. Die bestond grotendeels, maar niet uitsluitend, uit zijn patiënten; ook anderen die zich betrokken voelden bij het leed van de patiënten schaarden zich achter Bastiaans. Hieronder wordt kort ingegaan op de manier waarop elk van deze onderwerpen in het onderzoek voor dit boek werd benaderd.

\section{Het Kz-syndroom}

De term ' $\mathrm{KZ}$-syndroom' - $\mathrm{Kz}$ is de afkorting van Konzentrationslager - werd begin jaren vijftig voor het eerst gebruikt door Deense onderzoekers, die daarmee de klachten van overlevenden van de concentratiekampen aanduidden. In Nederland kwam de term pas eind jaren zestig op onder psychiaters. Ze ijverden, met Bastiaans voorop, voor een speciale kliniek voor lijders aan het Kzsyndroom. Maar wie de ontwikkeling van de diagnose ' $\mathrm{Kz}$-syndroom' bekijkt, valt direct een aantal eigenaardigheden op. De diagnose maakte pas midden jaren zestig opgang onder psychiaters, terwijl zowel de term als de klachten onder de groep overlevenden al daarvoor bestonden. Daarnaast raakte de term eind jaren zeventig weer in onbruik terwijl de klachten nog steeds bestonden.

In zijn boek Mad travelers reikte de Canadese filosoof Ian Hacking een verklaring aan voor de opkomst en ondergang van aandoeningen als het KZ-syndroom. ${ }^{1}$ Hij deed dat aan de hand van een voorbeeld: de plotselinge opkomst van de fugue aan het einde van de negentiende eeuw in het Franse Bordeaux. Het was psychiater Tissié die de eerste lijders aan de fugue - fugueurs genoemd - beschreef in zijn boek Aliénés voyageurs uit 1887 . De fugueur verdween plotseling uit zijn woonplaats om enkele dagen later verward teruggevonden te worden, soms enkele honderden kilometers van huis, zonder geld, zonder identiteitspapieren en zonder dat hij wist hoe hij daar was beland.

De psychiatrie deelde geestelijke aandoeningen in die tijd in in twee categorieën: epilepsie en hysterie. De fugue leek van beide categorieën kenmerken te hebben. Er ontspon zich een strijd onder psychiaters: tot welke categorie behoorde de fugue? Wie erin slaagde de beste verklaring te geven, verdiende het aanzien en respect van zijn collega's. De fugue was voor patiënten een zeer vervelende aandoening, maar voor psychiaters een kans om hun kennis van het vakgebied uit te breiden, nieuwe, uitdagende ideeën te toetsen en zich te onderscheiden als expert op dat gebied.

Er was echter iets vreemds aan de hand met de fugue. Waar de verspreiding van een aandoening zich doorgaans weinig aantrekt van landsgrenzen, bleef de fugue aanvankelijk beperkt tot bepaalde gedeelten van Frankrijk en het noorden van Italië. Toen tien jaar na de uitbraak in Frankrijk het aantal fugueurs daalde, volgde een felle uitbraak in Duitsland en nog wat later in Rusland. Amerika bleef de fugue bespaard. 
De fugue is niet het enige voorbeeld van wat Hacking 'tijdelijke psychische aandoeningen' noemde. Shellshock, een aandoening die werd ontdekt bij frontsoldaten tijdens de Eerste Wereldoorlog, kent een vergelijkbare geschiedenis. Frontsoldaten die - vermoedelijk - in de nabijheid van een granaatontploffing waren geweest, gingen zich daarna vreemd gedragen.

De Eerste Wereldoorlog was de eerste moderne oorlog en werd gevoerd met modern wapentuig. Vooral de krachtige mortiergranaten, die overvloedig werden ingezet, leidden tot ongekende verliezen aan beide zijden. Soldaten wilden ontkomen aan het slagveld, maar dat was vrijwel onmogelijk: eervol het slagveld verlaten kon alleen door te sterven of gewond te raken door vijandelijk vuur.

Shellshock was een nieuw fenomeen en stelde artsen voor een raadsel. Sommige soldaten die voorheen gezond waren, vertoonden opeens verward gedrag. Psychiaters vermoedden dat de klachten van deze soldaten te verklaren waren door een nabije explosie: die zou het zenuwstelsel een grote schok hebben gegeven en zo een tekortkoming van het menselijk lichaam hebben blootgelegd.

De Britse psychiater Myers drong bij de legerleiding aan op erkenning van de nieuwe aandoening en na een jaar lobbyen lukte hem dat ook. De legerleiding gaf hem toestemming een speciale kliniek op te richten waar de gevallen van shellshock konden worden behandeld. De legerleiding erkende daarmee dat er iets bestond tussen lafheid en waanzin, maar vreesde ook dat soldaten shellshock zouden gaan aangrijpen om 'te vluchten in de ziekte'.

Om dat te voorkomen moest iedere diagnose worden voorzien van een $\mathrm{w}$ of een $\mathrm{s}$. De w stond voor Wounded en stond gelijk aan een verwonding aangebracht door de vijand. Daarmee kreeg de soldaat recht op het dragen van het speciale insigne; het betekende erkenning als oorlogsveteraan en recht op pensioengelden. De $s$ stond voor Sick; ziek worden aan het front gebeurde vaker maar viel buiten de verantwoordelijkheid van het leger. Het leger verzorgde de eerste noden, maar pensioen en erkenning bleven uit.

De nieuwe aandoening sprak, net als het nieuwe wapentuig, tot de verbeelding van het thuisfront. Het duurde niet lang of shellshock verscheen in kranten en tijdschriften en bood achterblijvers zo inzicht in de gruwelijke werkelijkheid aan het front. De diagnose drong door in het openbare leven, en figureerde in de brieven tussen soldaten en het thuisfront. Ondanks de voorzorgsmaatregelen gebeurde wat de legerleiding al gevreesd had: er ontstond een shellshock-epidemie, zonder dat daarbij het onderscheid tussen w en $\mathrm{s}$ altijd was te maken. Binnen enkele maanden na de opening van zijn speciale kliniek, berichtte Myers de legerleiding dat hij een fout had gemaakt en stelde hij voor de diagnose weer te schrappen. ${ }^{2}$

Het voorbeeld van de fugue liet zien dat psychiaters niet alleen belangeloze hulpverleners zijn. Motieven als ambitie, zucht naar roem en respect, en persoonlijk gewin spelen een rol bij het ontdekken en verklaren van een nieuwe aandoening. Het voorbeeld van shellshock liet zien dat aandoeningen soms 
ook een functie hebben. Shellshock bood de frontsoldaat zelfs een mogelijkheid levend én eervol van het front te komen.

Hacking hanteerde een metafoor om het ontstaan van deze categorie van tijdelijke psychische aandoeningen te begrijpen: de 'ecologische niche'. Sommige psychische aandoeningen hebben, net als organismen, een specifieke omgeving nodig waarin ze het beste gedijen. Verandert die omgeving, dan past de psychische aandoening zich aan of verdwijnt.

Tijdens het onderzoek voor dit boek werd het Kz-syndroom als zo'n aandoening beschouwd die afhankelijk van de vruchtbaarheid van de omgeving ontstaat, groeit of verdwijnt. De maatschappelijke omstandigheden waarbinnen psychiaters het $\mathrm{Kz}$-syndroom ontdekten, de functie die het vervulde in hun carrière, de plaats die het innam binnen de bestaande wetenschappelijke denkbeelden, de gevoeligheid van buitenstaanders voor het leed van de patiënten, de belangen van patiënten bij het erkend worden als lijder aan het Kz-syndroom, bleken factoren die minstens zo belangrijk waren voor het begrijpen van de succesvolle verspreiding van de diagnose, als de symptomen van de lijders eraan. Een boek over Bastiaans, die door psychotherapeut $K$. van der Velden al eens werd aangeduid als 'de Keizer van het $\mathrm{Kz}$-syndroom', kan dus niet geschreven worden zonder aandacht voor de maatschappelijke en wetenschappelijke omstandigheden waarin hij en de aandoening zich voordeden. ${ }^{3}$

De methode-Bastiaans

Het tweede belangrijke onderdeel van Bastiaans' succes, volgens hemzelf nauw verbonden met het KZ-syndroom, was zijn behandelmethode. Die bestond uit een combinatie van verschillende technieken, waarvan de twee belangrijkste het gebruik van LSD en pentothal (een narcosemiddel) waren. Hoewel het bestaan en voortbestaan van een behandelmethode in het algemeen afhankelijk is van de effectiviteit, spelen doorgaans ook andere factoren een rol: commerciële belangen, persoonlijke voorkeuren, maatschappelijke, morele en juridische barrières, schadelijke bijeffecten en het voorhanden zijn van alternatieven.

Dat dit ook gold voor de methode-Bastiaans, bleek het duidelijkst toen deze dreigde te verdwijnen. Bastiaans en zijn patiënten hadden het idee overgebracht dat de methode een laatste redmiddel was: als alle andere behandelingen (van andere psychiaters) hadden gefaald, bood de methode-Bastiaans soelaas. De emoties over het verdwijnen van de behandeling liepen daardoor hoog op. Het verdwijnen van de methode werd door Bastiaans' aanhang vergeleken met een 'executie': alleen al het wegvallen van het idee dat er behandeling mogelijk was, zou tot dodelijke slachtoffers kunnen leiden. ${ }^{4}$ De angst voor schadelijke gevolgen als de methode zou verdwijnen werd gedeeld door overheidsinstanties. Zij vreesden 'hernieuwde traumatisering' van slachtoffers. ${ }^{5}$

De kwestie liep zo hoog op dat er Kamerdebatten over werden gevoerd, overheidsrapporten geschreven, werkgroepen ingesteld, wetenschappelijk onder- 
ek gestart en een speciale stichting werd opgericht die het wetenschappelijk rk van Bastiaans zou voortzetten. De methode-Bastiaans, en daarmee ook stiaans zelf, werd zo onderwerp van een publiek debat. Maar waarom maakdie methode zoveel los?

Bastiaans' aanhang

n derde reden om met een wijdere blik Bastiaans' succes te bezien, is het aanel van zijn aanhang daarin. Toen Bastiaans' methode midden jaren tachtig eigde te verdwijnen, brak onder zijn patiënten (maar niet alleen zijn patiën1) een storm van verontwaardiging los. In plaats van wetenschappelijke bejzen te verzamelen, mobiliseerden ze media en politici, en chanteerden en dreigden tegenstanders om hun psychiater en zijn methode te behouden.

Zonder de hulp van zijn patiënten was Bastiaans niet geworden wie hij werd. meldden zich speciaal bij hém voor een behandeling. Binnen de behandelmer gaven ze zich aan hem bloot, daarbuiten kwamen ze voor hem op. In de zer dan veertig jaar dat hij werkzaam was als psychiater, heeft Bastiaans enle honderden patiënten kortere of langere tijd in behandeling gehad.

De term 'patiënt' wordt in dit boek overigens alleen gebruikt om aan te dui$n$ dat iemand in behandeling is geweest bij Bastiaans. In werkelijkheid ging relatie tussen Bastiaans en zijn patiënten vaak verder. Patiënten bleven na t einde van hun behandeling contact met hem houden en speelden soms een lin de behandeling van andere patiënten. Bastiaans wierp zich op zijn beurt als hun belangenbehartiger; hij bood hulp bij het aanvragen van een uitke$\mathrm{Ig}$, het innen van verzekeringsgelden, en bij politieke kwesties.

Om die kant van het verhaal te belichten, zijn in de navolgende hoofdstukn portretten opgenomen van patiënten. Die portretten konden gemaakt rrden doordat de patiënten zich in het openbaar over hun behandeling hebn uitgelaten of doordat er toestemming was verkregen van nabestaanden. egang tot de medische dossiers bleek om verschillende redenen niet moger. De dossiers die Bastiaans had aangelegd waren reeds vernietigd; tot de ssiers die door anderen waren aangelegd, werd de toegang geweigerd. ${ }^{6}$

Ondanks de ontbrekende medische dossiers bleek er voldoende informatie orhanden. Patiënten waren geïnterviewd door journalisten, hadden zich lai filmen, een boek geschreven over hun behandeling of werden politiek acfom zich in te zetten voor hun psychiater. Familie en nabestaanden bezaten ms prachtig materiaal, zoals een hele collectie brieven verstuurd uit concentiekamp Sachsenhausen, persoonsbewijzen en repatriëringspapieren van rangarbeiders. Van anderen bleken verklaringen en dagboeken te vinden op $\mathrm{t}$ NIOD. Voor het schrijven van de portretten werd, waar mogelijk, gebruikmaakt van primaire bronnen.

De keus bij de portretten viel op oorlogsslachtoffers die door Bastiaans zijn handeld. Het eerste portret betreft een van Bastiaans' eerste patiënten uit 
1950, verzetsstrijder en communist Nico Mourer. Het laatste portret betreft Trix Terwindt, die vanaf 1969 tot haar dood in 1987 in behandeling was. Ook is er een portret van schrijver en overlevende van Auschwitz Gerhard Durlacher opgenomen. Eibert Meester, een vooraanstaand PvdA-lid, meldde zich begin jaren zeventig voor behandeling, Jacques Kopinsky meldde zich eind jaren zeventig en zou tot in de jaren negentig contact houden met Bastiaans. Naast deze grotere portretten komen in de tekst regelmatig kleinere portretten voor.

De keus voor de geportretteerde patiënten is niet representatief voor Bastiaans' hele patiëntenbestand. Aangezien het medisch archief van Bastiaans was vernietigd, bleek het niet mogelijk exact te achterhalen hoeveel patiënten hij in behandeling heeft gehad, wie zij waren, voor welke problemen zij zich meldden, hoe hun behandeling eruitzag en of deze geslaagd was. Wel bleek uit uitspraken van Bastiaans dat hij ook patiënten behandelde die de oorlog niet hadden meegemaakt, of die zich meldden voor andere problemen dan een oorlogstrauma. Maar de groep oorlogsslachtoffers stond aan de basis van zijn succes; dat was dan ook de groep die in dit onderzoek de meeste aandacht kreeg.

Vragen die bij het schrijven van de portretten een rol speelden, waren onder andere: Waarom kwamen patiënten bij Bastiaans terecht? Hoe zag hun behandeling eruit? Waren zij genezen? Waarvan waren ze genezen? Wierpen zij zich op als verdediger van hun psychiater, en waarom wel of niet?

\section{Autobiografische reconstructie}

Bastiaans' behandeling had tot doel patiënten tot een betere reconstructie van hun verleden te brengen; alleen wanneer de witte vlekken in het geheugen werden ingevuld kon, zo was zijn uitgangspunt, genezing plaatsvinden. Zijn patiënten moesten terug naar 'de hel' van het concentratiekamp. Ze moesten, zoals Bastiaans het uitdrukte, 'het crematorium weer ruiken' om te genezen.

Over de therapeutische reconstructie schreef socioloog Abram de Swaan in een essay getiteld 'De maatschappelijke verwerking van oorlogsverledens':

'Die verwerking is in de eerste plaats een individuele aangelegenheid: iedere overlevende tracht zijn eigen belevenissen zo te ordenen dat er iets van samenhang ontstaat, misschien zelfs een zin in de gebeurtenissen te vinden is, of althans een verklaring. Zo een autobiografische reconstructie wordt niet in isolement ondernomen. Integendeel, in de samenleving zijn allerlei noties, modellen, verhalen beschikbaar die iemand kan aanwenden in de redactie van zijn eigen levensverhaal. Sterker nog, sommige van die ideeën worden iemand haast onontkoombaar opgedrongen door anderen, hij heeft ze te verwerken in zijn versie van zijn lotgevallen, hoe pijnlijk of onwelkom ze hem ook mogen zijn. In dat opzicht is de meest individuele verwerking van de meest persoonlijke ervaringen toch maatschappelijke arbeid. ${ }^{7}$ 
Volgens De Swaan is de reconstructie van het eigen verhaal niet alleen het resultaat van feitelijke, historische gebeurtenissen, maar wordt die evenzeer beinvloed door de sociale omgeving waarin die plaatsvindt. De persoonlijke reconstructie moet passen in de reconstructie zoals die op maatschappelijk niveau plaatsvindt. Dat is een lastige taak en daarom heeft men soms de hulp nodig van een behandelaar bij de 'redactie' van het eigen levensverhaal. Behandelaars vormen tijdens de behandeling de eerste toetssteen van patiënten; bij hen kan de reconstructie worden getoetst aan noties, modellen en verhalen die buiten de behandelkamer leven.

Maar behandelaars zijn geen neutraal doorgeefluik van maatschappelijke normen en modellen. Hoe graag ze dat ook willen voorkomen, ze beïnvloeden vaak de reconstructie met hun eigen, persoonlijke of professioneel ingegeven ideeën en voorkeuren. Soms is die invloed sterk, zoals geheugenpsychologen als Merckelbach, Crombag en Wagenaar hebben laten zien. Er kunnen zelfs vertekeningen in reconstructies door ontstaan. ${ }^{8}$ De autobiografische reconstructies die ontstonden in Bastiaans' behandelingen worden in dit boek gezien als het gecombineerde resultaat van feitelijke, historische gebeurtenissen, heersende maatschappelijke normen en modellen, en Bastiaans' ideeën en voorkeuren.

Het gebruik van sociologische begrippen als Hackings 'ecologische niche' en De Swaans' 'autobiografische reconstructie' kan de indruk wekken dat het lijden van patiënten als niet reëel wordt beschouwd; dat de klachten worden gezien als het resultaat van een proces dat zich voltrekt buiten de patiënten om, en daarmee onwaarachtig zijn. Dat is een misverstand. Beide auteurs erkennen dat patiënten zich met reële klachten melden bij hun hulpverlener. Ze erkennen ook dat met de herkenning, de presentatie en de betekenisgeving belangen zijn gemoeid van psychiater, patiënt en omgeving, en dat er gebruiken ontstaan, en culturele en maatschappelijke invloeden bestaan.

\section{Geraadpleegde bronnen}

Onder de belangrijkste primaire bronnen die werden gebruikt, vallen de archieven van de instellingen waar Bastiaans kortere of langere tijd werkzaam was: de Universiteit van Amsterdam, de Rijksuniversiteit Leiden en Centrum '45. Ook enkele privécollecties bevatten belangrijke informatie, met name de collecties van voormalig hoogleraar huisartsengeneeskunde B.S. Polak en voormalig hoogleraar psychiatrie dr. H.G.M. Rooijmans.

Dit boek gaat behalve over Bastiaans ook over de context waarin zijn succes ontstond, over de wetenschappelijke en maatschappelijke ontwikkelingen die hem eerst in het zadel hielpen en hem uiteindelijk ten val brachten. Daarbij wordt stilgestaan bij Bastiaans' bijdrage aan die ontwikkelingen en de wijze waarop die ontwikkelingen hem in staat stelden successen te behalen, te behou- 
den of te verliezen. Het is een samenspel van psychologische, historische en sociologische onderwerpen. De context waarin hij een succes werd, wordt als belangrijker gezien dan zijn persoonlijke kwaliteiten; zonder deze context was Bastiaans geen succes geworden. Dit boek is daardoor geen pure biografie die probeert inzicht te geven in de diepere, persoonlijke motieven van Bastiaans.

Uit de inmiddels omvangrijke literatuur over de nasleep van de Tweede Wereldoorlog blijkt dat de collectieve herinnering onderhevig was (en is) aan veranderingen. De omvang van de interesse groeide en kromp in de afgelopen zestig jaar, en ook de manier waarop op de oorlog werd teruggekeken, veranderde. Over deze conjunctuur van de herinnering werd eerder al door verschillende auteurs geschreven. De belangrijkste die voor dit boek zijn geraadpleegd, zijn de historici Blom, De Haan en Van Vree en de sociologen De Swaan en Withuis. ${ }^{9}$ Vooral het werk van de laatste bleek erg bruikbaar voor het begrijpen van Bastiaans' succes. Hun werk tezamen schetst het decor waartegen het verhaal van Bastiaans en zijn patiënten zich afspeelt.

Voor enkele onderwerpen die een rol speelden in Bastiaans' carrière, zoals de Universiteit van Amsterdam in oorlogstijd, de Psychosomatische Werkgroep, de drie van Breda, de geschiedenis van de Leidse psychiatrie, de psychoanalyse in Nederland, het gebruik van LSD in de psychiatrie, de opkomst van de traumacultuur, en de herinnering aan de Tweede Wereldoorlog, kon ik gebruikmaken van bestaand onderzoek.

Bastiaans liet zich regelmatig interviewen. Hij was een van de eerste psychiaters die zo toegankelijk waren voor journalisten. Bovendien wist hij zelf journalisten te bespelen; als hij in nood zat 'regelde' hij een interview waarin hij zijn verhaal kon doen. Interviewers konden na publicatie soms rekenen op een bedankbriefje, of het tegendeel als het resultaat hem niet was bevallen.

De documentatieafdelingen van een aantal landelijke kranten en tijdschriften zijn bezocht en de diverse knipselmappen in diverse archieven vormden een rijke bron van informatie.

De rol van de overheid is onderzocht aan de hand van de Handelingen van de Eerste en Tweede Kamer, verslagen van commissiezittingen, overheidsrapporten en het materiaal dat zich bevindt bij het Nationaal Archief. Ook zijn bijna dertig interviews gehouden met personen die direct of indirect met Bastiaans te maken hebben gehad. Hun namen staan achter in dit boek vermeld.

Buiten al dit schriftelijk materiaal is gebruikgemaakt van de geluidsbanden die bewaard zijn gebleven van Bastiaans' behandelingen. De collectie geluidsbanden berust bij Stichting Cogis en is voor dit onderzoek geïnventariseerd. Om een indruk te krijgen van het materiaal is een klein gedeelte ook beluisterd.

\section{Opbouw van dit boek}

Dit boek gaat over Bastiaans' rol in de persoonlijke en maatschappelijke verwerking van de oorlog. Dat was de basis van zijn roem. Andere aspecten van 
Bastiaans' professionele leven krijgen in deze studie daardoor geen of minder aandacht. Zijn werkzaamheden als hoofd van het Psychoanalytisch Instituut, zijn betrokkenheid bij de Balintgroepen in Nederland (intervisiegroepen van huisartsen), de manuele therapie, zijn behandeling van verkeersslachtoffers en zijn betrokkenheid bij een acupunctuurkliniek in Duitsland vallen buiten het kader van dit boek.

Deel I van dit boek (de hoofdstukken 2, 3 en 4) bestrijkt de periode 1917-1964. In hoofdstuk 2 wordt kort Bastiaans' eigen oorlogsverleden besproken. Hij begon na de oorlog als een jonge wetenschapper, die als chef de clinique in het Amsterdamse Wilhelmina Gasthuis en als eerste psychiater van de Psychosomatische Werkgroep hoge ogen gooide, maar daarbuiten weinig bekendheid genoot. In deze periode legde Bastiaans in zijn proefschrift (1957) de intellectuele basis voor zijn 'methode' en zijn visie op de problematiek van oorlogsslachtoffers. Hoe ontstond die visie, welke rol speelde het $\mathrm{Kz}$-syndroom in zijn proefschrift en in welke traditie stond de methode-Bastiaans?

Zijn wetenschappelijke arbeid op de Universiteit van Amsterdam werd in 1964 bekroond met een hoogleraarschap aan de Rijksuniversiteit Leiden. Daar begint deel II (de hoofdstukken 5,6 en 7). Het bestrijkt de eerste acht jaar van zijn hoogleraarschap, van 1964 tot 1972. De maatschappelijke ontwikkelingen in deze periode leidden tot de publieke bekendheid met het $\mathrm{KZ}$-syndroom. Hoogtepunt vormde het politieke en maatschappelijke debat rond de vrijlating van drie Duitse oorlogsmisdadigers, waarin Bastiaans zijn psychiatrische kennis in stelling bracht. Zijn pleidooi tegen vrijlating had grote gevolgen, zowel voor hemzelf als voor de uitkomst van het debat.

Deel III, beschreven in de hoofdstukken 8, 9 en 10, belicht de periode van 1972 tot 1982 . Het was een periode waarin Bastiaans in relatief isolement werkte in zijn Jelgersmakliniek aan de Rijksuniversiteit Leiden. Zijn methode genoot landelijke bekendheid en had een blijvende aantrekkingskracht op slachtoffers; zij zagen zijn behandeling als laatste redmiddel. De innige band die ontstond tussen Bastiaans en zijn patiënten bleek ook een keerzijde te hebben. Aan deze periode kwam in 1982 een einde toen bleek dat Bastiaans met emeritaat moest. Zijn methode dreigde hierdoor te verdwijnen.

Deel Iv bestaat uit de hoofdstukken 11 en 12, die de periode 1982-1987 beschrijven. Het is de periode waarin Bastiaans en zijn aanhang zich in een strijd begaven met overheid en universiteit. De strijd, die zich afspeelde in pers en politiek, leek te gaan over het voortbestaan van de methode-Bastiaans. Bastiaans' aanhangers gebruikten dreigementen en chantage om hún behandeling te behouden. Behalve de motieven van Bastiaans' aanhang wordt ook de rolvan de overheid en de universiteit betrokken in de analyse.

Tot slot volgt een terugblik. 
I

Aanloop

1917-1964 


\section{Vormingsjaren}

'Hij was lang, torende boven iedereen uit en had blond, strak achterover gekamd haar. Hij was altijd plechtig gekleed. Hij droeg een pak met een stijve boord, we noemden dat een "vadermoordenaar". Dat was uitzonderlijk, hij was de enige in ons jaar die er zo plechtig bij liep. Hij was een gedreven, uitstekende student, die zijn studie vlot en goed deed.'1

MAURITS FRENKEL, STUDIEGENOOT VAN BASTIAANS, 2005.

\section{Inleiding}

Jan Bastiaans werd geboren op 27 mei 1917 in Rotterdam als eerste kind van het remonstrantse echtpaar Jan Bastiaans sr. en Cornelie Carolina Henriette Nina Tengbergen. ${ }^{2}$ Drie jaar na zijn geboorte kreeg hij een zusje en twee jaar later volgde een tweede zusje. Het gezin bleef tot 1935 in Rotterdam wonen, verhuis de daarna naar Hilversum en kort daarna naar Bloemendaal. Bastiaans' vader werd in Noord-Holland leraar Algemeen Vormend Individueel Onderwijs aan het Kennemer Lyceum in Overveen. ${ }^{3}$

In 1936 deed Bastiaans zijn eindexamen voor het gymnasium. Liefhebberijen waren volgens de leerlingkaart techniek en radio. ${ }^{4}$ Nog datzelfde jaar begon hij met zijn studie geneeskunde aan de Universiteit van Amsterdam. Hij werd direct actief in het studentenleven. ${ }^{5}$ Hij schreef zich in als lid van de studentenvereniging Unitas Studiosorum Amstelodamensium (USA), die aan het begin van de 20 ste eeuw was opgericht als tegenhanger van het traditionele Amsterdamsch Studenten Corps (ASC). In tegenstelling tot het ASC had de USA geen ontgroeningen en waren zowel mannen als vrouwen lid van de vereniging. De lage contributie en de informele sfeer die binnen de USA heerste, maakten dat de vereniging door haar eigen leden als modern werd gezien. ${ }^{6}$

In 1938 werd Bastiaans bestuurslid van de Medische Faculteitsvereniging 
der Amsterdamsche Studenten (MFAS), waar hij indruk maakte op de overige studenten door zijn kordate optreden en lange voorkomen. ${ }^{7}$ Na zijn kandidaatsexamen in juni 1939 werd hem gevraagd lid te worden van het exclusieve medisch dispuut Bis Repetita Placent (BRP). ${ }^{8}$ Dit - al in 1882 opgerichte - gezelschap kende een rijke historie en prominente oud-leden, onder wie de eerste hoogleraar psychiatrie van de Rijksuniversiteit Leiden, dr. G. Jelgersma, en de Utrechtse hoogleraar psychiatrie dr. H.C. Rümke. ${ }^{9}$ De leden van BRP kwamen om de paar weken bijeen voor een lezing over een medisch onderwerp. Op zo'n bijeenkomst was altijd een hoogleraar ${ }^{10}$ aanwezig. Om lid te worden moest een student zijn kandidaatsexamen hebben gehaald en worden voorgedragen door een hoogleraar.

Tijdens zijn studietijd brak de oorlog uit. Volgens Bastiaans zelf waren zijn 'gruwelijke ervaringen', die hij in een interview met Elsevier uit 1985 zelfs 'zeer traumatisch' noemde, bepalend geweest voor zijn latere specialisatie in de hulpverlening aan oorlogsslachtoffers. ${ }^{11} \mathrm{Hij}$ suggereerde dat zijn oorlogsverleden niet alleen zijn motivatie vormde om slachtoffers te behandelen, maar het zou ook bijdragen aan zijn succes daarin. Het stelde hem in staat zich in te leven in wat zijn patiënten hadden doorstaan; beter dan psychiaters die in een concentratiekamp hadden gezeten (zij kampten met hun eigen problemen) en beter dan psychiaters die de oorlog niet hadden meegemaakt (die konden zich niet inleven in wat de oorlog had betekend). Daarnaast gaf zijn verleden zijn patiënten het vertrouwen dat hun behandelaar wist waar zij het over hadden. Vertrouwen dat bij artsen en hulpverleners die dergelijke ervaringen niet hadden, ontbrak. ${ }^{12}$

Ondanks de betekenis die Bastiaans hechtte aan zijn oorlogsverleden, werden de details ervan nooit bekend. Alleen enkele tegenstrijdige uitspraken in de pers gaven een beeld van wat zich had afgespeeld: de ene keer sprak hij van een 'indirecte rol', de andere keer van lidmaatschap van een 'geheime dienst'. ${ }^{13}$ Dan weer zou hij gevaar op deportatie hebben gelopen en zelfs een korte periode ondergedoken zijn geweest, dan weer was hij gewond geweest en had hij vanuit zijn ziekbed lijdzaam moeten toezien hoe medestudenten werden weggevoerd. ${ }^{14}$ Volgens een andere lezing was hij tijdens de oorlog tweemaal bijna komen te overlijden en was hij na de bevrijding alsnog bijna aan de gevolgen van de oorlog bezweken. ${ }^{15}$ Wat zijn de feiten?

\section{Oorlogsjaren}

In februari 1940 werd Bastiaans door de leden van de USA gekozen tot rector. In die periode waren de spanningen in Nederland ten gevolge van de dreigende oorlog aan het oplopen. Een deel van de studenten werd gemobiliseerd en liep, in afwachting van het uitbreken van de oorlog, college in militair uniform. 
Omdat zijn doctoraalexamen niet lang meer op zich liet wachten kreeg Bastiaans vrijstelling van de mobilisatie.

In de vroege ochtend van 10 mei 1940 vielen de Duitsers Nederland binnen en werd onder andere Schiphol gebombardeerd. Op de Universiteit van Amsterdam werden de colleges gestaakt, maar promoties en examens vonden die dag nog wel doorgang. In de dagen die volgden, wachtten de meesten af wat komen ging. ${ }^{16}$

Het merendeel van de Nederlanders pakte na de capitulatie op 15 mei het normale leven zo goed en zo kwaad als het ging weer op, maar sommigen probeerden een verandering te bewerkstelligen. Er ontstonden initiatieven die gericht waren op het vormen van een eenheidsbeweging. In de landelijke politiek ontstond de Nederlandse Unie. Naar analogie van de Unie probeerde de net afgestudeerde Leidse jurist H.A.M. van der Heijden tot een landelijke studentenvereniging te komen, de 'Nationale Studenten Federatie' (NSF). Per universiteitsstad zou er één sociëteit komen waarvan alle studenten verplicht lid werden. Ook nationaalsocialistische studenten zouden lid worden van de vereniging, die uitdrukkelijk niet anti-Duits was. ${ }^{17}$

Bastiaans raakte enthousiast over de plannen en werkte samen met zijn medestudenten $\mathrm{H}$. Hutte en $\mathrm{K}$. Stapel, die hij nog kende van de middelbare school, een plan uit voor het Amsterdamse studentenleven. Het voorzag in de oprichting van een nieuwe vereniging die commissies kende voor sport, kunst, studiebelangen en perszaken. Er zou zelfs een eigen tuchtrechtspraak komen, en de vereniging zou de administratie voeren over de universitaire gezondheidszorg. Bovendien stelde het drietal voor om de besturen van de oude gezelligheidsverenigingen op te heffen en de verenigingen onder één centraal bestuur te laten vallen. ${ }^{18}$

Van der Heijdens plan voor de NSF was vanwege de toelating van NSB'ers echter omstreden en stuitte op groeiende weerstand. Het plan van Bastiaans maakte, door de opheffing van de oude verenigingen, de bedenkingen alleen maar groter. De verenigingen waren niet van zins hun eigen besturen te ontbinden en tradities die al jaren bestonden te verlaten, om vervolgens op te gaan in een vereniging met een Duitsgezind karakter. Bastiaans, die als rector van een grote gezelligheidsvereniging vaandeldrager van de Amsterdamse uitwerking was, kreeg dan ook bij alle verenigingen nul op het rekest. ${ }^{19}$ Het kwam eind juli 1940 nog wel tot het publiceren van een NSF-manifest maar het plan stierf een snelle dood.

Het mislukken van zijn hervormingsplan was een bittere pil voor Bastiaans, niet in de laatste plaats omdat ook zijn eigen usA het voorstel terzijde had geschoven. Toen Bastiaans in september 1940 de nieuwe leden van de USA toesprak, verweet hij de overige studentenverenigingen gebrek aan idealisme. ${ }^{20}$ Maar de teleurstelling betekende niet dat Bastiaans zich afzijdig hield van vergelijkbare initiatieven. Dat bleek toen een aantal maanden later onder leiding 
van de Utrechtse student M. Mërzer Bruyns een federatie van contactcommissies ontstond die voornamelijk overleg voerde over gezamenlijke acties. De identiteit en autonomie van de afzonderlijke verenigingen bleven in die opzet intact, en de federatie kon daarom rekenen op deelname van veel verenigingen. Per studentenstad werd een contactcommissie opgericht, bestaande uit vertegenwoordigers van de verschillende studentenverenigingen. De Amsterdamse contactcommissie stond onder voorzitterschap van student Ynso Scholten, Bastiaans zat namens de USA en de MFAS in de commissie. ${ }^{21}$

Toen in oktober 1940 alle universiteitsmedewerkers werden gedwongen een niet-Joodverklaring te ondertekenen ontstond er grote onrust onder de studenten. Op de Leidse universiteit werd, na de beroemde rede tegen de Duitsers van hoogleraar dr. R.P. Cleveringa, op 29 november 1940 gestaakt. Het gevolg was dat de Duitsers tot sluiting van de universiteit overgingen.

Ook in Amsterdam klonken onder studenten na het bekendmaken van de maatregel direct geluiden om een staking uit te roepen..$^{22} \mathrm{Na}$ het bericht van de sluiting van de Leidse universiteit vreesde rector Brouwer dan ook dat de onrust zou overslaan naar Amsterdam, en hij verzon een list. Hij liet diezelfde avond nog vervroegd de kerstvakantie ingaan waardoor een staking niet mogelijk was. Toen tijdens deze vakantie bleek dat de Groningse universiteit niet tot staking was overgegaan, verdween de drang tot staken ook bij de Amsterdamse studenten. ${ }^{23}$

De sfeer werd in Amsterdam daarna snel grimmiger. De eerste fascistische knokploegen hadden in de zomer al door de Jodenbuurt gelopen en op 7 oktober 1940 werden 116 vooraanstaande Nederlanders gearresteerd en overgebracht naar concentratiekamp Buchenwald. ${ }^{24}$ Op de dag dat de Duitsers Joden verboden te werken aan de universiteit, gaf de Joodse internist dr. J.J. Groen zijn laatste college. Een student sprakna afloop van het college een dankwoord, waarna de hele collegezaal, op enkele NSB'ers na, uit protest tegen de antiJoodse maatregelen opstond en applaudisseerde voor Groen. Enkele leden van BRP stapten op Groen af en vroegen hem de organisatie van een symposium te begeleiden. Groen stemde toe en koos als thema voor het symposium 'bloed'. ${ }^{25}$

Op de uitsluiting van de Joodse medewerkers volgde snel de uitsluiting van de Joodse studenten. Rector Brouwer ontving begin 1941 een vertrouwelijk bericht van J. van Dam, de secretaris-generaal van het departement van Opvoeding, Wetenschap en Kultuurbescherming. Van Dam, tevens hoogleraar Duits aan de Amsterdamse universiteit, vroeg nu zijn eigen rector en de rectoren van andere universiteiten de instelling van een numerus clausus voor Joodse studenten voor te bereiden.

De situatie in Amsterdam werd daarna steeds onrustiger. Eind februari 1941 vond de eerste grootscheepse razzia in de Jodenbuurt plaats. Honderden Jood- 
se mannen werden opgepakt en afgevoerd. Als reactie hierop brak onder het trampersoneel een staking uit, die uitliep op de massale Februaristaking. Studenten en hoogleraren wilden ook tot staking overgaan en rector Brouwer spoedde zich naar de plekken waar onrust leek te ontstaan om te sussen, iets wat steeds weer lukte.

De eerder naar Buchenwald afgevoerde hoogleraar Noordenbos werd in april 1941 vrijgelaten. Hij was aangeslagen maar ging direct weer aan het werk. Maurits Frenkel, studiegenoot van Bastiaans, herinnerde zich hoe het eerste college van Noordenbos begon:

'Bij zijn eerste college na zijn gevangenschap in april $1941 \mathrm{kwam}$ Bastiaans, als contactpersoon tussen studenten en faculteit, de collegezaal binnen en vroeg de zaal, op verzoek van de familie, geen teken van demonstratie te geven. Er was ook geen teken van demonstratie. Het was stampvol, maar het was doodstil. Doodstil. Veel indrukwekkender dan wat voor gejoel ook. ${ }^{26}$

Het satirische studentenblad Propria Cures had vanaf het begin van de bezetting de confrontatie met de Duitsers gezocht, en hield er rekening mee dat er vroeger of later maatregelen zouden volgen. Begin 1941 was het zover: er gingen geruchten dat de Duitsers het blad wilden opheffen. De redactie wilde nog een laatste editie uitgeven met daarin een kritisch stuk over de secretaris-generaal van het departement van Volksvoorlichting en Kunsten, de NSB'er dr. T. Goedewaagen. Rector Brouwer wist van het kritische stuk en verbood, in overleg met de Amsterdamse burgemeester E.J. Voûte en Van Dam, de uitgave. Maar hij was te laat: het blad verscheen, mét het kritische stuk over Goedewaagen.

Na deze laatste uitgave van Propria Cures zonnen de Duitsers op maatregelen tegen de individuele redacteuren. Terwijl rector Brouwer probeerde de gevolgen voor de redacteuren te beperken, gooide Bastiaans onbedoeld olie op het vuur door een gedicht te schrijven waarin hij het blad herdacht. ${ }^{27}$ Hij deed dat in Unitas, het tweewekelijks verschijnende blad van de USA, waarvan hij sinds begin 1941 hoofdredacteur was. ${ }^{28}$ In een ander stuk, dat verscheen op 5 juni 1941, blikte hij terug op het voorgaande studiejaar en stond stil bij zijn afgevoerde medestudenten en docenten:

'Niet allen tegelijk als door een ramp, maar langzaam na elkaar in groepjes of apart. Het deed aan sterven denken door een langzaam voortschrijdende ziekte, die men niet bestrijden kan. [...] Toen men tenslotte een middel tegen de kwaal gevonden dacht te hebben, was het ineens vacantie. ${ }^{29}$

Met de laatste opmerking had hij de list van rector Brouwer bedoeld. Behalve de rector moest vooral Van Dam het ontgelden. Zijn 'goede bedoelingen' wer- 
den belachelijk gemaakt en hij werd neergezet als een hoogleraar die buiten de universitaire gemeenschap stond. In mindere mate bespotte Bastiaans ook de kersverse, Duitsgezinde burgemeester Voûte en secretaris-generaal Goedewaagen.

Van Dam, Voûte en Goedewaagen, ook al op de korrel genomen door Propria Cures, wilden dat er tegen Bastiaans maatregelen werden genomen. Op 13 juni moest hij zich melden bij het departement van Volksvoorlichting en Kunsten in Den Haag, het departement van Goedewaagen. Volgens een verslag over de affaire van rector Brouwer werd Bastiaans door twee Nederlandse ambtenaren streng toegesproken en werd hem opgedragen om Unitas positiever te laten schrijven over de bezetter..$^{30}$

'Wanneer men toch op deze wijze zou doorgaan, zou het met zijn blad en met hemzelf wel ongelukkig afloopen. ${ }^{31}$

Maar Van Dam en Voûte waren niet tevreden met alleen een standje, en drongen bij rector Brouwer aan op een schorsing van drie maanden. Brouwer riep Bastiaans bij zich en hoorde zijn kant van het verhaal. Hij had met zijn stuk duidelijk willen maken dat onder studenten wantrouwen heerste jegens Van Dam en Voûte. Brouwer schreef in het verslag dat hij van het voorval maakte:

'Bij dit onderhoud is de heer Bastiaans, die zeer intelligent en een uitstekende leerling is, mij wel nader gekomen dan tot dusverre het geval was. Ik wist nooit precies wat ik aan hem had, vond hem vroeger draaierig en wat slap. ${ }^{32}$

Bastiaans vroeg de rector of het zin had zijn excuses aan te bieden aan Van Dam, maar de rector betwijfelde of hij zou worden toegelaten. De contactcommissie stelde zich op achter Bastiaans. Een schorsing voor het beledigen van de rector vonden zij acceptabel, maar een schorsing voor de uitingen over de twee Duitsgezinde bestuurders zagen ze als een keuze vóór Van Dam en Goedewaagen. De rector wist Van Dam en Goedewaagen uiteindelijk te kalmeren en legde Bastiaans een schorsing op van zeven dagen. De schorsing ging in op 26 juni 1941, maar Bastiaans kreeg dat pas op 3 juli te horen en had er dus geen last van. ${ }^{33}$

Op 20 augustus 1941 werd Unitas alsnog verboden door de Duitsers..$^{34}$ De negen redactieleden van Propria Cures werd verboden zich in te schrijven aan universiteiten en hogescholen. Dat verbod was net zo symbolisch als Bastiaans' schorsing; de meeste redactieleden studeerden door tijdens de oorlog. ${ }^{35}$

In oktober $1941 \mathrm{kwam}$ er een verbod voor Joden op het lidmaatschap van gezelligheidsverenigingen. Dat was voor alle studentenverenigingen reden zich op te heffen. De universiteit bleef nog open, maar niemand wist hoe lang dat nog zou duren. Zolang het nog kon werd er gestudeerd. Uit de voormalige gezelligheidsverenigingen groeide het illegale studentenverzet. ${ }^{36}$ Hun bestuurs- 
leden werden zo veel mogelijk buiten de illegale activiteiten gehouden, omdat zij te veel in de gaten liepen. Een nieuwe garde, die - omdat ze niet of nauwelijks bekend was bij de bezetter - radicalere acties kon beginnen, nam het roer over. $^{37}$

Begin april 1943 werden studenten gedwongen een loyaliteitsverklaring te ondertekenen, waarin ze beloofden geen acties te ondernemen tegen de bezetter. Wie niet tekende werd uitgesloten van de universiteit. Het ondertekenen van de verklaring werd door studenten gezien als lakmoesproef: zij die tekenden, kozen partij voor de bezetter. Er kwam een actie op gang om studenten te weerhouden van tekenen; in Amsterdam werden 'omkletsploegen' ingezet. Die actie slaagde, minder dan twintig procent van de studenten in Amsterdam tekende de verklaring. De universiteit stroomde leeg.

Eind april 1943 stuurde de Duitsgezinde procureur-generaal dr. J. Feitsma een brief naar Van Dam. Hij was teleurgesteld over het lage percentage tekenaars en drong aan op actie. Bij de brief stuurde hij een lijst met 43 namen van studenten, waaronder die van Bastiaans, die:

'[...] min of meer actief hebben deelgenomen aan de actie tegen de zg. loyaliteitsverklaring hunner medestudenten. [...] Ik vlei mij niet met de hoop, dat ik U hiermede de namen der zg. voormannen, de aanvoerders der cellen van verzet heb verschaft. Deze voormannen werken achter de schermen en vallen, dank zij hun zwijgzaamheid minder op dan hun werktuigen. ${ }^{38}$

Volgens de historicus dr. J. Knegtmans, die een uiterst gedetailleerde geschiedenis van de Universiteit van Amsterdam in oorlogstijd schreef, werd de lijst van Feitsma niet door de Duitsers gebruikt. ${ }^{39}$ In de periode waarin de kwestie rond de loyaliteitsverklaring speelde, was Bastiaans al vertrokken uit Amsterdam. Kort voor de opheffing van de USA in 1941 had hij zijn doctoraalexamen gehaald.$^{40}$ Daarna was hij naar Den Haag getrokken om als semi-arts te werken bij de 's-Gravenhaagsche Diakonessen-Inrichting, het latere Bronovo Ziekenhuis. ${ }^{41}$ Bastiaans assisteerde de arts H.P. Wijnen bij chirurgische ingrepen. Veel kan Bastiaans dus niet te maken hebben gehad met de protesten tegen de loyaliteitsverklaring. Bovendien werd hij in de herfst van 1942 uitgeschakeld; zijn been raakte deels verlamd.

Over de oorzaak van de verlamming deed Bastiaans tegenstrijdige uitspraken. Volgens een interview met journaliste Bibeb in 1970 kreeg hij een verkeerde injectie in zijn been tijdens een operatie. In 1981 zei hij tegen de interviewer van de Hadgse Courant dat hij de onfortuinlijke injectie kreeg voor de behandeling van een longontsteking, iets wat hij in 1983 tegenover NRC Handelsblad weer herhaalde, om vervolgens in 1984 tegenover Arts en Wereld weer terug te keren naar de operatie. In 1985 zei hij tegen Elsevier dat het was gegaan om een blindedarmoperatie. In zijn boek Isolement en bevrijding uit 1986 schreef hij dat 
hij de injectie kreeg naar aanleiding van een ongeval. ${ }^{42}$ Wat precies de aanleiding was blijft dus onduidelijk, maar dat zijn been beschadigd raakte is zeker.

Het verplegend personeel van het Haagse ziekenhuis bestond uit zusters van de orde van diaconessen. ${ }^{43}$ Vanwege het chronische tekort aan bedden werd Bastiaans zo lang op de kraamafdeling gelegd, waar onder anderen de toen vierendertigjarige 'proefzuster' Helena Visser hem verzorgde. Visser was in 1937 ingetreden in de orde en zat in de laatste fase voor de uiteindelijke inzegening. ${ }^{44}$ Bastiaans en Helena Visser werden verliefd op elkaar.

Nadat Bastiaans werd ontslagen uit het ziekenhuis, moest hij een tijdlang rust houden. Een deel van zijn herstelperiode bracht hij door op boerderij 'De Hoogte' in het Groningse Oldehove bij de familie Gaaikema. Hij kende de familie Gaaikema al doordat hij vanwege zijn astma wel eens korte tijd bij hen had gelogeerd. Op De Hoogte liep hij nog een tijd met een beugel aan zijn been, en hij probeerde met een 'elektriseeraparaat' de schade nog wat te beperken. ${ }^{45}$ Voor zover zijn gezondheid het toeliet, hielp Bastiaans mee op het land. Later assisteerde hij een korte periode een huisarts in de buurt van Grootegast. ${ }^{46} \mathrm{De}$ omstandigheden tijdens de oorlog waren relatief goed in Oldehove; van een tekort aan voedsel was geen sprake en de sfeer op het platteland van NoordGroningen was, anders dan in de Randstad, betrekkelijk ontspannen.

Uiteindelijk keerde Bastiaans terug naar het Haagse diaconessenziekenhuis, waar hij nog korte tijd werkte op de afdeling cardiologie. De omstandigheden waaronder gewerkt en geleefd moest worden werden steeds slechter. Eind 1944 strandde de opmars van de geallieerden aan de Nederlandse rivieren. Vanaf die tijd was het zuiden van Nederland bevrijd gebied. Het betekende voor de rest van de bevolking razzia's, voedsel- en brandstoftekorten en standrechtelijke executies. De winter van 1944-1945 zou de geschiedenis ingaan als 'de Hongerwinter'.

Voor Bastiaans waren deze laatste oorlogsmaanden ook om andere redenen veelbewogen. De liefde voor proefzuster Helena Visser, begonnen tijdens zijn periode op de kraamafdeling, was na zijn terugkeer in Den Haag alleen maar sterker geworden. ${ }^{47}$ Visser raakte in de lente van 1944 zwanger van Bastiaans. Tegelijk met het nieuws van haar zwangerschap, bereikte Bastiaans het bericht dat zijn vader, die al lange tijd ernstig ziek was, op sterven lag. In juni 1944 stierf zijn vader, een maand voordat hij met Helena Visser in het huwelijk trad.

In november trok het stel van Den Haag naar Haarlem en trok in bij Bastiaans' moeder. Daar troffen ze een vol huis aan. Sinds het begin van de oorlog was de zoon van een uit Duitsland gevlucht Joods echtpaar ondergebracht bij het gezin, en vanaf de zomer van 1943 gebruikten ook de ouders van de jongen het huis aan de Delftlaan als onderduikadres. Ze sliepen in een grote kast op zolder. ${ }^{48}$ Behalve de drie onderduikers logeerden ook twee broers uit Nederlands Oost-Indië bij het gezin; ze waren voor de oorlog voor een opleiding naar 
Nederland gekomen, maar konden na het uitbreken van de oorlog niet meer terugkeren. Ook Bastiaans' vijf jaar jongere zus woonde nog thuis. ${ }^{49}$

Op 2 december 1944 beviel Helena Bastiaans in het Diakonessenziekenhuis in Haarlem van een twee-eiige tweeling, een jongen en een meisje. Na twaalf dagen stuurde de behandelend arts moeder en beide kinderen naar huis. ${ }^{50}$ Een elektrisch noodkacheltje moest de beide baby's warm houden, maar twee maanden daarvoor hadden de Duitsers de stroomvoorziening aan particulieren al gestaakt. ${ }^{51}$ Tevergeefs meldde Bastiaans zich nog bij de Duitsers om een uitzondering te maken..$^{52}$ Desondanks overleefden alle aanwezigen in huize Bastiaans, ook de beide baby's en de drie onderduikers, de oorlog.

Bastiaans schreef zijn succes deels toe aan zijn oorlogsverleden, zoals in de inleiding al werd gezegd, zonder daarbij details prijs te geven over wat hij had meegemaakt. In interviews aan het einde van zijn carrière, veertig jaar na de bevrijding, schetste hij een wat diffuus beeld van zijn oorlogsverleden. Hij zou in het 'studentenverzet' en bij de 'geheime dienst' hebben gezeten, en 'gevaar op deportatie' hebben gelopen.

Met zijn verzet doelde hij op zijn periode als rector van de USA. De manoeuvres van bestuur en studenten om de universiteit open te houden werden door historici aangeduid met de term 'legaal verzet'. ${ }^{3}$ 'De geleidelijke overgang naar het illegale verzet hield gelijke tred met de ernst van de consequenties die volgden op dat verzet. Naarmate de reactie van de Duitsers verschoof van reprimandes, bedreigingen en lichte straffen naar arrestaties, gijzelingen, deportaties en executies, verschoof het verzet van legaal naar illegaal.

De Duitsers wilden in de eerste periode van de oorlog orde en rust bewaren. Omdat zij de universiteiten wilden openhouden, reageerden ze aanvankelijk niet of mild op protesten. De Leidse en Delftse studenten waren in november 1940, bij het ontslag van de Joodse hoogleraren, de eersten die met een staking hun grens stelden en bij de Duitsers een sluiting provoceerden. De Amsterdamse studenten, van wie Bastiaans een van de leiders was, hielden het langer vol. De besturen hieven hun verenigingen pas in oktober 1941 op nadat de Joodse studenten gedwongen werden hun lidmaatschap op te zeggen. ${ }^{54}$ Pas in april $1943 \mathrm{kwam}$ het tot een massale actie met de weigering om de loyaliteitsverklaring te ondertekenen. Het grootste deel van het Amsterdamse universitaire leven kwam toen stil te liggen. Maar tot een door studenten geforceerde sluiting van de Amsterdamse universiteit, waar Bastiaans in een interview naar verwees, kwam het echter nooit.

Wanneer hij sprak van 'gevaar op deportatie', doelde hij waarschijnlijk op het gevaar dat hij liep na de weigering van de loyaliteitsverklaring. Weigeraars liepen het risico tewerkgesteld te worden in Duitsland (wat iets anders was dan gedeporteerd worden naar een concentratie- of vernietigingskamp). Hoe groot dat gevaar was is onduidelijk, maar veel last had Bastiaans er niet van. Histori- 
cus Knegtmans interviewde Bastiaans over diens periode in Amsterdam tijdens de oorlog. Daarin vertelde Bastiaans dat hij zich niet kon herinneren last te hebben gehad van het feit dat zijn naam op een lijst stond. ${ }^{55}$

Hij moet met zijn deels verlamde been ook een weinig bruikbare indruk hebben gemaakt voor de dwangarbeid. Bovendien was er de bezetter zeer veel aan gelegen het medisch bedrijf draaiende te houden. Met de arrestatievan een semi-arts schoten ze zichzelf in de voet. ${ }^{56}$ Bastiaans werkte als semi-arts in een grotendeels door de Duitsers gecontroleerd ziekenhuis, en eind 1944, toen de Duitsers aan de verliezende hand waren en de chaos groeide, durfde hij zich te melden bij de Duitse instanties met de vraag de stroomtoevoer te hervatten.

Bastiaans had weliswaar een handtekeningenactie georganiseerd voor het terughalen van de gegijzelde hoogleraren, zich kritisch uitgelaten in Unitas en geweigerd de loyaliteitsverklaring te tekenen, maar hij stelde zijn oorlogsverleden, zonder concreet te worden, ernstiger en heroïscher voor dan het was. Bastiaans liet vanaf de bevrijding merken dat hij aan de 'goede' kant had gestaan. Hij pochte in een gedenkboek van de USA uit 1951 dat de studentenwereld de eerste groep was die de gevolgen van de bezetting had gevoeld. ${ }^{57}$

In een ander interview vertelde hij met enige trots dat hij de eerste geschorste student was aan de Universiteit van Amsterdam. Hij vermeldde niet dat negen leden van Propria Cures de toegang tot het gehele hoger onderwijs werd ontzegd. Hij vertelde er ook niet bij dat in januari 1941 een redacteur van Libertas ex Veritate een kritisch stuk had moeten bekopen met een paar weken gevangenisstraf, terwijl Bastiaans' schorsing symbolisch was. ${ }^{58}$

Bastiaans was niet de enige die zijn oorlogsverleden dramatiseerde. Na de oorlog was de vraag of iemand 'goed' of 'fout' was geweest een belangrijke vraag, en dat leidde, zoals in hoofdstuk 9 blijkt, vaker tot vertekende reconstructies. De vraag die rest is of Bastiaans' succes als behandelaar valt te verklaren uit zijn oorlogsverleden. Het is onwaarschijnlijk. Hij werd immers bekend met het behandelen van overlevenden van concentratie- en vernietigingskampen. Hun ervaringen stonden mijlenver af van wat hij zelf had meegemaakt. Misschien kwam Bastiaans nog het dichtst bij de waarheid in een interview met journaliste Bibeb uit 1970, toen hij zei:

'Ik kwam niet in die hel maar ik heb me zo goed ingeleefd, dat ik dacht de mensen te kunnen begrijpen. ${ }^{59}$

\section{De Psychosomatische Werkgroep}

Anders dan wat hij daar zelf over zei werd Bastiaans' keuze voor de behandeling van oorlogsslachtoffers niet in de oorlog gemaakt. Zijn specialisatie ontwikkelde zich geleidelijk. Het begon bij zijn eerste werkgever, de Universiteit van Amsterdam, waar hij in november 1945 in dienst kwam en zijn assistentschap 
vervulde bij de hoogleraar psychiatrie dr. L.M. van der Horst. ${ }^{60}$ Omdat Bastiaans gedurende de oorlog lange tijd als assistent had kunnen doorwerken, kon hij binnen een halfjaar na de bevrijding zijn artsexamen halen en beginnen met zijn specialisatie. ${ }^{61}$ In de oorlog had hij zijn assistentschap vervuld bij chirurgie en interne geneeskunde, maar zijn lengte van 193 centimeter zat hem bij deze disciplines in de weg. ${ }^{62}$ Door het vele staande werk zou hij, zeker met zijn deels verlamde been, last krijgen van zijn rug. Hij koos voor de psychiatrie.

Gelijktijdig met zijn opleiding in het Wilhelmina Gasthuis begon hij een opleiding tot psychoanalyticus. Hij ging daarvoor in leeranalyse bij Jeanne Lampl-de Groot, een vooraanstaand psychoanalytica, die haar leeranalyse bij de grondlegger van de psychoanalyse zelf, Sigmund Freud, had gehad. ${ }^{6_{3}}$

In 1947 werd Bastiaans eerste assistent bij de internist dr. J.J. Groen van de Tweede Kliniek voor Inwendige Ziekten an het Wilhelmina Gasthuis in Amsterdam. Dezelfde Groen die tijdens de oorlog door Bis Repetita Placent was gevraagd om een symposium voor te zitten. Voor de oorlog had Groen in Amerika kennisgemaakt met de psychosomatiek, de studie van de samenhang tussen lichamelijke en psychische processen. Tijdens de oorlog werd de bewegingsvrijheid van de Joodse Groen steeds verder ingeperkt. Door een huwelijk met een niet-Joodse vrouw en hulp van het verzet wist hij uit de handen van de Duitsers te blijven. De anti-Joodse maatregelen ontnamen hem al snel de toegang tot de universiteit, later de mogelijkheid tot publiceren en nog later de mogelijkheid om niet-Joodse patiënten te behandelen.

De psychosomatiek bleef Groen tijdens de oorlog fascineren en hij verdiepte zich meer en meer in de achtergronden van zijn almaar kleiner wordende groep Joodse patiënten. Het begon met korte praatjes, maar die liepen steeds vaker uit op urenlange gesprekken. 's Nachts werkte hij de gesprekken uit en raakte er meer en meer van overtuigd dat er een verband bestond tussen de fysieke aandoeningen en de psychische achtergrond van zijn patiënten. ${ }^{64}$

$\mathrm{Na}$ de oorlog nam Groen tijdelijk de leiding van het ziekenhuis van de Centraal Israëlitische Ziekenverpleging op zich. Dat was een particulier ziekenhuis in Amsterdam, bedoeld voor de Joodse gemeenschap, waar veel overlevenden van de kampen na hun terugkeer werden behandeld. Groens hart lag echter bij het onderzoek, en hij wilde terug naar de universiteit. Een positie als hoogleraar ging aan zijn neus voorbij, maar hij werd wel benoemd tot eerste geneesheer van Paviljoen 7 van het Wilhelmina Gasthuis van de Universiteit van Amsterdam.

Groen zag kans een subsidie te krijgen van de Rockefeller Foundation, een Amerikaanse organisatie die onderzoek subsidieerde naar zogenaamde 'dark cormers' in de geneeskunde. Met de subsidie zette Groen de Psychosomatische Werkgroep op, waarin hij het onderzoekuit zijn oorlogsjaren voortzette. Groen had een uitgesproken idee over de samenhang tussen psyche en soma: lijders aan dezelfde lichamelijke aandoening vertoonden niet alleen dezelfde licha- 
melijke symptomen, maar vertoonden ook op psychisch vlak overeenkomsten. Deze psychosomatische specificiteit werd het belangrijkste onderzoeksobject van de Werkgroep

Volgens de Werkgroep bezat de persoonlijkheidsstructuur bepaalde eigenaardigheden waardoor een stresssituatie voor de één te overwinnen was, en voor de ander een 'psychisch trauma' werd. ${ }^{65}$ Zo'n psychisch trauma leverde vaak onbewuste - spanningen op, die resulteerden in het ontstaan van de aandoening. De Werkgroep onderzocht voor een aantal aandoeningen wat de specifieke persoonlijkheidsstructuur van de patiënten was en in welke specifieke situaties het psychisch trauma ontstond.

In eerste instantie richtte de Werkgroep haar aandacht op een groep verdachte aandoeningen die zich bij uitstek leende voor dergelijk onderzoek. Het ging om aandoeningen waar de klassieke, somatisch gerichte geneeskunde maar moeilijk een verklaring voor kon vinden, zoals maagzweren (ulcus ventriculi), hoge bloeddruk, astma en chronische ontstekingen aan de darmen (colitis ulcerosa). Hoewel de Werkgroep zich hoofdzakelijk op deze groep aandoeningen richtte, werden psyche en soma als één geheel gezien; alle somatische aandoeningen hadden dan ook in meer of mindere mate een psychische component. $^{66}$

Het onderzoek werd verricht door een internist, een psycholoog, een fysioloog en een psychiater. Het ging aanvankelijk om respectievelijk Groen, J.M. van der Valk, S.J. Vles en Bastiaans. Later kwamen daarbij: de internist H.E. Pelser; $M$. Frenkel, die later hoogleraar interne geneeskunde aan de Erasmus Universiteit werd; Johan Barendregt, psycholoog, verantwoordelijk voor veel van het psychologisch testwerk en statistische berekeningen, later hoogleraar psychologie in Amsterdam; G.A. Ladee, later hoogleraar psychiatrie aan de Erasmus Universiteit Rotterdam.

Bastiaans vervulde een cruciale rol in de Werkgroep: als psychiater was hij verantwoordelijk voor het leggen van de link tussen ziekte en psyche. ${ }^{67} \mathrm{Hij}$ maakte daarbij gebruik van de psychoanalyse, die psychische problemen zag als resultante van onbewuste conflicten die hun wortels hadden in de vroege jeugd. Deze algemene psychoanalytische regel werd door de psychosomatici overgenomen en verder uitgebreid. In de psychoanalyse lag de nadruk op de psychische manifestatie van die conflicten. De Werkgroep voegde daar de somatische manifestatie aan toe: het woeden van het onbewuste was niet alleen merkbaar aan psychische symptomen, maar kon zich ook uiten in fysieke aandoeningen.

Wanneer patiënten binnenkwamen bij de Werkgroep werden ze door alle vier de disciplines onderzocht, en er werd een biografische anamnese opgesteld. Dit uitgebreide medisch-sociale rapport beperkte zich niet tot de relevante medische voorgeschiedenis van de klachten, maar bestreek het hele leven van een patiënt. De relatie met de ouders, de emotionele ontwikkeling in 
de puberteit, de seksualiteit en latere conflicten werden erbij betrokken, net als het ontstaan, verloop en verdwijnen van somatische aandoeningen. Zo werd een levensgeschiedenis gereconstrueerd waarbij de verhaallijnen begonnen in de vroege jeugd en doorliepen tot de recente problemen. Door het gedetailleerd overzicht in de biografische anamnese kon vrijwel altijd een relatie worden gelegd tussen het ontstaan en verloop van de fysieke klachten en de emotionele ontwikkeling.

$\mathrm{Na}$ enkele jaren onderzoek had de Werkgroep de persoonlijkheidsstructuur van de lijder aan colitis ulcerosa blootgelegd, een chronische ontsteking van de darmen. De lijder kenmerkte zich in zijn optreden als 'slap', 'gemiddeld', 'sentimenteel-beleefd', was 'matig actief' en 'ijverig', 'plooibaar' en 'maatschappelijk matig succesvol'. Hij was 'niet zelfstandig, afhankelijk van de partner' (die vaak pas op late leeftijd werd gevonden) en 'imiteerde levensnormen van anderen'. Ze werden wel omschreven als 'klevers'. Bovendien waren ze vaak onzeker, angstig en impotent. ${ }^{68}$

Ook de kenmerken van de situatie waarin de klachten van de lijder aan colitis ulcerosa ontstonden of verergerden waren door de Psychosomatische Werkgroep in kaart gebracht. Het ging om situaties waarbij een 'acuut liefdesverlies' werd ervaren of waarin de lijder alleen werd gelaten, vernederd of grof beledigd, vooral wanneer vernederingen betrekking hadden op de mannelijkof vrouwelijkheid. ${ }^{69}$

Bastiaans werd op het Wilhelmina Gasthuis gewaardeerd door collega's, hij werd liefkozend 'Jan-Bas' genoemd..$^{70}$ Maar ook professioneel werd zijn werk gewaardeerd, en al in 1951, vier jaar nadat hij was begonnen als assistent en drie jaar voor hij begon met zijn promotieonderzoek, publiceerde hij samen met Groen en Van der Horst een boekje, getiteld Grondslagen der klinische psychosomatiek. Daarin werd beschreven hoe de Werkgroep te werk ging en werden de eerste resultaten gepresenteerd. ${ }^{11}$ Bastiaans had zich ontwikkeld tot een wetenschapper met een brede interesse.

\section{Prognose en effect van psychotherapie en psychoanalyse}

Naast zijn werk bij de Psychosomatische Werkgroep, zijn eerste liefde, besteedde Bastiaans veel tijd aan de psychoanalyse, zijn tweede liefde. Nadat hij in 1950 zijn specialisatie tot psychiater had afgerond en was ingeschreven in het register van psychiaters, kon hij ook optreden als volwaardig behandelaar. ${ }^{22}$ In 1954 werd hij benoemd tot directeur van het Psychoanalytisch Instituut (PAI) in Amsterdam en was daar verantwoordelijk voor de scholing en opleiding van psychoanalytici.

In 1952 maakte de Britse psycholoog H.J. Eysenck een opmerking die bij veel therapeuten en psychiaters kwaad bloed zette. Op basis van onderzoek gedaan door anderen naar het effect van therapie op neuroticisme concludeerde hij dat: 
'The figures fail to support the hypothesis that psychotherapy facilitates recovery from neurotic disorder. ${ }^{73}$

Hij voegde daaraan toe dat dat niet betekende dat psychotherapie géén effect had, maar wel dat het nog niet te meten was. Ondanks deze nuancering vatten psychiaters zijn opmerking op als een aanval op hun metier.

Ze zetten de tegenaanval in. In Nederland werd onder leiding van Bastiaans en psycholoog Barendregt een ambitieus onderzoek uitgevoerd naar het effect van psychoanalyse en psychotherapie. ${ }^{74}$ Barendregt ontfermde zich net als bij de Psychosomatische Werkgroep over de psychologische testmethoden en de statistische bewerking van de resultaten, Bastiaans organiseerde en coördineerde de toewijzing van patiënten aan de therapieën en de verslaglegging.

Aan het onderzoek, getiteld Prognose en effect van psychotherapie en psychoanalyse, namen 315 patiënten deel, die zich hadden aangemeld bij het Amsterdamse Psychoanalytisch Instituut voor een behandeling. De patiënten werden uitgebreid onderzocht met een aantal psychologische tests. ${ }^{75} \mathrm{Op}$ basis van de resultaten werd in de stafvergadering van het Psychoanalytisch Instituut door de aanwezige psychiaters besloten aan welke conditie een patiënt werd toegewezen. Dat kon zijn: psychoanalyse, psychotherapie of deelname aan een controlegroep die geen enkele vorm van therapie of begeleiding kreeg. Tweeënhalfjaar na deze toewijzing werden bij de patiënten nogmaals dezelfde psychologische tests afgenomen. De verwachting was dat de invloed van de therapie te zien zou zijn in de resultaten van de tests. ${ }^{76}$

De resultaten waren teleurstellend: geen van de tests liet een statistisch significant verschil zien tussen voor-en nameting. De enige kleine uitzondering was een leugenschaal die was opgenomen omdat Bastiaans en Barendregt veronderstelden dat 'de leugenscore wellicht een goede maat zou zijn voor de zelfkennis van een patiënt. Dit omdat de meeste "leugenvragen" een al of niet toegeven van menselijke zwakheden' betroffen. Psychoanalyse leidde tot een verbeterd zelfbeeld waardoor personen minder geneigd waren te liegen. De scores van de psychotherapie- en de controlegroep lieten geen verandering zien, maar de score van de psychoanalysegroep liet wel een statistisch significante daling van het aantal leugens zien.

Het magere resultaat was voor Bastiaans een lastige boodschap aan zijn collega's van het PAI. Na de verspreiding van het interne rapport kwam er een stroom van kritiek los waaruit bleek dat de analytici iets heel anders hadden verwacht van het onderzoek. Het werd ook duidelijk dat psychoanalytici geen kaas hadden gegeten van psychologisch onderzoek, en er zelfs zeer afwijzend tegenover stonden. Dat leverde het soort kritiek op waar Barendregt pas op in wenste te gaan als die werd gepubliceerd; dan zou veel kritiek volgens hem wel achterwege blijven. ${ }^{77}$

Het bestuur van het PAI weigerde aanvankelijk zelfs publicatie van de resul- 
taten, maar Barendregt en Bastiaans zetten door. Het onderzoek werd kort na voltooiing gepubliceerd in een Engelstalig boek van Barendregt, en Bastiaans presenteerde het op een internationaal congres..$^{78}$ De conclusie was genuanceerd en leek veel op wat Eysenck had beweerd: definitieve conclusies over de effectiviteit van therapie waren niet te trekken. Een stapje vooruit was dat de leugenscore mogelijk een weg was waarlangs in vervolgonderzoek een effect gemeten kon worden.

In zijn periode op de Tweede Kliniek werd Bastiaans gegrepen door de psychosomatiek zoals die door Groen werd bedreven. Bastiaans zou hem later 'mijn grote leermeester' noemen. ${ }^{79}$ Hij publiceerde veel, samen met Groen, en over zeer uiteenlopende onderwerpen. De periode in Amsterdam was voor Bastiaans een bloeiperiode. Het effectiviteitonderzoek samen met Barendregt was zelfs vooruitstrevend te noemen. Bastiaans had zich ontwikkeld tot een veelbelovend wetenschapper.

Daarnaast was hij ook een kundige chef de clinique op het Wilhelmina Gasthuis en directeur van het PAI. Onder de medewerkers van het Wilhelmina Gasthuis genoot hij aanzien. ${ }^{80}$

De volgende stap in zijn carrière was het behalen van zijn doctorstitel. Pas met zijn promotieonderzoek begaf hij zich op het terrein waar hij furore zou gaan maken: de behandeling van oorlogsslachtoffers. In 1954 startte Bastiaans een onderzoek naar de psychosomatische klachten van een bijzondere groep: verzetsstrijders die in aanmerking wilden komen voor een speciale uitkering. 


\section{Het proefschrift - psychosomatische gevolgen van onderdrukking en verzet}

'Een zeer belangrijk proefschrift dat in menig opzicht aandacht verdient buiten de lezerskring die meestal voor een dergelijk werkstuk is voorbeschikt." NRC OVER BASTIAANS' PROEFSCHRIFT, 1957.

\section{Inleiding}

Al tijdens de oorlog hadden verzetsstrijders de Stichting 1940-1944 opgericht, die invalide verzetsstrijders na de oorlog moest bijstaan door, zo stond in de statuten te lezen:

'het verzorgen van de morele, geestelijke en materiële noden van personen of groepen van personen, die tijdens de bezetting door daad of houding tot het binnenlands verzet hebben bijgedragen[....$^{32}$

Toen de oorlog langer bleek te duren dan gedacht, werd de naam aangepast: 'Stichting 1940-1945'. Aanvankelijk probeerde de Stichting zelf middelen te verzamelen om de hulp gestalte te geven, maar ze kreeg bij de regering gedaan dat in 1947 een tijdelijke wettelijke regeling werd getroffen: de Wet Buitengewoon Pensioen (WBP). Daarin werd vastgelegd dat verzetsstrijders die invalide waren geworden door het verzet een uitkering konden krijgen. ${ }^{3} \mathrm{Om}$ in aanmerking te komen voor een Buitengewoon Pensioen, moest iemand op de eerste plaats een verzetsstrijder met onbesmet blazoen zijn geweest. De aard of omvang van het verzet speelde een ondergeschikte rol, zolang van collaboratie maar geen sprake was geweest. Ten tweede moest het verzet dusdanige lichamelijke of geestelijke schade hebben veroorzaakt dat iemand invalide was geworden. Er moest dus sprake zijn van een causaal of een verergerend verband tussen het gepleegde verzet en de invaliditeit. 
Deverwachting was dat binnen een jaar na inwerkingtreding van de wet alle aanvragen binnen zouden zijn, maar dat bleek niet het geval. Er bleven zich verzetsstrijders melden voor een uitkering, zij het wel steeds minder. De regering besloot daarop de Wet Buitengewoon Pensioen in stand te houden. De mogelijkheid om aanvragen in te dienen bij de Buitengewone Pensioenraad (BPR) bleef bestaan. De Stichting 1940-1945 bleef betrokken; zij ondersteunde aanvragers bij de aanvraagprocedure en voerde een deel van het feitenonderzoek uit.

Naarmate de oorlog verder in het verleden kwam te liggen, werd het vaststellen van het causaal verband lastiger. Steeds vaker bleek er een lange periode tussen de oorlog en het ontstaan van de klachten te bestaan; de klachten werden in zo'n geval 'verlate gevolgen' genoemd. Niet alle klachten die zich na de oorlog openbaarden stonden in verband met de oorlog, maar hoe kon een arts in een individueel geval een onderscheid maken? Het was deze vraag die Bastiaans in zijn proefschrift wilde onderzoeken. Het proefschrift werd later gebruikt door Bastiaans en zijn aanhang om aan te tonen dat hij vroeger dan anderen oog had gehad voor de speciale problemen van verzetsstrijders.

Hieronder wordt eerst kort de problematiek rond het vaststellen van het causaal verband beschreven, zoals die begin jaren vijftig bestond. Vervolgens wordt Bastiaans' antwoord daarop beschreven. Bastiaans' werkwijze wordt geillustreerd aan de hand van de meest uitgebreide gevalsbeschrijving die hij in zijn proefschrift gaf. Het ging om een van de eerste overlevenden van de kampen die hij in behandeling had: de verzetsstrijder Nico Mourer.

\section{Oordelen en causale verbanden}

Vrijwel vanaf de inwerkingtreding van de Wet Buitengewoon Pensioen worstelden medici met de vraag hoe zij een oordeel konden geven over het verband tussen invaliditeit en oorlog. Dat bleek bijvoorbeeld uit een artikel van de Utrechtse hoogleraar psychiatrie dr. H.C. Rümke uit $1951 .{ }^{4}$ Een verzetsstrijder, die tijdens de oorlog onderduikers in huis had gehad en om die reden was gearresteerd en anderhalf jaar in een concentratiekamp had doorgebracht, meldde zich met klachten als hoofdpijn, slapeloosheid, vergeetachtigheid en concentratieverlies bij zijn huisarts. De huisarts vermoedde een verband met de oorlog en raadde de man aan een Buitengewoon Pensioen aan te vragen.

Dat bracht hem bij de Stichting 1940-1945, die hem door twee artsen liet onderzoeken. Geen van beiden kon een verband met de oorlog vaststellen; de man was in het jaar voor de aanvraag van werkgever gewisseld en was daarbij in ernstige financiële problemen geraakt. De twee artsen vonden dat een veel aannemelijker verklaring voor zijn klachten, en de aanvraag werd afgewezen.

De man spande een beroepszaak aan, en de Stichting 1940-1945 vroeg de kli- 
niek van Rümke om een uitgebreide observatie en wederom om een oordeel over de oorzaak van de klachten. Rümke sprak uitgebreid met de man en concludeerde dat hij een deel van de psychotraumatische gebeurtenissen in de oorlog niet had verwerkt. Volgens Rümke was er daarom wél sprake van een verband met de oorlog.

Rümkes verslag typeert het dilemma van de keuringsarts. Die moest in zijn beoordelingen vele factoren meewegen: factoren van vóór de oorlog (bijvoorbeeld invloeden van opvoeding en erfelijkheid), tijdens de oorlog (bijvoorbeeld ernst van ondervoeding, aard en zwaarte van arbeid, ziekten) en ná de oorlog (bijvoorbeeld ziekten, opvang, sociale problemen). De geneeskunde bood geen systematiek om te bepalen welke van de factoren de meeste invloed had. Daardoor was er niet zozeer sprake van een 'causaal verband' dat kon worden vastgesteld maar meer van een 'oordeel over het causaal verband'. Artsen aan wie werd gevraagd een oordeel te geven, waren daarbij aangewezen op hun inlevingsvermogen.

De problematiek rond de beoordelingen van het causaal verband was geen exclusief Nederlands probleem. In andere Europese landen bestonden na de oorlog vergelijkbare uitkeringen en vergelijkbare problemen in de uitvoering. In 1954 vond in Kopenhagen voor het eerst een internationaal congres plaats over de medisch-juridische problemen bij de beoordeling van het causaal verband bij gedeporteerden. Later volgden nog meer congressen over de gevolgen van vervolging en gevangenschap. ${ }^{5}$

Op het congres in Kopenhagen waren vertegenwoordigers aanwezig uit Nederland, België, Luxemburg, Duitsland, Frankrijk, Denemarken, Italië, Polen, Oostenrijk en Rusland. Vanuit Nederland was de eerste medisch adviseur van de Buitengewone Pensioenraad aanwezig: dr. W.F. Noordhoek Hegt, tijdens de oorlog een van de leiders van het artsenverzet.

Op het congres bleek dat de gedeporteerden tijdens of kort na hun deportatie leden aan velerlei kwalen: oog- en gehoorbeschadigingen; kwalen aan de nieren en urinewegen; verminkingen van ledematen; rugklachten; maag- en darmkwalen; infecties; longklachten, waarvan de meest voorkomende tbc was.

Deze klachten kwamen bij gedeporteerden vaker voor dan bij niet-gedeporteerden, maar daarmee was in individuele gevallen nog niet vast te stellen of er een causaal verband bestond. De bacteriële infectieziekte tbc bijvoorbeeld, had in de kampen veel slachtoffers geëist. Het lag dus voor de hand dat gedeporteerden die ná hun bevrijding aan tbc kwamen te lijden, hun infectie hadden opgelopen in de kampen. Echter, de besmetting kon ook ná de oorlog hebben plaatsgevonden. In het eerste geval had een aanvrager recht op een uitkering, in het tweede geval niet. Konden artsen tussen de deportatie die eindigde in 1945 en de tbc die in 1953 begon een verband vaststellen?

Toen hierover aan het einde van het congres een vraag werd gesteld, presen- 
teerden de Franse onderzoekers Dreyfus en Fichez hun aanpak van dit probleem. Wanneer iemand door de Franse overheid eenmaal was erkend als gedeporteerde, dan werd de tbc, ook als die pas jaren na de deportatie manifest werd, toegeschreven aan de deportatie, wat een verhoogde uitkering opleverde. Voor het toegekend krijgen van een uitkering was het bewijzen van een causaal verband in Frankrijk niet meer van belang. ${ }^{6}$

Deze aanpak haalde een morele last van de schouders van de Franse keuringsartsen. Het was echter geen antwoord op de vraag of er ook daadwerkelijk een causaal verband bestond en hoe artsen dat konden vaststellen. In landen waar een dergelijke regeling ontbrak, zoals Nederland, bleven de beoordelingen worstelingen tussen de wetenschappelijke kennis en het inlevingsvermogen van de arts.

Op het congres kwam ook een ontdekking van de Deense onderzoekers K. Hermann en P. Thygesen ter sprake. Zij hadden de klachten van de kleine groep (iets minder dan zeshonderd) gedeporteerde Deense verzetsstrijders onderzocht, die vrijwel allen aan een patroon van somatische en psychische klachten bleken te lijden. De somatische klachten bestonden voornamelijk uit rusteloosheid, vermoeidheid, gebrek aan concentratie, gebrek aan eetlust, hoofdpijn, duizeligheid, geheugenstoornissen, emotionele labiliteit, zweetaanvallen, hartkloppingen, verminderde weerstand en diarree. Als psychische klachten noemden ze: depressieve klachten, emotionele labiliteit, angst, schrikachtigheid en prikkelbaarheid.

Ook personen die niet in een kamp hadden gezeten, hadden wel eens last van diarree, hoofdpijn, depressieve klachten of angst, maar dat de symptomen samen voorkwamen, en vaker en ernstiger dan bij niet-gedeporteerden, maakte volgens de Denen dat er sprake was van een specifiek syndroom. Ze gaven het de naam 'KZ-syndroom'. In de oorlog hadden de gevangenen in de kampen het Duitse woord voor concentratiekamp, Konzentrationslager, afgekort tot ' $\mathrm{Kz}$. ${ }^{8}$

Over de oorzaak van het $\mathrm{Kz}$-syndroom waren de Denen uitgesproken: dat was de extreme verhongering in de kampen. De verhongering had onherstelbare fysieke schade aan de hersenen toegebracht, die op haar beurt allerlei psychische en somatische gevolgen had. Andere factoren, zoals spanningen tijdens het verzet, lichamelijke en psychische martelingen bij arrestatie en mishandelingen in de kampen, speelden een ondergeschikte rol in het ontstaan van het KZ-syndroom. ${ }^{9}$

Uit andere landen werden vergelijkbare klachten gerapporteerd bij teruggekeerde gedeporteerden: in Frankrijk bleek 74 procent, in Noorwegen 84 procent en in Denemarken zelfs go procent van de onderzochten te lijden aan het Kz-syndroom. ${ }^{10}$

De resultaten van de Franse onderzoekers Fichez en Dreyfus, die op het congres in Kopenhagen hun onderzoek presenteerden, bevestigden het Deense vermoeden dat het om een hongersyndroom ging. ${ }^{11}$ De Franse onderzoekers 
hadden slachtoffers behandeld met een kuur waarbij ze zestien uur per dag in een kunstmatige slaap werden gehouden en calorierijk voedsel kregen toegediend, waardoor ze snel in gewicht toenamen. Bij velen waren de klachten na de behandeling verdwenen of verminderd, wat een bevestiging leek van de conclusie van de Denen.

De formulering van het $\mathrm{Kz}$-syndroom bood keuringsartsen de mogelijkheid om een min of meer objectieve maat te hanteren in de vaststelling van de ernst van de klachten. Aangezien de verhongering als oorzaak werd gezien, kon de mate van gewichtsverlies gebruikt worden om de mate van invaliditeit te bepalen. ${ }^{12}$

Tijdens de gezamenlijke discussie aan het einde van het congres in Kopenhagen, ging Noordhoek Hegt in op de ontdekking van de Denen. Ook onder de aanvragers van een Buitengewoon Pensioen in Nederland werden klachten vergelijkbaar met het $\mathrm{Kz}$-syndroom waargenomen, ook al kon Noordhoek Hegt bij gebrek aan onderzoek nog geen cijfers noemen. Maar de situatie in Nederland was anders geweest dan in Denemarken. De bevolking in de bezette gedeelten van Nederland had in het laatste oorlogsjaar, tijdens de Hongerwinter, óók grote honger geleden; de verhongering was in Nederland dus niet beperkt gebleven tot de gedeporteerden. ${ }^{13}$

Het kon daarom volgens Noordhoek Hegt niet zo zijn dat verhongering de enige factor was, anders zou ook een groot gedeelte van de Nederlandse bevolking moeten lijden aan het Kz-syndroom. Volgens Noordhoek Hegt onderscheidde de groep verzetsstrijders zich van de rest van de bevolking doordat ze aan grotere spanningen hadden blootgestaan. Bovendien hadden gedeporteerde verzetsstrijders aan nog weer grotere spanningen en honger blootgestaan dan de niet-gedeporteerde verzetsstrijders. Hij sprak op het congres de hoop uit dat er onderzoek zou worden gedaan naar het verband tussen honger én spanningen in de oorlog met lichamelijke kwalen. ${ }^{14}$

Nadat hun medisch adviseur was teruggekeerd van het congres in Kopenhagen, bracht de BPR een brochure uit waarin de belangrijkste ontwikkelingen uit het buitenland werden samengevat. Noordhoek Hegt schreef in het voorwoord:

'Het is zeer wel denkbaar, dat juist op dit gebied van de menselijke ziekten, ontstaan door de ontzettendste toestanden van verschrikking, verhongering en infecties, de wederzijdse beïnvloeding van psyche en soma bijzonder groot is, waardoor het m.i. eenzijdig en gevaarlijk is de oorzaken te veel in de organische sfeer te zoeken. ${ }^{15}$ 
Volgens hem had de verhongering behalve fysieke schade - zoals de Denen beweerden - ook, en misschien wel vooral, psychische schade veroorzaakt. De oorzaak van aandoeningen als het $\mathrm{KZ}$-syndroom zou dus wel eens meer psychisch dan somatisch kunnen zijn. Hij riep de artsen op om zich niet te veel te laten leiden door de strikte afbakening van de Denen.

In het algemeen bestond er in de jaren vijftig slechts een geringe bereidheid om psychische problemen te herkennen en te erkennen. Bastiaans observeerde bijvoorbeeld bij patiënten en artsen van het Wilhelmina Gasthuis dat zij gereserveerd stonden ten opzichte van psychische problemen. Hij zag daarin 'een angst voor de angstwekkende krachten die in het zielenleven, zowel van de gezonde als van de zieke mens, sluimeren'. ${ }^{16}$ Volgens Bastiaans was er onder medici die geconfronteerd werden met oorlogsslachtoffers zelfs sprake van het collectief loochenen van het psychische leed, waardoor zij alleen oog hadden voor de acute, lichamelijke reacties op de oorlogsstress. ${ }^{17}$ Patiënten en artsen stemden in de jaren veertig en vijftig bijvoorbeeld ook eerder in met opname voor lichamelijk herstel dan voor psychisch herstel. ${ }^{18}$

Deze terughoudendheid ten opzichte van psychische, en dus ook psychosomatische, problemen bij artsen en patiënten beschreef ook historica dr. A. Mooij. Volgens haar hadden psychiaters weliswaar al snel na de oorlog geschreven over de psychische gevolgen van de oorlog, maar werden teksten 'voor kennisgeving aangenomen, zonder dat er verder gevolg aan werd gegeven'. ${ }^{19}$ Het maakte er de beoordeling van het causaal verband niet makkelijker op.

\section{Stress en spanningen}

In hetzelfde jaar dat Noordhoek Hegt zijn voorwoord schreef, begon Bastiaans

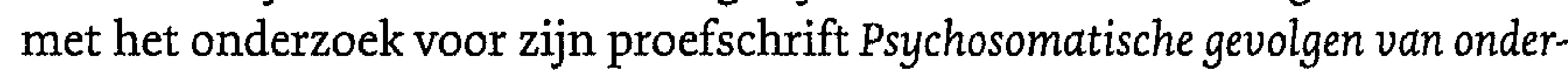
drukking en verzet, dat in 1957 zou verschijnen. Het werd de eerste grote Nederlandse studie naar de problemen van verzetsstrijders en bleef jarenlang het Nederlandse standaardwerk over de gevolgen van de oorlog op verzetsstrijders. Bastiaans schreef in de inleiding over de oordelen over het causaal verband:

'Duidelijk bleek dat [...] artsen [niet] in staat konden worden geacht een wetenschappelijk verantwoord oordeel te geven omtrent de samenhang van bijzondere vormen van oorlogsstress en de daarna optredende ziekte en invaliditeit. [...]. Hun oordeel miste daardoor, althans in een aantal van de gevallen, evenzeer een wetenschappelijke grondslag als het oordeel van de directe omgeving van het "slachtoffer van het verzet", die op grond van evidentiegevoel meestal tot het causaal of verergerend verband concludeerde. ${ }^{20}$ 
In zijn inleidende hoofdstukken zette Bastiaans de achtergrond van zijn onderzoek uiteen. Hij plaatste die in de context van het buitenlandse onderzoek, zoals dat onder andere op het congres in Kopenhagen was gepresenteerd. De nadruk lag dus op de gevolgen van deportatie. Hij haalde het Minnesota-experiment aan, een Amerikaans experiment waarbij zesendertig proefpersonen zich vrijwillig hadden onderworpen aan ondervoeding en gemiddeld een kwart van hun gewicht verloren. ${ }^{21}$ De proefpersonen hadden dezelfde symptomen vertoond als de Deense teruggekeerde gedeporteerden. Maar toen ze weer hun normale gewicht hadden bereikt, waren de symptomen, in tegenstelling tot bij de Deense groep, verdwenen. ${ }^{22}$ Het experiment was een bevestiging van het vermoeden dat verhongering niet de enige oorzaak kon zijn van het Kzsyndroom. Bastiaans suggereerde dat, wanneer de Denen rekening hadden gehouden met psychische factoren, zij tot een andere conclusie waren gekomen. Volgens Bastiaans zou het wel eens zo kunnen zijn dat bijvoorbeeld de angstigste gedeporteerden het grootste gewichtsverlies hadden geleden.

Het onderzoek in het buitenland betrof overlevenden van de kampen; bij Bastiaans' onderzoek betrof het verzetsstrijders. Hij vergeleek de groepen die in het buitenland werden onderzocht (overlevenden van concentratie-, vernietigings- of interneringskampen) met de groep die hij onderzocht (verzetsstrijders, of die nu in een kamp hadden gezeten of niet). De ervaringen van de groep die Bastiaans onderzocht voor zijn proefschrift, varieerden van het bezorgen van illegale kranten tot het jarenlang verblijven in concentratiekampen.

Om die kloof te overbruggen gebruikte Bastiaans het begrip 'traumatiserende stress'. Het begrip 'stress' had begin jaren vijftig al opgang gemaakt onder psychosomatici en brak door nadat de Canadese endocrinoloog dr. Hans Selye zijn 'General Adaptation Syndrome' publiceerde. ${ }^{23}$ Selye beschreef daarin hoe er, wanneer het interne (biologische) evenwicht van organismen door externe stress verstoord raakte, een aanpassingsproces in werking trad om het evenwicht weer te herstellen. Na te lange of te hevige stress strandden de pogingen tot evenwichtsherstel, wat leidde tot uitputting en soms zelfs tot de dood. Selye benoemde de verschillende fasen van het aanpassingsproces na de aanvankelijke stress als 'alarmfase', 'aanpassingsfase' en 'uitputtingsfase. ${ }^{24}$

Bastiaans zag het aanpassingsproces van Selyes proefdieren terug in de problematiek van de verzetsstrijders. Hij onderscheidde 'normale stress' en 'traumatiserende stress'. Normale stress zette een aanpassingsmechanisme in werking dat het evenwicht deed herstellen; na traumatiserende stress lukte het datzelfde aanpassingsmechanisme niet om het oorspronkelijke evenwicht te herstellen. Het leidde tot spanningen die een 'chronische psycho-somato-traumatische zwaktetoestand' veroorzaakten, een toestand vergelijkbaar met het Deense KZ-syndroom. ${ }^{25}$

Of stress traumatiserend was, werd enerzijds bepaald door de situatie en anderzijds door de persoon. Iedere situatie leverde een bepaalde vorm en een 
bepaalde intensiteit van stress op. De ene persoon was weerbaarder tegen bepaalde vormen en een bepaalde intensiteit van stress dan de andere. De psychosomatische problemen van verzetsstrijders verschilden dus niet principieel van die van anderen.

De introductie van het begrip 'stress' bood Bastiaans het voordeel dat hij met één begrip uiteenlopende ervaringen als oorzaak van onbewuste spanningen kon aanwijzen: zowel fysieke factoren (honger, verwondingen en ziekten) als psychische (angst, bedreiging, verdriet en eenzaamheid). Zowel de stress van een kunstschilder die 'licht illegaal werk' verrichtte, tijdens de oorlog tbc opliep en daarvoor in 1944 enkele maanden in een kuuroord verbleef, als de stress van een kapper die vanaf het begin van de oorlog verzet pleegde, vanaf zijn arrestatie in 1941 in verschillende concentratiekampen verbleef en daar onder andere moest aanschouwen hoe zuigelingen voor de ogen van hun moeders werden gewurgd, kon leiden tot onbewuste spanningen. ${ }^{26}$

De spanningen die zo ontstonden konden zich, soms jaren later, uiten in psychische en lichamelijke klachten. Soms gebeurde dat in afwisseling: het ene moment kwamen de onbewuste spanningen aan de oppervlakte als depressie of angstigheid, de andere keer als maagzweer of astma. ${ }^{27}$ De vorm waarin de spanningen zich manifesteerden, was afhankelijk van iemands situatie en actuele problemen; maar de spanning zelf was een reactie op een specifieke gebeurtenis in het verleden.

Bastiaans was voor zijn onderzoek geïnteresseerd in zes aandoeningen die bij de Psychosomatische Werkgroep al bijzondere aandacht kregen: astma, longtuberculose, overgewicht (adipositas), maagzweren (ulcus ventriculi), hoge bloeddruk (essentiële hypertensie) en musculoskeletale syndromen. Deze zes psychosomatische aandoeningen werden door hem ieder in een apart hoofdstuk besproken.

Eerst gaf Bastiaans een kort overzicht van wat er bekend was van de psychiatrische achtergronden van de aandoeningen bij niet-verzetsstrijders. Vervolgens beschreef hij aan de hand van korte gevalsbeschrijvingen van verzetsstrijders hoe jeugdconflicten tot aanpassingsmechanismen hadden geleid, hoe die aanpassingsmechanismen werden gereactiveerd door stress in de oor$\log$, en hoe ze na de oorlog tot de aandoening leidden.

Bij de Psychosomatische Werkgroep had Bastiaans van 1947 tot 1954 veertig verzetsstrijders onderzocht. Na zijn ervaringen met deze 'pilotgroep' onderzocht hij de aandoeningen aan de hand van dossiers van aanvragen voor een Buitengewoon Pensioen. Hij kreeg daarvoor de beschikking over de dossiers van een bepaalde groep aanvragers: aanvragers bij wie, op verzoek van de BPR of de Stichting 1940-1945, een psychiatrische observatie was uitgevoerd. ${ }^{28} \mathrm{Bij}$ alle dossiers die Bastiaans gebruikte voor zijn onderzoek naar de psychosomatische klachten, vermoedde de medisch adviseur dus dat er sprake was van psychische problemen. Andere aanvragers - die wel aan een van de zes psycho- 
somatische kwalen leden maar niet door de adviseur als psychisch geval waren doorverwezen - vielen dus buiten zijn onderzoek. Het lag voor de hand dat de groep 'niet-psychische gevallen' een andere psychische achtergrond kende dan de groep die Bastiaans onderzocht. ${ }^{29}$ Of dat verschil relevant was, werd door Bastiaans niet onderzocht.

Uit deze dossiers selecteerde Bastiaans die dossiers waarin in ieder geval een van de zes aandoeningen voorkwam. Hij onderzocht de aandoeningen dus bij een uiterst geselecteerde groep. Dat maakte zijn onderzoek methodologisch kwetsbaar. Stel bijvoorbeeld dat Bastiaans had gevonden dat alle astmalijders die hij onderzocht een bepaald soort oorlogsstress hadden doorstaan. Dan kon niet de conclusie worden getrokken dat die oorlogsstress tot astma leidde; het betekende hooguit dat iemand die dat soort oorlogsstress had doorstaan én door de BPR als psychisch geval werd bestempeld, astma kon ontwikkelen. Om de invloed van dat soort oorlogsstress te bepalen, was het nodig om te weten of er ook personen waren die wel die oorlogsstress hadden doorstaan maar geen astma ontwikkelden. Die kennis had Bastiaans niet, hij bekeek alleen de groep dossiers waarin beide voorkwamen.

De selectie van de dossiers op psychosomatische aandoening leverde Bastiaans te weinig dossiers op. Dat kwam doordat het merendeel van de observaties had plaatsgevonden in de Psychiatrische en Neurologische Kliniek van de Rijksuniversiteit te Utrecht, die onder leiding stond van Rümke. De Utrechtse kliniek had de observaties beperkt tot onderzoeken die gebruikelijk waren voor psychiatrische afwijkingen; dat laatste was tenslotte het verzoek van de BPR geweest. Daarbij werd weinig tot geen aandacht besteed aan lichamelijke klachten. Die ontbraken dus veelal in de observatierapporten. ${ }^{30}$

Om het materiaal toch geschikt te maken voor zijn onderzoek, speurde Bastiaans in de Utrechtse dossiers naar aanwijzingen voor (psycho)somatische aandoeningen. Soms was uit een dossier op te maken dat een aanvrager bijvoorbeeld hoge bloeddruk had, zonder dat dat expliciet als diagnose was vermeld in het uiteindelijke observatierapport. Bastiaans rangschikte een dergelijk dossier dan alsnog onder de categorie 'hoge bloeddruk'. De aanvrager werd daarmee dusvan een 'psychisch geval' een 'psychosomatisch geval'. Bij hoeveel dossiers Bastiaans deze bewerking uitvoerde en op basis van welke gegevens hij dat deed, beschreef hij niet. Het was voor de lezer van zijn proefschrift dus niet uit te maken of het een terechte bewerking was.

Deze-en andere ${ }^{31}$-slordigheden en methodologische overwegingen maakten de validiteit van Bastiaans' onderzoek beperkt. Maar dergelijke overwegingen speelden destijds geen grote rol. Het was de tijd waarin de psychoanalyse hoogtij vierde in de psychiatrie. Psychiaters lieten zich van hun beste kant zien door mooi beschreven en goed geanalyseerde gevalsbeschrijvingen. Bastiaans hield die lijn vast. De overtuigingskracht van zijn onderzoek was gelegen in de vele gevalsbeschrijvingen, die meer dan een kwart van zijn proefschrift uitmaakten. ${ }^{32}$ 
Om Bastiaans' werkwijze bij de beoordeling van het causaal verband te begrijpen, wordt hieronder de eerste uitgebreide gevalsbeschrijving uit zijn proefschrift besproken. Het was een van zijn intensiefst bestudeerde patiënten; de man was bijna vijfhonderd uur in behandeling bij Bastiaans. In zijn proefschrift besteedde hij er dan ook bijna dertig pagina's aan, een aanzienlijk aantal voor een proefschrift dat iets minder dan vijfhonderd pagina's telde. De gevalsbeschrijving was bedoeld als een 'voorbeeld bij uitstek' van de manier waarop de psychosomatiek ingezet kon worden bij het beoordelen van het causaal verband. ${ }^{33}$ Bastiaans was zo onder de indruk van het verhaal van de man dat hij het bijna dertig jaar na het verschijnen van zijn proefschrift nogmaals opvoerde in een boek dat hij samenstelde na zijn afscheid als hoogleraar. Het was drie decennia later nog steeds een van de 'zeer indrukwekkende ervarin gen' met psychosomatische klachten van verzetsstrijders. ${ }^{34}$

De verzetsstrijder die in de gevalsbeschrijving anoniem werd opgevoerd werd door mij, door de identieke levensverhalen, herkend als de communist en verzetsstrijder Nicolaas Antonius Mourer. Dit werd later door diens zoon ook bevestigd. ${ }^{35}$ In het portret hieronder wordt Mourers geschiedenis vóór zijn komst bij Bastiaans beschreven. Om Bastiaans' werkwijze in de vaststelling van het causaal verband te illustreren wordt na onderstaand portret Bastiaans' psychosomatische reconstructie van dezelfde geschiedenis gegeven.

\section{Portret: Nico Mourer}

In 1936 was na jaren van onrust de Spaanse Burgeroorlog uitgebroken tussen de rechtse, fascistische aanhangers van generaal Franco en de republikeinse, vaak communistische, groeperingen. Kort na het begin van de burgeroorlog werden Internationale Brigades opgericht, bestaande uit communisten en sympathisanten uit de hele wereld, die met hun Spaanse kameraden ten strijde trokken. Ongeveer 35000 'interbrigadisten' meldden zich in Parijs aan voor de strijd, onder wie 600 afkomstig uit Nederland. ${ }^{36}$

De toen zesendertigjarige Nicolaas Antonius Mourer was opgegroeid in een groot katholiek Brabants gezin en had korte tijd op de Koninklijke Militaire Academie doorgebracht. Hij had zijn opleiding niet afgemaakt. Hij was meer en meer betrokken geraakt bij het communisme en sloot zich in 1936 aan bij de interbrigadisten. Hij werd ingedeeld als officier bij de artillerie van het Thälmann-bataljon.

In een naoorlogs verslag beschreef Mourer hoe in 1938 benauwde uren aanbraken voor zijn bataljon in een bergdorpje. ${ }^{37}$ Het bataljon werd ingesloten door de vijand, vliegtuigen cirkelden boven hen en ze konden geen kant op. De enige uitweg, een smalle bergweg die naar een brug over het dal leidde, werd onder schot gehouden door een groot kanon van Franco's troepen. Mourers 
bataljon zag hoe verschillende motorkoeriers door dat kanon werden beschoten bij een poging de brug over te steken.

Mourer verzon een list. Het kanon, dat steeds dezelfde plek voor de brug onder schot nam, moest rekening houden met de snelheid van het voertuig dat het wilde raken; schoot het te vroeg dan sloeg de granaat vóór het voertuig in, schoot het te laat dan erachter. Mourer stelde voor om in volle snelheid op de brug af te rijden en dan, enkele meters voor de inslagplek, plotseling te remmen, te wachten tot de granaat was ingeslagen en dan snel over de brug verder te rijden. Bij drie van de vier vrachtwagens slaagde de opzet, bij de vierde deels. De vrachtwagen stond net te laat stil, werd deels getroffen door de granaat maar wist nog wel de overkant van de brug te bereiken. Mourer, die wel ongeschonden de brug over wist te steken, zag het bloederige resultaat: vier doden en veertien gewonden, van wie sommigen zwaar verminkt. ${ }^{38}$

In maart 1939 kwam er een einde aan de oorlog in Spanje, en Mourer keerde terug naar Groningen. Bij terugkomst in Nederland werd de interbrigadisten het Nederlanderschap ontnomen; ze hadden gevochten in de krijgsmacht van een vreemde mogendheid en dat was bij wet verboden. De interbrigadisten werden daarmee stateloze burgers. Ze moesten zich regelmatig melden bij de vreemdelingenpolitie, konden geen overheidsfuncties vervullen, moesten bij iedere nieuwe baan een werkvergunning aanvragen en hadden actief noch passief stemrecht..$^{39}$ Mourer zou nog veel last krijgen van zijn stateloosheid, maar al snel dienden zich andere problemen aan: de Duitsers vielen op 10 mei 1940 Nederland binnen.

Mourer werd vanwege zijn communistische sympathieën en zijn rol in de Spaanse Burgeroorlog vanaf het begin van de oorlog in de gaten gehouden door de Duitse SD. Volgens een naoorlogse verklaring aan het RIOD weerhield dat hem er niet van een wacht op te richten die waakte over de veiligheid van Joodse stadsgenoten, en mee te werken aan de productie van de illegale krant Noorderlicht. ${ }^{4^{\circ}}$ Op 25 juli 1941 werd Mourer gearresteerd. De SD wist dat hij banden had met de organisatie rond Noorderlicht en wilde van hem weten waar een van deleiders zich bevond. Omdat Mourer zijn kaken stijf op elkaar hield, kreeg hij flinke klappen te verduren. Hij werd doorgestuurd naar het Huis van Bewaring, waar hij in de maand augustus bijna dagelijks werd verhoord. ${ }^{41}$

Eind augustus werd Mourer opeens met rust gelaten. Dat maakte hem ongerust. Zouden de overige leden van Noorderlicht zijn gearresteerd? Begin oktober werd Mourer meegenomen naar het hoofdbureau van de SD voor een verhoor, waarbij hij voor een laatste keer stevig aan de tand werd gevoeld. ${ }^{42} \mathrm{Zijn}$ donkere vermoedens bleken waarheid: niet alleen de gezochte leider was opgepakt, maar bijna de hele groep rond Noorderlicht. ${ }^{43}$ Op 3 oktober 1941 werd Mourer op transport gezet naar concentratiekamp Sachsenhausen in de buurt van Berlijn. ${ }^{44}$ 
Sachsenhausen

In Sachsenhausen voerde de ss een schrikbewind over de gevangenen. Overtreding van een verbod leidde tot lichte straffen als inhouding van rantsoen of een verbod op het sturen en ontvangen van brieven. Een zwaardere straf was de beruchte 'bok': daarbij werd de gestrafte voorovergebogen op een houten tafel (de 'bok') vastgebonden, en werden hem met een rubber slang vijfentwintig slagen 'aufdem Arsch' toegediend (in extreme gevallen vijftig of vijfenzeventig). De uiterst pijnlijke wonden leverden een groot gevaar op infectie op en konden door de gebrekkige medische verzorging en onhygiënische omstandigheden de dood betekenen.

Uiterst pijnlijk was ook het 'am Pfahl hängen': met de armen achter de rug gebonden werd een gevangene aan zijn handen omhooggetakeld en zo enkele uren ten voorbeeld opgehangen. In 1942 werd deze straf afgeschaft, maar werden openbare executies door ophanging ingevoerd, waarbij de hele kampgemeenschap moest toekijken. ${ }^{45}$

Een paar maal per dag traden alle gevangenen in weer en wind aan voor het appel op de grote binnenplaats. Tienduizenden gevangenen moesten, opgesteld in keurige rijen, wachten tot alle hoofden waren geteld. Terwijl iedereen zo in de houding stond, klonk soms op de achtergrond het geklos van het 'Schuhläuferskommando': gestrafte gevangenen, meestal Joden, liepen met zware bepakking in te klein of te groot schoeisel een parcours met verschillende hindernissen (waterbak, zand, grind) rond de centrale appelplaats, vaak tot de dood erop volgde. ${ }^{46}$

Overdag werden de gevangenen tewerkgesteld in verschillende werkcommando's. Door de slechte voeding leidde zwaar werk snel tot uitputting en niet lang daarna tot de dood. Het werk varieerde van steenhouwen tot ijzergieten, van het aanleggen van wegen tot het lossen van schepen. Minder zware commando's waren de administratieafdeling, het schilderatelier of het zogeheten Kabelcommando, waarbij gevangenen de beschermende laag van elektrische leidingen verwijderden. Om te overleven was het dus zaak om in een zo licht mogelijk commando ingedeeld te worden.

Mourer was bij aankomst in Sachsenhausen niet helemaal onvoorbereid op wat hem te wachten stond. Tijdens zijn tijd in Spanje had hij van zijn Duitse kameraden al van het bestaan en de globale gang van zaken in de concentratiekampen gehoord. In Sachsenhausen ontmoette hij weer oud-Spanjestrijders en communisten, en dat bood hem voordelen. Zoals in veel kampen was een deel van de organisatie van Sachsenhausen uitbesteed aan de gevangenen zelf. Door het verdelen van functies en rangen onder de gevangenen, kon de Duitse inzet bij de dagelijkse gang van zaken beperkt blijven. Omdat sommige communisten - die voor het uitbreken van de oorlog doelwit waren van de nazi's al zeer lange tijd vastzaten, namen zij vaak belangrijke posten in. Zij waarschuwden Mourer voor de gevaren van het kamp. Soms schoven ze hem zelfs 
wat extra eten toe of hielpen hem zijn werk in zijn commando te klaren. Toen Mourer met dysenterie in de ziekenbarak lag kreeg hij van hen extra soep. ${ }^{47}$

Toch konden Mourers connecties hem niet altijd beschermen. In juli 1942 werd hij overgeplaatst naar een buitenkamp van Sachsenhausen, het Klinkerwerk Oranienburg, kortweg 'Klinker'. ${ }^{48}$ Achter deze naam ging een van de meest beruchte commando's van Sachsenhausen schuil. ${ }^{49}$ De gevangenen werkten in weer en wind in een steengroeve of op de nabijgelegen laad- en losplaats voor schepen. Het regime was strenger en het werk zwaarder dan in het moederkamp. Mourer verloor veel gewicht. Op zijn dieptepunt woog hij nog maar 48 kilo..$^{50}$

In juli 1943 keerde hij terug naar het hoofdkamp, waar zijn vrienden hem op de Kommandaturkammer plaatsten, een administratieafdeling waar hij verschoond bleef van zware fysieke arbeid. Daar maakte hij heimelijk een overzicht met alle namen en nummers van de Nederlandse gevangenen in het kamp. Dat aantekenboekje vormde na de bevrijding de basis voor de repatriëring van de Nederlanders. ${ }^{51}$

\section{Bevrijding}

Mourer was onder de Nederlandse kampbewoners gezien. Hij was voor hen een vertrouwensman. Dat kwam niet in de laatste plaats door zijn inspanningen om het moreel hoog te houden. Mourer zat in de 'broodcommissie', die brood inzamelde voor zieke landgenoten in de ziekenbarak..$^{52}$ En tijdens een bezoek van het Rode Kruis aan het kamp wist Mourer de Rode Kruis-medewerkers, ondanks het wakend oog van de ss, subtiel duidelijk te maken dat er te weinig pakketten binnenkwamen. ${ }^{53}$

Vrijwel iedere twee weken mochten de gevangenen een brief versturen. Mourer liet geen gelegenheid voorbijgaan en stuurde, ook in zijn periode op Klinker, brieven naar zijn vrouw. De meeste van die brieven zijn bewaard. ${ }^{54} \mathrm{De}$ brieven werden gecensureerd door de Duitsers en verraden daardoor weinig van de werkelijke gang van zaken in het kamp. Door Mourers gebruik van het alter ego Klaus wist hij in bedekte termen soms toch een tipje van de sluier op te lichten. Na terugkomst uit Klinker in het moederkamp schreef hij zijn vrouw bijvoorbeeld:

'Bin froh das Klaus wieder seine Buroarbeit hat und alte Adresse und es ihm und seine Freunde jetst soviel besser geht dann früher. Ist er Dick geworden? War auch wohl nötig nach voriges Jahr. 55

Mourer zou na de oorlog aan zijn vrouw schrijven dat hij op dat moment 48 kilo woog.

Medio april 1945 werd het onrustig in het kamp. Grote groepen gevangenen vertrokken lopend, onder begeleiding van ss'ers, naar onbekende bestemmin- 
gen. Het waren de beruchte dodenmarsen, waarbij maar een enkeling aan de dood wist te ontkomen. In het kamp bleven ongeveer drieduizend zieken achter, samen met een klein aantal gevangenen dat hen verzorgde. De spanning was groot onder de achterblijvers; er deden geruchten de ronde dat de ss'ers geen getuigen wilden achterlaten en het kamp in brand zouden steken.

Op 21 april 1945 om 11 uur's avonds was het stil in het kamp. De ss was weg, de uitkijktorens waren verlaten. Een ooggetuige die samen met Mourer in het kamp was achtergebleven, noteerde na de oorlog:

'Hier unten im Keller sind Mirek, Wascek, Viktor, Wille Jackson, Hans, Werner, Jan von Tbc., Nico, Fritz Bischoff [van Heemskerck], Pith vom Massageraum, die Holländerin Thiene von Oberspree, Wallodia und Michael sein Freund, spähen im Lager herum. [...] Sonntag, den 22. früh. Das erste Mal im Lager kein Wecken, keine ss. Am Tor steht ein "Häftling" Wache. [...] Um 11 Uhr plötzlich ein Rufen im Lager: "Ruski, Ruski, die Russen sind da." Alles stürmt hinaus auf den Appellplatz. Da am Tor Rotarmisten! ${ }^{56}$

Kort na de bevrijding door de Russen werd Mourer ziek. In zijn eerste brief aan zijn vrouw na de bevrijding schreef hij:

'Zeven artsen waren niet in staat een diagnose te stellen. Koorts, koorts en nog eens koorts. Vier weken lang! Maar ik ben nu compleet genezen. Heb zelfs mijn gewicht weer terug. Alles is goed hier! Geen zorgen om mij en nu hoef ik niet te liegen zoals ik vier jaaren heb moeten doen. ${ }^{57}$

Een maand na dit bericht, in augustus 1945, was het eindelijk zover: Mourer stond aan de grens bij Nieuweschans. Binnen een maand na terugkomst was hij aan het werk als adjunct-hoofdredacteur van de regio-editie van het communistische dagblad De Waarheid, dat vanuit Meppel lezers in de regio Noorden Oost-Nederland bediende. Dat was een belangrijke functie omdat een groot deel van de achterban van de CPN in Groningen en omgeving zat. ${ }^{58}$

Geertje van der Molen had vóór Mourers arrestatie nog meegewerkt aan de productie van Noorderlicht en was na de oorlog werkzaam op de redactie van De Waarheid. Ze bleef haar hele leven onder de indruk van Mourers levensverhaal en schreef in 1987 een lovend portret over hem. Ze beschreef daarin dat de redactie van De Wadrheid onder de indruk was en aangestoken werd door Mourers energieke, enthousiaste en gedreven instelling. Tijdens verkiezingstijd werkte hij overdag op de redactie, reed's avond door de regio om lezingen te geven, en liep tot slot nog even op de redactie binnen om de volgende dag voor te bereiden. Hij wist mensen te inspireren, ook al was hij soms erg streng. ${ }^{59}$ Van der Molen herinnerde zich zijn woorden: 
'Zo lang ik je uitfoeter, zo lang heb ik nog vertrouwen in je. Pas als ik geen aanmerkingen meer maak, alleen maar vriendelijk ben, heb ik opgegeven een communistisch journalist van je te maken. ${ }^{.60}$

Hoewel Mourer zich stortte op zijn werk, was in deze eerste jaren na zijn terugkeer uit Sachsenhausen de oorlog geen afgedane zaak. Af en toe publiceerdehij verhalen over zijn tijd in Spanje en Sachsenhausen. ${ }^{61}$

In De Waarheid van 8 november 1947 werd Mourer geïnterviewd naar aanleiding van zijn onderscheiding door de Fédération Internationale des Anciens Prisonniers Politiques des Camps de Concentration Allemands, een internationale organisatie van voormalig politieke gevangenen. Mourer had tijdens een bezoek van het Rode Kruis aan Sachsenhausen laten doorschemeren dat de gevangenen te weinig voedselpakketten kregen. Dat was een moedige daad geweest, aangezien de Duitsers erbij aanwezig waren. Mourer gaf niet veel om de onderscheiding; liever zag hij dat hij zijn Nederlanderschap terugkreeg, zo vertelde hij De Waarheid.

Mourer bleef zich bekommeren om zijn voormalige kampgenoten en hun nabestaanden. ${ }^{62}$ Hij gaf regelmatig zijn medewerking aan de opsporing van niet-teruggekeerde landgenoten en de opsporing en vervolging van oorlogsmisdadigers. Ook nam Mourer zitting in het bestuur van Expogé, de vereniging voor ex-politieke gevangenen, die zich hard maakte voor de belangen van voormalig gedeporteerden.

\section{Colitis ulcerosa}

Eind 1947 ging het steeds slechter met Mourer. De abonnementscijfers van De Waarheid liepen terug, en het bestuur van de krant besloot de Groningse redactie op te heffen. Mourer werd gedegradeerd van hoofdredacteur tot advertentieverkoper, en moest bovendien met zijn vrouw en kinderen verhuizen naar Amsterdam. ${ }^{6_{3}}$

In 1948 werd hij gekozen tot lid van de Eerste Kamer voor de CPN, maar hij kon die rol niet vervullen omdat hij nog steeds stateloos was. ${ }^{64}$ Invloedrijke oudkampgenoten, zoals voormalig minister van Openbare werken en Wederopbouw dr. J.A. Ringers en opperstalmeester van de koningin W.F.K. Bischoff van Heemskerck, stelden geloofsbrieven op waarin ze pleitten voor teruggave van Mourers Nederlanderschap.$^{65}$ Het mocht niet baten: het lidmaatschap van de Eerste Kamer ging door het ontbrekende Nederlanderschap aan hem voorbij. ${ }^{66}$ In dezelfde periode wilde de vereniging Expogé juridische erkenning krijgen. Dat was niet mogelijk zolang ook statelozen lid waren van de vereniging. Aanvankelijk werd gehoopt op naturalisatie van de statelozen, maar toen dat niet gebeurde was Mourer gedwongen op te stappen als lid van het bestuur.

Alsof dat nog niet genoeg was, kreeg Mourer last van darmbloedingen. Tijdens een operatie in september 1948 werden verklevingen van zijn darmen los- 
gemaakt en werd zijn blinde darm verwijderd. ${ }^{67} \mathrm{Na}$ de operatie bleef hij last houden van de wond die was ontstaan. Zijn huisarts, Theo van Reemst, zelf oud-Spanjestrijder en kennis van Mourer uit zijn tijd in Groningen, ontdekte dat er verbandgaas in de wond was achtergebleven. Bij de tweede operatie, nodig om het verbandgaas te verwijderen, raakten zijn darmen ernstig beschadigd. ${ }^{68}$ De artsen vreesden voor zijn leven. ${ }^{69}$

Mourer overleefde en ging voor drie maanden naar Warschau voor een rustkuur. Dat was kort na zijn vertrek uit het bestuur van Expogé. Het verblijf in Warschau deed Mourer goed en de artsen verklaarden hem genezen. Hij kon naar huis mits hij beloofde af en toe een vitaminekuur te nemen ('Ook levertraan -verdomme'). ${ }^{70}$ Mourer was optimistisch en schreef kort voor zijn terugkeer aan zijn vrouw:

‘'k geloof dat je me nog nooit zo goed zag!?72

Mourers optimisme bleek onterecht. De artsen stelden colitis ulcerosa bij hem vast, een chronische ontsteking van de darmen. Een halfjaar na zijn terugkeer uit Warschau was hij nauwelijks nog in staat te werken, en hij vroeg ten slotte een Buitengewoon Pensioen aan. De Stichting 1940-1945 vroeg een uitgebreide observatie aan bij de psychiatrische afdeling van het Wilhelmina Gasthuis van de Universiteit van Amsterdam, omdat men vermoedde dat de colitis ulcerosa een psychische oorsprong had. Maar het verblijf op de psychiatrische afdeling deed Mourers toestand snel verslechteren. Daarop besloten de artsen hem door te verwijzen naar de Tweede Interne Afdeling, de thuisbasis van de Psychosomatische Werkgroep, waar Bastiaans werkte.

Psychosomatische reconstructie van Mourers geschiedenis In zijn proefschrift beschreef Bastiaans hoe de psychosomatische werkwijze op Mourer werd toegepast. Hij liet hem onderzoeken door internist, psycholoog en fysioloog en onderhield ook zelf intensief contact met hem. Bastiaans meende al snel te constateren dat Mourer telkens na situaties waarin hij werd gekrenkt en een gevoel van machteloosheid ervoer, last kreeg van bloedingen. Hij vermoedde dat Mourers rectum bij de spanning die deze situaties opriepen spastisch reageerde, waardoor kleine interne bloedinkjes ontstonden..$^{72}$

Met deze interpretatie was de eerste stap in het psychosomatische onderzoek gezet: er was een specifieke stresssituatie ontdekt - een situatie waarin sprake was van krenking en machteloosheid - waarop Mourer psychosomatisch reageerde. De volgende stap was achterhalen waarom juist deze situatie voor zoveel spanning zorgde, waarom juist de gevoelens van krenking en machteloosheid voor colitis ulcerosa zorgden, en niet andere situaties die spanning opriepen. 
Hiervoor greep Bastiaans terug op de psychoanalytische ideeën over de ontwikkeling van de persoonlijkheid. Volgens de leer van de psychoanalyse wordt in de vroege jeugd, in de relatie met de ouders, de persoonlijkheid gevormd. Vroege seksuele driften en de relatie met de ouders spelen een belangrijke rol in de vorming van de persoonlijkheid. Het gespreksonderwerp verschoof daarom naar Mourers jeugd. Bastiaans schetste een beeld van Mourers moeder als een hardwerkende, vrome vrouw die niet tegen haar man was opgewassen. Ze speelde volgens Bastiaans een onbelangrijke rol in Mourers leven. Zijn vader daarentegen speelde een cruciale rol. Als voormalig kermisgast had hij zich opgewerkt tot gerespecteerd zakenman. Hij geneerde zich voor zijn achtergrond en wilde dat zijn elf kinderen niet tot een dergelijk niveau zouden afzakken. De opvoeding stond daarom in het teken van de voorbereiding op een leven van hard werken. Zijn vader stelde thuis een regime in waar passiviteit en luiheid taboe waren, net zoals zwak of ziek zijn. Hij ondersteunde dat regime regelmatig met harde klappen.

Lange tijd werd Mourers leven bepaald door zijn drijvende vader, tegen wiens klappen hij machteloos stond. Maar op zijn zestiende kwam hij, als eerste van het gezin, in verzet en bedreigde zijn vader vanaf de bovenverdieping van het ouderlijk huis met een geweer. Vanaf dat moment nam Mourer het op voor de zwakkeren in het gezin en gaf leiding aan de 'opstand tegen vader'. Mourers opstand richtte zich niet alleen op zijn vader. Ook een lokale politieagent die hem wilde bekeuren, moest het bezuren: vanaf een hoge toren urineerde Mourer op diens hoofd. ${ }^{73}$

Dit in verzet komen, het opkomen voor de machtelozen, werd volgens Bastiaans Mourers manier om met machteloosheid om te gaan. Dat reactiemechanisme zag Bastiaans ook terug in Mourers verbintenis met het communisme, waar het collectief belangrijker was dan het individu; hij zag het terug in zijn leidende rol in het verzet en in de kampen, en in zijn bestuurslidmaatschap van Expogé. Mourer had een manier gevonden om met zijn grootste zwakke punt, machteloosheid, om te gaan.

Nadat Bastiaans dit had vastgesteld kwam de vraag op hoe ditreactiemechanisme in verband was te brengen met Mourers colitis ulcerosa. Daarvoor gebruikte Bastiaans een andere ontdekking: volgens hem waren de klachten van verzetsstrijders verbonden met specifieke stresssituaties in de oorlog. De nerveuze klachten van aanvragers waren niet het resultaat van een algehele rusteloosheid, maar een specifieke reactie op een specifieke gebeurtenis.

Bastiaans beschreef hoe Mourer bij hun eerste ontmoeting op 8 september 1950 opviel door zijn robuuste gestalte, wat opgetrokken schouders en felle, expressieve blik. Mourers blik verried volgens Bastiaans een:

'voortdurende waakzaamheid en bereidheid om aan te vallen of zich te verdedigen zodra dit nodig mocht blijken. Innerlijk moet hij in een enorme span- 
ning leven die hij met grote krachtsinspanning tracht te beheersen. Kennelijk is hij voorbereid op dit gesprek dat vermoedelijk [...] een gevaarsituatie betekent, mogelijk een verhoor. ${ }^{74}$

De stress van het dreigende verhoor had Mourer tijjdens de oorlog in een staat van paraatheid gebracht; vergelijkbare omstandigheden ná de oorlog brachten dezelfde reactie teweeg. Het verblijf in het Wilhelmina Gasthuis herinnerde Mourer aan het verblijfin het kamp. Dat Mourer slecht sliep en vaak's nachts wakker werd, relateerde Bastiaans aan de vier maanden dat Mourer steeds om één uur's nacht uit zijn cel in Groningen werd gehaald voor verhoor. Dat Mourer in de kliniek iedere ochtend stipt op tijd aan het ontbijt verscheen, kwam volgens Bastiaans omdat voor Mourer het ontbijt een herbeleving van het ochtendappel betekende. De medische onderzoeken die Mourer moest ondergaan voor zijn aanvraag voor een Buitengewoon Pensioen, stonden volgens Bastiaans gelijk aan 'medische experimenten' en deden Mourer zich een 'Probekaninchen' voelen.75

Bastiaans herkende aan deze 'subtiele anomalieën in het gedrag' dat de spanningen van specifieke stresssituaties - meestal onbewust - nog aanwezig waren. De kleine onregelmatigheden in het gedrag wezen de goede verstaander erop dat de aanvrager nog 'in het kamp leefde'. In het geval van Mourer noemde hij wel dertig van dergelijke gedetailleerde duidingen die een verband legden tussen de klachten en Mourers verblijf in de kampen. ${ }^{76}$ De onderliggende veronderstelling van Bastiaans was steeds dat er een authentieke, specifieke gebeurtenis in het verleden ten grondslag ligt aan het gedrag in het heden.

Maar welke gebeurtenis stond in verband met de colitis ulcerosa? Het antwoord daarop kon een verklaring geven voor de klachten én, als het een gebeurtenis in Sachsenhausen betrof, recht geven op een uitkering. Maar het ontdekken van de specifieke gebeurtenissen - de sleutelscènes - was vaak lastig. Het ging om traumatische gebeurtenissen waarvan de herinnering vaak verdrongen was. In een klassieke psychoanalytische behandeling kostte het soms jaren om deze herinneringen op te diepen uit het onbewuste. Om in de beperkte tijd van een observatie toch tot de kern door te kunnen dringen, gebruikte Bastiaans soms een speciale techniek: de narcoanalyse.

Bij de narcoanalyse kreeg de patiënt een barbituraat toegediend - bij Bastiaans was dat pentothal - dat normaliter gebruikt werd als narcosemiddel bij operaties. Wanneer het in een lichte dosis werd toegediend, ontstond er een roes waarin het mogelijk leek om makkelijker toegang te krijgen tot herinneringen, ook herinneringen aan de sleutelscènes.

Mourer kreeg tijdens zijn observatieperiode twaalfmaal een narcoanalyse. Hij vertelde daarin over gruwelijkheden die hij in nuchtere toestand niet vermeldde: op de bok had hij 75 slagen geïncasseerd, het Schuhlaufen (het afleggen van het ongelijke parcours rond de centrale appelplaats) had hij gedaan tot hij 
niet meer kon, en zelfs het gevreesde 'am Pfahl hangen' was bij Mourer voltrokken. ${ }^{7}$ Maar de zwaarste mishandeling speelde zich af op Klinker:

\begin{abstract}
'Martelingen zijn aan de orde van de dag: één van de kampbeulen heeft het speciaal op hem voorzien. Op een dag worden twintig mannen ter dood gebracht via het inbrengen van een waterslang in het rectum waarbij het darmkanaal wordt opgespoten tot het perforeert. Onder hen is de patiënt. Tijdens de marteling verzet hij zich zo hevig dat verschillende mannen op zijn rug gaan zitten om hem vast te houden. Wanneer men hem dood waant wordt hij op de lijkenhoop gesmeten vanwaar hij uren later, wanneer vrienden nog enige levenstekenen bij hem ontdekken, door hen wordt weggesleept; in de eerste tijd is hij echter niets meer waard en van de eerste weken na de marteling weet hij zich ook later niets meer te herinneren. ${ }^{78}$
\end{abstract}

Mourer had zoveel martelingen doorstaan dat de 'keus' om juist op deze marteling psychosomatisch te reageren willekeurig leek. Volgens Bastiaans moest er een reden zijn waarom juist de spuitsituatie voor Mourer zo bijzonder was dat hij er na al die jaren psychosomatisch op reageerde. In de volgende narcoanalyse werd duidelijk dat de mishandeling inderdaad de gezochte sleutelscène was, toen Mourer beschreef:

'hoe de kampbeul tijdens de marteling kennelijk een orgasme kreeg en hoe diens lichaamsbouw en rood opgewonden gezicht hem deden denken aan vader die vroeger zo rood kon aanlopen wanneer hij patiënt sloeg. Voor de psychotherapeut wordt aldus begrijpelijk dat de spuitsituatie een traumatische jeugdsituatie heeft gereactiveerd en dat daarom een zuivere catharsis via afreageren van oorlogstraumata onvoldoende zal zijn. ${ }^{79}$

Bastiaans legde een verband tussen vaders rammelpartijen en de beulen van Sachsenhausen. De kern van Mourers problematiek was de machteloosheid die hij als kleine jongen tegenover zijn vader had ervaren ${ }^{80} \mathrm{Hij}$ had in de puberteit een manier gevonden om daarmee om te gaan: in verzet komen. Dat reactiepatroon - dat beschermingsmechanisme - had hij tijdens de marteling weer ingezet. Hij overwon de stress van de machteloosheid door zich tot het uiterste te verzetten, te persen tegen het water dat zich een weg uit zijn darmen wilde banen.

De prijs voor deze overwinning was hoog; de stress van de mishandeling en zijn verzet daartegen hadden het evenwicht verstoord. Volgens Bastiaans streed Mourer na de bevrijding wanhopig tegen het moeten erkennen dat de door de stress ontstane trauma's een blijvende nawerking hadden. ${ }^{{ }^{81}}$ Pas na de mislukte operatie aan zijn darmen brak Mourers verzet definitief. 
[Bij de mislukte operatie] gebourde nu just wat hil met uterste krachtsin spanning bij de spuitsituatie in het kamp had weten te voortomen. Terwijl zijn vrienden onkwamen had hij deze zwate stress averleefa. Tegetover de fout van de chirurg was hij ehter volkomen machteloos: door diensingreep

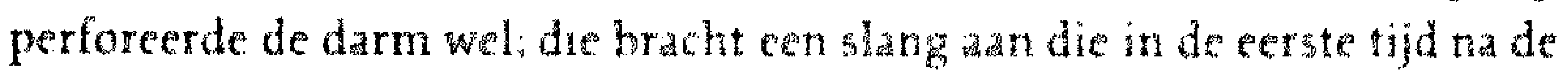
operatie niet mocht worden werwijerd that die pup erut" door diens houding nat het ont delken van de fout eengeestelijk palk slaggen door diens ingreep werdende artsen in he onbewaste van de patient ergerdan de beul die hem aan zijn vader had doen herinneren.

Daarmee was voor Bastiaans de redenering rond: hij had laten zien hoe er een lijn liep van Mourers jeugd (verzet tegen drijvende vader), naar de kampperiode (verzet tegen de kampbeul door te persen), de periode na de oorlog (verzet tegen ziekte), de mislukte operatie (gebroken verzet door de knoeiende arts), en de actuele klachten (colitis ulcerosa). Bastiaans toonde met zijn reconstructie aan dat Mourers colitis ulcerosa naar zijn oordeel in causaal verband stond met de oorlogsstress.

\section{Bij specifieke klachten horen specifieke gebeurtenissen}

De klacht waarmee Mourer zich meldde bij de Stichting 1940-1945 behoorde, net als de klachten van de rest van de door Bastiaans onderzochte aanvragers, tot de psychosomatische aandoeningen. Klachten dus waar de reguliere geneeskunde geen oorzaak voor kon vinden en waarvan de psychosomatici vermoedden dat de oorzaak psychisch was. Het verband tussen psychische factoren en vage somatische klachten was (en is) anders van aard dan een natuurwetenschappelijk verband, waarbij een oorzaak onvermijdelijk tot een gevolg leidt. Het betrof een oordeel van een arts dat leunde op de inschatting van een medicus, bijvoorbeeld een psychiater. Er zat dus een onvermijdelijk subjectief element in de beoordelingen. ${ }^{8_{3}}$

Dat was een bekend probleem. Het bleek onder andere uit de verschillen in invaliditeitspercentages die werden toegekend. Artsen konden in hun beoordeling aangeven dat maar een gedeelte van de invaliditeit door het verzet werd veroorzaakt. Bastiaans schatte deze invaliditeitspercentages gemiddeld bijna 17 procent hoger dan zijn Utrechtse collega's. ${ }^{{ }_{4}}{ }^{4}$ Maar het kon ook dramatischer gevolgen hebben, zoals in het eerdere voorbeeld van Rümkes verzetsstrijder: soms achtte de ene arts wel een verband aanwezig terwijl een ander dat niet vond.

De problemen bij de beoordelingen werden veroorzaakt door een aantal factoren. Bastiaans waarschuwde bijvoorbeeld voor de onbewuste drijfveren van de beoordelend arts: 
'Eigenlijk zou men zich dan ook bij ieder oordeel af moeten vragen: vanuit welke emotionele achtergronden wordt dit gegeven ${ }^{385}$

De onbewuste drijfveren die bij artsen een rol speelden, konden worden veroorzaakt door hun persoonlijke voor- en afkeuren. Als de aanvrager sympathiek of oprecht op de arts overkwam, of als de problematiek van de aanvrager raakte aan de eigen problematiek van de medicus, dan was het waarschijnlijk dat zijn oordeel daardoor werd beïnvloed.

Bastiaans wist voordat hij een Utrechts dossier analyseerde, welk oordeel de keuringsartsen over het verband hadden gegeven. ${ }^{86}$ In de overgrote meerderheid van de gevallen hadden de keuringsartsen het verband tussen klachten en oorlog aangenomen. ${ }^{87}$ Bastiaans onderzocht bij die dossiers dus niet of er een verband was, maar nam aan dat het er was, en zocht naar de rode lijn in het levensverhaal. Als de aandoeningen door andere artsen als een gevolg van de oorlog werden gezien, moest Bastiaans de verbanden boven water kunnen halen.

Daardoor ontstond het gevaar dat methodologen 'hindsight bias' noemen: aanwijzingen die de aandoening konden verklaren, werden eerder opgemerkt en kregen meer gewicht dan aanwijzingen voor alternatieve verklaringen. Afwijkende of tegenstrijdige informatie kon worden gebagatelliseerd of over het hoofd gezien. Zo vindt de onderzoeker wat hij verwacht te vinden en ziet hij andere verklaringen over het hoofd.

Bij de aanvragen waarover Bastiaans zelf een oordeel velde, speelde een andere factor een rol. Voor de aanvrager stond bij de observatie veel op het spel; de toekenning van een vaak broodnodig Buitengewoon Pensioen hing ervan af. De aanvrager had er dus belang bij dat de beoordelend arts ervan overtuigd raakte dat zijn klachten in verband stonden met de oorlog. Het kon zijn dat aanwijzingen die dat verband konden bevestigen eerder werden gerapporteerd of meer nadruk kregen, terwijl andere aanwijzingen onderdrukt of gebagatelliseerd werden. Psychiaters en andere medici, ook Bastiaans, waren bekend met deze mechanismen en duidden dergelijke vertroebelende factoren aan met termen als 'ziektewinst' en 'renteneurose'. ${ }^{88}$

Bastiaans achtte zichzelf en zijn patiënten gevrijwaard van deze gevaren. Hij concludeerde uit zijn observaties dat zelfs de meest getroffen verzetsstrijders zich als gezond presenteerden en helemaal niet als ziek wensten te worden gezien. Bovendien waren psychoanalytici volgens Bastiaans het best gewapend tegen subjectieve invloeden op de beoordeling. Die waren immers getraind in het doorzien van de eigen en andermans onbewuste motieven. Hij vertrouwde op zijn klinisch inzicht en wuifde daarmee de gevaren van zijn methode weg. Dat was niet terecht, zoals hieronder zal worden aangetoond.

De werkwijze die Bastiaans bij Mourer gebruikte om tot een oordeel te komen over het causaal verband, was exemplarisch voor alle bijna honderd ge- 
valsbeschrijvingen waarop zijn betoog was gebaseerd. Bij ieder dossier dat hij onderzocht, bracht hij de vroege jeugd van de aanvrager en de daarin ontwikkelde persoonlijkheid in kaart. Door een nauwgezette reconstructie van de oorlogsperiode en de jeugd probeerde hij verband te leggen tussen specifieke gebeurtenissen en specifieke klachten. ${ }^{89}$

Bastiaans besteedde daarbij geen of weinig aandacht aan alternatieve bronnen van stress. Zo was het opmerkelijk hoe makkelijk hij over Mourers periode in Spanje heen stapte, terwijl dat toch indrukwekkende jaren waren geweest. Mourer had gevochten aan het front en kameraden zien sneuvelen en verminkt raken, deels onder zijn verantwoordelijkheid. Hij was zelf gewond geraakt en in een ziekenhuis terechtgekomen.$^{90} \mathrm{Hij}$ had gevochten, in een vreemd land, onder moeilijke omstandigheden, en hij had verloren. Het waren jaren waarin Mourer, in Bastiaans' termen, stress, zelfs zware stress, had doorstaan. Het was zelfs oorlogsstress geweest. ${ }^{91}$

Bastiaans vatte de Spaanse Burgeroorlog samen met het eufemisme 'werken in internationaal politiek verband in het buitenland'. ${ }^{92}$ Mourer had hem verzekerd dat de tijd in Spanje 'de beste tijd van zijn leven was geweest' en Bastiaans nam daar genoegen mee. Geen van beiden had er belang bij om veel aandacht aan de Spaanse periode te besteden of daar een verband mee te leggen. Wanneer Mourers colitis ulcerosa door de stress uit Spanje of iets anders werd veroorzaakt, had Mourer geen recht op een uitkering. ${ }^{93}$

Behalve dat bepaalde onderdelen van Mourers verleden niet werden genoemd en de invloed van andere bronnen van stress buiten beschouwing werd gelaten, slopen er historische onnauwkeurigheden en onwaarheden in Bastiaans' redeneringen. Zo schreef Bastiaans over Mourers periode in het Groningse Huis van Bewaring:

'De SD wil hem murw krijgen; vier maanden lang wordt hij iedere nacht om één uur uit zijn cel gehaald en door de beruchte SD figuren ter plaatse verhoord en gepijnigd. Daarbij wordt hij bij herhaling in de buik getrapt en bewusteloos geslagen. ${ }^{94}$

Mourer sprak in 1948 met A. Treurniet, een onderzoeker van het RIOD die zelf overlevende van concentratiekamp Buchenwald was, en die hij kende van het bestuur van Expogé. ${ }^{95}$ In het gesprek met Treurniet, waarvan een uitgebreid verslag bewaard bleef, vertelde Mourer dat hij in de ruim twee maanden dat hij in Groningen werd vastgehouden, maar één maand bijna dagelijks werd ondervraagd en niet, zoals Bastiaans schreef, vier maanden. Daarbij werden hem valse verklaringen van medeverzetsstrijders voorgelegd en sloeg zijn ondervrager 'erop los', maar dat hij bij herhaling bewusteloos was geslagen noemde hij niet. ${ }^{96}$

Bastiaans schreef dat Mourer was betrapt bij een complot en als straf werd 
overgeplaatst naar Klinker. ${ }^{97}$ Het complot waar hij op doelde, was de aanslag op de ss-generaal Reinhard Heydrich, die eind mei 1942 plaatsvond in de omgeving van Praag, ver van Sachsenhausen, ver van Mourer. Heydrich stierf een week later aan complicaties die waren opgetreden bij zijn operatie. Mogelijk werd Mourer als onderdeel van een algemene vergeldingsmaatregel overgeplaatst naar Klinker, maar niet omdat hij onderdeel van het complot tegen Heydrich was.

Deze historische onjuistheden in Bastiaans' beschrijving lijken onbelangrijke details. Ze gaven weliswaar een vertekend beeld van Mourers verleden, maar leken Bastiaans' redenering niet te raken. Toch is dit een zorgwekkende constatering. De werkwijze van de Psychosomatische Werkgroep was erop gericht specifieke klachten te herleiden tot specifieke gevolgen van de stress van bepaalde gebeurtenissen. Bastiaans' verklaring van klachten was gebaseerd op het herleiden van specifieke klachten als gevolg van specifieke gebeurtenissen. De overtuigingskracht van zijn redenering zat in de frappante overeenkomsten tussen de traumatische gebeurtenissen en de latere aandoeningen; als die gebeurtenissen niet, of op een andere wijze, hadden plaatsgevonden viel zijn redenering weg.

Dat wordt duidelijk bij nadere bestudering van de anomalieën in Mourers gedrag waarin Bastiaans spanningen uit de oorlog herkende. Mourer was begin jaren vijftig begonnen met een academische studie en ervoer grote spanningen voor de examens. Ook voor de veelvuldige medische keuringen in het kader van zijn aanvraag voor een Buitengewoon Pensioen was hij nerveus. Té nerveus, volgens Bastiaans. Hij zag in de nervositeit een herhaling van wat er in de oorlog was gebeurd:

'Het examen en ook de medische keuringen, die sinds zijn aanvraag tot buitengewoon pensioen maar al te vaak moeten worden verricht, staan voor hem gelijk [...] met "keuring voor de gaskamer". ${ }^{98}$

Of de keuringen en examens vergelijkbare emoties opriepen met de spanningen die Mourer had ervaren bij de selecties voor de gaskamer, was maar de vraag. Historici zijn tot op heden niet in staat geweest duidelijkheid te krijgen over de omvang van het gebruik van de gaskamer in Sachsenhausen..$^{99}$

$\mathrm{Na}$ de bevrijding van het kamp troffen de Russen een kleine ruimte aan van tweeënhalf bij drie meter met een gedemonteerde installatie, waarvan ze vermoedden dat het een gaskamer was. ${ }^{100}$ In het proces dat door de Russen in 1947 tegen verdachten van de moorden in Sachsenhausen werd gevoerd, bekenden twee verdachten dat het een gaskamer betrof. De één dateerde de totstandkoming in de herfst van 1943, de ander in 1942. Geen van beiden kon het exacte aantal vergassingen noemen. Een oud-gevangene van Buchenwald, Eugen Kogon - vooral bekend geworden met zijn boek Der ss-staat -, schreef een boek 
over het gebruik van gaskamers in het Duitse Rijk, waarin ook Sachsenhausen voorkwam. De enkele getuigenissen over de gaskamer die hij had gevonden, bevestigden het idee dat het was gegaan om kleine aantallen. Het ging dan hoofdzakelijk om executies van personen die van buiten het kamp werden binnengebracht, niet om bewoners van het kamp zelf. ${ }^{101}$

Het was dus mogelijk dat Mourer tijdens zijn verblijf in Sachsenhausen wist van het bestaan van de gaskamer of daar een vermoeden van had. Maar het gebruikvan de gaskamer was beperkt en kwam incidenteel voor; van regelmatige selecties van gevangenen voor de gaskamer was in Sachsenhausen geen sprake. Bij het uitvoeren van executies werd in Sachsenhausen de voorkeur gegeven aan de galg en een speciale 'nekschotinstallatie'.

In Bastiaans' reconstructie van het verleden had Mourer alle gebruikelijke lijfstraffen in Sachsenhausen doorstaan: de bok, het Schuhlaufen en het am Pfahl hangen. Volgens Bastiaans waren onder andere Mourers lagerugklachten daar een gevolg van. ${ }^{102}$ Toch was het onwaarschijnlijk dat Mourer de zwaarste lijfstraffen had ondergaan; een voormalig gevangene beschreef in het naoorlogse proces tegen een voormalig kampbewaker hoe hij, na aan de paal gehangen te zijn, maandenlang zijn armen niet kon gebruiken. ${ }^{103}$ In een ander proces beschreef een getuige hoe de meeste gevangenen na vijfentwintig klappen op de bok zo verwond waren dat ze weggedragen moesten worden, en vijftig slagen werden vaak niet overleefd. ${ }^{104}$ Als Mourer inderdaad vijfenzeventig slagen op de bok had ondergaan dan was hij, als hij het had overleefd, voor lange tijd uitgeschakeld geweest. Toch schreef Mourer twee keer per maand een handgeschreven brief naar huis; een frequentie die hij onmogelijk had kunnen volhouden als hij zo ernstig mishandeld was.

Bovendien had Mourer enkele jaren voor zijn opname bij Bastiaans een aantal keren gesproken met ambtenaren die vermiste Nederlanders opspoorden of informatie verzamelden voor de berechting van oorlogsmisdadigers. In die gesprekken, waarvan de verslagen bewaard zijn gebleven, werd regelmatig gesproken over de gruwelijkheden die in Sachsenhausen plaatsvonden. Mourer noemde alle drie de lijfstraffen; hij vertelde dat hij erbij moest staan en toezien hoe anderen de straf ondergingen, niet dat hij die zelf had ondergaan. ${ }^{105}$

Het hart van Bastiaans' analyse was de sleutelscène in Klinker; volgens hem had de stress van de spuitsituatie een blijvende spanning achtergelaten, die zich steeds weer manifesteerde en uiteindelijk tot de colitis ulcerosa had geleid. Met de ontdekking van die scène vielen voor Bastiaans het verleden (situatie thuis en daaruit ontwikkelde persoonlijkheid) en het heden (de colitis ulcerosa) samen.

Maar al tijdens Mourers verblijf op het Wilhelmina Gasthuis waren er twijfels over de authenticiteit van de herinnering aan de spuitsituatie. Artsen konden zich niet voorstellen dat Mourer de mishandeling zou hebben overleefd. ${ }^{106}$ Bastiaans twijfelde niet aan de herinnering, voor hem was die realiteit. Dat was 
niet terecht. In zijn periode in Klinker, waar de opspuiting zou hebben plaatsgevonden, schreef Mourer brieven aan het thuisfront. Dat had hij niet kunnen doen als hij zo mishandeld was geweest. Bovendien zou de mishandeling plaats hebben gevonden op een grote groep, was hij van een uiterst gruwelijk karakter en bedoeld als voorbeeldstraf. Dergelijke mishandelingen zouden door verhalen van anderen na de oorlog naar buiten moeten zijn gekomen. Maar in de literatuur die over het kamp verscheen, kwam een dergelijke mishandeling niet voor, en in de naoorlogse processen tegen de ss'ers van Sachsenhausen werd de opspuiting niet genoemd. ${ }^{107}$

Freek Bischoff van Heemskerck maakte Mourer van december 1941 tot mei 1945 van dichtbij mee in Sachsenhausen, en leerde hem echt goed kennen in het strafkamp Klinker. ${ }^{108}$ Bischoff van Heemskerck was een van de personen die samen met Mourer in Sachsenhausen achterbleven toen de dodenmarsen begonnen. $\mathrm{Na}$ de oorlog hielden ze incidenteel contact. ${ }^{109}$ Als Mourer na de mishandeling inderdaad door vrienden van de lijkenhoop was weggesleept, dan was Bischoff van Heemskerck waarschijnlijk een van hen geweest, en anders had hij het van hen gehoord. In 2006 achtte hij het, desgevraagd, onmogelijk dat Mourer op die manier mishandeld was en hij daar niets van had geweten. ${ }^{110}$

Mourers gevalsbeschrijving legt een fundamenteel probleem van Bastiaans' werkwijze bloot. Bastiaans wilde in zijn proefschrift aantonen dat een nauwkeurige analyse van de psychische en lichamelijke toestand tijdens de jeugd, de oorlog en de periode daarna noodzakelijk was om een causaal verband te ontdekken. Mourer was daar een voorbeeld van. Soms moest er narcoanalyse worden toegepast om de specifieke gebeurtenissen op te diepen, maar als die eenmaal gevonden waren vielen de puzzelstukjes in elkaar. Bastiaans vertrouwde op de herinnering van zijn patiënten en maakte die tot de kern van zijn redenering, zonder dat hij andere bronnen gebruikte om die herinnering te verifiëren. Of het nu ging om gebeurtenissen in de vroege jeugd of tijdens de oorlog, Bastiaans ging uit van de betrouwbaarheid van de herinnering aan de gebeurtenis en de herinnering aan de reactie op de gebeurtenis.

Wanneer de historische feiten niet gecontroleerd werden of konden worden, bleef Bastiaans' redenering - en daarmee zijn oordeel over het causaal verband - afhankelijk van het vertrouwen dat werd gesteld in de authenticiteit van de herinnering. Met het wegvallen van de sleutelscène viel de redenering achter zijn oordeel als een kaartenhuis in elkaar: zonder de spuitsituatie had de specifieke stress niet plaatsgevonden; zonder die stress had ook niet de specifieke spanning kunnen ontstaan; zonder die spanning kon de colitis ulcerosa daar ook geen gevolg van zijn. Met andere woorden: zonder de specifieke gebeurtenissen viel de basis onder zijn verklaring weg.

Een aantal van de feiten in Mourers reconstructie was te verifiëren. Maar in 
andere gevallen was het onmogelijk om de authenticiteit te controleren. Een goed voorbeeld daarvan is te vinden in de tweede uitgebreide gevalsbeschrijving in Bastiaans' proefschrift. Hij besprak daarin een patiënte wier rugklachten de reden waren voor haar aanvraag van een Buitengewoon Pensioen. ${ }^{111}$ In de voorgeschiedenis van de vrouw was noch in de oorlog, noch daarvoor of daarna een verklaring te vinden voor de klachten, en haar aanvraag werd afgewezen. Maar toen ontdekte Bastiaans tijdens de narcoanalyse:

'dat patiënte met een aan zekerheid grenzende waarschijnlijkheid, onder invloed van dreiging of hardhandig lichamelijk aanraken door een van de bewaaksters, in de gevangenis van een ijzeren trap is gevallen[... ${ }^{1}{ }^{112}$

De ontdekking van Bastiaans introduceerde het historisch belangrijke feit dat de patiënte tijdens gevangenschap door toedoen van een bewaker was gevallen. De artsen waren het erover eens dat een val de rugklachten kon verklaren. Of de vrouw daadwerkelijk was gevallen en of ze daarbij was geduwd of bedreigd, viel niet meer vast te stellen. Objectieve bewijzen daarvoor ontbraken, het enige bewijs was de tijdens de narcoanalyse ontdekte gebeurtenis van de patiënte. De Centrale Raad van Beroep, die de beroepszaak van de vrouw behandelde, raakte overtuigd van de duw en wees de vrouw alsnog een Buitengewoon Pensioen toe. ${ }^{113}$

Zoals eerder al gezegd, werden de gevalsbeschrijvingen in Bastiaans' proefschrift anoniem gepresenteerd. Hoe vaak daarbij in de behandeling de historische feiten en de reconstructie ervan verschilden, laat zich dus niet meer vaststellen. ${ }^{114}$ Maar een eenmaligeuitzonderingwas Mourernietinzijn proefschrift. In de volgende hoofdstukken zullen nog twee voorbeelden uit Bastiaans' proefschrift worden gegeven.

In hoofdstuk 9 wordt nader ingegaan op het ontstaan van dergelijke vertekeningen in de reconstructie. Het is wel goed alvast op te merken dat het geen uitzonderlijk verschijnsel is. In Nederland hebben geheugenspecialisten als Merckelbach, Crombag en Wagenaar uitvoerig onderzoek gedaan naar het ontstaan van valse herinneringen tijdens een behandeling, en het afleggen van valse verklaringen door verdachten tijdens een politieverhoor. ${ }^{115}$

\section{Reacties op het proefschrift}

In de psychiatrie van de jaren vijftig was het werk van Freud, de psychoanalyse, nog de dominante theorie. Binnen die traditie was de onderzoekswijze van Bastiaans niet ongebruikelijk: gevalsbeschrijvingen, voorafgegaan door een literatuuroverzicht, gevolgd door duidingen en nieuwe, algemeen geldende inzichten. Het was niet ongebruikelijk dat de beschrijving van een enkel geval de basis vormde voor een artikel. Bastiaans' proefschrift kende een groot aan- 
tal casussen en won daarmee aan gezag. Bovendien was hij een psychoanalyticus van formaat; hij had zijn leeranalyse bij Jeanne Lampl-de Groot ondergaan, en was directeur van het Psychoanalytisch Instituut. Dat gaf autoriteit aan zijn observaties en zijn proefschrift kon dan ook rekenen op enthousiaste reacties.

$\mathrm{Na}$ de succesvolle verdediging van zijn proefschrift op 31 januari 1957, oogstte Bastiaans veel lof. Zelfs in de pers verschenen lovende berichten. NRC schreef bijvoorbeeld:

'Een zeer belangrijk proefschrift dat in menig opzicht aandacht verdient buiten de lezerskring die meestal voor een dergelijk werkstuk is voorbeschikt. ${ }^{116}$

De oprichter van het Nederlands Psychoanalytisch Genootschap en lector medische psychologie en psychoanalyse aan de Universiteit van Amsterdam, dr. A.J. Westerman Holstijn, onderschreef de psychosomatische mechanismen die Bastiaans had geobserveerd en had bewondering voor de grondige theoretische besprekingen en de vele casussen. Westerman Holstijn vond er ook een verklaring in voor:

'het opvallende feit [...] dat men sommige psychosomatosen (bv. astma en maagaandoeningen) in de kampen, hoe erg de toestand er soms ook was, vaak ineens zag verdwijnen! Immers, de conflicten van het dagelijkse leven, die aan het lijden ten grondslag lagen, vervluchtigden er geheel. ${ }^{117}$

Ook psychoanalyticus E. de Wind, zelf overlevende van Auschwitz, die al in 1949 over de psychische gevolgen van het verblijf in concentratiekampen had gepubliceerd, had niets dan lof:

'Dr. Bastiaans heeft $[\ldots]$ met een grote mate van objectiviteit jarenlang de zuiver wetenschappelijke en menselijk welwillende houding tegenover de door hem onderzochte groep weten te handhaven. Hij heeft zodoende een werk geschapen, dat zowel van algemeen psychiatrische als van psycho-analytische zijde op hoog wetenschappelijk niveau wordt geacht. ${ }^{118}$

Het Nieuw Israelietisch Weekblad roemde de moderne, psychoanalytische manier waarmee Bastiaans aanvragers had onderzocht. Het blad sprak de hoop uit dat het proefschrift van praktische waarde werd bij de uitkering van pensioenen. ${ }^{119}$

In tegenstelling tot de ontvangst bij psychoanalytici, was de ontvangst onder andere medici minder hartelijk. Volgens de historici Van Daal en DeKnechtvan Eekelen, die in opdracht van de Joannes Judah Groen Stichting voor Interdisciplinair Gedragswetenschappelijk Onderzoek een biografie schreven over Groen, Bastiaans' leermeester bij de Psychosomatische Werkgroep, was het 
succes van de psychosomatiek in Nederland beperkt. ${ }^{120}$ Het was sterk gebonden aan de persoon van Groen. Diens radicale variant van de psychosomatiek, vooral de psychosomatische specificiteit en het uitbundige gebruik van de psychoanalyse, kon niet rekenen op grote wetenschappelijke interesse. ${ }^{121}$ Toen Groen in 1958 naar Israël vertrok, kwam aan de meest productieve periode van de psychosomatici in Nederland een einde. ${ }^{122}$ Gedurende de jaren zestig nam de belangstelling voor de psychosomatiek af. ${ }^{123}$

\section{Conclusies}

Bastiaans' proefschrift werd in de jaren na publicatie als het Nederlandse standaardwerk gezien door nationale en internationale auteurs die schreven over de gevolgen van de oorlog. ${ }^{124}$ Dat kwam enerzijds doordat het het eerste en enige grote onderzoek was naar de klachten van verzetsstrijders; bij gebrek aan concurrerend onderzoek werd het vanzelf een standaardwerk. Anderzijds bood zijn proefschrift een oplossing voor de problemen die speelden bij het beoordelen van het causaal verband.

Door de klachten van verzetsstrijders te zien als het gevolg van onbewuste spanningen ten gevolge van traumatische gebeurtenissen, konden de verlate klachten eindelijk worden begrepen. Dat klachten soms jaren na de bevrijding ontstonden, was geen reden meer om een verband met de oorlog te verwerpen. Bovendien konden die verlate klachten allerlei vormen aannemen. Onder de mogelijke klachten vielen volgens Bastiaans de al genoemde psychosomatische aandoeningen als astma, overgewicht en maagzweren, maar later kwamen daar ook hartklachten, diabetes, multiple sclerose en dementie bij.

Het succes van Bastiaans' proefschrift bleef vanaf de publicatie in 1957 sterk verbonden met de problematiek van de aanvragen voor een Buitengewoon Pensioen. Bastiaans had de groep verzetsstrijders gebruikt om de ideeën van de psychosomatiek te onderzoeken. De klachten die hij daarvoor bij hen onderzocht, kwamen ook voor bij personen die niet in het verzet of in een kamp hadden gezeten. De wetten die van toepassing waren op verzetsstrijders waren dus ook van toepassing op niet-verzetsstrijders. Reacties op stress werden bij verzetsstrijders, net als bij anderen, bepaald door de aanleg van de persoon en de aard en intensiteit van de stress. Verzetsstrijders vormden dus, toen Bastiaans begon met zijn onderzoek, niet een principieel andere groep.

Het succes van de ideeën in zijn proefschrift werd vooral veroorzaakt door het feit dat hij een oplossing bood voor de problemen van de medisch adviseurs van de Stichting 1940-1945. Zij stonden dan ook open voor de ideeën van de psychosomatiek. Bastiaans bood een methode om alle somatische klachten in essentie te herleiden tot een gevolg van de oorlog. Dat was meer dan wat somatisch gerichte artsen de aanvragers konden bieden. 


\section{De methode-Bastiaans}

\footnotetext{
'Welnu, wanneer na een periode van 15 jaren, het middel zijn nut niet heeft bewezen, moet men wel besluiten, dat het nut niet groot kan zijn, misschien wel in het geheel niet aanwezig is.'

PROF.DR. J. BOOIJ OVER LSD-THERAPIE, 1968.
}

\section{Inleiding}

In zijn proefschrift besteedde Bastiaans ook kort aandacht aan de resultaten van de behandeling van verzetsstrijders. Dat deed hij niet op basis van zijn eigen, nog beperkte, ervaringen daarmee, maar op basis van dossiers van andere psychiaters. Op aanraden van de medisch adviseurs van de Stichting 1940-1945 en de BPR waren van 1945 tot 1955 namelijk 92 verzetsstrijders psychiatrisch behandeld. De behandelende psychiaters hadden kwartaalverslagen uitgebracht, en op basis daarvan concludeerde Bastiaans in het laatste hoofdstuk van zijn proefschrift dat:

'de behandeling [van verzetsstrijders] voor alles een palliatief karakter moet dragen, dat een psycho-analytische behandeling zelden geïndiceerd is en dat een narcoanalytische behandeling slechts zin heeft bij enkele gevallen waar de traumatische werking beperkt is gebleven'.

De vooruitzichten voor de behandeling van verzetsstrijders waren volgens Bastiaans 'weinig hoopgevend'. Vooral als de oorlogsstress hoog was geweest, de patiënten op leeftijd waren en ze na de oorlog slecht waren opgevangen, moest de behandeling gericht zijn op het zo draaglijk mogelijk maken van het bestaan. Genezing was vrijwel uitgesloten. ${ }^{3}$

Nog geen tien jaar na het verschijnen van zijn proefschrift had Bastiaans 
zijn verwachtingen over de behandeling van verzetsstrijders niet alleen drastisch herzien, maar trad hij zelfs naar buiten met een speciale behandeling voor verzetsstrijders en slachtoffers van de kampen, die in Nederland bekend werd als 'de methode-Bastiaans'. ${ }^{4}$ Met die methode kon hij, zo was de suggestie, zelfs de zwaarst getroffenen genezing geven.

In dit hoofdstuk wordt het ontstaan van de methode-Bastiaans beschreven. Hoe paste die in de ontwikkeling van andere technieken? Hoe uniek was die methode eigenlijk? En hoe moet Bastiaans' veranderde inschatting over de effectiviteit van behandelingen geïnterpreteerd worden?

\section{Ontdekken en herbeleven}

De kern van de methode-Bastiaans was het ontdekken van de sleutelscènes. Die hadden in zijn proefschrift ook al een belangrijke rol gespeeld bij het verklaren van psychosomatische kwalen. Bastiaans en de patiënt gingen in de behandeling op zoek naar de specifieke traumatische gebeurtenissen die de klachten konden verklaren. De verdrongen herinneringen aan de sleutelscènes en de intense emoties die daarbij hoorden, werden in de behandeling opgeroepen om een doorbraak te forceren.

Patiënten moesten schreeuwen, huilen, met Bastiaans over de grond rollen of tegen zijn borst uithuilen. Om dat te bewerkstelligen, gebruikte hij alles wat kon helpen. Patiënten werden naakt onder een deken gelegd, ze kregen afbeeldingen van Hitler of ss'ers te zien, er werd marsmuziek gedraaid, aan patiënten werd gevraagd in de houding te gaan staan of het nummer dat zij in de kampen droegen op te noemen. Om de beklemming van de onderduiksituatie na te bootsen, liet Bastiaans patiënten plaatsnemen onder een laken dat over twee stoelen hing. ${ }^{5}$ Soms speelde Bastiaans een rollenspel waarin hij nu eens als kampbewaker, dan weer als kampgenoot optrad, daarin soms bijgestaan door zusters of assistenten in opleiding. Alles werd in het werk gesteld om een situatie te creëren waarin de patiënt herinneringen en emoties wist te produceren die de klachten konden verklaren.

De twee kernprocessen van Bastiaans' behandeling: ontdekken en herbeleven, waren ontleend aan de psychoanalyse. Ze werden al door de grondleggers van de psychoanalyse, Breuer en Freud, gepubliceerd in hun studies naar hysterie aan het einde van de negentiende eeuw. ${ }^{6}$ Breuer en Freud beschreven hoe hun patiënten genazen wanneer zij zich de traumatische gebeurtenissen die voorafgingen aan hun ziekte weer herinnerden. Voorwaarde was wel dat de bijbehorende emoties werden herbeleefd. Deze catharsis, een heftige emotionele ontlading, was noodzakelijk voor het genezingsproces:

'Our observations have shown [...] that the memories which have become the determinants of hysterical phenomena persist for a long time astonishing 
freshness and with the whole of their affective colouring. We must however, mention another remarkable fact [...] that these memories, unlike other memories of their past lives, are not at the patients disposal. On the contrary, these experiences are completely absent from the patients' memory when they are in a normal psychical state, or are only present in highly summary form. Not until they have been questioned under hypnosis do these memories emerge within the undiminished vividness of a recent event. ${ }^{7}$

Freud en latere psychoanalytici namen aan dat er een speciaal geheugenmechanisme was dat traumatische gebeurtenissen uit het bewustzijn verdrong. De herinneringen en emoties bij zulke gebeurtenissen vormden zo'n bedreiging voor het psychisch evenwicht, dat ze uit het bewustzijn werden verbannen. In het voorgaande hoofdstuk werd al beschreven dat de verdringing zelden optimaal was en zich in symbolische vorm in psychische of psychosomatische klachten uitte, maar dat zorgde altijd nog voor minder problemen dan het in volle hevigheid toelaten van herinneringen en emoties.

De behandelvorm die Freud ontwikkelde, de psychoanalyse, was erop gericht de amnesie voor de gebeurtenissen op te heffen en zo de herinnering te bevrijden uit het 'onbewuste'. Na de ontdekking van de verdrongen gebeurtenissen kon de volgende cruciale stap in het behandelproces worden gezet: het los laten komen van de bijbehorende emoties.

De klassieke manier waarop psychoanalytici probeerden de kernprocessen op gang te brengen was erg arbeidsintensief. Een patiënt moest een aantal jaren dagelijks een uur lang bij de psychoanalyticus op de divan zijn verhaal doen. Het bleek een weinig efficiënte behandeling, die niet voor alle problemen en niet voor alle patiënten geschikt was. De patiënt moest de hoge kosten kunnen dragen en daarnaast in staat zijn tot enige reflectie op en verbalisatie van zijn gevoelsleven. Dat bleek niet voor iedereen weggelegd. Er werd al snel gezocht naar wegen om het therapeutisch proces te versnellen. ${ }^{8}$

\section{Narcoanalyse en psycholyse}

Een van die wegen was het gebruik van hypnose. Dit hulpmiddel, dat door Freud zelf weer was verlaten, werd tijdens de Eerste Wereldoorlog opnieuw in gebruik genomen door Duitse psychiaters, toen grote aantallen soldaten kwamen te lijden aan shellshock. Sommige psychiaters gingen er ook toe over om de herbeleving te provoceren met andere hulpmiddelen; ze introduceerden bijvoorbeeld de 'vijand' in de vorm van een pop waarop de patiënt dan zijn woede kon botvieren. ${ }^{9}$

In de jaren dertig deden medicijnen hun intrede bij deze vormen van behandeling. De familie van de barbituraten leek het meest geschikt. Barbituraten verschilden onderling in de snelheid waarmee het effect merkbaar werd en in 
de duur van het effect, maar de algemene werking was altijd dezelfde: verdoving. Ze werden toegepast als slaap-en narcosemiddel, en in lage doseringen als tranquillizer. De patiënt herinnerde zich later niets van de roes; er trad amnesie op. ${ }^{10}$ Pentothal, amytal, veronal en evipan zijn de bekendste namen van barbituraten die in de psychiatrie werden gebruikt. ${ }^{11}$

Een van de eerste psychiaters die uitgebreid publiceerden over de behandelingen met pentothal was de Engelse psychiater J.S. Horsley. Hij nam waar dat patiënten die een lage dosis pentothal kregen toegediend, niet buiten bewustzijn raakten maar in een lichte roes tussen waak en slaap bleven. Tijdens die roes leek er sprake van hypermnesie: het geheugen werkte uitermate goed en herinneringen die in nuchtere toestand ontoegankelijk waren, bleken tijdens de roes zeer toegankelijk. Horsley kreeg in een sessie van een uur net zoveel boven water als hij zonder gebruik van pentothal in een maand zou hebben bereikt. ${ }^{12}$ Hij doopte zijn nieuwe techniek 'narcoanalysis'.

De narcoanalyse werd tijdens de Tweede Wereldoorlog breder ingezet en bleek succesvol. Artsen en psychiaters stonden onder grote druk om getroffen soldaten weer inzetbaar te maken voor het front. De Britse psychiater W. Sargant beschreef in Battle for the Mind hoe hij in die oorlogsjaren de narcoanalyse verder uitwerkte. Hij diende frontsoldaten het barbituraat thiopenthal toe en liet hen de episodes die voor hun uitschakeling hadden gezorgd herbeleven:

'an endeavour would be made to make him re-live the episode that had caused his breakdown. Sometimes the memory would have to be brought to the surface again. At other times it was fully remembered, but the strong emotions originally attached to it had since been suppressed. The marked improvement in the patient's nervous condition was attributed to the releasing of these original emotions. It was also found that the emotions which were most profitably released - or "abreacted", as the psychiatric term is - were those of fear and anger; little could be done by making, say, a melancholic patient weep and become more depressed. ${ }^{13}$

De narcoanalyse werd vanaf dat moment een van de instrumenten die psychiaters ter beschikking stonden om de verdringing op te heffen en de herbeleving te versnellen. In de Angelsaksische landen werd de narcoanalyse al in de jaren dertig toegepast, met in de oorlog een toename van het gebruik. In Nederland deed het middel pas na de Tweede Wereldoorlog zijn intrede. Bastiaans, die kort na de oorlog begon met narcoanalyses, was dus een van de eersten in Nederland die ermee werkten. ${ }^{14}$

In zijn proefschrift voerde Bastiaans de narcoanalyse op als de 'pentothalprovocatie': een manier om in korte tijd tot de kern van de problematiek door te dringen. Het was vooral bedoeld om in de beperkte tijd die er voor een observatie in het kader van een aanvraag voor een Buitengewoon Pensioen was, toch 
een volledig beeld te krijgen van de achtergrond van de aanvrager. Voor wat tijdens de roes werd verteld, trad amnesie op; de patiënt wist naderhand niet meer wat hij had gedaan of verteld. Dat maakte dat het therapeutisch effect vaak teniet werd gedaan. Dikwijls was aanvullende therapie nodig.

Aan het gebruik van pentothal kleefden ook risico's. Dat bleek onder andere uit het proefschrift van de Utrechtse psychiater A. Poslavsky, Over het gebruik van pentothal in de psychiatrische kliniek, dat in 1953 verscheen. ${ }^{15}$ Bij te hoge dosering kon de ademhaling of de hartslag tot stilstand komen. ${ }^{16}$ Poslavsky had daarom, op advies van de narcoseafdeling, altijd beademingsapparatuur paraat als hij een narcoanalyse uitvoerde.

Niet alleen konden er complicaties optreden, maar het gebruik van pentothal bleek ook geen garantie dat de kernprocessen werden ondersteund. Dat illustreerde Poslavsky aan de hand van de behandeling van een 22-jarige telefoniste.

De telefoniste meldde zich in oktober 1946 op de psychiatrische kliniek te Utrecht, waar Poslavsky werkte. Ze bleek zwanger zonder dat zij zich kon herinneren hoe dat zo was gekomen. Ze kon zich wel herinneren dat ze op de avond van 12 maart 1946 niet lekker was geworden en een collega om water had gevraagd. Daarna was ze duizelig geworden. Twee uur later was ze wakker geworden, hangend op een stoel, zonder dat ze wist wat er was gebeurd. Tijdens de narcoanalyses herinnerde de telefoniste zich dat ze was overweldigd door twee mannen.

Eind januari 1947 beviel zij. Als het kind medio maart was verwekt, kon het niet pas na half januari geboren zijn, aangezien een zwangerschap niet langer dan tien maanden kan duren. Poslavsky probeerde haar de logica hiervan duidelijk te maken, maar de telefoniste bleef bij haar verhaal. Totdat ze een paar maanden later een brief naar Poslavsky stuurde, waarin zij schreef dat ze eind april of begin mei 1946, toen ze voor haar werk per trein naar Den Haag reisde, was achtervolgd naar haar hotelkamer. Uit een nieuwe narcoanalyse bleek dat haar achtervolger haar had overweldigd. Ditmaal was Poslavsky overtuigd van de waarheid van haar verhaal. De patiënte leek ook opgelucht te zijn na de ontdekking.

Maar Poslavsky vervolgde het verhaal:

'Men zal zich na het lezen van het voorafgaande onze verbazing begrijpen, toen de ontknoping van deze zaak plaatsvond. Het bleek namelijk, dat patiënte enkele maanden later desgevraagd mededeelde een kortdurende seksuele relatie te hebben onderhouden en wel op een tijdstip, dat zeer wel in overeenstemming gebracht kon met worden met de datum van de partus. ${ }^{17}$

De telefoniste was niet de enige bij wie tijdens de narcoanalyse valse herinneringen bovenkwamen. 
Poslavsky gaf ook het voorbeeld van de herinneringen van een matroos die in de Tweede Wereldoorlog bij de slag in de Javazee op de Nederlandse kruiser Hr.Ms. De Ruyter zat, toen deze werd getorpedeerd. Het schip zonk en de man dobberde enkele dagen op open zee en zag hoe een zwaar verminkte vriend verdronk. Hij kwam in krijgsgevangenschap en werd door de Japanners tewerkgesteld, en was ten slotte ooggetuige van de atoomaanval op Nagasaki. Bij de nabespreking van de narcoanalyse moesten patiënt en arts concluderen dat niet alle herinneringen berustten op feitelijke gebeurtenissen. ${ }^{18}$

Poslavsky waarschuwde in zijn proefschrift voor een al te licht geloof in de authenticiteit van de herinneringen die tijdens een narcoanalyse naar boven kwamen. ${ }^{19}$ De narcoanalyse had dus soms een averechts effect: er konden herinneringen worden opgeroepen mét de bijbehorende emoties, zonder dat die herinneringen authentiek waren. Het onderscheid tussen valse en authentieke herinneringen was noch door de psychiater noch door de patiënt altijd te maken. Poslavsky kende aan de valse herinneringen nog wel enige therapeutische waarde toe, maar dan moest de psychiater wel ontdekken dat het om valse herinneringen ging.

Bastiaans kende Poslavsky en diens proefschrift goed; Poslavsky had Bastiaans geholpen bij een deelonderzoek van zijn proefschrift. Bovendien kende Bastiaans de risico's van de narcoanalyse ook uit eigen ervaring. Internist Henk Pelser, een collega van Bastiaans op het Wilhelmina Gasthuis die ook een tijdlang verbonden was aan de Psychosomatische Werkgroep, herinnerde zich in een interview in 2005 de behandeling van een patiënt die Bastiaans in zijn proefschrift opvoerde. ${ }^{20}$

Deze patiënt, een Nederlandse man, was bij het uitbreken van de oorlog via Duinkerken naar Engeland gevlucht en daar opgeleid tot commando, waarna hij dienst nam in het Canadese leger. In 1943 vocht hij met de commandotroepen van het First Canadian Army in Afrika, bij El Alamein en Tobroek. Toen hij bij die gevechten een schampschot opliep, goot hij ter ontsmetting whisky in de wond. Eenmaal wierp een van zijn kameraden zich vóór hem toen ze onder vuur werden genomen en kwam om. Uit wraak besloop de man de Duitser die zijn kameraad had neergeschoten en sneed zijn buik open. Tijdens een aanval op een Deens kustdorp raakte zijn beste vriend ernstig gewond. Hij torste hem op zijn rug naar de zee en zwom daar, nog steeds met zijn gewonde vriend, naar een gereedliggende onderzeeër. Aangekomen op de onderzeeër stierf zijn vriend alsnog.

Al deze herinneringen kwamen boven tijdens de narcoanalyse en gingen gepaard met heftige emotionele uitbarstingen en heropvoeringen van de situaties. Pelser was er bijvoorbeeld bij toen deze patiënt tijdens de narcoanalyse de verwarmingsbuizen van het Wilhelmina Gasthuis inklom alsof hij wilde ontsnappen aan zijn belagers. Eenmaal beneden bleken zijn handen onder de bla- 
ren te zitten; de patiënt was zo opgegaan in zijn rol dat hij de gloeiend hete verwarmingsbuizen niet had gevoeld.

Pelser herinnerde zich dat Bastiaans zeer onder de indruk was van het verleden van deze patiënt, en dat hij pogingen ondernam om de man een onderscheiding te bezorgen. Maar de naam van de commando bleek niet bekend te zijn bij de Canadese autoriteiten. ${ }^{21}$ Het First Canadian Army had zelfs nooit in El Alamein of Tobroek gevochten en had ook geen aanvallen uitgevoerd op Deense kustdorpen. ${ }^{22}$

Los van de vertekeningen die soms ontstonden, had Bastiaans nog een andere reden waarom hij in 1957 gereserveerd had moeten staan tegenover de narcoanalyse. Hij uitte in het laatste hoofdstuk van zijn proefschrift, waarin hij de resultaten van behandelingen door andere psychiaters besprak, grote twijfels over de toepassing van de narcoanalyse.

'Een indruk die uit vele kwartaalrapporten van de behandelende psychiaters verkregen werd was dat de voorstelling, dat men bij de oorlogsneurotische toestanden zoals die in deze studie voor de ex-verzetslieden zijn beschreven langs cathartische weg veelal reeds in korte tijd een gunstig resultaat zou kunnen behalen, als obsoleet moet worden aangeduid. ${ }^{23}$

Hij schreef dat het gebruik van pentothal bij de meest kwetsbare groep verzetsstrijders - degenen die in een kamp hadden gezeten - bovendien tot hersenbeschadigingen kon leiden. Op basis van de kwartaalrapporten verwierp Bastiaans niet alleen de narcoanalyse, maar ook andere methoden die gericht waren op een eenmalige heftige ontlading van emoties.

Deintroductie van de barbituraten in de psychiatrische praktijk werd gevolgd door de introductie van vele andere medicijnen. Het luidde het begin in van de biologische psychiatrie, die de psychoanalyse als basis losliet. De psychiatrie maakte daardoor in de jaren vijftig een revolutie door; er werden medicijnen ontdekt - zoals bijvoorbeeld chloorpromazine - die het aangezicht van psychiatrische klinieken voorgoed deden veranderen. Voor het eerst hadden psychiaters een middel in handen waarmee ze een ernstige aandoening als schizofrenie de baas konden. In de decennia daarna volgden meer medicijnen voor meer aandoeningen, die genezing of verlichting van klachten brachten zonder dat er sprake was van langdurige therapieën, of ontdekken en herbeleven. ${ }^{24}$

Maar ook de psychoanalytisch georiënteerde therapieën profiteerden van de nieuwe medicijnen. Begin jaren vijftig deden de hallucinogenen daar hun intrede. ${ }^{25}$ Het bekendste lid van deze familie was lyserginezuurdiëthylamide, kortweg LSD. In 1943 hadden de Zwitserse chemici Hofmann en Stoll, die in dienst waren van het chemisch concern Sandoz, een onderzoek gepubliceerd. 
Hierin beschreven zij hoe ze met behulp van bestanddelen van de schimmel 'moederkoren' werkzame stoffen hadden weten te produceren in het laborato rium. Een van die stoffen was L.SD. ${ }^{\text {at }}$ Sandoz. was geinteresseerd in de schim mel omdat deze van oudsher werd toegepast om barensween op te wekken; mogelijk kon uit de werkzame bestanddelen cen nieuw medicijn worden ont wikkeld.

Onderzoeker Hofmann had per ongeluk een kleine hoeveelheid isn bin nengekregen en was overvallen door de sterke effecten van het middel. Hij was aanvankelijk wat duizelig geworden en gevoelig voor licht, maar later volgden hallucinaties van felle kleurpatronen. Al met al was het geen onprettige erva ring, en hij besloot het middel een tweede keer uit te proberen. Dat leverde een veel minder aangename ervaring op: hij kreeg het gevoel bezeten te zijn door demonen, werd angstig en vreesde te zullen sterven. Een te hulp geschoten arts kon niets voor hem doen. Na een paar uren mamen de ergste angsten af en kon hijgenieten van dezelfde caleidoscopische kleurformaties als hij de eerste keer had gezien."?

Sandoz liet zijn oorspronkelijke plan voor I.SD - het opwekken van barensweeën - varen en onderzocht de psychische effecten. In 1947 verscheen het eerste, exploratieve onderzoek naar de psychische effecten van ISD. ${ }^{2 / 2}$ In hetzelfde jaar bracht Sandoz LSD op de markt onder de naam 'Delysid'. In de brochuretekst werd melding gemaakt van de verschillende manieren waarop het mid. del te gebruiken was. Volgens de fabrikant riep het tijdelijke psychoses op, waardoor psychiaters zelf konden ervaren wat hun patienten doormaakten tijdens een psychose. Daarnaast claimde de brochure dat het middel, net als barbituraten, verdrongen herinneringen makkelijker kon losmaken. ${ }^{29}$ Claims overigens, die door het exploratieve onderzoek niet werden ondersteund. De verwachtingen op dat gebied werden in het wetenschappelijke artikel zelfs getemperd. Maar de voorzichtige woorden van het artikel pasten niet in de verkoopstrategie van Sandoz en verdwenen uit de brochuretekst.

Vertegenwoordigers van Sandoz trokken door Europa en Amerika en verspreidden op kleine schaal gratis of tegen kostprijs Delysid aan psychiaters..$^{30}$ Ondanks de ontbrekende wetenschappelijke evidentie voor de 'ontdekkende' werking van LSD, trok het middel de aandacht van een aantal behandelaars en onderzoekers. In de jaren vijftig zag een deel van hen in LSD de veilige en efficiënte opvolger van pentothal. LSD had niet de gevaarlijke bijeffecten van barbituraten, en leek sneller en makkelijker te leiden tot de kerndoelen van de psychotherapeutische behandeling: ontdekken en herbeleven. Anders dan bij de narcoanalyse bleef de patiënt zich tijdens de LSD-roes bewust van wat er gaande was en trad er geen amnesie op.

De ontwikkelingen op het gebied van de LSD-behandelingen stonden niet stil. Op een aantal symposia en congressen eind jaren vijftig, begin jaren zestig, stond het gebruik van hallucinogenen in de psychiatrie centraal. ${ }^{31}$ Niet alleen 
LSD werd gebruikt, maar ook psilocybine en mescaline, middelen waarvan de effecten vergelijkbaar zijn met die van LSD, zij het minder extreem en minder lang. Een deel van de psychiaters gebruikte LSD als hulpmiddel om het proces van ontdekken en herbeleven te versnellen. Illustratief was het experiment in Powick Hospital bij Londen, de eerste kliniek waar LSD werd toegepast als min of meer reguliere behandelvorm. ${ }^{32}$

Een groep vrouwelijke patiënten - onder wie psychopaten, hysterici en lijders aan schizofrenie - die al jaren van (falende) behandelingen achter de rug hadden, kreeg in Powick Hospital gezamenlijk LSD toegediend. Onder invloed van LSD ging de groep op zoek naar verdrongen jeugdherinneringen. Om dat te vergemakkelijken vonden de sessies plaats in een speciale kamer:

'furnished somewhat along the lines of a child guidance play therapy room. I was assisted by a female nurse who was prepared to play the role of the mother to the group. ${ }^{33}$

Er was een kleine zandbak, wat klei, teddyberen, een poppenhuis en een krijtbord. De psychiater en de zuster traden respectievelijk op als vader en moeder, om het de vrouwen makkelijker te maken hun emoties toe te laten. Negatieve emoties konden worden gericht op een vader- en moederpop. De poppen werden regelmatig gebruikt om de opgekropte agressie op te botvieren. De onderzoeker die het experiment had geleid, rapporteerde hoopvolle resultaten van de behandeling. ${ }^{34}$

Zo ontstond eind jaren vijftig bij een aantal psychiaters de indruk dat LSD een alternatief was voor pentothal. De patiënt bleef zich tijdens de roes bewust van wat er om hem heen gaande was en er trad geen amnesie op. Bovendien greep LSD niet in op het ademhalingssysteem en de hartslag, zodat fatale complicaties zich niet voordeden. De opvolger van de narcoanalyse werd 'psycholyse' genoemd: een combinatie van psychoanalyse en LSD-therapie.

Bastiaans maakte voor het eerst kennis met LSD aan het eind van de jaren vijftig, toen promovendus F. van Ree op het Wilhelmina Gasthuis experimenten met het middel uitvoerde. Van Ree was geïnteresseerd in de 'modelpsychose' die LSD volgens de fabrikant Sandoz opriep, en vroeg vrienden en collega's, onder wie ook Bastiaans en Barendregt, deel te nemen aan zijn experimenten. Barendregt was enthousiast en haalde zelfs een aantal vrienden over om mee te doen, maar Bastiaans weigerde..$^{35} \mathrm{Het}$ zou nog enkele jaren duren voordat hij LSD zou inzetten in zijn behandelingen.

\section{Authenticiteit en effectiviteit}

Een belangrijke les uit zowel de geschiedenis van de narcoanalyse als de psycholyse was dat de middelen op zichzelf geen voorspelbaar therapeutisch ef- 
fect hadden. De middelen veroorzaakten weliswaar bij iedereen dezelfde farmacologische symptomen, maar de inhoud en de beleving van de roes verschilden. De een zag onder invloed van LSD prachtige kleurschakeringen en genoot van de veranderde kijk op de wereld, de ander werd angstig en paranoïde, weer een ander werd verdrietig, bij nog weer anderen deed het emotioneel niet zoveel.

Medisch historicus dr. S. Snelders, die in 2000 promoveerde op het gebruik van LSD in de psychiatrie in Nederland, omschreef het resultaat van een roes als 'het samenspel van drug, set en setting'. De ervaring van de patiënt wordt beïnvloed door de verwachtingen en de houding van de betrokkenen bij de roes (de set); dus zowel door de verwachtingen van de psychiater als die van de patiënt zelf. Daarnaast speelt de politieke, sociale en culturele omgeving waarin de drug wordt genomen (de setting) een rol en de farmacologische werking van het middel zelf (de drug). ${ }^{36}$

Iemand die bang was voor de effecten, liep een grotere kans op een onprettige ervaring dan iemand die een religieuze ervaring verwachtte. De Amerikaanse LSD-onderzoeker en hoogleraar psychiatrie dr. S. Cohen deed ooit de observatie dat freudiaans georiënteerde therapeuten na LSD-sessies vaak traumatische jeugdherinneringen rapporteren bij hun patiënten, en jungiaans georiënteerde therapeuten vaak archetypische beelden. ${ }^{37}$ De LSD-roes, maar ook de pentothalroes, werd dus beïnvloed door de verwachtingen van de patiënt en de verwachtingen van de behandelaar.

De Amerikaanse psychologe dr. A. Piper presenteerde in 1993 een overzicht van de literatuur over de narcoanalyse en vergelijkbare behandelingen. Ze ontdekte dat in de onderzoeken naar narcoanalyse de herinneringen nooit waren getoetst op hun authenticiteit. ${ }^{3}$ Waren de herinneringen die werden opgediept ook daadwerkelijk herinneringen aan gebeurtenissen die hadden plaatsgevonden? Ze concludeerde:

'In summary, any memory surfacing under [a barbiturate] should be considered of questionable reliability until independently corroborated. Memories retrieved in an [barbiturate]-induced trance are likely to contain both fact and fantasy in a mixture that cannot be accurately determined without external verification, ${ }^{39}$

Psychiaters op zoek naar de verdrongen herinneringen aan traumatische gebeurtenissen, moesten met het gebruik van LSD en pentothal dus oppassen. De herinneringen die bovenkwamen, werden beïnvloed door verwachtingen van therapeut en patiënt, en het was voor beiden lastig om de authenticiteit te bepalen.

Andere psychiaters maakten juist gebruik van de kneedbaarheid van het geheugen tijdens de roes. De eerdergenoemde Britse psychiater Sargant schreef 
openhartig over zijn narcoanalyses bij frontsoldaten. Hij merkte dat niet alle emoties even effectief waren: vooral woede en angst leidden tot een verbetering bij de patiënt. In de sessies ging hij dan ook op zoek naar situaties waarin die emoties een rol hadden gespeeld.

Sargant ging na verloop van tijd een stap verder. Hij had gemerkt dat het niet nodig was om soldaten een authentieke gebeurtenis te laten herbeleven. Wanneer een soldaat bijvoorbeeld na een tankgevecht was ingestort, liet Sargant hem zich tijdens de sessie inbeelden dat hij gevangenzat in een brandende tank en moest vechten om eruit te komen. Het belangrijkste was dat de soldaat heftige emoties doormaakte. Of hij ook daadwerkelijk in een brandende tank had gezeten was niet belangrijk voor het succes van de behandeling. ${ }^{40}$ Sargant liet dus de authentieke ervaring los als voorwaarde voor succes. Door de patiënt te verleiden tot heftige emoties, of die nu gekoppeld waren aan authentieke gebeurtenissen of niet, kon genezing worden bereikt.

Sargant kon zich die lichtzinnige omgang met het verleden veroorloven omdat de omstandigheden waarin hij opereerde - als psychiater net achter de frontlinie - hem noopten tot een beperkte taakopvatting: soldaten moesten zo snel mogelijk weer in staat zijn terug te keren naar het front. Zo werd de authenticiteit van de gebeurtenissen opgeofferd aan de effectiviteit van de behandeling. Eenzelfde ontwikkeling als bij Sargant was ook te ontdekken bij psychiaters die met LSD werkten in hun behandeling. ${ }^{41}$

Bij Bastiaans en zijn patiënten lag dat anders. Bastiaans kwam uit een psychoanalytische traditie, waarin het ontdekken en herbeleven betrekking had op authentieke gebeurtenissen en niet op ingebeelde situaties. Bastiaans was in zijn behandelingen op zoek naar de traumatische gebeurtenissen die ten grondslag lagen aan de klachten. Het was de bedoeling, althans zo bracht hij dat herhaaldelijk onder woorden, dat patiënten de folteringen weer voelden en het crematorium weer roken. ${ }^{42}$

De patiënten die zich bij hem meldden, deden dat vaak, zo schreef Bastiaans, omdat ze met de mensen in hun directe omgeving zelden of nooit konden spreken over wat hen was overkomen. Ze hadden het gevoel tegen een muur van ontkenning aan te lopen. Bastiaans hoorde vaak van de verzetsstrijders die hij sprak:

'Ze willen me niet begrijpen, ik kan hierover alleen maar praten met ex-verzetslieden. ${ }^{43}$

Voor andere patiënten was de authenticiteit van de oorlogservaringen om een andere reden belangrijk; zij traden doelbewust met hun ervaringen in de openbaarheid. Zewierpen zich op als vertegenwoordiger van een groep slachtoffers of wijdden een literair oeuvre aan hun ervaringen. Sommigen deden dat al voordat ze bij Bastiaans in behandeling gingen. Anderen werden er juist door 
de behandeling toe aangezet om voor het voetlicht te treden en op te treden als boodschapper van de verschrikkingen van de oorlog. ${ }^{44}$

De schrijver G.L. Durlacher was kritischer jegens zijn eigen geheugen dan menig historicus jegens zijn bronnen. Hij meldde zich midden jaren tachtig ten einde raad bij Bastiaans. Het portret van Durlacher laat zien hoeveel waarde sommige van Bastiaans' patiënten hechtten aan de authenticiteit van hun herinneringen.

\section{Portret: Gerhard Durlacher}

Gerhard Leopold Durlacher, geboren in Baden Baden (Duitsland), vluchtte in 1937 samen met zijn ouders voor de nazi's naar Rotterdam. Het Joodse gezin wist een tijdlang uit handen van de Duitsers te blijven, maar werd uiteindelijk toch opgepakt en op transport gezet. In mei 1944 kwam Durlacher, na drie dagen en twee nachten in gesloten veewagons te hebben doorgebracht, aan in Auschwitz-Birkenau.

'Pas uren later vind $\mathrm{ik}$ mijzelf met mijn vader terug op de vlakte achter Krematorium III waarvan ik toen de functie nog niet kende of kon bevatten: staande of zittend op harde, zwarte grond, ontdaan van alles behalve de verfomfaaide en door het transport vervunsde kleding, zoekend in de mensenmassa naar gezinsleden, snakkend naar water, wachtend als vee voor het abattoir. ${ }^{25}$

Durlacher kwam terecht in blok B-II-B, het Familienlager, waar de omstandigheden slecht waren, zij het iets minder slecht dan in de overige blokken. De Joden in het Familienlager werden achter de hand gehouden voor het geval het Rode Kruis een bezoek wilde brengen aan het modelkamp Theresienstadt; de Joden in het Familienlager zouden dan worden overgebracht naar het modelkamp. Durlacher zat daar samen met zijn vader en soms lukte het hun zelfs om hun vrouw en moeder te vinden aan de andere kant van het prikkeldraad.

'Wij hebben haar en kleren, hongeren zonder te verhongeren, Kapo's die slaan maar zelden doden, wij kunnen woorden wisselen met verwanten. ${ }^{46}$

In de zomer van 1944 vond er een selectie plaats. De beruchte Engel des Doods, Josef Mengele, voerde de selectie persoonlijk uit. Durlacher werd samen met 99 andere jongens uitgekozen en overgebracht naar een tijdelijke quarantaineafdeling. Hij liet zijn vader en moeder achter, en toen hij twee dagen later uit de quarantaine kwam, was het hele Familienlager 'aufgelöst'. Zevenduizend mensen waren van de aardbodem verdwenen, letterlijk in rook opgegaan. Iets wat Durlacher pas jaren later zou ontdekken.

Durlacher wist Auschwitz ternauwernood te overleven. Hij was bij zijn be- 
vrijding op sterven na dood. In een hospitaal in Opper-Silezië herstelde hij langzaam.

'Juni is tijdloos. Voedsel deelt de dagen in, genezing en gewicht de weken. Wij praten over vroeger, onze jeugd, onze verwanten. "Waar kom jij vandaan?", "Waar wil je naartoe?" Zelden valt een kampnaam; wij hoeven elkaar niets te vertellen. Wij willen overdag vergeten wat voor ons de nacht vergalt. ${ }^{37}$

Terug in Nederland wachtte hem een koude douche. Zijn familieleden werden vermist, zijn ouderlijk huis werd bewoond door mensen die hem niet binnenlieten, voormalige buren en bekenden wilden niet naar zijn verhalen luisteren.

Hij begon aan een studie geneeskunde maar brak die weer af wegens gezondheidsproblemen. Toen hij zijn vrouw leerde kennen, vertelde hij haar veel van de verhalen waar hij later over zou schrijven. Maar zodra hun eerste kind was geboren, werd er niet meer over de oorlog gesproken in de eerste persoon enkelvoud. Hij vond het gênant, schaamde zich voor zijn oorlogsverleden. Hij wilde zijn kinderen er niet mee belasten. Het nummer dat bij aankomst in Auschwitz in zijn arm was getatoeëerd, liet hij verwijderen.

\section{Ziek van de oorlog}

In de jaren tachtig drongen de oorlog en zijn gezondheid zich als twee onafscheidelijke en niet te vermijden eenheden aan hem op. Durlacher doceerde inmiddels sociologie aan de Universiteit van Amsterdam, en de eveneens daar werkzame socioloog Abram de Swaan vroeg hem twee boeken te recenseren voor het tijdschrift De Gids.

Het ging om The terrible secret van Walter Laqueur en Auschwitz and the allies van Martin Gilbert uit respectievelijk 1980 en $1981 .{ }^{48}$ In de boeken werd duidelijk dat de geallieerden al tijdens de oorlog wisten van het bestaan van de vernietigingskampen, maar het onderwerp van ondergeschikt belang vonden. Zoals een door Durlacher geciteerde diplomaat het uitdrukte tijdens een vergadering op het geallieerde hoofdkantoor:

'In my opinion a disproportionate amount of time of the Office is wasted on dealing with these wailing Jews. ${ }^{49}$

Durlacher was geschokt. Hij was in Auschwitz-Birkenau toen hij aan de hemel de witte condensstrepen van geallieerde bommenwerpers zag. Hij hoorde, voelde, hoe de bommen op de nabijgelegen fabrieken van I.G. Farben vielen. Het had hem en anderen moed gegeven. Ze zagen het als een teken dat de buitenwereld wist wat er gaande was en hen niet in de steek zou laten. Die bommen van hoop bleken nu toevalstreffers, blindgangers te zijn geweest. 
Zijn gezondheid liet hem in de periode dat hij de boeken las meer en meer in de steek. Hij had een lage weerstand en de ene longontsteking volgde de andere op. Zijn bloeddruk was te hoog en hij moest zich steeds vaker en langer ziek melden. Een bedrijfsarts opperde dat er mogelijk een verband was met zijn oorlogsverleden, maar Durlacher moest daar aanvankelijk niets van weten; hij had een afkeer van gepsychologiseer. Zijn gezondheid bleef echter slecht en hij vreesde de rest van zijn leven ziek door te moeten brengen. Ten einde raad nam Durlacher de suggestie van zijn bedrijfsarts over en riep de hulp van een psychiater in. Hij zag geen alternatief.

Durlacher had vertrouwen in de deskundigheid en ervaring van Bastiaans, hoewel hij twijfels had over de ISD-behandeling. Hij nam contact op met de Jelgersmakliniek en vroeg om meer informatie. Hij kreeg een boekje $\mathrm{e}^{50}$ en de documentaire van Van Gasteren toegestuurd, en liet zich daardoor overtuigen. Hij maakte een afspraak.

\section{De behandeling}

Nadat Durlacher had aangeven in behandeling te willen, moest hij wachten tot hij gebeld zou worden voor een afspraak. Het was uiteindelijk Bastiaans zelf die belde en hem uitnodigde voor een LSD-sessie de volgende dag. De volgende dag reed Durlacher naar Oegstgeest. De sessie duurde tot twaalf uur die nacht en werd afgesloten met een dosis librium. Bastiaans belde na de sessie met de vrouw van Durlacher en meldde haar het resultaat van de sessie:

'Uw man is klaar. Er is veel losgekomen. Hij komt morgen thuis. ${ }^{.51}$

Na deze woorden werd de verbinding verbroken en begon het gespannen wachten op Durlachers thuiskomst. Durlachers echtgenote wist niet wat ze moest verwachten. Hoe laat zou haar man thuiskomen? In welke staat verkeerde hij? Moest zij nog voorzorgsmaatregelen nemen? Pas rond vier uur de volgende middag stapte Durlacher in Oegstgeest in zijn auto en reed naar huis. Thuis aangekomen was hij verward en huilerig, hij herhaalde zichzelf voortdurend. In de dagen die volgden luisterde hij, zoals opgedragen door Bastiaans, naar de geluidsbanden van zijn sessie. Het viel hem zwaar.

Een week na de eerste sessie had hij samen met zijn vrouw een kort nagesprek bij Bastiaans. Bastiaans en Durlacher waren tevreden: ze spraken over platen beton die waren gebroken en bunkers die waren gebarsten. Na het gesprek gingen Durlacher en zijn vrouw naar huis, in afwachting van het volgende telefoontje dat hem naar Oegstgeest zou roepen. Durlacher kreeg uiteindelijk acht LSD-sessies en herinnerde zich achteraf:

'Die LSD-therapiën vond ik iets verschrikkelijks. Ik heb het acht keer gehad en toen was ik geestelijk eigenlijk dood. Daarna ben je drie weken lang niet meer 
jezelf. [Bastiaans] neemt alles op de band op: je reacties, je verhalen en dat moet je dan thuis een paar keer beluisteren. Het kwaad wordt er gewoon uitgekotst. Ik kan er nu niet meer naar luisteren. Het heeft me lichamelijk geen goed gedaan, het is te erg, maar dat heeft me wel opengebroken. Als ik dit niet gehad had, was ik waarschijnlijk allang dood geweest. Bastiaans is een verstandig man geweest, hij heeft me aangeraden daarna in analyse te gaan. Bij een andere psychiater. Dat was een uitstekend advies. ${ }^{.52}$

$\mathrm{Na}$ de behandeling bij Bastiaans onderging Durlacher jarenlang een klassieke psychoanalyse. De oorlog bleef lange tijd nadrukkelijk op de voorgrond aanwezig.

"Ik wilde [...] het "waarom" en het "hoe" van onze catastrofe weten en daarmee mijn eigen coördinaten leren kennen. Hoe hadden wij geleefd en overleefd, hoe was onze bevrijding, hoe onze thuiskomst? En waarom hield de wereld zich blind en doof tijdens de zwartste uren in de oorlog en daarna? Onderzoek in bibliotheken en archieven liet heel veel vragen open en heel veel antwoorden deden pijn. ${ }^{53}$

Durlacher kwam in contact met psychiater - en tevens overlevende van Auschwitz - E. de Wind, en begon met hem een onderzoek. ${ }^{54}$ Centraal stond de vraag waarom sommigen in leven bleven en anderen ten onder gingen in de kampen. Hij las ieder boek over de oorlog waar hij de hand op wist te leggen. Een tijdlang liep hij ook rond met plannen om andere slachtoffers te helpen.

Durlacher begon ook te schrijven over de oorlog, over zijn ervaringen. Het kostte hem veel moeite. Als hij wat schreef, kwam hij vaak huilend uit zijn werkkamer met de woorden: 'Ik heb weer een beginnetje', om vervolgens een stukje tekst voor te lezen aan zijn vrouw. Die laatste werd weer deelgenoot van zijn leven en zijn gevoelens, ook die waar hij het zo moeilijk mee had.

Dat was ook de belangrijkste verbetering die zijn omgeving constateerde na de behandeling bij Bastiaans. Durlacher werd opener, toegankelijker, wat niet betekende dat hij opeens vaak of graag over de oorlog sprak. Toen Adriaan van Dis hem uitnodigde voor een interview, stemde hij toe onder de voorwaarde dat het interview werd opgenomen in een studio zonder publiek. Zijn boeken waren een manier om er niet over te hoeven spreken. Als zijn kinderen naar zijn ervaringen vroegen, verwees hij naar zijn boeken: 'Lees die eerst maar.'

Troostende illusie

De boeken van Durlacher maakten indruk op het Nederlandse publiek, en hij werd regelmatig uitgenodigd voor interviews, lezingen en debatten. Het waren aangrijpende en eerlijke verhalen over zijn ervaringen tijdens de oorlog en de nasleep daarvan. 
Een bijzonder aspect van zijn aanpak was dat hij heel precies wilde zijn in wat hij schreef. Toen Durlacher schreef dat de markiezen van een hotel eruitzagen als 'de parten van een meloen', ging hij op zoek naar foto's die dat konden bevestigen. ${ }^{55}$ Toen een auteur een fictieverhaal schreef over Auschwitz en daarin een scène beschreef waarin bloeddorstige honden zich stortten op de Joden die uit de veewagons werden geslagen, vond Durlacher dat kwalijk: bij het ontladen van de wagons in Auschwitz werden geen honden op de mensen losgelaten; dat gebeurde in Treblinka, een ander vernietigingskamp..$^{56}$

'Als er nu te literair over de oorlog geschreven wordt, zullen de mensen straks een onzuiver beeld van de oorlog hebben. Een onwaar beeld. ${ }^{57}$

Hij voelde zich verplicht om in ieder detail nauwkeurig te zijn. Hij was bang dat, als hij een feit verkeerd opschreef, dat tegen hem gebruikt zou worden; dat hij daarmee Holocaust-ontkenners in de kaart speelde. Toch kende ook Durlachers meedogenloze drang tot nauwgezette reconstructie zijn grenzen. In De zoektocht beschreef hij de zoektochtnaarde 99 jongens met wiehij in Auschwitz zat. ${ }^{58}$ Tijdens een reünie beschreef een van hen, Yehuda, hoe in Auschwitz soms een van de jongens werd aangewezen om Kapo te spelen over de andere jongens. Yehuda bewaarde goede herinneringen aan deze periodes waarin een 'quasi-Kapo' toezicht had gehouden. Durlacher deelde die herinnering niet:

'Al te helder staat mij een incident voor ogen waarbij een quasi-Kapo uit onze groep één van ons bloedig en meedogenloos in elkaar sloeg. Ik bespaar Yehuda die herinnering, want waarom zou ik hem beroven van de illusie van hechte kameraadschap? ${ }^{59}$

Durlacher wilde zijn oude kampgenoot niet beroven van de troostende gedachte dat er in de zwartste periode van hun leven onderling in ieder geval vriendschap en kameraadschap was geweest. Hij kende deze vervorming ook van zichzelf:

'In de jaren bij Bastiaans probeerde ook ik het mooier te maken dan het was. Ik dacht toen echt in termen van: de jongens. Ik gebruik die term nog wel eens, maar van een echte groep was in feite geen sprake. Het was een bij elkaar gegooid zooitje jongens dat soms wel, soms niet solidair was. ${ }^{60}$

Durlacher gunde zijn oude kampgenoot de warme herinnering van kameraadschap en solidariteit, ook al wist hij dat die herinnering vals was. Zijn eigen herinnering was anders, genuanceerder, minder warm en troostend. ${ }^{61}$ 


\section{Medisch en recreatief gebruik}

ruik van LSD beperkte zich eind jaren vijftig niet meer tot de aanvankeur medische setting; het werd naast een geneesmiddel ook een genotsDat begon bij een van de pioniers van het psychiatrisch LSD-onder$\geq$ eerdergenoemde dr. Sydney Cohen. Cohen was midden jaren vijftig $e$ indruk van het middel geraakt en startte een onderzoek. Hij vroeg :rs op te treden als proefpersonen omdat hij vermoedde dat zij veel beaat waren woorden te geven aan hun LSD-roes.

jvers als Gerard Heard, Allan Ginsberg, William Burroughs en Aldous voerden zelfexperimenten uit waarover ze rapporteerden. Huxley pule in 1954 zelfs een lofzang op het middel in zijn boek Doors of Percepti$z e$ 'proefpersonen' gebruikten $L S D$ ook als genotsmiddel. Het raakte in oredere kring bekend en werd eind jaren vijftig 'an intellectual fun

e Amerikaanse Harvard University werd het medisch juk waaronder dan toe gebukt was gegaan, definitief afgeschud onder aanvoering van linische psychologie T.F. Leary. Leary was niet op zoek naar de wortels s sychose of de versnelling van het therapeutisch proces. Voor hem had -roes een eigen kwaliteit: het bieden van een venster op de oneindige waar Huxley in zijn Doors of Perception over had geschreven.

enten raakten enthousiast over de religieuze en mystieke ideeën van Jesterkt door zijn inmiddels gegroeide achterban stapte Leary begin stig in het zoeklicht van de media en wierp zich op als woordvoerder Psychedelische beweging. LSD moest voor iedereen beschikbaar worlere burger had het recht om zijn 'doors of perception' te openen. Het toe1 recreatief gebruik baarde LSD-pionier Cohen al in 1959 zorgen en was m reden te breken met mensen als Huxley. ${ }^{64}$

:ecreatief gebruik van LSD waaide over naar Nederland, waar het in de a de jaren zestig eveneens onderdeel werd van de jeugdcultuur. Het was zet groepje kunstenaars rond de dichter Simon Vinkenoog dat LSD ge$\therefore$ Ook psycholoog Barendregt was geïnteresseerd in het middel en ge: het zowel bij zijn wetenschappelijke experimenten als samen met :n in de privésfeer.

5 het recreatief gebruik van LSD bleek ook nadelen te hebben. Het kon :ot langdurige somberheid, zelfmoordpogingen of psychoses die lang den en zelfs na weken of maanden spontaan terugkeerden. ${ }^{65}$ Vanaf het 1 van de jaren zestig verschenen er berichten in de pers over ongelukken, noord begaan onder invloed van LSD. ${ }^{66}$ LSD, tot dan toe slechts bekend kleine kring kunstenaars, intellectuelen en bohemiens, kreeg grote be:id. Het middel boezemde angst in: het was kleurloos, smaakloos en kon :st minieme hoeveelheden al geweldige effecten veroorzaken.

e onder druk van de berichten in de media - waarvan het dreigement 
van de recalcitrante provobeweging om het Amsterdamse leidingwater te besmetten met LSD het meest spectaculaire was - werd LSD in 1966 in Nederland opgenomen op lijst I van de Opiumwet. Dat was dezelfde lijst waar ook cocaïne, heroïne en morfine op stonden. In diezelfde periode volgden verboden in andere landen, en ook de Verenigde Naties vaardigden een verbod uit op recreatief gebruik. In Nederland bleef het mogelijk voor artsen om, net als bij morfine, een ontheffing van het verbod aan te vragen.

Medisch historicus Snelders beschreef dit verbod als een breuk in de geschiedenis van het medisch gebruik van LSD. ${ }^{67} \mathrm{Zijn}$ redenering laat zich als volgt samenvatten: de maatschappelijke onrust over de ongelukken bij recreatief gebruik stelde ook het gebruik van LSD in een medische setting in een kwaad daglicht. Snelders betoogde dat behandelaars en onderzoekers zich niet wisten te verzetten tegen deze zwartmakerij, of dat niet wilden, en dat zij om die reden vanaf 1966 afzagen van gebruik van het middel.

Er zijn vraagtekens te zetten bij deze redenering. De berichten in de media over LSD werden in de jaren voorafgaand aan het verbod weliswaar overheerst door de angst voor ongelukken, maar het betrof slechts angst voor de gevolgen van recreatiefgebruik, niet voor medische toepassing. In de berichtgeving over de ongelukken met LSD werd het recreatief gebruik veroordeeld, terwijl de mogelijkheid voor medisch gebruik open werd gelaten. ${ }^{68}$

Het verdwijnen van LSD uit het instrumentarium van de medici werd niet alleen veroorzaakt door een overheidsverbod; het werd mede veroorzaakt door een gebrek aan belangstelling. Vóór het verbod werd in de medische vakbladen in Nederland niet tot nauwelijks over het middel geschreven. De animo voor het middel was nooit groot geweest. In Nederland bleef het gebruik van LSD in psychiatrische behandelingen beperkt. Snelders noemde in zijn proefschrift maar zeven namen van psychiaters. ${ }^{69}$ De Hoofdinspecteur van de Volksgezondheid voor de Geneesmiddelen, dr. P. Siderius, schreef in een nota in 1966 dat er maximaal tien psychiaters in Nederland waren die met het middel hadden gewerkt. ${ }^{70}$ Ná het verbod werd van de mogelijkheid om ontheffing aan te vragen maar door drie psychiaters gebruikgemaakt. ${ }^{71}$

Dat dergelijke ontheffingen wel werden verleend, toonde aan dat de overheid openstond voor gemotiveerd gebruik door medici. Dat werd nog eens onderstreept toen de overheid, twee jaar na opname van LSD op de Opiumlijst, een documentaire subsidieerde waarin het medisch gebruik van LSD een prominente rol speelde. ${ }^{2}$ Bovendien voerde het Rijksinstituut voor Volksgezondheid (RIVG) in opdracht van de Inspectie voor de Geestelijke Volksgezondheid in de jaren 1969-1977 een onderzoek uit naar de mogelijk schadelijke invloed van LSD en psilocybine op chromosomen. ${ }^{73}$ Het was een teken dat de overheid aandacht had voor de zaak, maar zeker niet direct de LSD-therapie een halt wilde toeroepen.

Toch leek het jaar 1966, het jaar waarin het middel verboden werd, het einde 
van deze zijstroom van de psychiatrie in te luiden. Een enkele uitzondering daargelaten, koesterden medici in 1966 weinig illusies meer over de toepasbaarheid van LSD. Ze vonden de voordelen niet opwegen tegen de risico's of waren van mening dat er voldoende alternatieven voorhanden waren.

Drie psychiaters zagen na het ingaan van het verbod nog wél heil in het middel en vroegen bij het Staatstoezicht op de Volksgezondheid een ontheffing aan. Dat waren Bastiaans, G.W. Arendsen Hein en C.H. van Rhijn. De eerste twee kregen een ontheffing, maar Van Rhijn, die al vanaf het midden van de jaren vijftig met het middel had gewerkt, kreeg er geen. De reden was waarschijnlijk dat hij niet verbonden was aan een kliniek. Hij was daar overigens niet rouwig om. Hij schakelde over op een techniek die hij 'geleid dagdromen' noemde, waarvan hij later claimde dat deze succesvoller was dan LSD-therapie. $^{74}$

Psychiater Arendsen Hein gebruikte al vanaf het einde van de jaren vijftig LSD in zijn praktijk. Aanvankelijk paste hij het toe als alternatief voor de narcoanalyse, maar later neigde hij meer naar de psychedelische visie van Leary. Arendsen Hein had op de kliniek waar hij werkte alleen een behandeltaak; van hem waren niet per se onderzoeksresultaten te verwachten. Dat gebeurde ook niet na 1966. Arendsen Hein ging nog tot zijn pensioen in 1977 door met LSDbehandelingen op de kliniek, daarna nog enkele jaren in zijn privépraktijk. ${ }^{75}$

\section{Omstreden maar mediageniek}

Wanneer Bastiaans precies zijn eerste LSD-behandeling uitvoerde, laat zich niet meer vaststellen. In een interview in 1974 zei hij dat hij in 1961 voor het eerst LSD had toegepast; in 1968 schreef hij in een brief dat hij pas sinds 1964 , na de aanvaarding van zijn hoogleraarschap aan de Rijksuniversiteit Leiden, met enige regelmaat LSD toepaste. ${ }^{7}$ In ieder geval was Bastiaans op het moment dat hij een ontheffing aanvroeg nog niet lang bezig met het gebruik van LSD.

Het aanvragen van de ontheffing leek in tegenspraak met de sombere beweringen in zijn proefschrift uit 1957 over de effectiviteit van cathartische behandelingen zoals de narcoanalyse. In een artikel in 1970 had hij deze sombere verwachtingen herhaald. ${ }^{77}$ De reden hiervoor was dat de emotionele ontladingen volgens hem aanvankelijk wél tot een verlichting van de symptomen leidden, maar dat het resultaat niet blijvend was. Meestal waren na enkele maanden de klachten in volle hevigheid weer terug. Bovendien hadden de narcoanalyses een ongunstige invloed op "het meestal toch reeds licht diffuus beschadigde hersenweefsel' van de verzetsstrijders.$^{78}$ Deze teleurstelling in de narcoanalyse bleef Bastiaans tot het einde van zijn carrière herhalen: 
'Bij een eerste na-onderzoek over de resultaten van narcoanalyse bleek mij in het begin van de jaren zestig dat er bij jaren tevoren behandelde patiënten, toch weer herhalingen van hun kampsyndromen waren opgetreden dan wel van psychosomatische ziekten die al dan niet met kampsyndromen verbonden waren. ${ }^{79}$

Het na-onderzoek dat Bastiaans hier noemde, werd nooit gepubliceerd. Wat het precies inhield, bleef daarom onbekend. Een voor- en nameting met behulp van een gevalideerde vragenlijst? Een onderzoek in medische dossiers? Een indruk die hij had? Toch was het voor Bastiaans een belangrijk onderzoek, aangezien de negatieve resultaten hem deden zoeken naar alternatieve methoden. Die zoektocht bracht hem bij LSD. Het falen van de narcoanalyse bracht hem bij de psycholyse.

Bastiaans presenteerde zijn greep naar LSD dus als het resultaat van wetenschappelijke ontwikkeling: onderzoek had geleid tot verbetering van zijn therapeutische instrumenten. Hij schilderde daarbij de narcoanalyse af als inferieur aan de LSD-therapie. Ondanks deze ${ }^{i}$ wetenschappelijke ontwikkeling'bleef hij pentothal toepassen. Sterker nog: in de behandelingen waarbij hij een middel gebruikte, paste Bastiaans in de meerderheid van de gevallen pentothal toe. LSD was dus geen vervanging maar eerder een uitbreiding van zijn therapeutische instrumenten.

Ondanks Bastiaans' beperkte ervaring met het gebruik van LSD, stond de LSD-therapie sinds 1966, het jaar waarin LSD op de Opiumlijst werd geplaatst, in de belangstelling. Door de spectaculaire verhalen rond het recreatief gebruik, was het een mediageniek onderwerp. Journalisten meldden zich bij Bastiaans met vragen over de behandeling. Bastiaans roemde in interviews en tvoptredens de LSD-therapie. ${ }^{80}$

In dat jaar verscheen bijvoorbeeld de Nederlandse vertaling van een boek van LSD-pionier Sydney Cohen over het medisch gebruik van LSD: Bastiaans brak in het voorwoord een lans voor het medisch gebruik. ${ }^{81}$ Hij werd in datzelfde jaar op de Duitse televisie geïnterviewd en liet daar enkele filmfragmenten zien van LSD-sessies van verzetsstrijders die bij hem in behandeling waren. ${ }^{82}$ De Duitse en Nederlandse pers waren onder de indruk. Zoals Het Vrije Volk, dat kopte:

'De aangrijpende LSD-film van prof. Bastiaans: "Duitse tv-mensen werden er verlegen onder"., ${ }^{83}$

In december 1966 gaf Bastiaans samen met dr. N. Speijer, buitengewoon hoogleraar sociale psychiatrie aan de Leidse universiteit, een interview waarin hij wederom de loftrompet stak over LSD. ${ }^{84} \mathrm{Hij}$ vertelde hoe verzetsstrijders die op het oog niets mankeerden, de kampen opnieuw beleefden: 
'Tijdens een LSD-kuur stuitte je gewoon op een vulkaan. [...] Het mishandeld worden, de doodssituatie. Ze ruiken het crematorium opnieuw, horen de geluiden, zien de gezichten. ${ }^{85}$

De pessimistische vooruitzichten uit zijn proefschrift maakten halverwege de jaren zestig plaats voor een hoopvol uitzicht op genezing. Een hoop die Bastiaans samen met cineast Louis van Gasteren in 1967 besloot vast te leggen in een film waarin de LSD-behandeling een hoofdrol speelde. Bij deze film wordt in hoofdstuk 6 uitgebreid stilgestaan.

Bastiaans presenteerde de LSD-therapie als een noodzakelijke behandeling voor degenen die door de oorlog het zwaarst getroffen waren; hij zag het als de enig mogelijke uitweg voor hen uit de misère. Van begin af aan verdedigde Bastiaans zijn LSD-behandeling door te wijzen op het uitzonderlijke leed van oorlogsslachtoffers. Die vervlechting van LSD-therapie en de problematiek van oorlogsslachtoffers was niet vanzelfsprekend. Andere psychiaters hadden met hetzelfde doel als Bastiaans - het losmaken van herinneringen en emoties - verslaafden, homoseksuelen en dwangneurotici behandeld met het middel. Zij reserveerden de behandeling niet voor een specifieke groep patiënten.

In weerwil van Bastiaans' optimistische uitspraken in de pers werd de LSDtherapie door collega's kritisch bekeken. In 1968 sloeg de onverschillige houding onder Nederlandse psychiaters ten opzichte van LSD om in een kritischafwachtende houding.

Het startschot daarvoor werd gegeven door dr. J. Booij, hoogleraar geneeskunde aan de Vrije Universiteit in Amsterdam, die in een artikel in het Nederlands Tijdschrift voor Geneeskunde (NTVG) felle kritiek leverde op de LSD-therapie. ${ }^{86}$ Hij deed dat naar aanleiding van de zelfmoord van een patiënt van hem die ooit met LSD was behandeld. Booij zag een verband tussen de zelfmoord en de behandeling. Hij waarschuwde dat de enthousiaste verhalen over LSD niet ondersteund werden door gedegen onderzoek met behulp van controlegroepen. En dat was geen nieuwe kritiek; al in de jaren vijftig was deze kritiek te horen geweest. Booijs conclusie was onverbiddelijk:

'Welnu, wanneer na een periode van 15 jaren, het middel zijn nut niet heeft bewezen, moet men wel besluiten, dat het nut niet groot kan zijn, misschien wel in het geheel niet aanwezig is. ${ }^{87}$

Het artikel van Booij had tot gevolg dat ook andere hoogleraren hun ideeën over LSD lieten horen. Prof.dr. G.A. Ladee, hoogleraar psychiatrie aan de Erasmus Universiteit Rotterdam, was een ervaringsdeskundige. Toen hij nog als assistent werkzaam was op het Wilhelmina Gasthuis, had hij als vrijwilliger meegedaan aan Van Rees experimenten. ${ }^{8}$ Ladee zag wel toepassingen van het middel in de psychiatrie, zij het onder strikte voorwaarden. 
Prof.dr. P.C. Kuiper, hoogleraar psychiatrie aan de Universiteit van Amsterdam, hield dat jaar voor het ledencongres van de Koninklijke Nederlandse Maatschappij ter Bevordering der Geneeskunde een lezing over psychedelica. I-Iij sprak voornamelijk over het recreatief gebruik. Hij kon zich wel verplaatsen in de jeugd, die het middel leek te omarmen, maar benadrukte dat in de A msterdamse kliniek LSD niet werd gebruikt als therapeutisch middel. ${ }^{89}$

Prof.dr. H.M. van Praag, die in 1970 de eerste hoogleraar biologische psychiatrie in Nederland zou worden aan de Rijksuniversiteit Groningen, noemde LSD omstreden, met vooral buiten de kring van medici hartstochtelijke pleitbezorgers, en binnen de kring van medici tegenstanders. Van Praag was geïnteresseerd in de biologische aspecten van LSD en vond die de moeite van het onderzoeken waard. Hij achtte het te vroeg om de hoop op nuttige toepassing van LSD op te geven, en stelde de oprichting van een landelijk onderzoeksteam voor. ${ }^{90}$ Van Praags interesse lag niet in de therapeutische toepassing van het middel maar in de fysiologische werking. De therapeutische waarde van de psycholyse was volgens hem 'onzeker' en 'omstreden', zij het wel het onderzoeken waard.

De discussie liet zien dat de hoogleraren van mening waren dat onder medisch toezicht de gevaren beheersbaar waren, en dat ongecontroleerd recreatief gebruik als gevaarlijk moest worden beschouwd. Over de therapeutische waarde in een medische setting liepen de verwachtingen uiteen: sommigen vroegen zich af of op dat vlak überhaupt iets verwacht mocht worden, anderen waren hoopvoller. Maar allen waren het erover eens dat de therapeutische waarde nog bewezen moest worden, en dat dat alleen kon door gecontroleerd onderzoek uit te voeren.

Bastiaans had al eens eerder, samen met psycholoog Barendregt, een omvangrijk onderzoek naar de effectiviteit van psychotherapeutische behandelingen uitgevoerd, en beschikte over de middelen om dergelijk onderzoek uit te voeren. Hij leek de aangewezen persoon om de merites van de LSD-therapie vast te stellen. Maar Bastiaans liet in de discussie onder de hoogleraren in het NTVG niets van zich horen.

Zijn vermoedelijk eerste en enige rapportage over zijn LSD-therapie die verderging dan gevalsbeschrijvingen, gaf Bastiaans op een congres van de British Psychological Society in Londen in 1969, een jaar na het debat in het NTUG. Daar berichtte hij over de resultaten van zijn eerste 36 LSD-behandelingen: 9 Patiënten waren sterk vooruitgegaan, 14 in mindere mate verbeterd, 11 lieten geen verbetering zien en 2 patiënten waren achteruitgegaan..$^{91}$ In een artikel uit 1970 schreef hij nog dat afgewacht moest worden of de gunstige resultaten van de behandeling ook standhielden na enkele jaren.$^{92}$ Hoe Bastiaans het effect van de behandelingen had vastgesteld was overigens onduidelijk, maar het liet zien dat zelfs bij hem niet alle behandelingen een succes waren, en dat hij nog twijfelde aan de duurzaamheid van die successen. 


\section{Conclusies}

Vanaf het midden van de jaren zestig werd voor Bastiaans' behandelingen de uitdrukking 'de methode-Bastiaans' gebruikt. Die uitdrukking deed vermoeden dat wat er in de behandelkamer plaatsvond een unieke, door Bastiaans ontwikkelde behandeling was. Maar de hierboven beschreven geschiedenis laat zien dat de methoden die Bastiaans gebruikte, de narcoanalyse en de psycholyse, al enkele tientallen jaren oud waren. Van LSD kan worden gezegd dat het al in onbruik was geraakt voor Bastiaans ermee begon. Wat Bastiaans in zijn behandelkamer deed, hadden psychiaters vóór hem al eerder gedaan. Hij was de enige die dergelijke methoden bleef toepassen. Dat maakte hém wel uniek, maar zijn methode niet.

Bovendien was van beide instrumenten bekend dat er nadelen en soms zelfs gevaren aan kleefden. De roep om studies naar de effectiviteit werd door Bastiaans genegeerd. Noch over de effectiviteit van de narcoanalyse noch over die van de psycholyse legde Bastiaans wetenschappelijke verantwoording af. De bezwaren tegen beide methoden - het risico van het ontstaan van valse herinneringen zonder dat de behandelaar dat in de gaten had, het gevaar van soms levensgevaarlijke complicaties, de vraagtekens bij de effectiviteit - weerhielden hem er niet van zijn methode vanaf het midden van de jaren zestig in de media te presenteren als het laatste redmiddel voor overlevenden van de kampen.

De mediacampagne die hij voerde, was succesvol. Vanaf eind jaren zestig stond zijn methode bij het grote publiek bekend als een ultieme behandeling die bij de ernstigste gevallen soelaas kon bieden. Terwijl wetenschappers en psychiaters sceptisch stonden tegenover het gebruik van LSD, vertrouwde het grote publiek op Bastiaans' expertise en zijn belofte van genezing. De kloof die bestond tussen de wetenschappelijke onderbouwing en het maatschappelijke vertrouwen in de LSD-behandeling zou pas twintig jaar later zichtbaar worden. 
II

Doorbraak

1964-1972 


\section{De paradox van het $\mathrm{kz}$-syndroom}

'Men gaat uit van het standpunt dat slachtoffers niet langer kunnen wachten op medisch-statistisch bewijs."

DR. E.A. COHEN OVER CAUSAAL VERBAND BIJ KZ-SYNDROOM, 1969.

Inleiding

Bastiaans bleef na de voltooiing van zijn proefschrift werkzaam als chef de clinique op het Wilhelmina Gasthuis. Uit zijn wetenschappelijke publicaties sprak een blijvende interesse voor de psychosomatiek en de consequenties daarvan voor psychoanalytische behandeling. Zijn werk als chef de clinique en assistent van de hoogleraar werd gewaardeerd, en de net aangestelde hoogleraar psychiatrie dr. P.C. Kuiper drong in 1962 bij het College van Curatoren van de Universiteit van Amsterdam aan op bevordering van Bastiaans tot lector, een rang net onder die van hoogleraar. ${ }^{2}$ Dat was financieel aanvankelijk niet haalbaar, maar toen in 1963 het geld was gevonden wilde het bestuur van de faculteit Geneeskunde dat Bastiaans direct werd benoemd:

'Dr. Bastiaans is een voortreffelijke chef de clinique, een goed docent, een betrouwbaar medicus, die zeer gezien is bij assistenten en studenten. Hij is een uitstekend vakman en op de hoogte van de litteratuur. Het is een groot voorrecht dat hij zijn gaven en zijn kundigheid in dienst stelt van de psychiatrische universiteitskliniek. ${ }^{3}$

Enkele maanden nadat Bastiaans was aangesteld als lector medische persoonlijkheidsleer, werd hij benaderd door de Rijksuniversiteit Leiden, die op zoek was naar een opvolger voor de hoogleraar psychiatrie dr. E.A.D.E. Carp. Met Bastiaans' achtergrond als directeur van het Psychoanalytisch Instituut in Amsterdam, leek Leiden een veelbelovende hoogleraar binnen te halen. Het 
benoemingsrapport roemde Bastiaans' organisatorische gaven. Bastiaans werd in november 1963 benoemd tot hoogleraar psychiatrie in Leiden en directeur van de Jelgersmakliniek, de Leidse universitaire psychiatrische kliniek. ${ }^{4}$

Bastiaans schreef, op verzoek van de Curatoren van de Rijksuniversiteit Leiden, nog voor zijn ambtsaanvaarding een ambitieus ontwikkelingsplan voor een nieuw 'Instituut voor Psychiatrische Wetenschappen', dat binnen tien jaar moest zijn gerealiseerd en dan zijn opgenomen in de rest van het academisch ziekenhuis. ${ }^{5}$ Het aantal afdelingen van het Instituut zou worden uitgebreid van 3 naar 5 , het aantal personeelsleden van 43 naar 125 en het aantal patiënten van 80 naar 120 .

Bastiaans stelde specifieke eisen aan de nieuwbouw, die een perceel van 6 hectare zou moeten bestrijken:

'Zulks omdat het zich min of meer vrijelijk kunnen bewegen van psychiatrische patiënten in de belevingsruimte zo belangrijk is voor het bereiken van een goed therapeutisch resultaat. ${ }^{6}$

De Curatoren van de Universiteit Leiden konden zich vinden in de plannen, maar hadden noch de mogelijkheid noch de middelen om een dergelijk omvangrijk en kostbaar project toe te zeggen. Afgesproken werd dat Bastiaans bij zijn aanstelling in ieder geval zes nieuwe medewerkers zou krijgen. De verdere uitwerking van de plannen moest hij in overleg met de medische faculteit regelen. Zijn plannen moesten passen bij de rest van de nieuwbouwplannen voor het ziekenhuis. ${ }^{7}$

In een memorandum uit 1970 moest Bastiaans concluderen dat er weinig van het plan was terechtgekomen. De geplande uitbreiding van het aantal personeelsleden voor 1965 was zelfs in 1970 nog niet bereikt. Hij noemde het traject een 'Leidensweg' en voelde zich bedrogen door het bestuur van zijn faculteit en het College van Curatoren:

'De vraag moge hiermede verbonden worden in hoeverre het zin heeft dat Faculteitsbesturen en Colleges van Curatoren hoogleraren aantrekken in het vooruitzicht dat de door hen goedgekeurde ontwikkelingsplannen toch geen enkele kans van slagen hebben. ${ }^{8}$

De plannen voor de herinrichting van de academische ziekenhuizen in Nederland hadden zijn eigen plannen doorkruist. De nieuwbouwplannen golden niet alleen voor Leiden, maar ook voor Utrecht en Amsterdam, en werden landelijk gecoördineerd. Hoewel Bastiaans in het plan voor zijn Instituut de wens had uitgesproken de Jelgersmakliniek te laten opgaan in het grotere Academisch Ziekenhuis Leiden (AZL), wilde hij de eis van de 6 hectare grond voor de psychiatrie niet loslaten. Die eis zou nimmer ingewilligd kunnen worden, dus 
verzette Bastiaans zich tegen opname in het AzL. De ontwikkeling van de Leidse psychiatrie belandde begin jaren zeventig in een jarenlange impasse.

Bastiaans' interesse voor de gevolgen van de oorlog leek na zijn proefschrift een sluimerend bestaan te leiden; uit zijn plannen voor het Instituut, zijn oratie en zijn wetenschappelijke publicaties van die periode bleek geen buitengewone belangstelling voor het onderwerp. Wel hielp hij verzetsstrijders soms nog bij aanvragen voor een Buitengewoon Pensioen en had hij enkele van hen in behandeling.

In 1961 vond in Den Haag een internationaal congres plaats over de verlate gevolgen van de oorlog. Dr. F. Wibaut, oogarts en tijdens de oorlog betrokken bij het artsenverzet, presenteerde daar de resultaten van een onderzoek onder de aanvragers van een Buitengewoon Pensioen. Hij had geïnventariseerd wat de meest voorkomende klachten waren onder die groep. ${ }^{9}$ Bastiaans was aanwezig als toehoorder op het congres.

$\mathrm{Na}$ zijn aantreden als hoogleraar psychiatrie, zou Bastiaans echter spoedig uitgroeien tot dé expert op het gebied van de verlate gevolgen van de oorlog. Zijn naam zou er onlosmakelijk mee verbonden blijven. Vanaf het midden van de jaren zestig werd door psychiaters en onderzoekers aan die gevolgen de naam ' $\mathrm{KZ}$-syndroom' gegeven. ${ }^{10}$ Maar wat werd er bedoeld met die term?

\section{De Wind en de Spätfolge-groep}

De sociologe dr. J. Withuis en de historica dr. A. Mooij wezen er enkele jaren geleden op dat het idee dat er pas rond 1970 voor het eerst over de psychische gevolgen van het verblijf in de kampen werd nagedacht, een mythe was. ${ }^{11} \mathrm{Al}$ tijdens de oorlog waren er psychiaters die daar aandacht aan besteedden, zoals A.J.W. Kaas, J.A.M. Meerloo, J. Tas, A.A. van Dantzig, E. de Wind, en ook de arts E.A. Cohen. Zij behoorden tot een generatie auteurs die hier direct na de oorlog over schreef. ${ }^{12} Z$ e behandelden in hun publicaties hoofdzakelijk de reacties van gevangenen tijdens hun verblijf in de kampen, maar in enkele artikelen werd al voorzichtig gewezen op de gevolgen voor de wat langere termijn.

In de daaropvolgende jaren hield slechts een beperkte groep medici, psychiaters en juristen zich bezig met dit onderwerp. Er vonden enkele congressen plaats waar over de langere-termijngevolgen van de oorlog werd gesproken. ${ }^{13}$ Was er sprake van problemen die alleen bij de groep overlevenden van de kampen voorkwamen en niet bij anderen? Hoe kon een verband worden gelegd tussen latere klachten en de omstandigheden in de oorlog? De vaststelling van het causaal verband bleef een lastig maar belangrijk probleem. Soms was de toekenning van een uitkering of schadevergoeding ervan afhankelijk. 
Begin jaren zestig verschenen er nieuwe onderzoeken, zoals Psychiatrie der Verfolgten van Ritter von Baeyer, Häfner en Kisker, en Psychische Spätschäden nach politischer Verfolgung van Paul en Herberg, die internationaal de aandacht trokken. ${ }^{14}$ De aandacht onder psychiaters voor de gevolgen van verblijf in de kampen groeide ook in Nederland. Aanleiding hiervoor was de toekenning van Duitse schadevergoedingen aan overlevenden.

De oordelen over het causaal verband waren een belangrijk onderwerp in de boeken. Het probleem was nu lastiger dan enkele jaren na de oorlog. Sommige overlevenden hadden enkele jaren, soms zelfs tien of twintig jaar lang, een ogenschijnlijk normaal bestaan geleid voordat ze ziek werden. Hoe kon worden vastgesteld dat klachten die zich pas twintig jaar na de oorlog openbaarden, een verlate reactie waren op wat er in de oorlog was gebeurd?

Psychiater E. de Wind nam in januari 1964 het initiatief voor een nieuw Nederlands onderzoek naar deze verlate gevolgen. Het veronderstelde verband tussen de verlate klachten en de oorlog was volgens hem evident, maar nog nooit onderbouwd met cijfers. In een brief aan de latere hoogleraar huisartsengeneeskunde B.S. Polak wees hij erop dat het verband in individuele gevallen wel aannemelijk te maken was, maar nooit te verifiëren. Het steunde op de stelling dat de overlevenden eerder stierven en vaker ziek waren dan personen uit controlegroepen, die niet gedeporteerd waren geweest. ${ }^{15}$ Maar zelfs die laatste aanname was volgens De Wind nog nooit met cijfers onderbouwd. ${ }^{16}$

In 1964 richtte De Wind de 'Spätfolge-groep' op. ${ }^{17}$ Op 31 januari vond op het RIOD de eerste bijeenkomst plaats. Aanwezig waren: Bastiaans, net benoemd tot hoogleraar psychiatrie; dr. L. de Jong, historicus van het RIOD; dr. H. Hers, internist en overlevende van Sachsenhausen; dr. W.M.E. Noach, lector in de criminologie; B.A. Sijes, onderzoeker van het RIOD. De Wind sneed op deze bijeenkomst het kernprobleem van de verlate gevolgen aan. Of het nu ging om de Duitse Wiedergutmachungs-gelden of het Nederlandse Buitengewoon Pensioen, alle onderzoeken kampten met hetzelfde basisprobleem, aangezien, zo zei De Wind:

'alle onderzochte personen één factor gemeenschappelijk hebben: zij hebben zich als ziek gemeld. Bovendien hebben zij zich ziek gemeld met een doel: het verkrijgen van een schadeloosstelling. [V]an bepaalde Duitse zijde wordt wel gesteld dat de Wiedergutmachung de ziekteverschijnselen activeert en dus velen van de patiënten [...] in wezen rente-neurotici zijn. ${ }^{18}$

Omdat overlevenden zich meldden voor een uitkering, hadden zij er belang bij om klachten te presenteren. Zo stond er dus een 'beloning' op het hebben van klachten. Was die beloning er niet geweest, dan hadden zij zich wellicht niet gemeld met klachten. 
De Wind presenteerde een cynische methodologische vondst. Hij wilde in een nieuw onderzoek de verlate gevolgen onderzoeken bij een groep die geen aanspraak kon maken op een uitkering, maar wel gedeporteerd was geweest: de Nederlandse Joden. Bij hen wilde hij klachten die later dan twee jaar ná de oorlog waren ontstaan, onderzoeken. ${ }^{19}$ Dat was mogelijk omdat Joden in Nederland in het begin van de jaren zestig een eenmalige schadevergoeding aan konden vragen bij het Centraal Afwikkelingsbureau Duitse Schadeuitkeringen (CADSU) ${ }^{20}$ Het CADSU had op die manier een omvangrijk adressenbestand opgebouwd. De Wind en zijn Spätfolge-groep wilden hier een steekproef uit trekken om de aanwezigheid van verlate gevolgen te onderzoeken.

Uit de notulen van de eerste bijeenkomsten bleek dat de onderzoekers het onderwerp uiterst delicaat vonden. ${ }^{21}$ Konden overlevenden wel benaderd worden voor een dergelijk onderzoek? Bastiaans' psychologen van de Jelgersmakliniek, die een enquête zouden opstellen, hadden aanvankelijk bezwaren. Ze betwijfelden of het verantwoord was om overlevenden te belasten met vragen naar hun verleden, uit vrees dat de emoties die dat opriep schadelijk zouden zijn. ${ }^{23} \mathrm{Ze} \mathrm{stel-}$ den uiteindelijk wel een vragenlijst op, die echter nooit gepubliceerd is.

De historicus dr. Lou de Jong had ervaring met het interviewen van overlevenden van de kampen. Hij wist te melden dat zijn interviewers vaak na twee weken moesten stoppen omdat ze de verhalen van de geïnterviewden niet meer aankonden. Hij vroeg zich tegelijkertijd af of het voor de overlevenden zelf ook zo belastend was; hoewel de gesprekken soms emotioneel werden, waren overlevenden achteraf vaak blij over hun ervaringen gesproken te hebben.

De groep zelf besloot alleen 'ervaren medici en psychologen van boven de veertig' in te zetten om de enquêtes af te nemen. De oorspronkelijk ambitieuze plannen van de Spätfolge-groep liepen uiteindelijk op niets uit, waarschijnlijk als gevolg van de weigering van het CADSU inzage te geven in het adressenbestand. ${ }^{22}$

Het werk van de groep van De Wind had de complexiteit van de problematiek van de verlate gevolgen blootgelegd. Als personen uit de groep overlevenden van de kampen eerder stierven en vaker ziek waren dan personen uit controlegroepen, dan was dat een aanwijzing dat de groep overlevenden kwetsbaarder was door het verblijf in de kampen. Maar niet alle overlevenden werden ziek en niet alle ziekten van overlevenden waren te wijten aan een verblijf in de kampen. Ook binnen de groep overlevenden konden klachten door andere factoren worden veroorzaakt, zoals ouderdom, ongelukken of erfelijkheid.

Een onderzoek dat zou aantonen dat personen uit de groep overlevenden gemiddeld eerder stierven en vaker, ernstiger en langer ziek waren dan personen uit controlegroepen, zou het beantwoorden van de causaliteitsvraag in individuele gevallen dus niet meteen makkelijker maken. Het zou de verlate gevolgen wel aannemelijker kunnen maken en als basis kunnen dienen voor 
verder onderzoek. Maar zoals het initiatief van De Wind liet zien, waren onderzoekers en instanties huiverig om de overlevenden via een dergelijk onderzoek te belasten met hun verleden. Vermoedelijk staakte de Spätfolge-groep haar werk begin $1966 .^{24}$

\section{Het ontstaan van de paradox}

De aandacht voor de verlate gevolgen groeide, ook in andere landen, en de gevolgen kregen een naam. De onderling uitwisselbare begrippen ' $\mathrm{KZ}$-syndroom', '(post)concentratiekampsyndroom', 'survivor-syndrome' en 'kampsyndroom' deden hun herintrede in de medisch-psychiatrische literatuur. In dit boek wordt de voorkeur gegeven aan de term ' $\mathrm{KZ}$-syndroom' aangezien dit de term is die Bastiaans doorgaans gebruikte. ${ }^{25}$

Een van de grote namen op het gebied van de verlate gevolgen was de Noorse hoogleraar psychiatrie dr. Leo Eitinger. Hij had als Jood Buchenwald en Auschwitz overleefd en zich na de oorlog gespecialiseerd in onderzoek naar en behandeling van de gevolgen van de kampen. Vooral zijn onderzoek uit 1964 onder gedeporteerde Noorse verzetsstrijders en gedeporteerde Joden die na de bevrijding naar Israël waren geëmigreerd, bracht hem internationaal grote bekendheid. ${ }^{26}$

Eitinger gebruiktein zijn onderzoek de term ' $\mathrm{Kz}$-syndroom', een term die de Denen al in 1954 hadden gebruikt, maar niet met dezelfde betekenis. Hij hanteerde een strikte definitie, waarbij het $\mathrm{Kz}$-syndroom pas werd vastgesteld wanneer er vijf symptomen van een lijst van elf werden gesignaleerd. ${ }^{27}$ In zijn verklaring van het $\mathrm{KZ}$-syndroom had hij 'verhongering', de belangrijkste oorzaak in de definitie van de Denen, vervangen door 'stress'. Eitinger legde in zijn onderzoek de nadruk op fysieke stress (ziekte, mishandeling, slaaptekort, et cetera), maar hij maakte ook gebruik van de ideeën van de psychosomatiek: chronische psychische stress kon volgens hem een even desastreuze invloed hebben en tot de symptomen leiden. ${ }^{28}$

$\mathrm{Na}$ de pogingen van De Wind om een onderzoek te starten, duurde het nog een paar jaar voor het $\mathrm{kz}$-syndroom zijn intrede deed in de medisch-psychiatrische literatuur in Nederland. Het eerste artikel dat in een Nederlands wetenschappelijk tijdschrift verscheen over het $\mathrm{kz}$-syndroom, was vermoedelijk het artikel uit 1969 van dr. E.A. Cohen. Cohen was in 1952 gepromoveerd op een proefschrift over de psychologie van de kampgevangene. ${ }^{29} \mathrm{Hij}$ gaf een overzicht van de resultaten en gedachten die onderzoeken in het buitenland, voornamelijk Denemarken en Noorwegen, hadden opgeleverd. Hij presenteerde zelf geen onderzoeksresultaten.

Er volgden meer auteurs: in 1970 Bastiaans met zijn eerste artikel over het Kz-syndroom, in 1973 de psychiaters A. Hustinx en dr. H. Musaph. ${ }^{30}$ In 1976 
schreef psycholoog L. van Ravesteijn een artikel vanuit het perspectief van de behandelaar. ${ }^{31}$ Anderen, zoals De Wind, Noordhoek Hegt en psychiater Meerloo, schreven ook over verlate gevolgen, maar niet expliciet over het $\mathrm{Kz}$-syndroom. ${ }^{32}$ Alle artikelen waren beschouwingen gebaseerd op onderzoek uit het buitenland, soms aangevuld met een of meerdere gevalsbeschrijvingen uit de eigen praktijk. Geen van de auteurs presenteerde kwantitatief of systematisch uitgevoerd onderzoek zoals bijvoorbeeld Eitinger had gedaan.

Het ontbrak daardoor in Nederland aan een eenduidige omschrijving van het Kz-syndroom. Dat gaf psychiaters de ruimte het begrip een eigen invulling te geven. Tekenend hiervoor was de wijze waarop psychiater H. Musaph in 1973 zijn artikel over het $\mathrm{Kz}$-syndroom opende:

'Onder het post-concentratiekampsyndroom (afgekort $\mathrm{KZ}$-syndroom) versta $i k$ het complex van geestelijke en lichamelijke verschijnselen, dat kenmerkend is voor mensen die langdurig een zwaar psychisch oorlogstrauma hebben doorgemaakt. ${ }^{33}$

Musaph beschreef in de eerste persoon enkelvoud wathij als het Kz-syndroom zag. De gemene deler onder de auteurs was dat klachten die meer dan twintig jaar na de bevrijding ontstonden en in verband stonden met de oorlog, 'verlate klachten' waren. Het Nederlandse $\mathrm{Kz}$-syndroom kende zowel psychische als somatische symptomen, zoals: snelle vermoeibaarheid op zowel geestelijk als lichamelijk vlak, prikkelbaarheid, voortijdige veroudering en sterfte, angstklachten, slaapstoornissen (onder andere nachtmerries), depressieve klachten, seksuele moeilijkheden, denk- en geheugenstoornissen, hartklachten, aandoeningen aan de bloedvaten, diabetes, reumatische klachten, hernia's. ${ }^{34}$

De Nederlandse auteurs benadrukten dat het vooral een 'psychisch oorlogstrauma' was. Niet de chronische ondervoeding, de vlektyfus, de tbc, de zware fysieke arbeid, de uitputting of de mishandeling kwam centraal te staan, maar de psychische traumatisering in de kampen. Bastiaans noemde als specifieke psychische oorzaak vaak: 'machteloosheid leidend tot een contactisolement'. Voor De Wind stond 'de confrontatie met de dood' centraal, en Musaph noemde vooral 'de vervolging en de dehumanisering'.

De psychosomatiek was uitermate geschikt als verklaringsmodel voor het $\mathrm{Kz}$ syndroom. Ook de Noor Eitinger was een 'psychosomaticus', hoewel niet zo radicaal als de leden van de Psychosomatische Werkgroep. Met behulp van de psychosomatiek konden zowel de somatische klachten als de 'verlaatheid' van de gevolgen worden begrepen. De stress van de kampen leidde tot spanningen; die spanningen konden door verdringing jarenlang opgepot blijven en uiteindelijk tot psychische en somatische klachten leiden. Het was dan ook niet toe- 
vallig dat drie van de auteurs die over het $\mathrm{KZ}$-syndroom schreven - Bastiaans, Hugenholtz en Musaph - verbonden waren geweest aan de Psychosomatische Werkgroep.

Het multisymptomatische karakter van het $\mathrm{Kz}$-syndroom was kenmerkend in de Nederlandse publicaties. Het probleem was niet zozeer welke symptomen bij het $\mathrm{KZ}$-syndroom pasten, als wel welke symptomen er niet bij pasten. Het causaal verband werd het onderscheidende kenmerk voor het $\mathrm{KZ}$ syndroom; het onderscheid tussen bijvoorbeeld een 'normaal' hartinfarct en een $\mathrm{Kz}$-syndroom was dat het laatste een causaal verband met de oorlog kende.

De auteurs waren zich bewust van de moeilijkheden die zich voordeden bij het oordelen over een causaal verband tussen klachten en de oorlog. Ze waren vrijwel allemaal op de een of andere manier betrokken bij het aanvraagproces voor een Buitengewoon Pensioen en later de Wet Uitkering Vervolgingsslachtoffers. In 1970 schreef psychiater, lector antropologische psychopathologie en medisch adviseur van de Stichting 1940-1945, dr. P.Th. Hugenholtz, over de problemen die daarbij kwamen kijken. ${ }^{35}$ Het was voor hem ook, en misschien wel vooral, een menselijke kwestie: het vaststellen van het verband was noodzakelijk voor het verkrijgen van een uitkering.

Het oordeel over het verband werd bovendien bemoeilijkt doordat patiënten zelf de neiging vertoonden een verband met de oorlog te ontkennen. Het $\mathrm{KZ}$-syndroom kon alleen door een kundig psychiater worden vastgesteld, een psychiater die voeling had met de problematiek van de slachtoffers. De arts dr. E.A. Cohen schreef daarover in 1969:

'[D]e niet-specifieke deskundigen kunnen bijna niet meer het onderscheid maken tussen de invaliditeit die veroorzaakt wordt door de late gevolgen van verzet en deportatie, en de invaliditeit die het gevolg is van de hogere leeftijd en later doorgemaakte ziekten. ${ }^{36}$

Cohen pleitte ervoor om de keuringen alleen te laten doen door artsen die zelf ook gevangen hadden gezeten, en bij twijfel de aanvrager altijd het voordeel van de twijfel te geven. ${ }^{37}$ De Stichting 1940-1945, die betrokken was bij de aanvragen voor een Buitengewoon Pensioen, had om die reden keuringsartsen in dienst die uit het verzet afkomstig waren en voeling hadden met de problematiek. ${ }^{38}$

Musaph waarschuwde voor slachtoffers met een 'pathologische gezondheid'. Dat waren slachtoffers die de kampen of het verzet hadden overleefd en 'weigerden' symptomen te vertonen; zij verzetten zich tegen de ziekte. Maar zoals een douanier een smokkelaar bij de grensovergang herkent aan zijn pogingen om normaal te lijken, herkenden psychiaters de lijders aan het $\mathrm{kZ}$-syndroom. $^{39}$ 
Hugenholtz schreef in 1970 dat jonge artsen vaak niet in staat waren het verband te herkennen. Doordat ze het niet herkenden, miskenden ze de problemen van de overlevenden. Dat gebrek aan erkenning was voor de overlevenden vaak een nieuwe frustratie:

'Erkenning is ook de gewoon menselijke zaak van "Begrijp je nu, waarom ik huil?" Maar helaas zijn er - en natuurlijk komen er eerder meer dan minder artsen, die zich meer beroepen op onderzoeksgegevens als röntgenfoto's en al of niet verwijde ventrikels of op de gegevens van de statistiek en de literatuur (alsof dat iets zou bijdragen tot begrip voor de concrete situatie van de patiënt), dan dat ze willen meevoelen en begrijpen. Men beroept zich dan liever op de "objectiviteit" van het onderzoek, dan dat men zich durft te begeven in de "subjectiviteit" van het lijden en het waarom daarvan.40

Het tonen van begrip voor de klachten van de overlevende was belangrijker dan de wetenschappelijke onderbouwing van het causaal verband. Zo sloop er een oneigenlijk element in het gebruik van de diagnose: het was niet alleen een technisch instrument voor psychiaters, maar kreeg ook een maatschappelijke functie: psychiaters konden er hun begrip voor de problemen van overlevenden mee tonen.

De groep die kon lijden aan het $\mathrm{Kz}$-syndroom dijde steeds meer uit. Dat kon enerzijds omdat er geen beperking werd aangebracht in de symptomen die konden wijzen op het $\mathrm{kz}$-syndroom; vrijwel alle klachten konden worden veroorzaakt door de oorlog. Anderzijds was een verblijf in de kampen geen noodzakelijke voorwaarde meer. Ook psychische spanningen waaraan geen kampverleden ten grondslag lag, konden tot een $\mathrm{kz}$-syndroom leiden. De Nederlandse auteurs waren van mening dat ook niet-gedeporteerde verzetsstrijders en niet-gedeporteerde Joden aan het syndroom konden lijden. Ookzij konden aan ondraaglijke spanningen hebben blootgestaan tijdens bijvoorbeeld een onderduikperiode. In de jaren zeventig ontdekten de auteurs zelfs dat 'explosies, aardbevingen, schipbreuken en overstromingen' in vredestijd konden leiden tot een $\mathrm{Kz}$-syndroom. ${ }^{41}$

Hoewel de Nederlandse wetenschappers de grenzen van het Kz-syndroom oprekten, bleven zij verwijzen naar de onderzoeken uit het buitenland. Maar konden de resultaten van die onderzoeken representatief worden geacht voor die andere groepen? Het werd door de Nederlandse auteurs niet onderzocht. Op basis van theoretische overwegingen en ervaringen in de eigen praktijk werd het $\mathrm{kz}$-syndroom ingevuld.

De groep psychiaters achtte het causaal verband bij veel klachten dan wel aanwezig, andere artsen hadden grote moeite om dat verband aan te tonen. Dat had tot gevolg dat bij de aanvragen voor een Buitengewoon Pensioen eind jaren zestiglange wachtlijsten ontstonden, met de bijbehorende frustraties. $\mathrm{Om}$ 
daar een einde aan te maken, voerde de overheid in 1970 voor de Wet Buitengewoon Pensioen de 'omgekeerde bewijslast' in. ${ }^{42}$ Bij verzetsstrijders die meer dan 60 procent invalide waren en ten minste drie maanden gevangen hadden gezeten of op een andere manier aan buitengewoon zware en langdurige spanningen hadden blootgestaan, werd voortaan het causaal verband aangenomen, tenzij hun klachten duidelijk door een andere oorzaak waren ontstaan. Volgens Cohen was de nood onder overlevenden te hoog geworden, en was dat besef ook doorgedrongen tot de overheid:

'Men gaat uit van het standpunt dat slachtoffers niet langer kunnen wachten op medisch-statistisch bewijs. ${ }^{33}$

Daarmee werd de oplossing die in Frankrijk kort na de oorlog al in gebruik was, nu ook in Nederland ingevoerd. Het werd eenvoudiger om een uitkering toe te kennen, maar eens te meer was gebleken dat het vaststellen van het causaal verband een lastige kwestie was. Zo ontstond eind jaren zestig de paradox van het Nederlandse Kz-syndroom: iedereen nam aan dat het bestond, maar niemand kon het bewijzen.

\section{Het $\mathrm{kz}$-syndroom volgens Bastiaans}

In mei 1970 kwam Bastiaans' eerste voor wetenschappers bedoelde tekst over het Kz-syndroom gereed. Deze zou pas in 1973 worden gepubliceerd als hoofdstukin een boek onder de titel 'Vom Menschen im $\mathrm{kZ}$ und vom $\mathrm{Kz}$ im Menschen'. In de tekst wekte hij de indruk dat hij al sinds de oorlog onderzoek deed naar het $\mathrm{KZ}$-syndroom en de behandeling ervan. Die suggestie was niet helemaal terecht; hij had weliswaar naam gemaakt met de behandeling van verzetsstrijders, maar dat had zich niet vertaald in onderzoek. Desondanks beschreef hij, zich beroepend op zijn ervaring, de drie fasen die het syndroom volgens hem vertoonde. Hij baseerde zich hierbij deels op zijn proefschrift, waarin hij een literatuurstudie over het Deense Kz-syndroom had opgenomen. ${ }^{44}$

De eerste fase, die in de eerste maanden na de oorlogsstress intrad, kenmerkte zich door aspecifiek nerveus gedrag, rusteloosheid, prikkelbaarheid, nachtmerries met herbelevingen van de oorlogservaring, vermoeidheid en zwakte. Soms ook klachten aan de orgaansystemen (bijvoorbeeld hart- en vaatstelsel, maag- en darmstelsel, ademhalingsstelsel), en het bewegingsapparaat.

Dan, na een periode van enkele maanden tot enkele jaren waarin de symptomen van de eerste fase soms verdwenen, volgde de tweede fase, die werd bepaald door depressies en een toestand van 'chronisch gespannen prikkelbare overactiviteit'. Ook in deze fase konden psychosomatische syndromen ontstaan zoals hoge bloeddruk, hartinfarct, maagzweren, reumatische klachten en astma. In deze fase was het moeilijk om het verband met de oorlog waar te nemen.

100 
In de derde fase kon volgens Bastiaans soms het 'Targowla-syndroom' ontstaan. De Franse psychiater Targowla had na de Eerste Wereldoorlog veteranen gezien die, in een toestand van verlaagd bewustzijn, door bepaalde prikkels herbelevingen van de traumatische ervaringen kregen, alsmede nachtmerries en andere slaapproblemen, angsten, depressies en paranoïde gedachten. In extreme gevallen konden de spanningen ook tot de dood leiden..$^{45}$

Bastiaans beschreef het $\mathrm{KZ}$-syndroom als een aanpassingsproces dat begon in de kampen en daarna een leven lang werkzaam bleef. Het was geen autonoom proces dat zich exclusief bij de overlevende voltrok; de fasering die Bastiaans zag in het $\mathrm{kz}$-syndroom, hield volgens hem gelijke tred met de medische, maar ook maatschappelijke erkenning van het probleem. Zo zag hij de verdringing, die bij vele overlevenden na terugkeer was ingetreden, terug in de reactie van medici en maatschappij op de problemen van de overlevenden direct na de bevrijding. Er was volgens hem een 'collectieve loochening', een nietwillen-weten:

'Als steeds bestaat bij er bij niet-psychiaters de cultureel begrijpelijke doch duidelijke weerstand tegen opvattingen van psychiaters en psychosomatici, doch het lijkt wel of in deze uitzonderlijke situatie de mensheid in het algemeen en de medici in het bijzonder eigenlijk niet geconfronteerd willen worden met wat nawerking van extreme mentale beschadiging in feite is. ${ }^{346}$

Overlevenden kwamen in wat Bastiaans een 'contactisolement' noemde: ze waren niet in staat te spreken over wat hun was overkomen en probeerden het te vergeten, te verdringen. Het gevolg was dat artsen zich richtten op de wél zichtbare, lichamelijke klachten. Doordat de overlevenden hun spanningen onderdrukten, ontstonden de klachten van de tweede fase. In de jaren vijftig werden overlevenden dus grotendeels in de tweede fase 'gedrongen' door een maatschappij die niet wilde luisteren naar hun noden. Dat was precies de fase waarin het verband moeilijk te herkennen bleek.

Het KZ-syndroom was een uitgesproken voorbeeld van de psychosomatiek. Dat was dan ook de discipline die, volgens Bastiaans, voor het eerst de collectieve loochening had doorbroken. De psychosomatiek had de verbanden gezien voordat de andere medische disciplines daartoe in staat waren. In een interview met Bibeb in 1970 vertelde Bastiaans dat hij al lang had opgegeven om collega-medici met wetenschappelijk onderzoek te overtuigen:

'Dan kan je proberen uit al je onderzoekingen te komen tot een bewijs dat absoluut waterdicht is. Maar mijn ervaringen draag je niet in een boek over. Dat blijven voor de tegenpartij ervaringen van gekken, geleverd door een psychiater die zelf gek is. ${ }^{37}$ 
Bij de overige medici en de rest van de maatschappij was er sprake van loochening van het besef dat de klachten van overlevenden verlate gevolgen waren van de oorlogsstress:

'Veel medici willen van psychosomatische verbanden niets weten. Dit nietaanvaarden is eigenlijk niet zozeer een aangelegenheid van niet-weten, alswel een aangelegenheid van niet-willen-weten of niet-kunnen-weten op grond van dreiging die een dergelijke erkenning van "causaal verband" voor de onderzoekers en andere betrokkenen kan impliceren. Als men een dergelijk verband moet accepteren, moet men ook durven erkennen dat men zelf, vroeg of laat, wel eens het slachtoffer zou kunnen worden, lichamelijk slachtoffer van onverwerkte spanningen. ${ }^{48}$

Die loochening werd volgens Bastiaans pijnlijk zichtbaar bij de aanvragen voor een uitkering. Of een causaal verband werd vastgesteld, was in die procedures volgens hem afhankelijk van de houding van de beoordelend arts ten opzichte van dit vraagstuk; erkende deze de psychosomatiek, dan was een verband eerder en makkelijker aan te tonen dan wanneer hij de psychosomatiek verwierp.

Zo raakte Bastiaans' psychosomatiek vervlochten met het $\mathrm{Kz}$-syndroom. Wie het bestaan van het Kz-syndroom erkende, erkende ook de psychosomatiek. Wie het Kz-syndroom niet erkende, verwierp niet alleen de psychosomatiek, maar wilde ook niet weten van de gruwelen in de kampen.

Bastiaans' gedachten over het $\mathrm{Kz}$-syndroom veranderden na het eerste artikel uit 1970 niet principieel meer. Hij schreef over het $\mathrm{KZ}$-syndroom in datzelfde jaar een artikel in het Militair Geneeskundig Tijdschrift; in 1973 een hoofdstuk in een boek, getiteld 'Vom Menschen im Kz und vom Kz im Menschen' en in 1974 een artikel in het Nederlands Tijdschrift voor Geneeskunde. De artikelen bevatten geen nieuwe gedachten ten opzichte van het artikel uit 1970. Grote delen van de teksten werden zelfs letterlijk overgenomen.

Wat wel gebeurde, was dat de groep personen die aan het $\mathrm{Kz}$-syndroom konden lijden, steeds omvangrijker werd. Dit fenomeen deed zich niet alleen bij Bastiaans voor, maar ook bij de anderen die over het $\mathrm{KZ}$-syndroom schreven. Lag in de eerste artikelen nog de nadruk op de overlevenden van de kampen, spoedig kwamen daar de niet-gedeporteerde verzetsstrijders en ondergedoken Joden bij. In 1974 schreef Bastiaans over het KZ-syndroom:

'Het $\mathrm{KZ}$-syndroom is in feite dan ook uitdrukking van een permanente, chronisch geworden blokkering van goede menselijke betrekkingen, uitdrukking ook van een te grote betekenis van de polariteit van macht en onmacht in het menselijk bestaan. En daarmede is het ook uitdrukking van de aantasting van de humane of ontgrensde bestaanswijze, aantasting van de zekerheid schenkende innerlijke ervaring van vrijheid en compleetheid. ${ }^{49}$ 
De oorzaak van het $\mathrm{Kz}$-syndroom, oorspronkelijk beschadigingen opgelopen in de kampen, werd in steeds abstractere termen beschreven. Zo abstract dat ook personen die niet in een kamp hadden gezeten eraan konden lijden.

Anderen volgden hem daarin. Cohen, die in 1972 weer een artikel over het KZ-syndroom als bewezen feit schreef, nam Bastiaans' suggestie van de loochening over. De medische stand had volgens hem na de oorlog zelfs verkeerde adviezen gegeven waardoor de problemen erger waren geworden. Cohen was vol lof over Bastiaans:

'Baanbrekend werk verricht Bastiaans met zijn psychotherapeutische behandeling met gebruikmaking van LSD-25; op deze manier heeft hij in de laatste jaren resultaten verkregen die met de klassieke psychotherapeutische methoden niet of nauwelijks konden worden bereikt. Hoe belangrijk dit ook is, van niet minder belang is het feit dat ten minste aan één Nederlandse - te weten Leidse - universiteit de nieuwe artsengeneraties vertrouwd worden gemaakt met de essentie van het post-concentratiekampsyndroom. ${ }^{50}$

Bastiaans presenteerde in zijn artikelen soms ook de vervroegde veroudering en de verhoogde sterftekans van lijders aan het Kz-syndroom als bewezen feit. Het was de basisaanname van de verlate gevolgen geweest: de groep overlevenden is kwetsbaarder en sterft eerder dan vergelijkbare controlegroepen. De Wind en later ook Cohen hadden op de ontbrekende medisch-statistische onderbouwing van deze aanname gewezen, maar die leemte niet kunnen opvullen. Ze hadden de stelling desondanks als uitgangspunt genomen voor hun beschouwingen over het KZ-syndroom.

In 1976, tien jaar na de Spätfolge-groep, presenteerde dr. W.F. Noordhoek Hegt, de eerste medisch adviseur van de Buitengewone Pensioenraad, de resultaten van een onderzoek naar deze basisaanname: hij had onderzocht of overlevenden van de kampen leden aan vroegtijdige veroudering en daardoor eerder stierven. In samenwerking met het Informatiebureau van het Rode Kruis en het Centraal Bureau voor de Statistiek (CBS) was een steekproef getrokken uit de groep van ongeveer achtduizend overlevenden van de kampen waarvan het Rode Kruis de gegevens bezat. Van ieder persoon in de steekproef werd nagegaan of deze nog in leven was of reeds was overleden, en wat in dat geval de doodsoorzaak was. De sterftecijfers werden vergeleken met dievan de gehele Nederlandse bevolking.

Het resultaat was schokkend, ook voor de onderzoekers: de sterfte onder de overlevenden van de kampen bleek in de periode 1945-1968 beduidend lager te zijn dan bij de gehele Nederlandse bevolking. Bij mannen was het sterftepercentage 28 procent lager, bij vrouwen zelfs 42 procent lager dan bij de rest van de bevolking. ${ }^{51}$

Bastiaans liet in een reactie op het onderzoek van Noordhoek Hegt weten 
dat de resultaten geen enkele consequentie hadden voor de gedachten over het KZ-syndroom. Als het onderzoek de jaren tussen 1968 en 1976 erbij had betrokken, waren er volgens Bastiaans mogelijk heel andere conclusies getrokken. Bovendien stond bij velen het

'leven op een laag pitje, waarbij je dan wel niet dood gaat, maar toch weinig werkelijk leeft in de zin van leven in het teken van vitaliteit en welbevinden'.52

Bastiaans' redenering was dat lijders aan het $\mathrm{kz}$-syndroom niet of minder intensief konden deelnemen aan het arbeidsproces. Ze trokken zich vaak terug en vereenzaamden. Ze brachten dus veel tijd door in huis, waardoor ze minder gevoelig waren voor welvaartsaandoeningen, en minder snel overleden aan bijvoorbeeld verkeersongelukken. Het $\mathrm{kZ}$-syndroom bood wel bescherming tegen de dood maar niet tegen een ongelukkig leven.

Het gemak waarmee Bastiaans over de resultaten van het onderzoek van Noordhoek Hegt heen kon stappen, liet zien dat in 1976 de realiteit van het Kzsyndroom boven alle twijfel was verheven.

De maatschappelijke functie van het kz-syndroom

Bastiaans presenteerde het $\mathrm{KZ}$-syndroom behalve als het resultaat van persoonlijke verdringing ook als het resultaat van een collectieve vorm van verdringing. Het $\mathrm{KZ}$-syndroom was dus ook een uiting van een maatschappelijk probleem, een probleem van niet-willen-erkennen. Sociologe Jolande Withuis beschreef in haar studie Erkenning - over de opkomst van de traumacultuur - hoe het Kzsyndroom om die reden een katalysator kon worden van het proces van erkenning.

Midden jaren zestig groeide de aandacht voor de individuele gevolgen van de overlevenden; aanvankelijk alleen voor de Joodse overlevenden, maar al snel ook voor de gedeporteerde verzetsstrijders en vervolgens voor de niet-gedeporteerde verzetsstrijders. ${ }^{53}$ Overlevenden gingen zich steeds meer als slachtoffer presenteren, niet alleen als slachtoffer ín de oorlog maar ook als slachtoffer ná de oorlog.

De expliciete verwijzing naar de kampen in de term ' $\mathrm{kz}$-syndroom' maakte het tot een beladen begrip; het riep beelden op van gaskamers en prikkeldraad, van tot op het bot vermagerde lichamen, holle ogen, stapels lijken en rokende schoorstenen, van Zyklon- $B$, veewagons, vlektyfus en tbc, van medische experimenten, van prikkeldraad en getatoeëerde nummers, van de geïndustrialiseerde moord op de Joden. Het kz-syndroom werd het symbool voor de gevolgen van al die gruwelen, gevolgen die niet alleen door slachtoffers werden ervaren, maar ook door experts waren vastgesteld.

Binnen de psychiatrie was men zich bewust van de kracht van dergelijke as-

104 
sociaties en de maatschappelijke functies die dat had, en niet iedereen was daar even gelukkig mee. Dat bleek bijvoorbeeld nadat Bastiaans en Cohen in 1971 in het Nederlands Militair Geneeskundig Tijdschrift beiden hun visie op het $\mathrm{KZ}$-syndroom hadden gegeven. Zij hadden in hun bijdragen geschreven dat stresssituaties die in belangrijke mate in ernst met die van langdurige opsluiting overeenkomen' ook tot een $\mathrm{Kz}$-syndroom konden leiden. Er volgde een ingezonden brief van kolonel-arts M.B. Bloch, waarin deze zich afvroeg waarom de naam van de diagnose dan verwees naar een concentratiekamp:

'Het is alleszins terecht, als de geestelijke of lichamelijke invalide een zorgenvrij bestaan gewaarborgd wordt, zowel financieel als geestelijk en lichamelijk, maar zodra wij uitzonderingsposities gaan scheppen t.a.v. ... concentratiekampslachtoffers, slachtoffers van de ss, slachtoffers van de milieu-verontreiniging (verkeersagenten bv!), onderduikers, Engelandvaarders, mijnwerkers, arbeiders uit continu-bedrijven, illegale werkers, dakwerkers, leidekkers, slachtoffers van verkeers- en andere ongevallen, enz. enz. plegen we onherroepelijk een vorm van discriminatie en dan bewust! ${ }^{54}$

Bloch stelde voor om overlevenden van de kampen niet te discrimineren en de verwijzing naar een kamp los te laten. Beter was het om te spreken van een 'naweesyndroom' of een 'post-stress-syndroom'.

Hustinx deed in 1973 een vergelijkbare poging. Door niet meer te spreken van een $\mathrm{KZ}$-syndroom zou volgens hem stigmatisering worden voorkomen (de afkorting ' $K Z$ ' zou sommigen doen denken aan de term 'krankzinnig') en zou recht worden gedaan aan hen die niet in een kamp hadden gezeten, maar vergelijkbare klachten hadden. Hij stelde voor de bredere term 'existentieel emotioneel stress-syndroom' te gebruiken. ${ }^{55}$

Bastiaans, maar ook bijvoorbeeld Hugenholtz, vond dat het vervangen van de speciale diagnose tekort zou doen aan de bijzondere achtergrond van de slachtoffers. Met het gebruik van de term ' $\mathrm{Kz}$-syndroom' kregen oorlogsslachtoffers erkenning voor hun bijzondere status. ${ }^{56}$ Daaruit bleek dat het KZsyndroom al snel meer was dan alleen een psychiatrische diagnose; het hielp de emancipatie van een bijzondere groep.

Zowel onder overlevenden als bij de rest van de maatschappij groeide het besef van het bijzondere leed van de overlevenden. Langzaam maar zeker werd het $\mathrm{KZ}$-syndroom ontdekt. Het duurde niet lang voordat er een roep om betere hulpverlening kwam. D. de Loos, overlevende van de kampen Natzweiler en Dachau, had zich na de oorlog ingespannen voor voormalig kampgenoten die in moeilijkheden waren gekomen. Naar aanleiding van de mogelijke vrijlating van drie Duitse oorlogsmisdadigers zette hij zijn gedachten op papier: 
'Trouwens, de medische wetenschap begint gelukkig nu langzamerhand te begrijpen, welk een enorme geestelijke en lichamelijke ravage Aus der Fünten en zijn 2 lotgenoten uitgericht hebben, een ravage die zich de laatste jaren hoe langer hoe duidelijker begint af te tekenen, een ravage die versterkt wordt door de medemens, enerzijds, die niets begrijpt, door de bevoegde Overheidsinstanties, anderzijds, die in het verleden niets of bijna niets deden voor al deze mensen om ze sociaal of op andere wijze te steunen. ${ }^{57}$

In zijn stuk gaf De Loos Bastiaans' Jelgersmakliniek als voorbeeld voor de belabberde omstandigheden waaronder de hulpverlening plaatsvond. Bastiaans was uit ruimtegebrek gedwongen om oorlogsslachtoffers in dezelfde zaal onder te brengen als 'misdadigers die ter observatie opgenomen zijn'. Een schande, volgens De Loos, en een teken van de onverschilligheid waarmee overheid en maatschappij met de slachtoffers omgingen..$^{88}$

Hans Teengs Gerritsen, eveneens overlevende van Natzweiler en Dachau, schrok van de omstandigheden waaronder zijn vriend Maliepaard, verzetsstrijder en overlevende van kamp Vught en Dachau, in de Jelgersmakliniek verkeerde. Maliepaard was na de oorlog de steun en toeverlaat van vele overlevenden geweest; hij werd door hen liefkozend 'de eik' genoemd. Maar in 1970 was Maliepaard ingestort en opgenomen in de Jelgersmakliniek, waar Teengs Gerritsen hem opzocht:

'Ik dacht: het kan niet zoals Piet hier zit. Een kale kamer, met alleen een bed, een tafel en een stoel. Dat is een verschrikking. Je hebt het $\mathrm{Kz}$ overleefd en dan kom je opnieuw in een soort $\mathrm{KZ}$ terecht. Dat is geen omgeving voor iemand die in het verzet heeft gezeten en de ontberingen van een kamp heeft doorstaan. ${ }^{59}$

Toen Maliepaard Teengs Gerritsen belde met het verzoek te helpen bij het oprichten van een speciale kliniek voor lijders aan het $\mathrm{Kz}$-syndroom, hoefde hij niet lang na te denken. ${ }^{60}$ Teengs Gerritsen was na de oorlog een invloedrijk en succesvol zakenman geworden en een persoonlijke vriend van prins Bernhard. Samen met onder anderen Bastiaans, Maliepaard en de hoogleraar sociale psychiatrie dr. N. Speijer werd een initiatiefgroep gevormd.

In mei 1970 had de groep op Paleis Soestdijk in het bijzijn van prins Bernhard en minister van Defensie W. den Toom een eerste bespreking. Volgens Den Toom was de beste manier om de medewerking van het kabinet te krijgen, dat Bastiaans en Speijer een formeel verzoek zouden doen aan de staatssecretaris van Sociale Zaken en Volksgezondheid, dr. R.J.H. Kruisinga.

Het verzoek van Bastiaans en Speijer werd in juli 1970 ingediend bij de staatssecretaris, die al snel liet weten positief tegenover de plannen te staan. In december van dat jaar installeerde de staatssecretaris de Werkgroep Post-con- 
centratiekampsyndroom met als voorzitter Noordhoek Hegt. ${ }^{61}$ De Werkgroep moest antwoord geven op een aantal vragen, waaronder:

'Kan met behulp van de huidige wetenschap in theoretische en in praktische zin de diagnose "Post-concentratiekamp-syndroom" met zekerheid worden gesteld? [...] Is het wenselijk het onderzoek en de behandeling van deze lijders te concentreren in een centraal instituut? [...] Is het wenselijk dat vanuit een dergelijk instituut aan de Nederlandse artsen bekendheid wordt gegeven over dit syndroom en de behandeling van de lijders daaraan? ${ }^{62}$

De Werkgroep had niet veel tijd nodig om antwoorden te formuleren; binnen drie maanden werd aan de staatssecretaris een positief advies gegeven. Van enig voorbehoud bij de diagnose ' $\mathrm{Kz}$-syndroom' was geen sprake: die was 'met zekerheid' te stellen. Ter onderbouwing werd Bastiaans' beschrijving van het $\mathrm{KZ}$-syndroom in drie fasen gegeven.

Het rapport van de Werkgroep benadrukte de bijzondere status van de patiënten, die een categorale behandeling - een aparte kliniek speciaal gereserveerd voor de behandeling van de groep - rechtvaardigde:

'Het aanbevolen centrum dient niet op te gaan in een psychiatrische universiteitskliniek of in een psychiatrisch ziekenhuis, vooral ter voorkoming van ongewenste en hernieuwde traumatisering van de betrokkenen ten gevolge van al dan niet tijdelijke gelijkschakeling met de "gewone" psychiatrische patiënten. ${ }^{63}$

De nieuwe kliniek, speciaal voor lijders aan het $\mathrm{kz}$-syndroom, moest een nationaal instituut worden met een landelijke uitstraling; een 'modelboerderij', zoals Bastiaans later schertsend zou schrijven. ${ }^{64}$

Binnen een maand na het advies van de Werkgroep, minder dan een jaar nadat het idee was ontstaan, gaf de staatssecretaris toestemming voor de bouw van een speciale kliniek voor lijders aan het $\mathrm{KZ}$-syndroom. Het markeerde het begin van de jarenlange uitzonderingspositie van oorlogsslachtoffers in de Nederlandse psychiatrie.

\section{Conclusies}

Voordat het $\mathrm{KZ}$-syndroom voor het eerst verscheen in Nederlandse medischwetenschappelijke tijdschriften, had het zijn intrede al gedaan in kranten en tijdschriften. Cohen en Bastiaans lieten zich in de pers uit over de problemen van de overlevenden, en gebruikten daarbij vanaf 1965 de term ' $\mathrm{KZ}$-syndroom'. Vooral Bastiaans schetste altijd een donker scenario. In een interview in 1965 met de Volkskrant zei hij bijvoorbeeld over het $\mathrm{KZ}$-syndroom: 
'Maar nu, twintig jaar later, moeten we vaststellen dat niemand zonder kleerscheuren door die tijd heen gekomen is. Het moet ernstig betwijfeld worden, of de mensen met de attitude van "mij heeft dit niets gedaan", niet inderdaad ziek zijn. Het is begrijpelijk dat de symptomen bij deze mensen moeilijk te herkennen zijn. [...] De laatste tien jaar constateren we een toenemend aantal gevallen van oud-verzetsmensen die ineens overlijden door een hartziekte. Men mag aannemen, dat hier sprake is van een verlaat gevolg van het lijden in de kampen. ${ }^{65}$

Hij schetste vanaf het midden van de jaren zestig een verontrustend beeld voor overlevenden van de kampen: ze leden allemaal aan het $\mathrm{KZ}$-syndroom. De symptomen konden zich jarenlang schuilhouden. Mensen konden een normaal bestaan hebben opgebouwd en dan opeens last krijgen van het Kz-syndroom. Zelfs in mensen die uiterlijk onaangedaan leken, kon een slapende vulkaan schuilgaan.

De toename van het aantal sterfgevallen, die Bastiaans in het midden van de jaren zestig zei waar te nemen, was volgens hem inherent aan het Kz-syndroom. Dit vertelde hij in 1966 aan Haagse Post. De overlevenden waren steeds slechter in staat hun verdringing in stand te houden. De druk van de baan viel door pensionering weg, de kinderen gingen het huis uit; er ontstond rust. Dit veroorzaakte barsten in de verdringing, waardoor de symptomen na al die jaren naar buiten konden komen. Ineens herinnerde het geluid van een typemachine aan mitrailleurschoten, en een stuk touw aan een galg. ${ }^{66}$

Het is niet onmogelijk dat Bastiaans op zijn Jelgersmakliniek een toenemende druk ervoer van overlevenden met klachten. Hij was landelijk bekend geworden als de expert op dat gebied, zijn kliniek kreeg daarmee een aanzuigende werking. Maar of dit de uitspraak rechtvaardigde dat het aantal overlevenden met klachten toenam, was maar de vraag. Dat gold ook voor de scenario's die hij beschreef: kwamen er werkelijk alleen gepensioneerden bij hem op de Jelgersmakliniek?

Behalve dat overlevenden niet eerder bleken te sterven, zoals bleek uit het onderzoek van Noordhoek Hegt, is het ook de vraag of ze meer klachten hadden. Als het aantal aanvragen voor een Buitengewoon Pensioen als graadmeter voor het leed van verzetsstrijders - van wie een deel ook overlevende van de kampen was - wordt genomen, dan was er in 1965 geen sprake van een toename van dat leed. Vanaf de bevrijding was er een dalende trend zichtbaar geweest, die zich midden jaren vijftig stabiliseerde tot ongeveer 250 nieuwe aanvragen per jaar. Toen Bastiaans in 1965 begon met het verspreiden van zijn onheilsboodschap, lieten deze cijfers geen verandering zien.

De vraag of er een causaal verband bestond tussen klachten en een verblijf in de kampen, was onbeantwoord, daar had De Wind al in 1964 op gewezen. Doordat 
Nederlandse auteurs de resultaten van buitenlands onderzoek projecteerden op een andere, almaar uitdijende groep patiënten, leed het Nederlandse $\mathrm{kz}$ syndroom aan een magerder wetenschappelijke onderbouwing dan het buitenlandse onderzoek.

Dat neemt niet weg dat er een zekere consensus bestond over het Kz-syndroom; het was een realiteit geworden. De snelle besluitvorming rond de oprichting van de speciale kliniek bevestigde de realiteit van het $\mathrm{KZ}$-syndroom, en de groeiende betrokkenheid bij de problematiek. Overlevenden van de kampen waren slachtoffers, maar niet zomaar slachtoffers: het was een bijzondere groep, die met de nodige omzichtigheid behandeld moest worden.

Dat bewustwordingsproces werd nog eens versterkt toen Bastiaans een film over het Kz-syndroom ging maken. 


\section{Begrijpt u nu waarom ik huil...}

'is het nodig, dat een apart programma gewijd wordt aan het lijden van onze landgenoten in Duitse gevangenschap en speciaal dan in de concentratiekampen?"1

LOU DE JONG IN INLEIDING OP AFLEVERING VAN TELEVISIESERIE DE BEZET-

TING, 1961 .

Inleiding

In de loop van de eerste twee decennia na 1940-1945 nam de publieke belangstelling voor de oorlog af. Nederland zag zich voor de zware taak gesteld het verwoeste land op te ruimen en weer op te bouwen. De vreugde van de bevrijding taande snel.

Bovendien verschenen er nieuwe problemen aan de horizon: de koloniën streden om onafhankelijkheid en de Koude Oorlog diende zich aan. Deze economische en politieke omstandigheden vroegen om een houding van aanpakken en vooruitkijken. De jaren vijftig werden daarom de jaren van wederopbouw, van de broekriem aanhalen en doorwerken, van tucht en ascese. Zeer tegen de zin van sommigen, bleek de oorlog geen breuk in de geschiedenis te zijn, die voor omvangrijke maatschappelijke veranderingen zorgde. De vooroorlogse zuilen werden in ere hersteld.

In de jaren zestig konden de vruchten van de harde arbeid worden geplukt. Onder invloed van de groeiende welvaart en de ontspanning in de internationale verhoudingen veranderde Nederland. Het leidde tot een radicale omwenteling in het politieke en maatschappelijke landschap. De ontzuiling zette in, de kerken liepen leeg, de disco's vol. De pers verloor haar onschuld en opeens was er kritiek op de gevestigde orde te horen. Emancipatiebewegingen kwamen opzetten, waarin minderheden gelijke rechten eisten voor mannen en vrouwen, voor hetero's en homo's. De mondige burger was geboren. 
Dat veranderingsproces werd nog eens versterkt door de opkomst van de televisie: de cabareteske spotlust of serieus bedoelde maar afwijkende mening van de enkeling kon nu uitvergroot de huiskamers in geslingerd worden. Zo bereikten feiten, ideeën en meningen die voorheen alleen bekend waren bij een kleine club, nu een groot publiek.

Jongeren zongen zich los van hun ouders en ontwikkelden een eigen cultuur. De Beatles veranderden voorgoed het geluid op de radio, en drugs als marihuana, hasj en LSD werden gebruikt om hun onafhankelijkheid te bevestigen. Ze zetten zich af tegen de autoriteiten en voerden een vrijheidsstrijd tegen de burgermansmoraal. Het was de tijd van provo's, kabouters, dolle mina's, Damslapers en studentenprotesten. ${ }^{2}$

De samenleving werd deze jaren gevoeliger voor psychische problemen. Het leidde tot een explosieve groei van de geestelijke gezondheidszorg. Een voorbeeld: het aantal aanmeldingen voor de voorloper van het huidige RIAGG, het Instituut voor Multidisciplinaire Psychologie (IMP) steeg in Amsterdam van 133 in 1960 naar meer dan 900 in $1970 .{ }^{3}$ Voor hulpverleners werd het goed gebruik om zich niet alleen te laten registreren als psycholoog, arts, of psychiater, maar ook als psychotherapeut. Het werd door onderzoekers ooit 'le phénomène hollandais' genoemd. ${ }^{4}$

In 1971 kwam het boek Wie is van hout... van psychiater Jan Foudraine uit. Het werd een doorslaand succes; niet alleen bij professionele hulpverleners maar ook en vooral bij leken. Foudraine wilde aantonen dat er zin in de waanzin van schizofrenie zat; dat deze psychiatrische aandoening sociale en maatschappelijke componenten had. Het succes van zijn boek was een teken van de gegroeide interesse voor psychische problemen. ${ }^{5}$ Het liet ook zien dat het taboe dat rustte op geestelijk ziek zijn aan het verdwijnen was. Het gekke werd minder gek, het normale werd gekker. Dit leidde tot nieuwe experimenten in de psychiatrie zoals de antipsychiatrie. ${ }^{6}$

Het leed van een groep bijzondere mensen, de slachtoffers van de oorlog, zou de inzet worden van een van de meest beladen politieke debatten van de vorige eeuw: het debat over de vrijlating van de laatste drie oorlogsmisdadigers. Bastiaans zou daarin als hoogleraar psychiatrie met kennis van dat leed een belangrijke rol spelen.

\section{Hernieuwde aandacht voor de oorlog}

Aan onze nationale herinnering aan de oorlog was in de jaren vijftig, zoals historicus Blom schreef, 'de norm van verzet' opgelegd. 7 De oorlog werd bekeken door de bril van goed en fout, van collaborateurs en verzetsstrijders. Het had een nationaal verhaal opgeleverd, dat historicus Frank van Vree ooit als volgt samenvatte: 
'van de aanranding van een onschuldig en onwetend volk, dat echter door zijn geestelijke kracht en onverzettelijkheid, onder bezielende leiding van zijn vorstin, het kwaad overwint en in wezen ongebroken en gezuiverd uit deze worsteling tevoorschijn komt. De prijs is hoog, maar de gerechtigheid zegeviert. $^{8}$

In dat beeld was geen ruimte voor het leed van afzonderlijke groepen, laat staan van individuen. Er werd geen onderscheid gemaakt tussen Joden, verzetsstrijders, slachtoffers van bombardementen of represailles, en krijgsgevangen militairen. Bij herdenkingen stond de nagedachtenis van de gevallenen en hun nabestaanden centraal. Over het leed van de nog levende slachtoffers, dat soms nog steeds voortduurde, werd nauwelijks tot niet gesproken. Van Vree schreef hierover dat het praten over, laat staan het tonen van, lichamelijk en psychisch lijden als onesthetisch, immoreel en contraproductief werd gezien..$^{9}$

Een voorbeeld daarvan waren de inleidende woorden die RIOD-historicus Lou de Jong sprak bij een aflevering van zijn televisieserie De Bezetting. Bij de uitzending (in 1961) over de concentratie- en vernietigingskampen, zei De Jong:

'is het nodig, dat een apart programma gewijd wordt aan het lijden van onze kampgenoten in Duitse gevangenschap en speciaal dan in de concentratiekampen? ${ }^{10}$

De Jong koos ervoor toch beelden van de kampen op te nemen omdat deze een wezenlijk onderdeel van de Duitse overheersing waren geweest; een eerlijke geschiedschrijving kon niet voorbijgaan aan de concentratiekampen. De kijker moest door de zure appel heen bijten.

De populariteit van De Jongs televisieserie paste in de groeiende aandacht voor de Tweede Wereldoorlog, die in het begin van de jaren zestig ontstond. In 1961 begon het proces tegen voormalig nazitopman Adolf Eichmann, de man die grotendeels verantwoordelijk was geweest voor de geoliede deportatie van de Joden naar de vernietigingskampen. Het werd wereldwijd op de voet gevolgd, ook in Nederland, en richtte de schijnwerper op de Jodenvervolging. In Nederland werd het zwijgen daarover definitief verbroken, toen de historicus Jacques Presser in 1965 Ondergang publiceerde. "

In Ondergang beschreef Presser in emotionele bewoordingen hoe de slachting onder de Nederlandse Joden zich voor de ogen van de Nederlandse bevolking had voltrokken. Het percentage Joden dat in Nederland de oorlog had overleefd, was, zeker in vergelijking met andere landen, schrikbarend laag. Van de meer dan 100000 Joden die voor de oorlog in Nederland woonden en in de oorlog werden afgevoerd, waren er maar 6000 teruggekeerd uit de vernietigingskampen. Het was een verontrustende wetenschap. Hoe was dit te rijmen 
met het idee van een wijdverbreide verzetshouding onder de Nederlanders?

Hoogleraar politieke geschiedenis dr. Ido de Haan, die onderzoek deed naar de veranderende herinnering aan de Jodenvervolging, sprak van het ontstaan van een 'nationaal trauma' over dat onderwerp. ${ }^{12}$ De aandacht voor de Jodenvervolging brak het paradigma van goed en fout open en leidde, zoals de historicus Jan Bank het beschreef, tot 'een bijna collectief besef van tenminste passieve schuld' bij de rest van de bevolking. ${ }^{13}$

\section{De politieke strijd van de Vriendenkring Sachsenhausen}

De sociologe Jolande Withuis onderzocht voor haar boek Na het kamp, dat in 2005 uitkwam, hoe overlevenden van de Duitse concentratiekampen na de oorlog omgingen met hun verleden en met elkaar. ${ }^{14}$ Ze gaf haar boek als ondertitel Vriendschap en politieke strijd. Vriendschap en politieke strijd bleken vaak moeilijk samen te gaan na de oorlog, zeker onder overlevenden van de kampen. Groepen die vóór de oorlog gescheiden waren - zoals communisten en Oranjegezinden - bleven dat ook na de oorlog, zelfs als men samen in een kamp had gezeten.

Niet een gedeeld verleden maar een overeenkomstige politieke ideologie bepaalde in de meeste gevallen of een vriendschap mogelijk was. Withuis' studie liet dan ook zien dat zich onder organisaties als de Vriendenkring Buchenwald en het Dachaucomité veelal personen verenigden met gelijke politieke ideeën, die gezamenlijke doelen nastreefden. De Koude Oorlog maakte dat de organisaties elkaar daardoor de erfenis van het kampverleden betwistten.

Een zo'n organisatie was de eind jaren vijftig opgerichte stichting 'We nemen het wéér niet!', die later opging in de Vriendenkring Sachsenhausen (vKs). ${ }^{15}$ De vKs bestond uit communisten en communistisch-gezinden, en dat was duidelijk terug te zien in het doel dat ze zich in de statuten stelden:

'De bevordering van de sociale gelijkheid en het bestrijden van vormen van sociale ongelijkheid zoals het fascisme, waar en hoe het zich ook manifesteert. ${ }^{, 16}$

Wat de leden bond, was dus niet een gedeeld verleden in het kamp maar een gedeelde ideologie. Dat verklaarde ook waarom niet alle leden oud-gevangenen van concentratiekamp Sachsenhausen waren; ook 'anti-fascisten' die niet in het kamp hadden gezeten, waren lid. ${ }^{17}$ De vks presenteerde het fascisme, met al zijn uitwassen, als het gevolg van maatschappelijke processen die nog steeds bestonden. De gruwelen in de concentratiekampen waren in hun ogen niet een eenmalige gebeurtenis in de geschiedenis, maar een uitvloeisel van een politiek systeem. De Duitse kampen waren dan wel verdwenen, het systeem dat ze had gebouwd was dat nog niet. Oorlogen als die in Korea, Cam- 
bodja en Vietnam werden beschouwd als herhalingen van de Tweede Wereldoorlog.

De vks bracht vanaf januari 1961 onregelmatig het blad Nooit weer! uit. ${ }^{18}$ In de exemplaren die in de jaren zestig uitkwamen, werd de transformatie die zich aan de kant van de overlevenden voltrok duidelijk. De titel van het blad was bedoeld als aansporing:

'Het memoriam, de eerbied voor de gevallenen, de offers en het doorstane leed zullen dan pas waarde hebben, wanneer het gedragen wordt door een positief nooit weer. Alles uit de geschiedenis van Sachsenhausen, wat dit kan bevorderen, zullen we aan de vergetelheid moeten ontrukken en uitdragen zo ver we maar kunnen. ${ }^{19}$

Toen begin jaren zestig bijvoorbeeld bij het herdenkingsmonument in het voormalige kamp Sachsenhausen in de DDR een plek voor de Nederlanders werd vrijgemaakt, viel de vks de eer te beurt om de expositie te vullen. Secretaris Joop Telling nam de organisatie hiervan op zijn schouders en riep in het bulletin van de vKs op om aandenkens en overblijfselen van het kamp ter beschikking te stellen. Met succes, want enkele maanden later kon hij melden dat onder andere 'een op het lijf gedragen afscheidsbrief' en 'een koperen aansteker vervaardigd van een granaathuls met een foto van het graf van de maker, een georganiseerde schilderskwast, waar het hele blok zich mee inzeepte voor het scheren', maar ook 'officiële overlijdensaktes' en teksten van kampliederen waren gedoneerd..$^{20}$ De echtgenote van een oud-kampbewoner had zelfs aangeboden een vlag te borduren zodat:

'[we] de nationale driekleur, alsmede de rode driehoek, het prikkeldraad, het blauwwit onzer gevangeniskleding met de naam van onze Vriendenkring Sachsenhausen wellicht boven de hoofden van tienduizenden in en rond Sachsenhausen zien wapperen.' ${ }^{21}$

De vks organiseerde reizen naar het voormalige kamp en bood daarbij financiële steun. Voor de reizigers werden kleurige herdenkingsinsignes geperst van vilt, de bezoeken zelf werden soms op film vastgelegd.

Veel energie stak de vKs in de tentoonstelling 'Onderdrukking en Verzet'. Deze werd in 1963 ingericht in reactie op het bericht dat studenten tijdens hun ontgroening 'Dachautje speelden', volgens deleden een teken van het beperkte historische besef van de jeugd. De tentoonstelling moest de kennis over wat er zich daadwerkelijk in de kampen had afgespeeld, overdragen, en tegelijkertijd laten zien dat dergelijke uitwassen geen verleden tijd waren. Zou dat niet gebeuren dan zouden naoorlogse generaties: 
'er ook niet op voorbereid [zijn] om dit geweld te voorkomen of te keren als er zich ergens een situatie zou gaan ontwikkelen die opnieuw het leven van bevolkingsgroepen zou bedreigen. ${ }^{22}$

Tegenover de gruwelen van de Duitsers plaatste de vks een beeld van kameraadschap en verzet dat heerste onder de gevangenen. Tijdens een discussieavond in 1963 naar aanleiding van de berechting van een aantal bewakers van Auschwitz, werd de vraag gesteld of de gevangenen alleen op eigenbelang uit waren. Joop Telling antwoordde dat:

'naast ongebreideld egoïsme, illegale organisaties van gevangenen werkzaam waren, die sabotagedaden verrichtten, voedsel verzorgden voor doodzieke gevangenen, verzet voorbereidden tegen liquidaties van gevangenen. Er werd zelfs wapensmokkel bedreven. ${ }^{23}$

Naast voorlichting stond de berechting van oorlogsmisdadigers hoog in het vaandel van de vks geschreven. Berichten over de vrijlating van misdadigers en processen tegen niet-berechte misdadigers werden nauwlettend in de gaten gehouden. Een openbare aanklager die een proces voerde tegen oud ss'ers, kreeg van de vKS een telegram waarin werd aangedrongen op hogere straffen; de NAVO ontving een brief waarin erop werd gewezen dat hoge officieren van het voormalige Duitse leger belangrijke functies bekleedden binnen de NAVO. $^{24}$

De Nederlandse regering kon ook rekenen op de aandacht van de vks toen in 1966 een van de vier nog in Nederland gevangenzittende Duitse oorlogsmisdadigers, Willy Lages, werd vrijgelaten. Lages leek een terminale aandoening te hebben en de Nederlandse artsen durfden de riskante operatie niet aan. Lages vroeg en kreeg verlof van minister van Justitie prof.dr. Ivo Samkalden om geopereerd te worden in Duitsland. Aangezien Duitsland geen onderdanen uitleverde, betekende het verlof dat Lages niet meer terug zou keren naar zijn Bredase gevangenis. ${ }^{25}$ De vKs stuurde een telegram naar minister Samkalden.

'De Vriendenkring protesteert krachtig tegen de beslissing die een krenking is van de nagedachtenis van de slachtoffers en van het rechtsgevoel van de nabestaanden. ${ }^{26}$

De vks beriep zich op het leed van de gevallenen in de kampen en hun nabestaanden.

Het leed van de overlevenden - hun naoorlogse psychisch en lichamelijk lijden - speelde in 1966 nog geen rol in de argumenten van de vKs. Maar in hetzelfde jaar dat Lages werd vrijgelaten, kwam daar verandering in. Withuis beschreef in haar boek hoe de maatschappelijke omslag in het denken over de 
oorlog midden jaren zestig ook merkbaar werd in de manier waarop het kampverleden werd ingezet door organisaties als de vks. Zij ontdekten de kracht van hun identiteit als slachtoffer.

\section{'Schutzhäftling 42.392, meldet sich'}

De cineast Louis van Gasteren sloeg in de oorlog een Joodse onderduiker met een stuk hoogspanningskabel dood. Hij zei later dat de liquidatie nodig was omdat de onderduiker hem en anderen dreigde te verraden. Nog in de oorlog werd hij voor de moord veroordeeld tot vier jaar gevangenisstraf. Een jaar na de oorlog werd hem gratie verleend. ${ }^{27}$

In 1966 kwam Van Gasteren in het nieuws. Op 19 maart werd er een tentoonstelling geopend waar foto's te zien waren van de ongeregeldheden rond het huwelijk van prinses Beatrix en prins Claus. De politie trad hard op tegen de organisatoren van de controversiële tentoonstelling, maar sloeg daarbij een toevallige voorbijganger in elkaar. Van Gasteren filmde de mishandeling en bood het materiaal aan aan een televisiezender. ${ }^{28} \mathrm{Op}$ de uitgezonden beelden werd geschokt gereageerd.

In datzelfde jaar vroeg Van Gasteren de medewerking van de vKs voor een autobiografische film waarin hij de relatie tussen 'geslagene en slaander' in beeld wilde brengen. Hij wilde daarvoor beelden van een oud-gevangene die onder invloed van LSD vertelde over zijn ervaringen in de kampen, combineren met beelden van een ss'er onder invloed van LSD.

Het idee van een film waarin een overlevende van de kampen vertelde over zijn oorlogsverleden was niet nieuw. In 1964 al had de jonge cineast At van Praag een scenario van Bud Linschoten aan Bastiaans voorgelegd. ${ }^{29}$ Het script voor de film van Van Praag, getiteld Psychosomatische gevolgen van de oorlog, bevatte vijf portretten van overlevenden met verschillende achtergronden: een overlevende uit kamp Dachau, een overlevende van het Joodse getto Theresienstadt, een slachtoffer van medische experimenten, een overlevende van de Spaanse Burgeroorlog en een geïnterneerde uit voormalig Nederlands-Indië.

In juni 1964 was er in het concept van het script nog sprake van narcoanalyse, maar bij de uiteindelijke opnames werd LSD gebruikt: een aanwijzing dat in die periode de LSD-therapie bij Bastiaans vorm begon te krijgen. ${ }^{30}$

De film van Van Praag werd niet voltooid, ${ }^{31}$ maar enkele beelden van de LSDsessies werden in 1966, aansluitend op een vierdelige samenvatting van De Jongs televisieserie De Bezetting, uitgezonden op de Duitse zender WDR. Het maakte diepe indruk op de Duitse kijkers. De uitzending werd ook in Nederland uitgezonden, maar dan zonder de beelden van Van Praag. Volgens de historicus Chris Vos, die onderzoek deed naar de verfilming van de oorlog, was dat om redenen van privacy. ${ }^{32}$ 
Van Gasteren hoopte dat de voorzitter van de vks, de socioloog dr. H.Ph. Milikowski, zich beschikbaar wilde stellen. ${ }^{33}$ Milikowski was in 1942 vanwege zijn Joodse achtergrond opgepakt en via kamp Vught op transport naar Auschwitz gezet. Daar was hij geselecteerd voor het uiterst geheime Bernhardkommando, dat in opdracht van de Duitsers valse Britse ponden en Amerikaanse dollars vervaardigde. ${ }^{34}$ Het commando werd aanvankelijk in Sachsenhausen gehuisvest, maar zou met het naderen van de geallieerden enkele malen worden verhuisd.

Milikowski ging niet in op het verzoek van Van Gasteren, vermoedelijk omdat hij geen LSD wilde nemen. Hij vermoedde dat Joop Telling wel bereid zou zijn, en legde hem het verzoek voor. ${ }^{35} \mathrm{Na}$ overleg met zijn vrouw stemde Telling toe, en Milikowski bracht hem in contact met Van Gasteren. ${ }^{36}$

Telling had kort na de oorlog een gedetailleerd verslag geschreven over zijn periode in de kampen. Een kopie van het verslag is bewaard gebleven en bevindt zich op het NIOD. ${ }^{37}$ Telling was, toen de oorlog uitbrak, als 21-jarige werkzaam op het kantoor van de werf van de Nederlandse Scheepsbouw Maatschappij (NSM) in Amsterdam- Noord. In september 1941 kwamen er twee leden van de SD op de werf, die ontdekten dat Telling in het bezit was van een exemplaar van de illegale communistische krant De Waarheid. Voldoende reden voor de SD'ers om hem te arresteren en na een verhoor over te brengen naar het Huis van Bewaring.

Het was het begin van een vier jaar durende tocht langs verschillende concentratiekampen. In december 1941 werd hij overgebracht naar kamp Amersfoort, eind februari 1942 naar concentratiekamp Buchenwald, in maart 1943 naar concentratiekamp Ravensbrück, en in mei arriveerde hij in Sachsenhausen, waar hij tot eind februari 1945 bleef. De laatste maanden van de oorlog bracht hij door in de kampen Bergen Belsen, Bärth en Pölitz..$^{38}$

Na de oorlog kon Telling weer terecht bij de werf van de NSM. De werf had zijn vrouw tijdens de oorlog financieel gesteund en ging daarmee door, ook toen Telling na terugkomst bijna twee jaar was uitgeschakeld door tbc. De zuiveringscommissie van de werf onderzocht hoe het kon dat de SD op zoek was gegaan naar Telling. Het leverde de naam op van een mogelijke verrader, maar verder dan een verdenking kwam het niet. ${ }^{39}$

Van 1947 tot 1966 werkte Telling op de werf. In 1966 werd hij afgekeurd wegens fysieke klachten. ${ }^{40}$ Toen Van Gasteren met zijn verzoek kwam, had Telling net een aanvraag voor een Buitengewoon Pensioen ingediend.

Van Gasteren zocht, nadat Telling zijn medewerking had toegezegd, contact met Bastiaans. ${ }^{41}$ Waarschijnlijk deed hij dat omdat kort daarvoor LSD op de Opiumlijst was geplaatst en alleen gebruikt mocht worden door medici die een ontheffing hadden gekregen, zoals Bastiaans. Bastiaans zegde Van Gasteren zijn medewerking toe en bood zelfs aan de opnames te doen in Leiden. Ook wierp hij zich op als referent in de subsidieaanvragen. 
Op 19 mei 1967 vond Tellings eerste LSD-sessie plaats in een barak op het terrein van de Jelgersmakliniek. Naast Bastiaans waren Van Gasteren aanwezig, diens filmploeg (met onder anderen Jan de Bont als cameraman) en Dick van Tol, psychiater en chef de clinique van de Jelgersmakliniek. De sessie begon in de ochtend en duurde tot ver in de middag.

Hoe Van Gasteren de beelden van Telling precies wilde gebruiken in zijn autobiografische film bleef onduidelijk; de film werd nooit gerealiseerd. Van Gasteren en Bastiaans kregen namelijk een idee voor een andere film met:

'wetenschappelijke en edukatieve doeleinden, in het bijzonder voor de opleiding van medici, medische studenten, paramedici, maatschappelijk werkers en al diegenen die bij de revalidatie van ex-gevangenen zijn betrokken'. ${ }^{2}$

Het tweetal begon direct met de montage en binnen een paar maanden was een ruwe versie gereed. Bastiaans vroeg subsidie aan bij de Rijksuniversiteit Leiden - waar hij werkte -, de Nationale Federatie voor de Geestelijke Volksgezondheid (NFGV), Stichting 1940-1945, de Buitengewone Pensioenraad en het Ministerie van CRM. Alle partijen werden uitgenodigd voor een viewing van de ruwe versie met als doel de meningen te inventariseren om zo tot een definitieve film te komen. De viewing had het beoogde resultaat en de financiering kwam rond ${ }^{43}$ Alle partijen droegen bij aan de kosten, de NFGV wierp zich op als beheerder van de film, de universiteit als opdrachtgever. Anderhalf jaar later, eind maart 1969, was de film gereed.

Uit een transcriptie van de versie uit 1969 blijkt dat de eerste versie van de film een veel rauwer begin kende dan de versie die bewaard is gebleven in de verschillende archieven..$^{44}$ In de eerste scène van deze versie vertelde Telling over zijn laatste maanden in Bergen Belsen, dat daar het recht van de sterkste had gegolden. Het was 'vreten of gevreten worden':

'Om mezelf te handhaven heb ik een ander, die op sterven lag, [...] met nog een makker uit z'n bed gelegd onder het motto: jou baat tóch niks meer, jij bent morgen tóch dood. Dat bed is voor ons, we gaan er met z'n tweeën in en hij wàs ook dood de volgende morgen. Natuurlijk ook al, omdat we hem op de stenen hadden gelegd. Want die drang was sterk, de drang om te overleven. Ik heb altijd de vaste wil gehad om te blijven leven onder alle omstandigheden door. ${ }^{245}$

Nadat de lijst met kampen en gevangenissen waar Telling had gezeten - negen in totaal - voorbij was gerold, verschenen er beelden van de kampen. Stille beelden van uitgemergelde mannen met holle ogen die in de lens staarden, huilende vrouwen, niet meer in staat om op te staan, die de hand van hun bevrijders kusten. Een arm met daarin een nummer getatoeëerd. Kuilen met stapels lijken. Mannen die half vergane lijken als een zak botten op hun nek na- 
men en in de kuilen wierpen. Een lange minuut gleden deze gruwelbeelden voorbij, beelden die toen nog niet vaak te zien waren geweest.

Daarna volgden beelden van Bastiaans die in een Leidse collegezaal uiteenzette hoe iedereen na de oorlog, ook Telling zelf, dacht dat met rust en goede voeding de klachten zouden verdwijnen. Bastiaans stelde de retorische vraag:

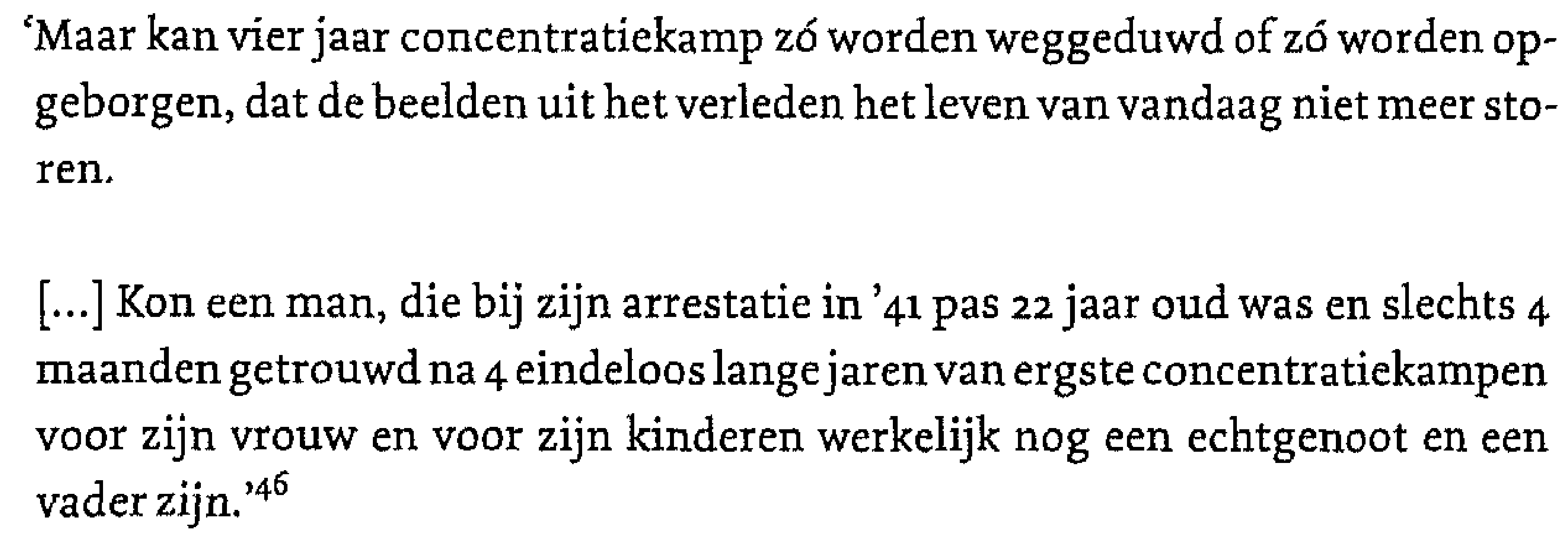

[...] Kon een man, die bij zijn arrestatie in ' 41 pas 22 jaar oud was en slechts 4 maanden getrouwd na 4 eindeloos lange jaren van ergste concentratiekampen voor zijn vrouw en voor zijn kinderen werkelijk nog een echtgenoot en een vader zijn. ${ }^{36}$

Telling verkeerde volgens Bastiaans in de derde fase van het $\mathrm{KZ}$-syndroom, de meest gevaarlijke fase. De jarenlange spanningen leidden tot vervroegde veroudering, verhoogde nervositeit en konden zelfs een plotselinge dood tot gevolg hebben.

Bastiaans beschreef hoe bij Telling, net als bij de patiënten in zijn proefschrift, de oorlog en het kamp tot in de kleine details van het gedrag doordrongen. Als voorbeeld noemde hij dat het eerste kind van Telling en zijn vrouw, een dochter, een mannennaam kreeg. Zij werd vernoemd naar de man die Telling had gered in Sachsenhausen.

Bastiaans vertelde de kijkers dat Telling afgesloten was geraakt van zijn gezin en zijn omgeving doordat hij niet sprak over zijn ervaringen, en zijn emoties niet kon uiten. De enige manier om zich te bevrijden uit dat isolement, dat psychische concentratiekamp, was terug te keren. Dat kon, zo vertelde Bastiaans, door in een beschermde, veilige omgeving een dosis LSD te nemen, waarna de emoties tot ontlading konden worden gebracht. Na deze inleiding volgden de beelden van de LSD-sessie zelf.

In de eerste beelden zat Telling in een luie stoel te wachten op de eerste verschijnselen van de LSD. Na vijf minuten gaf hij aan dat hij nerveus was en het gevoel had te moeten huilen. Hij had de woorden nog niet uitgesproken of hij sloeg de handen voor zijn gezicht en barstte in tranen uit. Het isolement was doorbroken.

Bastiaans vroeg hem eens voor te doen hoe hij op appel moest staan. Het leidde tot een aangrijpende scène waarin Telling, terwijl Bastiaans zijn hand vasthield, zijn kampnummer opnoemde:

'Schutzhäftling 42.392, meldet sich.' 
De makers hadden al in 1969 de oorspronkelijke titel van de film, Concentratiekampsyndroom onderzocht met $L S D$ aangepast. ${ }^{47}$ Het begrip van het publiekvoor de tranen van de hoofdrolspeler, dát was waar het om ging. Daarom werd de nieuwe titel: Begrijpt u nu waarom ik huil.... De film was niet meer bestemd voor een gespecialiseerd publiek van hulpverleners, maar voor het brede publiek. ${ }^{8}$

De opdrachtgever en beheerder lieten zich door de gewijzigde koers en het enthousiasme van de makers echter niet van de wijs brengen. De NFGV en de afgevaardigde van het Ministerie van CRM zagen niets in een openbare vertoning. Zij hielden de makers aan de oorspronkelijke onderwijsdoelstelling van de film en de daarbij behorende, beperkte doelgroep. ${ }^{49}$ Tussen het Ministerie van CRM, Van Gasteren en Bastiaans werd vastgelegd dat het vertoningsrecht van de film bij de NFGV kwam te liggen, die erop toezag dat de film alleen werd vertoond aan een publiek dat werkzaam was in de hulpverlening aan oorlogsslachtoffers..$^{50}$

De NFGV nam kopieën op in haar filmotheek en zorgde voor de verdere distributie. Om dat laatste in goede banen te leiden, liet de directeur van de NFGV, de oud-verzetsstrijder mr. J. le Poole, door de Stichting Gvo onderzoeken aan wie en onder welke voorwaarden de film getoond kon worden..$^{51}$ In $1970 \mathrm{kwam}$ het rapport van het $\mathrm{G} v \mathrm{v}$ uit. In de inleiding stond dat verschillende groepen verschillende doelen aan de film toekenden, die niets met onderwijs te maken hadden. Genoemd werden onder andere het overbrengen van een humanitaire boodschap en het nastreven van betere regelingen ten behoeve van oud-verzetsstrijders en vervolgden.

De effecten van de film waren onderzocht bij twee groepen: een eerste groep bestaande uit personeel van de GGD, studenten en docenten van een opleiding maatschappelijk werk, en leerlingen uit de bovenbouw van gymnasium, lyceum en HBS; een tweede groep bestaande uit vierentwintig speciaal geselecteerde oud-verzetsstrijders en hun echtgenotes, en weduwen van gevallen verzetsstrijders. Zij waren door medewerkers van de Stichting 1940-1945 uitgezocht omdat ze een 'hoog incasseringsvermogen' hadden.

De selectie van de verzetsstrijders bleek niet overbodig; de observatoren noteerden heftige reacties, twee personen verlieten tijdens de vertoning zelfs geemotioneerd de zaal. In de discussie achteraf haalden velen herinneringen op aan hun eigen verleden. Bij iets minder dan de helft ging dat gepaard met 'huilen, hakkelen, trillen, onsamenhangend praten, stemverheffing en gesticuleren'. ${ }^{52}$ Pogingen van de discussieleider om de film zelf tot onderwerp van de discussie te maken, hadden weinig resultaat. Bij enkele deelnemers traden in de weken na de vertoning verschijnselen op als slapeloosheid of terugkerende herinneringen in de droom. ${ }^{53}$

De heftige emoties die de film opriep bij deze geselecteerde groep, deden het GVo vrezen voor de mogelijke gevolgen bij slachtoffers met een lager incasseringsvermogen. Maar het grootste bezwaar tegen een openbare vertoning was 
dat er valse verwachtingen zouden worden gewekt over de mogelijkheden van behandeling. De onderzoekers concludeerden:

'In het algemeen lijkt op grond van de geobserveerde reacties vertoning van de film voor ex-concentratiekampgevangenen niet raadzaam. Temeer daar de film bij hen illusies kan wekken betreffende hun eigen kans op herstel die vermoedelijk niet waargemaakt kunnen worden. ${ }^{54}$

De bezwaren die het $\mathrm{GV}$ o had tegen openbare vertoning werden overgenomen door de NFGV. Bastiaans zou samen met Van Gasteren en Van Tol langs universiteiten, ziekenhuizen, symposia en congressen in binnen- en buitenland trekken om de film te vertonen en van commentaar te voorzien. Van angst voor kwalijke gevolgen was bij hen geen sprake: onder het aanwezige publiek bevonden zich soms voormalig gedeporteerden. ${ }^{55}$

\section{Een besloten maar koninklijke première}

Bastiaans had de subsidiegevers ervan overtuigd dat met de film een onderwijskundig doel was gediend: studenten en hulpverleners konden van de film leren over het $\mathrm{Kz}$-syndroom en de LSD-therapie. Hij had de subsidie gekregen onder voorwaarde dat de film slechts vertoond zou worden aan 'diegenen die bij de revalidatie van ex-gevangenen zijn betrokken'.

Maar nog voordat de NFGV de opdracht voor het onderzoek op papier had gezet, kreeg de film al een groter publiek.

Bastiaans organiseerde op 14 mei 1969 in het Haagse Metropole-Tuschinskitheater een grootse première van Begrijpt $u$ nu waarom ik huil... Hij nodigde zelfs koningin Juliana uit. Le Poole, toch al niet gecharmeerd van Bastiaans' optreden, was onaangenaam verrast, maar protesteren had geen zin meer. De uitnodigingen waren de deur al uit en de koningin had toegezegd. De op geschept papier gedrukte uitnodiging vermeldde:

'Deze film betreft een psychiatrische behandeling met toepassing van LSD 25 van een ex-verzetsman die in 1945 uit de concentratiekampen terugkeerde en als zovele lotgenoten vele jaren na de oorlog lijdende was aan de psychische en psychosomatische gevolgen van hetgeen hij had doorgemaakt.

De film maakt duidelijk hoe achter een façade van een jarenlang in stand gehouden schijnaanpassing het onuitsprekelijke leed schuil gaat dat, vanuit de verdringing het na-oorlogse ziekzijn in belangrijke mate bepaalt. Het LSD 25 werd hierbij gekozen als hulpmiddel bij de psychotherapie. ${ }^{56}$

Naast de koningin waren aanwezig: minister president P.J.S. de Jong; minister van CRM, dr. M.A.M. Klompé; minister zonder portefeuille drs. B.J. Udink, en 
enkele wetenschappers en journalisten. De film werd kort door Bastiaans ingeleid, waarbij hij het tweeledig doel ervan benadrukte: het wekken van begrip voor het leed van de overlevenden en het laten zien van het mechanisme van verdringing.

Na het voorbijrollen van de credits aan het einde van de film bleef het stil in de zaal. Het publiek schuifelde naar de foyer, waar sherry en hapjes op de gasten stonden te wachten. De koningin bekende aan een journalist onder de indruk te zijn. Ze had het gevoel 'wel erg binnenskamers' te hebben gekeken.

Een onderwijsfilm over een gespecialiseerd onderwerp, bedoeld voor een gespecialiseerd publiek, was in première gegaan in aanwezigheid van pers en koningin. Dat schiep een lastige situatie voor de pers: ze moesten schrijven over een film die feitelijk maar een handjevol van hun lezers zou kunnen zien.

Het gebruik van LSD stuitte niet op verbazing of verzet, het kon zelfs rekenen op begrip, getuige de kop van De Gooi-en Eemlander: 'Medische wetenschap dringt door in de geest van een lijdend mens'. ${ }^{57}$ Ook psychiater $C$. van den Emde Boas schreef in een recensie dat hij onder de indruk was van de film en dat LSD inderdaad mensen leek te kunnen openbreken. De scepsis die hij bij een aantal collega-psychiaters waarnam, zou wel eens tot gevolg kunnen hebben dat 'het kind met het badwater wordt weggegooid'..$^{8}$

Het Parool deed een poging de lezer uit teleggen hóé LSD de psychiater hielp door te dringen in de geest:

'De persoonlijkheid wordt [door LSD] wel zwakker, maar veel minder star - het verdedigingsmechanisme is minder actief en daardoor is men ontvankelijker geworden voor eigen mentale processen zowel als voor indrukken van de buitenwereld. ${ }^{59}$

Of de lezer veel begreep van deze uitleg was maar de vraag. Wat moest die zich voorstellen bij een ' $z$ wakkere maar mindere starre persoonlijkheid'?

De tranen van Telling spraken voor de recensenten boekdelen; het ondraaglijke leed van hem en zijn lotgenoten had zich een plaats in de schijnwerpers veroverd. De enige recensent die uit de toon viel was B.J. Bertina van de Volkskrant. Hij richtte zijn pijlen op de hoofdpersoon. Hij zag in Telling een:

'van huis uit nogal zeurderige man met een behoefte om door zijn omgeving voor voller te worden aangezien dan hij is. Zijn ervaringen in de kampen vormen nu de kapstok voor zijn neuroses. Zonder een verblijf in de kampen zouden dezelfde neuroses kunnen zijn ontstaan, maar dan met een minder spectaculaire kapstok [...]. De man, van wie wij nu begrijpen waarom hij heeft gehuild, had een duidelijke behoefte om door zijn vrouw en kinderen of als held of als martelaar te worden aanvaard. ${ }^{90}$ 
De recensie werd Bertina uiterst kwalijk genomen. Er volgden ingezonden brieven, en collega-journalisten reageerden in columns. ${ }^{6}$ Hoe dúrfde Bertina als leek op de stoel van de specialist te gaan zitten. Een andere recensent van de Volkskrant, H.R. de Vries, was een van de weinigen die het opnamen voor Bertina. Hij zette bovendien vraagtekens bij de rol van Bastiaans:

'Voor niemand, maar zeker niet voor een arts, mag het enig verschil maken of iemands leed wordt veroorzaakt door een "geheiligd" oorlogsverleden of andere calamiteiten in zijn persoonlijk leven. Geeft het feit dat iemand in een concentratiekamp heeft gezeten hem meer recht op therapeutische geïnvolveerdheid van de kant van de arts dan een ander $?^{362}$

De vraagtekens van Bertina en De Vries gingen verloren in een storm van verontwaardigde reacties. Hierop plaatste de Volkskrant een interview met Milikowski, de voorzitter van de vKs. ${ }^{63}$

Milikowski was ontstemd over de kritiek van Bertina. Hij had bewondering voor de authentieke wijze waarop de makers van de film de menselijke tragedie hadden vastgelegd. Hij was echter niet helemaal tevreden over de film; zijn verwachtingen waren niet uitgekomen:

'Welke uitwerking zal de film op het publiek hebben bij vertoning op de televisie of in de bioscoop? Zal ze als anti-oorlogsfilm werken, die de mensen waarschuwt, alarmeert tegen de voortwoekering van het fascisme? Dat is niet te verwachten omdat in de film het verband niet wordt gelegd tussen fascisme in het verleden en het fascisme in het heden. ${ }^{64}$

Zijn kritiek werd gevoed door een consequent vasthouden aan de communistische interpretatie van de oorlog: de hoofdpersoon was ziek omdat de idealen waar hij in de oorlog voor had gevochten nog steeds werden bedreigd. Het gevaar van de kampen bestond immers nog steeds. De film maakte van de oorzaak van de problemen een individuele aangelegenheid, en deed daarmee te kort aan de maatschappelijke en politieke oorzaken. Telling was volgens Milikowski ziek door zijn 'angst voor het hedendaags fascisme', niet door de spanning van de oorlog. ${ }^{65}$

Milikowski zag wel de kracht van de film; hij verwachtte dat deze effect zou sorteren bij ambtenaren van uitkeringsinstanties. Mogelijk zouden hierdoor de ambtelijke molens sneller en menselijker gaan draaien. Maar hij was tegen de openbare vertoning van de film; hij vond dat de anonimiteit van Telling bewaard moest blijven. Hij maakte zich daarom ook boos over de plannen van Bastiaans om driehonderd oud-verzetsstrijders te laten beslissen over openbare vertoning.

Psychiater C. van den Emde Boas was samen met Bastiaans' naaste collega, 
dr. N. Speijer, eveneens van mening dat openbare vertoning 'de grenzen van de medische ethiek' voorbij zou gaan. ${ }^{66}$ Ook de recensent van Het Parool, O.M. de Vaal, vond openbare vertoning te ver gaan, net als Bertina. ${ }^{67}$

\section{Propagandistische effecten}

De besloten première en de reacties die daarop volgden, verhoogden vermoedelijk de nieuwsgierigheid onder het grote publiek. Toch leek de film veroordeeld tot een leven in college- en congreszalen. ${ }^{68}$ Vanaf 1969 werd de film vertoond voor een publiek van studenten, hulpverleners en betrokkenen bij de behandeling van en zorg aan oorlogsslachtoffers.

Het $\mathrm{Kz}$-syndroom was al eerder in krantenartikelen verschenen. Wat het preciés was bleef een zaak voor de echte experts als Bastiaans, maar dat het groot psychisch en lichamelijk lijden inhield was iedereen duidelijk, zeker na het zien van de film. De tournee langs universiteiten, congressen en studieavonden, bereidde een generatie hulpverleners voor op de klachten van oorlogsslachtoffers. En op de LSD-therapie.

Dat laatste bracht de arts S. Timmers er in 1970 toe in een kritiek te schrijven dat van de film een 'ongewenst propagandistisch effect' uitging, ook al werd deze vertoond aan een gespecialiseerd publiek. ${ }^{69}$ De LSD-therapie was, zoals in hoofdstuk 4 werd beschreven, in 1968 onder vuur komen liggen bij een aantal hoogleraren. Die discussie had laten zien dat de merites van de ISD-therapie nog niet duidelijk waren. Desondanks was er nu wel al een film waarin de therapie werd gepresenteerd als een reguliere behandeling met een succesvol resultaat bij een ernstige aandoening.

Timmers' vraagtekens bij het effect van de film waren terecht, meer dan hij toen wist. Zelfs Bastiaans had op het moment van de opnames nauwelijks ervaring met de LSD-behandeling; Telling behoorde waarschijnlijk tot de eerste tien patiënten die hij met LSD behandelde. ${ }^{70}$

Bovendien was Tellings gedrag tijdens de LSD-sessie atypisch. Tijdens de narcoanalyses die Bastiaans uitvoerde in het kader van zijn proefschrift, kropen patiënten onder het vloerkleed of klommen in de verwarmingsbuizen om te ontkomen aan hun achtervolgers. Ook de hoofdrolspelers in de scènes die cineast Van Praag filmde, kwamen 'tot een navrante, realistische uitbeelding van hun oorlogservaringen', aldus een recensie in Haagse Post. Een man kronkelde van de pijn door de martelingen die hem in de oorlog waren toegebracht, en er was:

'een vrouw te zien die tijdens de LSD-sessie ineen krimpt onder de stokslagen die haar worden toegebracht, ondanks dat er geen stok in de behandelkamer is. ${ }^{71}$

Het waren indrukwekkende beelden geweest, die Bastiaans beschreef als kenmerkend voor de ingrijpende LSD-behandeling. ${ }^{72}$ 
Van dat alles was bij de sessie van Telling echter geen sprake. De beelden waren veel minder spectaculair, subtieler. Weliswaar werd Telling soms emotioneel en barstte dan in tranen uit, maar hij bleef ingetogen en beheerst. De film liet een overlevende zien met voorstelbare emoties. Juist dat maakte dat de film oprecht en authentiek overkwam; de kijker werd zich bewust van de overeenkomsten in plaats van de verschillen tussen hem en de patiënt.

Timmers' kritiek beperkte zich tot de belofte op genezing die uitging van de film. Toch blijkt dat ook het andere onderwerp van de film, het $\mathrm{kZ}$-syndroom, niet vrij is geweest van manipulaties van de makers.

In de film en in de interviews die Bastiaans naar aanleiding van de première gaf, wekte hij de indruk dat Telling een ernstig zieke patiënt was, die door de spanningen plotseling dood zou kunnen neervallen. Dat gaf de film een extra lading: hier was geen sprake van een intieme ontboezeming, maar van de redding van iemands leven tijdens een psychiatrische behandeling. De film wekte de indruk dat de kijker getuige was van de eerste LSD-behandeling van een lijder aan het KZ-syndroom. Maar wanneer werd die diagnose - KZ-syndroom bij Telling gesteld: voor of nadat hij de LSD-sessie kreeg?

Telling had op het moment dat Van Gasteren hem vroeg om mee te werken aan de film net een aanvraag voor een Buitengewoon Pensioen gedaan. Datwerd hem uiteindelijk toegekend vanwege 'fysieke klachten' maar het is onduidelijk of daarbij sprake was van een Kz-syndroom. ${ }^{73}$ Dat lijkt onwaarschijnlijk: zoals eerder werd beschreven was het $\mathrm{KZ}$-syndroom in 1967 nog maar net geïntroduceerd. Er waren niet veel artsen die de term gebruikten. Telling kwam pas in contact met een van de weinige experts op het gebied van het Kz-syndroom nadat hij zijn medewerking aan de film had toegezegd; Bastiaans en Telling ontmoetten elkaar enkele dagen voor de LSD-sessie voor de eerste maal. ${ }^{74}$

Bovendien kwam het initiatief voor de gefilmde sessie van Van Gasteren, die op zoek was naar een overlevende van de kampen die het aandurfde onder invloed van LSD zijn verhaal te doen. Hij was niet op zoek naar een psychiatrisch patiënt, lijdend aan het Kz-syndroom. Vandaar dat hij Milikowski had benaderd die, voor zover bekend, niet leed aan een $\mathrm{Kz}$-syndroom of in behandeling was voor klachten ten gevolge van de oorlog. ${ }^{75}$ Telling kreeg de sessie omdat Van Gasteren hem had gevraagd, niet omdat er een medische noodzaak was.

Deze aanleiding voor de gefilmde sessie werd het publiek onthouden, en de makers probeerden het publiek ervan te overtuigen dat Telling de symptomen van het $\mathrm{KZ}$-syndroom vertoonde.

Bastiaans schetste in de film de lijders aan het $\mathrm{kz}$-syndroom als mensen die niet in staat waren te spreken over wat hun was overkomen. Hun verleden was zo ondraaglijk, dat zij de gruwelijkste delen ervan hadden verdrongen en over andere delen niet wilden of konden spreken. Juist dat gedwongen zwijgen maakte hen ziek. Om hen uit dit 'contactisolement' te halen hadden ze de LSDbehandeling nodig. 
Tellings aangrijpende woordenstroom tijdens de film werd daarmee een bewijs van het succes van de LSD-behandeling: die liet Telling eindelijk spreken over de gruwelen van de kampen.

In een nagesprek van psychiater Dick van Tol met Telling werd dat nog eens benadrukt. Van Tol wees erop dat 'het mechanisme van verdringing' hem 'zelden zo duidelijk was geworden' als bij de herinnering van Telling aan een incident in Bergen Belsen: bij dit incident werd een Joodse vrouw, die het verbod had genegeerd om te spreken met iemand aan de andere kant van het prikkeldraad, onmiddellijk neergeschoten.

Maar: in het verslag dat Telling kort na de oorlog had geschreven, en dat Bastiaans kort voor de sessie kreeg te lezen, stond beschreven hoe Telling in Bergen Belsen naast een vrouw stond toen een jonge ss'er op haar afliep:

'Zonder waarschuwing nam deze zijn geweer van zijn schouder, liep tot enige meters van de vrouw en knalde haar neer. Verbijsterd stonden allen toe te kijken. [...] Wij waren heusch wel wat gewend, doch hadden nog niet gezien, dat een man een vrouw als een dolle hond om niets neerknalde. Zelfs de collega's van den ss-man staken hun afkeuring niet onder stoelen of banken. De jonge held bleef er echter volkomen onbewogen onder. Ik kan wel zeggen, dat ik heusch niet gauw meer ergens van onder de indruk kom, doch nu stond ik werkelijk paf. ${ }^{76}$

Niet alleen deze scène kwam voor in het verslag. Alle concrete herinneringen aan de kampperiode die Telling tijdens de LSD-sessie noemde (dat waren er niet zoveel), kwamen erin voor: zijn arrestatie, de slag in zijn nek, zijn eigen afranseling, het aanschouwen van de executies. Van het ontdekken van verdrongen herinneringen was dus geen sprake.

Behalve dat Telling in zijn verslag gedetailleerd over zijn tijd in de kampen had geschreven, had hij in de jaren voorafgaand aan de sessie ook veel over die periode gesproken. Hij had die niet verdrongen en hij had die ook niet willen vergeten.

Het advies dat Bastiaans wel eens gaf aan voormalig gevangenen om terug te keren naar de plek des onheils, was aan Telling niet besteed: hij had dat initiatief in 1960 zelf al genomen. Hij had een tentoonstelling ingericht in Sachsenhausen én in Nederland. Hij deed mee aan discussieavonden waar hij vertelde over de gruwelen én de kameraadschap in de kampen; hij ging naar reünies van voormalig Sachsenhausers. Vergeten was voor Telling onmogelijk, hij wilde iedereen herinneren aan wat daar was gebeurd. De film was voor hem een manier om een nog groter publiek te bereiken. De strijd van de vks was er juist op gericht de herinnering aan de kampen levend te houden.

Bij de effectiviteit van de LSD-behandeling zoals Bastiaans die schetste, waren vraagtekens te zetten. In de film werd de behandeling gepresenteerd als 
succesvol: Telling kon weer een 'normaal' bestaan leiden. Maar tijdens de tournee van Begrijpt u nu waarom ik huil... langs universiteiten, werd verteld dat Telling inmiddels weer onder behandeling was. ${ }^{77}$ De verbetering was blijkbaar van tijdelijke aard geweest. Een geslaagde behandeling betekende dus gek genoeg niet dat de klachten niet konden terugkeren. Telling bleef arbeidsongeschikt en zou niet meer gaan werken.

De stelligheid waarmee Bastiaans Telling bestempelde als een lijder aan het $\mathrm{Kz}$-syndroom was, gezien de vele vraagtekens, niet terecht. Het propagandistisch effect dat volgens Timmers van de film uitging gold dus evenzeer voor de LSD-therapie, over het $\mathrm{KZ}$-syndroom. Ondanks de vele vraagtekens rond het $\mathrm{KZ}$-syndroom en de LSD-therapie, zowel in het algemeen als in het geval van Telling, werden beide onderwerpen gepresenteerd als geaccepteerde wetenschappelijke successen. De film knoopte twee onderwerpen uit de psychiatrie aan elkaar, die daarna maar moeilijk te scheiden waren: het KZ-syndroom en de LSD-therapie.

Bastiaans zou dit gedwongen huwelijk op deze manier blijven presenteren. Als hij schreef over het $\mathrm{KZ}$-syndroom werden er altijd gevalsbeschrijvingen gegeven van LSD-behandelingen. De LSD-behandeling bevestigde de ernst van het Kz-syndroom; de genezing bevestigde de kracht van de LSD-behandeling.

\section{Hofman en het slachtofferschap}

De film bleef enkele jaren gereserveerd voor hulpverleners, studenten en anderen die werkzaam waren in de hulpverlening aan oorlogsslachtoffers. Een nieuwe generatie hulpverleners werd zo voorbereid op de gevolgen van de oorlog én de soms noodzakelijke behandeling met LSD.

Dat de film alleen gedraaid werd voor een gespecialiseerd publiek was grotendeels te wijten aan de schroom die nog bestond voor het laten zien van geestelijk en lichamelijk lijden. Telling, die aanvankelijk slechts meewerkte aan een autobiografische film van Van Gasteren, bleek bereid zich ook te laten portretteren als lijder aan het $\mathrm{KZ}$-syndroom. Het was een eerste teken van de verandering die zich voltrok bij de slachtoffers zelf; zij waren steeds meer bereid zich als slachtoffer te laten zien. Telling gaf aanvankelijk wel toestemming om de beelden van zijn sessie in dat verband te vertonen maar voorlopig alleen tijdens besloten vertoningen van de film. Bovendien wenste hij anoniem te blijven.

Maar de bereidheid om in het openbaar te spreken over het eigen slachtofferschap groeide razendsnel. Nog geen maand na de première van Begrijpt u $u$ wadrom ik huil... liet een andere patiënt van Bastiaans zich wél met naam en toenaam portretteren voor het Algemeen Handelsblad. ${ }^{78}$ Zijn naam was Karel Hofman. Hij was tijdens de oorlog in Rotterdam actief geweestin het verzet, en had onder andere Joden aan een onderduikadres geholpen. In 1942 werd hij ge- 
arresteerd en na verhoor ondergebracht in kamp Amersfoort. Na veertien maanden werd hij overgebracht naar kamp Vught. Op 19 november 1943 werd hij weer vrijgelaten. ${ }^{79}$

Hofman was vermoedelijk Bastiaans' eerste patiënt die in het openbaar getuigenis aflegde van zijn genezing door de behandeling met LSD. Evenals Telling ging hij echter na zijn behandeling niet meer aan het werk. Hij overleed in 1970, een jaar na de behandeling, aan een hartaanval, volgens Bastiaans veroorzaakt door de opwinding over een krantenbericht. ${ }^{80}$

In het interview, dat werd afgenomen door de journalist $\mathrm{W}$. Woltz, vertelde Hofman dat hij vanaf midden jaren vijftig in toenemende mate klachten had gekregen: hoofdpijn, vermoeidheid, nachtmerries en 'een trage hartslag'. De artsen konden geen lichamelijke oorzaak ontdekken. In 1967 kwam Hofman bij Bastiaans terecht, die begreep wat er aan de hand was. Hij vertelde Hofman dat het in de oorlog heldhaftig was om te zwijgen, maar dat hij nu moest praten. Om hem daarbij te helpen, gaf hij hem een LSD-behandeling.

Hele kolommen van het interview werden gevuld met beschrijvingen van afgrijselijke, sadistische martelingen, die Hofman had moeten aanschouwen. De meest gruwelijke mishandeling was die waarbij negen Joden werden vermoord. Hofman beschreef hoe hij negen opgesloten Joden tegen de regels in voedsel had gebracht. Het voedsel werd ontdekt, en na een flinke mishandeling werd Hofman verraden. Als straf moest hij toekijken hoe de Joden aan hun scrotum negen meter hoog werden opgehesen, waarna ze met hun schedels op de betonnen vloer te pletter sloegen. ${ }^{81}$ Hofman werd met zijn gezicht in een van de opengebarsten schedels geschopt, waarna de ss'er riep:

$$
\text { 'Jodenvrienden moeten jodenbloed drinken. }{ }^{82}
$$

Het werd een van de scènes die Bastiaans vaak als voorbeeld gebruikte om de problematiek van de slachtoffers te illustreren. ${ }^{8_{3}}$

Overigens lijkt de mishandeling van de Joden die Hofman beschrijft onwaarschijnlijk: het optillen van aan man aan zijn scrotum is nauwelijks mogelijk, het scrotum zou afscheuren. Bovendien hebben andere overlevenden van kamp Amersfoort nooit iets over deze mishandeling verteld. ${ }^{84}$

Frappanter aan het interview is dat Hofman zichzelf schetste als een gevangene die van de ene naar de andere mishandeling werd gesleept, iemand die tot het uiterste werd getergd en een willoze getuige was van de meest onmenselijke mishandelingen en vernederingen, onderwijl zelf geslagen door zijn bewakers. Een slachtoffer.

Dat was een heel ander beeld dan dat hij in 1951 aan een onderzoeker van het RIOD had geschetst. Daarin vermeldde hij hoe de dagelijkse routines - het verdelen van het eten, het indelen in commando's, de administratie van overlede- 
nen - zoals in alle kampen, ook in Amersfoort en Vught grotendeels waren overgelaten aan de gevangenen zelf. Op die manier ontstond in de meeste concentratiekampen een hiërarchie onder de gevangenen, en in die hiërarchie had Hofman carrière gemaakt. ${ }^{85}$

In zijn functies als Stubeälteste en later als Blockschreiber had hij beslist over straf en beloning van andere gevangenen. Hij had daarmee levens gered, maar wanneer de omstandigheden daarom vroegen, sloeg hij anderen ook het ziekenhuis in. ${ }^{86} \mathrm{Hij}$ was onderdeel van een systeem waarin hij altijd slachtoffer, maar soms ook dader was. Los van de vraag of dat een vermijdbaar of zelfgekozen lot was, liet Hofman in deze verklaring een heel andere kant van zichzelf zien dan in het interview met Woltz in 1969.

Ook Hofmans verhaal over het voedsel geven aan de Joden zag er in 1951 heel anders uit. In zijn verklaring aan de onderzoeker van het RIOD beschreef hij hoe alle gevangenen in kamp Amersfoort in de kantine voedsel konden kopen, behalve de Joden. Met de kerst van 1942 had Hofman, samen met andere prominenten van de Stubedienst, onder de gevangenen geld ingezameld, zodat ze tijdens de kerstnacht als kerstgeschenk fruit bij de Joden in bed konden leggen. Dat was volgens Hofman best een gevaarlijke actie gebleken, want enkele Joden hadden de volgende dag iets te opzichtig het fruit opgegeten. Het had bijna tot ontdekking geleid.

Enkele dagen later ontdekte de Stubedienst bij toeval een handgeschreven briefje waarin stond hoe de Stubedienst onder het voorwendsel van een kerstgeschenk voor de Joden geld had ingezameld, maar vervolgens dat geld in eigen zak had gestoken. Dat was verraad. Hofman stelde samen met anderen een onderzoek in. Onder dreiging van onthouding van voedsel voor het hele blok moest de dader zich melden. Toen dat niet gebeurde, vergeleek een grafoloog het handschrift op het briefje met de handschriften van de verdachten. Uiteindelijk werd een schuldige aangewezen en door Hofman en anderen in elkaar geslagen.

Naast de vraag aan welke verhalen van Hofman de grootste historische authenticiteit moet worden toegekend, was het belangrijkste van Hofmans verhaal dat hij in 1969 een heel ander beeld schetste dan hij in 1951 had gedaan. De context waarin de reconstructie tot stand kwam, verschilde natuurlijk: tegenover een onderzoeker van een wetenschappelijk instituut wordt een ander verhaal verteld dan tegen een hulpverlener of interviewer. Maar de verschillen bij Hofman waren te groot om alleen daardoor verklaard te worden: in iets minder dan twintig jaar tijd was in zijn autobiografische reconstructie de trotse Stubeälteste vervangen door een willoos slachtoffer en een getuige van gruwelijk lijden.

Hofman had zich aanvankelijk uitgesproken tegen openbare vertoning van Begrijpt u nu wadrom ik huil... Hij was na de besloten viewing voor verzetsstrijders - nog voor de première - 'weer helemaal in zijn angsten gekomen'. Dat 
wilde hij anderen niet aandoen. Maar op aandringen van Bastiaans had hij zijn mening herzien. In het interview met Woltz brak hij een lans voor openbare vertoning

'Deze film móét op de televisie, maar met een voorwoord van professor Bastiaans. Duidelijk zal dan moeten blijken dat LSD zonder medische begeleiding gevaarlijk is. Maar ik geloof nu, dat iedereen moet weten wat het concentratiekampsyndroom is, waarom oud-gevangenen vijfentwintig jaar na de oorlog zonder directe oorzaak geestelijk afknappen. ${ }^{87}$

Hofman hoopte met zijn verhaal 'begrip te wekken'. Als dat lukte, zou het achterliggende doel - het verhogen van de pensioenen voor verzetsstrijders en de versnelling van de aanvraagprocedures - ook sneller bereikt worden.

Een paar maanden na het interview met Woltz was er sprake van de mogelijke vrijlating van enkele oorlogsmisdadigers. Hofman schreef nogmaals zijn gruwelijke verhaal in Geestelijk Weerbaar, het weekblad van de rechtse Nationale Federatieve Raad Voormalig Verzet Nederland ${ }^{88} \mathrm{Hij}$ had een paar andere voormalig gedeporteerden bereid gevonden ook hun verhaal te doen. Net als bij het interview met Woltz was het de bedoeling om met begrip voor het leed in de kampen een hoger doel te bereiken, ditmaal het vasthouden van de oorlogsmisdadigers.

\section{Conclusies}

De doelen die Telling en de vKs wilden bereiken, verschilden eind jaren zestig niet met die van begin jaren zestig. Nog steeds wilden zij berechting van nog loslopende oorlogsmisdadigers, langere straffen, een stop op voortijdige vrijlatingen, verbeteringen in pensioenvoorzieningen en versnelling van de aanvraagprocedures.

Begin jaren zestig beriepen ze zich bij overheden en het Openbaar Ministerie op de nagedachtenis van de gevallenen en het rechtsgevoel van de nabestaanden. Ze maakten tentoonstellingen en publicaties om een 'anti-fascistisch' bewustzijn te creëren. Door in te gaan op het verzoek van Van Gasteren kon Telling een bijdrage leveren aan dat politieke streven van de vKs.

Withuis beschreef in haar boek $\mathrm{Na}$ het kamp hoe andere kampcomités en belangenorganisaties van verzetsstrijders vergelijkbare doelen nastreefden, maar dat al die organisaties door politieke tegenstellingen nooit een gezamenlijke vuist konden of wilden maken. ${ }^{89}$ Eind jaren zestig veranderde dat. De Koude Oorlog was wat minder koud geworden, en Withuis beschreef hoe de comités en organisaties elkaarleken tevinden in het slachtofferschap. Eenvoorbeeld van die ontdooiende verhoudingen was dat zowel de rode Telling als de rechtse Hofman zijn slachtofferschap liet zien. De rechtse Hofman pleitte er zelfs voor 
de film met daarin de linkse Telling in het openbaar te vertonen, zodat hun gezamenlijke doelen konden worden bereikt.

De publieke interesse voor de individuele psychische gevolgen van de oorlog groeide. Dat was al gebleken uit de initiatieven van Van Praag en Van Gasteren, en het bleek nog eens bij de première van de film. De aanwezigheid van de koningin was het uitroepteken achter die ontwikkeling. Tegelijkertijd was er nog sprake van een zekere terughoudendheid tegenover overlevenden: konden die een confrontatie met verhalen van andere overlevenden aan? Was dat niet te belastend?

Bastiaans wilde met de film, zo zei hij tijdens de inleiding voor de koningin, begrip wekken voor het leed van de slachtoffers. Voor een op kennisvermeerdering gerichte en objectiverende wetenschapper was dat een vreemd doel. Desalniettemin zou Bastiaans deze lijn doorzetten. De film werd ook nog wat aangepast voor dat doel: het rauwe begin, waarin Telling beschreef hoe hij een stervende medegevangene op de koude vloer van de barak had gelegd, werd vervangen door shots van foto's van Telling als baby.

$\mathrm{Na}$ de succesvolle première riep Bastiaans verzetsstrijders op een briefkaart te tekenen waarin werd aangedrongen op bredere vertoning. ${ }^{90}$ De overlevenden zelf werden zich bewust van de kracht van hun slachtofferschap en waren steeds meer bereid hun verhaal te doen.

Met de publieke interesse groeide ook de compassie voor de overlevenden. De reacties op Bertina's stuk lieten zien dat twijfel aan het leed van de hoofdpersoon kon rekenen op felle reacties. Maar dat leed in een openbare uitzending in beeld brengen, was nog een stap te ver. Het was wel 'erg binnenskamers', zoals de koningin zei.

Tellings leed werd langzaam prijsgegeven aan de openbaarheid. Hij had in 1967 nog een verklaring ondertekend waarin hij alleen zijn akkoord gaf voor vertoning van de beelden 'ten behoeve van geïnteresseerden in deze materie in de ruimste zin voor niet-openbare vertoning. ${ }^{.1}$ Hij wilde geen openbare vertoning want:

"Ik wil niet bekend worden als "Jan de huilebalk". ${ }^{92}$

In 1972, drie jaar na de première, beheerste het lijden van de overlevenden een van de heftigste politieke en maatschappelijke debatten van de vorige eeuw: het debat over de gratiëring van drie Duitse oorlogsmisdadigers. De overlevenden van de kampen vermoedden dat de film een krachtig politiek instrument zou kunnen zijn in dat debat. De weerstand tegen openbare vertoning werd steeds moeilijker houdbaar. 


\section{De drie van Breda}

'In de laatste weken zijn wij in toenemende intensiteit opnieuw geconfronteerd met het feit, dat ruim 30 jaar geleden vrijwel geheel Europa tot een veld van strijd en in feite ook tot één groot concentratiekamp werd."

BASTIAANS TIJDENS DE OPENBARE HOORZITTING OVER DE VRIJLATING VAN

DE LAATSTE DRIE OORLOGSMISDADIGERS, 1972.

Inleiding

In de zomer van 1969 voerde minister van Justitie mr. C.H.F. Polak geheime besprekingen met de verschillende fractievoorzitters. Hij deed een voorzichtige poging om een wetswijziging door te voeren waarmee levenslanggestraften de mogelijkheid zouden krijgen tot voorwaardelijke invrijheidstelling. Nederland was op dat moment een van de weinige landen in Europa waar levenslanggestraften ook daadwerkelijklevenslang vastzaten, tenzij deKroon hun gratie verleende. In het verleden was het al wel voorgekomen dat aan oorlogsmisdadigers gratie werd verleend, maar in 1969 was de situatie anders.

De laatste drie nog gevangenzittende Duitse oorlogsmisdadigers, F. Fisscher, F.H. aus der Fünten en J.J. Kotälla, gaven aan een gratieverzoek in te willen dienen. Dat de koningin gratie zou verlenen aan oorlogsmisdadigers werd in het heersende klimaat echter als te gevoelig gezien. Daarom wilde Polak een wetswijziging invoeren waarmee ingrijpen van de koningin overbodig werd. Voorzichtig tastte hij de mening van de fractievoorzitters af. ${ }^{2}$

Het plan van Polak lekte uit en er volgde een verhit publiek debat over de vrijlating van 'de drie van Breda'. Voorstanders wezen op het gelijkheidsbeginsel: voor de wet is iedereen gelijk, dus als 'gewone' misdadigers na een bepaalde periode vrijkomen, dan ook oorlogsmisdadigers. Bovendien, welk juridisch doel diende het nog ze vast te houden? Tegenstanders wezen op de uitzonder- 
lijk wrede en unieke misdaden van de drie; misdaden die dus buiten de normale rechtsgang vielen. Het plan van Polak haalde het niet.

In de discussies werd het leed van de slachtoffers steeds meer als argument gebruikt. De eerdergenoemde Hofman verzamelde in 1969 verhalen van overlevenden van de kampen, van wie sommigen direct contact hadden gehad met (een of meer van) de drie oorlogsmisdadigers. Samen met zijn eigen gruwelijke verhaal verschenen de getuigenissen in het blad Geestelijk Weerbaar/Voormalig Verzet Nederland, officieel orgaan van de Nationale Federatieve Raad van het Voormalig Verzet Nederland ( $\mathrm{NFR} / \mathrm{VVN}) \cdot{ }^{3}$ Hoe kon er sprake zijn van vrijlating van misdadigers als hun slachtoffers nog dagelijks te lijden hadden onder de gevolgen van de mishandelingen?

In de discussie rond de drie maakte de politieke verdeeldheid plaats voor emotionele eenheid, zoals Withuis beschreef in haar boek Erkenning. ${ }^{4}$ De slachtoffers, die in de jaren daarvoor door hun onderlinge verdeeldheid niet in staat waren geweest om gezamenlijk op te trekken, sloten zich aaneen in de strijd tegen vrijlating. Ze gebruikten daarbij hun psychisch leed - dat de naam Kz-syndroom had gekregen - als argument. Dat bleek een uiterst krachtig wapen.

\section{Aanloop: Van Agt is voor vrijlating}

De poging van Polak was de generale repetitie voor een hernieuwde poging tot vrijlating in 1972. Op een kennismakingsreceptie met de politieke pers in september 1971 gaf de nieuwe minister van Justitie in het kabinet van minister president Biesheuvel, mr. Dries van Agt, een explosief visitekaartje af. Gevraagd naar zijn gedachten over de oorlogsmisdadigers in Breda, antwoordde hij dat hij, net als zijn voorganger Polak, vóór vrijlating was. Hij voegde eraan toe dat hij zijn kansen om dat te realiseren wel lager inschatte dan die van zijn Joodse voorganger, aangezien hij 'een Ariër' was.

De veenbrand die in 1969 al even bovengronds was gekomen, laaide nu hoog op. De volgende dag stond zijn opmerking op de voorpagina's van de kranten en stroomden de ingezonden brieven binnen bij de redacties. Briefschrijvers vroegen zich af of er ook weer een ' $\mathrm{T}$ ' in de paspoorten afgedrukt zou worden, en wensten dat Van Agt spoedig naar het land der Ariërs zou vertrekken. De toon was gezet. Wekenlang stonden de kranten vol over de kwestie: vrijlaten of niet.

In oktober 1971 lagen de drie gratieverzoeken op het bureau van Van Agt. In antwoord op de vraag uit de Kamer of hij, als hij tot vrijlating overging, de Kamerleden zou consulteren, nam Van Agt een cruciale beslissing: hij beloofde de Kamer te raadplegen over de kwestie. Dat was bijzonder, want gratiëring was een voorrecht van de Kroon; daar was staatsrechtelijk gezien geen ruggespraak met het parlement voor nodig.

Van Agt legde de gratieverzoeken eerst voor aan de twee hoogste rechterlij- 
ke colleges, die een advies zouden uitbrengen. ${ }^{5}$ In januari 1972 kwamen de adviezen: volgens de colleges konden de drie worden gegratieerd. Toen Van Agt, zoals beloofd, zijn voornemen tot gratiëring op 16 februari per brief bekendmaakte aan de Kamer, barstte het publieke debat los. De Kamer organiseerde, vooral op aandringen van D'66-Kamerlid mr. A.M. Goudsmit, voorafgaand aan het Kamerdebat een openbare hoorzitting, waarop iedere organisatie die daar om verzocht, zich kon laten horen.

In de periode voor de hoorzitting werd het debat over vrijlating gevoerd in de media. Voor- en tegenstanders lieten van zich horen. Vooral door tegenstanders werden daarbij de gevolgen van vrijlating voor de slachtoffers benadrukt. Dat werd voor veel Kamerleden ook de belangrijkste factor bij het bepalen van een standpunt. De slachtoffers zelf brachten in emotionele stukken hun leed naarvoren.

Voorstanders van vrijlating vonden echter dat men leed niet als doorslaggevend argument kon gebruiken. Procureur-generaal bij de Hoge Raad G.E. Langemeijer, die al in een vroeg stadium te maken had met de mogelijke gratiering van de drie, drukte dat als volgt uit:

'Je moet respect hebben voor de gevoelens van mensen, die direct of indirect door de naziterreur getroffen zijn, maar je kunt geen objectief oordeel van ze verlangen, en dan mag hun oordeel ook niet beslissend zijn. ${ }^{6}$

Daarom werd er veel waarde gehecht aan de inschatting van psychiaters en hulpverleners, die met enige afstand en expertise iets over de gevolgen konden zeggen. Bastiaans speelde daarbij als hoogleraar psychiatrie een prominente rol. Hij was na de première van Begrijpt u nu waarom ik huil... voor het grote publiek dé expert, en onder verzetsstrijders een geliefd psychiater. Aan zijn inschatting van de gevolgen werd grote waarde gehecht. In de aanloop naar het Kamerdebat werd hij regelmatig geïnterviewd.

Bastiaans nam in deze periode onder de slachtoffers een verergering van het $\mathrm{Kz}$-syndroom waar. ${ }^{7}$ De nervositeit nam toe, de angsten werden sterker en het gevoel van machteloosheid groeide. Ook lichamelijke kwalen werden sterker: de toch al hoge bloeddruk werd nog hoger en bestaande reumatische aandoeningen en hartklachten namen toe. ${ }^{8}$ Slachtoffers vielen Bastiaans daarin bij, zoals de communist en voorzitter van het Nederlands Auschwitz Comité, J. Slagter:

'Het Kz-syndroom culmineert na een kwart eeuw. [...] Er zijn er die uitsluitend thuis zitten te wachten op de dood. ${ }^{9}$

In de aanloop naar de openbare hoorzitting schatte Bastiaans het aantal lijders aan het $\mathrm{KZ}$-syndroom op 30000 tot 40000 personen. Het was de eerste keer dat 
in de kranten een aantal werd genoemd, de eerste keer dat de omvang van het probleem in een getal werd uitgedrukt. Eenmaal genoemd bleef het getal terugkomen in de discussies van die dagen. Het werd door anderen herhaald zonder dat publiekelijk de vraag werd gesteld waar het eigenlijk op gebaseerd was.

Bastiaans was niet de enige psychiater die de problemen van slachtoffers zag verergeren. Ook psychiater Herman Musaph, die veel oorlogsslachtoffers in zijn praktijk had, ontving een toenemend aantal telefoontjes van verontruste patiënten. Hij zag het aantal 'noodgevallen' toenemen. ${ }^{10}$ De Rotterdamse psychiater Fentener van Vlissingen voorzag dramatische ontwikkelingen bij vrijlating; hij voorspelde een klopjacht op de drie die zou eindigen in een bloedbad. $^{11}$

In een interview met De Tijd op 19 februari stelde Bastiaans dat de problemen van de slachtoffers door alle aandacht waren verergerd, en dat juist om die reden vrijlaten hem de beste optie leek; anders zou er binnen korte tijd opnieuw onrust ontstaan als er een nieuw gratieverzoek kwam. ${ }^{12}$ De stelligheid van zijn uitspraak nam echter onder de toenemende druk van de slachtoffers al snel af. Dat bleek toen hij enkele dagen later een brief aan rabbijn A. Soetendorp schreef. Bastiaans had met veel slachtoffers gesproken en allemaal hadden ze behoefte aan rust; voor de een betekende dat vrijlating, voor de ander juist niet. Vanuit medisch-psychiatrisch oogpunt zag Bastiaans maar één dwingende eis: meer sociale zekerheid voor de slachtoffers in de vorm van uitkeringen en hulpverlening. Hij 'neigde' nog steeds naar vrijlating, maar gebruikte een voorzichtiger formulering dan enkele dagen daarvoor. ${ }^{13}$ Op 22 februari herhaalde hij zijn uitspraak in Achter het Nieuws: hij 'tendeerde' naar vrijlating. ${ }^{14}$

Op 23 februari had Bastiaans 's ochtends een twee uur durend gesprek met Van Agt. In een interview dat een paar uur na het gesprek werd afgenomen door Trouw zei Bastiaans dat hij Van Agt had gezegd dat er maar één goede oplossing was: een onderzoek naar de voor-en nadelen van vrijlating, en dat in de vorm van een enquête voorleggen aan het volk. ${ }^{15}$ Dit plan zou echter totverder uitstel leiden, en daar was geen tijd meer voor. Bastiaans zette nogmaals het dilemma uiteen: óf de klap ineens óf steeds maar weer opnieuw de wonden openrijten. Van Agt had hem verteld dat hij geen garantie kon geven dat de drie niet nogmaals een gratieverzoek in zouden dienen. Bastiaans 'tendeerde' daarom nog steeds naar vrijlating, maar het was een duivels dilemma. ${ }^{16}$

$\mathrm{Na}$ het interview met Trouw spoedde Bastiaans zich naar perscentrum Nieuwspoort, waar rabbijn A. Soetendorp een besloten voorstelling van Begrijpt u nu wadrom ik huil... had georganiseerd voor Kamerleden. Na afloop was er gelegenheid om vragen te stellen. Bastiaans wilde op de bijeenkomst geen stelling meer nemen voor of tegen vrijlating, maar waarschuwde dat een vrijlating slapende vulkanen tot uitbarsting kon brengen: de gevolgen waren niet te voorspellen. ${ }^{17}$ Hij benadrukte dat over de effecten van vrijlating geen 'weten- 
schappelijk verantwoorde' cijfers te geven waren, maar dat hij wel de indruk had dat de meeste slachtoffers nadelige gevolgen zouden ondervinden. ${ }^{18}$

\section{De openbare hoorzitting}

De animo voor de hoorzitting op donderdag 24 februari 1972 was zo groot dat deze werd gehouden in de zaal waar normaal de Tweede Kamer vergaderde. In totaal gingen 39 sprekers namens 43 organisaties in op de uitnodiging. Centraal in de hoorzitting stond de vraag wat de grootste gevolgen zou hebben: vrijlating in één keer of steeds opnieuw de discussie over vrijlating. Telkens weer wilden de Kamerleden van de sprekers weten hoe zij de gevolgen van beide opties inschatten.

In de betogen van de sprekers klonken regelmatig de argumenten door die Bastiaans in de dagen voorafgaand aan de hoorzitting had laten horen. Izak Zadoks, die sprak namens drie Joodse organisaties, benadrukte dat het wetenschappelijk onderzoek naar het Kz-syndroom had aangetoond dat de gevolgen van de oorlog met het klimmen der jaren niet waren afgenomen maar juist toegenomen.

De spreker namens het Nederlands Ravensbrück Comité wees de minister op het wetenschappelijk onderzoek in het proefschrift van Bastiaans uit 1957. En, net als de Werkgroep Stichting ' 40 -'45 Zuid-Holland, vroeg het Comité of de minister nog steeds niet had gehoord van het Kz-syndroom. Wist hij niet dat er een nieuwe kliniek werd gebouwd speciaal voor de behandeling van de aandoening?

Voormalig verzetsstrijder W. Kicken, vertegenwoordiger van de Landelijke Organisatie Oud-Illegale Strijders, nam tijdens de hoorzitting ook het woord. $\mathrm{Na}$ een lang betoog waarin hij vertelde over zijn gevangenschap in de Duitse kampen, besloot hij met de woorden:

'Mijn laatste vraag is of de heer Van Agt ons wellicht op de barricaden wil drijven om de drie van Breda zelf te liquideren. Dat zal beslist niet uitblijven.'

Tekenend voor de grimmige sfeer tijdens de openbare hoorzitting was de reactie op dit dreigement: het publiek ontving het met applaus. ${ }^{19}$

De voorzitter van de Nederlandse Zionistenbond, Cohen, herinnerde de aanwezigen aan de 'vreselijke film' die de avond daarvoor was vertoond voor de Kamerleden, en die het leed had laten zien dat bij 30000 slachtoffers nog doorwerkte.

Mevrouw Glastra van Loon-Boon, vertegenwoordigster van het Comite Stichting Oranje Hotel, verhoogde de schatting van Bastiaans met nog eens 10000 , zodat het aantal slachtoffers volgens haar tussen de 40000 en 50000 kwam te liggen.

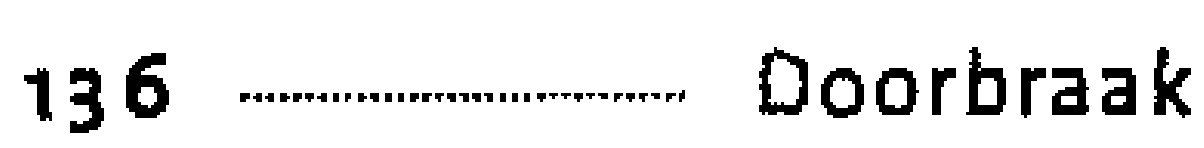


A.J. Kliest sprak namens de Landelijke Kontakt-Groep verzetsgepensioneerden en (LKG) baseerde zijn betoog op Bastiaans' uitspraken over verergering van de symptomen bij mensen die al 'onder zeer grote psychische druk en lichamelijke verminking' leefden.

Volgens Lavell van de Contactcommissie Verzetsgepensioneerden van de noordkop van Noord-Holland, was het concentratiekampsyndroom een levenslange straf voor de slachtoffers, zonder hoop op genezing.

De Nationale Federatieve Raad van het voormalig verzet, vertegenwoordigd door Van den Heuvel, had met zijn achterban vele argumenten tegen vrijlating verzameld, maar het draaide volgens de Raad maar om één ding: het diep menselijke van het probleem:

'Tk dring er op aan, dat - gelet op het menselijke element - de slachtoffers niet opnieuw door deze zee van psychische ellende worden geleid.'

Sunier, geneesheer-directeur van het Sinai-centrum, een Joodse instelling voor geestelijke gezondheidszorg, benadrukte dat de Kamerleden meer gewicht aan het oordeel van de psychiaters moesten hechten dan aan dat van de slachtoffers zelf. Hij verwachtte van vrijlating 'een felle heractualisering van gevoelens' zonder dat hoop op een oplossing werd geboden. Hij waarschuwde dat als de drie werden vrijgelaten, dit tot een toeloop van patiënten zou leiden in zijn kliniek.

Musaph sprak namens het Comité van Vrienden van de Israëlitische artsenorganisatie Afdeling Nederland. Hij was in de week voorafgaand aan het debat gebeld door een vrouw die door de dreigende gratiëring 's nachts wakker schrok in de angst dat ze gehaald zou worden voor de gaskamer. Ook hij voorspelde een toename van de klachten. Andere sprekers meldden dat zij telefoontjes hadden ontvangen met de boodschap van patiënten dat ze zelfmoord zouden plegen als tot vrijlating werd overgegaan.

Volgens de voorzitter van de vKs Milikowski was de kern van het probleem een politieke zaak: hoe was anders te verklaren dat een motie waarin werd voorgesteld de Joodse slachtoffers een volwaardig pensioen toe te kennen tot tweemaal toe werd geweigerd, terwijl de drie misdadigers op vrije voeten werden gesteld. ${ }^{20}$ Milikowski vermoedde antisemitische tendensen bij het kabinet.

Telling nam als tweede spreker namens de vrs ook nog even kort het woord en wees op de gruwelijkheden die een van de oorlogsmisdadigers op eigen initiatief had aangericht. Hij besloot met:

'Daarom zeggen wij, oud-gevangenen van concentratiekamp Sachsenhausen: wij zijn tegen gratiëring. Geen gratie. Niet loslaten. Zitten laten. Niet meer over babbelen.' 
Hoogleraar strafrecht L. Hulsman sprak namens de Coornhertliga, een vereniging die strafrechthervorming nastreefde. De liga was een van de weinige voorstanders van vrijlating die het aandurfden te spreken op de hoorzitting. Maar het spreken werd Hulsman moeilijk gemaakt, hij werd uitgescholden voor 'fascist' en 'NSB'er'. En alles werd uitgezonden op televisie.

Voor Bastiaans stond in de discussie rond de drie veel op het spel. Hij was de hoogleraar die, naar eigen zeggen, al sinds de jaren vijftig had gepleit voor een betere behandeling van slachtoffers. Hij werd algemeen gezien als de man die het Kz-syndroom onder de aandacht had gebracht, en genoot onder leden van het voormalig verzet groot vertrouwen. Aanvankelijk had hij zich vóór vrijlating uitgesproken, maar gaandeweg was hij minder stellig geworden. Welk standpunt zou hij innemen nu het erop aankwam?

Bastiaans begon zijn betoog met te stellen dat hij als mens tegen de doodstraf was en nog meer tegen levenslange gevangenisstraf. Maar na analyse van de reacties van de weken daarvoor, moest hij terugkomen op een belangrijke aanname in zijn redenering. Hij was er steeds van uitgegaan dat vrijlating tot een tijdelijke verergering van de symptomen zou leiden; na verloop van tijd zou het effect wegebben en zou de herwonnen zekerheid rust brengen, meer rust dan vóór de vrijlating. $\mathrm{Nu}$ twijfelde hij an die tijdelijkheid. Hij was er niet meer van overtuigd dat de rust zou weerkeren en hij vreesde dat slachtoffers door de vrijlating blijvend last zouden houden van de verergerde klachten. Hij beriep zich op zijn kennis en ervaring als psychiater en wetenschapper bij die inschatting. Hij pleitte tegen vrijlating.

Binnen enkele dagen was Bastiaans van voor-in tegenstander van vrijlating veranderd. Van Agt was door die draai ontdaan. ${ }^{21}$ Hij had aan het gesprek met Bastiaans op 23 februari de indruk overgehouden dat hem was geadviseerd de drie vrij te laten. ${ }^{22} \mathrm{Hij}$ meende daarmee in Bastiaans een belangrijke steun te hebben gevonden in zijn voornemen de drie vrij telaten. Hij noemde het 25 jaar na de hoorzitting zelfs 'een van de grieven die in mij branden bij de herinnering aan deze zaak'. Ook minister-president Biesheuvel sprak Bastiaans naderhand aan op zijn veranderde mening. ${ }^{23}$

Bastiaans hield vol dat hij niet van mening was veranderd, maar dat hij tijdens de hoorzitting meer tijd had gehad om zijn standpunt toe te lichten. ${ }^{24} \mathrm{Het}$ gesprek met Van Agt had echter twee uur geduurd; dat was aanzienlijk langer dan de spreektijd tijdens de openbare hoorzitting. Wat er in het gesprek met Van Agt precies werd gezegd is niet meer te achterhalen. ${ }^{25}$ Uit de krantenartikelen en interviews van de periode valt wel op te maken dat Bastiaans in de aanloop naar de zitting steeds minder stellig werd in zijn uitspraken. Tijdens de discussie bij de besloten voorstelling, waar Van Agt ook aanwezig was, liet Bastiaans al horen dat de groep die door vrijlating benadeeld zou worden, de grootste was. Bastiaans maakte dus inderdaad een draai, maar die was enigszins te voorzien geweest.

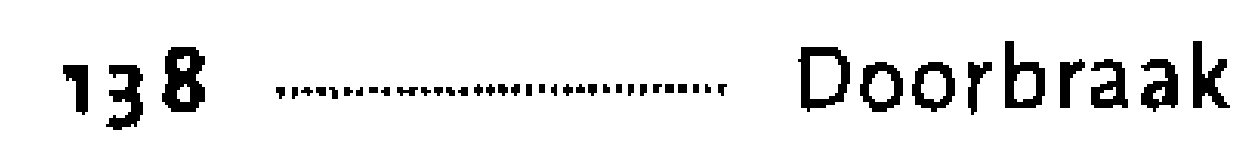


De film wordt in de strijd geworpen

Na de openbare hoorzitting was de strijd nog niet gestreden. De hoorzitting had een informerende functie; het wachten was nu op het debat in de Tweede Kamer waarin een motie van PvdA-Kamerlid J.J. Voogd zou worden behandeld. In de motie werd het kabinet ontraden de drie vrij te laten. Als de motie werd aangenomen, zou het moeilijk worden voor het kabinet om alsnog tot gratiëring over te gaan. De druk op politici werd opgevoerd.

Hans Jacobs, afdelingschef van de nieuwsrubriek Achter het Nieuws van de VARA, meldde tijdens de stafvergadering op 24 februari dat hij Begrijpt u nu wadrom ik huil... wilde uitzenden. ${ }^{26}$ Bastiaans had inmiddels zijn medewerking al toegezegd; hij dacht dat met een goede in- en uitleiding de film geschikt was voor openbare uitzending. Telling, zich inmiddels ook bewust van de kracht van de film, had zijn bezwaren tegen openbare vertoning laten varen. Desondanks werd op de stafvergadering, op twee onthoudingen na, unaniem tegen uitzending gestemd. Een tweede vergadering onder leiding van de voorzitter van de VARA, André Kloos, leverde hetzelfde resultaat op; de medewerkers van de VARA waren huiverig voor de reacties die een vertoning zou oproepen. ${ }^{27}$

Jacobs nam geen genoegen met de beslissing van de stafleden en vroeg het dagelijks bestuur om een uitspraak. Dat vergaderde op vrijdagochtend en was van mening dat de uitzending wél doorgang moest vinden.$^{28}$ De weerstand tegen uitzending was groot binnen de VARA. Van Gasteren werd zelfs's nachts door een VARA-medewerkster uit zijn bed gebeld met de vraag waarom hij toch die uitzending door wilde laten gaan. ${ }^{29}$

Op zaterdagochtend 26 februari 1972 maakte de vara bekend dat die avond tijdens een speciale uitzending van Achter het Nieuws de film zou worden vertoond.

Een aantal psychiaters, onder wie Musaph, schreef een brandbrief aan de VARA waarin ze waarschuwden dat uitzending wel eens kwalijke gevolgen voor oorlogsslachtoffers kon hebben. ${ }^{30}$ Musaph maakte zich grote zorgen over de mogelijke 'acute psychische, exogene reacties' die zouden optreden bij het aanschouwen van de film. ${ }^{31}$ Ter voorbereiding op die reacties richtte hij in het Amsterdamse Wilhelmina Gasthuis een omvangrijk crisiscentrum in, een 'psychische eerstehulppost', om zo de 'mogelijke pathologische reacties te kunnen behandelen'. ${ }^{2}$ Het ziekenhuis ontruimde een zaal en een aantal kamers, en ook andere hulpposten in de hoofdstad en in Leiden stonden klaar om de stromen patiënten op te vangen. In Hilversum waren twaalf telefonistes, geïnstrueerd door Musaph, tot 24 uur na de uitzending paraat om bellers te woord te staan.

Voorstanders van vrijlating waren niet automatisch tegenstanders van uitzending. Psychiater J.L.J. Lumeij vermoedde dat de film emoties zou oproepen, maar hij achtte dat niet per se schadelijk. Het uiten van emoties zou wel eens 
helend kunnen werken. ${ }^{33}$ Ook waren niet alle tegenstanders van vrijlating voor uitzending; $\mathrm{mr}$. G. Aalders, voorzitter van vereniging van voormalige politieke gevangenen Expogé, vreesde de gevolgen van de emoties die zouden worden opgeroepen door de film, en drong er bij de VARA en Bastiaans op aan dat de film niet werd uitgezonden. ${ }^{34}$ Ook benaderde hij minister P.J. Engels van CRM. Die benaderde op zijn beurt Bastiaans en beriep zich op de afspraken die zijn ministerie indertijd met hem en Van Gasteren had gemaakt. ${ }^{35}$

Bastiaans zelf twijfelde ook. De vrijdag voor de uitzending zocht hij contact met de jurist van de NFGV, mr.J. van den Bergh. Die liet weten tegen openbare uitzending te zijn en hij herinnerde Bastiaans aan de afspraak uit 1969 dat de film alleen voor een gespecialiseerd publiek vertoond mocht worden. Maar volgens Bastiaans was er door de toevoeging van enkele scènes, waarin een nagesprek met Telling plaatsvond, een geheel nieuwe film ontstaan die niet onder het contract viel. Van den Bergh lichtte vicevoorzitter dr. M.H. Cohen Stuart in, die direct contact zocht met Bastiaans. Het lukte hem echter niet Bastiaans te bereiken, en Bastiaans belde die zaterdag ook niet meer terug. ${ }^{36}$

Alle commotie had het dagelijks bestuur van de VARA wel ernstig aan het twijfelen gebracht. Het Nos Journaal van zeven uur meldde dat het bestuur van de VARA nog in beraad was en twijfelde of de uitzending, die voor een uur later gepland stond, doorgang moest vinden. Minister Engels had er kort tevoren bij het bestuur op aangedrongen de film niet te vertonen. ${ }^{37}$ Uiteindelijk besloot het bestuur vóór uitzending, met de redenering: als volksvertegenwoordigers de film kunnen zien, dan ook het volk. ${ }^{38}$

Om acht uur die avond verschenen er vier psychiaters in beeld, onder wie Bastiaans en Van Tol, de chef de clinique van de Jelgersmakliniek. Naast hen waren bijzonder hoogleraar socialeverzekeringsgeneeskunde J.A. Weijel en medisch adviseur van de Stichting 1940-1945 dr. P.Th. Hugenholtz aanwezig. Presentator Hans Jacobs van Achter het Nieuws las een korte verklaring van het bestuur van de VARA voor, waarna hij het woord gaf aan Bastiaans.

Bastiaans ging kort in op de commotie rond de vraag of de film uitgezonden moest worden. Hij vertelde dat hij de film inmiddels al 'honderden' keren had vertoond, ookvoor een lekenpubliek, en dat daarbij steeds was gebleken dat'de film een menselijk document is dat over de gehele wereld begrip wekt voor het niet-verjaarde leed van slachtoffers van wreedheid'. Volgens Bastiaans was het van belang en zelfs ieders plicht om de mogelijkheid van bevrijding onder de aandacht van de slachtoffers te brengen:

'Dat is niet de bevrijding van 1945, maar de medische mogelijkheid om in menselijke zin en in een menselijk klimaat bevrijd te worden van onmenselijkheid. Deze film geeft een perspectief: deze zal u niet achterlaten in machteloosheid. ${ }^{39}$ 
Bastiaans vergeleek tijdens het voorgesprek de LSD-behandeling zelfs met een openhartoperatie en een niertransplantatie: hoewel de materiële voorzieningen nog niet overal beschikbaar waren, was de behandeling in staat al het lijden op te lossen. Het was een kwestie van financiële middelen en de juiste techniek toepassen.

Hugenholtz benadrukte dat de film zélf ook een therapeutische bedoeling had: de door de film losgemaakte emoties zouden leiden tot verwerking van die emoties. Ook psychiater Weijel benadrukte het belang van afreageren:

'Alle ernstige traumatische belevenissen moeten kunnen worden afgereageerd, door erover te praten. Mijnheer Hugenholtz zei het al daarnet, emoties moeten loskomen willen we het verleden kunnen loslaten. ${ }^{30}$

Daarnaast hoopte Weijel dat de film ook effect zou hebben op de regering:

'De regering reageert niet op signalen die ze krijgt. En emoties zijn signalen. De regering verhardt in een stoere regeer-houding, wordt autoritair en daarmee weert ze emoties af en brengt daarmee het probleem nog veel verder van huis.'

De film wekte volgens Bastiaans begrip voor het leed van de slachtoffers en liet zien dat zij genezen konden worden. Het was niet vreemd als er emoties loskwamen bij het kijken naar de film; Bastiaans kende gevallen waarbij huilbuien soms uren duurden. Maar die emoties moesten er toch een keer uit. De film pleitte volgens hem dus niet voor of tegen vrijlating: hij bracht hoop op bevrijding van het $\mathrm{Kz}$-syndroom.

Om de 'bevrijdingsboodschap' te versterken, was de film uitgebreid met een aantal shots uit een nagesprek van psychiater Van Tol met Telling en diens vrouw. Telling was na de eerste sessie met Bastiaans bij Van Tol in behandeling gekomen en had bij hem nog enkele LSD-sessies ondergaan. ${ }^{41}$ Beiden vertelden over het succes van de behandeling: Telling was vrij van nachtmerries en kon weer een min of meer normaal bestaan leiden. Aan het einde van de film liep Telling gearmd met zijn vrouw door het park, op weg naar de Albert Heijn.

De uitzending maakte veel, overwegend positieve reacties los bij de kijkers. Recensent van de Volkskrant Jan Bank had het bekijken van de film ervaren als een mogelijkheid om enigszins mee te beleven wat een overlevende van de kampen doormaakte. ${ }^{42}$ Bij de VARA kwamen naderhand 151 , en bij Bastiaans 175 brieven binnen..$^{43}$ De telefonistes kregen meer dan 800 telefoontjes te verwerken, waarvan maar een kleine 200 negatieve reacties. ${ }^{44}$ De verwachte toestroom van in moeilijkheden geraakte oorlogsslachtoffers bleef uit. Musaph meldde in een artikel waarin hij terugblikte op de avond van de uitzending dat zich geen patiënten met acute klachten hadden gemeld. In het Wilhelmina Gasthuis meldde zich één patiënt, maar niet vanwege klachten die door de uitzending waren ontstaan. ${ }^{45}$ 
De openbare hoorzitting, de uitzending van de film, het emotionele geweld van de slachtoffers en de waarschuwingen van de psychiaters hadden hun effect. De dag na de besloten voorstelling op Nieuwspoort was al gebleken dat de film voorstanders kon doen omzwaaien. Kamerlid Geurtsen (VvD), die de openbare hoorzitting had voorgezeten, was na het zien van de film aan het twijfelen gebracht. ${ }^{46}$ De film had ook D'66-voorman Hans van Mierlo een extra duwtje in de rug gegeven: hij stelde zijn mening bij en werd tegenstander van vrijlating. Kamerlid P.A. de Ruiter van de PvdA had lang getwijfeld. De film had die twijfel versterkt:

'Je geeft die dertig- tot veertigduizend slachtoffers een nieuwe optater door die drie vrij te laten. ${ }^{47}$

Zelfs jurist Langemeijer werd door het heftige debat aan het twijfelen gebracht. Niet door de felheid van de emoties; die had hij, zoals het eerdere citaat liet zien, wel verwacht. Maar dat de mogelijkheid van vrijlating bij slachtoffers 'psychische storingen en zelfs lichamelijke ziekteverschijnselen' veroorzaakte, mogelijk zelfs met de dood tot gevolg, ging hem te ver. Het deed hem twijfelen of de drie niet toch vast moesten blijven zitten. ${ }^{48}$

De motie-Voogd werd aangenomen en een paar dagen later, op 4 maart, kwam het kabinet met een verklaring waaruit bleek dat ook de regering gezwicht was voor de emotionele druk:

'De Regering aanvaardt tevens de in de Kamer aangevoerde argumenten dat in deze bijzondere gevallen naast juridische de sociaal-psychologische factoren sterker in het oordeel dienen te worden betrokken. ${ }^{49}$

Het kabinet stelde een groep van deskundigen aan waarvan de leden 'geacht kunnen worden vertrouwen te genieten in kringen van de illegaliteit en van de vervolgden'. Deze groep zou het kabinet in de toekomst adviseren over de vrijlating van de drie. Het lot van de drie werd vanaf dat moment dus bepaald door de slachtoffers. ${ }^{50}$

\section{Onduidelijkheid over het aantal slachtoffers}

In het publieke debat was de aanwezigheid van een verleden in het kamp een criterium sine qua non voor het $\mathrm{Kz}$-syndroom. Niet voor niets was ' $\mathrm{KZ}$ ' een directe verwijzing naar de kampen. Dit debat ging over het leed van de overlevenden van de concentratie- en vernietigingskampen; zij waren de slachtoffers van de drie oorlogsmisdadigers geweest, hún gruwelijke verhalen verschenen in kranten en tijdschriften en waren te horen bij de openbare hoorzitting. Telling was uit die kampen teruggekomen. Beelden van die kam- 
pen waren te zien geweest in Begrijpt u nu waarom ik huil...

Bastiaans beweerde in interviews dat alle overlevenden van de kampen leden aan het $\mathrm{Kz}$-syndroom..$^{51}$ Daar waren niet alle overlevenden van de Duitse kampen het mee eens. Jules Schelvis bijvoorbeeld, een van de weinige Nederlanders die vernietigingskamp Sobibor wisten te overleven, zag zichzelf niet als psychiatrisch patiënt:

'Psychiater? Ik zou niet weten wat ik die man zou moeten vragen of zeggen. ${ }^{52}$

Yvo Pannekoek, verzetsstrijder en overlevende van kamp Dachau, had naar eigen zeggen geen last van zijn kampverleden, hij ging zelfs zover een 'positief $\mathrm{KZ}$-syndroom' te formuleren. Hij had van de kampen enkele positieve resten overgehouden en nam die ook bij anderen waar:

'Ik weet nu met grote zekerheid dat ik nooit bang zal zijn [in extreme situaties]. Dat geeft een grote rust en een gelijkmoedigheid in het denken over de dood en het lijden. Ik ben de kampen ingegaan als een gedeeltelijk geïnformeerde en dus zeer nieuwsgierige waarnemer van de maatschappelijke structuur van deze samenleving. Deze bleek, hoe absurd ook, na enige tijd betrekkelijk eenvoudig en overzichtelijk. [...] Door dit alles is voor mij een sfeer ontstaan van speelse onverschilligheid die het best gesymboliseerd wordt door l'Indifferent van Watteau, en die mij het leven gemakkelijker en aangenamer maakt. ${ }^{53}$

De voorbeelden van Schelvis en Pannekoek laten, ook al lijken het uitzonderingen te zijn, zien dat Bastiaans' stelling dat alle overlevenden van de kampen leden aan het $\mathrm{KZ}$-syndroom niet door iedereen werd beaamd. Het is ook onduidelijk of bijvoorbeeld auteurs als De Wind en Cohen, die zelf de zwaarste kampen hadden overleefd, zichzelf zagen als lijdend aan het Kz-syndroom.

Tijdens de publieke discussie rond de vrijlating van de drie van Breda had Bastiaans het aantal lijders aan het $\mathrm{KZ}$-syndroom geschat op 30000 à 40000 . Die schatting was een eigen leven gaan leiden en ook door anderen tijdens de openbare hoorzitting regelmatig herhaald. De omvang van het probleem werd zo een symbool voor het tekortschieten van de overheid: hoe had over zo'n grote groep heen gekeken kunnen worden? Maar wie had Bastiaans bedoeld?

In 1969 schreef de arts E.A. Cohen het vermoedelijk eerste artikel over het $\mathrm{Kz}$-syndroom. Hij schatte dat 7000 Nederlandse politieke gevangenen en 6000 Nederlandse Joden de kampen hadden overleefd. ${ }^{54}$ De schattingen van het aantal teruggekeerden (politieke gevangen, Joden en anderen) worden tot op de dag van vandaag gebruikt, en Bastiaans kende ze al sinds hij aan zijn proefschrift werkte. ${ }^{55}$ Wanneer Bastiaans' stelling klopte dat alle teruggekeerden aan een $\mathrm{Kz}$-syndroom leden, dan zouden dat er dus 13000 zijn. 
Toch schatte Bastiaans in hetzelfde jaar dat Cohen over het $\mathrm{Kz}$-syndroom schreef, drie jaar voor de openbare hoorzitting, in een interview met Haagse Post dat een groep van 3000 à 4000 overlevenden van de concentratiekampen 'in meer of mindere mate aan psychische stoornissen' leed. ${ }^{56}$ Een jaar later, in 1970 , stelde Bastiaans aan minister van Onderwijs en Wetenschappen dr. G.H. Veringa (KVP) voor om een speciale kliniek te realiseren voor de behandeling van de 'enkele duizenden' slachtoffers die leden aan het $\mathrm{Kz}$-syndroom. Het ging om overlevenden van de kampen en 'ex-militairen, destijds gedeporteerde Joodse landgenoten, sommige ondergedokenen, slachtoffers van de Japanse concentratiekampen'. ${ }^{57}$ In 1971 werd die schatting overgenomen door de commissie die moest adviseren over de nieuwe kliniek voor lijders aan het KZ-syndroom. Bastiaans was lid van die commissie. ${ }^{58}$ Dat aantal was behapbaar voor de nieuwe kliniek en de minister zegde op basis daarvan geld toe voor de bouw ervan.

Toen nog geen jaar later de problematiek van de drie van Breda zich aandiende, schatte Bastiaans het aantal lijders aan het $\mathrm{Kz}$-syndroom ineens op 30000 à 40000 . Dat was een vertienvoudiging ten opzichte van zijn eerdere schattingen. Maar waarom paste Bastiaans in zo'n korte tijd zijn schatting zo drastisch aan?

En: als Bastiaans' uitspraak dat alle overlevenden van de Duitse kampen in ieder geval leden aan het $\mathrm{Kz}$-syndroom voor waar werd genomen, welke achtergronden kenden die resterende 17000 tot 27000 lijders aan het Kz-syndroom dan? Door de niet omschreven criteria voor het $\mathrm{kZ}$-syndroom was het mogelijk om ook personen zonder kampverleden onder de groep slachtoffers te scharen, zoals bijvoorbeeld niet-gevangen verzetsstrijders die onder extreme spanning hadden gestaan. Dat hadden andere auteurs ook gedaan. Maar Bastiaans' schatting betekende dat meer dan twee derde van de lijders aan het $\mathrm{KZ}$-syndroom nooit in een concentratiekamp had gezeten.

Enkele maanden na de discussie rond de drie legde Bastiaans in een besloten vergadering uit welke groepen hij had bedoeld: Joden en verzetsstrijders (gedeporteerd of niet), slachtoffers uit voormalig Nederlands-Indië, militairen én de kinderen van al deze groepen. ${ }^{59}$

Eerst waren de resultaten van het buitenlandse onderzoek naar het KZ-syndroom geprojecteerd op andere groepen, zoals niet-gedeporteerde verzetsstrijders en ondergedoken Joden. Bastiaans projecteerde ze vervolgens op nog weer andere groepen: slachtoffers uit voormalig Nederlands-Indië en de kinderen van al deze groepen. Maar was er met de oprekking van Bastiaans nog wel sprake van een min of meer omschreven ziektebeeld? Leed de dochter van een onderduiker op het platteland van Oost-Groningen inderdaad aan dezelfde klachten als een overlevende van Auschwitz die zijn hele familie had verloren?

Bastiaans legde er geen verantwoording over af. Hij liet zich steeds meer leiden door die andere functie van het $\mathrm{Kz}$-syndroom: de erkenning van het leed 
van de slachtoffers. Met die blik was ook zijn zwaai van voor- naar tegenstander van vrijlating te verklaren. Net zomin als de psychiatrie een causaal verband met de oorlog kon bewijzen, kon de psychiatrie voorspellen wat de gevolgen van een eventuele vrijlating zouden zijn. Door tegen vrijlating te pleiten, won hij definitief het vertrouwen van een grote groep slachtoffers.

\section{Conclusies}

Dat overlevenden van de kampen streden tegen de vrijlating van oorlogsmisdadigers was geen nieuw fenomeen; al sinds de oorlog volgden zij de berechting van oorlogsmisdadigers zeer kritisch. Het viel dus te verwachten dat ze zich zouden roeren toen de vrijlating van de drie van Breda aan de orde kwam.

Bastiaans had zich vanaf midden jaren zestig in de media geprofileerd als expert op het gebied van de gevolgen van de oorlog. Steeds had hij erop gewezen dat deze gevolgen nog altijd desastreus waren. Dat geluid werd opgepikt door de slachtoffers: het psychische leed dat het gevolg zou zijn van de vrijlating van de drie van Breda, werd een zwaarwegend argument. In het heersende maatschappelijke klimaat van gegroeide gevoeligheid voor psychische problemen, en vragen over de rol van Nederland in de oorlog, werd dat leed een krachtig politiek instrument.

Bastiaans gaf de overlevenden een hooggeleerde legitimatie voor de verontwaardiging over hun eigen lot: het leed dat zij ervoeren, werd nu door wetenschappers onderschreven. Datwerd nog eens versterkt door Bastiaans' optreden in de media, vooral natuurlijk met de uitzending van Begrijpt $u$ nu waarom ik huil...

Volgens de historicus Chris Vos was de film er mede de oorzaak van dat de publieke opinie verschoof van een gelijke verdeling van voor- en tegenstanders van vrijlating, naar een meerderheid tegen vrijlating. ${ }^{60}$ Ook de sociologe Jolande Withuis noemde in haar studie naar de opkomst van de traumacultuur, Erkenning, de gevolgen van de uitzending 'immens' ${ }^{6}$ Beiden doelden niet alleen op de directe gevolgen: het vasthouden van de drie.

Het leed, dat in alle toonaarden werd aangevoerd in ingezonden brieven, interviews voor televisie en radio, demonstraties en wilde uitroepen tijdens de openbare hoorzitting, kreeg met de film een gezicht. Het $\mathrm{Kz}$-syndroom was in het collectieve bewustzijn gegrift. Het werd het symbool van de ravage die de Duitsers hadden aangericht, en vervulde daarmee een nieuwe rol: het vergemakkelijken van de dialoog over het leed. Het leed van de slachtoffers werd nu algemeen aanvaard als een probleem; een probleem waar niet-slachtoffers mede schuld aan hadden. Toen de speciale kliniekvoor slachtoffers van de oorlog werd geopend, werd er gesproken van 'de inlossing van een ereschuld'. Vanaf 1972 namen oorlogsslachtoffers een speciale plaats in in het maatschappelijk verkeer.

De uitzending van de film had ook immense gevolgen voor Bastiaans' carrière. Het 'propagandistische effect' van de film was met de in- en uitleiding 
door Bastiaans op televisie vervolmaakt. De boodschap dat LSD-behandeling een oplossing bood voor het $\mathrm{KZ}$-syndroom, werd zelfs de kern van de uitzending.

Dehoop die Bastiaans daarmee gaf op genezing was vals. In zijn proefschrift was hij al somber geweest over de resultaten van de behandeling van verzetsstrijders, en drie jaar voor de uitzending van Begrijpt $u$ nu waarom ik huil... had hij op een congres nog beweerd dat niet alle behandelingen geslaagd waren. In besloten kring had hij toegegeven dat niet iedereen te helpen was. ${ }^{62}$ Maar vanaf de uitzending zou die nuance ontbreken. Hulpverleners hadden volgens Bastiaans de plicht om hun patiënten te wijzen op de mogelijkheid van 'bevrijding' door een LSD-behandeling.

Bastiaans sprong, net als de slachtoffers zelf, in het gat dat was ontstaan tussen de medische kennis over de psychische en lichamelijke oorlogsgevolgen en de maatschappelijke behoefte aan leniging ervan. Door zijn schatting van het aantal lijders aan het $\mathrm{KZ}$-syndroom op te schroeven van 3000 naar 40000 gooide hij olie op een toch al hoog uitslaande brand. Niet alleen in kwalitatieve zin waren de problemen van oorlogsslachtoffers al die jaren miskend, ook in kwantitatieve zin was over een groot probleem heen gekeken. Met de film liet hij zien dat zijn LSD-behandeling een oplossing bood voor het leed; hij had van het $\mathrm{Kz}$-syndroom een behandelbaar probleem gemaakt. Daar waren zowel slachtoffers als niet-slachtoffers mee geholpen.

Zo had Bastiaans zich in de eerste acht jaar van zijn hoogleraarschap weten op te werken tot een landelijke bekendheid; niet door baanbrekend wetenschappelijk onderzoek, maar door zich op te werpen als spreekbuis van oorlogsslachtoffers. Vanaf 1972 stond hij publiekelijk bekend als de man van het $\mathrm{KZ}$ syndroom en de LSD-therapie. Hij was veranderd van wetenschapper in belangenbehartiger. Het luidde een nieuwe periode in van zijn carrière, waarin hij zich voornamelijk bezighield met de behandeling van patiënten. Een periode waarin hij een innige relatie met zijn patiënten opbouwde. 


\section{III}

Bestendiging

1972-1982 


\section{De strijd om Centrum ' 45}

'Hij is ijdel, een pietsie paranoïd, oneerlijk, neemt altijd te veel hooi op zijn vork. Hij voelt zich voortdurend bedreigd en vecht."

DR. W.F. NOORDHOEK HEGT OVER BASTIAANS, 28 MEI 1973.

Inleiding

Het besef dat sommige groepen oorlogsslachtoffers dringend behandeling behoefden, was in de jaren voor de discussie rond de drie al gestaag gegroeid. Het had ook al voor verbeteringen gezorgd: de overheid had uitkeringsprocedures herzien en de omgekeerde bewijslast ingevoerd. In 1973 zou de Wet Uitkering Vervolgingsslachtoffers worden ingevoerd, waarmee ookJoodse overlevenden aanspraak konden maken op een uitkering.

Het kroonjuweel van wat Withuis het 'oorlogswelzijnsbeleid' noemde, was de nieuwe kliniek voor lijders aan het $\mathrm{KZ}$-syndroom. De voorbereidingen voor de oprichting van deze kliniek waren in 1970 begonnen, en na de discussie rond de drie kwam de kliniek volop in de belangstelling. De overheid sprak van de inlossing van een ereschuld. Alom werd de druk gevoeld om het leed van de slachtoffers te lenigen. De nieuwe kliniek was het brandpunt van die breed gedragen compassie.

Bastiaans was nauw betrokken bij de totstandkoming. Het eerste idee ervoor was op zijn Jelgersmakliniek ontstaan. Op basis van zijn initiatief had de Werkgroep Post-concentratiekampsyndroom, die de minister adviseerde over de bouw van de kliniek, tot oprichting geadviseerd. In de motivering werd gebruik gemaakt van Bastiaans' beschrijving van het $\mathrm{Kz}$-syndroom. Volgens het advies van de werkgroep moest er een blijvende 'functionele binding' tussen de Jelgersmakliniek en de nieuwe $\mathrm{Kz}$-syndroomkliniek tot stand worden gebracht. $^{2}$ 
Bastiaans zag de nieuwe kliniek - zoals dr. P. Baan, adviseur van het voorlopig bestuur van de kliniek, het omschreef - als 'bekroning op vijfentwintig jaar denken en werk'. ${ }^{3}$ Hij had er hoge verwachtingen van: het zou een topkliniek worden, een vooruitgeschoven post die andere centra voorzag van kennis en knowhow over de behandeling van het $\mathrm{Kz}$-syndroom. Hij zag zichzelf als de gedoodverfde directeur, en aanvankelijk zagen anderen dat ook zo. Totdat bleek dat hij geen directeur kon worden.

\section{Directeur of consulent-adviseur?}

Op 19 april 1971, een jaar vóór de discussie rond de drie losbarstte, was er een voorlopig bestuur gevormd dat de bouw van de kliniek voor lijders aan het $\mathrm{KZ}$ syndroom zou begeleiden. ${ }^{4}$ De nieuwe kliniek zou plaats bieden aan 20 plekken voor klinische behandeling en 200 plekken voor poliklinische behandeling per jaar. ${ }^{5}$ De behandelingen zouden bestaan uit een combinatie van individuele psychotherapie, groepstherapie, arbeidstherapie en sociotherapie. De nieuwe kliniek zou alleen in uitzonderlijke gevallen de LSD-therapie toepassen; de behandeling nam een plaats in naast de andere behandelingen. ${ }^{6}$

$\mathrm{Al}$ snel kwam er een tegenslag voor Bastiaans. Tijdens de tweede vergadering van het voorlopige bestuur, op 4 juni 1971, meldde hij dat zijn faculteit vreesde dat zijn werkzaamheden voor de nieuwe kliniek een te zware belasting zouden zijn en zijn werk op de Jelgersmakliniek in gevaar zouden brengen. ${ }^{7}$ Bastiaans werd aangeboden buitengewoon hoogleraar te worden in combinatie met het directeurschap van de nieuwe kliniek. Hij zou dan nog maar deels betrokken zijn bij de universiteit en moest afstand doen van zijn Jelgersmakliniek en de bijbehorende verantwoordelijkheden als opleider en directeur. De faculteit zou met een dubbelfunctie waarbij Bastiaans én directeur was van de nieuwe kliniek én hoogleraar-directeur van de Jelgersmakliniek, niet akkoord gaan. ${ }^{8}$ Hij moest kiezen.

Bastiaans koos vrijwel onmiddellijk: hij bleef als hoogleraar-directeur op de Jelgersmakliniek. Hij bleef betrokken bij de nieuwe kliniek, maar in welke rol en met welke bevoegdheden was voorlopig onduidelijk. Gedurende de oprichtingsfase trad hij op als bestuursadviseur. Hij woonde de bestuursvergaderingen bij, die op zijn werkkamer in de Jelgersmakliniek werden gehouden en werden genotuleerd door zijn secretaresse. Zijn formele rol in de nieuwe kliniek werd vanaf de herfst van 1971 aangeduid als 'consulent-adviseur', zonder dat daar expliciet verantwoordelijkheden aan werden gekoppeld.

Het eerste bestuur dat na de formele oprichting op 20 augustus 1971 de stichting beheerde, bestond uit afgevaardigden uit de gezondheidszorg en oorlogsgerelateerde organisaties. Voorzitter werd prof.dr. P. Muntendam, oud-gevangene van kamp Vught, voormalig directeur-generaal van het Ministerie van wVC en op dat moment curator van de RUL. Als vicevoorzitter werd Hans Teengs Gerritsen benoemd. Hij was al vanaf het allereerste initiatief betrokken 
bij de kliniek, samen met Piet Maliepaard, een vooraanstand verzetsstrijder en voormalig patient van Bastiaans. Verder hadden zitting in het bestuur: Noordhoek Hegt; mr. A.H. van Namen, voorzitter van de Stichting 1940-1945: mr. K.H. Gaarlandt, Commissaris van de Koningin in Drenthe en oud gevan gene van kamp Vught; generaal-majoor en Inspecteur bij de Geneeskundige Dienst van de Koninklijke Landmacht A.D.A. van Overeem; de Amsterdamse hoogleraar sociale geneeskunde dr. A. Querido.

Dr. P.A.H. Baan en dr. C. Buis, beiden Inspecteur voor de Geestelijke Volksge zondheid, traden op als adviseurs van het bestuur. In de zomer van 1971 werd prins Bernhard zelfs bereid gevonden het erevoorzitterschap te accepteren. ${ }^{3}$ Bastiaans woonde, hoewel hij geen bestuurslid was, wel de bestuursvergade ringen bij totdat de nieuwe kliniek haar deuren zou openen.

Bastiaans was, net als het bestuur, in een optimistische stemming. Hoe de samenwerking eruit zou zien, zou zich vanzelf uitwijzen. Dat dic er zou komen, daar twijfelde niemand aan. Zelfs in de statuten van de stichting die de kliniek zou beheren werd de samenwerking met Bastiaans' Jelgersmakliniek opgenomen:

'het stichten en instandhouden van een centrum voor behandeling van het post-concentratiekampsyndroom en al hetgeen daarmede in de ruimste zin verband houdt, een en ander in nauwe samenwerking met een psychiatrisch ziekenhuis: ${ }^{10}$

Hoewel Bastiaans geen directeur zou worden, zag het ernaar uit dat zijn invloed op de nieuwe kliniek aanzienlijk zou zijn. De notulen van de vergadering waarin Bastiaans meldde dat hij geen directeur kon worden, verraden dan ook geen teleurstelling. Er moest gewoon een andere vorm worden gevonden voor de samenwerking. Bastiaans en het bestuur gingen daarop op zoek naar een nieuwe directeur en namen de bouw van de kliniek ter hand.

Dat de kliniek in Oegstgeest nabij de Jelgersmakliniek zou komen, was vanaf het begin duidelijk. In overleg met de gemeente als eigenaar en Bastiaans als gebruiker van het terrein, werd het voetbalveld van de Jelgersmakliniek bestempeld als bouwlocatie. Bastiaans nam zitting in de bouwcommissie en ging samen met H.F.Ph. Hers - een in het KZ-syndroom gespecialiseerd internist, overlevende van concentratiekamp Sachsenhausen en goede vriend van prins Bernhard - vol enthousiasme aan de slag met de architect. ${ }^{11}$

De bijzondere status van de toekomstige patiënten stelde volgens Bastiaans en Hers zijn eisen aan de architectuur van het gebouw; die moest iedere herinnering aan het kamp vermijden. Dat betekende dat lange, rechte gangen moesten worden voorkomen, dat alle kamers een deur naar buiten kregen, en dat er een gezellige samenkomstruimte was, waar gezamenlijk de maaltijd genuttigd kon worden. Dat laatste uiteraard zonder dat men in de rij hoefde te staan, 
zoals dat in het kamp moest. Allerlei hoekjes en verborgen plekjes moesten de patiënten de gelegenheid geven zich terug te trekken. Zo ontstond als het ware een anti-KZ-syndroomarchitectuur, die erop was gericht zo min mogelijk aanstoot te geven.

Toen bleek dat de toegangsweg naar de kliniek over het terrein van de Jelgersmakliniek zou lopen, werd dat onacceptabel gevonden. De patiënten van de kliniek wilden niet geassocieerd worden met psychiatrische patiënten, zij waren tenslotte niet krankzinnig. Na overleg met de gemeente werd er een alternatieve, eigen toegangsweg aangelegd. De bouw vorderde gestaag, mede door de hulp van prins Bernhard bij het overwinnen van bureaucratische obstakels.

Bastiaans werd regelmatig geïnterviewd over de nieuwe kliniek en werd daardoor, samen met Teengs Gerritsen, het gezicht naar buiten. Daardoor werd de binding tussen hem en de kliniek sterk. Hij onderstreepte dit nog eens door de kliniek te presenteren als het gevolg van zijn jarenlange inspanningen; eindelijk kwam er een einde aan 'zijn' strijd voor erkenning van het leed van de oorlogsslachtoffers. In de berichtgeving was, in een verwijzing naar de nieuwe kliniek, soms ook sprake van 'de kliniek van prof. Bastiaans'.

Ondertussen had de zoektocht naar een nieuwe directeur het bestuur bij dr. W.L. Meijering gebracht, die op dat moment inspecteur bij de Inspectie voor de Geestelijke Volksgezondheid was. Meijering had ervaring als groepstherapeut, maar niet met de behandeling van oorlogsslachtoffers. Hij was leidinggevende geweest bij het Militair Neurose Hospitaal Austerlitz. Bovendien had Meijering een halfjaar gevangengezeten in Sachsenhausen. ${ }^{13}$ Tijdens de bestuursvergadering van 6 januari 1972 koost het bestuur, inclusief Bastiaans, Meijering als de meest geschikte kandidaat voor het directeurschap.

Er waren nog twee kwesties die moesten worden opgelost voordat Meijering kon worden aangesteld. De eerste betrof een gevoelige kwestie tussen Meijering en dr. N. Speijer, hoogleraar sociale psychiatrie aan de RUL. Meijering had in zijn vorige functie, als inspecteur bij de Inspectie voor de Geestelijke Volksgezondheid, de psychiatrische inrichting Dennendal in zijn portefeuille gehad. Naar aanleiding van misstanden aldaar was aan Speijer gevraagd een onderzoek te doen. Een van Speijers conclusies was dat Meijering te laat had ingegrepen, waarna deze op non-actief was gesteld. Speijer was binnen de Jelgersmakliniek onder andere verantwoordelijk voor de sociotherapie, waar ook de patiënten van de nieuwe kliniek gebruik van zouden maken. Dat betekende dat beide heren regelmatig moesten samenwerken, en daar had geen van beiden oren naar. Het bestuur vroeg Baan te bemiddelen tussen de twee.

De tweede kwestie betrof de relatie tussen Bastiaans en de nieuwe directeur. Met de komst van Meijering werd het belangrijk diens taken en bevoegdheden vast te leggen. In een eerste antwoord op de vraag hoe Bastiaans de samenwerking zag, antwoordde deze dat hij als consulent-adviseur van de kliniek de psy- 
chiaters 'op de hoogte wilde brengen van de medische technieken en behandelwijzen' en 'de mogelijkheid wilde hebben tot overleg en advies over de behandeling'. Dat klonk vrijblijvend, maar het bestuur wilde meer duidelijkheid: bij wie lag straks de uiteindelijke bevoegdheid, wie besliste welke behandeling werd gegeven op de kliniek: Meijering of Bastiaans? Hoever strekte de autonomie van de kliniek?

Binnen het bestuur liepen de gedachten daarover uiteen. Volgens hoogleraar Querido moest Meijering Bastiaans als leermeester erkennen; in een behandelingsconflict moest de mening van Bastiaans prevaleren. Noordhoek Hegt haalde voorbeelden aan van klinieken in het buitenland waar de directeur zelf de uiteindelijke beslissing nam. Teengs Gerritsen zag het allemaal als scherpslijperij: bij een goed team was het niet nodig dergelijke zaken te regelen. Het bestuur zou op basis van een nota van Bastiaans over zijn rol een beslissing nemen. ${ }^{14}$

In februari werd de nota, die mede was opgesteld door Querido en Buis, besproken in het bestuur. De nota was vooral een bevestiging van Bastiaans' status als initiatiefnemer van de kliniek en expert op het gebied van het Kz-syndroom. De nota beschreef dat het idee voor de kliniek in de boezem van zijn Jelgersmakliniek was ontstaan. De ervaringen daar hadden de noodzaak van een speciale kliniek duidelijk gemaakt, en daar bestond de meeste kennis en ervaring aangaande de problematiek en de behandeling ervan. Het was volgens Bastiaans vanzelfsprekend dat hij een belangrijke rol speelde in de nieuwe kliniek aangezien hij:

'een van de eersten is geweest, die in Nederland de aandacht heeft gevestigd op het $\mathrm{Kz}$-syndroom en dit verschijnsel diepgaand heeft bestudeerd en bovendien bijzondere ervaring heeft met een bepaalde wijze van behandeling, n.l. de psychotherapie gefaciliteerd met LSD toediening'. ${ }^{15}$

Verzetsstrijders hadden 'veel vertrouwen in de leiding van de Jelgersmakliniek' en de nieuwe kliniek moest daar rekening mee houden. Afgezien van deze zelfbewieroking, bevatte de nota ook enkele concrete punten waarop samenwerking kon plaatsvinden. De directeur, die in overleg met Bastiaans door het bestuur werd aangesteld, kon voor ieder aspect van de behandeling Bastiaans in consult roepen. Daarnaast zou in goed overleg uitwisseling van personeel en kennis over het Kz-syndroom plaatsvinden en werd Bastiaans betrokken bij het wetenschappelijk onderzoek van de kliniek.

Bastiaans werd in het stuk aangeduid als 'hoogleraar-directeur' en Meijering als 'geneesheer-directeur'. Dat gaf aan dat Bastiaans' rol in het Centrum aanzienlijk zou zijn; Meijering hoefde Bastiaans niet als meerdere te erkennen, maar volledig autonoom was hij ook niet. In de laatste clausule van de nota stond dat eventuele geschillen tussen hen zouden worden voorgelegd aan een 
geschillencommissie van drie die een bindend advies zou uitbrengen. Het bestuur vroeg een jurist om de laatste clausule verder uit te werken zodat er een definitieve beslissing kon worden genomen.

In afwachting van het antwoord van de jurist kwam het eerste contact tussen Bastiaans en Meijering tot stand. De laatste stuurde Bastiaans zijn rapport over LSD-behandelingen uit 1965 toe, dat hij ooit, in zijn functie als Inspecteur voor de Geestelijke Volksgezondheid, had opgesteld. ${ }^{16}$ Nadat hij vier klinieken in Engeland had bezocht waar LSD werd toegepast, was hij toen tot de conclusie gekomen dat, mits de juiste voorzorgsmaatregelen in acht werden genomen, LSD-behandeling een plek verdiende tussen andere vormen van behandeling. ${ }^{17}$ Bastiaans op zijn beurt stuurde een dankbriefje en stelde hem ervan op de hoogte dat hij binnenkort een hoofdstuk in een boek zou publiceren over zijn LSD-behandeling. ${ }^{18}$

lets meer dan een week nadat de nota van Bastiaans was besproken in de bestuursvergadering, maakte Van Agt zijn voornemen voor de vrijlating van de drie oorlogsmisdadigers bekend. In de weken dat de kwestie van de vrijlating speelde, lagen de activiteiten van de bestuursleden stil. Nadat het stof van het debat wat was neergedaald kwamen het bestuur en Bastiaans weer bij elkaar om de bevoegdheden verder uit te werken.

\section{Groeiende moeilijkheden}

De openbare hoorzitting en de uitzending van Begrijpt $u$ nu waarom ik huil... veroorzaakten irritaties tussen Bastiaans en het bestuur. Vooral bestuurslid Noordhoek Hegt was woedend op Bastiaans. De vergelijking tussen de LSD-behandeling en een niertransplantatie, die Bastiaans in de uitzending had getrokken, was hem een doorn in het oog. Hij nam het Bastiaans zeer kwalijk dat deze valse hoop op genezing had gewekt:

'De nieuwe film suggereert dus: eind goed al goed. Behandeling kan, ook nu nog, helpen. Alle kans op een geweldige run op ons nieuwe kliniekje. ${ }^{19}$

Ook andere bestuursleden hadden hun vraagtekens bij Bastiaans' optreden. Bijvoorbeeld over de gestegen schatting van het aantal slachtoffers. In de voorafgaande besprekingen en het advies van de Werkgroep Post-concentratiekampsyndroom was steeds de schatting aangehouden van 'enkele duizenden'. Op basis daarvan was de nieuwe kliniek gebouwd. Maar Bastiaans had op de hoorzitting een schatting laten horen van tussen de 30000 en 40000 . Hoe moest die toename verklaard worden? Wat waren de gevolgen van die schatting voor de nieuwe kliniek $?^{20}$

In de vergaderingen daarna zag Bastiaans steeds meer beren op de weg voor de nieuwe kliniek. Zo was er onrust uitgebroken onder zijn personeel en pa- 
tiënten over het voetbalveld, waar de kliniek op werd gebouwd; het werd al maanden node gemist. De kwestie Meijering-Speijer vroeg ook om een oplossing; zonder medewerking van Speijer zou het onmogelijk zijn de noodzakelijke samenwerking met de nieuwe kliniek tot stand te brengen. Bastiaans benadrukte dat hij én Speijer aan de basis van het initiatief hadden gestaan, maar dat Speijer nu aan de kant gezet dreigde te worden. ${ }^{21}$ En hij had van een Leidse wethouder begrepen dat de benodigde vergunningen voor het heien van de eerste paal nog niet op orde waren.

Ook zocht Bastiaans contact met de pers. In de Volkskrant gaf hij een kijkje in de interne ontwikkelingen. Hij noemde onder andere de moeilijke relatie tussen Meijering en Speijer, waarvan de problemen zijns inziens wel oplosbaar waren. Speijer was bereid tot samenwerking, en aan de pers liet Bastiaans weten dat Meijering de belangrijkste kandidaat was; een geschikte kandidaat bovendien.

'Professor Bastiaans, een van de geestelijk vaders van het $\mathrm{kz}$-paviljoen en leider van de Jelgersmakliniek, zou dr. Meijering graag als directeur benoemd zien. Een van de overwegingen is dat deze specialist zelf zes maanden in het concentratiekamp Sachsenhausen gevangen heeft gezeten. ${ }^{22}$

Op het eerste gezicht leken dat onschuldige uitspraken, maar het bestuur was niet gediend van deze berichtgeving; publiciteit zorgde voor ruis en misverstanden en kon de bemiddelingspoging van Baan doorkruisen. Daarnaast had prins Bernhard toegezegd om op 16 april de eerste paal voor de nieuwe kliniek te zullen slaan. Negatieve publiciteit was daarom uit den boze.

Alle voorzichtigheid ten spijt verscheen een dag voor het slaan van de eerste paal in dagblad Het Binnenhof een interview met Bastiaans waarin hij liet weten dat de keus van het bestuur voor Meijering een ongelukkige was geweest. De kwestie met Speijer stond een goede samenwerking in de weg én Meijering was niet bekend met Bastiaans' 'opvattingen en denkwijzen'. Met dat laatste doelde hij waarschijnlijk op Meijerings gebrek aan ervaring met de LSD-therapie, maar dat zei hij er niet bij.

Volgens Bastiaans had het bestuur misbruik gemaakt van zijn afwezigheid toen hij voor een conferentie naar Mexico was. In die tijd had het bestuur Meijering benaderd en bovendien een beslissing genomen zonder hem daarin te betrekken. Een commissie zocht nu naar de oplossing van een conflict dat er nooit geweest zou zijn als het bestuur in november niet zo 'koortsachtig' naar een directeur had gezocht:

'Wanneer men even had gewacht tot mijn terugkeer, dan had ik het bestuur zo de geschikte vent kunnen geven. ${ }^{23}$ 
Bastiaans deed het voorkomen alsof het bestuur hem willens en wetens had gepasseerd. Maar de beslissing voor Meijering werd genomen op een vergadering waar ook Bastiaans bij aanwezig was. ${ }^{24}$ In de pers had hij zich daarna zelfs lovend over Meijerings aanstelling uitgelaten vanwege diens kampervaring.

$\mathrm{Na}$ het interview in Het Binnenhof kwamen het bestuur en Bastiaans in een vertrouwelijke vergadering bijeen. Bastiaans verontschuldigde zich en wees met een vinger naar de pers, die zijn woorden verdraaid zou hebben. Maar dat wilde volgens hem niet zeggen dat in het interview geen valide kritiek stond. Meijering had, aldus Bastiaans:

'maar een half jaar kampervaring, bovendien is het gevaar groot dat hij te veel

betrokken wordt bij de emoties die loskomen tijdens de psychotherapie.'.

Bastiaans wilde nu dat een medewerker van zijn Jelgersmakliniek tot directeur werd benoemd. Het bestuur wees hem erop dat hij tijd genoeg had gehad om met kandidaten te komen, maar dat niet had gedaan. De kandidaat die Bastiaans nu voorstelde was een ondergeschikte van hem, wat duidde op een masterslave-relatie tussen Bastiaans en de kandidaat en daarmee tussen Bastiaans en de kliniek. Datwas onwenselijk. Bovendien vond het bestuur Meijering wél een geschikte kandidaat. $\mathrm{Na}$ de halve verontschuldigingen werd de vergadering besloten met de afspraak dat Bastiaans de pers niet meer te woord zou staan. Het nam Bastiaans' onvrede niet weg.

De notulen van de bestuursvergaderingen noemen geen expliciete beslissing, maar uit de verdere acties van het bestuur bleek dat men Bastiaans' invloed op de kliniek wilde beperken. De kliniek moest autonoom functioneren zonder hulp van de Jelgersmakliniek en zonder inmenging van Bastiaans.

\section{Bastiaans buitenspel}

Dat vroeg om een doortastende aanpak, en met dat oogmerk werd in mei 1972 $\mathrm{mr}$. J. le Poole gevraagd als gedelegeerd lid van het bestuur. Historica Hinka Piersma gaf aan de korte biografie die zij over Le Poole schreef de ondertitel 'verzetsman voor het leven'. ${ }^{26} \mathrm{Ze}$ doelde daarmee op zijn compromisloze, vaak als recalcitrant ervaren, optreden. Le Poole was, zoals in hoofdstuk 6 werd beschreven, vóór zijn tijdelijke intrede in het bestuur van de kliniek directeur van het NFGV geweest, en had in die hoedanigheid te maken gehad met Bastiaans. ${ }^{27} \mathrm{Hij}$ zou in de maanden dat Meijering de werkzaamheden van zijn vorige baan afrondde, de nieuwe kliniek op poten zetten en een geduchte tegenstander van Bastiaans worden.

Le Poole begon ermee de bestuursvergaderingen te verplaatsen, die tot dat moment op Bastiaans' werkkamer op de Jelgersmakliniek hadden plaatsgevonden. Ze werden voortaan in Den Haag gehouden zonder Bastiaans' notu- 
liste. Daarmee was de toon gezet. Langzaam maar zeker werd de kliniek uit Bastiaans' handen getrokken.

Meijering was na het rumoer rond het slaan van de eerste paal ook voorzichtig geworden, en had de voorwaarden geformuleerd waaronder hij directeur wilde worden. Hij wilde zelf kunnen beslissen over opname en ontslag van patiënten; de behandeling van patiënten moest in overleg met hem en in overeenstemming met het therapeutische klimaat worden geregeld; personeel werd alleen met zijn toestemming aangenomen, en er moesten duidelijke werkafspraken met Bastiaans komen. ${ }^{28}$

Le Poole zorgde ervoor dat de nieuwe kliniek niet meer afhankelijk was van de faciliteiten van de Jelgersmakliniek. Meijering, die op de achtergrond al wel betrokken was, bleek toe te kunnen met een kleinere ruimte voor sociotherapie dan was gepland, zodat die alsnog kon worden aangebouwd aan de kliniek. De op de Jelgersmakliniek geplande sociotherapie kon daardoor op de nieuwe kliniek worden uitgevoerd. De kwestie Meijering-Speijer loste zich vanzelf op: Speijer kondigde aan met pensioen te gaan.

Als klap op de vuurpijl werd onder aanvoering van Le Poole een statutenwijziging doorgevoerd. De expliciete verwijzing naar het post-concentratiekampsyndroom werd geschrapt uit de doelstelling en vervangen door een algemenere formulering. De nieuwe kliniek was bedoeld 'voor medischpsychologische behandeling en begeleiding van verzets- en oorlogsslachtoffers. ${ }^{29}$ Ook de exclusieve samenwerking met de Jelgersmakliniek werd vervangen door een algemene samenwerking met andere ziekenhuizen en hulpverlenende instanties. Zelfs de naam van de kliniek, 'Centrum Postconcentratiekampsyndroom', werd veranderd. Even speelde het bestuur met de gedachte om de kliniek 'Huize Wilhelmina' te noemen. Het werd uiteindelijk $^{\text {'Centrum }}{ }^{\prime} 45^{\prime} .^{30}$

Op 2 oktober bezochten Muntendam en Van Namen, beiden bestuurslidvan het Centrum, Bastiaans en vertelden hem 'dat de idee, dat Centrum' ' 45 als het ware een verlengstuk van de Jelgersmakliniek is, als definitief verlaten moet worden beschouwd'. ${ }^{1}$ Wat nog restte, was de rol die Bastiaans persoonlijk wenste te spelen in het Centrum. Muntendam en Van Namen legden hem de keus voor uit drie functies: bestuurslid, adviseur van het bestuur, of consulent voor directeur en staf. Het was niet mogelijk zowel het bestuur als de directeur en de staf te adviseren, omdat hij daarmee een onevenredig grote invloed op het Centrum zou krijgen. ${ }^{32}$

Bastiaans was ontdaan: het adviseurschap van het bestuur betekende voor hem 'persoonlijk' in zijn 'verhouding tot de jongens' veel. Hij wilde dat 'de jongens', zoals hij in navolging van Teengs Gerritsen de verzetsstrijders noemde, de verzekering kregen dat zijn knowhow werd overgedragen aan het Centrum. Een consulentschap, waarbij hij alleen in specifieke gevallen werd betrokken bij de behandeling, was daarvoor niet voldoende. Hij wilde ook op bestuurlijk 
niveau richting kunnen geven aan het Centrum. Maar het bestuur hield vast aan zijn besluit, en in november 1972 leek Bastiaans akkoord te gaan met een compromis: hij nam genoegen met het consulentschap en werd tevens voorzitter van de Raad van Advies. ${ }^{33}$

Bastiaans was grotendeels buitenspel gezet. De man die in februari nog op televisie zijn visie op de problematiek rond de drie had gegeven, wiens film Nederland wakker had geschud, wiens ideeën over het $\mathrm{kz}$-syndroom aan de basis van Centrum ' 45 hadden gelegen, had zijn krediet bij het bestuur verspeeld. De kliniek die in zijn ogen zijn geesteskind was, ging een eigen weg. Maar ook al leek in november 1972, na zijn akkoord met het bestuur, de strijd verloren, Bastiaans gaf niet op. Hij ontketende een nieuwe strijd, die niet werd gevoerd tijdens vergaderingen en overleg maar in de media.

\section{Hart en levensdoel}

Na het bezoek van Muntendam en Van Namen riep Bastiaans de hulp in van zijn patiënten. Tijdens groepsgesprekken op de Jelgersmakliniek spuide hij zijn grieven over de gang van zaken rond het Centrum. ${ }^{34}$ Hij presenteerde zijn probleem, het feit dat hij buitenspel was gezet, als een probleem voor delijders aan het Kz-syndroom; zonder zijn inbreng kon het Centrum nooit de zorg verlenen die zo hard nodig was.

Die suggestie werd door een aantal vooraanstaande verzetsstrijders die bij hem in behandeling waren geweest overgenomen. Een van hen was Piet Maliepaard, de andere 'geestesvader' van het Centrum, die nauw betrokken was gebleven bij de bouw van het Centrum; hij zat in de bouwcommissie, die toezicht hield op de bouwactiviteiten. Hij raakte overtuigd van het gedeelde probleem van Bastiaans en de slachtoffers. In oktober 1972 stak hij op een bijeenkomst van de Landelijke Kontakt-Groep verzetsgepensioneerden (LKG) de loftrompet over zijn psychiater:

'In Nederland was het mede dr. J. Bastiaans, die reeds spoedig na de bevrijding geconfronteerd werd met het $\mathrm{Kz}$-syndroom, hetgeen niet vreemd was, gezien zijn bindingen met het voormalige verzet. Hij heeft het niet alleen intens bestudeerd en er over gepubliceerd maar ook direkt daadwerkelijk een methodiek ontwikkeld die zoniet de gehele genezing dan toch een aanmerkelijke verlichting aan slachtoffers bracht. [...] Het is de zeer grote verdienste en persoonlijke gave van prof. Bastiaans, dat hij in staat is met ieder van onze getroffen makkers, met hen hun persoonlijke gang door de hel van de concentratiekampen mede te ondergaan. Psychisch heeft hij zelf vele honderden concentratiekampen doorlopen. [...] Door de beslissing van de Medische Faculteit ontviel de basis van al onze illusies en inspanning. Een desillusie die ons allen trof en vooral prof. Bastiaans zelf, die een levenswerk moest prijsgeven. [...] 
soonlijk weet ik dat prof. Bastiaans een zeer moeilijke periode, zoniet de eilijkste periode in zijn leven, door moet maken om hier de juiste beslis$\mathrm{g}$ te nemen. Zijn hele hart en levensdoel is gericht op hulp aan de slachtofi van het verfoeilijke systeem van de Duitse kampen. ${ }^{35}$

paard riep deleden van de LKG op om de bouwvan het Centrum nauwlet$n$ de gaten te houden en inspraak in de besluitvorming te eisen.

patiënten van Bastiaans' Jelgersmakliniek meldden zich zo nu en dan onkondigd op de bouwplaats van het nabijgelegen Centrum om te kijken $\geq$ bouw vorderde. In december $1972 \mathrm{kreeg}$ een groep patiënten die in be:ling was op de Jelgersmakliniek, een rondleiding van Meijering door het voltooide gebouw. Meijering vertelde hun dat, ook al was het gebouw nkort gereed, het benodigde personeel voor de klinische patiënten (die z overnachten in de kliniek) nog ontbrak. Het kon nog enkele maanden voordat dat gedeelte van het Centrum zijn deuren opende. De dagbeling van het Centrum kon wel al voor de opening van start gaan.

volgden krantenberichten waarin gewag werd gemaakt van vertraging bouw van het Centrum. De groep patiënten van de Jelgersmakliniek ef een brief aan Meijering. Ze voelden zich 'door verleden en toekomst verbonden' met het Centrum, dat zij van 'landelijke en mondiale beteke:htten. Maar na de rondleiding vreesden ze dat het nieuwe Centrum 'als selloos monument' zou blijven staan, en ze riepen op tot actie; de nood de slachtoffers was te hoog om een paar maanden te wachten. ${ }^{36}$

1 deel van Bastiaans' patiënten liet zich op de wachtlijst voor de klinische ng plaatsen, waardoor er nog voor de opening een opnamestop afgekonIreigde te moeten worden. Tijdens een bestuursvergadering waarin dit rake kwam, stelde Bastiaans, die nog steeds de vergaderingen bijwoonde, Im de groep op de wachtlijst toch alvast te laten overnachten op de klinifdeling van het Centrum. Het Centrum kon dan als hotel fungeren voor Iten van de Jelgersmakliniek. Volgens Bastiaans was dat ook voor Meijeuttig, want de patiënten hadden 'ervaring als klinisch patiënt' en konden telpen in zijn nieuwe rol als directeur. ${ }^{37}$

$\mathbf{t}$ bestuur zag vooral in de onrust onder verzetsstrijders een bedreiging. paard genoot groot aanzien onder verzetsstrijders en zijn voortdurende tstokerij kon het vertrouwen in het nieuwe Centrum onder de toekom?atiënten wegnemen. Zonder dat vertrouwen kon het Centrum nooit een $s$ worden. Het bestuur zocht daarom naar wegen om Maliepaard tevre₹ stellen. Hij kreeg een functie als receptionist aangeboden, maar wei- Uiteindelijk werd hij, op suggestie van Teengs Gerritsen, gevraagd als zurvan het bestuur', zonder dat hij de door hem gewenste inspraak kreeg $\mathbf{t}$ personeelsbeleid van het Centrum..$^{38}$ Maliepaard startte direct een tenbureau' waar ontevreden patiënten van het Centrum terechtkonden. 
Bastiaans zelf hield ook niet op met druk op het bestuur uitoefenen. Hij beklaagde zich wederom over het feit dat hij en zijn patiënten het al maanden zonder voetbalveld moesten stellen. Hij vond dat 'moreel en zakelijk onverantwoord' en wilde dat de kwestie snel werd opgelost. ${ }^{39}$ Zijn ontevredenheid kwam in de vergaderingen via dergelijke omwegen naar voren, maar in geen van de vergaderingen stelde hij zijn werkelijke probleem aan de orde. Hij voerde zijn strijd via de media.

Bij Meijering ontstond daardoor zelfs even het idee dat de problemen waren opgelost. Tijdens een bestuursvergadering van eind februari 1973, kort voor de officiële opening, vertelde Meijering dat de samenwerking met Bastiaans 'in alle opzichten plezierig' was. ${ }^{40}$

Maar met het naderen van de opening op 16 mei groeide het ongenoegen bij Bastiaans en zijn patiënten zienderogen. De groeiende belangstelling van de media voor het nieuwe Centrum bracht journalisten bij Bastiaans. Een maand voor de opening gaf Bastiaans een interview aan Wim Wennekes, een journalist van De Gelderlander. Op 5 mei, Bevrijdingsdag 1973, verscheen het interview met 'professor J. Bastiaans - van het Kz-syndroom' in de zaterdagbijlage. Wennekes beschreef eerst zijn bezoek aan het nieuwe Centrum, waar hij 'veel grafisch werk aan bijna alle muren' aantrof, en 'hagelwitte kantoormeubelen [meubelen] zoals je ze uitsluitend denkt aan te treffen in de burelen van snelle reclamejongens'. Hij herhaalde de woorden van de directeur van Centrum ' 45 , Meijering:

'Als de laatste patiënten over tien tot vijftien jaar dood zijn is het gebouw heel geschikt als motel. Het ligt vlak langs de autoweg. ${ }^{41}$

Nee, dan de 'uitgeleefde' Jelgersmakliniek van professor Bastiaans. De laatste vond het nieuwe Centrum té mooi:

'Het is net het Hiltonhotel. De mensen waarvoor het Centrum bedoeld is herkennen die sfeer niet. Ik ben benieuwd of ze zich er thuis zullen voelen. ${ }^{42}$

Bastiaans was gepasseerd als directeur terwijl het Centrum zijn idee was geweest. Nu mocht hij ook niet het woord voeren bij de opening. Maliepaard, die wel was uitgenodigd om te spreken, was solidair met zijn psychiater en weigerde te spreken:

'Als ik spreek, dan zou ik opening van zaken willen geven en dat kan ik niet doen waar de Koningin bij is. ${ }^{23}$ 


\section{De mythe van de methode-Bastiaans}

Op 16 mei 1973 werd in het bijzijn van de koningin en de prins het Centrum geopend. Het kabinet noemde in een persbericht de opening van het Centrum'de inlossing van een ereschuld', waarmee de bijzondere status van de slachtoffers nog eens werd bevestigd. Teengs Gerritsen had zich over Bastiaans laten ontvallen dat hij 'een punthoofd kreeg van die man'. Op de dag van de opening bood Bastiaans hem, bij wijze van grap, een trofee aan in de vorm van een punthoofd. De foto van de overhandiging haalde enkele kranten.

Het was een van de weinige ontspannen momenten op een voor Bastiaans treurige dag. De kliniek werd feestelijk geopend, terwijl hij moest toezien hoe zijn buitenlandse collega's die over het $\mathrm{Kz}$-syndroom hadden geschreven, zoals de Noor Eitinger, de Deen Lønnum en de Fransman Fichez, zich vol bewondering door het nieuwe gebouw lieten leiden. ${ }^{44}$ Voor Bastiaans, die het Centrum als zijn geesteskind zag, moet het een vernederende ervaring zijn geweest.

De dag na de opening zette Bastiaans de aanval op het Centrum door. De kans dat er door onderhandeling met het bestuur iets aan de situatie zou veranderen was klein; alleen door ingrijpen van buitenaf kon een verandering worden geforceerd. Daarvoor zette Bastiaans een van zijn patiënten in: het Eerste Kamerlid voor de PvdA Eibert Meester. Meester had zich eind april op aanraden van zijn arts gemeld voor behandeling in de Jelgersmakliniek, en was binnen twee weken in de ban geraakt van Bastiaans' strijd om het Centrum. De dag na de opening diende hij bij mr. I. Vorrink, de net aangetreden minister van Volksgezondheid en Milieuhygiëne, Kamervragen in over het Centrum.

Meester roemde in zijn vragen Bastiaans' tomeloze inzet voor de slachtoffers: volgens Meester behandelde en onderzocht Bastiaans al meer dan vijfentwintig jaar lijders aan het $\mathrm{kz}$-syndroom en moest hij dat, door gebrek aan mankracht, zeven dagen per week doen. Bastiaans genoot 'een brede internationale bekendheid en waardering' met zijn ISD-behandeling, waarmee hij 'voortreffelijke resultaten' had weten te bereiken. Hoe kon het dan dat Meijering, die geen enkele ervaring met de behandeling van oorlogsslachtoffers had, was benoemd tot directeur van het Centrum? Bastiaans was de enige juiste man geweest, dat vonden ook de slachtoffers zelf, die na de onrust in de media over de kwestie 'in grote onzekerheid' verkeerden. Meester riep de minister op een onderzoek in te stellen naar de gang van zaken. ${ }^{45}$

In die dagen na de opening legde Bastiaans in interviews steeds een verband tussen het niet doorgaan van het directeurschap en de LSD-behandeling. In een interview met journalist Louis Sinner van het Algemeen Dagblad zei hij dat er op het ministerie weerstand tegen de behandeling bestond; die zou niet passen in de strijd tegen illegaal druggebruik. Op de vraag van de journalist of in de behandeling geen gevaar school voor de patiënt antwoordde Bastiaans: 
'In het buitenland zijn er nogal wat ongelukken mee gebeurd. Men moet een zeer gespecialiseerd psychiater zijn om er mee te kunnen werken. Ik mag zeggen dat ik zo'n psychiater ben. Ik heb al zo'n honderd slachtoffers met LSD behandeld. ${ }^{46}$

Een andere journalist, Ferry Eiselin van Het Parool, schreef dat Bastiaans, de 'grote, door iedereen erkende initiator van het Centrum', teleurgesteld was in het bestuur maar desondanks bereid was 'zijn krachten te geven aan de behandeling van de patiënten in het nieuwe centrum'. Volgens Bastiaans was door de uitzending van Begrijpt $u$ nu waarom ik huil... de indruk ontstaan dat hij alleen maar LSD gebruikte. Dat was niet terecht, aangezien hij ook andere methoden gebruikte en 'niet meer dan twintig' patiënten met LSD had behandeld. ${ }^{47}$

Zo herschreef Bastiaans de geschiedenis tot de mythe waarin hij als psychiater, tegen de stroom in, al sinds de oorlog op was gekomen voor de belangen van zijn patiënten. Eerst had hij gestreden voor de erkenning van hun problemen, wat had geleid tot de recente ontdekking van het $\mathrm{KZ}$-syndroom; nu moest hij strijden voor het behoud van zijn uiterst effectieve behandeling, waarmee het leed van zijn patiënten kon worden gelenigd. Dat zij genezen zouden kunnen worden met normale middelen was een illusie; wie dat dacht, ging voorbij aan het uitzonderlijke leed dat zij hadden doorstaan.

Met de uitzending van Begrijpt $u$ nu waarom ik huil... werd bij velen de suggestie gewekt dat de LSD-behandeling werkte, zelfs bij de meest ernstige gevallen. Volgens Bastiaans was het een noodzakelijk instrument voor de behandeling van slachtoffers; de 'zeer specifieke ervaring' die voor de behandeling nodig was, ontbrak echter bij Meijering en zijn personeel..$^{48}$ Hoe kon het Centrum, dat was opgericht om de broodnodige, speciale zorg te verlenen aan deze slachtoffers, ooit zijn doel bereiken zonder hem en zijn LsD-behandeling?

Bastiaans kon rekenen op de steun van een aantal vooraanstaande verzetsstrijders die bij hem in behandeling waren geweest. Maliepaards toespraak, waarin hij zei dat Bastiaans al 'honderden psychische concentratiekampen' had doorstaan, was een voorbeeld van het grote ontzag dat zij voor hem hadden. Zij zagen hem als bondgenoot in hun strijd om erkenning en droegen hem op handen. Zij namen de suggestie over dat het Centrum niet voldeed.

'Prof. Bastiaans is de enige man die alles van het post-concentratiekampsyndroom weet. Wat de huidige directeur dr. Meijering en de staf er van zullen maken moeten we maar afwachten. ${ }^{249}$

E.W. van Hemert, lid van Pelita - een stichting die de belangen van slachtoffers van de Japanse interneringskampen en de Bersiap-periode behartigde - liet weten hulpbehoevenden uitsluitend naar Bastiaans door te zullen sturen..$^{50}$ 
Ook onder verzetsstrijders klonken dergelijke geluiden..$^{51}$ Op het jaarlijkse congres van Expogé werd een motie aangenomen waarin het bestuur van Expogé werd opgedragen alles in het werk te stellen om een optimale verzorging van patiënten in het Centrum te waarborgen..$^{52}$

Het bestuur van het Centrum had grote moeite om zich te weren tegen de media-aandacht die Bastiaans genereerde. Volgens Sunier, directeur van de Sinai-kliniek en lid van de Raad van Advies, moest het Centrum zijn positie nog veroveren:

'Alleen Bastiaans kan signalen uitzenden. Het Centrum heeft nog geen signalen. Bastiaans heeft de macht in deze situatie. ${ }^{53}$

Het bestuur wilde Bastiaans niet voor het hoofd stoten. Het zag zijn steun, en daarmee die van een deel van de toekomstige patiënten, als noodzakelijk. Bastiaans profileerde zich steeds meer als de voorvechter van de LSD-behandeling, en het was daarom moeilijk om publiekelijk kritiek te uiten op de methode.

Alleen Le Poole durfde een poging aan om Bastiaans met gelijke middelen te bestrijden. In een kort interview aan Het Parool liet hij weten dat experts twijfelden aan de methode-Bastiaans, dat niet alle patiënten met deze intensieve methode konden worden behandeld. Een ambulante vorm van behandeling, waarbij patiënten één of meerdere keren per week op het Centrum kwamen, was efficiënter. ${ }^{54} \mathrm{Op}$ Le Poole's interview volgde een ingezonden brief van verzetsstrijdster, overlevende van Mauthausen en patiënte van Bastiaans, Trix Terwindt. Volgens Terwindt wist Le Poole niets van $\mathrm{kz}$-patiënten, niets van de 'Anne Franks die het kamp overleefden'. Bovendien was Le Poole een jurist, geen psychiater:

"De woorden "de deskundigen in het algemeen" worden een lachertje, als je 25 jaar lang reeksen doktoren, specialisten en psychiaters passeerde, die niets aan je konden verrichten of nodeloos opereerden en dan door een van prof. Bastiaans methoden van een hel in een bevrijd en normaal gelukkig leven teruggebracht wordt. ${ }^{55}$

Het werd het bestuur allengs duidelijker dat de aanhoudende publiciteit het succes van het Centrum in de weg kwam te staan. Dat besef werd versterkt nadat Teengs Gerritsen contact had opgenomen metP. Reijntjes, een verzetsman die net als Teengs Gerritsen onder andere in Natzweiler en Dachau had gezeten. Reijntjes was verslaggever bij de Nos en verzekerde Teengs Gerritsen dat iedereen op de redactie bereid was 'te ageren tegen Meijering en het bestuur'..$^{\text {'6 }} \mathrm{Het}$ illustreert het toenmalige klimaat: de pers was overwegend op de hand van Bastiaans. Bastiaans werd met zijden handschoenen benaderd door journalisten. 
In een poging het tij te keren, besprak het bestuur enkele opties. Teengs Gerritsen stelde voor een televisieoptreden te arrangeren met Bastiaans en de rest van het bestuur; op die manier kon in één klap publiekelijk de ruzie worden bijgelegd en de onrust worden weggenomen. De rest van het bestuur gaf de voorkeur aan stille diplomatie.

Voorzitter Muntendam stelde voor om Bastiaans om schriftelijke excuses te vragen. De excuses zouden niet in de openbaarheid komen, maar wel voldoende zijn om de minister gerust te stellen. Bastiaans leed dan geen gezichtsverlies. Uiteindelijk vroeg men Hugenholtz, die samen met Bastiaans zitting had in de Raad van Advies, een compromispoging te ondernemen. Op dat moment was de betekenis van Bastiaans voor het functioneren en welslagen van het Centrum nog boven iedere twijfel verheven. Hugenholtz verwoordde het belang van Bastiaans voor het Centrum als volgt:

\footnotetext{
'Bastiaans is niet alleen persoonlijk de man die het initiatief heeft genomen en men zou haast willen zeggen, de belichaming is van alles wat er op wetenschappelijk terrein ten bate van de oorlogsslachtoffers is ondernomen, maar nog veel belangrijker is, dat hij voor de talloze slachtoffers van het verzet de hoop symboliseert op genezing. ${ }^{57}$
}

In juni rapporteerde Hugenholtz dat Bastiaans hem had geaccepteerd als bemiddelaar. Bastiaans bleek vooral gegriefd te zijn door het niet mogen spreken op de opening. De Raad van Advies had hem daarin ook gesteund. Bastiaans ging ermee akkoord dat de zaak buiten de publiciteit werd gehouden, en inmiddels vonden er gesprekken plaats tussen hem, Hugenholtz en Meijering waarin werd geprobeerd tot een oplossing te komen. ${ }^{58}$

Bastiaans liet weten dat hij twee samenwerkingsverbanden onderscheidde: de samenwerking tussen de klinieken en de samenwerking tussen hem en het Centrum. De samenwerking tussen de klinieken moest geregeld worden door zijn college van bestuur en het bestuur van het Centrum..$^{59}$ Persoonlijk wilde hij enkele uren per week op het Centrum werken voor besprekingen met de staf over problemen met patiënten. Daarnaast wilde hij betrokken worden bij de behandeling van lastige, ingewikkelde patiënten en wilde hij LSD-behandelingen kunnen uitvoeren in het Centrum. Medewerkers van het Centrum moesten daarbij assisteren want dat had een 'grote educatieve waarde'. ${ }^{60}$

Voorzitter Muntendam meldde in juni 1973 aan de minister dat Hugenholtz een bemiddelingspoging ondernam. De gesprekken verliepen volgens Muntendam in een 'vriendelijke en collegiale sfeer'. ${ }^{61}$ Maar nog in dezelfde maand bleek dat Bastiaans achter Hugenholtzs rug om trachtte een doorbraak te forceren, waarbij hij wederom de publiciteit niet schuwde. 


\section{Het gesprek op Soestdijk}

Bastiaans wist Meester zover te krijgen dat hij prins Bernhard om een gesprek verzocht. Een afschrift van de brief hierover was naar minister-presidentJ. den Uyl gestuurd. De prins twijfelde aanvankelijk of hij moest ingaan op het verzoek, maar nadat Bastiaans hem had verzekerd dat een dergelijk gesprek' goed was voor de therapie van Meester' had hij toegezegd. ${ }^{62}$

Het gesprek op Paleis Soestdijk vond plaats op 5 juli 1973. Aanwezig waren: prins Bernhard en eerste stalmeester W.F.K. Bischoff van Heemskerck; Bastiaans; Trix Terwindt, patiënte van Bastiaans; Joop Telling; D'66-kamerlid mr. A.M. Goudsmit; Teengs Gerritsen; H.P.J. van Ketwich Verschuur, voorzitter van Expogé; dr. A. Braun, een medewerker van Bastiaans; Eibert Meester. Hugenholtz, die op het laatste moment van de 'lijmpoging' hoorde, was ook aanwezig.

Uit Hugenholtz' verslag van de bijeenkomst blijkt hoe hoog de emoties bij Bastiaans' aanhang opliepen. Nadat de prins was gestart met aan te geven dat hij niet wilde interfereren in het werk van Hugenholtz maar alleen een luisterend oor wilde bieden, kreeg Telling het woord. Die hield een zeer beladen betoog, vol dreiging over wat er allemaal zou gaan gebeuren als Bastiaans niet aan zijn trekken zou komen. Hugenholtz:

'[A]lsof bij wijze van spreken morgen een of andere aktie voor de deur zou staan, het Centrum bezet zou kunnen worden of iets van dien aard.'

Meester suste de woorden van Telling, maar hield vervolgens een niet minder emotioneel betoog over de goede werken van Bastiaans. ${ }^{63} \mathrm{Hij}$ stelde de oprichting van een brugstichting voor: de Jelgersmakliniek en het Centrum zouden beide onderdeel worden van een overkoepelende stichting.

Van Ketwich Verschuur, de voorzitter van Expogé, wees op de onrust onder zijn achterban, die bovendien op het punt stond de publiciteit te zoeken. De oorzaak van de problemen was volgens hem een beleidsprobleem: het bestuur had geweldig werk gedaan, maar was door de enorme berg werk die al was verzet vermoeid geraakt. Hij stelde voor om drie nieuwe leden toe te voegen aan het bestuur; die zouden de 'vertrouwenscrisis' kunnen doorbreken en de rust doen wederkeren. ${ }^{64}$

Het gesprek op Paleis Soestdijk bleef zonder resultaat voor Bastiaans. Meesters plan voor een brugstichting was een doodgeboren kind; de Jelgersmakliniek viel onder de universiteit, het was niet mogelijk die onder het bestuur van een externe stichting te brengen.

Expogé stuurde na het gesprek op Paleis Soestdijk telegrammen naar het bestuur van het Centrum, waarin het bleef aandringen op uitbreiding van het bestuur. Van Ketwich Verschuur kwam op eigen verzoek zijn standpunt nog eens toelichten bij het bestuur en schreef, toen dat geen effect leek te hebben, 
een kritisch stuk in Aantreden, het verenigingsblad van Expogé. De bemoeienis van Expogé leidde tot grote ergernis binnen het bestuur van het Centrum, wat uiteindelijk tot gevolg had dat Teengs Gerritsen zijn lidmaatschap van Expogé opzegde. Maar Bastiaans was daar niet mee geholpen.

Voor Hugenholtz, die Bastiaans al jaren kende, betekende het gesprek op Soestdijk een omslag. Hij was tot dan toe altijd van de goede wil van Bastiaans uitgegaan, maar op de bijeenkomst zag hij diens manipulatieve kant:

'Het merkwaardige was eigenlijk, dat er een bijeenkomst was van allerlei mensen die [...] uit het hoofd geleerde lesjes opzeiden, of het oplazen van papier en als je dan vroeg wat er gebeurde, dan waren dat alleen loftuitingen op Bastiaans, het was een soort van bewieroking. Bastiaans zat er vrij onbewogen tussen. Toen ik eens naar hem keek kreeg ik de indruk dat het een soort De Gaullehouding was. Hij liet het zich allemaal aanleunen, hij liet iedereen uitspreken en hij zei bij het afscheid dat het misschien wel goed was dat ik er bij was geweest $[. ..]{ }^{35}$

Volgens Hugenholtz was de bijeenkomst geënsceneerd door Bastiaans om zo een doorbraak te forceren. Bastiaans wees in de verdere gesprekken met Hugenholtz de verantwoordelijkheid af; die lag volgens hem bij de groep oud-verzetsstrijders en ex-patiënten, daar had hij geen greep op. ${ }^{66}$ Hugenholtz en het bestuur werden hoe langer hoe meer gesterkt in hun overtuiging dat het Centrum beter af was zonder Bastiaans. Tegelijkertijd wilden ze hem niet bruuskeren; zijn steun aan het Centrum betekende ook steun van een deel van de toekomstige patiënten.

De antwoorden van de minister op Meesters Kamervragen kwamen in december. De organisatie van de klinische activiteiten van Centrum ' 45 was volgens de minister 'nog niet tot volledige ontplooiing gekomen', maar zij wilde zich niet mengen in de kwestie. De benoeming van een directeur was de verantwoordelijkheid van het bestuur. Bovendien wees de minister erop dat Bastiaans geen bezwaren had laten horen toen Meijering werd benoemd. Ze ging ervan uit dat in onderling overleg de kwestie zou worden opgelost. Het door Meester gewenste onderzoek bleef uit, het Centrum bleef autonoom.

De antwoorden van de minister betekenden het einde van de hoop van Bastiaans op een grotere invloed op het Centrum. De minister had in haar antwoorden nog gehint op een vorm van samenwerking tussen Centrum en Jelgersmakliniek, maar dat was inmiddels erg lastig geworden; niemand binnen het Centrum, Meijering noch het personeel, was daartoe bereid. Sunier, lid van de Raad van Advies van het Centrum, concludeerde: 
'Elke grondslag voor een bloeiende co-existentie van Centrum ' 45 en de Jelgersmakliniek als twee complementaire activiteiten ten behoeve van één clientèle ontbreekt. ${ }^{, 67}$

Bastiaans was zelf ook tot die conclusie gekomen en trok zich terug op zijn Jelgersmakliniek. Hij bleef, op verzoek van de Stichting 1940-1945, nog wel lid van de Raad maar bedankte voor het voorzitterschap ${ }^{68}$ Hij had de strijd verloren.

\section{Conclusies}

Bastiaans' optreden tijdens de discussie rond de drie van Breda, en de uitzending van de film, hadden hem landelijke bekendheid opgeleverd en bovendien de loyaliteit van een deel van de verzetsstrijders. Hij zette dat succes in bij zijn strijd om het Centrum; hij creëerde de mythe dat zonder zijn LSD-behandeling het Centrum nooit succesvol kon worden. De LSD-behandeling, die in feite slechts een onderdeel van het behandelaanbod van de nieuwe kliniek zou worden, werd opgeblazen tot doorslaggevende factor.

Bastiaans, de man wiens 'hart en levensdoel' volgens Maliepaard lagen bij het verzachten van het leed van oorlogsslachtoffers, bezorgde het Centrum een moeilijke start. Het moest de imagoschade die door Bastiaans en zijn aanhang was aangericht weer zien te herstellen. ${ }^{69}$ Bastiaans' Jelgersmakliniek bleef in de ogen van vele slachtoffers de plek bij uitstek; wie naar het Centrum ging, ging naar het Centrum, wie naar de Jelgersmakliniek ging, ging naar Bastiaans.

Bastiaans had door de kwestie het vertrouwen en aanzien dat hij genoot bij zijn collega's verloren. Hij had zich ontpopt als een manipulatieve en opportunistische tegenstander. Zo had Bastiaans aanvankelijk de kampervaring van Meijering als een voordeel gezien, maar toen Meijering uit de gratie was, werd diens kampervaring tegen hem gebruikt. In het ene interview had Bastiaans 'niet meer dan twintig' patiënten met LSD behandeld, in het andere 'meer dan honderd'. Samen met Hers had Bastiaans de architect begeleid bij het ontwerpen van het Centrum, maar toen het gebouw er eenmaal stond, was het volgens hem té mooi en zouden de patiënten zich er niet thuis voelen. Wanneer hij werd aangesproken op zijn onrustzaaiende patiënten 'had hij geen greep op hen', als hij in nood zat, riep hij hun hulp in. Het steeds weer terugkomen op gemaakte afspraken, het inzetten van de media; het zou in een andere situatie al veel eerder tot problemen hebben geleid.

Hugenholtz en Noordhoek Hegt, die beiden veel ervaring hadden met de problemen van verzetsstrijders, hadden Bastiaans' handelen met verbijstering aangezien. Noordhoek Hegt, die na de openbare uitzending van Begrijpt u nu waarom ik huil... al ontdaan was over Bastiaans' optreden, werd na de commotie rond de opening woest en schreef een korte profielschets van Bastiaans: 
'Hij is ijdel, een pietsie paranoïd, oneerlijk, neemt altijd te veel hooi op zijn vork. Hij voelt zich voortdurend bedreigd en vecht. Hij voelt zich een voorvechter voor de "Goede" beschouwingen over het ontstaan van het post-concentratiekampsyndroom (zie o.a. indelingen in stadia etc.) en voor de "Goede" therapie o.a. LSD. Hij misbruikt zijn verhouding tot zijn patiënten in dit gevecht. [...] Hij gebruikt journalisten en ontkent dan weer dat hij zijn aantijgingen heeft gezegd, maar ziet er niet tegenop ze weer te herhalen. Hij houdt zich vrijwel nooit aan zijn woord. ${ }^{70}$

Maar Bastiaans had iets in handen wat anderen niet hadden: de exclusieve LSDbehandeling, waarmee hij de bijzondere status van zijn patiënten benadrukte. Het verschil met Meijering, de directeur van Centrum ' 45 was groot: die was dan wel directeur van een speciale kliniek voor slachtoffers van de oorlog, maar hij gebruikte geen speciale instrumenten. Na de Kamervragen van Meester schreef Meijering zelfs aan het bestuur van het Centrum:

'In wezen is het $\mathrm{kz}$-syndroom niet anders dan de syndromen die we bij andere patiënten aantreffen. [...] De normale regels van de psychotherapeutische behandeling zijn ook op het $\mathrm{Kz}$-syndroom van toepassing. ${ }^{71}$

Of Meijering nu gelijk had of niet, voor een deel van de slachtoffers was Bastiaans met zijn LSD-behandeling veel aantrekkelijker. Zijn methode bevestigde dat hun leed uitzonderlijk was; zó uitzonderlijk dat het niet met de gangbare middelen verzacht kon worden. De patiënten vonden bij Bastiaans de erkenning die zij zochten. 


\section{De reconstructie van oorlogsverledens}

\footnotetext{
: iedereen van hen gold, dat het afzeggen van een afspraak zoiets zou zijn m de Messias op te bellen en hem te zeggen dat hij zijn Komst maar even st uitstellen."

EL DE-NUR (PATIËNT VAN BASTIAANS) OVER BASTIAANS, 1989.
}

\section{Inleiding}

het debat rond de vrijlating van de drie van Breda als de discussie rond ecteurschap van het Centrum liet zien dat Nederland zich betrokken bij de problemen van oorlogsslachtoffers. Ze werden gezien als een bije groep met bijzondere problemen, die bijzondere aandacht verdien$\mathbf{n}$ aan die gegroeide compassie uiting te geven, werden regelingen die g gaven tot de uitkeringen versoepeld en werd de voorlichting aan famirienden geïntensiveerd. Deze openheid en aandacht deed de behoefte specialiseerde hulp ook stijgen.

$\geq$ inleiding van dit boek werd het citaat van socioloog De Swaan aangevaarin deze stelt dat de verwerking van een verleden - zeker van een oor:leden - in een psychiatrische behandeling niet alleen persoonlijke, ok maatschappelijke arbeid is. Patiënten reconstrueren tijdens de being hun verleden en proberen er lijn in aan te brengen, er soms zelfs zin geven. Bij die reconstructie spelen niet alleen persoonlijke ervaringen , maar ook de noties, ideeën en modellen die op dat moment in de maatij leven.

iaans had met de film Begrijpt u nu waarom ik huil... een standaardmodel : d voor oorlogsslachtoffers: ernstig fysiek en psychisch lijden geduren>orlog werd gevolgd door een periode van schijnbare gezondheid. De ing kon of wilde niet luisteren naar de verhalen van de slachtoffers, 
waardoor de slachtoffers de schijn van gezondheid ophielden. Ondertussen liep de psychische spanning op, wat uiteindelijk leidde tot lichamelijke en geestelijke instorting, waarbij soms de dood in de ogen werd gekeken. De intensieve, dramatische behandeling bij Bastiaans werd beloond met genezing.

De mythe dat de methode-Bastiaans zelfs de meest hopeloze gevallen kon helpen, werd regelmatig herhaald in de pers. Het betrof niet alleen verhalen van Bastiaans zelf; ook oud-patiënten lieten zich interviewen of schreven boeken over hun ervaringen. Bastiaans was daardoor, ondanks de verloren strijd om Centrum '45, hét gezicht gebleven op het gebied van de behandeling van oorlogsslachtoffers.

De gevoeligheid voor de problemen van oorlogsslachtoffers en de mythische verwachtingen van Bastiaans' methode hadden ook een keerzijde. Dat bleek in het midden van de jaren zeventig toen er een boekje verscheen over de LSD-behandeling van PvdA-senator Eibert Meester. Meester was in behandeling gekomen bij Bastiaans en had zich intensief bemoeid met de kwestie rond het directeurschap van Centrum ' 45 . Hij had Kamervragen gesteld en een lijmpoging van prins Bernhard geïnitieerd. Zijn betrokkenheid bij het werk van Bastiaans was daar niet gestopt. Op verzoek van Bastiaans had hij journalist Wim Wennekes toestemming gegeven een verslag te maken over zijn behandeling. ${ }^{2}$

Het bleef niet bij een verslag. Uiteindelijk werd er een boekje gemaakt, getiteld Allemaal rottigheid, allemaal ellende, waarin Meester figureerde. Het boekje presenteerde, net als Begrijpt u nu waarom ik huil..., het $\mathrm{Kz}$-syndroom en de LSDbehandeling als een gedwongen huwelijk. Enerzijds wilde het aandacht geven aan de bijzondere problemen van oorlogsslachtoffers, anderzijds aan de bijzondere behandeling met LSD. Om het belang van het boekje te benadrukken, had prins Bernhard een opdracht meegegeven, die op de eerste pagina werd afgedrukt:

'Om enigszins te weten wat er in de oorlog hier is gebeurd en hoezeer velen erdoor hebben geleden - en er dikwijls nog door lijden - zou iedereen dit boek moeten lezen. ${ }^{3}$

Maar toen het boekje in de publiciteit kwam, bleek dat Meesters oorlogsverleden er anders uitzag dan in het boekje stond beschreven.

\section{Portret: Eibert Meester}

Niet lang nadat in februari 1946 de PvdA was ontstaan uit de voormalige SDAP, werd Eibert Meester (1919-1999) voorzitter van de jongerenorganisatie van de nieuwe partij. Meester, afkomstig uit een 'rood nest', zou zijn hele carrière verbonden blijven aan de PvdA. Hij klom op van voorzitter van de jongerenorganisatie naar gemeenteraadslid in de hoofdstad naar gewestelijk secretaris, tot- 
dat hij in 1958 algemeen secretaris en penningmeester van het hoofdbestuur van de partij werd. In die positie zou hij jarenlang waken over de partijdiscipline.

Vanaf midden jaren zestig verloor zijn politieke carrière echter aan glans. Een nieuwe generatie politici was opgestaan en verdrong de oude partijtop. Deze Nieuw Links'ers hadden lak aan oude conventies en vastgeroeste structuren en lieten van zich horen waar dat kon. De nieuwe stroming was succesvol en de oude garde, onder wie Meester, werd daarvan het slachtoffer. Meester nam in 1967 ontslag als secretaris-penningmeester. Hij bleef nog als senator zitten in de Eerste Kamer en probeerde, met weinig succes overigens, de PvdA uit de ban van de Nieuw Linksbeweging te krijgen.

In 1973 werd Meester na een hartaanval opgenomen in het ziekenhuis. 's Nachts, in een ijldroom, noemde hij de oorlog. De behandelend arts kreeg daardoor het vermoeden dat Meesters hartklachten niet alleen een fysieke oorzaak hadden. Hij verwees Meester door naar Bastiaans, die hem op 24 april 1973 opnam in de Jelgersmakliniek. ${ }^{4}$ Nauwelijks een week na zijn opname, op 1 mei 1973, kreeg Meester zijn eerste LSD-behandeling.

Op het moment dat Meester zich meldde bij de Jelgersmakliniek bevond de strijd tussen Bastiaans en Centrum' 45 zich op een hoogtepunt. Bastiaans werd in die dagen regelmatig benaderd door journalisten. Een van hen was Wim Wennekes. Louis Frequin, hoofdredacteur bij De Gelderlander, had Wennekes gevraagd Bastiaans te interviewen. Frequin, voormalig verzetsstrijder, wilde aandacht besteden aan de perikelen die op dat moment speelden rond de opening van Centrum ' 45 . Na het interview had Wennekes gevraagd of hij eens bij een LSD-sessie aanwezig mocht zijn. Enkele dagen later werd hij opgebeld door Bastiaans: Wennekes mocht aanwezig zijn bij een sessie van Meester om daar verslag van te doen. Het artikel verscheen op Bevrijdingsdag in De Gelderlander. ${ }^{5}$

Een maand na het verschijnen van het verslag ontving Wennekes een brief van Meester. ${ }^{6}$ Samen met prins Bernhard, met wie hij op goede voet stond, had Meester bedacht dat het grote publiek nader kennis moest maken met de behandeling van oorlogsslachtoffers. Meester stelde Wennekes voor een boekje van zijn behandeling te maken. Als voorproefje plakte Meester een dummy in elkaar: eerst een inleiding van Bastiaans, dan een hoofdstuk met daarin het al gepubliceerde verslag van de LSD-sessie, vervolgens een nog te schrijven verslag van de laatste LSD-sessie en tot slot een bijdrage van Meester. Volgens Meester moest het een boekje opleveren met daarin, zoals hij dat zelf omschreef, een:

'portret van een verzetsman in optima forma. Ik denk hierbij aan zijn leven in de meest uitgebreide zin: zijn jeugd, opleiding, instelling, gezondheid, diepere oorzaak en gevolg van daden, organisatie, improvisatie, inventiviteit, zijn werk, zijn lijden, zijn bevrijding, zijn eindsprint en ontspannen. ${ }^{7}$ 
Wennekes stemde toe, woonde nog enkele sessies van Meester bij, en kreeg van de overige de geluidsbanden te horen.

Op 14 maart 1975 verscheen, gesubsidieerd door het Prins Bernhard Cultuurfonds, Allemaal rottigheid, allemaal ellende. Het boekje kreeg veel aandacht in de media, niet het minst dankzij de opdracht van prins Bernhard. Bastiaans benadrukte bij de boekpresentatie dat het niet de bedoeling was geweest de LSD-therapie als panacee voor alle oorlogsslachtoffers te presenteren, maar 'om bij velen begrip te wekken voor wat het is om getraumatiseerd te zijn'.

Het boekje kreeg als ondertitel Het $\mathrm{KZ}$-syndroom van Willem van Salland. Het pseudoniem van Meester was een verwijzing naar de streek in Overijssel waar hij zijn grootste verzetsdaden had gepleegd. Korte tijd was het giswerk wie er achter het pseudoniem zat. Daar kwam snel verandering in: Meester deelde gesigneerde exemplaren uit en het werd een publiek geheim dat Van Salland dezelfde was als Meester. Hij genoot van het succes van zijn boekje en het aanzien dat hem dat opleverde. Hij vroeg, op advies van Bastiaans, een Buitengewoon Pensioen aan en kreeg dat toegewezen. Een oude vriend vroeg of hij lid wilde worden van Expogé, de vereniging van voormalig gedeporteerden. Ook dat deed Meester. En toen er een verzoek om een tv-interview binnenkwam, stemde hij eveneens toe. Hij besloot zelfs zijn pseudoniem prijs te geven.

Hoewel Allemaal rottigheid, allemaal ellende een goed einde kende, en Bastiaans op een congres de behandeling van Meester aan zijn collega's presenteerde als geslaagd, ging het in de dagen voorafgaand aan de uitzending van het tv-interview niet goed met Meester. Zijn vrouw schreef zelfs heimelijk een brief aan Bastiaans waarin ze haar zorgen uitte. ${ }^{9}$ Op de regenachtige vrijdagavond vóór de tv-uitzending was Meester, na de onheilspellende mededeling aan zijn vrouw dat hij 'met zichzelf tot waarheid wilde komen', uit huis vertrokken. Toen hij tegen halftwee's nachts nog steeds niet was teruggekeerd, riep zijn vrouw de hulp in van een vriend. Vlak voordat deze een zoekactie op touw wilde zetten met de politie, zagen ze in de verte Meester aankomen. ${ }^{10}$

Twee dagen later, op zondagavond 20 april 1975, de avond waarop het interview met Meester zou plaatsvinden, verscheen om tien over halftien Ad Langebent, presentator van het televisieprogramma Heel de mens, in beeld en sprak de volgende woorden:

"Vanavond had u in dit programma Heel de mens kennis kunnen maken met een man, die hevig aan het oorlogssyndroom heeft geleden: Eibert Meester, 55 jaar, van huis uit instrumentmaker. Op 10 mei 1940 ging hij als twintigjarige in het verzet. Zoals zoveel verzetsmensen werd hij door Duitsers gefolterd en is hij ternauwernood aan de dood ontkomen. Zijn oorlogservaringen grepen hem zo aan, dat hij twee hartinfarcten kreeg en de afgelopen twee jaar om zijn geestelijke en lichamelijke evenwicht te hervinden acht keer in een psychiatrisch inrichting een zogenaamde LSD behandeling onderging. 
Dankzij deze betandeling masr ook door zijn doonettingsvermogen was het leven van de heer Meester weer de moeite warard geworden. Vlak voor deze uit zending is er in zijn gezondheidstoestand echter cen inzinking gekomen, die volgens zijn psychiater - professor Bastians - onverwatht kwam. Voor de heer Meester hopen wij dat deze kentering in zijn gezondherdstoestand tijde. lijk zal zijn."

Meesters 'kentering" volgde op de berichten die zijn eerste vrouw, Tini Vogt. verspreidde over zijn oorlogsverleden. De berichten zouden cen einde kunnen maken aan zijn nieuwe status als oorlogsslachtoffer.

Het huwelijk met Vogt was kort na de oorlog ontbonden en de twee hadden elkaar daarna uit het oog verloren. Met de publiciteit rond zijn behandeling bij Bastiaans en zijn bemoeienissen met de kwestie rond het Centrum, had Meester haar aandacht weer getrokken, Zij verbaasde zich over de rol van oorlogs slachtoffer die hij zich had aangemeten en geloofde niets van zijn oorlogsver. leden. Ze had Meester in de oorlog van dichtbij meegemaakt en wist niets van een verblijf in een concentratiekamp, zoals hij in de pers had laten doorsche. meren.

Na de eerste berichten had ze het weekblad Vrij Nederland enkele namen aan de hand gedaan van personen die konden getuigen dat Meester nimmer gevangen had gezeten en evenmin intensief verzet had gepleegd. Vrij Nederland deed niets met de brief en Vogt liet de zaak rusten.

In januari 1975 hoorde Vogt via een familielid dat nog steeds contact had met Meester, dat hij een aanvraag had gedaan voor een Buitengewoon Pensioen. Ze wist nog niets van de ophanden zijnde presentatie van Allemaal rottigheid, allemaal ellende. Ze besloot wederom actie te ondernemen en stuurde een brief naar de Stichting 1940-1945:

'Naar ik heb vernomen wil de heer Eibert Meester [...] proberen cen uitkering van uw Stichting te krijgen als "oorlogsslachtoffer". Nu zit mij dit zogenaamde oorlogsslachtoffer spelen van deze man al langer dwars, vandaar dat ik $u$ hierover schrijf.[...] ledereen van die leeftijd kan zich wel oorlogsslachtoffer noemen en naar professor Bastiaans stappen. Ik vind dit een groot onrecht ten opzichte van werkelijke oorlogsslachtoffers. Ik kan mij enorm kwaad maken over de houding van deze man, die zelfs openlijk durft te stellen, dat hij in een concentratiekamp heeft gezeten. Vermoedelijk wil hij in de publiciteit staan en vooral interessant doen.[... In Zwolle had hij wel contact met de verzetsbeweging, maar een belangrijke rol heeft hij hierin niet gespeeld. ${ }^{.12}$

Vogt voegde bij de brief aan de Stichting een kleine biografie van Meester, waarin ze diens verleden bij de socialistische jeugdbeweging Arbeiders Jeugd Centrale (AJC) beschreef, zijn werkzaamheden tijdens de oorlog in Zwolle - en 
hoe hij daarbij een stukje staal in zijn linkeroog kreeg -, zijn verblijf in Amsterdam en terugkomst in Zwolle eind 1944. En dat zij op 2 mei 1944 met Meester was getrouwd.

Vooral dat laatste alarmeerde de Stichting. Meester had het huwelijk in de gesprekken met de rapporteurs van de Stichting niet vermeld. Hij had het ook niet vermeld op het formulier voor de aanvraag van een Buitengewoon Pensioen, waarin daar wel naar werd gevraagd. Vogt stuurde ook een brief naar de verantwoordelijke staatssecretaris van het Ministerie van CRM, Wim Meijer. Die nam vervolgens persoonlijk contact op met Bastiaans om te voorkomen dat de uitzending doorgang zou vinden. Bastiaans nam daarop contact op met Langebent, die besloot de uitzending te annuleren.

Bastiaans legde Vogt in een gesprek de belangrijkste elementen voor uit de reconstructie van Meesters oorlogsverleden zoals die tijdens de behandeling was ontstaan: het ontploffen van het kruitschip in Zwolle dat Meester op zijn geweten zou hebben, het leidinggeven aan een groep verzetsstrijders waarvan iedereen sneuvelde, de zeven weken durende gevangenschap in het hoofdkwartier van de SD aan de Amsterdamse Euterpestraat, het verblijf in de koepelgevangenis van Arnhem, het kloven van Meesters vingers en de ontsnapping aan het vuurpeloton in kamp Amersfoort. Bastiaans waarschuwde bovendien dat als de zaak in de publiciteit kwam, de gezondheid van Meester schade zou kunnen oplopen, dat het mogelijk zelfs tot zijn dood zou leiden. Daarnaast was hij bang dat de kwestie zou worden aangegrepen om zijn therapievorm stop te zetten.

Vogt reageerde koeltjes dat zij neutraal stond tegenover LSD-behandelingen, maar dat zij geenszins wilde stoppen met het stellen van vragen. Ze vertrouwde erop dat de Stichting 1940-1945 de zaak verder zou uitzoeken. ${ }^{13}$

Het was voor Bastiaans net als voor Vogt wachten op de resultaten van het onderzoek van de Stichting. Die bleken anders uit te pakken dan Vogt had verwacht: ze kreeg te horen dat, hoewel Meesters verhalen niet geverifieerd konden worden, hij zijn pensioen zou behouden. Dat gebeurde uit 'humanitaire overwegingen'. Vogt werd bedankt voor haar betrokkenheid en gevraagd de zaak stil te houden. Dit was voor Vogt een zeer onbevredigend resultaat. ${ }^{14}$

Binnen de Stichting ontstond ook onvrede over de uitkomst. Een van de rapporteurs die betrokken waren bij het onderzoek naar Meester, tipte een journalist van het weekblad Panorama, Peter Gerritse. De belangrijkste tip die hij de journalist gaf, was eens met Vogt te praten. Op 1 april $1976 \mathrm{kwam}$ Panorama met een vervroegde editie. Het hoofdartikel had als kop 'Kamerlid en Meesterfantast?'.

Onder druk van de publiciteit werd de zaak-Meester nogmaals onderzocht, nu door de BPR. Enkele weken later werd Meesters Buitengewoon Pensioen ingetrokken. Hij werd geroyeerd als lid van Expogé, zegde zijn lidmaatschap van de Eerste Kamer op en trok zich terug in de anonimiteit. 
Bastiaans was over de kwestie zeer ontdaan. Hij zou tegen Wennekes zeggen dat zijn auto-ongeluk, dat hij kort na de Panorama-publicatie had gehad, een rechtstreeks gevolg was van de affaire. Hij had daarbij zijn hand gebroken. ${ }^{15}$ Naar buiten toe hield Bastiaans zijn rug recht. In een interview met journalist A.J. Heerma van Voss voor de Haagse Post antwoordde hij op de vraag of het voor hem krenkend was geweest dat hij als expert van het $\mathrm{Kz}$-syndroom had verzuimd te ontdekken dat Meesters verhalen niet authentiek waren:

'Het krenkt even je zelfgevoel. Maar je weet ook dat je niet almachtig bent. [...] Als ik primair een recherche-taak had gehad en ik er dan ingeluisd was, had ik het veel erger gevonden. ${ }^{.16}$

Meester was volgens Bastiaans een pathologische leugenaar, iemand die het liegen niet kan laten. Zijn ziekte maakte hem zo'n goede leugenaar dat hij zelfs een ervaren psychiater om de tuin had weten te leiden. De oorzaak van de leugens lag dus in zijn ziekte; daar kon verder niemand wat aan doen, Bastiaans niet en zelfs Meester zelf niet. Daar bleef het bij. Bastiaans' reputatie als deskundige bleef ongeschonden.

\section{De sociale fuik}

Bastiaans' verklaring dat Meester een pathologische leugenaar was, werd overgenomen door verzetsstrijders. In 1984, acht jaar nadat de problemen rond Meester in de openbaarheid waren gekomen, werd in het verenigingsblad van de Landelijke Kontakt Groep verzetsgepensioneerden (LKG), De Koerierster, een overzicht gegeven van tien gevallen waarbij was getwijfeld of het Buitengewoon Pensioen terecht werd uitgekeerd. Daarin stond te lezen over Meester:

'Begin 1975 verscheen een boekje, waarin de verzetservaringen van E.M. werden beschreven zoals hij die aan de journalist W. had verteld. [...] Tijdens het onderzoek was duidelijk gebleken dat E.M. een ernstige psychiatrische patiënt was en dat de overdreven verhalen ten nauwste met zijn ziekte samenhingen. ${ }^{17}$

Het is tekenend voor de bescherming die Bastiaans genoot bij verzetsstrijders, dat nergens in de beschrijving zijn naam werd genoemd. Nergens werd vermeld dat Meester de verhalen niet aan Wennekes maar aan zijn psychiater had verteld. Bovendien had die psychiater de diagnose Kz-syndroom gesteld; wat zei deze misser over de andere diagnoses van deze psychiater? Door Meester te beschrijven als een uitzondering die het gevolg was van een exotische psychiatrische aandoening, hoefden al die vragen niet beantwoord te worden en bleef de positie van Bastiaans als expert bewaard. 
Een nadeel van deze benadering was dat een aantal opvallende kenmerken van Meesters verhaal buiten beschouwing bleef. Ten eerste bleef de nadruk in de publiciteit liggen op de grootste vertekeningen in zijn reconstructie: de ontsnapping aan een vuurpeloton en zijn gevangenschappen. Dat leidde tot de conclusie dat Meester een grote leugenaar was, een fantast. Maar zo stond hij bij familie, vrienden en collega's tevoren niet bekend. De vertekeningen beperkten zich tot zijn oorlogsverleden en bestonden vóór de behandeling al, zij het in veel mildere mate.

Ten tweede zat er een zekere ontwikkeling in de presentatie van zijn oorlogsverleden. In de jaren vijftig verwees Meester naar de 'actieve rol in de illegaliteit' die hij in de oorlog had gespeeld. Er hing in die periode een 'sfeer van verzet' rond Meester, zoals een persoonlijke vriend van hem het ooit beschreef. ${ }^{18}$ Een sfeer die niet concreet werd gemaakt met anekdotes. In de jaren zeventig vertelde hij in persoonlijke kring dat hij 'gevangen had gezeten'. Tijdens de behandeling bij Bastiaans werden de verhalen uitgebreider en gedetailleerder.

De vertekeningen in Meesters reconstructie ontstonden dus niet pas tijdens de behandeling bij Bastiaans; het proces van vertekening was al voor hij in behandeling kwam, begonnen. Zijn komst naar de Jelgersmakliniek is het best te begrijpen als het resultaat van zijn gang door een 'sociale fuik'. ${ }^{29}$ Een vis die een fuik in zwemt, passeert steeds kleiner wordende kamers, van waaruit het steeds moeilijker is terug te keren naar de vorige kamer.

De eerste kamer van de sociale fuik strekte zich uit van de bevrijding tot begin jaren zeventig. De nationale herinnering aan de Tweede Wereldoorlog werd, zoals historicus Blom ooit analyseerde, lange tijd overheerst door termen als collaboratie en verzet. ${ }^{20}$ Het legde de norm van verzet op aan de generatie die de oorlog had meegemaakt. Dat vertaalde zich regelmatig in de vraag of iemand 'goed' of 'fout' was geweest in de oorlog: goed was de verzetsstrijder, fout was de Duitser, fouter de collaborateur. Zelfs de suggestie alléén van een fout verleden was voldoende om een einde te maken aan een carrière.

Om die reden hield CDA-politicus mr. W. Aantjes zijn oorlogsverleden, waarin de letters 'ss'voorkwamen, jarenlang geheim. Toen eind jaren zeventig dat verleden alsnog openbaar werd gemaakt, was het inderdaad gedaan met zijn politieke carrière. Op de vraag van Aantjes aan zijn partijgenoot, de latere minister-president dr. R.F.M. Lubbers, of een politieke carrière nog opportuun was, uitte die zijn twijfels:

'Naar mijn inschatting is er in deze samenleving met haar gebrek aan heldere normen een volstrekt vertekend beeld van de oorlogsjaren: "je was goed of fout". De realiteit van "grijs" wordt volstrekt genegeerd. Daarom kan men niet oordelen maar slechts veroordelen (of bejubelen). ${ }^{21}$ 
Het andere uiterste van de norm vormden de verzetsstrijders. $\mathrm{Zij}$ waren voorbeelden waaraan anderen, die minder heldhaftig waren geweest, zich konden spiegelen. Belangrijke nog levende verzetsstrijders waren vaak richtingbepalend in het publieke debat. Een verleden als verzetsman betekende aanzien, en hielp bij het veroveren van een maatschappelijke positie. Historicus Ido de Haan beschreef het als volgt:

'Men werd in politieke en sociale zin kwetsbaarder als men [oud-verzetsstrijders] tegen zich in het harnas jaagde en degene die zijn argumenten wist te omkleden met de reputatie van het verzetsverleden had in ieder geval al een deel van het pleit gewonnen. ${ }^{.22}$

Meester had zich, net als het merendeel van de bevolking, in het grijze middengebied bevonden. Toen na de oorlog de vraag naar voren kwam of Meester 'goed' of 'fout' was geweest, moest ook Meester de balans opmaken. Hij had een Joodse onderduiker een vals paspoort overhandigd, hij had illegale kranten doorgegeven en aan het einde van de oorlog had hij geholpen bij de opvang van vluchtelingen uit het westen van het land. Hoewel het geen spectaculaire verzetsdaden waren geweest, kon Meester zich presenteren als 'goed'.

Behalve dat Meester 'goede daden' had verricht, had hij ook bij een bedrijf gewerkt dat bekend stond als kriegswichtig, dus van belang voor de Duitse oorlogsindustrie. Later werkte hij in een bedrijf dat was geconfisqueerd van een Joodse ondernemer. Om te voldoen aan de norm van verzet, moest men steeds afwegen wat wel en wat niet verteld kon worden. Soms betekende dat delen van het verleden verzwijgen of afzwakken, soms betekende dat delen uitvergroten.

Sommigen gingen in huiselijke kring zo ver om hun eigen verleden wat anders voor te stellen. In de biografie over Annie M.G. Schmidt van Annejet van der Zijl stond bijvoorbeeld te lezen hoe Schmidt zich schaamde voor haar blijkbaar te passieve houding tijdens de oorlog. Ze mat zich een wat grotere rol aan dan ze in werkelijkheid had gespeeld; ze loog bijvoorbeeld dat ze anti-Duitse versjes had geschreven voor de illegale krant Het Parool. ${ }^{23}$

Anderen gingen nog verder. Een voorbeeld daarvan waren de leugens van psychiater Frank van Ree, die hij in zijn autobiografie beschreef. Hij vertelde familie en vrienden dat hij 'in het verzet' had gezeten en beschreef hoe hij met een handgranaat een Duitse vrachtauto tot ontploffing had gebracht. Drie soldaten zouden daarbij zijn omgekomen. Als bewijs liet hij een foto zien van een brandende vrachtwagen. Het verhaal was, zo schreef hij in zijn autobiografie, verzonnen. De verklaring die hij voor zijn leugens gaf liet zien hoe sterk de norm van verzet was: 
'In de naoorlogse tijd was iedereen die niet goed was geweest, fout. En fout had $i k$ niet willen zijn. ${ }^{24}$

De norm van verzet maakte het oorlogsverleden een beladen kwestie. Een verzetsverleden, of de suggestie daarvan, leverde voordelen op. Zelfs de schijn van een fout verleden leverde moeilijkheden op. Het willen voldoen aan de norm van verzet verklaarde waarom Meester een 'sfeer van verzet' om zich heen had gecreëerd.

In de jaren zeventig veranderde Meesters reconstructie. Behalve een rol gespeeld te hebben in de illegaliteit, liet hij nu doorschemeren gevangene te zijn geweest. Hij was een slachtoffer. Die verandering van zijn oorlogsverleden was een spiegeling van de veranderde maatschappelijke omgeving waarin die tot stand kwam. Meester was inmiddels in de tweede kamer van de sociale fuik beland.

Voor de periodisering en typering van de tweede kamer van de sociale fuik wordt hieronder intensief gebruikgemaakt van het werk van de sociologe Jolande Withuis. Haar boek Erkenning, waarin ze de opkomst van de huidige traumacultuur analyseert, werd als basis gebruikt voor de hieronder beschreven ontwikkelingen. ${ }^{25}$

Withuis beschreef de drastische veranderingen op het gebied van de herinnering aan de Tweede Wereldoorlog, die zich voltrokken vanaf het midden van de jaren zestig. ${ }^{26}$ De norm van verzet bleef weliswaar bestaan, maarwerd steeds meer overschaduwd door de aandacht voor het leed van slachtoffers. Withuis beschreef in haar boek hoe nog levende slachtoffers - aanvankelijk Joodse gedeporteerden, al snel gevolgd door verzetsstrijders - zich begaven in een strijd om erkenning van hun leed. Dat was een succesvolle strijd die, geholpen door de uitzending van Begrijpt $u$ nu waarom ik huil..., had geleid tot een grote compassie met oorlogsslachtoffers. De snelle bouw van Centrum ' 45 was daar een blijk van, net zoals de instelling van de Wet Uitkering Vervolgingsslachtoffers - een uitkering speciaal voor vervolgden, zoals Joden en zigeuners - en de invoering van de omgekeerde bewijslast, waardoor verzetsstrijders het voordeel van de twijfel werd gegund bij de oordelen over het causaal verband. Oorlogsslachtoffers konden rekenen op steun, zorg en aandacht.

Een gevolg van de strijd om erkenning was dat de voorlichting over het $\mathrm{KZ}$ syndroom werd geïntensiveerd. Bastiaans trok langs universiteiten en symposia en vertoonde daar Begrijpt u nu wadrom ik huil.... Het Nationaal Centrum voor Geestelijke Volksgezondheid verspreidde na de uitzending van Begrijpt $u$ nu waarom ik huil... een informatiepakket met daarin 'informatie over het verwerken van ervaringen uit de oorlog. ${ }^{27}$ Er werden adressen verstrekt waar hulp kon worden gezocht, en aanwijzingen gegeven aan vrienden en familie voor het omgaan met een oorlogsslachtoffer in hun midden.

Al die aandacht voor de gevolgen van de oorlog zette een proces in gang dat 
de socioloog Abram de Swaan 'proto-professionalisering' noemt. ${ }^{2 R}$ Leken en professionals raakten doordrongen van de kwalijke gevolgen van de oorlog, hoorden over het $\mathrm{kZ}$-syndroom, namen de terminologie over en begonnen klachten bij zichzelf en anderen te herkennen. Het $\mathrm{Kz}$-syndroom was niet meer een term die werd gereserveerd voor experts. Ook andere medici en leken kenden de term en gebruikten hem.

Het $\mathrm{kZ}$-syndroom werd weliswaar bekend als een ernstig probleem maar het bleef tegelijkertijd lastig te herkennen. Het was zo onduidelijk beschreven dat alle mogelijke klachten als een symptoom ervan konden worden gezien. Zelfs voor artsen en psychiaters was het niet altijd duidelijk wanneer er sprake was van een $\mathrm{Kz}$-syndroom. Vrijwel alle lichamelijke en psychische klachten konden in verband staan met de oorlog: hoge of lage bloeddruk, reuma, diabetes, hernia's, astma, nachtmerries, depressies en paniekaanvallen. Psychoanalyticus Jan Thiel, die Bastiaans nog kende van het bestuur van het PAI, beschreef het stellen van de diagnose ' $\mathrm{KZ}$-syndroom' meer als een beslissing dan als een vaststelling:

'Er ging een duidelijke traumatische ervaring aan vooraf, maar uiteindelijk was het zo dat als de dokter het zegt, dan is het zo. Zo'n soort syndroom was het. ${ }^{27}$

Het besef dat de oorlog diepe wonden had geslagen, dieper dan gedacht, werd na 1972 gemeengoed. Het bestaan van een ernstige aandoening als het $\mathrm{KZ}$-syndroom vroeg om alertheid. Mensen met klachten, hun familie en vrienden, huisarts en sociaal werker moesten bij een vermoeden een expert inschakelen. Het gaf die experts, waarvan Bastiaans de bekendste was, een unieke positie.

Niet alleen Bastiaans was verantwoordelijk voor deze ontwikkeling. Andere artsen en psychiaters hadden er ook een aandeel in. E.A. Cohen bijvoorbeeld, liet zich al in de jaren zestig interviewen over het $\mathrm{Kz}$-syndroom, en ook Musaph, Hugenholtz en De Wind lieten van zich horen in de pers. Dat deden ook verzetsstrijders en gedeporteerden, van wie de persoonlijke verhalen verschenen in boeken en interviews.

De verspreiding van het idee dat de oorlog nog lange tijd gevolgen kon hebben, was winst. Slachtoffers die soms al jarenlang klachten hadden, voelden zich ineens erkend en durfden naar buiten te treden. Familie en vrienden begrepen waarom hun naasten zich vreemd gedroegen. Zij zagen in dat de klachten reëel waren, dat iemand zich niet aanstelde. Het lijden kreeg een naam en dat stelde gerust; men was niet de enige. Er kwam steeds meer ruimte voor slachtoffers om te spreken over hun verleden en hulp te zoeken.

De proto-professionalisering leidde ertoe dat bij leken steeds vaker het vermoeden rees dat klachten een gevolg van de oorlog waren. Zeker als iemand al eens iets had laten doorschemeren van zijn oorlogsverleden. Dat leidde toteen 
steeds grotere vraag naar specifieke hulp voor de gevolgen van de oorlog. Centrum ' 45 kon in 1976 bijvoorbeeld het aantal aanmeldingen niet aan en vroeg de overheid om de bouw van nieuwe centra. ${ }^{30}$ Het leidde ook tot een groei in het aantal aanvragen voor een Buitengewoon Pensioen. Om daarvoor in aanmerking te komen moest iemand klachten hebben die in verband stonden met de oorlog.

Iemand die dicht bij het aanvraagproces zat, L. Beurkens, voorzitter van het district Zeeland van de Stichting 1940-1945, zag het proces van proto-professionalisering zich voor zijn ogen voltrekken. In een gedenkboek ter gelegenheid van het veertigjarig bestaan van de Stichting beschreef hij hoe hij de klachten van de aanvragers in meer dan twee decennia had zien veranderen, en niet alleen ten goede..$^{31}$ Vooral de verandering na de invoering van de omgekeerde bewijslast in 1970, had hij met lede ogen aangezien. Aanvragers gebruikten het Buitengewoon Pensioen volgens hem vaak om een aanvulling op hun normale pensioen te krijgen, zonder dat er sprake was geweest van verzet. In het gedenkboek zei Beurkens:

'Bastiaans heeft veel goed werk gedaan, maar nu schrijft iedereen klakkeloos de door hem beschreven symptomen op. Nu krijg je er de uitwassen van. Je leest telkens in die rapporten: ik kan niet slapen, als ik wakker word heb ik allemaal visioenen. [...] Als het goed zat met alles dan zou je toch eigenlijk die aanvragen klakkeloos moeten goedkeuren, het zou waarachtig waar moeten zijn wat die mensen invullen. Maar dat is gewoon niet zo. ${ }^{32}$

Het aantal aanvragen voor een Buitengewoon Pensioen steeg in die jaren dramatisch. De toename was zo groot dat eind jaren zeventig de voorzitters van de BPR en de Stichting 1940-1945, respectievelijk G.W.D. Soeteman en G. Londo, gezamenlijk de noodklok luidden bij de staatssecretaris van CRM, die verantwoordelijk was voor de uitvoering van de WBP. De instanties bezweken bijna onder de hoeveelheid aanvragen voor een Buitengewoon Pensioen, die in 1977 een hoogtepunt bereikte van bijna 1300. Dat was een verzesvoudiging van het aantal aanvragen tien jaar daarvoor, toen het $\mathrm{KZ}$-syndroom net in de publiciteit was gekomen..$^{33}$

In de tweede kamer van de sociale fuik stonden de oorlog en de gevolgen daarvan zó in het brandpunt van de belangstelling, dat alternatieve oorzaken makkelijk over het hoofd werden gezien, gebagatelliseerd of verworpen. Voor personen die zich de eerste kamer binnen hadden gemanoeuvreerd, was de stap naar de volgende kamer snel gezet. Op z'n minst werd door slachtoffers, familieleden, huisartsen of specialisten het zekere voor het onzekere genomen en een expert ingeschakeld.

Dat verklaarde dat Meester - die, toen hij in het ziekenhuis kwam te liggen, bijna zevenenvijftig jaar oud was en bijna twee pakjes per dag rookte - niet als 
normale hartpatiënt werd beschouwd. De arts die Meester in het ziekenhuis hoorde ijlen, koos het zekere voor het onzekere en liet hem onderzoeken door de expert op dat gebied: Bastiaans. Hij stuurde hem daarmee de derde kamer van de sociale fuik in.

De eerste kamer van de sociale fuik had gemaakt dat men zich bewust werd van het belang van het oorlogsverleden. De tweede kamer zorgde ervoor dat sneller dan voorheen het vermoeden ontstond dat lichamelijke of psychische klachten werden veroorzaakt door dat verleden, en dat daar makkelijker hulp voor werd gezocht. In de derde kamer meldden patiënten zich voor een behandeling bij een gespecialiseerde arts of psychiater met het doel dat vermoeden verder uit te werken. Wanneer de precieze verbanden tussen de klachten en gebeurtenissen in het verleden bloot waren gelegd, zouden de klachten verdwijnen.

Bastiaans had, zoals gezegd, een bijzondere plaats in die gespecialiseerde hulpverlening. Hij werd door niet-gespecialiseerde artsen gezien als de expert waar zij patiënten naar konden doorverwijzen. De mythe van de methode-Bastiaans maakte dat hij ook door patiënten werd gezien als degene een oplossing had.

Behalve de hoop op genezing van hun klachten, speelden ook andere motieven een rol om zich bij hem te melden. Patiënten zagen een behandeling door Bastiaans vaak als een voorrecht. Dat was mede te danken aan Bastiaans' pogingen de problemen van de slachtoffers een zekere glans te geven. Aan de buitenwereld benadrukte hij dat zijn patiënten niet zomaar slachtoffers waren, net zomin als ze zomaar psychiatrische patiënten waren, die in een regulier behandelcentrum behandeld konden worden. Hij gaf ze een gevoel van exclusiviteit, van bijzonder-zijn.

Volgens Bastiaans waren zijn patiënten behept met een 'sterk karakterpantser' ${ }^{34}$ Het waren personen die:

'in hun vooroorlogse bestaan vrij redelijk en actief functioneerden maar die door de overmacht van de oorlogsstress in hun mogelijkheid tot vrije expressie aanzienlijk werden geblokkeerd' ${ }^{35}$

In een andere tekst omschreef hij ze als 'geremde vechters':

'personen met een rijke levenservaring die echter door traumatische gebeurtenissen "stil" waren geworden en daardoor niet meer normaal konden functioneren'. ${ }^{36}$

Zijn patiënten hadden een gezond, actief bestaan geleid, ze hadden een rijke en positieve levenservaring (bijvoorbeeld verzetsactiviteiten) en waren door noodlottige, van buiten komende factoren beschadigd geraakt. De patiënten waren diep vanbinnen vechters, doorbijters, wat betekende dat hun lijden 
vooral wat zei over de ernst van de gebeurtenissen; andere, minder sterke vechters waren in dezelfde omstandigheden ten onder gegaan.

De patiënten voelden zich gestreeld en beantwoordden de loftuitingen met een mateloze bewondering voor hun psychiater. De bewondering voor Bastiaans nam soms mythische proporties aan. Als Bastiaans tijdens een behandeling de vaderfiguur speelde, konden de patiënten bij hem uithuilen en dat deden ze ook. Ze gaven zich aan hem over en kropen op zijn schoot of huilden tegen zijn brede borst uit. Hij werd tijdens de sessies door zijn patiënten liefkozend 'papa Bas' genoemd. ${ }^{37}$ Het vertrouwen in en het aanzien van Bastiaans was zo groot dat een buitenlandse patiënt na zijn verblijf in de Jelgersmakliniek opmerkte over zijn medepatiënten:

'Voor iedereen van hen gold, dat het afzeggen van een afspraak zoiets zou zijn als om de Messias op te bellen en hem te zeggen dat hij zijn Komst maar even moest uitstellen. ${ }^{38}$

'Bij Bastiaans is iedereen een oorlogsslachtoffer'

Wie bij Bastiaans terechtkwam, kwam op de dependance van de Jelgersmakliniek. Dat was een oude villa tussen het groen, wat verscholen van de weg en de rest van de gebouwen van de Jelgersmakliniek. Het gebouw telde ongeveer twaalf overnachtingsplaatsen, waar patiënten die een LSD- of pentothalbehandeling hadden ondergaan een nacht konden verblijven. De 'zwaarste gevallen', die meer begeleiding nodig hadden, konden langer blijven, soms enkele dagen, weken of maanden. Andere patiënten, minder zware gevallen, meldden zich één of meer keren per week voor dagbehandeling. Ze hadden gesprekken met een psycholoog of een psychiater (soms, maar niet altijd, Bastiaans), groepsgesprekken of creatieve therapie.

Behalve met hun psychiater en het verplegend personeel hadden de patiënten ook contact met elkaar. Ze spraken over hun problemen, vierden in 'de Jel' het kerstfeest en herdachten er de vierde en de vijfde mei. ${ }^{39}$ Soms werden de tafels aan de kant geschoven en was er ruimte voor feest en dans. Er konden boeken worden geleend uit de kleine bibliotheek van de dependance.

Soms betrok Bastiaans patiënten bij het werk op de Jelgersmakliniek, en gaf hij ze een 'opleiding'. Zij ondersteunden daarna op vrijwillige basis de behandeling van andere patiënten - ook narcoanalyses en LSD-therapieën - of voerden gesprekken met reeds ontslagen patiënten die een terugval hadden of vreesden. ${ }^{40}$ Anderen hielpen in de bibliotheek of bij de administratie. Weer anderen, zoals Meester en Maliepaard, schoten hun psychiater te hulp door in de media of de politiek aandacht te vragen voor de problemen, wanneer hij in moeilijkheden zat.

Het samenbrengen van lotgenoten had in Centrum ' 45 geresulteerd in een 
hiërarchie onder de patiënten. P. de Koning en M. Oosterbaan, beiden therapeuten op het Centrum, beschreven in 1978 in het Maandblad Geestelijke volksgezondheid (MGv) de onderlinge concurrentie onder patiënten: onderduikers durfden in het bijzijn van gedeporteerden, die het in hun ogen veel zwaarder hadden gehad, niet over hun problemen te spreken. De vervolgden uit voormalig Nederlands-Indiëwerden gezien als 'tweederangsslachtoffers' voor wie met tegenzin een plaatsje werd ingeruimd.

Het Centrum was, zo schreven de beide therapeuten, bedoeld voor hen die 'goed' waren geweest, dus voor verzetsstrijders. Bij hen observeerden zij dan ook sentimenten die erop duidden dat ze vonden dat vervolgden dankbaar moesten zijn voor hun behandeling op het Centrum. Onder verzetsstrijders werd door het gewapende deel neergekeken op het ongewapende deel, en daardoorheen speelden verschillende politieke achtergronden een rol. ${ }^{41}$

Ook op de dependance van de Jelgersmakliniek ontstond een dergelijke hiërarchie. Sociaal verpleegkundige Joop Brouwer was jarenlang werkzaam op de Jelgersmakliniek en ondersteunde Bastiaans bij vele LSD- en pentothalsessies. Zij herinnerde zich in, een interview met het televisieprogramma Andere Tijden uit 2000, hoe onder patiënten op de Jelgersmakliniek een wedijver bestond:

'De mensen die LSD kregen voelden zich meer, zij hadden het meeste leed en dan stond je het hoogst in rang.' ${ }^{\prime 2}$

De hiërarchie op het Centrum werd bepaald door het leed dat iemand had ervaren. Op de Jelgersmakliniek voegde zich daar een element bij: de hoeveelheid aandacht die iemand kreeg van de professor. Die was af te lezen aan het soort behandeling dat iemand kreeg - een narcoanalyse, LSD-behandeling of andere behandeling; overnachten op de Jelgersmakliniek of alleen dagbehandeling maar er waren ook andere voorrechten. Soms nam Bastiaans patiënten mee naar de colleges die hij gaf op de Rijksuniversiteit Leiden, en stelde hen daar voor aan het aanwezige publiek als zijn 'medewerkers'. Aanwezigheid bij de colleges zou patiënten inzicht geven in hun problematiek, wat het genezingsproces ten goede zou komen. ${ }^{43}$ Het verkrijgen van dergelijke voorrechten vormde voor patiënten een alternatieve manier om erkenning te krijgen. De LSD-behandeling was de ultieme vorm van erkenning en Bastiaans sprong daar zuinig mee om.

Bastiaans schiep huizenhoge verwachtingen over het succes van zijn behandelingen, superlatieven schoten vaak tekort. Dat bleek bijvoorbeeld bij jurist mr. C. Veraart, met wie Bastiaans begin jaren tachtig samenwerkte bij de ondersteuning van aanvragen voor een Buitengewoon Pensioen. Veraartleed aan MS, een aandoening met klachten variërend van verlammingen en oogklachten tot 
spasmen en depressies. Veraart beschreef in een autobiografisch boek over zijn ziekte hoe Bastiaans tegen hem zei:

'Chris, weet je wel dat ik [jaren geleden] een boek heb geschreven waarin ik uiteenzet dat $M S$ een psychische oorzaak heeft. Je moet eens bij me komen in De Villa in de Jelgersmakliniek in Oegstgeest. Met een spuitje breng ik je dan onder zeil en in de schemerige toestand als je uit de narcose komt, haal ik het trauma bij je weg. Ik maak mee dat hier mensen weer zonder krukken naar buiten lopen. ${ }^{14}$

Veraart had zijn twijfels over de narcoanalyse en de LSD-therapie, maar liet zich overtuigen door Bastiaans' status als hoogleraar; Bastiaans was tenslotte 'niet de eerste de beste'. Hij kreeg twee narcoanalyses, waarin Bastiaans tevergeefs op zoek ging naar verdrongen trauma's. Hij ontdekte alleen, zoals Veraart het omschreef, een stralende jeugd, een goede relatie met zijn ouders en een gezonde werklust. Toen Bastiaans voorstelde om in de derde narcoanalyse dan maar terug te gaan naar het prenatale stadium, bedankte Veraart. ${ }^{45}$

Veraart had zelf geen vermoedens over een eventuele psychische oorsprong van zijn Ms. Bovendien leek hij denarcoanalyses te ondergaan onder het motto 'baat het niet, dan schaadt het niet'. Van een dergelijke ongedwongenheid en openheid was bij veel van Bastiaans' patiënten geen sprake. In zijn kliniek meldden zich vaak patiënten die wél een vermoeden hadden over de oorzaak van hun klachten: dat was volgens hen vaak de oorlog. Er kon nauwelijks nog sprake zijn van een onbevooroordeelde blik bij Bastiaans en zijn patiënten, waardoor in de behandeling niet de vraag centraal stond of klachten in verband stonden met de oorlog maar hoe.

Het werd voor Bastiaans steeds moeilijker om weerstand te bieden aan de gedachte dat klachten werden veroorzaakt door de oorlog. Verzetsstrijder mr. Piet Coumou, voorzitter van de Stichting Samenwerkend Verzet (ssv), had veel contacten met oud-verzetsstrijders en artsen. Coumou herinnerde zich in een interview hoe sommige artsen over Bastiaans dachten:

'Bij Bastiaans is iedereen een oorlogsslachtoffer.' ${ }^{36}$

Dat wist Coumou ook uit eigen ervaring. Toen Coumou last kreeg van een loslatend netvlies en vier keer moest worden geopereerd voordat het weer bleef zitten, suggereerde Bastiaans dat dat een relatie met de oorlog had. Hij bood aan de kwestie te onderzoeken met een narcoanalyse. ${ }^{47}$ Coumou sloeg het aanbod beleefd af. Soortgelijke ervaringen, waarbij Bastiaans klachten duidde als een gevolg van de oorlog, hadden ook andere collega's en bekenden. ${ }^{48}$

Het was voor zowel de patiënt als voor Bastiaans moeilijk om tijdens de behandelingen te ontdekken dat de klachten niet een gevolg waren van de oorlog. 
Het leidde tot een selffulfilling prophecy, waarvan het onvermijdelijke resultaat het vinden van een traumatische gebeurtenis was.

Dat beschreef ook psychotherapeut $\mathrm{K}$. van der Velden, die Bastiaans vergeleek met de 19e-eeuwse neuroloog Charcot. Charcot had zich gespecialiseerd in hysterie en gaf regelmatig demonstraties van hysterici om zo zijn ideeën te illustreren. De feilloze manier waarop de patiënten keer op keer dezelfde symptomen vertoonden, sterkte hem - en anderen - in zijn opvattingen. Maar hij vergat dat hij en zijn medewerkers die patiënten, bewust en onbewust, hadden geïnstrueerd; ze wisten wat er van hen werd verwacht en gaven daar gevolg aan.

Iets vergelijkbaars speelde bij Bastiaans in de behandelkamer. De patiënten wilden in de gunst van hun psychiater blijven, en wisten wat er van hen werd verwacht: zij moesten de juiste gebeurtenis produceren. Een gebeurtenis die Bastiaans tevredenstelde. Bastiaans vond altijd een traumatische gebeurtenis en zag zijn ideeën keer op keer bevestigd. Maar hij vergat dat hij die ook wilde vinden, en dat zijn patiënten dat wisten. Hij had geen oog voor de druk die er bestond om een verband te vinden, een druk die zo groot was dat er soms vertekeningen in de reconstructie ontstonden. Zozeer dat er herinneringen bovenkwamen die niet waren gebaseerd op authentieke ervaringen. Zoals bij Meester.

Bij een bespreking van het geval-Meester werd door de psychotherapeut $\mathrm{K}$. van der Velden, en later door de psychologen Crombag en Merckelbach, gewezen op de sturende manier waarop Bastiaans zijn therapie bedreef. ${ }^{49}$ Met zijn suggestieve vragen droeg hij een verklaring aan voor de klachten, in plaats van dat de patiënten daar zelf mee kwamen.

Voor Bastiaans en zijn patiënten waren die vragen niet dwingend of suggestief; al voordat de patiënten een voet over de drempel van Bastiaans' behandelkamer hadden gezet, was hun immers duidelijk dat de oorzaak van hun problemen in de oorloglag. Bastiaans deed watervan hem werd verwacht: doorvragen tot de kern van de problemen was blootgelegd en er een bevredigende reconstructie was gemaakt.

In hoofdstuk 4 werd beschreven hoe technieken als de narcoanalyse en de LSD-behandeling het geloof in de authenticiteit van de herinneringen deden groeien, zonder dat dat gerechtvaardigd was. Dat zou kunnen betekenen dat de vertekeningen het gevolg waren van die middelen, en dat de suggestieve vragen van Bastiaans, zoals hierboven beschreven, een laatste duwtje in de rug waren. De genoemde technieken waren echter niet noodzakelijk om vertekeningen te doen ontstaan; dat bleek uit het verhaal van Jacques Kopinsky. Kopinsky kreeg noch een narcoanalyse noch een LSD-behandeling, en maakte desondanks een reconstructie die niet was gebaseerd op authentieke ervaringen. 


\section{Portret: Jacques Kopinsky}

Jacques Kopinsky werd in de jaren tachtig bekend om zijn kunstwerken, voornamelijk tekeningen, die waren gebaseerd op zijn ervaringen tijdens de oorlog. Zijn tekeningen waren een klein wonder: toen hij voor zijn kleinkinderen een paashaas wilde tekenen, herkenden die er een kat in. ${ }^{50}$ Tekenen kon Kopinsky alleen over de oorlog, en dan alleen als hij werd overvallen door het verleden en in een soort trance kwam. Het was zijn manier geworden om met het verleden om te gaan, en dat had hij geleerd bij Bastiaans.

Kopinsky had na de oorlog een tijdlang moeite gehad met het vinden van een baan, maar was uiteindelijk terechtgekomen bij een bedrijf dat stalen raamkozijnen produceerde. Nadat zijn werkgever hem in de jaren zeventig een andere werkplek had gegeven, dicht bij een raam dat hem deed denken aan tralies, was zijn gezondheid snel achteruitgegaan. Hij werd somber en was veel ziek. Tijdens koortsaanvallen zag hij onder zijn bed een groen uitgeslagen menselijk hoofd verschijnen. Hij wist niet van wie het hoofd was, of wat het betekende. Op aanraden van zijn kinderen, die behalve wat onduidelijke uitspraken nooit iets van hun vader hadden gehoord over zijn oorlogsverleden, meldde Kopinsky zich eind 1976 op de Jelgersmakliniek. ${ }^{51}$

Bastiaans liet Kopinsky creatieve therapie ondergaan. Daarbij was het de bedoeling om door te tekenen of te boetseren problemen inzichtelijk te maken en mogelijk zelfs te verwerken. Het kostte moeite maar Kopinsky wist uiteindelijk in klei het hoofd te boetseren dat aan hem verscheen tijdens zijn koortsaanvallen. Het verhaal dat daarbij hoorde kwam ook boven.

In kamp Amersfoort zag Kopinsky hoe Kötalla, een van de latere drie van Breda, een Jood doodsloeg. Toen Kopinsky daar wat van zei, moest hij voor straf een dag en een nacht lang een kruiwagen duwen met daarin de dode Jood. Het was het hoofd van de dode Jood, dat levenloos tegen de rand van de kruiwagen bonkte, dat aan hem verscheen in zijn koortsdromen. Na het boetseren van het hoofd volgden meer kunstwerken die waren geïnspireerd op Kopinsky's ervaringen in de oorlog.

Hij had gezien hoe zijn kleine Joodse nichtje Liesje, dat graag ballerina wilde worden, door de Duitsers uit haar huis werd gesleurd. De kapotte knieën van haar kousjes kwamen hem weer voor ogen en werden in een potloodtekening vastgelegd. Bastiaans schuwde de confrontatie niet in de therapie: nadat Kopinsky van klei een beeld van Liesje had gemaakt, smeet Bastiaans het voor zijn ogen op de grond. Kopinsky moest immuun worden voor de emoties die Liesje bij hem opriep.

Bastiaans liet Kopinsky ook opdrachten uitvoeren. Zo moest hij bijvoorbeeld prikkeldraad doorknippen, als symbool voor zijn eigen bevrijding. Samen met zijn vrouw ging hij naar een weiland en knipte daar een stuk prikkeldraad weg. Ook moest hij zich melden in het Duitse ziekenhuis waar hij gedurende de oorlog een paar dagen was verpleegd. Als bewijs dat hij daar was 
geweest, moest hij een kaart met een stempel van het ziekenhuis aan Bastiaans laten zien.

De behandeling slaagde en Kopinsky voelde zich opgelucht. Hij durfde nu eindelijk zijn vrouw te vertellen dat hij Joods was. Hij bleef nieuwe tekeningen, schilderijen en boetseerwerk maken en werd ontdekt door de directeur van museum Flehite in Amersfoort. Die nodigde hem uit voor een expositie.

Kopinsky kon daarna rekenen op veel media-aandacht, mede veroorzaakt door de manier waarop zijn kunstwerken tot stand kwamen. De lokale televisie raakte gefascineerd en maakte een documentaire over Kopinsky. ${ }^{52} \mathrm{Hij}$ kwam in contact met andere voormalig gevangenen van kamp Amersfoort, onder wie de beroemde Gerrit Kleinveld. ${ }^{53}$ Kleinvelds spectaculaire ontsnapping uit het kamp was ooit verfilmd door regisseur Gerard Soeteman in De Bunker, met Thom Hoffman in de hoofdrol. ${ }^{54}$ Kopinsky raakte betrokken bij de oprichting van het Verzetsmuseum in Amsterdam en maakte het beeldmerk van het huidige Nationaal Monument Kamp Amersfoort.

Kopinsky was behalve verzetsman ook Jood. Hij vertelde in interviews dat hij om die reden was afgevoerd via Buchenwald naar het Joodse getto Theresienstadt. Op een morgen was hij op transport gezet. Hoeveel dagen hij in de treinwagon had doorgebracht wist hij niet. Zijn redding kwam toen een geallieerd vliegtuig de trein beschoot, en de deur op een kier kwam te staan. Hij was uit de trein gesprongen en had zo zijn leven weten te redden.

Kopinsky's status als vervolgde vormde in 1989 de aanleiding voor een tentoonstelling in Haarlem. Onder de titel 'Oorlogsherinneringen' werd het werk van Kopinsky gecombineerd met fragmenten uit het dagboek van de gedeporteerde Joodse Etty Hillesum. ${ }^{55}$

Kopinsky's succes was ook Bastiaans' succes: het was zijn behandeling die Kopinsky in staat had gesteld zijn kunst te maken. Steeds als er een opening van een expositie was, werd Bastiaans gevraagd een korte toespraak te houden.

Toch was er twijfel over de verhalen van Kopinsky. Bijvoorbeeld eind jaren negentig, toen de weinige overblijfselen van Kamp Amersfoort - de muurschilderingen in het kantoor van de kampcommandant - werden gerestaureerd. Zekerheid omtrent de identiteit van de maker van de schildering was er niet, maar er ging een gerucht rond dat het de voormalig gevangene László Weiss was. Kopinsky wist dit te bevestigen en vertelde journalisten hoe hij de verf mengde in de houtwerkplaats terwijl Weiss de schilderingen maakte. ${ }^{56}$

Weiss' zoon raakte door de publiciteit geïnteresseerd en ging op onderzoek uit. Hij deed een vreemde ontdekking: zijn vader had nooit in kamp Amersfoort gezeten. László Weiss werd op 3 juni 1944 opgepakt en naar kamp Vught gestuurd, van waaruit hij vermoedelijk in september op verder transport naar Duitsland werd gezet. Hij overleed op 26 maart 1945 in Bergen Belsen. ${ }^{57}$ Weiss kon dus niet de schilder zijn geweest en Kopinsky niet zijn hulpje. 
Er waren meer opvallende tegenstrijdigheden, zoals de datering die Kopinsky gaf van zijn eerste aankomst in kamp Amersfoort. Die verschilde per interview: in het ene interview was dat in de zomer van $1941,{ }^{58}$ in het andere begin $1942^{59} \mathrm{en}$ in weer een ander was het in $1943{ }^{60}$

Kopinsky had wel in kamp Amersfoort gezeten, maar om een andere reden dan hij tijdens en na de behandeling bij Bastiaans vertelde. De Duitsers hadden een regeling ingesteld die bekend werd als de 'arbeidsinzet': Nederlandse mannen werden via het Gewestelijk Arbeidsbureau opgeroepen om zich te melden voor tewerkstelling, veelal in Duitsland. Dat ging soms door middel van collectieve oproepen, waarvan de bekendste de jaarklassenacties waren. Daarbij werden alle mannen die waren geboren in een bepaald jaar opgeroepen. De jaarklasse waartoe Kopinsky behoorde, de jaarklasse 1924, moest zich in juni 1943 melden op het Arbeidsbureau.

Kopinsky deed dat en haalde op 22 juni 1943, zo blijkt uit het archief van de gemeente Amsterdam, zijn paspoort op waarmee hij de volgende dag naar Duitsland kon reizen. ${ }^{61}$ Hij kwam te werken in de fabrieken van Thyssen, een groot industrieel complex in het Duitse Ruhrgebied. Na een maand werd hij ziek, en van 1 augustus 1943 tot 17 augustus 1943 werd hij behandeld in het St. Johannes-Hospital in Duisburg-Hamborn. ${ }^{62}$ Zijn vader kwam hem vermoedelijk ophalen en hij keerde terug naar Amsterdam.

Kopinsky had geen toestemming om terug te keren en werd in Amsterdam opgepakt. Bij wijze van straf moest hij korte tijd doorbrengen in kamp Amersfoort. Veel langer dan drie maanden kan hij daar niet hebben gezeten: hij kwam eind augustus terug in Nederland en vertrok, blijkens de bewaard gebleven registratiekaart, op 10 december 1943 vanuit Amersfoort per trein weer naar Duitsland. ${ }^{63}$

Daar werd hij weer ziek en op 15 december 1943 kreeg hij toestemming van het Arbeitsamt om terug naar Amsterdam te reizen. ${ }^{64}$ Daar lukte het Kopinsky om in januari 1944 een baan te krijgen bij de firma Wegerifs Lampenfabriek N.v. i.o. aan de Herengracht 156 , als schilder. ${ }^{65}$ Hij kreeg een Ausweis, een document waaruit bleek dat hij voldeed aan de arbeidsinzet, en daarmee bleef tewerkstelling in het buitenland hem verder bespaard.

Hoe is onduidelijk, maar op 25 mei 1945 liep Kopinsky in de handen van de geallieerden in Tsjecho-Slowakije. In februari 1945 was de aandacht van de Duitsers opgeslokt door de 'totale oorlog'; iedereen die tijdens razzia's bruikbaar leek, werd gearresteerd en ingezet in de oorlogsindustrie. Het is mogelijk dat zijn Ausweis hem in de laatste maanden van de oorlog niet voldoende bescherming bood en hij alsnog tewerk werd gesteld. Vanuit Tsjecho-Slowakije keerde Kopinsky op 2 juni 1945 weer terug in Amsterdam. ${ }^{66}$

Hoewel de reconstructie op basis van Kopinsky's papieren verleden een heel ander beeld oplevert dan Bastiaans' behandeling, zijn niet alle onduidelijkheden opgelost. Duidelijk is dat hij niet werd gedeporteerd vanwege zijn verzets- 
daden of Joodse afkomst. Hij was een man die, net als honderdduizenden anderen, de pech had voor de arbeidsinzet te worden ingezet.

Dit was ook de reconstructie die Kopinsky in 1950 makkte bij de Sociale Dienst in Amsterdam toen hij daar een uitkering aanvroeg. Hij gaf daarin een overzicht van zijn arbeidsverleden; dat vertoonde alleen een gat in de maanden dat hij in Duitsland tewerk was gesteld. In 1953 vroeg hij nogmaals een uitkering aan, toen viel er nog steeds een gat in zijn arbeidsverleden. Over de reden van dat gat schreef hij toen aan de Sociale Dienst: 'in Kamp Amersfoort en naar Duitsland'. ${ }^{67}$

Een jaar later, in 1954, vroeg Kopinsky een Buitengewoon Pensioen aan. Omdat geen toegang werd verleend tot het dossier van de Buitengewone Pensioenraad, is het onduidelijk op basis van welke verzetsdaden hij dat deed. In zijn aanvraag voor een Buitengewoon Pensioen vermeldde hij alleen dat hij tewerk was gesteld in Duitsland, maar noemde niet dat hij een tijd in Buchenwald en Theresienstadt had doorgebracht. ${ }^{68}$ Het Buitengewoon Pensioen werd hem niet toegekend.

Rest nog het mysterie van zijn kunstwerken. Hoe kon hij zulke kunstwerken maken? Kopinsky's ongeoefende handen bleken meer creatieve ervaring te hebben dan hij in interviews beweerde. In 1941 stond Kopinsky ingeschreven als leerling bij het Instituut voor Kunstnijverheid voor de opleiding natuurtekenen. ${ }^{69}$ En hij had vóór, tijdens en na de oorlog als lampenkapschilder gewerkt. Na de oorlog maakte hij voor zijn kinderen regelmatig tekeningen, en hij boetseerde Afrikaanse dodenmaskers van papier-maché. Voldoende ervaring om tekeningen te maken en te boetseren.

\section{Het belang van oorlogsverledens}

Het verhaal van Kopinsky benadrukt nog eens dat oorlogsverledens belangrijke verledens zijn. Nog een paar voorbeelden. Louis van Gasteren, die samen met Bastiaans Begrijpt unu waarom ik huil... maakte, had in de oorlog een Joodse onderduiker vermoord. De moord was volgens Van Gasteren een verzetsdaad. Journalisten Bart Middelburg en Erik Slot publiceerden uitgebreid over de kwestie en twijfelden aan Van Gasterens motief. Ze konden beiden rekenen op rechtszaken, aangespannen doorVan Gasteren. ${ }^{70}$ Politicus mr. Willem Aantjes verzweeg jarenlang een deel van zijn oorlogsverleden. Toen dat gedeelte alsnog boven water kwam en daar het woord ss in voorkwam, was zijn politieke carrière voorbij. ${ }^{11}$ Friedrich Weinreb, wellicht Nederlands grootste oorlogsfantast, bedroog tijdens de oorlog Joden die dachten bij hem een veilige aftocht te kunnen kopen. Na de oorlog ontstond een jarenlang publiek gevecht over de motieven en achtergronden van Weinrebs zwendel. ${ }^{72}$

Oorlogsverledens hadden invloed op het maatschappelijk aanzien, zoals in de hierboven genoemde voorbeelden, of ze dienden financiële belangen, zoals 
bij de aanvragen voor een Buitengewoon Pensioen. Dan kon dat verleden de basis vormen voor de toekenning van een uitkering.

Sommige patiënten ontleenden aan hun oorlogsverleden een identiteit en maakten het tot onderwerp van kunstwerken of boeken. Anderen gebruikten het om zich aan te sluiten bij een vereniging van lotgenoten. De Israëlische schrijver Yehiel De-Nur baseerde een heel oeuvre op zijn ervaringen in Auschwitz voordat hij zich bij Bastiaans meldde. Na zijn periode bij Bastiaans schreef hij een boek over zijn behandeling..$^{73}$ Acteur M. Bueno de Mesquita schilderde na zijn behandeling op de Jelgersmakliniek een serie tableaus, gebaseerd op de herinneringen aan Auschwitz die tijdens de behandeling naar boven waren gekomen. ${ }^{74}$ Ook de al eerder genoemde Durlacher en Kopinsky traden naar buiten met boeken en kunstwerken waarin hun oorlogsverleden een belangrijke plaats innam.

Oorlogsverledens speelden in de jaren zeventig niet alleen op persoonlijk niveau een belangrijke rol, maar ook op maatschappelijk niveau. Het was volgens psychiaters het oorlogsverleden van de overlevenden dat voor klachten zorgde. Vanwege die klachten werden de drie van Breda vastgehouden, werd Centrum ' 45 opgericht, werd de omgekeerde bewijslast ingevoerd en kwam de Wet Uitkering Vervolgingsslachtoffers tot stand. Niet-slachtoffers werden zich ervan bewust dat zij door het verleden verbonden waren met de slachtoffers. Zij wilden hun 'ereschuld' inlossen, genoegdoening geven voor jarenlange miskenning van de problemen die door een zeer reëel verleden waren veroorzaakt.

Al deze belangen die speelden rond het eigen oorlogsverleden, maakten dat de reconstructie zoals die in de behandeling bij Bastiaans tot stand kwam, meer was dan alleen een manier om te genezen van klachten. Het leek alleen te gaan om individuele gezondheidsbelangen - patiënten meldden zich tenslotte in eerste instantie om verlost te worden van hun klachten - maar die andere belangen speelden wel degelijk een rol. Zo wees Bastiaans zijn patiënten bijvoorbeeld op het bestaan van de uitkeringen, die dat verleden kon opleveren.

Het betekende ook dat Bastiaans' verantwoordelijkheid bij de reconstructie verder reikte dan alleen de behandeling van de klachten van zijn patiënten. $\mathrm{Pa}$ tiënten vertelden hun familie en vrienden over hun 'hervonden' verleden, zochten soms de publiciteit, figureerden in Bastiaans' gevalsbeschrijvingen, schreven boeken of vroegen een uitkering aan. Ondanks die grotere verantwoordelijkheid, sloeg Bastiaans waarschuwingen voor de vertekeningen die tijdens zijn behandelingen ontstonden in de wind.

Waarschuwingen voor de manier waarop Bastiaans te werk ging waren al vroeg te horen. De socioloog Milikowski, die Bastiaans, Van Gasteren en Telling bij elkaar bracht, schreef kort na de koninklijke première over de manier waarop Bastiaans de hoofdpersoon in Begrijpt u nu waarom ik huil... behandelde; 
De psychiater [Bastiaans] zit daar in z'n grote spreekkamer voor z'n indrukwekkende bibliotheek, als de alwetende, de al begrijpende, al vergevende patriarch, die met fluweelzachte stem het zielig hoopje mens dat tegenover hem zit, toespreekt. Het is een gecamoufleerde autoritaire houding die in feite de patiënt in een ondergeschikte positie brengt en die niet zal nalaten de antwoorden te beïnvloeden van de patiënt die daarin terechtkomt. Hij is als een kind dat z'n vader in diens verwachtingen niet wil teleurstellen en vertelt wat deze wil horen. [...] Hij wordt als klei in de handen van een pottenbakker. ${ }^{75}$

De affaire rond Meester was een volgende waarschuwing, en een jaar na de publiciteit rond Meester legde historicus Lou de Jong in een conceptversie van deel 8 van zijn serie Het Koninkrijk der Nederlanden in de Tweede Wereldoorlog, buiten het oog van de media een ander maar vergelijkbaar geval bloot. In de lopende tekst van de conceptversie beschreef De Jong de gruwelijke praktijken van Ilse Koch, de vrouw van de kampcommandant in Buchenwald. In een voetnoot citeerde hij daarbij uitgebreid een gevalsbeschrijving uit Bastiaans' proefschrift waarin gruwelijkheden begaan door Koch een rol speelden. ${ }^{76}$

Het ging om de derde uitgebreide gevalsbeschrijving in Bastiaans' proefschrift. Bastiaans beschreef daarin hoe de betreffende patiënte op Dolle Dinsdag, in september 1944, tijdens een razzia betrapt werd met een afbeelding van koningin Wilhelmina op zak. Nadat ze had geweigerd de Hitlergroet te brengen, werd ze gearresteerd en op transport gezet naar Polizeiliches Durchgangslager Amersfoort. Korte tijd later kwam ze in concentratiekamp Buchenwald terecht.

De patiënte vertelde Bastiaans hoe ze in Buchenwald talloze vernederingen en martelingen had ondergaan. Ze vertelde hoe ze samen met andere gevangenen op de appelplaats spiegels vasthield terwijl Koch, gezeten te paard, zichzelf van alle kanten bekeek. De patiënte beleefde tijdens de narcoanalyse een martelsituatie opnieuw waarin ze samen met andere vrouwen naar een mannenbarak werd gebracht. De mannen werden voor hun ogen gecastreerd; sommige vrouwen moesten daarbij helpen, waarna ze werden gedwongen tot het in de mond nemen van het afgesneden genitaal en het eten van de gekookte lichaamsdelen van de mannen. Ze moest regelmatig grote groepen Joodse kinderen met speelgoed naar de rand van massagraven lokken, alwaar de kinderen met een mitrailleur werden neergeschoten. Ze was getuige geweest van medische experimenten waarbij mensen, ouder en kind, met de huid aan elkaar werden genaaid, waarna ze in gips werden gegoten.

De Jong concludeerde in de concepttekst kortweg:

'Het lijdt voor ons geen enkele twijfel dat geen van deze z.g. feitelijkheden zich in Buchenwald voorgedaan heeft. Ilse Koch bijvoorbeeld is, zoals wij al vermeldden, in de lente van ' 42 uit het kamp verdwenen. ${ }^{177}$ 
De redenering van De Jong was correct. Het echtpaar Koch verdween in 1942 uit Buchenwald. Als de vrouw in 1944 inderdaad in Buchenwald was gekomen, had ze Koch daar niet meer kunnen zien. Bovendien vermelden standaardwerken over Buchenwald - zoals bijvoorbeeld het onlangs verschenen Der Ort des Terrors $^{78}$ - wel medische experimenten in Buchenwald (onder andere met het vlektyfusvirus), maar de uiterst sadistische en barokke gruwelijkheden van dit geval komen daar niet in voor. Ook niet de nodeloos ingewikkelde inzet van 'lokspeelgoed' bij de executie van kinderen.

Bastiaans had zelf ook enige twijfels gehad over het verhaal van de vrouw. In een interview met journaliste Bibeb van Vrij Nederland in 1970 kwam het verhaal ter sprake van de ontmaagding van de vrouw met een bajonet. Dat gedeelte van haar verhaal was verzonnen, volgens Bastiaans. Op de vraag van Bibeb hoe hij feit van fantasie kon onderscheiden, antwoordde Bastiaans:

'Dat is een van de moeilijkste taken. Je moet de informatie checken. En je merkt het aan de diepte van de emotie. [...] Ik heb toneelspelers gevraagd of ze dat konden naspelen, dat huilen op het moment dat de emotie doorkomt. "Nee", zeiden ze. ${ }^{79}$

Naast het checken van het verhaal, was het belangrijkste instrument om de authenticiteit van de herinneringen van zijn patiënten vast te stellen, de 'diepte van de emotie'. Dat was een zwak instrument, zoals het onderzoek van Poslavsky al had laten zien. Bastiaans wist dat en beaamde dat nog eens toen De Jong hem de concepttekst had voorgelegd; hij had vaker patiënten gehad die zich vergisten. De vergissing bij het geval dat De Jong beschreef, was volgens Bastiaans te wijten aan zijn onervarenheid in de beginjaren van de narcoanalyse:

'Ik behandelde de betreffende vrouw in 1950 of 1951. [...] Ik was [toen] zeer onder de indruk van wat er uit kwam als men narcoanalyse ging toepassen en wanneer de mededelingen een levensecht karakter hadden waren wij natuurlijk iets te snel geneigd daaraan ook werkelijkheidskarakter te verlenen. Later zijn wij veel voorzichtiger geworden. ${ }^{80}$

Toen De Jong het geval beschreef, was het meer dan vijfentwintig jaar geleden dat Bastiaans de vrouw had behandeld. Ondanks de geruststellende woorden aan De Jong dat hij voorzichtiger was geworden en niet meer alleen vertrouwde op de 'diepte van de emotie', was het een jaar eerder bij Meester om dezelfde reden weer misgegaan. In een interview over die kwestie met de journalist A.J. Heerma van Voss had Bastiaans zich namelijk op dezelfde manier verdedigd:

'Als je een uur met iemand op de grond ligt te rollen omdat hij meent dat hij in de Euterpestraat door je kapot geslagen wordt, of dat hij in een hinderlaag zit... ${ }^{81}$ 
Dan nog twijfelen aan de authenticiteit van de herinneringen was niet in hem opgekomen. Heerma van Voss legde hem de vraag voor of het voor hem krenkend was geweest dat hij als deskundige van het $\mathrm{kz}$-syndroom geen onderscheid had kunnen maken tussen een fantast, zoals Bastiaans Meester presenteerde, en een echte patiënt. Bastiaans antwoordde dat dat niet het geval was. Het ging hem om de ziekte van de patiënt, niet om de authenticiteit van de gebeurtenissen. Dat was dezelfde reactie die hij aan de Panorama-journalisten gaf toen die hem om een reactie vroegen:

'Heren, ik ben geen rechercheur. I $\mathrm{k}$ ben medicus en ik ben dus uitsluitend geinteresseerd in zijn ziektebeeld. ${ }^{82}$

Bastiaans' redenering was: een medicus is geïnteresseerd in ziektebeelden en dus niet in feiten. Maar juist zijn idee over het ontstaan van ziektebeelden - de psychosomatiek en de psychosomatische specificiteit - ging uit van een authentieke traumatische gebeurtenis als oorzaak van de klachten. Hij gebruikte in de sessies LSD en pentothal om verdrongen herinneringen aan authentieke gebeurtenissen op te sporen.

Naar buiten toe wekte Bastiaans ook de indruk dat hij hechtte aan de authenticiteit. Als hij zei dat patiënten in de behandeling 'het crematorium weer moesten ruiken', dan bedoelde hij dat zij die geur al eerder hadden geroken. Als hij patiënten onder een laken zette om de onderduiksituatie na te bootsen, dan deed hij dat omdat patiënten al eerder in een onderduiksituatie hadden gezeten. Hij had zichzelf dus wel degelijk een 'recherchetaak' toebedeeld, alleen gebruikte hij voor het beoordelen van de kwaliteit van zijn werk de 'diepte van de emotie'.

Zelfs bij uitzonderlijk schokkende en vanuit historisch oogpunt omstreden verhalen bleef Bastiaans vertrouwen op wat er in de behandeling naar boven was gekomen. Dat bleek toen eind jaren zeventig een van zijn patiënten getuige bleek te zijn geweest van een van de gruwelijkste nazipraktijken: het verwerken van menselijke resten in gebruiksvoorwerpen.

Vanaf de bevrijding van concentratiekamp Buchenwald deden geruchten de ronde dat Ilse Koch, de vrouw van de kampcommandant die tot 1942 in dienst was geweest, een lampenkap gemaakt van mensenhuid in haar vertrek had staan. Een lamp bekleed met vlakken van bruin leer, wat geconserveerde mensenhuid had kunnen zijn, werd na de bevrijding van Buchenwald gefilmd door de geallieerden. Eind jaren zeventig meldde zich bij Bastiaans een patiënt die tijdens zijn behandeling meer over de lampenkappen vertelde.

De man had al tevergeefs enkele internisten gezien en de artsen vreesden nu dat het niet meer lang zou duren of de man zou komen te overlijden. ${ }^{8}$ Bastiaans onderwierp hem aan een LSD-behandeling en al snel kwam de sleutelscène boven water. De man was 1941 in Buchenwald terechtgekomen en stierf in dat jaar bijna de hongerdood. Hij wist, schreef Bastiaans in 1986, 
'zijn leven te redden door te gaan werken in een sectiekamer waar hij voor kampleiders lampekappen moest maken van de aan lijken ontnomen huid. ${ }^{84}$

Een paar weken na de ontdekking van deze herinnering was de bloeddruk van de man weer gedaald en kon hij een normaal leven leiden. Bastiaans had zijn leven gered.

Het gemak en de graagte waarmee Bastiaans dit geval presenteerde in artikelen - hij gebruikte het in drie artikelen - staan in schril contrast met de moeite die juristen kort na de oorlog, en historici na hen, hadden om de gruwelijke beschuldigingen te bewijzen. In het proces tegen deze Ilse Koch konden de beschuldigingen van de lampenkap niet worden bewezen, maar het gruwelverhaal had toen al de kranten gehaald.

Lange tijd maakte een lamp die vermoedelijk was gemaakt van mensenhuid deel uit van de collectie van de gedenkplaats bij Buchenwald. Na de val van het communistisch regime werd hij op echtheid getest en bleek het om kunststof te gaan. ${ }^{85}$ De directeur van de gedenkplaats Buchenwald, dr. Volkhard Knigge, verklaarde enkele jaren geleden dat het verhaal van de lampenkap een eigen leven was gaan leiden. Volgens sommigen zou de standaard zelfs een geprepareerde menselijke voet zijn en de schakelaar gemaakt van een vingerkootje. ${ }^{86}$ Voor de industriële verwerking van mensenhuiden in lampenkappen in Buchenwald werden nooit harde bewijzen gevonden.

Wanneer Bastiaans zich had verdiept in de zaak, wat gezien de uitzonderlijke gruwelijkheid én gezien de waarschuwing van De Jong voor de hand had gelegen, dan had hij snel beseft dat hij of een uiterst belangrijke historische getuige in zijn behandelkamer had, of te maken had met een valse herinnering.

Overigens was het de vraag geweest of Bastiaans dan had geschroomd het geval te blijven gebruiken als casus. Na de ontmaskering van Meester bijvoorbeeld, bleef Bastiaans het boekje over diens behandeling, Allemaal rottigheid, allemaal ellende, gebruiken ter illustratie van zijn werkwijze. Als een journalist of geïnteresseerde wat meer wilde weten over zijn therapie, dan haalde Bastiaans het boekje uit de kast. ${ }^{87}$ Meester had zijn rol zo goed gespeeld dat hij als voorbeeld kon dienen voor andere slachtoffers.

Dat in de behandelingen bij Bastiaans herinneringen ontstonden waarvan het moeilijk was de authenticiteit vast te stellen, was geen incident. Dat blijkt, behalve uit de hierboven genoemde voorbeelden, uit een opmerking van de voormalig directrice van het Informatiebureau van het Nederlandse Rode Kruis, W. van der Noordaa-van der Veer, die ook zitting had in de leescommissie van De Jong. Uit de notulen van de vergadering waarin de concepttekst werd besproken, bleek dat zij uit ervaring wist dat patiënten van Bastiaans vaker herinneringen produceerden die niet waren gebaseerd op authentieke gebeurtenissen, of waarbij dat niet te verifiëren was.

Het Informatiebureau beheerde namelijk omvangrijke archieven waarin 
delen van kampadministraties, transportlijsten en repatriëringadministraties te vinden waren (en zijn). Het Informatiebureau speelde daarom een cruciale rol bij de verificatie van oorlogsverledens in het kader van een WBP- of WUVuitkering. Het bureau werd bij aanvragen gevraagd de zogenaamde 'harde feiten' te controleren; de archieven werden dan nagelopen op het voorkomen van de naam van de aanvrager.

Van der Noordaa-van der Veer kwam na lezing van de concepttekst met de mededeling dat het Informatiebureau bij toetsing van aanvragen van Bastiaans' patiënten veel vaker moeilijkheden ondervond:

\footnotetext{
'In de uitingen van de patiënten van deze arts, al dan niet onder invloed van de (drug) behandeling zijn waarheid en fantasie en/of (vermeende) ervaringen van anderen, die zij op zichzelf betrekken, zo dicht met elkaar verweven (getuige ook het rapport inzake Eibert Meester en de ervaringen die wij zelf met de wuv-rapportage hebben) dat het veelal niet mogelijk is hieruit de juiste toedracht te distilleren. ${ }^{.88}$
}

Uit de opmerking van Van der Noordaa-van der Veer bleek niet alleen dat bij anderen soms twijfels bestonden over de authenticiteit van de herinneringen van Bastiaans' patiënten, maar ook dat er een financieel belang gemoeid was met de reconstructie die bij Bastiaans ontstond; veel van zijn patiënten gebruikten die om aanspraak te maken op een uitkering. Pas tijdens de aanvraagprocedure bleek of de reconstructie bestand was tegen de controles van juristen en historici, die strenger waren dan die van Bastiaans. Wanneer dat niet lukte - en getuige de uitspraak van Van der Noordaa-van der Veer was dat geen uitzondering - ontstond er een dubbel probleem. Niet alleen kon er geen aanspraak worden gemaakt op een uitkering; er werd ook getwijfeld aan de oorzaak van de problemen. En dat terwijl de patiënten juist met veel moeite, na een vaak moeizame behandeling, die oorzaak hadden ontdekt.

\section{Conclusies}

Het zou onverstandig zijn om uit het bovenstaande de conclusie te trekken dat alle reconstructies in Bastiaans' behandelingen gebaseerd waren op niet-authentieke herinneringen. Hoewel de sociale fuik, de dynamiek op de Jelgersmakliniek, Bastiaans' bevooroordeelde blik, de LSD-behandeling en de narcoanalyse, en Bastiaans' suggestieve vragen de druk hoog opvoerden, betekende dat niet dat er automatisch een vertekening ontstond. Het risico daarop bestond echter wel, het was zelfs groter dan bij psychiaters die niet zo gespecialiseerd waren in de behandeling van oorlogsslachtoffers, en het leidde ook regelmatig tot vergissingen. Hoe vaak dat gebeurde, laat zich niet meer vaststellen, maar het waren geen incidenten. 
Overigens stonden herinneringen aan niet-authentieke gebeurtenissen het succes van een behandeling niet in de weg. Ook fictieve herinneringen kunnen een helende werking hebben; de bedenkervan de narcoanalyse kwam tenslotte ook tot deze conclusie. Zowel Meester als Kopinsky zei zich na de behandeling beter te voelen, en ook Bastiaans presenteerde beide gevallen als successen van zijn behandeling.

De Swaans beschrijving van therapeutische arbeid als maatschappelijke arbeid was van toepassing op Bastiaans. De noties en modellen van het slachtofferschap waren rijkelijk voorhanden, en de patiënten voegden zich daarnaar tijdens de behandelingen; ook als er geen overeenkomst was tussen de persoonlijke ervaring en de abstracte modellen die daarbuiten heersten.

In zulke gevallen moest er dan een oplossing gevonden worden om dat verschil te dichten. Bij Bastiaans en een deel van zijn patiënten leidde de combinatie van maatschappelijke compassie en Bastiaans' manier van werken tot ernstige vertekeningen in die reconstructie. Bastiaans nonchalante omgang met de authenticiteit van de herinneringen van zijn patiënten, liet daar alle ruimte toe. 


\section{Een voordelig bondgenootschap}

'Zo een man publiekelijk attaqueren, zelfs wanneer je het niet met hem eens bent, dat doe je niet. Mag je niet!"

R. VAN DAM, PATIËNT VAN BASTIAANS, ZONDER DATUM.

\section{Inleiding}

Het besef dat de oorlog diepe wonden had geslagen, verspreidde zich na 1972 snel. Verzetsstrijders en gedeporteerden grepen het $\mathrm{KZ}$-syndroom aan als middel om erkenning te krijgen. Hun psychisch lijden was in het debat rond de drie van Breda een sterk argument gebleken, en steeds meer groepen slachtoffers zouden dat argument ontdekken.

De ideeën over het Kz-syndroom pasten zich aan de komst van die nieuwe groepen aan. Ooit was het begonnen als een syndroom waar ernstig verhongerde overlevenden van de concentratiekampen aan leden. Nadat medici als Bastiaans hadden verklaard dat traumatische ervaringen tot dezelfde klachten - en dus tot het $\mathrm{Kz}$-syndroom - konden leiden, ontdekten ook andere groepen de schadelijke werking van hun verleden: onderduikers; dwangarbeiders; krijgsgevangen militairen; voormalig gevangenen van de Japanse interneringskampen; gedeporteerde homoseksuelen, Jehova's getuigen en zigeuners; slachtoffers van bombardementen en de Hongerwinter; Engelandvaarders: allen meldden zij zich als slachtoffer.

Allen hadden zij behoefte aan de erkenning van hun specifieke verleden en problemen, en deden zij een beroep op de hulpverlening. Er ontstond een wijdvertakt netwerk van hulpverleningsinstellingen, maatschappelijke instellingen en belangenorganisaties, die al deze groepen van hulp voorzagen. Dat gebeurde in de vorm van individuele psychotherapie, speciale spreekuren voor oorlogsslachtoffers, uitkeringen, reünies, voorlichting en herdenkingen. 
Het proces van medicalisering van het erkenningsstreven werd door de sociologe Jolande Withuis al eens beschreven in haar boek Erkenning. ${ }^{2}$ Dat proces kon niet plaatsvinden zonder de hulp van medici; zij waren de experts die de cruciale verbinding konden leggen tussen het leed van deze groepen slachtoffers en de oorlog. De slachtoffers waren afhankelijk van de bereidheid van de medici om hun klachten te erkennen als gevolgen van hun bijzondere ervaringen. Sommige medici spraken van verschillende typen 'oorlogssyndromen'; andere deden pogingen het leed van een groep te voorzien van een eigen naam, zoals het 'war-sailor syndrome's, het 'hiding-syndrome't en het 'Vietnam-syndroom'.

Bastiaans was een van de eerste medici die zich niet alleen opwierpen als hulpverlener maar ook als belangenbehartiger. Dat leidde tot een langdurig bondgenootschap tussen hem en de oorlogsslachtoffers, met name de verzetsstrijders. Zij erkenden Bastiaans als hun expert, als degene die hun problemen begreep. Bastiaans op zijn beurt bouwde zijn succes op zijn begrip voor dat leed en zijn gave het te lenigen. Hijlegitimeerde dat leed in kwesties waarin het door verzetsstrijders werd aangevoerd.

De basis van het bondgenootschap was het causaal verband. Alleen wanneer verzetsstrijders ziek waren als gevolg van de oorlog, konden zij aanspraak maken op de uitkeringen, de speciale hulpverlening en het maatschappelijk aanzien dat daarbij hoorde. In de loop der tijd bleken medici steeds meer moeite te hebben om het causaal verband vast te stellen. De medische inzichten waren veranderd. Dat maakte dat het bondgenootschap steeds belangrijker werd.

\section{Een begripvol klimaat}

Ook bij de overheid groeide het besef van de problemen van de diverse groepen slachtoffers. In 1975 ging, in opdracht van het Ministerie van CRM, het Werken Adviescollege (WAC) van start onder leiding van prof.dr. J.P. van Praag, om de toenemende behoefte aan immateriële (medische, psychologische en maatschappelijke) hulpverlening van al deze oorlogsslachtoffers in kaart te brengen en het bestaande aanbod te kanaliseren. De commissie hoorde partijen uit het hele veld: van Stichting 1940-1945 tot het Nederlands Auschwitz Comité, van de Bond van Nederlandse Militaire Oorlogsslachtoffers tot de Werkgroep Burger-oorlogsslachtoffers, en natuurlijk Bastiaans.

De onderliggende sentimenten die in 1972 al een belangrijke rol hadden gespeeld - het gevoel dat de maatschappij en de overheid tekort waren geschoten in de opvang van slachtoffers - werden in de hoorzittingen bevestigd en in de conclusies van het eindrapport, dat in 1978 verscheen, overgenomen. Het probleem onder de oorlogsslachtoffers bleek zelfs gegroeid. Van de 2000 ooo personen die volgens het WAC-rapport waren geconfronteerd met oorlogsgeweld, zouden er tussen de 10000 en 20000 'zwaar behoeftig' zijn en langdurende begeleiding van een psycholoog of een maatschappelijk werker nodig hebben. 
Daarnaast waren er meer dan 100000 personen 'licht behoeftig': zij hadden behoefte aan kortdurende maatschappelijke begeleiding, 'vooral in de uitkerings- en pensioensfeer'. ${ }^{5}$

Tot welke groep of categorie men ook behoorde, op de een of andere manier was er sprake van ziekte die in verband werd gebracht met de oorlog. Bastiaans bracht na het uitkomen van het WAC-rapport de uitspraken die hij had gedaan tijdens de openbare hoorzitting in 1972 nog eens in herinnering; hij zag de conclusies van het rapport als een bevestiging van zijn uitspraken van toen. Zijn schatting van 30000 lijders aan het $\mathrm{KZ}$-syndroom bleek vijf jaar later zelfs nog te laag.

Het tussentijdse rapport van het WAC, dat in 1977 verscheen, voorspelde zelfs dat door veroudering 'juist in de komende tien jaar' de problematiek onder oorlogsslachtoffers zou toenemen. Het kwam dan ook met een overvloed aan aanbevelingen en suggesties om de hulpverlening aan deze groep te verbeteren. Psychologen, psychiaters, maatschappelijk werkers en huisartsen moesten worden geschoold in de specifieke problematiek die zich voordeed bij de hulpverlening aan oorlogsslachtoffers. Zo moesten er lessen geschiedenis worden gevolgd opdat 'niet een barrière van onbegrip' zou bestaan tussen therapeut en patiënt. De behandeling van oorlogsslachtoffers als dagtaak werd als 'een onmogelijke opgave' ontraden. Gezien de zeer specifieke problemen van de verschillende groepen was vergaande specialisatie nodig: een kundig behandelaar van verzetsstrijders kon zich wel eens hulpeloos voelen tegenover de problemen van burgerslachtoffers van de oorlog.

Het WAC-rapport opperde dat er een vergelijkend onderzoek zou moeten komen om de aard en aanwezigheid van het $\mathrm{KZ}$-syndroom in andere landen te onderzoeken. Een interessante gedachte, waar helaas geen gevolg aan werd gegeven.

Dat het Buitengewoon Pensioen - ookwel 'verzetspensioen' genoemd - gold als een vorm van erkenning, werd ook in het WAC-rapport gesignaleerd. Het waarschuwde voor de kwalijke gevolgen ervan:

'Het [de uitkering] vormde voor vele betrokkenen zelfs het enige middel om erkenning te verkrijgen. [...] Immers zonder invaliditeit heeft men geen recht op een buitengewoon pensioen; zonder ziekten en gebreken geen recht op een uitkering. Ziekte of ziektegedrag wordt als het ware beloond. ${ }^{, 6}$

Eind jaren zeventig waren er zoveel individuele initiatieven en georganiseerde voorzieningen, wetten en organisaties op het gebied van de hulpverlening aan oorlogsslachtoffers, dat er - op advies van het WAC-rapport - een speciale stichting werd opgericht die als taak had slachtoffers wegwijs te maken in de overvloed aan hulpverlenende instanties. Dat werd het Informatie- en Coördinatieorgaan Dienstverlening Oorlogsgetroffenen (ICODO). ${ }^{7}$ 


\section{Sluiting Wet Buitengewoon Pensioen}

In de meer dan honderdvijftig pagina's aanbevelingen besteedde het WAC-rapport geen enkele aandacht aan misschien wel de belangrijkste kwestie: hoe kon worden vastgesteld of iemands klachten een gevolg waren van de oorlog? Deze blinde vlek van het WAC-rapport was tekenend voor de sfeer aan het eind van de jaren zeventig. Slachtoffers, overheid, maatschappij en hulpverleners waren overtuigd van de grote nood die er heerste ten gevolge van de oorlog, en wilden die graag lenigen. De middelen daarvoor waren er ook: er was een speciale kliniek, er waren uitkeringen en pensioenen, er waren belangenorganisaties met sociaal werkers, er waren eigen media, er was een informeel netwerk van hulpverleners en belangenbehartigers. Dat de klachten van de patiënten door de oorlog werden veroorzaakt, leek een vanzelfsprekendheid.

Toch was het dat niet. Bij de aanvragen voor een Buitengewoon Pensioen werd de discussie over het causaal verband op het scherp van de snede gevoerd. De in de Wet Buitengewoon Pensioen verankerde eis dat er een causaal verband bestond tussen de klachten en de oorlog, maakte dat medici een oordeel moesten geven over dat verband. Dat leidde regelmatig tot verschillen van inzicht. Niet alleen waren de feitelijke gebeurtenissen steeds moeilijker te verifiëren; de geneeskunde en de psychiatrie hadden ook grote moeite om het verband aan te tonen.

Voor de verzetsstrijders zelf was het vaak evident dat hun klachten door de oorlog waren veroorzaakt. De Landelijke Kontakt-Groep verzetsgepensioneerden (LKG), een van de eerste belangengroepen voor ontvangers van het Buitengewoon Pensioen, was daar uitgesproken over. De LKG werd al in 1965 opgericht, met als belangrijkste reden de 'zorg of de overheid wel de belofte kon nakomen zoals die in de WBP was neergelegd'. ${ }^{8}$ In 1990 werd in een terugblik door het bestuur van de LKG beschreven hoe er indertijd tegen het causaal verband werd aangekeken. De LKG was van mening dat,

'wanneer er gekwalificeerd verzet is geconstateerd en er invaliditeit aanwezig is, van welke aard ook, er een oorzakelijk verband is. En tevens een onveranderlijke invaliditeit van 100 procent. ${ }^{.9}$

Deelname aan het verzet was volgens de LKG zo ingrijpend, dat als een ziekte er al niet door werd veroorzaakt er toch altijd sprake zou zijn van 'een invloed'. Een zieke verzetsstrijder was dus altijd ziek door de oorlog. Andere mogelijkheden werden principieel uitgesloten.

Het radicale standpunt van de LKG was niet zozeer ingegeven door medischwetenschappelijke inzichten, als wel door die andere functie van het Buitengewoon Pensioen. Het pensioen werd gezien als meer dan alleen een financiële ondersteuning, net zoals het $\mathrm{Kz}$-syndroom meer was dan alleen een psychiatrische diagnose. Het was - zoals in het WAC-rapport ook al was gesignaleerd - 
een vorm van erkenning, die alleen kon worden verkregen als ex een verband tussen ziekte en oorlog was.

Het mechanisme van de sociale fuik maakte dat personen sneller als verzetsstrijder werden gezien en dat klachten sneller werden gezien als veroorzaakt door de oorlog. Dat betekende dat ook het aantal aanvragen voor een Buitengewoon Pensioen steeg. In 1977 was het aantal aanvragen voor een Buitengewoon Pensioenverzesvoudigd ten opzichtevan 1967. Steeds meer mensen herkenden hun klachten als een gevolg van de oorlog.

Hoewel de compassie met de oorlogsslachtoffers groot was, ook bij de medisch adviseurs van de BPR, bleek het voor medici nog steeds moeilijk om een gedegen oordeel te geven over het causaal verband. Het aantal afwijzingen was dan ook dramatisch hoog: meer dan zestig procent van de aanvragen werd eind jaren zeventig afgewezen. Meer dan de helft van de aanvragers, wier klachten naar eigen overtuiging in verband stonden met de oorlog, klopte voor niets aan bij de BPR.

Om een einde te maken aan deze schrijnende situatie, schreven de voorzitters van de Buitengewone Pensioenraad en de Stichting 1940-1945 in 1979 een brandbrief aan de staatssecretaris van CRM, J.G. Kraaijeveld-Wouters. Door het grote aantal aanvragen kwamen beide instellingen óm in het werk, wat leidde tot lange wachtlijsten en bijkomende frustraties. Bovendien waren zij zelf ook ontevreden over het grote aantal afwijzingen; dat wekte de suggestie van onwil. De directeuren weten de problemen aan het feit dat het 'zowel theoretisch als praktisch, onmogelijk' was het causaal verband vast te stellen. ${ }^{10} \mathrm{Ze}$ vroegen de Wet Buitengewoon Pensioen op termijn te sluiten.

De massale afwijzing door de Buitengewone Pensioenraad werd door de slachtoffers ervaren als een slag in het gezicht, als een miskenning van hun leed. Nu was er ook nog sprake van het sluiten van de WBP; alsof aan het leed van de oorlog een verjaringstermijn was gekoppeld. Dat leidde tot de paradox dat juist in het uiterst begripvolle klimaat aan het eind van de jaren zeventig, de oorlogsslachtoffers het beeld hadden van een koude, niet-begrijpende overheid.

\section{Oprichting van het Comité Vervolging en Verzet}

De groeiende problemen bij de aanvragen voor een Buitengewoon Pensioen leidden tot een tegenreactie. Op 23 augustus 1980 vond in het huis van B.S. Polak - voormalig wethouder en senator voor de CPN, en hoogleraar huisartsengeneeskunde -, die zich betrokken voelde bij de problemen van oorlogsslachtoffers, de oprichting plaats van een nieuw comité. Het was een idee van de verzetsstrijder en communist Berend Blokzijl. ${ }^{11}$ Blokzijl hielp al jaren op eigen initiatief aanvragers die in de problemen zaten. Hij kreeg daarbij de hulp van onder anderen de huisarts en oud-Spanjestrijder Theo van Reemst, de jurist $C$. Veraart, B.S. Polak én Bastiaans. 
Uit het verslag van de oprichtingsvergadering blijkt dat een vooraanstaand gezelschap van juristen, sociaal werkers, psychiaters, artsen en andere hulpverleners naar Polaks huis was gekomen. Naast de gastheer bevonden zich nog vier andere hoogleraren onder het gezelschap: de hoogleraren psychiatrie Bastiaans, M. Zeegers en G.A. Ladee, en de hoogleraar medische seksuologie dr. $\mathrm{H}$. Musaph. In totaal waren er zesentwintig personen aanwezig die direct of indirect te maken hadden met de hulp aan oorlogsslachtoffers. Onder hen mr. H.J.P. van den Meerendonk en dr. P.Th Hugenholtz, beiden betrokken bij de Stichting 1940-1945; drs. H.A.A. Mourits, destijds directeur van ICODO; J. Pasman, districtdirecteur van Stichting 1940-1945; dr. A.A. van Dantzig, psychiater en overlevende van onder andere Neuengamme; K.M.J. Ceha, destijds directeur van Centrum ' $45^{12}$

De vergadering werd, na een introductie van Polak, ingeleid met een emotioneel betoog van Hugenholtz. Hugenholtz wond er geen doekjes om: het leed van verzetsstrijders werd genegeerd. Hij betoogde dat de klachten van verzetsstrijders principieel anders van aard waren dan de klachten van andere slachtoffers. Om aan te geven wat er anders was, introduceerde hij de onduidelijke term 'major': 'de kwalitatieve onherleidbaarheid en onvergelijkbaarheid van de oorlogservaringen'. In tegenstelling tot andere slachtoffers, zoals bijvoorbeeld gijzelaars, waren de mensen in de kampen 'AFVAL!' zo riep Hugenholtz uit op de vergadering. Naar aanleiding van deze toespraak zou Hugenholtz het veelgeciteerde artikel in MGv schrijven, getiteld:'Hoe buitengewoon is "buitengewoon": over de maatschappelijke erkenning van de term "verzetsslachtoffer". ${ }^{13}$

Het idee dat het Buitengewoon Pensioen een vorm van erkenning was, had zich ookmeester gemaaktvan de aanwezigen. Dat bleek bijvoorbeeld toen naar een naam werd gezocht voor het op te richten comité. De eerste optie die ter sprake kwam, was 'Les Invalides', een verwijzing naar de manier waarop de Fransen erkenning gaven aan hun veteranen. De Franse veteranen, onder wie verzetsstrijders en gedeporteerden, mochten vooroplopen bij herdenkingen en werden met alle egards behandeld. Zij werden erkend en geëerd, iets waar het volgens de aanwezigen aan ontbrak in Nederland. De naam werd echter te frivool geacht en daarom werd er gekozen voor het eenvoudige 'Multidisciplinair Comité Vervolging en Verzet' (cvv).

De oprichting van het cvv had plaats in 1980 , vijfendertig jaar na de bevrijding. Het was niet het eerste initiatief dat gericht was op de ondersteuning van oorlogsslachtoffers. Wat wel nieuw was, was dat niet de slachtoffers zich organiseerden, maar de behandelaars van die slachtoffers. Artsen, psychiaters, psychologen en maatschappelijk werkers namen, ondersteund door juristen, een leidende rol in de behartiging van de belangen van oorlogsslachtoffers.

Bastiaans was ook aanwezig op de oprichtingsvergadering en had na het gloedvolle betoog van Hugenholtz kort het woord gevoerd. Hoewel hij betrokken was bij het cVv als bestuurslid, waren het vooral de ideeën uit zijn proef- 
schrift waarvan het CVv dankbaar gebruikmaakte. Zijn daarin uitgewerkte 'psychosomatiek voor verzetsstrijders' bood een manier om klachten, ook als die zich pas na vijfendertig jaar openbaarden, in verband te brengen met de oorlog.

In de medische wereld waren inmiddels de verwachtingen omtrent die vorm van psychosomatiek bijgesteld. De krachtige psychische mechanismen die Bastiaans in zijn proefschrift had beschreven, vonden nauwelijks nog steun onder medici. Maar medici die die ideeën wel onderschreven, kwamen makkelijker tot een positief oordeel over het verband dan anderen. Het CVV zag daarom graag dat de medisch adviseur van de BPR - degene die het finale oordeel over het causaal verband velde - werd vervangen door een psychosomaticus. De nog resterende psychosomatici, van wie Bastiaans de belangrijkste representant was, vormden zo een onmisbare schakel in het streven naar erkenning.

\section{Opnieuw de psychosomatiek}

In de brandbrief van de voorzitters van de BPR en de Stichting 1940-1945, die de aanleiding vormde voor de oprichting van het $\mathrm{cvv}$, werden de aanvragers in twee groepen verdeeld. De eerste groep betrof verzetsstrijders die intensief, georganiseerd verzet hadden gepleegd waarbij ze soms van hun vrijheid waren beroofd, maar waarbij in ieder geval sprake was geweest van grote spanningen. Deze groep leverde de minste problemen op; bij hen was doorgaans de omgekeerde bewijslast van kracht, waardoor ze bij voorbaat het voordeel van de twijfel kregen. Toekenning van een pensioen was alleen afhankelijk van de vraag of het verzet kon worden bewezen. Gezien het georganiseerde en intensieve karakter van het verzet was dat doorgaans geen probleem.

De tweede en grootste groep leverde wel grote problemen op. Het merendeel van de aanvragen die werden afgewezen, betrof personen die op eigen initiatief, zonder hulp van anderen, incidenteel verzet van kleine omvang hadden gepleegd (kabels doorknippen, kranten verspreiden, hand- en spandiensten verrichten) of slachtoffer waren geworden van het verzet van anderen. Als er wel getuigen konden worden genoemd én deze nog in leven waren, konden die zich vaak niets herinneren van wat de aanvrager vertelde, soms konden ze zich zelfs de aanvrager in het geheel niet meer herinneren, zo schreven de voorzitters. Materieel bewijs ontbrak vaak. ${ }^{14}$

Bij deze tweede groep stapelde de ene onzekerheid zich op de andere. De keuringsartsen van de BPR hadden moeite om het kleine verzet, dat soms wel mogelijk werd geacht maar niet bewezen kon worden, in causaal verband te brengen met de klachten. Kon klein verzet later grote gevolgen hebben?

Het cvv schoot deze laatste groep te hulp. Eind 1981 werd daarvoor de Stichting Dienstverlening Verzetsdeelnemers (SDV) opgericht. ${ }^{15}$ Waar het cVv zich 
beperkte tot beleidskwesties en in gesprekging met politici en het bestuurvan de BPR, ontfermde de SDV zich over individuele aanvragers door deze bij te staan in hun aanvraag- of beroepsprocedure. Aanvragers werden door de SDV toegewezen aan een jurist die makkelijk toegang had tot aan het $\mathrm{CVV}$ verbonden artsen en psychiaters.

In de archieven van B.S. Polak, voorzitter van het cvv, en C. Veraart, jurist voor de SDV, bevinden zich pleitnota's en gemotiveerde uitspraken in beroepszaken die aanvragers, soms bijgestaan door de $S D V$, aanspanden bij de Centrale Raad van Beroep (RvB). ${ }^{16}$ Hoewel iedere individuele zaak zijn eigen specifieke kenmerken had en de problematiek per aanvrager verschilde, geven deze documenten inzicht in de praktijk van de pensioenaanvragen van begin jaren tachtig. De problemen die zich voordeden in de zaken waren exemplarisch voor andere zaken, en lieten zien hoe moeilijk medici het hadden bij het geven van een oordeel over de verbanden.

De meeste zaken die in de pleitnota's en uitspraken werden behandeld, gingen om fysieke klachten, hoewel vaak vergezeld van psychische klachten. Bij al die zaken verschilden de medici in hun oordeel over het causaal verband. Wanneer de CRvB geconfronteerd werd met verschillende meningen, hanteerde ze vaak de aanpak die gevolgd werd bij de hieronder beschreven zaak, die diende in 1982. Bij deze zaak was de oorzaak van de suikerziekte van een verzetsstrijder onderwerp van discussie.

De zaak kende een voorgeschiedenis van meer dan vijftien jaar. Al in 1965 had de verzetsstrijder zijn eerste aanvraag gedaan. ${ }^{17}$ Acht tot twaalf jaar na de oorlog, rond zijn vijfenveertigste levensjaar, had hij last gekregen van suikerziekte (diabetes mellitus). Nadat zijn eerste aanvraag in 1965 was afgewezen, wachtte hij met het indienen van een nieuwe aanvraag tot 1976. Enkele bezwaarschriften en afwijzingen later was zijn zaak beland bij de Centrale Raad van Beroep. De BPR en de aanvrager, gesteund door Hugenholtz, stonden daarbij tegenover elkaar. Twistpunt was nog steeds de vraag of het ontstaan van de suikerziekte in verband stond met de oorlog.

De door de BPR geraadpleegde internist was stellig in zijn uitspraken: de suikerziekte werd volgens hem veroorzaakt door andere factoren dan het verzet. Bijna twee procent van de Nederlandse bevolking ontwikkelde in die jaren zonder aanwijsbare oorzaak suikerziekte. Bovendien was bij de aanvrager mogelijk sprake van erfelijke factoren; zijn grootvader had ook aan suikerziekte geleden.

Hugenholtz trad op als gemachtigde van de verzetsstrijder en bracht een rapport in dat was opgesteld door de internist dr. H.E. Pelser. ${ }^{18}$ Pelser was een voormalig lid van de Psychosomatische Werkgroep en een goede bekende van Hugenholtz. Pelser beschreef de aanvrager als een 'nuchtere, doelbewuste, onwankelbare en koelbloedige verzetsstrijder' die tot de 'harde kern van de Ne- 
derlandse illegaliteit' behoorde. Na de bevrijding meldde hij zich als opsporingsambtenaar, maar kreeg tijdens zijn werk te maken met beschuldigingen en verdachtmakingen. Het is onduidelijk om welke beschuldigingen het ging. De man raakte verbitterd.

In de jaren na de oorlog was zijn verbittering toegenomen. Gezagsdragers verloren in zijn ogen 'het traditionele godsvertrouwen' en in zijn eigen kerkgemeenschap 'vervaagde de geloofsbeleving'. Bovendien was hij nauwelijks in staat, ondanks zijn harde werken, zijn gezin te onderhouden. Hij besloot te emigreren. Tijdens de bootreis naar de nieuwe bestemming overviel de scheepsarts hem met het bericht dat zijn vrouw, ook aan boord, vermoedelijk aan een ongeneeslijke ziekte leed. Het bericht kwam aan ...

'als een bliksemslag die zijn toekomstbeeld verpulverde. In zijn belevingswereld ondervond hij deze tegenslag als een onverdiend verraad van de Nederlandse gemeenschap, waarover hij zich bovendien tegenover niemand kon uiten of beklagen. Luttele dagen later had hij diabetes mellitus! ${ }^{19}$

De internist van de BPR vond de verklaring van Pelser strijdig met de ideeën van de psychosomatiek. In een boek van de grondlegger van de Nederlandse psychosomatiek, prof.dr. J.J. Groen, stond weliswaar beschreven hoe na bepaalde vormen van stress suikerziekte ontstond, maar dat gebeurde altijd binnen enkele dagen tot maanden. Niet pas na enkele jaren zoals bij de aanvrager was gebeurd.

De CRvB, die om een uitspraak was gevraagd, zag twee ervaren medici die lijnrecht tegenover elkaar stonden. De een veronderstelde wél een verband tussen de suikerziekte en de oorlog, en de ander niet. Om uit de impasse te komen, riep de $C R v B$ de hulp in van een derde arts. Diens conclusie was dat het wel degelijk mogelijk was dat de suikerziekte in verband stond met het verzet, hoewel dat niet kon worden bewezen. Andere oorzaken voor de suikerziekte - zoals erfelijkheid - konden evenmin worden bewezen.

Dat was voor de $C R v B$ reden om het Buitengewoon Pensioen alsnog toe te kennen. In de Wet Buitengewoon Pensioen stond dat een uitkering niet werd toegekend als de invaliditeit 'duidelijk uit andere oorzaken' was voortgekomen. Die andere oorzaken konden niet duidelijk worden aangewezen, dus werd de aanvrager het voordeel van de twijfel gegeven. ${ }^{20}$

Bovenstaand voorbeeld laat zien dat de psychosomatiek zoals Bastiaans die had geïntroduceerd met zijn proefschrift, nog steeds een belangrijke rol speelde bij de beoordeling van het causaal verband. Pelsers betoog was een reprise van de redeneringen over het causaal verband uit Bastiaans' proefschrift. Psychosomatici, zoals Pelser, Bastiaans en Hugenholtz, gingen er nog steeds van uit dat er een specifieke relatie bestond tussen stressvolle gebeurtenissen, persoonlijkheid en klachten. 
De psychosomatiek bood ook uitkomst als er sprake was van één enkele traumatische gebeurtenis; ook dat kon leiden tot langdurige spanningen en daarmee tot latere klachten. Daarom moest volgens de SDV niet alleen de zwaarte van de feiten (bijvoorbeeld kampverblijf, verhoor, onderduik, rondbrengen illegale bladen) meewegen in de beoordeling van de ontstane spanningen, maar ook de beleving van die feiten. Die beleving kon per persoon verschillen; de een was prima bestand tegen de spanning van het verspreiden van illegale kranten, de ander veel minder. In het laatste geval konden wel degelijk verlate gevolgen ontstaan, ook al was er in de ogen van buitenstaanders slechts sprake van milde stress. ${ }^{21}$

Zoals bij de man wiens aanvraag voor een Buitengewoon Pensioen in 1976 was afgewezen, en die in 1983 met hulp van de SDV in beroep ging. SDV-jurist Veraart bracht tijdens de eerste zitting naar voren dat de aanvrager - met verder niet genoemde klachten - in de oorlog mogelijk getuige was geweest van een brand. Wat de man precies had gezien werd uit de stukken niet duidelijk, maar volgens de pleitnota was het een 'zeer traumatische ervaring.' ${ }^{22}$

Het verhaal van de brand was pas een jaar vóór de zitting bij de Centrale Raad van Beroep in een gesprek met een arts naar voren gekomen. De invloed van het aanschouwen van de brand, die Veraart in zijn pleidooi 'de' traumatische gebeurtenis noemde, had daarom niet kunnen worden meegewogen in het oordeel bij de eerste aanvraag. Was dat wel gebeurd dan was de keuringsarts, zo bepleitte Veraart, mogelijk tot een ander oordeel gekomen.

Om te verifiëren of de aanvrager inderdaad getuige was geweest van de betreffende brand, was Veraart samen met de aanvrager door het gebied getrokken waar deze had plaatsgevonden. Hij had, zo meldde hij in de tweede zitting bij de CRvB, vastgesteld dat de aanvrager getuige kon zijn geweest - en daarmee blijkbaar ook wás geweest - van de brand. Bovendien had hij de tegenstrijdige rapporten van de BPR en zijn eigen arts voorgelegd aan de deskundige bij uitstek: Bastiaans. Die was tot de conclusie gekomen dat de traumatische gebeurtenis inderdaad van invloed was op de invaliditeit. ${ }^{23}$

Het CVv drong bij de Buitengewone Pensioenraad aan op veranderingen in de aanvraagprocedure. Uit de correspondentie tussen het CVV en de BPR die zich in het archief van Polakbevindt, blijkt dat het cvv bijvoorbeeld bezwaar maakte tegen de gewoonte van de BPR om, wanneer iemand invalide was door een aandoening aan zijn voet, hij alleen werd gezien door een specialist op dat terrein, een orthopeed. Het cvv wilde dat behalve een specialist ook een deskundige werd geraadpleegd die oog had voor de psychische kant, liefst een psychosomaticus. Het CVV kreeg bij de BPR gedaan dat een aanvrager een zelfgekozen medicus bij de keuringen kon betrekken. ${ }^{24}$

Het cVv drong ook aan op inzage in het 'verzetsrapport' dat door de Stichting 1940-1945 werd opgesteld. In dat verzetsrapport werden de verzetsdaden 
geverifieerd. Getuigen werden gehoord en archieven werden nageplozen om zo veel mogelijk feiten te achterhalen. Lange tijd was het rapport niet ter inzage beschikbaar voor de aanvrager, of alleen bij hoge uitzondering ${ }^{25}$ Daardoor was het voor een arts met oog voor de psychische kant onduidelijk of zich bijvoorbeeld traumatische gebeurtenissen hadden voorgedaan. Het cvvkreeg ook dit gedaan bij de BPR.

Een gevolg van de maatregelen was dat de kans op ontdekking van verbanden tussen psychische spanningen en lichamelijke klachten werd vergroot. Dat dat vruchten afwierp, bleek bijvoorbeeld uit de zaak van de man wiens aanvraag uit 1978 - wegens hartklachten, nachtmerries en spanningen - was afgewezen. " Nadat de aanvrager de hulp van de sov had ingeroepen, was 'met hor. ten en stoten' voor het eerst de traumatische gebeurtenis ter sprake gekomen. De aanvrager had tijdens een vechtpartij twee Duitsers in het water geduwd. De twee waren daarop verdronken. De spanningen die hierdoor waren opgeroepen, konden de klachten van de man verklaren. Het verhaal van de vechtpartij werd ondersteund door een 'getuige'; deze was weliswaar niet bij het incident aanwezig geweest, maar had na de oorlog wel een dergelijk verhaal gehoord van de aanvrager. De BPR wilde de kwestie verifiëren in politieregisters, maar door het ontbreken van exacte informatie was dat onmogelijk. Voor de BPR was het incident daarmee niet bewezen en kon het daardoor ook geen oorzaak van de klachten zijn.

Veraart presenteerde op de zitting bij de CRvB een medicus die de klachten van de aanvrager zag als een gevolg van de vechtpartij. ${ }^{27}$ Hij reduceerde de kwestie tot de vraag of de vechtpartij had plaatsgevonden. Had die wél plaatsgevonden dan was de verklaring voor de klachten gevonden; had die niét plaatsgevonden dan lag de vraag weer open. Of de gebeurtenis had plaatsgevonden kon niet meer onomstotelijk worden bewezen. Dat was, gezien de lange periode die was verstreken en de sfeer van geheimhouding waarin het verzet werd gepleegd, niet zovreemd. Maar moest de aanvrager daarom een pensioen worden onthouden?

De psychosomatici werden door het CVv en de SDV beter in staat geacht de ingewikkelde en complexe verbanden tussen psychische spanningen en latere klachten te doorzien dan artsen uit andere disciplines. ${ }^{28}$ Van hun diensten en inzichten werd dan ook regelmatig gebruikgemaakt.

Buiten het domein van de aanvragen voor een Buitengewoon Pensioen kon de psychosomatiek echter rekenen op weinig waardering. De psychosomatiek - zoals die door Groen en anderen was geïntroduceerd in Nederland - speelde, zoals de biografen van Groen lieten zien, nauwelijks een rol van betekenis. Groens ideeën over psychosomatiek konden zelfs rekenen op scepsis bij medisch specialisten. De psychosomatiek kon begin jaren zeventig nog wel rekenen op bijval van huisartsen, maar ook die steun verdween in de loop van de 
jaren zeventig. Ook voor psychosomatici zelf was het in de jaren zeventig allengs duidelijk geworden dat hun discipline niet voor vol werd aangezien.

Tijdens een toespraak ter gelegenheid van het vijfentwintigjarig bestaan van de Psychosomatische Werkgroep in 1973, concludeerde Groen dat de problemen van vijfentwintig jaar daarvoor nog steeds bestonden: nog steeds werd de psychosomatiek niet aanvaard door collega's uit de andere medische specialisaties. De remedie lag volgens Groen in het doen van onderzoek. Voorlopig zou er geen onderwijs moeten worden gegeven in de psychosomatiek.

Groens opvolgers waren zich bewust van hun geïsoleerde positie in de medische wetenschap. Bastiaans had al in 1970 in een interview met journaliste Bibeb gezegd dat hij vruchteloze discussies voerde met andere medici over de psychosomatiek. Hij had toen al de hoop opgegeven om ze met wetenschappelijk onderzoek te overtuigen. ${ }^{29}$ Elf jaar later bleek uit een interview met de Haagsche Courant dat er nog niets was veranderd. Bastiaans zei onder andere:

'Door de verregaande sub-specialisatie in de geneeskunde kan een chirurg zich niet met zulke onzin bezighouden, en de psychiaters hebben al zoveel aan hun eigen vak, die gaan doorgaans niet in dat tussengebied werken. ${ }^{30}$

Pelser maakte in een brief aan Polak gewag van 'de nog altijd dominerende weerstand van internisten en aanverwante superspecialisten tegen de psychosomatische benaderingswijze'. Hij schreef dat artikelen van psychosomatici door de redacties van wetenschappelijke tijdschriften werden geweigerd, waardoor collega's niet in staat waren kennis te nemen van de psychosomatiek. Maar ook als dat wel was gebeurd, zouden volgens hem die collega's niet in staat zijn geweest om de psychosomatiek op haar wetenschappelijke merites te beoordelen:

'Het is alsof men het rapport van een waterbouwkundig ingenieur over b.v. een inpolderingprobleem zou kunnen laten beoordelen door een stedenbouwkundige! ${ }^{31}$

De weerstand onder medici werd veroorzaakt door de radicale kanten van de psychosomatiek, zoals de psychosomatische specificiteit en het uitbundige gebruik van de psychoanalyse. Bovendien werd door de psychosomatici gebruikgemaakt van uiterst kleine aantallen gevallen ter illustratie van de ideeën, en maakte men zelden gebruik van controlegroepen. Dergelijke kritiek was in 1974 al te horen in een artikel van de Groningse psychiater dr. H.G.M. Rooijmans, die in 1976 zou worden benoemd als hoogleraar psychiatrie aan de RUL, naast Bastiaans. In het NTVG besprak hij de theoretische onduidelijkheden en het ontbrekende empirisch bewijs voor de 'psychosomatische specificiteit'. ${ }^{32}$

In 1983 herhaalde Rooijmans in het NTVG zijn kritiek. Inmiddels had empi- 
risch onderzoek naar de oorspronkelijke psychosomatosen - de zeven aandoeningen die ook door de Psychosomatische Werkgroep werden onderzocht - laten zien dat voor een psychische oorzaak van die klachten geen aanwijzingen waren gevonden. De krachtige uitspraken van psychosomatici werden niet gedragen door het nieuwe onderzoek. Het directe causaal verband tussen specifieke gebeurtenissen, de psychische reactie daarop en het ontstaan van latere, somatische klachten was een achterhaalde gedachte geworden. ${ }^{33}$

De weerstand tegen de ideeën van de psychosomatiek betekende niet dat er geen gedachten bestonden over de samenhang van psyche en soma. ${ }^{34}$ Somatische klachten konden samengaan met psychische klachten. Chronisch ziekzijn kon zijn weerslag hebben op de psychische gesteldheid, wat weer enig effect kon hebben op somatische ziekten. Het was een complex samenspel waarin nog maar weinig inzicht was verkregen.

Ondanks de kritische geluiden was de psychosomatiek begin jaren tachtig nog steeds een onmisbare schakel bij de toekenning van een Buitengewoon Pensioen. De Wet Buitengewoon Pensioen vereiste een causaal verband, de $\mathrm{CRvB}$ was daarvoor aangewezen op de oordelen van medici. Belangengroepen zochten medici uit die hen konden helpen, waardoor de psychosomatiek een vaste gast bleef bij de uitkeringsaanvragen.

Ook medici die een minder radicale variant van de psychosomatiek gebruikten in hun oordelen, wrongen zich in allerlei bochten om een positief oordeel over het verband te geven. Dat bleek bijvoorbeeld toen de CRvB de hulp inriep van drie hoogleraren interne geneeskunde. ${ }^{35}$ Het ging om een verzetsstrijder die vermoedelijk al in de oorlog last had gehad van een steeds terugkerend 'drukkend gevoel op de maag'. Iets minder dan twintig jaar na de oorlog werd bij hem een maagcarcinoom ontdekt.

De vraag die de hoogleraren kregen voorgelegd van het $C R v B$, was of het maagcarcinoom duidelijk door andere oorzaken dan het verzet werd veroorzaakt of verergerd. De vraagstelling van het $C R v B$ liet zien dat niet hoefde te worden aangetoond dat er een verband was; er moest worden uitgesloten dat er een andere oorzaak aan ten grondslag lag. Dat was natuurlijk net zo onmogelijk.

Het verzoek aan de drie hoogleraren leverde een ketenredenering van waarschijnlijkheden op. Hun redenering was dat:

'tengevolge van de stress van het verzetswerk (en vaak ook van de moeilijke periode die na de bevrijding voor sommige verzetsstrijders volgde) een maagzweer zou [kunnen] zijn ontstaan die een verklaring zou kunnen zijn voor de herhaalde perioden van maagpijn [...]. Als volgende hypothese zou men dan moeten inlassen dat dit een maagzweer zou zijn geweest die bij röntgenonderzoek niet gevonden werd. [...] Uit een chronische maagzweer kan soms een carcinoom ontstaan maar meestal van een ander type dan het hier beschrevene. ${ }^{36}$ 
Twee van de hoogleraren oordeelden dat het 'verband niet uit te sluiten maar allerminst bewezen' was. De derde 'neigde toch iets meer naar het afwijzen van een verband'. ${ }^{37}$ Het begin van de ketenredenering lag nog steeds in de psychosomatiek: het ontstaan van een maagzweer ten gevolge van psychische spanningen tijdens en na de oorlog.

Devoorbeelden uit de uitspraken en pleitnota's laten zien dat de problemen die zich voordeden bij de aanvragen voor een Buitengewoon Pensioen dezelfde waren als die waar Bastiaans in zijn proefschrift mee was geconfronteerd. De oplossing ervoor was ook nog steeds hetzelfde: een oordeel van medici. Maar de ideeën over de psychosomatiek waren inmiddels veranderd, waardoor het nog lastiger was geworden voor medici om een positief oordeel over het verband te geven. Verzetsstrijders maakten dan ook dankbaar gebruik van de psychosomatici die er nog waren, zoals Bastiaans maar ook bijvoorbeeld Hugenholtz, Hers, Pelser en Musaph.

Het Centraal Orgaan Voormalig Verzet en Slachtoffers (covvs) en de Stichting Samenwerkend Verzet (ssv), twee overkoepelende belangenorganisaties voor verzetsstrijders en oorlogsslachtoffers, publiceerden in 1983 samen een nota over de zorg aan verzetsstrijders. Daarin werd voorgesteld dat de medisch adviseurs van de BPR bij 'twijfelgevallen en/of problematische gevallen' de hulp inriepen van Bastiaans of Hugenholtz..$^{38}$

\section{Onaantastbare positie}

Bastiaans was de éminence grise van de oorlogsslachtofferproblematiek. Die status had hij te danken aan het feit dat hij in zijn proefschrift een oplossing had aangedragen voor de beoordeling van het causaal verband. Van die oplossing werd door anderen gebruikgemaakt, en die waren schatplichtig aan hem; zijn proefschrift werd vaak aangehaald en hij werd gevraagd als getuige-deskundige of medisch specialist.

Behalve dat Bastiaans zich gesteund wist door medici die zich opwierpen als belangenbehartiger van oorlogsslachtoffers, werd zijn succes in die jaren ook veroorzaakt door de steun die hij genoot onder verzetsstrijders. Zij zagen hem als degene die hun leed op de kaart had gezet en die talloze kameraden van hun problemen had weten te verlossen. Hij was een psychiater die niet alleen verstand had van hun problemen, maar ook opkwam voor hun belangen. Hij deed dat in de rapportages bij de aanvragen voor een Buitengewoon Pensioen - wanneer een patiënt primair behoefte had aan een pensioen, regelde hij dat eerst voordat hij aan een behandeling begon ${ }^{39}$ hij deed dat ook in de behandelingen van individuele patiënten, en in publieke debatten zoals het debat rond de drie van Breda. De verzetsstrijders zagen hem als bondgenoot en beschermden hem. Dat maakte dat zijn positie onaantastbaar werd.

Dat was gebleken bij het debat rond de drie van Breda; daar had Bastiaans 
een draai gemaakt van vóór naar tégen vrijlating om de loyaliteit te winnen. Dat gebeurde ook bij de affaire rond CDA-politicus mr. Willem Aantjes, zonder dat hem dat kwalijk werd genomen.

De historicus dr. Roelof Bouwman beschreef in zijn proefschrift over Aantjes hoe al langere tijd geruchten de ronde deden over het oorlogsverleden van de fractievoorzitter van het CDA. In de herfst van 1978 leek RIOD-historicus Lou de Jong genoeg bewijzen in handen te hebben om met harde beschuldigingen naar buiten te treden..$^{40} \mathrm{Op}$ een overhaast georganiseerde persconferentie velde hij een hard oordeel. Aantjes was volgens De Jong uit eigener beweging lid geworden van de ss en had dat jarenlang verzwegen. Hij was mogelijk zelfs korte tijd cipier geweest. ${ }^{41}$

De klap kwam hard aan; Aantjes stond bekend als een integer en sympathiek politicus. Volgens De Jong was Aantjes al die jaren een wolf in schaapskleren geweest. Aantjes werd door de publieke opinie gedwongen zich terug te trekken als fractievoorzitter. Zelf gaf hij toe 'fouten te hebben gemaakt maar niet fout' te zijn geweest. Een dag na de persconferentie ontstond er twijfel over het onderzoek van De Jong. Waren zijn getuigen wel zo betrouwbaar geweest, waren de bewijzen wel zo waterdicht? Er volgde kritiek op De Jongs overhaast belegde persconferentie en er werden twijfels geuit over de kwaliteit van zijn onderzoek.

De mediasocioloog Peter Hofstede omschreef in NRC Handelsblad Bastiaans als 'een van de weinigen in Nederland die in zekere zin over het prestige beschikken om tegen prof. De Jong op te tornen'. En dat deed Bastiaans ook: hij sloot zich aanvankelijk aan bij de verontwaardigde geluiden over De Jongs optreden. De manier waarop Aantjes door De Jong was gekapitteld vond hij 'onmenselijk'.42 Bastiaans beschreef de presentatie van het rapport van De Jong als een 'soort volkstribunaal':

'Door het rapport van het RIOD zo in de publiciteit te brengen, wordt mr. Willem Aantjes publiekelijk gegijzeld met zijn hele gezin. Als medicus zeg ik: dit is onmenselijk. ${ }^{.43}$

Bastiaans beriep zich op zijn status als medicus en nam het op voor Aantjes. Maar zijn standpunt, geuit kort na de persconferentie, bleek lijnrecht te staan tegenover dat van veel verzetsstrijders. Dat bleek uit het vervolgvan de kwestieAantjes.

De twijfels over het onderzoek van De Jong hadden ertoe geleid dat er een nieuw, uitgebreider onderzoek naar Aantjes' oorlogsverleden werd gedaan door een commissie van drie wijze mannen. De resultaten daarvan werden bekend in de zomer van $1979 .{ }^{44}$ Het rapport van De Jong werd op vrijwel alle punten gecorrigeerd. Een van de onderzoekers, de historicus J. Bank, vatte de conclusie als volgt samen: 
'Ik zie Aantjes als een scharrelaar, iemand die zich door de mazen van het net heeft gewrongen. Hij gaat als postbeambte naar Duitsland, ziet daar de oorlog dichterbij komen en denkt: hoe kom ik hier weg? Hij besluit zich bij de Germaanse ss te melden om zo terug in Nederland te komen. Anderen zouden daar misschien morele bezwaren tegen hebben gehad, maar hij niet. Er zijn trouwens meer mensen geweest die deze weg hebben gekozen. ${ }^{2} 5$

Bastiaans had na De Jongs persconferentie gemaand tot terughoudendheid. Dat bleek achteraf een wijs advies te zijn geweest: het onderzoek pleitte Aantjes vrij van de ernstigste beschuldigingen. Maar de verzetsstrijders hadden zich inmiddels tegen Aantjes gekeerd. De norm van verzet, die nog steeds van kracht was, eiste dat een politicus vrij was van iedere smet en daar werd door verzetsstrijders streng op toegezien.

De scheldpartijen en bedreigingen die Aantjes sinds het begin van de kwestie ontving, gingen na de publicatie van het rapport van de commissievan drie door. Hij kreeg ettelijke telefonische en schriftelijke scheldpartijen te verduren en ontving zelfs bedreigingen op zijn huisadres. Een anoniem lid van het 'Voormalig Verzet Nederland' schreef bijvoorbeeld:

'Heb het lef niet in de Kamer te verschijnen, dan wordt $\mathrm{u}$ de lamp uitgeblazen. Geen fascisten in de Tweede Kamer. ${ }^{46}$

Ook publiekelijk klonken deze geluiden; weekblad Elsevier berichtte over een 'anonieme verzetsstrijder' die had aangekondigd dat Aantjes zou worden geliquideerd.

Een andere, wel bij naam genoemde verzetsstrijder - 'honderd procent invalide verklaard' - vertelde dat hij 's nachts wakker werd van een nachtmerrie waarin hij werd geëxecuteerd door een vuurpeloton onder leiding van Aantjes. ${ }^{47}$ Een andere verzetsstrijder, die in de oorlog ternauwernood aan arrestatie door de SD had weten te ontkomen, deed ook zijn verhaal. Zijn vrienden werden wél opgepakt en zonder proces geëxecuteerd. De man leed nog steeds onder die herinnering en voelde zich door de kwestie-Aantjes weer in het nauw gedreven. ${ }^{48}$

Verzetsstrijders gebruikten hun lijden als argument om te voorkomen dat Aantjes terugkeerde in de politiek. Een argument dat veel leek op het argument dat werd gebruikt in de discussie rond de drie van Breda.

Bastiaans kon niet achterblijven en moest, wilde hij het bondgenootschap met zijn verzetsstrijders niet onder druk zetten, zijn eerdere, terughoudende standpunt verlaten. Net als bij de discussie rond de drie maakte hij een draai. Bastiaans liet nu in de pers horen dat een politiek heroptreden van Aantjes bij 'honderdtwintigduizend personen het $\mathrm{KZ}$-syndroom zou kunnen activeren' net zoals de mogelijke vrijlating van de drie van Breda en de vrijlating van de 
van oorlogsmisdaden verdachte Menten dat eerder hadden gedaan. ${ }^{49}$

De terughoudendheid die hij zo graag bij De Jong had gezien was niet op hemzelf van toepassing; zelfs niet nadat was gebleken dat het oorlogsverleden van Aantjes minder 'fout' was dan aanvankelijk werd gedacht. In een radio-interview zei Bastiaans:

'De heer Aantjes heeft dat alles niet beseft. Psychisch heeft de heer Aantjes met zijn akties geweld uitgelokt. ${ }^{50}$

Dat de onthullingen over Aantjes' verleden emoties opriepen, was voorstelbaar; Aantjes ontkende zijn eigen aandeel daarin ook niet. Maar Bastiaans' krachtige bewoordingen - de 'grote psychische nood' zou het ' $\mathrm{KZ}$-syndroom activeren' - gaven die voorstelbare emoties een extra lading: alsof er bij de slachtoffers een bom zou afgaan.

Omdat het Bastiaans was die de uitspraken deed, kregen die uitspraken de status van waarheid. Het was volgens hem begrijpelijk dat verzetsstrijders reageerden zoals ze reageerden, ook al had Aantjes het niet zo kwaad bedoeld. Hij verhief de emoties van het voorstelbare naar het medisch-pathologische en legitimeerde die emoties én de daden die daaruit volgden. Hij gooide zo olie op het vuur van de toch al hoog opgelopen emoties. Of zijn verzetsstrijders met dat laatste waren geholpen is de vraag, maar ze kregen wat ze wilden: Aantjes trok zich terug.

Aantjes zelf had weerstand willen bieden aan de protesten en bedreigingen, maar hij wilde zijn gezin niet langer blootstellen aan de spanningen die de dreigementen opriepen. Biograaf Bouwman citeerde een brief van Aantjes aan het bestuur van het $C D A$ :

'Op een schokkende manier word ik verantwoordelijk gesteld voor gevoelens, die anderen hebben of zouden hebben. [...] Gevoelens van oorlogsslachtoffers worden politiek uitgespeeld, waardoor hun leed slechts wordt vermeerderd. ${ }^{51}$

Bastiaans' draai werd door niemand opgemerkt en zijn uitspraken over de activering van het $\mathrm{KZ}$-syndroom werden zonder hoorbare tegenreactie overgenomen door de kranten.

De kwestie-Aantjes liet zien dat het bondgenootschap voor beide partijen voordelig was. Wanneer in een kwestie de gevolgen voor verzetsstrijders speelden, ontstond in het begripvolle klimaat ruimte voor onderhandeling. Bastiaans bevestigde het leed van de verzetsstrijders, wat die groep een extra argument in handen gaf in hun strijd. Tegelijkertijd erkende de groep Bastiaans als expert; hij was tenslotte degene die hun leed begreep en zich publiekelijk daarover uitsprak. Die steun verhoogde Bastiaans' aanzien en maakte hem tot een 
machtsfactor van betekenis. Zelfs het publieke gedraai in zijn standpunten werd getolereerd.

Het bondgenootschap tussen Bastiaans en de verzetsstrijders was dus geen eenrichtingsverkeer. Op de zeldzame momenten dat er kritiek op Bastiaans was te horen, konden de critici rekenen op reacties. Dat gebeurde bijvoorbeeld bij de socioloog en voorzitter van de Vriendenkring Sachsenhausen, dr. H.Ph. Milikowski. Hij was vanaf Bastiaans' doorbraak met Begrijpt $u$ nu waarom ik huil... kritisch over diens behandelmethode. Al bij de eerste vertoningen van de film had hij zich gestoord aan de sturende manier waarop Bastiaans zijn therapie bedreef..$^{52}$ Hij bleef zich daarover opwinden, ook bij de presentatie van Allemaal rottigheid, allemaal ellende, waarin de behandeling van Meester werd beschreven.

Nadat Milikowski zijn kritiek had geuit in een artikel in De Nieuwe Linie, viel er een dikke enveloppe op zijn deurmat. ${ }^{53}$ De brief die erin zat, was ondertekend met 'Gerrit IJzer' - 'een pseudoniem van een ex-politieke gevangene, lijder aan het Kz-syndroom, oud-patiënt van de Jelgersmakliniek van prof.dr. J. Bastiaans en psycholoog van professie'. IJzer schreef:

'Ik kan er niet onderuit, Milikowski bedient zich van politieke praktijken die even infaam zijn [...] godverdomme Milikowski waarom moet jij je zonodig scharen in die rij van fanatieke klootzakken [...] Willem van Salland en de zijnen [...] en nog een paar miljoen [...] Milikowksi heb je dan goddomme niks geleerd [...] geen reet begrepen [...] hou dan in godsnaam je bek over het $\mathrm{Kz}$ syndroom en over bastiaans! ${ }^{54}$

De briefschrijver reageerde emotioneel op de kritiek van Milikowski en wist blijkbaar niet dat Milikowski verscheidene kampen als Jood had overleefd. De brief laat zien dat kritiek op Bastiaans niet werd geduld. De criticaster kon rekenen op tegenreacties, soms dreigende reacties.

Ook A.J. Kliest, voorzitter van de Landelijke Kontakt-Groep verzetsgepensioneerden (LKG), ondervond dat Bastiaans werd beschermd door zijn aanhang. Kliest had tijdens een bijeenkomst van de LKG uitspraken van Bastiaans aangehaald. Bastiaans had zich in een interview negatief uitgelaten over de opsporing van oorlogsmisdadigers. Hij was van mening dat het geld voor opsporing en berechting beter besteed kon worden aan de behandeling van oorlogsslachtoffers. Maar Kliest was het niet met hem eens, oorlogsmisdadigers moesten volgens hem wel degelijk worden opgespoord.

Volgens een van de toehoorders hield Kliest een 'hetzespeech van ongeveer een kwartier' aan het adres van Bastiaans. ${ }^{55}$ Prompt volgde een ingezonden brief in Aantreden, het verenigingsblad van Expogé, waarin R. van Dam, oudpatiënt van Bastiaans, zijn beklag deed: 
'Professor Bastiaans is voor het front van meer dan duizend LKG-leden door de heer Kliest gevonnist, zonder ooit over dit gewraakte krantenartikel te zijn benaderd of een en ander juist was overgekomen, zelfs zonder enige kans op verdediging zijnerzijds. ${ }^{56}$

Van Dam meldde dat onder de toehoorders van Kliest veel personen waren die baat hadden gehad bij Bastiaans'behandeling, onder wie hijzelf, en die dankzij zijn bemiddeling nu van een Buitengewoon Pensioen genoten. Er waren zelfs enkele aanwezigen die hun leven aan Bastiaans hadden te danken. De briefschrijver was het overigens wel met Kliest eens dat opsporing van oorlogsmisdadigers doorgang moest vinden. Maar kritiek op Bastiaans werd niet geduld.

Nico Wijnen, voorzitter van de Vriendenkring van Oud-Natzweilers (een vriendenkring van overlevenden van concentratiekamp Natzweiler), plaatste Van Dams brief in Natzweiler Berichten, het verenigingsblad. Hij deed er zelf een schepje bovenop door het relaas te vertellen van een vrouw die als kind een periode had doorgebracht in een Japans interneringskamp. Ze was in 1973 opgenomen in de Jelgersmakliniek nadat ze enkele zelfmoordpogingen had gedaan. $\mathrm{Na}$ een halfjaar had ze de dependance genezen verlaten, en was Bastiaans voor haar 'een van de geweldigste mensen' die ze kende. Na het verhaal over de vrouw waarschuwde Wijnen:

'Zo een man publiekelijk attaqueren, zelfs wanneer je het niet met hem eens bent, dat doe je niet. Mag je niet!'57

Wie aan Bastiaans kwam, kwam aan 'zijn patiënten en anderen van onze generatie'. En wie aan slachtoffers kwam, kon rekenen op felle reacties. Bastiaans bevestigde keer op keer de bijzondere status van oorlogsslachtoffers en kon daardoor rekenen op een loyale steun. Hij werd met alle egards behandeld; hij werd uitgenodigd bij reünies en de jaarlijkse 'Dag van het verzet'.

Omdat hij door verzetsstrijders op handen werd gedragen, dwong Bastiaans ook bij anderen respect af. W. op den Velde, die tijdens zijn assistentschap door Bastiaans publiekelijk te kijk was gezet omdat hij het (achteraf fictieve) oorlogsverleden van een patiënt niet had ontdekt, kon in zijn carrière niet om Bastiaans heen. Op den Velde was tijdens zijn assistentschap bij de Jelgersmakliniek in 1972 vertrokken uit onvrede over de manier waarop Bastiaans werkte. Maar toen hem in 1980 gevraagd werd medisch adviseur te worden bij de Stichting 1940-1945, ging hij toch even langs bij Bastiaans; diens 'zegen' was formeel niet noodzakelijk maar het was onverstandig om meteen een vijand te hebben. ${ }^{58}$

Ook historicus De Jong hield rekening met Bastiaans' aanzien onder verzetsstrijders. In het vorige hoofdstuk kwam het geval ter sprake dat De Jong beschreef in de voetnoot van zijn concepttekst (over een vrouw die tijdens de 
behandeling had ontdekt slachtoffer te zijn geweest van Ilse Koch, de gevreesde vrouw van de kampcommandant van Buchenwald, op een moment dat dat onmogelijk was). De Jong had met de noot willen laten zien dat niet alle verhalen over gruwelijkheden voetstoots moesten worden aangenomen.

Meelezer dr. E.A. Cohen, gepromoveerd op een proefschrift over zijn eigen ervaringen in de kampen, en degene die als eerste publiceerde over het KZ-syndroom, verbaasde zich niet meer over dergelijke groteske leugens wanneer er een uitkering in het vooruitzicht werd gesteld:

'Sinds er geld te verdienen is zijn vele verhalen helaas oneerlijk. Zo wilde een joodse vrouw extra geld hebben omdat ze in het experimentenblock had gezeten. Triest voor haar was dat [ik] vele maanden naast Block 10 had gezeten, waardoor ze door de mand viel. En het geval Meesters [sic] is vooral voor Bastiaans triest. Soms denk ik: wie heeft uit mijn vele publicaties over het post concentratiekamp syndroom de symptomen uit het hoofd geleerd. ${ }^{59}$

Alarmerend was dat Cohen het mogelijk achtte dat de symptomen van het $\mathrm{KZ}$ syndroom uit het hoofd te leren waren; dat maakte het voor artsen nog lastiger om het kafvan het koren te onderscheiden. Zijn opmerking stond ook in schril contrast met zijn eerdere uitspraken over de oordelen van artsen; hij had zich altijd een vurig voorstander getoond van het geven van het voordeel van de twijfel aan aanvragers van een Buitengewoon Pensioen. Dat voordeel van de twijfel was Meester noodlottig geworden en had geleid tot de dramatische ontknoping.

Belangrijker was Cohens opmerking dat het geval-Meester vooral voor Bastiaans triest was. Die mening hadden ook enkele andere meelezers. Zij zagen de noot graag geschrapt, omdat de kwestie die De Jong aansneed een herhaling was van het geval-Meester. Het zou Bastiaans - en zijn verzetsstrijders - in de problemen kunnen brengen. De Jong schrapte de noot en deed de toezegging er in een later deel op terug te komen.$^{60} \mathrm{De}$ Jong wilde Bastiaans' positie in den lande' niet in gevaar brengen. ${ }^{61}$

\section{Conclusies}

In de inleiding werd verwezen naar het werk van de sociologe Jolande Withuis, die de medicalisering van het erkenningsstreven van verschillende groepen slachtoffers beschreef. Door die medicalisering was het succes van het erkenningsstreven in sterke mate afhankelijk van de medewerking van medici. Bastiaans was in 1972, rond de kwestie van de drie van Breda, een van de eersten die zich achter dat streven hadden geschaard en zich buiten de paden van zijn professie begaven. Dat had een voordelig bondgenootschap opgeleverd: hij kon rekenen op de loyale steun van verzetsstrijders, en vice versa. 
In het begripvolle klimaat van de jaren zeventig bleken ook andere medici bereid die steun te geven. De oprichting van het cvv bijvoorbeeld was een blijk van de gegroeide compassie van de behandelaars met de slachtoffers. En net als Bastiaans beperkten zij zich bij de leniging van de noden van hun patiënten niet meer tot de behandelkamer; ze richtten een politiek orgaan op om de belangen van hun patiënten te verdedigen.

Ondanks de wil om slachtoffers te helpen, ontstonden er grote problemen bij de vaststelling van het causaal verband bij de aanvragen voor een verzetspensioen. Het ontbrak de medische wetenschap nog steeds aan instrumenten om een betrouwbaar oordeel te geven. Dit leidde tot een hoog percentage afwijzingen.

Wanneer artsen een positief oordeel over het causaal verband wilden geven, moesten zij vaak gebruikmaken van de - inmiddels achterhaalde - ideeën uit Bastiaans' proefschrift. De mechanismen die daarin stonden beschreven, waren nodig om het verband tussen fysieke klachten en de oorlog te kunnen leggen.

De instandhouding van Bastiaans' positie was dus van groot belang voor de verzetsstrijders. Kritiek op hem was onmogelijk; een publiekelijke aanval op iemand die zoveel betekende voor oorlogsslachtoffers was niet gepast. De verzetsstrijders legden zichzelf censuur op om hun bondgenoot te behouden, en kapittelden degenen die zich wel in het openbaar kritisch over hun psychiater uitlieten. Openlijke kritiek op Bastiaans bleef tot een minimum beperkt, en als er al sprake van was, traden er beschermingsmechanismen in werking, zoals de bedreiging van Milikowski. Bastiaans' draai bij de drie van Breda en de kwestie-Aantjes, en zijn blamage bij het geval-Meester, werden daardoor met de mantel der liefde bedekt.

Dejaren zeventig waren dan ook Bastiaans' topjaren. Hij en zijn proefschrift vormden een cruciale schakel in een belangrijke maatschappelijke kwestie: de leniging van de noden van oorlogsslachtoffers. Het maakte hem lange tijd onaantastbaar. 
Neergang

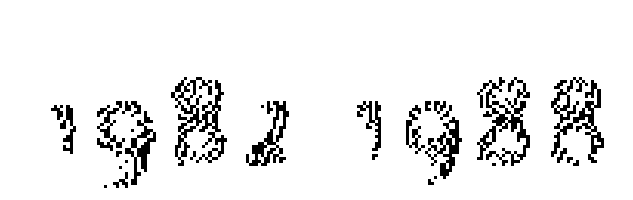




\title{
'Ik heb een symbolische functie'
}

\author{
'Het politiek doodvonnis over Bastiaans en over al zijn patiënten is uitgespro- \\ ken. Op 1 juni [1985] aanstaande vindt 'de executie' plaats. Maar ik zal dan naast \\ Bastiaans staan." \\ BESTUURSLID VAN WERKGROEP DEPENDANCE JELGERSMAKLINIEK \\ L. LIGTVOET, 1985
}

Inleiding

In de jaren tachtig verdween de generatie hulpverleners die zelf de oorlog had meegemaakt langzaam maar zeker van het toneel. Huisarts T. van Reemst, die jarenlang verzetsstrijders had bijgestaan, was in 1979 overleden, en eind 1982 nam dr. P.Th. Hugenholtz afscheid als medisch adviseur van de Stichting 19401945. Bij zijn afscheid sprak staatssecretaris van wVC, drs. J.P. van der Reijden, hem toe:

'U kunt met o.a. prof.dr. J. Bastiaans en dr. J.F.Ph. Hers gerekend worden tot de grondleggers van de wetenschap over het psychosomatische lijden van verzetsdeelnemers en vervolgden.'

Deze medici stonden bekend om hun begripvolle omgang met oorlogsslachtoffers. Met hun vertrek dreigde daaraan een einde te komen. Belangenorganisaties van verzetsstrijders ondernamen daarom pogingen om sommigen van hen nog even te behouden, zoals bijvoorbeeld dr. J.F.Ph. Hers, een oud-verzetsstrijder, die ook betrokken was geweest bij de bouw van Centrum ' 45 .

Hers was internist en stond bekend om de voeling die hij had met de problematiek van oorlogsslachtoffers. In het Academisch Ziekenhuis Leiden (AZL) hield hij spreekuren voor oorlogsslachtoffers. Toen hij in 1983 de pensioenge- 
rechtigde leftijd bereikte. richtte het Central Orgaan Voormalig Verzet en Slachtoffers (covvs) - cen overkoepelende organisatie van voormalig verzetsstrijders en oorlogsslachtoffers onder leiding van Hans Teengs Gerritsen - een speciaal fonds op, waardoor hij nog enkele jaren oorlogsslachtoffers kon hel. pen en een geschikte opvolger kon inwerken?

In augustus $198_{4}$, een jaar voor zijn definitieve afscheid, kondigde Hers in Aantreden, een blad voor voormalig politieke gevangenen, aan dat hij een opvolger had gevonden: dr. WJ. de Loos. Om het werk van De Loos te vergemak. kelijken, sprak hij in het stuk alvast zijn vertrouwen uit in zijn opvolger:

[Hii] is als internist zeer gemotiveed en heeft ter voorbereiding voor zijn werkzambeden de concentratickampen Auschwitz, Mauthausen en Natzweiler in persoon en alleen bezocht. [...] Zijn oom, de jurist, verbleef langdurig in de concentratiekampen Natzweiler en Ruchenwald."

Aan de poging om Hers te behouden en de zorg waarmee de overdracht van zijn taken gepaard ging, was te zien dat oorlogsslachtoffers hun hulpverleners met zorg uitkozen. Afscheid nemen kostte moeite. Toen het besef kwam dat Bastiaans zijn werk zou moeten neerleggen, waren de problemen vele malen groter dan bij Hers. Met het vertrek van Bastiaans zou niet alleen een betrokken medicus verdwijnen, maar ook een speciale behandelmethode en de meest invloedrijke bondgenoot in de strijd om erkenning.

\section{Van KZ-syndroom naar PTSS}

Voor een goed begrip van de moeilijkheden die ontstonden om Bastiaans' vertrek is het nodig om de succesvolle erkenning van het $\mathrm{kz}$-syndroom nader te bekijken.

Eind jaren zestig was met de oprichting van de Werkgroep Post-concentratiekampsyndroom een begin gemaakt met het creëren van een uitzonderingspositie voor oorlogsslachtoffers in de psychiatrie. Toen waren overheid en hulpverleners, onder aanvoering van Bastiaans, van mening dat de groep speciale problemen had die om speciale zorg vroegen. De oprichting van Centrum 45 was daar onder meer het resultaat van.

Door middel van het $\mathrm{xz}$-syndroom hadden de Joodse overlevenden van de vernietigingskampen (al snel gevolgd door de groep teruggekeerde gedeporteerde verzetsstrijders) erkenning gekregen voor hun problemen. De sociologe Jolande Withuis beschreef in haar boek Erkenning de brugfunctie die het $\mathrm{KZ}$-syndroom op deze manier vervulde. ${ }^{5}$ De overheid en de maatschappij waren zich, met de hulp van Bastiaans, bewust geworden van de gevolgen van traumatische gebeurtenissen, en hadden een manier gevonden om daarmee om te gaan: het bieden van speciale zorg. De speciale problemen werden op een speciale manier behandeld. 
Spoedig nadat de teruggekeerde gedeporteerde verzetsstrijders erkenning hadden gekregen, volgde erkenning voor de groep niet-gedeporteerde verzetsstrijders. Ook hun klachten waren een gevolg van een bijzonder psychisch trauma. Ze werden daarvan overtuigd door psychiaters als Bastiaans, die hun klachten vergeleken met de symptomen van het $\mathrm{KZ}$-syndroom. Zo kwamen er steeds nieuwe groepen slachtoffers bij. Aanvankelijk betrof het uitsluitend slachtoffers van de oorlog, maar vanaf het midden van de jaren zeventig werd ook gevreesd voor de gevolgen voor de slachtoffers van andere calamiteiten, zoals gijzelingen, mishandeling en incest.

De overheid droeg daaraan bij doordat zij zich verantwoordelijk voelde voor een adequate opvang van die nieuwe groepen. Toen in de jaren zeventig een aantal gijzelingen plaatsvond, zoals de beruchte treinkaping door Molukkers bij De Punt, ontstond er zorg over de gevolgen voor de gegijzelden. ${ }^{6}$ Er werd een speciale commissie opgericht die onderzoek verrichtte naar de mogelijkheden van nazorg voor gegijzelden. In januari 1976 benoemde staatssecretaris van Volksgezondheid en Milieuhygiëne J.P.M. Hendriks daarom de Centrale Beleids- en Ondersteuningsgroep (CBOG). Bastiaans werd in februari 1976 benoemd tot voorzitter van de Wetenschappelijke Onderzoeksgroep van de CBOG.

In 1979 leverde de onderzoeksgroep een rapport met de resultaten van haar wetenschappelijk onderzoek onder de gijzelaars. In de theoretische inleiding werd een directe parallel getrokken tussen de gijzelingen in de jaren zeventig en de gijzelingen en detenties die plaatsvonden tijdens de Tweede Wereldoorlog. ${ }^{7}$ Het was volgens het rapport onduidelijk hoeveel personen er klachten zouden ontwikkelen, maar waar dat zou gebeuren, zou blijken dat de klachten leken op die van oorlogsslachtoffers. ${ }^{8}$

Niet alleen in de symptomen, ook in de preventie werden parallellen getrokken. Het rapport refereerde aan de gebrekkige opvang van oorlogsslachtoffers en de desastreuze gevolgen die dat had gehad. De fout van toen moest met de gijzelaars van nu niet worden gemaakt, om herhaling van de geschiedenis te voorkomen.

De CBOG zorgde voor intensivering van de aandacht voor psychische trauma's, en voor verspreiding van de kennis daarover. De Ondersteuningsgroep was betrokken bij de instelling van het Schadefonds Geweldsmisdrijven, waar slachtoffers van een geweldsmisdrijf - waar ze buiten hun schuld bij betrokken waren geraakt en waarvan de schade niet op een andere manier te verhalen was - terechtkonden voor een eenmalige uitkering, en initieerde verder onderzoek naar de gevolgen van andere ingrijpende gebeurtenissen, zoals martelingen, gijzelingen, gewelds- en zedenmisdrijven. Het leidde tot het eerste Nederlandse psychotraumaonderzoek van prof.dr. P.B. Defares in Utrecht enlater tot de proefschriften van prof.dr. R.J. Kleber en dr. D. Brom. ${ }^{9}$

Het zorgde ervoor dat het psychisch trauma een steeds vertrouwder begrip 
werd. Bastiaans profiteerde aanvankelijk van deze ontwikkeling. Omdat hij vaak voor de troepen uitliep in de erkenning van de trauma's van nieuwe groepen slachtoffers, wist hij ook die nieuwe groepen aan zich te binden. Bastiaans herkende bij kinderen van NSB'ers, kinderen die hun jeugd hadden doorgebracht in een Japans interneringskamp, verkeersslachtoffers en zelfs bij voormalige kampbewakers de gevolgen van psychische trauma's. ${ }^{10}$ Hij bracht dat als een groot inzicht:

'Ik ontdekte namelijk meer en meer dat mensen die niet in een $\mathrm{kz}$ hebben gezeten, maar een rotjeugd hebben gehad, óók in een soort privé-kampsituatie kunnen zitten."1

Het leidde tot inflatie van het $\mathrm{kz}$-syndroom; het onderscheid tussen al die groepen leek niet meer te bestaan. Withuis beschreef hoe deze ontwikkeling doorzette en leidde tot een 'traumacultuur' waarin een verloren voetbalwedstrijd eveneens een traumatische gebeurtenis kan zijn.

Zover was het nog niet begin jaren tachtig. De 'nieuwe' groepen hadden een ervaring ondergaan - gijzeling, seksueel misbruik, marteling - die niets met een concentratiekamp te maken had. Daardoor werd de term KZ-syndroom steeds ongepaster. Vanaf 1980 kwam er een nieuwe term in zwang, overgewaaid uit Amerika: 'posttraumatische stressstoornis' (PTSs). Voor de nieuwe groepen was de introductie van PTSS winst; zij kregen erkenning voor hun problemen, net zoals slachtoffers van de Tweede Wereldoorlog dat eerder hadden gekregen met het $\mathrm{Kz}$-syndroom. De problemen van oorlogsslachtoffers werden steeds vaker aangeduid als een vorm van PTss en in de loop van de jaren tachtig raakte de term ' $\mathrm{KZ}$-syndroom' steeds meer in onbruik; het $\mathrm{KZ}$-syndroom ging ten onder aan zijn eigen succes. ${ }^{12}$

De komst van PTss leidde ertoe dat de groep oorlogsslachtoffers langzaam opging in de grote groep traumaslachtoffers die was ontstaan. De uitzonderingspositie van verzetsstrijders werd daarmee ondermijnd, terwijl ze nog wel steeds aan die uitzonderingspositie hechtten. Hun problemen werden geschaard onder dezelfde noemer als die van andere slachtoffers; iets waar ze altijd tegen gestreden hadden. Hun bondgenoten - de medici die hun de bijzondere status hadden gebracht - gingen nu het toneel verlaten, waardoor dat proces zich leek te versnellen. Het leidde tot verzet. De strijd om het behoud van Bastiaans, die hieronder wordt beschreven, is te zien als een voorbeeld van dat verzet.

\section{Problemen op de universiteit}

Bastiaans nam binnen de universiteit een geïsoleerde positie in. Zijn relatie met alle bestuurlijkelagen - college van bestuur, faculteit en vakgroep - was in 
deloop der jaren verstoord geraakt. Hijwerd gezien als een wispelturige dwarsligger die niet constructief meewerkte aan gezamenlijke oplossingen en bovendien regelmatig terugkwam op gemaakte afspraken. Het gevolg was dat de plannen voor nieuwbouw en reorganisatie om tot een geïntegreerd academisch ziekenhuis te komen - plannen die al speelden toen Bastiaans aantrad als hoogleraar - stillagen.

Een kritisch visitatierapport en Bastiaans' blijvende weigering om mee te werken aan de plannen voor nieuwbouw, waren de aanleiding voor de oprichting van een adviescommissie onder leiding van prof.dr. M. Vink. ${ }^{13}$ In november 1981 kwam de commissie-Vink met een eenvoudige oplossing: de twee afdelingen psychiatrie - die er waren sinds Rooijmans was aangesteld als hoogleraar klinische psychiatrie naast Bastiaans - zouden per 1 januari 1983 worden samengevoegd en onder één hoofd komen te vallen: Rooijmans.

De keus voor Rooijmans lag voor de hand; er was een wetswijziging in voorbereiding die de leeftijd waarop hoogleraren met emeritaat gingen, zou verlagen van zeventig naar vijfenzestig jaar. Als de wetswijziging nog in 1982 werd ingevoerd, restten Bastiaans nog slechts enkele maanden in zijn Jelgersmakliniek.

Het plan van de commissie-Vink betekende dat Bastiaans veel moest opgeven: het directeurschap van de Jelgersmakliniek, zijn functie als hoofd van de afdeling Psychiatrie I en zijn functie als verantwoordelijke voor de opleiding (een taak die was gekoppeld aan zijn functie als afdelingshoofd).

Wat hij terugkreeg, was een persoonsgebonden leerstoel, waardoor hij tot aan zijn emeritaat zijn werk op het gebied van de 'traumatologische psychiatrie en psychosomatiek' zou kunnen voortzetten op de dependance. Dat was hard nodig volgens Bastiaans. Twee maanden eerder had hij in een interview de komst van een nieuwe groep traumaslachtoffers aangekondigd: kinderen die slachtoffers waren geweest van de Japanse interneringskampen in Nederlands-Indië, en de daarop volgende Bersiap-periode. ${ }^{14}$ Zijn werk was nog lang niet klaar.

Hoewel de commissie-Vink Bastiaans in de voorbereidingen had betrokken en de indruk had gekregen dat hij zich kon vinden in de oplossing, was Bastiaans, toen hij in januari 1982 het voorstel ontving, onaangenaam verrast. ${ }^{25}$ In een brief aan zijn advocaat schreef hij dat hij een te grote verantwoordelijkheid had jegens de slachtoffers van man-made disasters. Hij was voor hen 'een haven van zekerheid'. Bovendien wilde hij niet onder Rooijmans werken. ${ }^{16}$

Bastiaans ging, met de jurist $\mathrm{C}$. Veraart van het $\mathrm{CvV}$ aan zijn zijde, in gesprek met het college van bestuur. Hij wilde de kwestie graag in der minne schikken. In een vertrouwelijke brief aan het faculteitsbestuur schreef collegevoorzitter mr. K.J. Cath over het gesprek dat hij met Bastiaans had gehad:

'Hij hecht hier te meer aan, omdat hij geen rel wil hebben. Hij denkt daarbij met name aan zijn relatie met de oorlogsslachtoffers en hun organisatie. ${ }^{17}$ 
Desondanks ontstond er binnen enkele weken onrust bij zijn achterban over de mogelijke beëindiging van zijn aanstelling. Het leidde direct tot een dreigement aan het adres van Rooijmans, die door Bastiaans en zijn aanhang gezien werd als de kwade genius achter de plannen. Op 24 maart 1982 viel op het huisadres van Rooijmans een brief op de deurmat:

'Wij behoren tot een groep mensen, die onze "zaak" proberen op een fatsoenlijke manier te verdedigen, maar we blijven mensen, die niet zullen schromen, als het werk met betrekking tot ons in gevaar komt, u op een minder zachtzinnige manier daaraan te herinneren. ${ }^{, 18}$

De dreigbrief werd anoniem ondertekend met 'enkele verzetsgepensioneerden'. Toen Rooijmans de brief aan Bastiaans liet lezen, bleek deze te weten wie het waren. Hij zou hun nog hebben gevraagd de brief niet te versturen, en beloofde Rooijmans hun te vragen te stoppen. ${ }^{19}$ De dreigbrief aan het adres van Rooijmans was een voorbode van wat komen ging.

Op aandringen van de voorzitter van het bestuur van het Academisch Ziekenhuis Leiden, J. Hendriks, werd gezocht naar een compromis. In mei 1982 werd vastgelegd dat Bastiaans aftrad als directeur van de Jelgersmakliniek, maar de verantwoordelijkheid hield over de dependance. Hij hoefde voor zijn behandelingen geen verantwoording aan Rooijmans af te leggen. De universiteit zou bovendien verlenging van zijn aanstelling aanvragen bij de minister en hem het gebruik gunnen van de dependance tot ten minste 1 juni 1985 en tot uiterlijk1 juni 1987. De universiteit stelde ook geld beschikbaar zodat Bastiaans een opvolger kon inwerken. ${ }^{20}$

De protesten van zijn achterban gingen door en werden steeds succesvoller. De Inspectie voor de Geestelijke Volksgezondheid ontving brieven van Bastiaans' aanhang en dat had effect. De Inspecteur, die enkele maanden eerder in een gesprek met de commissie-Vink had aangegeven dat het accent van de Leidse psychiatrie te veel op de langdurige psychotherapie lag, schreef aan het college van bestuur:

'Hoewel het niet op mijn weg ligt in uw beleid te treden, wil ik met nadruk wijzen op het grote geestelijke gezondheidszorgbelang, gemoeid met een ruime voortzetting van de nationaal en internationaal baanbrekende en erkende werkzaamheden van professor Bastiaans voor gepsychotraumatiseerde oorlogsslachtoffers of daarmee vergelijkbare personen. De geruchten over zijn positie hebben er reeds toe geleid, dat mij diverse signalen bereikten over een diepgaande onrust bij deze groep patiënten, die zich eens te meer verlaten en in de steek gelaten voelen. Voor de geestelijke gezondheidszorg is dit verontrustend. ${ }^{21}$ 
De Inspecteur wilde niet dat de indruk werd gewekt dat hij had aangedrongen op inperking van het werk van Bastiaans. Hij had niet de bedoeling gehad de langdurende psychotherapie, waar Bastiaans voor verantwoordelijk was, te verminderen, maar beoogde juist de andere disciplines te intensiveren. ${ }^{22} \mathrm{ZO}$ liep, buiten het oog van de media, de spanning rond Bastiaans' afscheid op.

In september 1982 diende zich een nieuwe rel aan, die wel de publiciteit haalde. Het personeel van de Jelgersmakliniek had jarenlang in steeds verder aftakelende gebouwen gewerkt. Herhaaldelijk was hun nieuwbouw beloofd, maar steeds konden die beloftes niet worden nagekomen. Toen in de zomer van 1982 dan eindelijk de nieuwbouw gereedkwam, wachtte voor een deel van hen een onaangename verrassing: het personeel van de dependance moest achterblijven in de oude, verkrotte villa. ${ }^{23}$ Bastiaans wilde niet verhuizen naar de nieuwbouw omdat de kamers in de nieuwe kliniek zijn patiënten zouden doen denken aan 'kleine celletjes'. Dat was juist voor mensen met een KZ-syndroom funest.

In een open brief aan het college van bestuur deden de verpleegkundigen hun beklag. ${ }^{24}$ De open brief werd opgepikt door twee Kamerleden van de PvdA, dr. W.A. de Pree en M.A. Müller-van Ast. Zij wilden van de minister weten waarom pas na voltooiing van de nieuwbouw was gebleken dat deze niet geschikt was voor de behandelingen van Bastiaans. De staatssecretaris van Welzijn, Volksgezondheid en Cultuur (wvc), drs.J.P. van der Reijden, antwoordde dat Bastiaans betrokken was bij de voorbereiding maar nimmer zijn speciale wensen kenbaar had gemaakt. ${ }^{25}$

Van der Reijden moet bedoeld hebben dat de eisen die Bastiaans in tweede instantie op tafel legde, anders waren dan de eisen die hij had gesteld bij de voorbereiding van de bouw. In de nieuwbouwplannen was namelijk rekening gehouden met de speciale wensen van Bastiaans: er was een kleine studio gerealiseerd waar hij zijn narcoanalyses en LSD-behandelingen zou kunnen uitvoeren. ${ }^{26} \mathrm{Hij}$ zei altijd in de veronderstelling te hebben verkeerd dat de nieuwbouw bedoeld was ter uitbreiding van zijn beddenbestand.

Bastiaans hield voet bij stuk en ging niet over naar de nieuwbouw. Hij wees naar het mei-akkoord, waarin was vastgelegd dat hij de beschikking hield over de dependance. Het gevolg was dat het deel van de nieuwbouw dat bedoeld was ter vervanging van de dependance leeg bleef staan. Het verplegend personeel was met moeite te overreden om te blijven werken in de dependance; de belofte dat ze niet langer dan tot 1 juni 1985 in de villa hoefden te blijven, trok hen over de streep.

Een zelfverzekerde Bastiaans liet zich vervolgens interviewen. ${ }^{27}$ Behalve dat de nieuwbouw niet voldeed, gaf het volgens hem geen pas dat juist hij, die de universiteit zo'n 'wereldnaam' had bezorgd, voor de voeten werd gelopen. Zijn aanblijven als directeur van de Jelgersmakliniek was volgens hem noodzakelijk en onvermijdelijk. 
'Ik wens zelf te kunnen uitmaken hoe ik werk en wanneer ik er mee ophoud. ${ }^{.28}$

De kwestie rond de leegstaande nieuwbouw had het college van bestuur echter alleen maar gesterkt in de overtuiging dat aan de periode-Bastiaans een einde diende te komen. Op 30 december 1982 overhandigde collegevoorzitter Cath persoonlijk de brief aan Bastiaans waarin hij werd ontslagen als directeur van de Jelgersmakliniek. ${ }^{29}$

\section{Meer dan een psychiater}

Ter gelegenheid van zijn afscheid als directeur van de Jelgersmakliniek, werd Bastiaans geïnterviewd voor NRC Handelsblad. Bij die gelegenheid liet hij weten dat hij voorvoelde dat met zijn ontslag een proces was ingezet dat verstrekkende gevolgen had. Hij beweerde dat hij de bedden die hem ter beschikking stonden altijd had gereserveerd voor oorlogsslachtoffers, en dat hij op die manier de Jelgersmakliniek haar bekendheid had gegeven. De jongere generatie psychiaters wilde niet werken volgens zijn methode. Volgens Bastiaans konden ze het werk niet aan, werden ze er zelfs beroerd van. ${ }^{3 \circ}$ Door het ontbreken van een opvolger zou zijn vertrek tot problemen onder de oorlogsslachtoffers leiden.

Bastiaans schetste het beeld dat hem plotseling de wacht was aangezegd en hij 'radicaal moest couperen' in zijn behandelcapaciteit. Hij nam het de universiteit kwalijk dat ze 'de benen onder zijn lijf vandaan sloegen', niet voor hemzelf maar voor zijn patiënten. Bastiaans wilde wat langer de gelegenheid krijgen om zijn werk te doen:

'Dat is niet omdat ik zo graag al dat werk wil blijven doen, maar omdat ik in Nederland een symbolische functie heb. ${ }^{31}$

Bastiaans doelde daarmee op de uitzonderingspositie die hij voor oorlogsslachtoffers had gecreëerd. Zijn kliniek en zijn methode boden hoop op genezing; ze waren een laatste strohalm voor radeloze slachtoffers. Volgens Bastiaans was onder hen nog zeker twintig jaar behoefte aan gespecialiseerde hulp..$^{32}$

Dat de problemen van oorlogsslachtoffers werden ervaren als bijzondere problemen was op dat moment al een traditie van bijna twintig jaar. Het WACrapport had eind jaren zeventig nog een uitroepteken achter deze opvatting gezet: voor oorlogsslachtoffers waren specifieke vormen van hulpverlening vereist. Bastiaans en zijn aanhang wisten de suggestie over te brengen dat met een eventueel vertrek van Bastiaans een noodzakelijk onderdeel van de specifieke hulpverlening aan oorlogsslachtoffers zou verdwijnen. In een maatschappij met een grote compassie voor oorlogsslachtoffers en een nog steeds 
groeiend besef van de desastreuze gevolgen van psychische trauma's, was dat een schrikbeeld. Wat zou er met de oorlogsslachtoffers gebeuren?

De zorgen over het mogelijk verdwijnen van de methode werden nog eens versterkt doordat Bastiaans de mythe had geschapen dat zijn 'revolutionaire' behandeling wetenschappelijk was onderzocht. Dat zijn methode niet werd overgenomen, werd door zijn aanhang gezien als een tekortkoming van andere hulpverleners; het maakte Bastiaans in hun ogen des te belangrijker.

Er zaten wel wat tegenstrijdigheden in deze uitspraken. Volgens Bastiaans werd zijn kliniek overspoeld door aanvragen voor behandeling van oorlogsslachtoffers en kon hij de druk niet aan; er zouden zelfs wachtlijsten zijn. Toch reserveerde hij niet de hele capaciteit van zijn dependance voor oorlogsslachtoffers - in tegenstelling tot wat hij daarover tegen journalisten zei. Ook andere slachtoffers werden er opgenomen en behandeld met LSD of pentothal. En als die methode zo effectief was, waarom was hij dan niet overgenomen door anderen?

Bovendien waren niet alle hulpverleners het erover eens dat er geen alternatieven bestonden voor de methode-Bastiaans. Centrum ' 45 werkte bijvoorbeeld al jaren zónder en had desondanks een volle wachtlijst. Directeur drs. H.A.A. Mourits van het ICODO, een organisatie met als een van de belangrijkste taken het verwijzen van oorlogsslachtoffers naar de juiste hulpverleningsinstantie, verklaarde de onrust uit de loyaliteitsgevoelens jegens Bastiaans:

'Laten we voorop stellen dat Bastiaans ontzettend veel mensen geholpen heeft en dat hij dat al deed in een tijd waarin nog weinig aandacht bestond voor oorlogstrauma's. Maar het is ook weer niet zo dat als hij stopt met zijn behandeling, we onze cliënten niet meer naar een goede behandelaar kunnen verwijzen. Mensen die door de oorlog beschadigd zijn, hebben echter het gevoel dat zij in de kou worden gezet, dat ze gekleineerd worden. En Bastiaans is hun symbool, dat was de man die pal stond voor hun belangen. Die willen zij niet laten vallen. ${ }^{33}$

Patiënten en oud-patiënten waren Bastiaans dankbaar voor hun behandeling. Er bestonden vaak diepgaande loyaliteitsgevoelens; een van hen verhuisde zelfs naar een woning in de buurt van Oegstgeest. ${ }^{34}$ De getuigenissen van deze loyale patiënten vormden een belangrijke schakel in de strijd om het behoud van de methode. Door te dreigen met suïcide deden zij een emotioneel appel op tegenstanders. Bovendien vormden hun getuigenissen het bewijs voor de werkzaamheid van de behandeling. Zij wisten uit eigen ervaring dat de behandeling werkte, die had hen naar eigen zeggen zelfs van de dood gered.

De methode-Bastiaans symboliseerde behalve de hoop op genezing ook de uitzonderingspositie die oorlogsslachtoffers innamen in de psychiatrie. Omdat de methode zo omstreden was, werd de bijzondere status benadrukt van 
degenen die ermee werden behandeld. Het lot van Bastiaans' methode en het lot van oorlogsslachtoffers raakten zo nauw met elkaar verbonden. Wie tegen voortzetting van de methode-Bastiaans was, ontkende het leed van de oorlogsslachtoffers.

Deze nauwe verbondenheid van Bastiaans, zijn methode en het leed van zijn patiënten kwam duidelijk naar voren toen schrijver en dichter Gerrit Komrij een column wijdde aan het vertrek van Bastiaans. Komrij had daarin zonder veel omhaal het $\mathrm{KZ}$-syndroom beschreven als een verzinsel van Bastiaans om patiënten aan zich te binden.

'Als prof. J. Bastiaans er niet was geweest, dan had het $\mathrm{Kz}$-syndroom niet bestaan. Door hem gingen sommige oorlogsslachtoffers zich weer hevig in hun oude leed verdiepen. Door hem kwamen er, dertig jaar na de oorlog, zelfs oorlogsslachtoffers bij die allang vergeten waren ooit oorlogsslachtoffer geweest te zijn. ${ }^{35}$

Komrij betoogde dat Bastiaans' $\mathrm{kz}$-syndroom een zelfbedachte constructie was, bedoeld om zichzelf te onderscheiden van andere psychiaters. Een constructie die hij met veel verve aan de man had weten te brengen door gebruik te maken van de media. Bastiaans was volgens Komrij zó succesvol dat hij na jaren van 'klantenlokkerij' inmiddels iedereen onder behandeling had 'die ooit een kwartier in een openbaar toilet zat opgesloten'.

Dat kwam Komrij te staan op stevige reacties, ook op zijn thuisadres. ${ }^{36} \mathrm{Er}$ volgden ingezonden brieven van sympathisanten en oud-patiënten van Bastiaans. M.H. Brave-Maks, ex-patiënte van Bastiaans, die in de oorlog als particulier secretaresse van prins Bernhard in Londen verbleef, verwoordde dat in een ingezonden brief als volgt:

'Het ergste is dat met deze misdadige laster jegens professor Bastiaans ook een hele bevolkingsgroep - zijn patiënten en anderen van onze generatie - beledigd en vernederd werd; mensen die - zo was hun aard - wél voor anderen maar niet voor zichzelf zullen opkomen. ${ }^{37}$

Uit de reacties bleek dat de column werd gezien als een aanval op Bastiaans én als een ontkenning van het leed van oorlogsslachtoffers. Komrij werd aangewreven niet te geloven dat ervaringen uit de oorlog überhaupt tot problemen konden leiden. ${ }^{38}$

Het beeld van de onschuldige slachtoffers die nauwelijks in staat waren een vuist te maken tegen onrecht was een vals beeld. Opkomen voor zichzelf konden de patiënten van Bastiaans, in tegenstelling tot wat Brave-Maks schreef, heel goed.

Een van hen, Trix Terwindt, zou een belangrijke steun voor Bastiaans wor- 
den in de strijd tegen zijn vertrek. Terwindt was een verzetsstrijdster die als spion slachtoffer was geworden van de Duitse contraspionage. Ze had bijna drie jaar gevangen gezeten, waarvan het laatste jaar in enkele van de zwaarste concentratiekampen. Vanaf $1969 \mathrm{kwam}$ ze bij Bastiaans in behandeling en bleef dat haar hele leven; tot haar dood kreeg zij vrijwel ieder halfjaar een LSDbehandeling of narcoanalyse. Het schiep een innige band en maakte haar tot een krachtige bondgenoot voor Bastiaans.

\section{Portret: Trix Terwindt}

Beatrix, kortweg Trix, Terwindt werd geboren op 27 februari 1911 als jongste van een welgesteld gezin uit Arnhem. Ze behoorde tot de eerste lichting stewardessen van de KLM maar moest eind jaren dertig haar pioniersjaren in de luchtvaart vaarwel zeggen vanwege de oorlogsdreiging. ${ }^{39}$

Terwindt wist in augustus 1942 te vluchten naar Engeland en meldde zich bij de geallieerde strijdkrachten; ze wilde wat doen. ${ }^{40} \mathrm{Ze} \mathrm{kwam} \mathrm{terecht} \mathrm{bij} \mathrm{een}$ organisatie die op het Europese vasteland een ondergronds netwerk in stand hield dat de taak had neergeschoten piloten terug te smokkelen naar Engeland. Terwindt kreeg een opleiding en zou de Nederlandse tak van die ondergrondse organisatie onder haar hoede nemen. ${ }^{41}$

$\mathrm{Na}$ een intensieve training werd ze in de stormachtige nacht van 13 op $14 \mathrm{fe}-$ bruari 1943 gedropt boven de Drentse heide. Haar ontvangstcomité, dat kort voor haar vertrek nog een telegram had gestuurd met de woorden: 'Welcome to the most courageous woman', stond haar op te wachten.

Maar haar ontvangstcomité bleek te bestaan uit Duitse militairen. Terwindt was in een val gelopen van de Duitse contraspionage, waar nog veel meer $\mathrm{Ne}-$ derlandse spionnen in zouden lopen.$^{42}$ De affaire werd bekend als het Englandspiel. Terwindt werd enkele dagen verhoord, zij het onder minder druk dan haar mannelijke medespionnen. ${ }^{43}$ De Duitsers, die nauwelijks konden geloven dat de Britten een vrouw als spion zouden sturen, overwogen zelfs even haar weer vrij te laten. ${ }^{44}$

Ze werd uiteindelijk overgebracht naar de gevangenis in Haaren, waar ze werd samengebracht met de andere slachtoffers van het Englandspiel. ${ }^{45}$ Overigens zonder dat ze hen te zien of te spreken kreeg. Terwindt zat alleen in een cel en de cellen naast haar waren leeg. Die eenzaamheid viel haar zwaar en ze verzocht om een celgenoot of een radio. Ze kreeg beide.

In mei $1944 \mathrm{kwam}$ er een einde aan de relatief gunstige omstandigheden waarin ze gevangenzat. Ze werd overgeplaatst naar de strafgevangenis in Scheveningen en op 10 mei werd ze op transport gezet naar het vrouwenkamp Ravensbrück in Duitsland. ${ }^{46}$ In januari 1945 werd ze overgebracht naar concentratiekamp Mauthausen, een concentratiekamp van de zwaarste categorie.

De gevangenen daar werden tewerkgesteld in een steengroeve, waar het 
grootste deel van de dag werd besteed aan het zinloos verslepen van zware blokken graniet. Het meest berucht was de stenen trap met 186 treden die de gevangenen, met op hun rug de zware granietblokken, moesten beklimmen. Wie viel, stortte met steen en al de treden af, of werd - als hij op een tree bleef liggen - door ss'ers geslagen tot hij dood was of weer op zijn benen stond. Waarna het spel weer opnieuw begon. Op 7 september 1944, vier maanden voor Terwindts aankomst in het kamp, waren op die trap alle uit Haaren afgevoerde slachtoffers van het Englandspiel op beestachtige wijze om het leven gebracht. ${ }^{47}$

Mauthausen betekende voor Terwindt bijna het einde. Haar redding kwam net op tijd toen Himmler eind april 1945 toestemming gaf om alle vrouwelijke gevangenen naar neutraal gebied te vervoeren. Vijf van de zevenenvijftig slachtoffers van het Englandspiel zouden de oorlog overleven, Terwindt was de enige vrouw.

Moeizaam herstel

Drie jaar na de oorlog begon Terwindt zich pas weer een beetje 'mens' te voelen. Hoewel de wonden nooit meer heelden, keek ze niet om in wrok of haat. Dat bleek al toen ze in 1948 vanwege haar rol in het Englandspiel werd opgeroepen om te getuigen voor een enquêtecommissie die het handelen van de Nederlandse overheid in oorlogstijd onderzocht. Ze sprak daar vol lof over een Nederlandse NSB-bewaker in Haaren, die veel brieven van haar en andere gevangenen naar buiten had gebracht. ${ }^{48}$

Dezelfde enquêtecommissie verrichte onderzoek naar de vraag of de regering haar gedeporteerde onderdanen wel voldoende had gesteund, bijvoorbeeld door het sturen van Rode Kruispakketten. Onder overlevenden van de kampen leefde het idee dat als de Nederlandse regering zich meer moeite had getroost en meer en betere pakketten had gestuurd, er aanzienlijk minder slachtoffers waren gevallen. Terwindt vond dat gezeur en liet dat merken middels een ingezonden brief:

'Gij, gevangenen, hebt gij sedert de wapenstilstand getekend werd, nog geen plaats gevonden in de opbouw en groei van ons vaderland om uw energie, die in de oorlog oplaaide, een uitweg te bezorgen? Zit ge nog steeds te wroeten in onverkwikkelijke oorlogsherinneringen: hoe erg gij het had, en hoe miskend gij zijt geweest en nog zijt? [...] Kom de oorlog is voorbij. Zoeken wij niet naar splinters in andermans ogen. Laat ons de betoonde vaderlandsliefde eren met het helpen van behoeftige nabestaanden der gevallenen, en ook met het geestelijke steunen van hen die onze vijanden waren. Laat ons ook nu "groot zijn in de dingen, waarin een klein land groot kan zijn": edelmoedigheid, verdraagzaamheid, naastenliefde; boven alles naastenliefde. [...] "We have great things to do."'49 
Terwindt verkeerde kort na de oorlog nog in de veronderstelling dat haar gezondheid alleen nog maar beter zou worden. Het omgekeerde bleek het geval. Ze kreeg een hartinfarct en werd na enkele jaren gedwongen te stoppen met werken. Hopend op herstel in een rustige omgeving, trok ze voor enkele jaren naar het buitenland. Ze keerde echter nog steeds met een slechte gezondheid weer terug.

Toen haar man in 1968 stierf, ging Terwindts gezondheid nog verder achteruit en kreeg ze last van nachtmerries over haar kampperiode. Ze liep van deskundige naar deskundige, maar geen van hen wist haar te helpen. Ten einde raad belandde Terwindt in 1969 bij Bastiaans. Ze eiste dat hij haar met LSD zou behandelen..$^{50}$

\section{Bastiaans verdient de Nobelprijs}

Het was het begin van een innige band met Bastiaans; twintig jaar lang kreeg Terwindt ongeveer twee keer per jaar een LSD-behandeling, later narcoanalyse. Als 'vaste klant' van Bastiaans kreeg ze zo tientallen behandelingen. Naar eigen zeggen had ze haar leven aan Bastiaans te danken, en deze verdiende volgens haar dan ook de Nobelprijs. ${ }^{51}$

Toen Bastiaans in 1974 benoemd werd tot Ridder in de Orde van de Nederlandse Leeuw, stuurde ze een briefje naar de Rijksuniversiteit Leiden waarin ze erop aandrong dat een afvaardiging van het college van bestuur aanwezig zou zijn bij de uitreiking:

'Voor ons, verzet- en kampslachtoffers, die door hem behandeld worden of genezen zijn is het zeer zeker een voldoening dat hij eindelijk officieel erkenning ondervindt, trots alle tegenwerking, zodat er minder van ons genezen kunnen worden dan de bedoeling was. ${ }^{52}$

Tijdens het debat rond de drie van Breda loofde ze in brieven aan minister Van Agt de goede werken van haar psychiater. Volgens haar was Bastiaans de enige psychiater die zich bekommerd had om het lot van de slachtoffers. Ze bleek nog niets van haar begrip voor de situatie waarin mensen als Aus der Funten, Kotälla en Fischer hadden verkeerd, te hebben verloren..$^{53} \mathrm{Ze}$ pleitte hartstochtelijk vóór vrijlating en verkeerde daarmee, onder oorlogsslachtoffers, in de minderheid. ${ }^{54}$ Het was tekenend voor de onafhankelijke, compromisloze positie die ze zich toeeigende.

Met dezelfde compromisloze houding vocht ze tegen het vertrek van Bastiaans. In reactie op de column van Komrij schreef Terwindt:

'Toen er een jongetje Komrij werd geboren, zat ik alleen in een cel met dichtgemetseld raam, bij kunstlicht, zonder enig contact dan Duitse SD-bewakers, aan mijn $\mathrm{kz}$-syndroom te breien. ${ }^{, 55}$ 
Volgens Terwindt had alleen al het vooruitzicht dat Bastiaans geen behandelingen meer zou doen, enkele voormalig gedeporteerden tot zelfmoord gedreven. ${ }^{56}$ Ze schreefbrieven naar Kamerleden, zocht contact met kranten, liet zich interviewen en schreef ingezonden brieven, waarin ze met gevoel voor theater haar standpunten uiteenzette:

'Ik ben in staat met mijn 76 jaren voor het eerst te demonstreren en een kei als grafsteen op het Binnenhof te leggen met een krans met een lint: "Hier herdenken wij de oorlogsslachtoffers die uit wanhoop een einde aan hun leven maakten, omdat hen door hun lotgenoten, die er beter afkwamen en door de instanties die zich deskundig oordeelden, de kans ontnomen was bevrijd te worden van hun $\mathrm{KZ}$-syndroom."'57

Omdat volgens haar Expogé, de vereniging voor voormalig politieke gevangenen, te weinig deed om Bastiaans te helpen zegde ze haar lidmaatschap op..$^{58}$ Terwindt zocht zelfs een gerucht uit dat Rooijmans' familie lid was geweest van de NSB. ${ }^{59}$ Wanneer dat waar zou zijn, wat niet zo was, zouden ze een extra troef in handen hebben om hem buitenspel te zetten. ${ }^{60}$

Toen een vriend zijn zorgen uitte over haar fragiele gezondheid, beloofde ze eerst de kwestie-Bastiaans tot een goed einde te brengen en dan haar biografie te schrijven. Pas dan zou ze sterven, beloofde ze. ${ }^{61}$ Haar biografie heeft ze nooit kunnen schrijven. Terwindt stierf in 1987 op 76 -jarige leeftijd.

\section{Werkgroep Dependance Jelgersmakliniek}

Bastiaans' aanhang organiseerde zich in december 1982 in de Werkgroep Dependance Jelgersmakliniek (WDJ). Maatschappelijk werkster Gé Bekker was de drijvende kracht en trad op als voorzitter. Bekker werkte vanaf het midden van de jaren zeventig bij de Stichting 1940-1945 als maatschappelijk werkster. Soms zag zij aanvragen voor een Buitengewoon Pensioen (later ook aanvragen voor andere uitkeringen) in haar ogen onterecht afgewezen worden. Ze was steeds meer betrokken geraakt bij de slachtoffers en ondersteunde hen bij aanvragen en beroepsprocedures. Ze kon daarbij altijd rekenen op de hulp van Bastiaans. Nu hij zelf in de problemen zat, nam ze het voor hem op.

Bekker vormde, samen met de arts L. Ligtvoet en de oud-verzetsman $\mathrm{H}$. Neijenhuis het bestuur van de Werkgroep. Dit drietal vertegenwoordigde de kern van Bastiaans' georganiseerde aanhang. Zij kregen de steun van belangenorganisaties voor verzetsstrijders, zoals de Stichting Samenwerkend Verzet (ssv), het Centraal Orgaan Voormalig Verzet en Slachtoffers (covvs), Stichting 1940-1945 en Expogé. De achterban van deze belangenorganisaties werd middels nieuwsbrieven op de hoogte gehouden van de ontwikkelingen. Naast deze organisaties waren er ook individuen, zoals Terwindt, betrokken bij de strijd van de wDJ.

234 ................................ Neergang 
De WDJ pleitte voor 'de continuïteit van de behandeling en de nazorg van oorlogsgetroffenen in het kader van de door prof. Bastiaans ontwikkelde therapieën. ${ }^{62}$ De nood was al jaren hoog volgens de Werkgroep:

'[R]eeds jarenlang wachtlijsten moesten worden bijgehouden voor "opname bij prof. Bastiaans", terwijl er signalen bijvoorbeeld ook vanuit het Maatschappelijk Werk, worden ontvangen, die zonder meer duiden op een sterk vermeerderde toestroom van patiënten lijdend aan enige vorm van oorlogssyndroom, zodat de opname- en behandelcapaciteit [vergroot dient te worden]. ${ }^{63}$

De groeiende stroom patiënten kon niet zonder Bastiaans en zijn methode. Volgens de WDJ was Bastiaans' LSD-behandeling wetenschappelijk onderbouwd, werd deze in binnen- en buitenland erkend en was de effectiviteit van Bastiaans' behandelingen bij ongeneeslijk zieke patiënten overduidelijk. In een brief aan het college van bestuur schreef de WDJ:

'Prof. Bastiaans [heeft] zeer veel publicaties omtrent de door hem ontwikkelde methode van gestuurde LSD-behandeling op zijn naam staan en er werd op dit gebied door hem ook veel wetenschappelijk onderzoek verricht, wetenschappelijk onderzoek waarvan de resultaten eveneens uitvoerig werden gepubliceerd, maar een dergelijke methodiek kan men nu eenmaal nooit uit een boekje leren. ${ }^{64}$

De onderbouwing van de claim dat Bastiaans wetenschappelijk onderzoek had gedaan, bestond uit een verwijzing naar één enkel artikel. Dat was bovendien het artikel waarin Bastiaans het geval-Meester beschreef als een succes. ${ }^{65}$

Feitelijk de enige aanwijzing die Bastiaans en zijn aanhang presenteerden voor het succes van de methode, waren de verhalen van patiënten. Maar die verhalen werden soms wat gunstiger voorgesteld dan ze in werkelijkheid waren. In een brief van de Werkgroep aan de minister van Welzijn, Volksgezondheid en Cultuur (wvc), mr. drs. L.C. Brinkman, werd de behandeling van Terwindt bijvoorbeeld als volgt opgevoerd:

'Na vele jaren van rondzwervingen langs diverse psychiaters en klinieken, na jarenlange versuffing door cederende psychofarmaca en slaapmiddelen (omdat zij werd bestempeld als hysterisch en ongeneselijk), kwam zij uiteindelijk bij prof. Bastiaans terecht, die haar in een jaar tijds, na behandelingen met LSD, weer leerde leven. ${ }^{66}$

Dat wekte de suggestie dat Terwindt in een jaar tijd was genezen. Terwindt was in 1969 onder behandeling gekomen van Bastiaans en bleef bijna twintig jaar lang regelmatig LSD- en pentothalbehandelingen ondergaan. 'Weer leren le- 
ven' was dus voor meerdere uitleg vatbaar. Het betekende in ieder geval niet dat de behandeling voorbij was.

Naast de pogingen van de Werkgroep om Bastiaans' werk als behandelaar nog enige tijd voort te laten duren, ontstond er een nieuw initiatief om zijn werk op wetenschappelijk gebied te behouden. Dat zou moeten geschieden door de instelling van een nieuwe leerstoel. De oud-verzetsstrijder mr. N.J.C.M. Kappeijne van de Coppello had deze taak op zich genomen. Hij had goede contacten in de Nederlandse politiek en was een gewaardeerd lid van Expogé. Kappeijne van de Coppello zat namens Expogé in de FILDIR (Fédération Internationale Libres des Déportés et Internés de la Résistance). Deze internationale koepelorganisatie van oud-politieke gevangenen leek bereid om een bijzondere leerstoel op het gebied van hulp aan oorlogsslachtoffers mede te financieren. De hoogleraar die de leerstoel zou gaan bekleden, kon het wetenschappelijk werk van Bastiaans dan voortzetten. ${ }^{67}$ Kappeijne van de Coppello zocht contact met collegevoorzitter Cath, vertegenwoordigers van de Inspectie voor de Geestelijke Volksgezondheid, Centrum ' 45 en Expogé, en probeerde de leerstoel geregeld te krijgen.

De inspanningen van Kappeijne van de Coppello zouden succesvol blijken, maar voltrokken zich buiten het oog van de media. Bastiaans en de WDJ daarentegen voerden de druk in de media steeds verder op. ${ }^{68}$ De wDJ bepleitte bij het college van bestuur, het Ministerie van WVC, politici en de Inspectie voor de Geestelijke Volksgezondheid de handhaving van Bastiaans' methode. In januari wist Terwindt, na contact te hebben opgenomen met voormalig verzetsstrijdster en KVP-politica dr. M.A.M. Klompé - die ze nog kende van haar middelbare school - een doorbraak te forceren. Klompé had goede banden met het voormalig verzet en de politiek, en bemiddelde tussen het college van bestuur en staatssecretaris Van der Reijden. ${ }^{69}$ De staatssecretaris gaf zijn directeur-generaal, drs. J. van Londen, de opdracht een bijeenkomst te beleggen met alle betrokkenen om de onrust weg te nemen.

Op 4 februari 1983 vond onder voorzitterschap van Van Londen op het Ministerie van wvC een overleg plaats tussen vertegenwoordigers van het bestuur van het Academisch Ziekenhuis Leiden, de Universiteit Leiden en de gemeentelijke psychiatrische instelling Endegeest, de Inspectie voor de Geestelijke Volksgezondheid en Bastiaans. Na afloop ging er een geruststellend telexbericht de deur uit: conform de afspraken in het mei-akkoord, zou Bastiaans aanblijven en zijn methode gehandhaafd blijven. De continuïteit van de zorg aan oorlogsslachtoffers was daarmee volgens alle partijen gewaarborgd. ${ }^{70}$

In de telex werd ook aangekondigd dat de Inspectie voor de Geestelijke Volksgezondheid een advies zou uitbrengen over de problemen rond de Jelgersmakliniek. Die taak werd uitbesteed aan dr.J.B. van Borssum Waalkes, Geneeskundig Hoofdinspecteur voor de Geestelijke Volksgezondheid. Hij voerde 
verdere gesprekken met alle betrokkenen en kwam in juni 1983 met een advies. $^{71}$

Daarin schreef Van Borssum Waalkes dat het aantal oorlogsgetroffenen door natuurlijk verloop weliswaar daalde, maar dat andere groepen zich aandienden: de tweede generatie (kinderen van verzetsstrijders en gedeporteerden), slachtoffers van andere oorlogen, vervolgden uit het buitenland en slachtoffers van andere geweldsmisdrijven en calamiteiten. De Inspectie wilde daarom dat er een 'psychotraumatologisch behandel- en onderzoekscentrum met een sterke universitaire betrokkenheid' kwam. Een nieuw op te richten leerstoel psychotraumatologie met een hoogleraar die was verbonden aan een kliniek, waarborgde de wisselwerking tussen behandeling en onderzoek. Centrum ' 45 was volgens het advies de ideale plek om een dergelijk psychotraumatalogisch onderzoeks- en behandelcentrum te vestigen.

Het advies leek alle partijen tevreden te stellen: Bastiaans kon blijven in zijn dependance en leek met de instelling van een leerstoel tevreden, de universiteit had zicht op een einde van het tijdperk-Bastiaans. De rust leek weergekeerd.

Het advies van de Inspectie was een eerste stap in het integratieproces waarbij oorlogsslachtoffers onderdeel werden van de grotere groep 'ernstig getraumatiseerden'. In het advies van Van Borssum Waalkes werd hun Centrum omgevormd van een kliniek voor oorlogsslachtoffers tot een kliniek voor psychotrauma's. Van Borssum Waalkes was zich bewust van de gevoeligheid van dit punt 'niet in het minst bij de patiëntengroeperingen zelf' en schreef dat het geruime tijd zou duren voordat het zover was. Een projectgroep zou dit proces 'voortvarend, maar tevens behoedzaam en zorgvuldig' moeten begeleiden. ${ }^{72}$

De eerste stap leek gezet. Bastiaans en zijn aanhang vonden het een 'voortreffelijk stuk'. ${ }^{73}$ Dat aanvankelijke enthousiasme werd veroorzaakt doordat in het rapport sprake was van de instelling van een projectgroep, en de WDJ zag daarin een rol weggelegd voor zichzelf. Als lid van de projectgroep zouden ze direct invloed houden op de pogingen tot behoud van de methode-Bastiaans.

Andere belangenorganisaties, zoals het covvs en de ssv, beseften dat het aantal verzetsstrijders in de jaren die volgden door natuurlijk verloop kleiner zou worden. In een reactie op het stuk van Van Borssum Waalkes schreven zij aan de staatssecretaris dat het desondanks belangrijk was dat 'ten hoogste vijftien jaar' de speciale medische behandeling van verzetsstrijders werd gecontinueerd. ${ }^{74}$ Voorlopig wilden verzetsstrijders hun uitzonderingspositie dus niet opgeven. 


\section{Geen uitzonderingspositie voor oorlogsslachtoffers}

$\mathrm{Na}$ het aantreden van Rooijmans op 1 januari 1983 als hoofd van de vakgroep, was Bastiaans doorgegaan zoals hij gewend was; dus ook met het geven van privileges aan bepaalde patiënten. Binnen een maand leidde dat tot een confrontatie.

Bastiaans gaf al jaren op dinsdagmiddag zijn drukbezochte colleges over psychotraumatologie en psychosomatiek en nodigde zijn 'medewerkers' - patiënten, oud-patiënten en sympathisanten - uit daarbij aanwezig te zijn. ${ }^{75}$ Soms deed hij daar een patiëntendemonstratie: patiënten werden uitgenodigd plaats te nemen voor de collegezaal waarna hij ze vragen stelde over hun problematiek. Bij dergelijke demonstratiecolleges stuitte de aanwezigheid van de 'medewerkers' op bezwaren van assistenten en anderen. De aanwezige studenten hadden een geheimhoudingsplicht, dus bij hen bleef de privacy van de patiënt bewaard. Maar wat was de status van de toehorende patiënten?

De weerstand onder collega's had ook nog een andere reden. Bastiaans nodigde wel eens patiënten uit om op te treden als demonstratiepatiënt, die onder behandeling waren bij een andere arts. Soms gebeurde dat zonder overleg met de behandelend arts. Niet alleen ging Bastiaans daarmee soms tegen de wil van de andere arts in, maar tijdens zo'n demonstratie kon de deskundigheid en autoriteit van die arts ook worden ondermijnd. ${ }^{76}$

Een voorbeeld daarvan herinnerde W. Op den Velde zich tijdens een interview. Op den Velde was destijds assistent bij Bastiaans en zou jaren later medisch adviseur worden bij de Stichting 1940-1945. Tijdens zijn assistentschap bij Bastiaans had hij de zorg over een patiënt bij wie het hem niet lukte de oorzaak van de klachten te vinden. Toen hij zich daarmee tot Bastiaans wendde, stelde die voor de man te vragen op te treden als demonstratiepatiënt.

De verbazing was groot toen de man tijdens het college opeens vertelde dat zijn klachten waren begonnen nadat hij was teruggekeerd van de oorlog in Korea, waar hij had gevochten in het Nederlandse leger. Bastiaans vroeg, in de volle collegezaal, aan Op den Velde waarom hij dat niet eerder had verteld. Deze kon niets anders antwoorden dan de waarheid: de patiënt had daar tegenover hem niets over losgelaten. Bastiaans vertelde daarna aan de toehoorders hoe belangrijk het was dat je je als behandelend arts verdiept in de geschiedenis en achtergrond van de patiënt; dat er anders brokken ontstaan. ${ }^{77}$

Overigens had de gekrenkte Op den Velde het er niet bij laten zitten en inzage gevraagd in het militair dossier van de patiënt. Daaruit bleek dat de patiënt ooit was afgekeurd voor militaire dienstplicht, nooit in het leger had gezeten, en dus ook niet in Korea had gevochten. Bastiaans was niet onder de indrukvan Op den Veldes onderzoek en vond hem een slechte verliezer. ${ }^{78}$

Dergelijke optredens en de onduidelijke status van de toehorende patiënten hadden ertoe geleid dat, al voor het aantreden van Rooijmans, assistenten en andere psychiaters van de Jelgersmakliniek weigerden om nog patiënten aan 
Bastiaans te leveren voor een demonstratie. Dat was lastig geweest, aangezien Bastiaans de scepter zwaaide over de Jelgersmakliniek. Met de komst van Rooijmans was daar verandering in gekomen.

In januari 1983, toen Rooijmans al aangetreden was, bleek Bastiaans toch een patiënt die niet onder zijn verantwoordelijkheid viel, te hebben uitgenodigd als demonstratiepatiënt. ${ }^{79}$ Tijdens een onderhoud tussen Bastiaans, Rooijmans en een vertegenwoordiger van de staf van de Jelgersmakliniek werd het incident besproken. ${ }^{80}$

Bastiaans verbaasde zich over de ophef; hij werkte al jaren zo en bij iedereen was genoegzaam bekend hoe hij invulling gaf aan zijn colleges. ${ }^{81}$ Hij zag zijn patiënten als zijn 'medewerkers' en al zijn medewerkers hadden toegang tot zijn collegezaal, ook als toehoorder. ${ }^{82}$ De weerstand onder zijn collega's om patiënten te leveren duidde hij als angst:

'Medewerkers in de kliniek zijn vaak bevreesd dat ik direct of indirect zal ontdekken dat er fouten worden gemaakt bij de behandeling, in het bijzonder bij de zo moeilijke behandeling van oorlogsslachtoffers. ${ }^{83}$

Dat Bastiaans zijn eigen patiënten demonstreerde, stond hem vrij; dat kon hem niet worden verboden. Maar het toelaten van patiënten als toehoorder bij de colleges kon hem wel worden verboden. Rooijmans, die verantwoordelijk was voor het onderwijs van de vakgroep Psychiatrie, liet een brief rondgaan onder het personeel én de patiënten dat het bijwonen van colleges door nietstudenten alleen was toegestaan met een ontheffing van de universiteit; de colleges waren bedoeld voor studenten, niet voor patiënten. ${ }^{84}$

Bastiaans begon een procedure bij het Ambtenarengerecht tegen het bestuur van zijn faculteit, en zocht de publiciteit. ${ }^{85}$ Zijn patiënten die op dat moment op de dependance in behandeling waren, schreven brieven aan het bestuur van de faculteit en het college van bestuur. ${ }^{86} \mathrm{Het}$ was alsof Bastiaans de brieven had gedicteerd: het bijwonen van de colleges droeg volgens de patiënten bij aan het inzicht in hun eigen situatie en daarmee aan het genezingsproces. De voorwaarde die het college had gesteld, het aanschaffen van een toehoorderskaart, werd gezien als een bestraffing van:

\footnotetext{
'degenen die met hun leven en gezondheid veil hebben gestaan voor de vrijheid van het land en waarvoor eminente voorgangers van $U$ voorop gelopen hebben zodat deze Universiteit als eerste in de oorlog werd gesloten. Wij hebben ieder op onze eigen wijze, geleden opdat ook deze Universiteit in vrijheid kan functioneren. ${ }^{87}$
}

De collegeaffaire was een voorbode van wat komen ging. In Bastiaans' ogen werd hij gedwarsboomd in het volhouden van een werkwijze die hij al jaren 
volgde. Hij had zijn colleges ook op een ander moment, exclusief voor zijn patiënten, kunnen houden. Rooijmans had dat ook gesuggereerd, maar Bastiaans wilde niet veranderen. Hij maakte zijn probleem tot een probleem van oorlogsslachtoffers. Twee jaar later zou hij in een interview zelfs beweren dat de door het verbod opgeroepen spanningen bijna het leven van een van zijn patiënten had gekost. ${ }^{88}$

Patiënten en sympathisanten probeerden met een beroep op hun verzetsverleden en de ernst van het leed, af te dwingen wat zij inmiddels als hun belang waren gaan zien. Soms werden daarbij dreigementen niet geschuwd. Dat de universiteit niet zwichtte, was te wijten aan de lange voorgeschiedenis: men was Bastiaans beu. Zo beu dat de collegevoorzitter zelfs liet uitzoeken of de universiteit zelfstandig de emeritaatsleeftijd voor hoogleraren kon verlagen zodat Bastiaans ontslagen kon worden. ${ }^{89}$ Dat liep op niets uit.

De collegeaffaire liet ook zien dat binnen de universitaire psychiatrie het integratieproces het eerst in gang werd gezet; de uitzonderingspositie voor oorlogsslachtoffers werd daar steeds moeilijker houdbaar. Rooijmans was een van de eersten die de consequentie trokken van de opkomst van PTSS. Hij zei hardop dat oorlogsslachtoffers net zo behandeld moesten worden als andere slachtoffers. Een houding waarmee hij zijn tijd ver vooruit was.

Voordat het Ambtenarengerecht de zaak over de collegeaffaire ongegrond zou verklaren, hadden zich alweer nieuwe problemen aangediend. In november 1983 werd duidelijk dat de aangekondigde wet waarmee de leeftijd voor het emeritaat van hoogleraren werd verlaagd van zeventig naar vijfenzestig, in augustus 1984 van kracht zou worden. Om de belofte aan Bastiaans - om zijn aanstelling tot 1 juni 1985 te verlengen - in te lossen moest het college een met redenen omkleed verzoek indienen bij de minister. Het college wilde daarom van de faculteit weten of verlenging noodzakelijk was. De faculteit legde op haar beurt de vraag neer bij degenen die daar het beste zicht op hadden - bij de vakgroep Psychiatrie: bij Rooijmans.

Op 23 januari 1984 vergaderde het bestuur van de vakgroep Psychiatrie over de kwestie. Ter voorbereiding was een conceptadvies rondgestuurd waarin de vraag centraal stond of ontslag van Bastiaans tot onoverkomelijke problemen zou leiden op het gebied van onderwijs, onderzoek of patiëntenzorg. De conclusie in het conceptadvies was dat dat niet het geval was.

Het onderwijs van Bastiaans was beperkt van omvang, anderen konden dat overnemen. Over zijn onderzoekswerkzaamheden werd in verhullende termen gesproken: er werd verwezen naar de jaarverslagen van de faculteit. Daarin was te zien dat Bastiaans nauwelijks publiceerde. En wat hij publiceerde was louter beschouwend van aard; het waren artikelen over allerlei onderwerpen..$^{90}$ Ook de patiëntenzorg kon worden overgenomen door de Jelgersmakliniek.

Aan het beeld van een exclusieve behandelkliniek voor oorlogsslachtoffers, 
zoals Bastiaans dat graag schetste, zou een einde komen. Oorlogsslachtoffers waren nog steeds welkom op de Jelgersmakliniek, maar de universiteit zou naar buiten toe niet meer de indruk wekken dat ze als aparte groep werden behandeld, noch dat ze aanspraak konden maken op een speciale behandelmethode. De vakgroep concludeerde dan ook dat een eventueel vertrek van Bastiaans niet tot ernstige schade aan onderwijs en onderzoek zou leiden. Zelfs niet tot schade aan de patiëntenzorg. ${ }^{91}$

Nadat Rooijmans de vergadering had geopend, kreeg Bastiaans als eerste het woord. Hij was woest, voelde zich miskend en herinnerde het bestuur nogmaals aan de gemaakte afspraken van mei 1982. Zijn onderwijs werd gewaardeerd door zijn studenten, en zijn patiënten waren allemaal zeer tevreden over hun behandeling en de resultaten daarvan. ${ }^{92}$ In de notulen van de vergadering valt te lezen hoe Bastiaans zijn tirade besloot met een dreigement aan het bestuur:

'Bastiaans wijst er voorts op dat grote groepen uit het voormalig verzet en ook de werkgroep Dependance met een groot aantal leden, gewapende mensen, achter hem staan en wat die er wel niet van zouden vinden en de vakgroep zouden kunnen aandoen. ${ }^{93}$

Toen hem dat commentaar opleverde, antwoordde Bastiaans dat het geen dreigement was 'maar een realiteit waarmee rekening moet worden gehouden'. ${ }^{94}$ Bastiaans' dreigende taal had geen effect: het conceptadvies werd met de grootst mogelijke meerderheid aangenomen. Rooijmans werd gesteund door de leden van de vakgroep Psychiatrie, het faculteitsbestuur en het college van bestuur. Rooijmans was de boodschapper van een breed gedragen beslissing. De universiteit had laten merken dat ze Bastiaans niet meer nodig had.

Het college voelde zich echter, ondanks het advies van de vakgroep, verplicht de overeenkomst die in 1982 was gesloten met Bastiaans te respecteren en zijn aanstelling te verlengen. $Z$ e deed dat echter wel met de minimale termijn; in februari 1984 bracht collegevoorzitter Cath Bastiaans het bericht over dat zijn aanstelling per 1 juni 1985 zou aflopen. ${ }^{95}$

Daarmee leek het einde van Bastiaans' carrière en methode in zicht. Maar Bastiaans en zijn aanhang wilden verdere verlenging en waren niet van plan zich door de universiteit te laten tegenhouden. De enige manier waarop verdere verlenging kon worden gerealiseerd was door ingrijpen van hogerhand. Wanneer de politiek overtuigd raakte van de noodzaak tot behoud van Bastiaans en zijn methode, kon wellicht een oplossing worden geforceerd. De aandacht van de wDJ richtte zich meer en meer op media en politici. 
Een politieke oplossing

Het werk van de WDJ leidde ertoe dat er op 12 juli 1984 in de Tweede Kamer schriftelijke vragen werden gesteld. De Kamerleden A.M. Lucassen-Stauttener en D.J.D. Dees (beiden van de VVD) zagen in het ontslag van Bastiaans een 'ernstig gevaar voor de kwaliteit en de continuïteit van de behandeling van oorlogsen andere geweldsgetroffenen'. ${ }^{\prime 6}$ De Kamerleden vroegen staatssecretaris Van der Reijden om een verzekering dat 'de specifieke zorg en bijzondere behandeling door prof. Bastiaans', ook voor de toekomst gehandhaafd bleef.

In september antwoordde Van der Reijden de Kamerleden dat hij uiteraard veel belang hechtte aan een goede hulpverlening voor oorlogs- en geweldsgetroffenen. Hij splitste de vragen op in twee onderdelen.

Het eerste was de voortzetting van Bastiaans' specifieke behandelmethode. Over de voortzetting daarvan wilde de staatssecretaris geen valse verwachtingen wekken: Bastiaans' ontheffing voor het gebruik van LSD was een uitzondering geweest, en het was zeer de vraag of die na het vertrek van Bastiaans nogmaals zou worden gemaakt. Over de vraag of en voor welke groepen de LSD-behandeling verantwoord was, zou de staatssecretaris de Gezondheidsraad om een advies vragen.

Het tweede onderdeel betrof de continuïteit van de hulpverlening aan oorlogsslachtoffers, waar in de vragen van de Kamerleden sprake van was geweest. Van der Reijden gaf een projectgroep de opdracht antwoord te geven op de vraag wat er met de hulpverlening aan deze groep moest gebeuren.

Op 18 september 1984 werd deze projectgroep, de Projectgroep Behandeling Oorlogs-en Geweldsgetroffenen (PBOG), door staatssecretaris Van der Reijden geinstalleerd met als opdracht:

'het ontwikkelen van een, in de gezondheidsregio Leiden gelegen, goed functionerend, wetenschappelijk verantwoord, samenstelsel van voorzieningen voor in Nederland woonachtige personen, die tengevolge van diepingrijpende, langdurige marteling, gijzeling of oorlogshandeling ernstig psychotraumatisch gelaedeerd zijn geraakt'. ${ }^{97}$

Naast een algemene oplossing voor de hulp aan lijders aan een psychotrauma, werd van de projectgroep ook een interim-advies verwacht, uit te brengen vóór i juni 1985, over de voortzetting van Bastiaans' werkzaamheden.

In zijn speech bij de installatie van de PBOG roemde Van der Reijden Bastiaans' baanbrekende werk: hij zou gewezen hebben op het bestaan van het $\mathrm{Kz}$ syndroom en had in woord en daad de hulpverlening aan de patiënten op gang gebracht. ${ }^{98}$ Ondanks deze lof beloofde de samenstelling van de projectgroep weinig goeds voor de voortzetting van Bastiaans' werkzaamheden. De leden bestonden uit afgevaardigden van de Leidse universiteit en Endegeest. Lid waren prof.dr. D. Schweizer en dr. G. Dallinga (beiden bestuurslid van het Acade- 
misch Ziekenhuis Leiden), mr. C.B.M. Bruens (namens het collegevan bestuur), dr. J.B. van Borssum Waalkes (hoofdinspecteur van de Inspectie voor de Geestelijke Volksgezondheid), drs. J.H.M. Peters (directeur Centrum '45) en Rooijmans. Als de staatssecretaris had gewild dat de methode-Bastiaans doorgang zou vinden, dan had hij geen ongelukkiger commissie kunnen samenstellen; met al deze partijen lag Bastiaans overhoop. Het enige lichtpunt voor Bastiaans was dat het voorzitterschap in handen was van prof. B.S. Polak, met wie hij samenwerkte in het cVv.

De WDJ, die had verwacht een lid aan de projectgroep te mogen leveren, was teleurgesteld. Ze verwachtte, terecht, weinig van het interim-rapport en zag de gang van zaken als een gebrek aan erkenning voor het leed van de slachtoffers. In een brief aan de verantwoordelijke minister schreef een lid van de WDJ:

\footnotetext{
'Want wat hier gebeurt, is even absurd en even misdadig als het verbieden van het gebruik van penicilline... op grond van het feit dat men mogelijk een hekel zou hebben aan Sir Alexander Fleming (de man die het penicilline heeft ontdekt). Ook al schaart het gehele voormalige verzet (kunt $U$ zich gezagsgetrouwere mensen voorstellen?) zich achter deze slachtoffers van oorlog en geweld, ook al regent het verzoekschriften, het lijkt dat het vonnis al is geveld: Bastiaans moet weg en Bastiaans' therapie moet verdwijnen! Het politiek doodvonnis over Bastiaans en over al zijn patiënten is uitgesproken. Op 1 juni aanstaande vindt "de executie" plaats.
}

Maar ik zal dan naast Bastiaans staan. ${ }^{99}$

Behalve berichten in de landelijke media en brieven aan politici had de Werkgroep middels een nieuwsbrief organisaties van oud-verzetsstrijders op de hoogte gehouden. De nieuwsbrieven werden afgedrukt in De Koerierster, het verenigingsblad van de Landelijke Kontakt-Groep verzetsgepensioneerden (LKG), en in Aantreden, het verenigingsblad van Expogé voor voormalig politieke gevangenen. ${ }^{100}$ De strategie om onrust te wekken onder verzetsstrijders werkte.

De voorzitter van de Stichting Samenwerkend Verzet, P. Molthof, had middels een ingezonden brief in Elsevier al laten weten: 'het gehele georganiseerde, gebundelde verzet staat achter prof. Bastiaans en wenst dat zijn werk wordt voortgezet. ${ }^{101} \mathrm{En}$ in het eerste nummer in 1985 van De Koerierster - Bastiaans had nog minder dan een halfjaar te gaan op de dependance - stond een kort bericht over de aanstaande sluiting van de dependance, met daaronder een noot van de redactie: 
'De schrik is vele oorlogsslachtoffers om het hart geslagen. De Dependance van de Jelgersmakliniek voor mensen met een oorlogssyndroom dreigt te worden gesloten. Komen zij nu terecht op de grote hoop psychiatrische patiënten, of kunnen zij blijven rekenen op de persoonlijke aanpak waarmee prof.dr. J. Bastiaans wereldbekendheid verwierf ?'102

Bastiaans zocht contact met prominente voormalig verzetsstrijders als W.Ch. J.M. van Lanschot, L. Frequin, Pim Boellaard en Nico Wijnen. ${ }^{103} \mathrm{Na}$ enkele gesprekken werd het idee geboren om samen met J.F. Beckman, lid van het hoofdbestuur van Expogé, belangenorganisaties voor verzetsmensen en oorlogsslachtoffers te mobiliseren, en een gezamenlijke oproep te doen aan de Kamerleden. ${ }^{104}$ Aan de belangenorganisaties werd gevraagd een brief te ondertekenen die zou worden aangeboden aan de vaste commissie voor wVC van de Tweede Kamer der Staten-Generaal. Deze commissie, bestaande uit leden van verschillende partijen, ontfermde zich onder andere over de problemen van oorlogsslachtoffers.

Eind december 1984 ontving de commissie de brief, die was ondertekend door tweeëntwintig organisaties, waaronder het covvs, ssv, Expogé en Stichting 1940-1945. ${ }^{105}$ In de brief werd de angst uitgesproken dat de methode die Bastiaans had ontwikkeld verloren zou gaan als diens aanstelling per 1 juni 1985 ten einde liep.

Behalve de brief van de organisaties werd een lijst met vijfenveertig adhesiebetuigingen voor het initiatief van Kappeijne van de Coppello aan de voorzitter van de commissie gestuurd. Onder de ondertekenaars waren onder anderen enkele oud-patiënten, maar ook de hoogleraren psychiatrie dr. M. Zeegers en dr. G.A. Ladee, en historicus dr. Lou de Jong. In de begeleidende brief werd nog eens de bijzondere status van de oorlogsslachtoffers benadrukt en hoe daaraan een einde zou komen wanneer Bastiaans zijn werk moest neerleggen:

'Daarna worden er problemen geschapen voor deze mensen, die buiten de gewone psychiatrische behandeling vallen. Zij zijn uiterst kwetsbaar, zullen zich in de steek gelaten voelen, zowel degenen die nog in behandeling zijn als zij, die nog op wachtlijsten staan. Het meest in de knel komen dan ook de exkampkinderen. [...] Een andere methode zou voor deze mensen, bijvoorbeeld uit Japanse kampen [...] fatale gevolgen kunnen hebben.' ${ }^{106}$

Bastiaans moest nog tot 1 juni 1987 de mogelijkheid hebben om door tewerken. Hij zou dan de gelegenheid hebben een opvolger in te werken en de jarenlange ervaringen met zijn methode' 'systematisch en wetenschappelijk verantwoord te boek te stellen'. Dat moest in de dependance gebeuren; dat was een uitstekende plek voor oorlogsslachtoffers, die, zoals de brief vermeldde, 'zich, bij voorkeur, niet gaarne in een ziekenhuis bevinden waarvan de te kleine patiën- 
tenkamers associaties met gevangeniscellen kunnen opwekken'. ${ }^{107}$ De methode-Bastiaans was voor oorlogsslachtoffers onmisbaar.

Behalve dat politici direct benaderd werden, werd ook de hulp van de pers ingeschakeld. Bastiaans gebruikte bijvoorbeeld Joris van de Berg, journalist van Vrij Nederland, die bij hem in behandeling was voor een alcoholverslaving, om een interview in het blad te krijgen. ${ }^{108} \mathrm{Het}$ plan slaagde en Bastiaans kon in januari 1985 zijn verhaal doen bij Nederlands bekendste en als kritisch bekendstaande journalist, Ischa Meijer. ${ }^{109}$

In het interview vertelde Bastiaans dat hij altijd het belang van zijn patiënten bovenaan had geplaatst. Hij had daarvoor zelfs feestjes aan zich voorbij laten gaan. Door die overgave was hij nooit in staat geweest om een opvolger in te werken. Rooijmans en de universiteit wilden hem nu niet de kans geven nog even door te werken en wilden bovendien Bastiaans' toonaangevende dependance verbouwen tot een bibliotheek.

Twee maanden later gaf Rooijmans in een interview met journalist Heerma van Voss zijn kant van het verhaal. Hij schuwde daarin de directe aanval niet; hij wees erop dat de methode-Bastiaans niet wetenschappelijk was geëvalueerd. Hij wees op Bastiaans' vorderende leeftijd en het risico op ongelukken. ${ }^{110}$ Hij noemde de slechte staat van de dependance en de onvrede onder het personeel. En waarom, vroeg Rooijmans zich af, zou Bastiaans in die twee jaar verlenging opeens wel een opvolger kunnen inwerken, en in de voorgaande twintig jaar van zijn hoogleraarschap niet?

Naar aanleiding van de brieven en de onrust onder verzetsstrijders besloot de vaste commissie op 26 februari 1985 enkele verontruste betrokkenen, onder wie Terwindt, uit te nodigen. Op een ter zitting uitgereikt pamflet noemde de WDJ de methode 'revolutionair', 'baanbrekend en van grote wetenschappelijke betekenis', en liet weten dat er werd gevreesd voor gevallen van suïcide bij stopzetting. Sprekers lieten weten zich 'verkocht en verraden' te voelen. ${ }^{111}$

'Het gaat hier om een grote groep gekreukelde en zeer kwetsbare mensen, die straks nergens meer naar toe kunnen. We moeten rekening houden met veel plotselinge sterfgevallen, niet zelden het gevolg van zelfmoord. ${ }^{, 12}$

Ook verzetsstrijder Piet Coumou, secretaris van de ssv, sprak op de bijeenkomst met de vaste commissie. Hij wist al wat de conclusie van het interimrapport zou worden:

'Bastiaans moet weg uit Leiden, Bastiaans moet verdwijnen... en met hem verstoot men zijn therapie, waaraan zo velen, in letterlijke zin, hun redding en levensgeluk hebben te danken. ${ }^{113}$ 
De bijeenkomst haalde het Nos Journaal, waarin Bastiaans nog eens olie op het vuur gooide door te beweren dat hem door de universiteit een zwijgplicht was opgelegd. Dat de universiteit direct een persbericht liet uitgaan waarin dat werd ontkend, hielp nauwelijks.

De volgende dag sprak de vaste commissie met de staatssecretaris, en bleek het effect van de pleidooien van de dag ervoor. Ook bij de Kamerleden bestond nu het idee dat de methode-Bastiaans een noodzakelijke behandeling was met uitzonderlijke eigenschappen. Kamerlid M.J.C. Worrell ( $\mathrm{PvdA}$ ) vond dat 'nu vaststaat dat de behandelingsmethode van prof. Bastiaans voor velen de enige oplossing betekent', die methode dan ook maar moest blijven bestaan ${ }^{114} \mathrm{Ka}$ merlid Kraaijeveld-Wouters (CDA) wenste een omgekeerde bewijslast voor de methode-Bastiaans. Bastiaans hoefde geen bewijzen voor de werkzaamheid van zijn methode op tafel te leggen; anderen moesten maar aantonen dat zijn methode niet werkte.

In zijn reactie probeerde staatssecretaris Van der Reijden voorzichtig een tegenwoord te bieden. Hoe zat het met de indicatiestelling, wanneer kreeg iemand de methode-Bastiaans? En was het in farmacologisch opzicht wel verantwoord om pentothal toe te dienen? Van der Reijden deed in het overleggeen toezeggingen; hij wilde wachten met verdere stappen totdat de projectgroepPolak zijn interim-rapport had uitgebracht, en de Gezondheidsraad zijn advies over de toepassing van LSD. ${ }^{115}$

In het debat met de Kamerleden werd Van der Reijden duidelijk dat de Kamerleden geen genoegen zouden nemen met een afscheid van Bastiaans per 1 juni 1985. Begin maart vond daarom in huize Polak een bespreking plaats tussen Hoofdinspecteur Van Borssum Waalkes, Polak, Kappeijne van de Coppello en Bastiaans om de voorwaarden uit te werken waaronder Bastiaans verder kon werken, buiten de rook van de universiteit. ${ }^{116} \mathrm{De}$ staatssecretaris probeerde zo een oplossing te vinden voor het probleem. Maar nog voordat die geregeld was, wisten Bastiaans en zijn achterban een politieke oplossing te forceren.

De leden van de vaste commissie waren na de hoorzitting en het debat met de staatssecretaris niet gerustgesteld. G.M.P. Cornelissen (CDA), een van de leden van de vaste commissie, liet zich in 1988 interviewen over de kwestie. Ze vertelde toen dat ze wist dat het gebruik van LSD in de psychiatrie ongebruikelijk was. Ze had ook brieven ontvangen van psychiaters die haar wezen op de gevaren van het gebruik van LSD. Maar wat nu als deze psychiaters zich vergisten of uit 'broodnijd' Bastiaans zwart probeerden te maken? Tegenover de signalen van psychiaters stonden de talloze brieven van verzetsmensen en oudpatiënten die zwoeren bij Bastiaans' behandeling. Cornelissen liet zich door de laatste overtuigen: 
'Voor mij kwam de definitieve omslag toen ik letterlijk bestookt werd met brieven van $[. .$.$] Trix Terwindt [...] die me schreef dat de methode-Bastiaans voor$ deze mensen en ook voor haarzelf, de laatste reddingsboei was geweest. ${ }^{117}$

Ook kamerlid Worrell (PvdA) ontving gemengde berichten, maar liet zich overtuigen door de brieven van de sympathisanten. ${ }^{118}$ Toen op 27 maart 1985 in de Tweede Kamer een debat plaatsvond over de hulpverlening aan oorlogsslachtoffers, kwam daarin onder andere de problematiek rond de voortzetting van Bastiaans' werk aan de orde. Worrell nam het woord:

'Wie erover hoort doch zich nauwelijks een voorstelling kan maken van de verschrikkingen die deze slachtoffers hebben doorgemaakt, verliest het recht om hun voor te schrijven welke hulpverlening voor hen geëigend is. ${ }^{119}$

De redenering van Worrell liet zien hoe groot het ontzag voor het leed van oorlogsslachtoffers was: wie zich hun leed niet kon voorstellen moest simpelweg zwijgen. Onder zijn aanvoering werd een motie ingediend waarin werd vastgelegd dat, aangezien er nog geen opvolger was, de regering maatregelen nam om de 'behandelingswijze van en door professor Bastiaans' zonder onderbreking ook na 1 juni 1985 te continueren. Uiterlijk per 1 juni 1987 moest in de opvolging van Bastiaans zijn voorzien, zodat zijn behandelwijze kon worden voortgezet. ${ }^{120}$ De motie van Worrell werd, met uitzondering van de Centrum Partij, met algemene stemmen aanvaard: de leden van de Tweede Kamer konden zich de verschrikkingen goed voorstellen en wisten ook welke behandeling daarbij moest worden toegepast.

Onder aanvoering van Kamerlid Lucassen-Stauttener werd een tweede motie ingediend. Daarin stond dat het wetenschappelijk werk van Bastiaans van groot belang werd geacht voor de toekomstige hulpverlening. Echter, per 1 juni 1985 zou dat werk niet zijn voltooid. Het kabinet werd opgeroepen maatregelen te treffen en initiatieven te ondersteunen om dat alsnog mogelijk te ma$\mathrm{ken}$. Deze motie werd met algemene stemmen aangenomen.

Nog voordat de projectgroep-Polak met een interim-advies was gekomen, nog voordat de Gezondheidsraad een uitspraak had gedaan over de LSD-therapie, was het voortbestaan van Bastiaans' werkzaamheden geregeld. Het was een overwinning voor Bastiaans en zijn achterban. Voorlopig bleef de methodeBastiaans, en daarmee de uitzonderingspositie van oorlogsslachtoffers, gehandhaafd. ${ }^{121}$ 


\section{Conclusies}

Sinds begin jaren zeventig namen oorlogsslachtoffers een bijzondere plaats in, zowel binnen de psychiatrie als daarbuiten. Er was een speciale kliniek voor oorlogsslachtoffers, er waren speciale uitkeringen én er was Bastiaans met zijn methode. Maar in de jaren zeventig hadden nieuwe groepen traumaslachtoffers hun intrede gedaan, en de psychiatrie erkende ook het leed van dié slachtoffers. Er werd een nieuwe term geïntroduceerd: 'posttraumatische stressstoornis' ( PTSs), waardoor het onderscheid in het leed van al die groepen kwam te vervallen. Dat zette een integratieproces in gang, dat een einde maakte aan de uitzonderingspositie van oorlogsslachtoffers.

De collegeaffaire was een van de eerste uitingen van dat integratieproces. Rooijmans was, conform de heersende opvattingen in de psychiatrie, niet bereid de ene patiënt beter of anders te behandelen dan de andere; patiënten met vergelijkbare problemen kregen een vergelijkbare behandeling. Dus geen bijzondere privileges voor oorlogsslachtoffers. Zijn standpunt was, zoals gezegd, zijn tijd ver vooruit; buiten de muren van de universitaire Jelgersmakliniek namen oorlogsslachtoffers nog steeds een uitzonderingspositie in. De spanning die deze scheefgroei veroorzaakte, werd duidelijk met Bastiaans' dreigende vertrek.

De maatschappelijke gevoeligheid voor de speciale noden van oorlogsslachtoffers bestond nog steeds. Bastiaans en de Werkgroep Dependance Jelgersmakliniek hadden daar handig gebruik van gemaakt. Door de methodeBastiaans te presenteren als een noodzakelijke behandeling waarmee zelfs in de ernstigste gevallen oorlogsslachtoffers geholpen konden worden, wisten zij de publieke opinie te mobiliseren.

De politici lieten zich leiden door de emotionele getuigenissen van patiënten en door Bastiaans' status. Met een beroep op het bijzondere leed van de patiënten en het vertrouwen in Bastiaans' kundigheid werd uitstel verleend. Niet omdat ook andere slachtoffers daarmee geholpen konden worden; niet omdat er geen alternatieve behandelingen waren; niet omdat andere hulpverleners de noodzaak ertoe voelden; niet omdat er hard wetenschappelijk bewijs lag voor de effectiviteit van de behandeling; uitsluitend en alleen omdat oorlogsslachtoffers hun uitzonderingspositie niet wilden opgeven, en vrijwel de gehele Tweede Kamer hun die niet wilde ontnemen. 


\section{Het einde van de methode-Bastiaans}

\footnotetext{
'Wat moet er dan met de oorlogsslachtoffers gebeuren? Voor die LSD vinden ze misschien over een tijd wat anders. Maar professor Bastiaans is niet te vervangen. Echt niet!'

ANONIEME PATIËNT, 1986 .
}

\section{Inleiding}

Sinds 1966 waren er nog maar twee Nederlandse psychiaters die een ontheffing hadden voor het toepassen van LSD, en vanaf 1977 was Bastiaans de enige. Verspreid over de rest van de wereld werkte er nog een handvol psychiaters met het middel, maar ook zij vormden een uitzondering. De psychiatrie had sinds de jaren zestig niet stilgestaan, en andere vormen van behandeling hadden hun intrede gedaan: gedragstherapie, groepstherapie, kortdurende psychotherapieën en medicijnen. Midden jaren tachtig was de LSD-therapie al twintig jaar een anachronisme. Bastiaans ging echter onverdroten voort met zijn LSD-behandelingen.

Dat deze situatie zo lang kon voortduren was te danken aan het bondgenootschap van Bastiaans en de verzetsstrijders. Bastiaans en zijn aanhang hadden de suggestie overgebracht dat de methode-Bastiaans in sommige gevallen de enige manier was om de bijzondere problemen van oorlogsslachtoffers te laten verdwijnen. Om die uitzonderingspositie in stand te houden, had de Tweede Kamer vrijwel unaniem vóór de moties van de Kamerleden Worrell en Lucassen-Stauttener gestemd, waarin het behoud van de methode-Bastiaans werd bepleit.

De verlenging van Bastiaans' aanstelling kwam daardoor in het teken te staan van zijn opvolging, van het behoud van zijn methode. Van der Reijden had daar in het debat voorafgaand aan het indienen van de moties een belang- 
rijke opmerking over gemaakt: de staatssecretaris kon noch voor de opvolging van Bastiaans noch voor de afronding van zijn wetenschappelijk werk zorg dragen. Wilde de methode-Bastiaans bewaard blijven, dan moest Bastiaans een opvolger aanwijzen en inwerken en zijn ervaringen op papier zetten. Dat kon niemand anders voor hem doen. De staatssecretaris kon Bastiaans financieel steunen en oplossingen aandragen bij praktische problemen - dat deed hij ook - maar het was Bastiaans zelf die zijn methode veilig moest stellen voor de toekomst.

Bastiaans had dat beaamd. Hij had zijn werk eerder willen vastleggen en overdragen, maar had altijd voorrang gegeven aan de behandeling van zijn patiënten. De nood onder hen was te hoog geweest. De achterstand die daardoor was ontstaan, zo was de gedachte van Bastiaans en zijn achterban, zou in de periode tot 1 juni 1987 worden ingehaald. Deze gedachte was door de Kamerleden overgenomen en in de moties vastgelegd. Bastiaans kon nu zijn jarenlange werk te boek stellen en een opvolger inwerken. Als dat eenmaal was gebeurd, zou een stichting een leerstoel beheren die zijn werk zou voortzetten.

Was het mogelijk om in twee jaar tijd te doen wat in twintig jaar niet was gelukt?

\section{Doorstart met overheidssteun}

Staatssecretaris Van der Reijden had al voordat de moties werden ingediend, pogingen ondernomen om Bastiaans te laten doorwerken. Van Borssum Waalkes, hoofdinspecteur van de Inspectie voor de Geestelijke Volksgezondheid, had daartoe gesprekken gevoerd met Bastiaans. De oplossing die daaruit was voortgekomen - voortzetting van zijn werkzaamheden bij een particuliere stichting in Den Haag - had Bastiaans afgewezen; ${ }^{2}$ hij vond het te ver reizen. Die afwijzing maakte het de staatssecretaris lastig, want Endegeest, de eigenaar van de dependance, had sloopplannen klaarliggen en wilde die na 1 juni in werking zetten.

De staatssecretaris vond echter een manier om Endegeest te stoppen. Zowel de vergunning als de subsidie voor de sloop moest worden afgegeven door het Ministerie van wvc, het ministerie van Van der Reijden. ${ }^{3}$ Het bood Van der Reijden een goede onderhandelingspositie en hij wist Endegeest te overreden de dependance nog een periode te verhuren. ${ }^{4}$

Toen de locatie geregeld was, moest nog een beherende organisatie worden gevonden. Voor het uitvoeren van Bastiaans' behandelingen waren uitgebreide faciliteiten nodig (slaap- en behandelkamers) en personeel. Centrum ' 45 leek de aangewezen organisatie. Op de dag van de stemming schreef de staatssecretaris daarom een verzoek aan het bestuur van Centrum ' 45 - een idee van Polak, de voorzitter van de overheidscommissie ( $\mathrm{PBOG}$ ) die zich onder andere boog over de voortzetting van Bastiaans' werkzaamheden - waarin hij vroeg of 
het Centrum de 'bestuurlijke verantwoordelijkheid' wilde dragen voor Bastiaans. ${ }^{5}$ Die zou dan nog twee jaar de gelegenheid krijgen om een opvolger in te werken en zijn wetenschappelijk werk af te ronden:

'genoemde termijn van twee jaar, ingaande 1 juni a.s., is voor mij onder geen beding verlengbaar, waar het de behandeling door prof. Bastiaans zelf in het kader van Uw stichting betreft. Ik wil daarover geen onduidelijkheid laten bestaan. $^{.6}$

Binnen het Centrum was de weerstand tegen Bastiaans 'collectief groot', zo schreef directeur Peters aan zijn bestuur in een nota over de vraag van de minister. Dat had deels nog te maken met de problemen uit het verleden bij de oprichting van Centrum ' 45 , deels met de vrees dat Bastiaans, net als hij bij de universiteit had gedaan, de publiciteit zou zoeken. ${ }^{7}$

Directeur Peters zag ook voordelen. Onder oorlogsslachtoffers bestond groot vertrouwen in Bastiaans en veel minder in het Centrum. Als het Centrum Bastiaans onderdak bood, zou mogelijk het vertrouwen dat Bastiaans genoot, overslaan op het Centrum. In een notitie aan het bestuur van het Centrum schreef Peters:

'Wij nemen daarmee goodwill over, want die hebben wij (behoudens oud-clienten) minder dan Bastiaans. ${ }^{8}$

Bovendien vond Peters de narcoanalyse in sommige gevallen een optie. ${ }^{9} \mathrm{Hij}$ schatte de positie van het Centrum goed in. In reactie op het advies van Van Borssum Waalkes hadden het covvs en de ssv, twee belangenorganisaties voor voormalig verzetsstrijders, een nota opgesteld over het 'medisch circuit voor deelnemers aan het verzet'. Dat circuit bestond voor beide organisaties uit de Jelgersmakliniek, de polikliniek waar Hers werkte, de medisch adviseurs van de Stichting 1940-1945 en de BPR. Centrum ' 45 werd er niet in genoemd..$^{10}$

Bestuurlijk onderdak verlenen aan Bastiaans, leek dan ook een buitenkans. Het ging om een periode van twee jaar; dat was een overzichtelijke termijn. Toen de staatssecretaris beloofde dat de extra behandelplekken die voor Bastiaans werden gecreëerd ook ná diens vertrek beschikbaar zouden blijven voor het Centrum, ging het bestuur overstag. ${ }^{11}$ Het betekende voor Centrum ' 45 de vervulling van de al langer bestaande wens tot uitbreiding van het behandelaanbod. ${ }^{12}$

Als boodschapper van het goede nieuws werd de projectgroep van Polak gebruikt. Die bood in mei 1985 haar interim-rapport aan aan staatssecretaris Van der Reijden. De projectgroep concludeerde dat alle betrokken instanties van oordeel waren dat voortzetting van Bastiaans' werk binnen de universitaire 
psychiatrische kliniek na juni 1985 niet noodzakelijk was, onmogelijk en zelfs onwenselijk. Alleen om aan de dringende wens van patiënten, ex-patiënten en verzetsorganisaties tegemoet te komen werd zijn werk voortgezet:

'[V]an toekomstige patiënten kan worden aangenomen dat zij c.q. velen van hen zullen wensen door professor Bastiaans behandeld te kunnen worden. ${ }^{.13}$

Op 28 juni 1985 nam de universiteit afscheid van Bastiaans. Tijdens een klein symposium werd de film Begrijpt u nu waarom ik huil... vertoond. ${ }^{14}$ De aanwezige afgevaardigden van verzetsorganisaties waren onder de indruk en zelfs ontroerd toen de hoogleraar in de zaal verscheen. ${ }^{15} \mathrm{Na}$ zijn afscheid van de universiteit ging Bastiaans een paar maanden met vakantie.

\section{Bemoeienis met de methode}

Het Centrum moest ondertussen alle zeilen bijzetten om Bastiaans van start te kunnen laten gaan. Het voormalig personeel van de dependance, dat in dienst was van Endegeest, had na Bastiaans' vertrek de keuze gekregen om te blijven werken in de dependance of te gaan werken in de nieuwbouw. Het personeel koos massaal voor het laatste. Dat betekende dat het Centrum nieuw personeel moest werven, en dat bleek niet zo eenvoudig. In oktober 1985 kon Bastiaans daarom wel beginnen met poliklinische behandelingen, maar voor de behandelingen met pentothal en LSD was meer en beter gekwalificeerd personeel nodig. Het duurde dus nog even voordat 'de methode-Bastiaans' een doorstart kon maken.

Er waren nog meer redenen waarom de LSD- en pentothalbehandelingen niet van start gingen. Bastiaans had tijdens zijn hoogleraarschap ongestoord zijn gang kunnen gaan; de ontheffing voor het gebruik van LSD was al die jaren routinematig verlengd, en voor het gebruikvan pentothal had hij geen vergunning nodig gehad. Zolang er geen klachten waren of andere signalen dat er iets mis was, was er voor de Inspectie geen aanleiding geweest om de behandelingen van Bastiaans nader onder de loep te nemen.

$\mathrm{Nu}$ Bastiaans' werkzaamheden bij het Centrum in het teken stonden van de overdracht van zijn methode, groeide de bemoeienis. Het Centrum, dat bestuurlijk verantwoordelijk was, wilde zekerheid van de Inspectie dat de behandelingen op een verantwoorde manier werden uitgevoerd. Op het Centrum had men geen ervaring met de behandelingen en de speciale zorg die daarbij hoorde (het laten overnachten van patiënten en de medische voorzorgsmaatregelen). Over beide behandelingen wilde het Centrum daarom een uitspraak van de Inspectie: wat waren de voorwaarden waaronder de methode-Bastiaans mocht worden toegepast?

Het antwoord omtrent de LSD-therapie werd gegeven door de Gezondheidsraad, een onafhankelijk wetenschappelijk adviesorgaan voor ministers en par- 
lement. De staatssecretaris had de Gezondheidsraad om een advies gevraagd over de wenselijkheid van LSD-therapie. Dat advies kwam in december 1985.

Over de LSD-therapie bestond, zo schreef de Gezondheidsraad in zijn advies, geen wetenschappelijke discussie. De behandeling was begin jaren zestig in onbruik geraakt en de interesse ervoor was sindsdien verdwenen. De taak van de Gezondheidsraad werd daarmee niet makkelijker: over de LSD-behandeling was in de recente psychiatrische literatuur geen informatie te vinden en experts bestonden er dus ook niet. Maar over de behandeling van oorlogsslachtoffers bestond wel literatuur, en er waren dus ook wetenschappers en psychiaters die advies konden geven over de aangewezen behandeling. ${ }^{16}$

De Gezondheidsraad redeneerde dat het voor een Nederlandse wetenschapper moeilijk zou zijn om onbevooroordeeld tegenover de materie te staan gezien de 'sterk emotioneel geladen discussie'. Daarmee werd gedoeld op de patiëntengroep. Om toch tot een uitspraak te komen, vroeg de Gezondheidsraad een aantal buitenlandse wetenschappers om advies. ${ }^{17}$

De expertise van de deskundigen varieerde van het behandelen van oorlogsslachtoffers tot kennis van de werking van psychofarmaca, van een brede kennis van de psychiatrie tot kennis van de specifieke gevolgen van extreme stress. Zo werd bijvoorbeeld de Noorse prof.dr. Leo Eitinger om advies gevraagd. Eitinger, overlevende van de Holocaust, had na zijn vroege publicaties over het $\mathrm{KZ}$-syndroom een internationale reputatie opgebouwd met zijn onderzoek naar de psychische en lichamelijke gevolgen van verblijf in de kampen. En de Britse prof.dr. M.H. Lader, die ook geraadpleegd werd, was een internationaal erkende autoriteit op het gebied van psychofarmaca.

Alle deskundigen waren van mening dat afdoend wetenschappelijk bewijs voor het nut van de toediening van hallucinogenen bij de behandeling van slachtoffers van oorlog en geweld ontbrak, evenals bewijs dat het niet werkte. De bewijzen die Bastiaans aanvoerde, zagen de deskundigen - hoeveel waardering ze ook voor hem hadden - als anekdotisch en als het gevolg van zijn bevooroordeelde houding ten opzichte van zijn patiënten. Bovendien kleefden er volgens de deskundigen risico's aan de toediening van hallucinogenen; er bestond gevaar op langdurende psychoses en soms zelfs op suïcide.

Op basis van de oordelen van de deskundigen stelde de Gezondheidsraad een advies op. Wanneer therapeuten claimden dat behandelingen met inzet van LSD tot betere resultaten leidden dan behandelingen zonder LSD, vond de Gezondheidsraad het 'niet onredelijk' dat zij daarvoor wetenschappelijke evidentie verzamelden. Dat bewijs had Bastiaans niet, dus de conclusie zou moeten zijn dat hij moest stoppen.

In een begeleidende brief bij het advies stelde de Gezondheidsraad echter dat de ontheffing aan Bastiaans wél kon worden gecontinueerd; enkele buitenlandse deskundigen hadden aangegeven dat in de ervaren handen van Bastiaans de risico's beheersbaar waren. Volgens dr. E. Borst-Eilers, de vicevoorzit- 
ter van de Gezondheidsraad, die de begeleidende brief bij het repport ondertekende, achtte de Gezondheidsraad:

'het niet uitgesloten dat stopzetting wan bedoelde behandeling van patienten die hun vertrouwen hetben gesteld in prol. Bastians en de door hem uitge voerde behandelingswijze op zich psychotraumatiserend kan werken."

Blijkens deze uitspraak kon de Gezondheidsraad zich vinden in de uitspraken van Bastiaans' aanhang niet alleen kon de methode-Bastiaans getraumatiseerde patienten genezen, van het bestaan ervan ging zelfs een preventieve werking uit. Bastiaans kreeg met de uitspraak van de Gezondheidsraad een officiele erkenning van de symbolische status van zijn methode. Maar nog steeds was er geen bewijs dat zijn methode effectief was; de uitspraak bevestigde alleen de mythische verwachtingen die erover waren ontstaan.

Het advies van de Gezondheidsraad werd door de staatssecretaris overgenomen, en dus stond Bastiaans niets meer in de weg om op het Centrum te beginnen met de LSD-behandelingen. De voorwaarden waaronder dat gebeurde, werden gelijkgesteld met die waaronder de narcoanalyses plaatsvonden.

Daar diende zich een probleem aan. Bij de Inspectie was een klacht binnengekomen van een patiënt die een narcoanalyse van Bastiaans had ondergaan. Het onderzoek van de Inspectie leverde uiteindelijk op dat er geen 'verwijtbare feiten of omstandigheden' waren gevonden en bleef daardoor zonder gevolgen voor Bastiaans. ${ }^{39}$ De klacht was wel reden voor de Inspectie om de narcoanalyse zoals Bastiaans die toepaste tegen het licht te houden. ${ }^{20} \mathrm{Het}$ was de eerste keer dat de Inspectie naar Bastiaans' behandelingen keek; het werd voor de Inspectie een onaangename verrassing.

Voor de narcoanalyses werd het barbituraat pentothal gebruikt, een middel dat ook als narcosemiddel bij operaties werd (en soms nog wordt) gebruikt. Voordat patiënten het middel bij een operatie kregen toegediend, werden ze eerst medisch onderzocht, zodat een veilige dosering kon worden bepaald. Overdosering kon namelijk leiden tot stilstand van de ademhaling en de hartslag. De dosering was afhankelijk van een aantal factoren, zoals het gewicht, het geslacht, de leeftijd en de lichamelijke conditie van de patiënt. Al die factoren samen bepaalden welke dosering verantwoord was.

Maar dergelijke voorzorgsmaatregelen bleken bij Bastiaans te ontbreken. Er vond geen medisch onderzoek plaats voorafgaand aan zijn narcoanalyses. Hij diende de pentothal in één keer toe met een injectienaald, de zogenoemde bolusmethode. ${ }^{21}$ De patiënten raakten niet alleen buiten bewustzijn, maar liepen ook het gevaar dat de ademhaling en de hartslag stil kwamen te liggen. Het had bij Bastiaans, toen hij nog bij de universiteit werkte, in ieder geval één keer tot problemen geleid..$^{22}$

De Inspectie won advies in bij hoogleraar anesthesiologie dr. J. Spierdijk 
van de RUL. Spierdijks mening liet aan duidelijkheid weinig te wensen over: de methode die Bastiaans gebruikte, omschreef hij als 'spelen met vuur'. ${ }^{23} \mathrm{De}$ Inspectie vroeg ook om een uitspraak van de Nederlandse Vereniging voor Anesthesiologie (NVA). De NVA antwoordde in april 1986, net als Spierdijk, dat de methode 'volstrekt onverantwoord' was en dat er óf een andere methode moest worden gebruikt óf een anesthesist aanwezig moest zijn, inclusief de benodigde apparatuur en voorzorgsmaatregelen. ${ }^{24}$

De Kamer had zich met de moties uitgesproken voor het behoud van de methode-Bastiaans, dus ook voor de narcoanalyse. De staatssecretaris moest, wilde hij niet tegen de wil van de Kamer ingaan, een werkbare oplossing vinden. Op verzoek van de Inspectie ontwikkelde een anesthesist van het Diaconessenhuis in Voorburg speciaal voor Bastiaans een nieuwe techniek, waarbij de pentothal niet in één keer, maar via een infuus continu en geleidelijk werd toegediend. Omdat de patiënten met deze methode nooit volledig buiten bewustzijn raakten, konden er geen gevaarlijke situaties ontstaan en was er geen anesthesist nodig. ${ }^{25}$

Het was vergeefse moeite: die methode stuitte op bezwaren van Bastiaans. Volgens hem was het ontwaken uit de narcose 'de essentie van zijn methode'. Juist daar kregen de patiënten een 'kick' van. ${ }^{26} \mathrm{Het}$ gevolg was dat voortaan aan alle narcoanalyses een uitgebreide medische screening vooraf moest gaan. ${ }^{27}$ Bovendien moesten de sessies plaatsvinden onder toezicht van een arts met ervaring in de anesthesie, die getraind was in reanimatie. Met het AZL werden afspraken gemaakt over hoe te handelen bij eventuele calamiteiten.

Nadat er een geschikte arts was gevonden die aanwezig kon zijn bij de narcoanalyses, en Bastiaans de toezegging had gedaan dat hij zijn patiënten zou laten screenen, bestond er voor de Inspectie geen belemmering meer om de narcoanalyses van Bastiaans door te laten gaan. ${ }^{28}$

De overheid en de controlerende instanties hadden zich na de bijna unanieme beslissing van de Tweede Kamer in bochten gewrongen om Bastiaans zijn gang te laten gaan: de politici hadden zich door patiënten en sympathisanten laten overtuigen met het argument van dreigende suïcides als de methode weg zou vallen; de staatssecretaris had Centrum ' 45 met een blijvende uitbreiding van het behandelaanbod ertoe verleid Bastiaans onderdak te verlenen; Centrum '45, dat graag de 'goodwill' die Bastiaans had overnam, ging ondanks de weerstand van het eigen personeel in zee met de omstreden psychiater; de Inspectie, die tot twee keer toe te horen kreeg dat de narcoanalyses zoals Bastiaans die toepaste onaanvaardbaar waren, ontwierp een 'nieuwe methode-Bastiaans' (die Bastiaans niet overnam); de Gezondheidsraad adviseerde, ondanks de uiterst kritische geluiden van de geraadpleegde experts over de LSD-behandeling, tot voortzetting van de LSD-behandeling uit angst voor 'hernieuwde traumatisering'. De uitzonderingspositie van oorlogsslachtoffers werd nog steeds breed gedragen. 
De zorgen die doorklonken in het rapport van de Gezondheidsraad en de bemoeienissen van de Inspectie stuitten bij verzetsstrijders op onbegrip. Verzetsstrijder mr. P. Coumou schreef een artikel in Aantreden, een blad voor voormalig politieke gevangenen, dat startte met het gezegde: 'Een profeet is in zijn eigen land niet geëerd.' De eis van de Inspectie dat patiënten voor de narcoanalyse eerst een medisch onderzoek ondergingen, vond Coumou rompslomp en geldverspilling; Bastiaans had duizenden van dergelijke behandelingen gedaan en nimmer was er een probleem geweest. ${ }^{29}$ De redactie van De Koerierster, het verenigingsblad van de LKG, kon verheugd melden dat ondanks 'de tegenwerking van de Gezondheidsraad' Bastiaans weer aan het werk kon..$^{3 \circ}$

Ook de psychiater Herman Musaph, die gepubliceerd had over het Kz-syndroom, nam het op voor Bastiaans. In een ingezonden brief in NRC Handelsblad schreef Musaph dat hij in de loop der jaren duizendmaal een met pentothal vergelijkbaar middel had toegediend. Op aanraden van een anesthesist had hij ooit beademings- en hartbewakingsinstrumenten aangeschaft, maar die hadden al die jaren werkeloos in de hoek van zijn behandelkamer gestaan. ${ }^{31}$

Bastiaans bleef laconiek onder alle ontwikkelingen. Hij vond de maatregelen overdreven, maar was blij dat hij weer van start kon. Tegen een journalist van dagblad Het Binnenhof zei hij dat er nog nooit ongelukken hadden plaatsgevonden. De arts die aanwezig moest zijn bij de sessies zou zich dan ook maar vervelen, schamperde hij. ${ }^{32}$ Bastiaans liet zich fotograferen in zijn met bossen bloemen gevulde werkkamer. Volgens hem was Van der Reijden de kwaadste niet, nu hij mocht doorgaan met zijn behandelingen. ${ }^{33}$ Bastiaans behandelde weer patiënten in zijn dependance.

\section{Wetenschappelijke bewijzen}

In de discussie rond Bastiaans' vertrek en het mogelijk verdwijnen van zijn methode, stelde niemand de vraag wat die methode nu precies inhield. De grote lijnen ervan waren duidelijk: een patiënt ondergaat in een veilige omgeving een ontlading van emoties, waardoor integratie van de traumatische gebeurtenissen in het normale bewustzijn kan plaatsvinden. Maar op welk moment en met welke redenen ging Bastiaans over op het gebruik van LSD? Wanneer en waarom op pentothal? Waren er contra-indicaties voor het gebruik van de middelen? Welke factoren speelden een rol bij het bepalen van de dosering? Wanneer werd een sessie gestaakt? Wat gebeurde er na de sessie? Waaruit bestond de nabehandeling? Hoe werd bepaald welk materiaal uit de sessie van belang was voor de nabehandeling? Patiënten werden verzocht te luisteren naar de bandopnames van de sessies; was dat een wezenlijk onderdeel van de behandeling? Wanneer wel, wanneer niet? Werd er gecontroleerd of de patiënten dat inderdaad hadden gedaan? Moesten de banden slechts beluisterd worden, of werden er ook bijbehorende opdrachten gegeven? Was er 
begeleiding nodig bij het beluisteren van de banden? Werd die altijd gegeven?

De details kende niemand, ook niet degenen die zo hartstochtelijk pleitten voor het behoud van de methode. Bastiaans deed er geheimzinnig over, volgens hem was zijn techniek een combinatie van psychodrama, psychoanalyse, manuele therapie, narcoanalyse en nog wat. Het was volgens hem uiterst lastig om die technieken onder de knie te krijgen en op de juiste manier te combineren, zeker voor jonge psychiaters, die niet bestand waren tegen de gruwelijke verhalen van de patiënten.

Niet alleen over de inhoud van de methode bestond onduidelijkheid; ook de effectiviteit ervan was onduidelijk. Bastiaans was daar in de media altijd even stellig als kort over geweest: de methode was uiterst effectief. Zijn aanhang had bij de leden van de vaste commissie voor wvc zelfs de indruk gewekt dat zijn methode wetenschappelijk onderbouwd was. Ze schreven dat hij 'talloze' publicaties over de LSD-behandeling op zijn naam had staan.

Maar Bastiaans had nimmer kwantitatieve gegevens over de resultaten van zijn werk gepubliceerd. De publicaties tijdens zijn hoogleraarschap, de periode waarin de inzet van LSD zijn handelsmerk werd, beperkten zich tot onderwerpen op het gebied van de klinische psychosomatiek en de psychoanalyse van traumatische gebeurtenissen. In een enkel artikel voerde hij LSD op in een (altijd glorieuze) bijrol in de bespreking van een casus. Maar nooit gaf hij een overzicht in maat en getal van zijn werk en het behaalde resultaat. ${ }^{34}$

De cijfers die hij wel gaf, riepen vragen op. In een artikel in 1970 schreef Bastiaans dat er sinds 1964 door hem twintig ex-verzetslieden met LSD waren behandeld. ${ }^{35}$ Op een congres in Jeruzalem in 1979 vertelde Bastiaans dat hij tot dat moment 'meer dan 6o' oorlogsslachtoffers met LSD had behandeld. ${ }^{36}$ Maar in een boek dat vier jaar later uitkwam en waarin Bastiaans een hoofdstuk schreef, vermeldde hij dat hij tweehonderd patiënten had behandeld met LSD in de periode $1969-1979 .{ }^{37}$

Over het succes van de behandelingen werd Bastiaans steeds korter en uitgesprokener. In 1970, toen hij dus twintig personen met LSD had behandeld, waren bij 'de meerderheid bevredigende resultaten' bereikt en vroeg hij zich af of de resultaten blijvend waren. Maar in 1983 wekte hij de indruk dat alle behandelingen geslaagd waren, en dat de meest indrukwekkende verbeteringen te zien waren bij overlevenden van de concentratiekampen en patiënten met psychosomatische klachten wier jeugd een 'soort privé-concentratiekamp' was geweest. ${ }^{38}$ In 1986 schreef Bastiaans dat 'doorgaans met zes tot acht zittingen kon worden volstaan', ${ }^{39}$

In het archief van Stichting Cogis, de opvolger van ICODo, bevindt zich een collectie bandopnames van sessies van Bastiaans en zijn patiënten. Het gaat om een incomplete collectie. ${ }^{40}$ Omdat het de enige bron is die een beeld kan 
geven van het aantal behandelingen dat Bastiaans uitvoerde, is voor het onderzoek voor dit boek de collectie geinventariseerd.

De collectie bestaat uit in total 809 banden met daarop 1420 sessies die in de periode tussen 1972 en 1989 zijn uitgevoerd. Van de laatste vijf jaar, waaronder de jaren bij het Centrum, zijn om onduidelijke redenen nauwelijks banden bewaard gebleven. ${ }^{4}$ Uit de bewaard gebleven banden blijkt dat door de jaren heen pentothal veel vaker werd toegepast dan LSD; in dertig procent van de ses. sies gebruikte Bastiaans een hallucinogeen, in zestig procent pentothal (in tien procent van de sessies was het onduidelijk om welk middel het ging). Bas. tiaans maakte dus meer gebruik van I.SD dan hij beweerde; hij sprak over tien procent van de gevallen. In de laatste jaren verschoof de verdeling nog verder richting pentothal.

Volgens de gegevens ontleend aan de collectie banden, werden er van 1972 tot 1988 door Bastiaans 144 personen met een hallucinogeen en 275 personen met een barbituraat behandeld. In totaal behandelde hij 388 personen; sommigen kregen dus zowel pentothal als LSD. Deze cijfers moeten als minimum worden gezien; in werkelijkheid werden meer sessies bij meer personen gedaan. Hoeveel meer laat zich niet meer vaststellen.

Gemiddeld bestond een behandeling uit ongeveer drieènhalve sessie (met een van beide middelen). Het aantal sessies per behandeling varieerde per persoon sterk: veruit de meeste patiënten kregen er één, enkele uitschieters kregen er meer dan twaalf. ${ }^{42}$

Bastiaans' uitspraken over de werkzaamheid van zijn behandelingen hadden bij zijn achterban de indruk gewekt dat hij onderzoek had gedaan. Dat hij werd geloofd, was niet zo vreemd, hij was tenslotte hoogleraar. Hij kende de basiskenmerken van dergelijk onderzoek goed; die waren sinds zijn eigen onderzoek met Barendregt naar de effectiviteit van psychoanalyse niet veranderd. Het gebruik van controlegroepen, gerandomiseerde toewijzing van patiënten en therapeuten aan experimentele groepen en controlegroepen, gestandaardiseerde voor- en nametingen van de gezondheidstoestand van de patiënt en tot slot publicatie van het onderzoek in een peer-reviewed tijdschrift.

Maar Bastiaans had nimmer dergelijk onderzoek gedaan naar zijn methoden, ook niet nadat daar in 1968 in de discussie onder hoogleraren over LSDtherapie in het $N T V G$ op was aangedrongen.

Met het rapport van de Gezondheidsraad was de bewijslast weer bij Bastiaans gelegd. Als hij wilde dat de methode werd gehandhaafd, moesten er aanwijzingen komen dat deze methode beter werkte dan andere methoden. Bastiaans kon na alle ophef niet anders dan die handschoen oppakken, en stelde in januari 1986 aan het Ministerie van wvC voor om een na-onderzoek te doen onder driehonderd van zijn voormalige patiënten. Aan de hand van dossiers en interviews met patiënten zou de werkzaamheid vastgesteld kunnen worden. 
Als leider van het onderzoek noemde hij de psycholoog dr. H.M. van der Ploeg. De toekomst van de LSD-therapie kwam nu te rusten op de schouders van Van der Ploeg. Alleen als uit zijn onderzoek zou blijken dat de methode werkte, bestond de kans dat deze bewaard bleef.

\section{Het onderzoek naar Bastiaans' LSD-therapie}

Van der Ploeg was in 1970 afgestudeerd bij de psycholoog J.T. Barendregt, een oud-collega van Bastiaans, en was daarna werkzaam geweest als psycholoog op de polikliniek van de Jelgersmakliniek. Van der Ploeg behandelde daar soms angstige of fobische patiënten met behulp van gedragstherapie. In die rol kwam hij wel eens met een patiënt bij Bastiaans. Van der Ploeg was onder de indruk van de klinische blik van Bastiaans; die wist volgens hem binnen een paar minuten tot de kern van de problematiek door te dringen. ${ }^{43}$

Vanaf 1976 werd het contact tussen Van der Ploeg en Bastiaans intensiever, toen zij beiden betrokken waren bij het door de overheidscommissie СвоG geinitieerde onderzoek naar de gevolgen van gijzelingen. Bastiaans zat in de begeleidingscommissie, terwijl Van der Ploeg en anderen het daadwerkelijke onderzoek verrichtten.

Een halfjaar voordat Van der Ploeg begon aan zijn onderzoek naar de methode-Bastiaans, had hij zelf nog de hulp van Bastiaans ingeroepen. Van der Ploeg wilde in contact komen met de Joegoslavische wetenschapper $\mathrm{dr}$. R. Grossarth-Maticek. Bastiaans had samen met Grossarth-Maticek een artikel gepubliceerd, en Van der Ploeg vroeg Bastiaans voor hem het eerste contact te leggen. ${ }^{44}$ Overigens is de omvang van Bastiaans' bijdrage aan het artikel onduidelijk. Vermoedelijk heeft hij er alleen zijn naam aan geleend. Dat was voor beiden voordelig: Bastiaans kreeg een 'gratis' publicatie in een wetenschappelijk tijdschrift, en Grossarth-Maticek kon de naam van een oudgediende in de psychosomatiek boven zijn artikel zetten.

Het onderzoek van Grossarth-Maticek trok in Nederland de aandacht, niet het minst omdat Bastiaans er in interviews de loftrompet over stak; het leek een bevestiging van de ideeën van de psychosomatiek. ${ }^{45}$ Grossarth-Maticek had spectaculair onderzoek gepresenteerd waarin voor het eerst een duidelijk statistisch verband tussen persoonlijkheidskenmerken en het ontstaan van kanker werd aangetoond.

Ook de Amerikaanse tabaksindustrie was geïnteresseerd in het onderzoek. Als de resultaten klopten, was de longkanker van rokers te wijten aan hun persoonlijkheid en niet aan de sigaret. Dat kon de tabaksindustrie veel geld schelen in de rechtszaken die door rokers werden aangespannen. Ook onder wetenschappers bestond belangstelling voor het onderzoek, alleen dan van heel andere aard: er bestond twijfel over de resultaten, ze waren te mooi om waar te zijn. De zaak werd op de spits gedreven toen de internationaal vermaarde Brit- 
se psycholoog prof.dr. H.J. Eysenck zich achter Grossarth-Maticek stelde.

Aan Van der Ploeg werd door een kritische Amerikaanse onderzoeker gevraagd te kijken of het materiaal van Grossarth-Maticekopnieuw geanalyseerd kon worden. Uiteindelijk bleek, onder andere door het onderzoek van Van der Ploeg, dat Grossarth-Maticek inderdaad geknoeid had met zijn onderzoeksmateriaal. ${ }^{46}$ Het causaal verband tussen persoonlijkheidskenmerken en kanker bleek niet aangetoond.

Toen Van der Ploeg begon met het onderzoek naar de methode-Bastiaans, stond hem geen 'ontmaskeringsonderzoek' voor ogen, zoals bij Grossarth-Maticek. Hij stond, zoals hij in een interview vertelde, 'neutraal-kritisch' tegenover de LSD-behandeling. Hij kende zowel de jubelverhalen van patiënten als de kritische geluiden van collega-behandelaars.

Met de evaluatie van de methode-Bastiaans werd Van der Ploeg voor een lastig methodologisch probleem gesteld. De voorwaarden voor een echt effectonderzoek waren inmiddels niet meer haalbaar; de behandelingen waren al uitgevoerd en er was geen controlegroep gebruikt. De enige manier om een verschil te meten tussen de toestand van de patiënt vóór de behandeling en daarna, was een reconstructie aan de hand van het medisch dossier. Over het onderzoek had Hoofdinspecteur Van Borssum Waalkes dan ook ooit de profetische woorden gesproken:

'Dit onderzoek staat of valt met de mate van nauwkeurigheid waarmee de dossiers zijn bijgehouden. ${ }^{47}$

Van der Ploeg vroeg een aantal psychiaters welke informatie zij in een dossier verwachtten aan te treffen over de gezondheidstoestand van een patiënt. Dat resulteerde in zeven categorieën: opnamegegevens, psychiatrische gegevens over het beloop, internistisch onderzoek, psychologisch onderzoek, neurologisch onderzoek, psychiatrische rapportage ten behoeve van uitkeringsinstanties en een ontslagbrief. Het meeste belang werd gehecht aan de opnamegegevens, de psychiatrische gegevens over het beloop, en de ontslagbrief. Op basis van deze drie hoofdgegevens kon de gezondheidstoestand vóór de behandeling gereconstrueerd worden.

De volgende stap was het achterhalen van de patiënten; wie waren er behandeld met LSD? Van der Ploeg gebruikte daarvoor de lijst met LSD-behandelingen zoals Bastiaans die verplicht was bij te houden voor het Staatstoezicht op de Volksgezondheid, de instantie die de ontheffing voor het gebruik van LSD verleende. Op die lijst waren in de periode dat aan Bastiaans ontheffing was verleend (van 24 april 1968 tot 2 april 1985) de namen van in totaal 209 patiënten genoteerd. De meesten van hen hadden meer dan één behandeling ondergaan. Naast naam, datum van de sessie en de hoeveelheid gebruikte LSD, werd de 
reden vermeld waarom iemand een behandeling onderging. Het aantal patiënten was dus flink lager dan de door Bastiaans beloofde 300 , maar leek voldoende voor een onderzoek.

De vraag van de Inspectie aan Van der Ploeg richtte zich op de effectiviteit van de behandeling bij oorlogsslachtoffers door Bastiaans. 40 patiënten vielen af omdat zij hoofdzakelijk door andere artsen waren behandeld; het ging om artsassistenten, andere psychiaters van de Jelgersmakliniek en therapeuten die onder verantwoordelijkheid van Bastiaans werkten. Nog eens 78 patiënten vielen af omdat hun problematiek niet in verband met de oorlog stond. 18 personen bleken reeds overleden of niet meer in Nederland woonachtig. Daardoor bleven er nog 73 personen over. Dat aantal was laag, maar nog steeds voldoende voor Van der Ploeg om verder onderzoek te doen..$^{48}$

De adresgegevens van de personen werden achterhaald, en in juli $1987 \mathrm{kreeg}$ Van der Ploeg toestemming van de Inspectie om zijn vooronderzoek voort te zetten en de dossiers in te zien. Van 16 personen was geen dossier te vinden. Dat kon, zo vermeldde Van der Ploeg in zijn onderzoeksverslag, zijn veroorzaakt doordat van patiënten die nog in behandeling waren de dossiers niet beschikbaar werden gesteld, of doordat er überhaupt geen dossiers te vinden waren. Daarmee was het aantal bruikbare dossiers geslonken van de door Bastiaans beloofde 300 naar 57.

De schok volgde toen de inhoud van de overgebleven 57 dossiers werd bekeken: het merendeel daarvan bleek nagenoeg waardeloos voor het onderzoek. Slechts 9 van de 57 dossiers bevatten alle drie de hoofdgegevens; bij nog eens 15 waren twee van de drie gegevens aanwezig. ${ }^{49} \mathrm{Bij}$ de rest ging het soms, zoals Van der Ploeg later in een interview vertelde, slechts om 'kerstkaarten en nietszeggende briefjes. ${ }^{.0}$ Dat was te weinig en te mager materiaal om een wetenschappelijk verantwoorde uitspraak over de effectiviteit van Bastiaans' methode te doen. Van der Ploeg moest zijn onderzoek staken.

De LSD-behandeling, waar patiënten voor op de barricaden waren gesprongen, waar politici zich hard voor hadden gemaakt, was nergens beschreven. Bastiaans zou daar in de resterende periode voor zorgen, en de fijne kneepjes overbrengen aan een opvolger. Maar dat alles had alleen zin als aangetoond kon worden dat de methode werkte; dat hij zelfs beter werkte dan andere methoden. Met het onderzoek van Van der Ploeg werd nu duidelijk dat het wetenschappelijk bewijs voor de effectiviteit van de methode er niet meer zou komen. ${ }^{11}$ Dat betekende niet dat de methode niet werkte; het betekende dat Bastiaans in twintig jaar werken met de LSD-therapie geen enkel bewijs had verzameld voor de werkzaamheid. Als de methode al werkte, was nu de kans verkeken dat andere patiënten en behandelaars daar baat bij zouden hebben. 


\section{Near accidents}

Het verslag van het onderzoek van Van der Ploeg kwam pas in de zomer van 1987 gereed. De gevolgen ervan voor Bastiaans zouden pas in de herfst van 1987 duidelijk worden. Tot die tijd kon Bastiaans in ieder geval doorgaan met zijn behandelingen op de dependance. Hij leek zich te hebben neergelegd bij de extra veiligheidsmaatregelen - een verplichte medische screening en de aanwezigheid van een arts - die hij van de Inspectie in acht moest nemen bij de behandelingen. Maar al snel ontstonden er grote problemen: Bastiaans ontwikkelde zich tot een tirannieke dwingeland die zich noch van zijn personeel, noch van de arts, noch van de Inspectie wat aantrok. Met alle gevolgen van dien.

Een van de eersten die tegen Bastiaans' eigengereidheid opliepen, was de arts die op last van de Inspectie aanwezig was bij de narcoanalyses. Hij merkte al snel de noodzaak van zijn anwezigheid bij de sessies. Nadat de pentothal was toegediend bij een patiënt, ontstond er een 'kritieke periode', waarin de ademhaling, hartslag, pols en gelaatskleur goed in de gaten moesten worden gehouden..$^{52}$ De pentothalroes had in zijn anwezigheid in ieder geval twee keer tot complicaties geleid. In één geval bleek de patiënt niet nuchter te zijn, waardoor deze moest braken; de arts had toen de maag van de patiënt moeten leegzuigen. In een ander geval kwam de ademhaling slecht op gang en had de patiënt een zwakke pols; de arts had zowel extra zuurstof gegeven als de beademing van de patiënt ondersteund met een beademingsballon. Als het Centrum een FONA-commissie had gehad - een commissie waar fouten, ongelukken en near accidents gemeld kunnen worden - had de arts dat gedaan..$^{53}$

De arts merkte ook dat het moeilijk was om Bastiaans aan de afspraken met de Inspectie te houden. Het kwam regelmatig voor dat Bastiaans een patiënt uitgenodigde voor een behandeling zonder dat door te geven aan het verplegend personeel. De patiënt meldde zich vervolgens op het afgesproken moment, en voor een medische screening was dan geen tijd meer. Volgens Bastiaanskonvanwege de ernstvan deproblematiekzo'nafspraakooknietverplaatst worden. De sessie vond dan doorgang met het risico op complicaties tot gevolg.

Dat risico werd nog groter toen de arts in augustus ziek thuis kwam te zitten. ${ }^{54}$ Vanaf dat moment was er niemand in de dependance aanwezig met voldoende kennis en kunde om een reanimatie uit te voeren of een maag leeg te pompen. De afwezigheid van de arts was voor Bastiaans geen reden de sessies te staken. Hij ging door zoals hij gewend was.

In juni 1986 werd er een opvolger gevonden: een jonge psychiater, die niet alleen bereid, maar zelfs enthousiast was om met Bastiaans samen te werken en zich diens methode eigen te maken. Het was de psychiater K. Mengelberg, die ooit naar aanleiding van het zien van Begrijpt $u$ nu waarom ik huil... had gekozen voor de psychiatrie. Hij bewonderde Bastiaans om de 'ijzeren conse- 
quentie' waarmee hij streed voor de belangen van zijn patiënten. Mengelberg begon zijn opleiding bij Bastiaans in september 1986, maar raakte al snel gedesillusioneerd.

Hij voerde zelfstandig narcoanalyses uit, maar voelde zich er niet gerust op dat alles goed ging. ${ }^{55}$ Bastiaans, de psychiater tegen wie hij zo had opgekeken, bleek onbereikbaar voor hulp, advies of overleg. Afkijken van de kunst, wat de bedoeling was, lukte daardoor niet. Bastiaans verscheen niet op stafvergaderingen, en op brieven van Mengelberg reageerde hij niet. Bovendien twijfelde Mengelberg steeds meer aan Bastiaans' kunnen. Hij kon geen regelmaat ontdekken in diens toepassing van pentothal, en enkele keren vond hij zelfs dat er geen narcoanalyse gegeven had mogen worden omdat de betreffende patiënten organische klachten hadden, waardoor er kans op complicaties was. ${ }^{56}$ Nog geen twee maanden nadat hij was begonnen, meldde Mengelberg zich daarom ziek.

Pas na zijn vertrek hoorde Mengelberg van de brief van de Nederlandse Vereniging voor Anesthesiologie, waarin deze haar zorg had uitgesproken over de manier waarop Bastiaans zijn narcoanalyses uitvoerde. Het bevestigde Mengelbergs gevoel dat hij aan iets afschuwelijks was ontsnapt. In een brief aan Bastiaans schreef hij:

'Maar ook zonder deze brief wist ik dat, als er iets mis zou gaan, Inspecteur en Tuchtrechter zonder pardon zouden zijn. Ik zou mij hebben schuldig gemaakt aan handelingen waarvoor al het oordeel "volstrekt onverantwoord" was uitgesproken. In geval van een ongeluk zou niet alleen het lot van de Dependance bezegeld zijn, ook mijn bevoegdheid als arts zou op het spel staan. ${ }^{57}$

Mengelberg belde Bastiaans op en deelde hem mee dat hij zich, ondanks zijn bewondering voor diens werk, terugtrokals opvolger. Bastiaans, teleurgesteld, merkte verwijtend op dat hij 'het wel weer alleen zou moeten opknappen'. ${ }^{58} \mathrm{Die}$ laatste opmerking viel Mengelberg zwaar. Hij had een baan opgegeven om bij zijn grote voorbeeld in de leer te komen; nu werd hem gebrek aan betrokkenheid verweten.

Bastiaans vertelde de pers en zijn achterban dat Mengelberg de verhalen van de patiënten niet had aangekund..$^{59}$ Door Mengelbergs vertrek op deze manier te presenteren, vestigde hij weer de aandacht op de bijzondere en omvangrijke problematiek van zijn patiënten; hun verhalen waren zo gruwelijk dat jonge psychiaters ze nog geen twee maanden konden aanhoren. Hij kon dat wel; hij was in staat de verhalen aan te horen en zijn patiënten te genezen.

De problemen op de dependance drongen door tot directeur Peters, die in november 1986 aan het bestuur rapporteerde dat de samenwerking tussen het personeel en Bastiaans verre van vlekkeloos verliep. Bastiaans, die van oudsher gewend was op autoritaire wijzeleiding te geven, zag het verplegend personeel 
als een 'verlengde arm'. Verplegend personeel was in die jaren echter een autonome rol gewend. Bovendien eiste Bastiaans hetzelfde werktempo van hen als hij zichzelf oplegde; dagen van zestien uur waren daarbij geen uitzondering. ${ }^{60}$ In december schreef directeur Peters weer een nota aan zijn bestuur. Die begon positief:

'Wat prof. dr. J. Bastiaans met patiënten kan bereiken is uiterst waardevol; en dient behouden. ${ }^{61}$

Maar hij had grote moeite met de manier waarop Bastiaans die waardevolle resultaten bereikte. De manier waarop hij omging met personeel én patiënten, baarde hem grote zorgen. Het niet naleven van de voorschriften van de Inspectie kwalificeerde Peters als 'onverantwoord medisch handelen' en hij stelde de Inspectie ervan op de hoogte. ${ }^{62}$ In een poging een overzicht te krijgen van de problemen, vroeg Peters het personeel hun ervaringen op papier te zetten.

Uit die brieven aan het bestuur van het Centrum blijkt de grimmige sfeer die was ontstaan op de dependance. Het personeel was verdeeld in voor- en tegenstanders van Bastiaans, een scheiding die grofweg liep tussen het verplegend personeel enerzijds en het behandelend personeel (de psychologen en Bastiaans' clandestiene 'medewerkers') anderzijds.

Volgens het verplegend personeel verloor Bastiaans zich in gesprekken met patiënten, en betrok hij die zelfs bij de financiële zaken van de dependance. Hij sprak tegenover patiënten zijn onvrede uit over het bestuur van het Centrum, en zette in het bijzijn van patiënten verplegend personeel voor schut. Hij ondermijnde hun gezag door roddels te verspreiden en gemaakte afspraken te negeren, liep weg uit vergaderingen of kwam in het geheel niet opdagen.

Het verplegend personeel had het gevoel niet serieus genomen te worden. Zo had Bastiaans zonder overleg een lichamelijk gehandicapte patiënt opgenomen, die veel aandacht van de verpleging eiste. Daarmee werd tekortgedaan aan de overige patiënten; Bastiaans dreigde de coördinator van het verplegend personeel met het inschakelen van de politiek als hij niet meer personeel kreeg. ${ }^{{ }_{3}}$ Het verplegend personeel schreef in een gezamenlijke brief aan Peters:

'De patiënten hebben de macht. De verpleegkundigen hangen er maar bij. [...] De Professor is vaak nors en autoritair en gaat onzorgvuldig met mensen om. ${ }^{64}$

In tegenstelling tot het verplegend personeel nam het behandelend personeel het op voor Bastiaans. Volgens een cesartherapeute, die zonder vergoeding werkte op de dependance, overdreef het verplegend personeel de problemen. Dat Bastiaans niet wilde overleggen was volgens haar geen enkel probleem; de

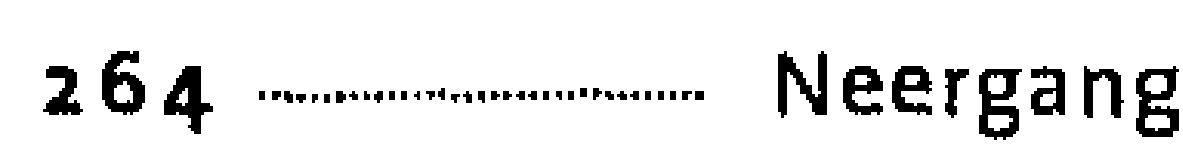


resultaten van Bastiaans' behandelingen 'spraken voor zich' en daar ging het om. ${ }^{65}$ De op de dependance werkzame psychologen schaarden zich ook achter Bastiaans. Zij voelden zich niet begrepen door het bestuur en zagen de onduidelijkheid over de toekomst van de dependance na Bastiaans' vertrek als oorzaak van de problemen. ${ }^{66}$ Die zorg werd mogelijk mede ingegeven door het feit dat zij in tijdelijke dienst waren; zodra Bastiaans zou vertrekken zou ook hun aanstelling aflopen.

In de brieven van Bastiaans' medestanders werd met geen woord gerept over de complicaties, die volgens het verplegend personeel vaker voorkwamen. Eén patiënt had vier hartinfarcten gehad en leed aan suikerziekte, reden voor een anesthesist om de narcoanalyse af te raden. Bastiaans gaf de man desondanks een injectie met pentothal; binnen enkele minuten na aanvang van de sessie kreeg de man pijn in de hartstreek en moest hij nitraattabletten innemen. De man kreeg daarna nog driemaal een narcoanalyse, de laatste zonder de aanwezigheid van de arts. ${ }^{67}$

Het ging vaker bijna mis. Een verpleegkundige beschreef in een brief aan directeur Peters hoe bij zeven patiënten complicaties waren ontstaan. Sommige patiënten waren na toediening van de pentothal uitgebarsten in heftige hoestbuien waarbij veel slijm werd opgegeven; soms waren ze daarbij in ademnood gekomen. Andere waren grauw weggetrokken of hadden een nauwelijks voelbare polsslag gehad. In enkele gevallen moesten patiënten zelfs worden beademd. ${ }^{68}$

Pogingen om Bastiaans te houden aan de voorzorgsmaatregelen hielpen niet; Bastiaans nam daarmee het risico op complicaties voor lief. Zijn behandelingen leidden in de periode bij het Centrum niet tot fatale ongelukken of klachten van patiënten, maar wel tot enkele near accidents. ${ }^{69}$

De problemen op de dependance en de gevaarlijke situaties die ontstonden bij de narcoanalyses waren voor het Ministerie en de Inspectie aanleiding om hun handen van Bastiaans af te trekken. De beslissing voor verlenging, waar Bastiaans op aandrong, werd aan het Centrum overgelaten. Maar dat had daar, net als eerder de universiteit, door de verstoorde verhoudingen en het risico van ongelukken geen zin meer in. Niettemin zwegen het Centrum, de Inspectie en het Ministerie over de bijna-ongelukken. De geluiden daarover speelden in de publieke discussie rond Bastiaans' afscheid die zich weer aandiende, geen enkele rol.

Eind maart 1987 kreeg Bastiaans van een afvaardiging van het bestuur te horen dat hij per 1 november van dat jaar zou worden ontslagen..$^{\circ}$ Dat was vijf maanden later dan oorspronkelijk met Van der Reijden overeengekomen. Ondanks de afspraak met het bestuur dat hij zich zou onthouden van contacten met de pers, plaatste De Telegraaf binnen enkele dagen de dreigende kop: 'Prof. Bastiaans dreigt dakloos te worden.' ${ }^{11}$ Het slotakkoord van de periode-Bastiaans was ingeluid. 


\section{De val van Bastiaans}

Bastiaans had al enkele keren uitstel gekregen en hij leek er zekervan dat dat nu wéér zou gaan lukken. Steeds had hij zich gesteund geweten door oorlogsslachtoffers, en dan met name verzetsstrijders. Die steun had hij te danken aan het feit dat hij zijn hele carrière de uitzonderingspositie van deze groep had beschermd. Bastiaans had het $\mathrm{Kz}$-syndroom bekendgemaakt, had aangedrongen op betere regelingen, had aan de basis van een speciale kliniek gestaan en had zich publiekelijk uitgesproken in maatschappelijke kwesties waar de verzetsstrijders een rol in speelden. Bovendien suggereerde hij dat hun problemen zo uitzonderlijk waren dat ze alleen met een bijzondere methode te behandelen waren.

Verzetsstrijders waren van dat laatste ook overtuigd geraakt, en hadden zich daarom steeds hard gemaakt voor het behoud van Bastiaans en zijn methode. De verlenging bij het Centrum was bedoeld om een opvolger in te werken zodat de methode niet verloren zou gaan. Daar leek met het vertrek van Mengelberg weinig van terecht te komen.

Of Bastiaans na Mengelbergs vertrek initiatieven ontplooide om een vervanger te vinden, is onduidelijk. Veel belang zou hij daar niet bij hebben gehad: zolang er geen vervanger was, was hij nodig om de methode te laten voortbestaan. Het vertrek van Bastiaans zou dus nog steeds het einde van de methode betekenen.

Inderdaad stonden er direct weer sympathisanten op om het voor Bastiaans op te nemen. Een verzetsstrijder sprak over het 'kaltstellen' van Bastiaans. Gé Bekker, woordvoerder van de Werkgroep Dependance Jelgersmakliniek, dreigde Centrum ' 45 met juridische stappen, overigens zonder uit te leggen wat die dan zouden zijn. Ook prof. B.S. Polak, die door Bastiaans per brief van alle ontwikkelingen op de hoogte was gehouden, nam het voor hem op. Blijkbaar had Bastiaans niets over de bijna-ongelukken geschreven, want Polak vond dat Bastiaans door moest kunnen gaan:

'Ik sta op het standpunt dat de behandeling die Bastiaans biedt, een behandeling is die die mensen nodig hebben en een behandeling die die mensen wensen. En dat voor deze bijzondere groep mensen alles gedaan moet worden om ze de behandeling te geven die ze nodig hebben en die ze wensen. En dat eigenlijk alle andere overwegingen daarvoor moeten wijken. ${ }^{72}$

Bastiaans had ook nog steeds regelmatig contact met M.J.C. Worrell, het Kamerlid dat de motie had ingediend waardoor hij had kunnen doorwerken. Worrell liet in een eerste reactie aan een journalist weten dat hij vreesde dat de continuiiteit van de zorg aan oorlogsslachtoffers weer in het gedrang zou komen. ${ }^{73}$

Een dag nadat Bastiaans de brief had gekregen waarin zijn ontslag per 1 no- 
vember formeel werd bevestigd, sprak de vaste commissie met de minister van Welzijn, Volksgezondheid en Cultuur, mr.drs. L.C. Brinkman (CDA), die het dossier-Bastiaans had overgenomen van de inmiddels afgetreden staatssecretaris Van der Reijden. ${ }^{74}$ Kamerlid Worrell moest erkennen dat de belofte van de staatssecretaris helemaal was nagekomen: Bastiaans had tot 1 juni 1987 door kunnen werken. Maar Centrum ' 45 had in Worrells ogen gefaald, want het had geen opvolger weten te regelen. Worrell drong aan op een verlenging van Bastiaans' aanstelling met een halfjaar, waarin dat alsnog kon gebeuren. Dat zou dan echt 'de allerlaatste verlenging van de diverse termijnen moeten zijn' voegde hij eraan toe. Minister Brinkman, die niet van zins was een verlenging te bevorderen, zou de zorgen van de Kamerleden overbrengen aan het bestuur. Brinkman wist wel te melden dat een oplossing mogelijk nabij was: het Centrum was met Bastiaans in gesprek over drie opvolgers. ${ }^{75}$

Het Centrum had in het voorjaar van 1987 drie opvolgers gevonden. ${ }^{76}$ Niet alle drie waren ze even overtuigd van het nut en de noodzaak van de methodeBastiaans, maar dat nam niet weg dat er drie personen zouden zijn met ervaring in de methode. Het ging om de aan Centrum ' 45 verbonden psychiater A. Boomer, de vrijgevestigde psychiater M. Kooyman en de arts A. Krumperman, voormalig hoofd van het Centrum Vluchtelingen. ${ }^{7}$ De periode om in te werken was kort: Krumperman en Boomer begonnen hun stages per 1 juli, Kooyman per 1 augustus, en de drie waren maar enkele uren per week beschikbaar.

Bastiaans was niet over alle drie de opvolgers even tevreden, maar Krumperman leek hem een veelbelovende opvolger. Krumperman was in 1987 al drieënzestig jaar oud; hij was zelfs al met de vut toen hij solliciteerde. ${ }^{78}$ Dat gaf weinig hoop op een langdurige voortzetting van het werk van Bastiaans. Het aantrekken van de drie opvolgers was vermoedelijk een poging van het Centrum om Bastiaans zijn belangrijkste troef - het ontbreken van een opvolger uit handen te nemen. En dat werkte.

Bastiaans paste zijn strategie aan. Hij had in mei 1987 , de maand waarin hij zeventig werd, een brief gestuurd naar minister Brinkman. In die brief gaf hij twee argumenten voor het verlengen van zijn periode in de dependance. Het eerste was het ontbreken van een opvolger; dat argument was met de komst van drie opvolgers niet langer houdbaar. ${ }^{79}$ Het tweede argument liet zien dat zijn wens om langer aan te blijven meer met zijn behoefte aan behandelen, zijn behandeldrift, te maken had, dan met het lijden van oorlogsslachtoffers.

In de brief zette Bastiaans uiteen dat het Centrum, als de opvolgers waren ingewerkt, de enige plek in Nederland was waar zijn methode kon worden toegepast. Het Centrum had nog steeds een statutaire verplichting om alleen 'erkende oorlogsslachtoffers' te behandelen: slachtoffers die een uitkering kregen in het kader van de WBP, wUV de in 1984 ingevoerde Wet uitkering Burgeroorlogsgetroffenen (WUBO) of een verzetsverklaring hadden van de Stichting 1940-1945. Ook al viel Bastiaans bestuurlijk onder het Centrum, zelf 
hield hij zich niet aan deze beperking: hij behandelde op de dependance ook niet-erkende oorlogsslachtoffers en slachtoffers van geweld en misdrijven. Dat werd door het bestuur oogluikend toegestaan, maar zodra Bastiaans was vertrokken zou aan die praktijk een einde komen. Dat betekende dus ook dat die andere slachtoffers verstoken bleven van zijn methode.

Bastiaans gebruikte dat laatste als argument om zijn aanstelling te verlengen. Hij vond het onverantwoord dat die andere slachtoffers het zonder zijn behandeling zouden moeten stellen. Het Centrum moest daarom zijn doelstelling verbreden, en omgevormd worden tot een algemeen traumacentrum; wat Van Borssum Waalkes eerder ook had voorgesteld. Tot het zover was, zou hem de kans gegeven moeten worden niet-erkende oorlogsslachtoffers te behandelen.

Deze strategie van Bastiaans viel bij de patiënten van de dependance in goede aarde, en zij drongen in brieven gericht aan de vaste commissie voor Welzijn en Volksgezondheid aan op verlenging. Niet alleen zij die op dat moment behandeld werden, zo schreven ze, maar ook de patiënten op de wachtlijst en een 'anonieme groep gewelds- en oorlogsslachtoffers die zich staande houden met de wetenschap dat zij zo nodig terecht kunnen bij het behandelteam van de dependance' wilden graag dat de methode ook voor hen beschikbaar bleef. ${ }^{80}$

Bastiaans zette met deze strategie het bondgenootschap met zijn verzetsstrijders onder druk. Die hadden hem tot dan toe gesteund omdat de behandeling noodzakelijk werd geacht voor hun bijzondere problemen. Dat Bastiaans zijn methode nu ook noodzakelijk achtte voor de bijzondere problemen van andere groepen, leverde onder verzetsstrijders niet direct steun op.

Hij bracht hen met zijn pleidooi voor verbreding van de doelstelling van het Centrum in een lastig parket: als ze achter Bastiaans gingen staan, verloren ze de eigen, speciale kliniek; als ze achter het Centrum gingen staan, verloren ze Bastiaans.

De kwestie kwam in juni aan de orde tijdens een bestuursvergadering van het Centrum, waarbij ook een vertegenwoordiger van het voormalig verzet was uitgenodigd. Het ging om J.F. Beckman, vicevoorzitter van Expogé, die eind 1984 met Bastiaans een brief aan de Tweede Kamer had gestuurd. Het bestuur van het Centrum was geïrriteerd over Bastiaans' optreden. Met name het bestuurslid prof. mr. A.L. Melai zei hem waar het op stond. Toen Bastiaans klaagde over de korte tijd die restte om zijn opvolgers in te werken, antwoordde Melai:

'Je hebt je hele leven gehad om honderden mensen in te werken! ${ }^{81}$

Bastiaans moest het doen met de drie opvolgers die er waren in de korte tijd die nog restte. Na zijn vertrek konden zijn opvolgers nog wel van zijn diensten als supervisor gebruikmaken, maar aan zijn behandelingen zou een einde komen. 
Beckman vond het belangrijk dat de methode-Bastiaans in het Centrum kon worden toegepast, en was ervan overtuigd dat dat kon als de opvolgers waren ingewerkt.

Vervolgens bracht Bastiaans zijn tweede argument in stelling: ook niet-erkende oorlogsslachtoffers én andere slachtoffers van geweld en misdrijven hadden behoefte aan zijn methode. Het Centrum moest in zijn ogen de doelstelling verbreden zodat ook hun behandeling mogelijk was; tot die tijd kon Bastiaans die groep in de dependance blijven behandelen. Het bestuur antwoordde dat het de doelstelling niet kon en niet wilde verruimen. Het Centrum was 'te beperkt' en kon het leed van die andere, veel grotere groep niet erbij nemen. Bovendien zouden die andere slachtoffers niet passen bij de huidige patiënten. De net aangetreden directeur van het Centrum, dr. J.N. Schreuder, verwoordde het als volgt:

'Het gemeenschappelijke lot is het bindende element. ${ }^{82}$

De opzet van Schreuders voorganger Peters om met het binnenhalen van Bastiaans de goodwill van verzetsstrijders te winnen, was geslaagd, zij het op een andere manier dan verwacht. Nu was het niet Bastiaans maar het bestuur van het Centrum dat de bijzondere status van de patiënten gebruikte om zijn doel te bereiken. Schreuder zou in een later interview, net als Bastiaans vóór hem, zeggen dat de problemen van de oorlogsslachtoffers met het klimmen der jaren groter werden. Het bracht hem tot de conclusie:

'We hebben de komende vijftien jaar nog genoeg te doen. ${ }^{83}$

Dat was wat de verzetsstrijders wilden horen: handhaving van hun uitzonderingspositie. Tijdens de vergadering kreeg het bestuur dan ook bijval van Beckman. Hij liet weten dat de Raad van Overleg van de Stichting 1940-1945, een overlegorgaan waar afgevaardigden van verzetsorganisaties zitting in hadden, het idee van een bredere doelstelling voor het Centrum resoluut had afgewezen:

'Het Verzet gaat op zijn achterste benen staan als er voor een verzetsman geen mogelijkheid voor opname is en wel voor een ander oorlogsslachtoffer. Men heeft de angst dat de verzetsmensen buiten de deur blijven staan. [...] De verzetsbeweging zal misschien in haar opvattingen veranderen, maar nooit accepteren dat een verzetsman buiten de deur komt te staan. Voor de nieuwe inzichten moet men langzaam klaar gemaakt worden. ${ }^{84}$

De verzetsstrijders wilden graag verlenging van Bastiaans' aanstelling, maar niet ten koste van hun speciale kliniek. De steun voor Bastiaans was er nog wel, maar de gezamenlijke vuist die organisaties van verzetsstrijders twee jaar eer-

12. Het einde van de methode-Bastiaans ………… 269 
der voor Bastiaans hadden gemaakt, werd nu niet meer gemaakt; dat zou een vuist tegen hun Centrum worden.

$\mathrm{Na}$ de vergadering bleven er nog enige tijd geluiden klinken om Bastiaans wat langer aan te houden, maar die waren minder krachtig dan voorheen. Bastiaans vond twee patiënten bereid om zich te laten filmen tijdens hun behandeling. In een IKON-documentaire was een patiënt te zien die werd behandeld met LSD, en een andere patiënt die behandeld werd met pentothal..$_{5}^{85}$ Voormalige patiënten schreven steunbetuigingen in Het Parool en in NRC Handelsblad. In De Telegraaf werd opgeroepen het bestuur van Centrum' 45 te bedelven onder 'een lawine van protesten'. ${ }^{86}$

Een groep (oud-)patiënten richtte de Vereniging voor Oorlogs- en Geweldsslachtoffers (VOG) op, die streed voor behoud van de LSD-behandeling en de narcoanalyse. Volgens de patiëntenvereniging kwam door de mythevorming rond de persoon Bastiaans, zijn methode ten onrechte in een kwaad daglicht te staan. ${ }^{87}$ De voG wilde het anders aanpakken. Een van hen verwoordde het als volgt:

'Wij zien professor Bastiaans niet als een godheid, wij doen niet aan persoonsverheerlijking. ${ }^{88}$

Net als de verzetsstrijders vóór hen beriepen ze zich op het grote leed dat ze hadden doormaakt. Leden van de vereniging verklaarden dat ze zelfmoord hadden gepleegd als ze niet waren behandeld met de methode-Bastiaans. Een van hen:

'Ik keek al uit naar een balk om me op te hangen toen ik bij hem kwam. ${ }^{89}$

De pleidooien van de voG tot behoud van de methode-Bastiaans, en de uitzending van de IKON-documentaire werden koel ontvangen in de pers. In $\mathrm{Het} \mathrm{Pa}$ rool vroeg de journaliste Johanna Fortuin zich in een lange en uiterst kritische bespreking van de documentaire af, waarom de patiënte die daarin figureerde zo vaag was over haar oorlogsverleden. Fortuin stelde ook vragen bij de voortdurende roep van patiënten om steeds maar meer Bastiaans. Was het wel verantwoord om daar steeds aan toe te geven?90

Sympathisanten als verzetsstrijder Piet Coumou bleven achter Bastiaans staan. Coumou had zich al vaker opgewonden over 'de kwestie-Bastiaans' en schreef in augustus 1987 een stuk in Aantreden, een blad voor voormalig politieke gevangenen. Hij was voor verlenging van Bastiaans' periode in de dependance, en schreef: 'voormalig verzet en de organisaties van oorlogsslachtoffers zullen het bestuur zeker zeer erkentelijk zijn. ${ }^{91}$ Zijn toon was veel minder dwingend dan voorheen, toen hij zich fel had gekeerd tegen de Inspectie en de universiteit. Stichting 1940-1945 stuurde namens de Raad van Overleg nog een 
verzoek naar de minister om verlenging van Bastiaans' aanstelling met nog een halfjaar..$^{92}$

Zonder de steun van de belangenorganisaties van verzetsstrijders was Bastiaans' vertrek onvermijdelijk geworden. Het werd daardoor ook mogelijk de onaantastbare positie van Bastiaans te doorbreken. Zeker voor directeur Schreuder, die zich inmiddels wél gesteund wist door de verzetsstrijders. Hij liet zich in een interview met Max van Weezel uit over de kwestie. Het vertrek van Bastiaans op 1 november 1987 was onvermijdelijk, en hij begreep niet waarom Bastiaans nogmaals uitstel wilde:

'Bastiaans heeft erkenning gekregen. Hij is een autoriteit. Hij laat dankbare patiënten achter. Hij wordt door oud-verzetsdeelnemers op handen gedragen. Is dat niet genoeg? Wat wil hij nog meer? Een standbeeld?'93

Op 5 november 1987 , vijf dagen nadat zijn dienstverband ten einde was gelopen, kwam de definitieve slag voor Bastiaans. Minister Brinkman had Bastiaans gevraagd naar zijn ministerie te komen, waar hem tijdens een onderhoud de teleurstellende resultaten werden medegedeeld van het onderzoek van Van der Ploeg. Ook kreeg hij te horen dat per 31 december 1987 zijn ontheffing voor LSD niet meer zou worden verlengd. ${ }^{44}$ Nog dezelfde dag stuurde de minister een korte brief met daarbij het rapport van Van der Ploeg naar de Tweede Kamer met dezelfde boodschap.

Het openbaar maken van het rapport van Van der Ploeg leidde tot geschokte reacties in de pers. Er verschenen koppen als 'Bastiaans tuimelt van voetstuk' en 'Onderzoek naar gevolgen LSD-behandeling Bastiaans mislukt'. ${ }^{95}$ Met het uitkomen van het onderzoek van Van der Ploeg werd duidelijk dat de methode waar al die tijd zoveel om te doen was geweest, nergens was beschreven. Dat was bovenal Bastiaans aan te rekenen: hij had de verwachtingen en de emoties hoog opgestuwd, maar had verzuimd zijn methode te onderzoeken. Hij had zelfs zijn werk niet goed geregistreerd en gedocumenteerd. Daardoor was er geen bewijs dat de methode werkte en dat zou er op basis van Bastiaans' gegevens ook niet meer komen. ${ }^{96}$

In de brief aan de Kamer schreef de minister dat de enige manier om duidelijkheid te krijgen over de effectiviteit van de LSD-behandeling het opzetten van een nieuw experiment zou zijn, waarbij nieuwe behandelingen met LSD zouden worden uitgevoerd. Maar het uit wetenschappelijke motieven onderwerpen van ouderen aan een zo ingrijpend experiment, stuitte bij de minister op medisch-ethische bezwaren. Bovendien was het de vraag wat er met de resultaten van zo'n onderzoek zou gebeuren: de bereidheid onder psychiaters om met LSD te werken was uiterst gering. ${ }^{97}$ Voortzetting van de methode-Bastiaans zonder Bastiaans leek daarmee van de baan. De minister 'neigde' tot stopzetting van de LSD-therapie na Bastiaans' vertrek. 
In februari 1988, Bastiaans was inmiddels niet meer werkzaam op het Centrum, werden de resultaten van Van der Ploegs onderzoek en het voorstel van de minister besproken in de vaste commissie. De Kamerleden begonnen hun vragen aan de minister met loftuitingen aan Bastiaans. Ze spraken allen hun waardering uit voor diens belangrijke werk, daar wilden ze niets aan afdoen. Ze waren wel verbaasd over de resultaten van Van der Ploegs onderzoek. Vooral Kamerlid Worrell verbaasde zich over het gebrek aan dossiers. Had de Inspectie dat niet eerder moeten ontdekken? En waarom had de universiteit toegestaan dat 'er op deze manier wetenschappelijk onderzoek is verricht'? Hij concludeerde in het gesprek met de minister:

'De conclusies over de methode lijken meer gebaseerd te zijn op mondelinge mededelingen, dan op feiten. ${ }^{.98}$

De Inspectie reageerde bij monde van Van Borssum Waalkes, die de minister tijdens de vragenronde terzijde stond. De dossiers van Bastiaans waren nooit een punt van zorg geweest; het was gebruikelijk voor artsen een dossier aan te leggen over hun patiënten. Zolang er geen aanwijzingen waren dat dat niet of onvoldoende gebeurde, was er geen reden voor de Inspectie of de universiteit om controles uit te voeren. Pas na het emeritaat van Bastiaans ontstonden er vragen over zijn methode, en pas tijdens het onderzoek van Van der Ploeg kwam de kwaliteit van de dossiers boven water. Tot die tijd had iedereen vertrouwd op de woorden van Bastiaans.

De minister liet weten dat enkele patiënten die al in behandeling waren, door Bastiaans' opvolgers eventueel nog behandeld konden worden met LSD. Of zij nieuwe patiënten in behandeling mochten nemen was de vraag; zij moesten daartoe een verzoek indienen. Dat verzoek zou kritisch worden beoordeeld door de Inspectie. Het betekende het einde van de methode-Bastiaans.

\section{Conclusies}

Bastiaans had zijn patiënten en zijn achterban in de waan gelaten dat zijn methode wetenschappelijk was onderzocht, en dat het van belang was die methode te behouden. Patiënten en achterban waren voor hem in de bres gesprongen en hadden politici onder druk gezet. Daarmee had Bastiaans eerst een verlenging van tien maanden weten af te dwingen bij de universiteit, en vervolgens nog eens twee jaar bij Centrum '45. Ook daar kreeg hij nog enkele maanden verlenging, waardoor hij tot na zijn zeventigste jaar, tot januari 1988, kon doorgaan met behandelen.

Bastiaans wilde doorgaan met behandelen zoals hij gewend was, niemand kon hem daarin stoppen. Die laatste jaren werden gekenmerkt door overmoed en dwingelandij, met als gevolg de bijna-ongelukken op het Centrum, de ver- 
ziekte sfeer onder het personeel op de dependance en een gespannen verhouding met het bestuur. Hij vond dat hij niet met pensioen hoefde op een leeftijd dat anderen dat wel moesten; hij kon, zonder bewijzen te leveren, krachtige uitspraken doen over de effectiviteit van zijn behandeling; hij vond dat hij zich niet aan de afspraken die met de Inspectie waren gemaakt hoefde te houden. Kortom: regels die voor iedereen golden, golden niet voor Bastiaans.

Met het toegeven aan zijn onweerstaanbare drang tot behandelen, stelde hij zijn eigenbelang boven dat van zijn patiënten. Die patiënten zagen in zijn gedrevenheid om door te gaan een ongekende betrokkenheid bij hun problemen. Ze voelden zich erdoor gestreeld en namen het op voor hun psychiater, maar liepen feitelijk het risico gewond te raken en in het ergste geval zelfs te sterven tijdens de behandeling. Onder de vlag van compassie met oorlogsslachtoffers, werden die oorlogsslachtoffers blootgesteld aan risicovolle behandelingen. ${ }^{99}$

Dat zijn behandeldrift werd gehonoreerd, was te danken aan het voordelig bondgenootschap met de verzetsstrijders. Hij wist hen lange tijd aan zich te binden, door zijn omstreden methode te presenteren als noodzakelijk voor hun behandeling. Hij bevestigde daarmee hun uitzonderingspositie. Pas toen hij dat standpunt verliet, verloor hij zijn belangrijkste steun: de steun van organisaties als Expogé, ssv, covvs en de Stichting 1940-1945, die zich lange tijd voor hem hadden ingezet. Pas toen kwam er een einde aan zijn machtspositie en daarmee aan zijn succes.

Wat restte was een treurige afgang, waarbij zijn status als wetenschapper was bezoedeld. Bastiaans zelf reageerde in de pers verbolgen op het rapport van Van der Ploeg: Van der Ploeg, die hij als medestander had beschouwd, had hem een loer gedraaid. Als Van der Ploeg naar zijn patiënten had geluisterd, was het resultaat anders geweest. ${ }^{100}$

Bastiaans staakte zijn activiteiten in zijn geliefde dependance, maar kondigde in een interview met De Telegraaf aan dat hij thuis, zonder LSD, verder zou gaan met behandelen; de nood onder traumaslachtoffers was te hoog. ${ }^{101}$ 


\section{Epiloog}

Met Bastiaans' vertrek van het Centrum kwam er een einde aan zijn machtspositie. Hij had de steun van de belangenorganisaties van verzetsstrijders verloren. Dit maakte geen einde aan de aantrekkingskracht die hij op patiënten uitoefende. Zij bleven zich bij hem melden en hij bleef hen behandelen: thuis, in een kliniek voor 'integrale geneeskunde' in de buurt van Nijmegen en in een hotel tegenover zijn oude dependance in Oegstgeest.

Zes jaar na zijn vertrek presenteerde De Telegraaf onder de titel 'Bevrijder uit het innerlijke kamp. Prof. Bastiaans (76) helpt wanhopige patiënten zolang hij kan', nog een interview met Bastiaans. Journaliste Yvonne Laudy trok enkele dagen met Bastiaans op en was aanwezig bij een narcoanalyse.

Bastiaans voerde nog altijd narcoanalyses uit, soms zelfs driemaal per dag. Nog steeds speelde hij 'de mof', 'der Schweinhund' of 'de Jap', en nog steeds kwamen in de behandelingen herinneringen boven aan uiterst gruwelijke gebeurtenissen. Het leverde ook nog steeds dankbare patiënten op, getuige de uitspraak van een van hen:

'De professor is dicht bij je. Bij hem ben je in veilige handen. Dat voel je."

Dergelijke geluiden over het vertrouwen dat Bastiaans wist te wekken bij zijn patiënten, waren vanaf het begin van zijn doorbraak te horen geweest. Een van de eerste patiënten die hij met LSD behandelde, zei in 1969 over zijn behandeling op de dependance:

'Professor Bastiaans en de andere artsen zijn geweldig. Ik voel me net als een kuiken dat in de broedmachine uit het ei komt en dan het eerste wat beweegt als moeder beschouwt. Bastiaans en zijn collega's zijn moeder voor mij geworden, zij hebben mij weer geboren laten worden., ${ }^{3}$ 
Zijn charisma, zijn reputatie en zijn vermogen om hen tijdens de behandelingen te raken, oefenden een blijvende, onweerstaanbare aantrekkingskracht uit op zijn patiënten. Zelfs nadat zijn institutionele loopbaan voorbij was, en er bijna-ongelukken hadden plaatsgevonden op het Centrum. Na Bastiaans' dood in 1997 bleef de herinnering aan hem levend; nog steeds verschijnen er af en toe interviews met voormalige patiënten in de krant, die vol lof over hun behandeling spreken. ${ }^{4}$

In hoeverre de LSD of de pentothal daar een rol in speelde, is maar de vraag. Om met de woorden van dr. J. van Londen, voormalig directeur-generaal van Volksgezondheid van het (toenmalige) Ministerie van wvc, te spreken: 'een glaasje limonade' was waarschijnlijk ook voldoende geweest. ${ }^{5}$

Bastiaans had er moeite mee afstand te doen van zijn rol als behandelaar. Hij leed in de laatste jaren van zijn leven aan - wat zich het beste laat omschrijven als - 'behandeldrift': hij kon het behandelen eenvoudigweg niet laten. Het had een groot deel van zijn carrière bepaald, hij was er bekend mee geworden, en volgens een deel van zijn patiënten was hij er ook heel succesvol in geweest. Uiteindelijk werd hij het slachtoffer van zijn behandeldrift. Het leidde tot een laatste pijnlijke affaire.

Het was de journaliste Yvonne Laudy opgevallen dat Bastiaans wat vergeetachtig was geworden. Bastiaans had dat zelf geweten aan vermoeidheid, wat gezien zijn leeftijd en nog drukke agenda aannemelijk klonk. Maar zijn vergeetachtigheid had een ernstiger oorzaak: Bastiaans leed, toen hij het interview gaf, al twee jaar aan alzheimer. Zijn alzheimer was er vermoedelijk de oorzaak van dat zijn beoordelingsvermogen hem steeds meer in de steek liet.

Toen Bastiaans werd gevraagd adviseur te worden van de School der Universele Wijsheid, een instituut waar studenten werden onderwezen in tarot, reïncarnatietherapie en numerologie, zegde Bastiaans toe. Hij vond, zo vertelde hij in een interview, de gedachte dat er zoiets was als een 'Universele Wijsheid' wel stimulerend. Hij voegde daaraan toe dat hij hechtte aan wetenschappelijk bewijs:

'Het wetenschappelijke bewijs is belangrijk, want er wordt veel gekletst. Velen proberen hun publiek maar wat wijs te maken, geloof voor wetenschap te verkopen. ${ }^{6}$

In 1993 viel Bastiaans 'ten prooi' aan de Amerikaan H.S. Lotsof. Lotsof was in 1962 afgekickt van zijn drugsverslaving nadat hij per toeval het middel ibogaine had gebruikt. ${ }^{7}$ Het middel had zijn behoefte aan drugs voor enkele weken onderdrukt en hij was daardoor voorgoed van zijn verslaving af. Sindsdien probeerde Lotsof in clandestien georganiseerde experimenten andere drugsverslaafden van hun verslaving af te helpen.

De behandeling met ibogaïne was niet zonder gevaar; wanneer onder in-

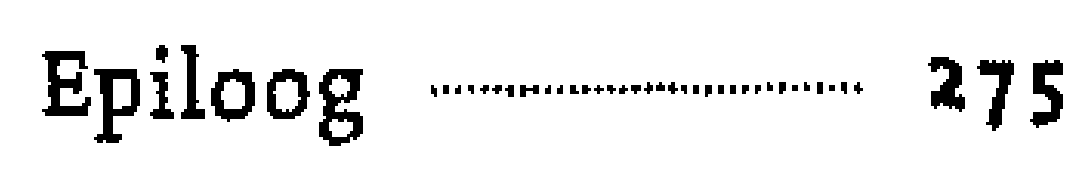


vloed van het middel toch drugs werden gebruikt, kon dat fatale gevolgen hebben. Het middel was in Amerika verboden en daarom was Lotsof uitgeweken naar Nederland, waar het middel nog niet onder de Opiumwet viel.

Hij vroeg de inmiddels zesenzeventigjarige Bastiaans de experimenten mede te begeleiden. Die ging daarop in en huurde in hotel Het Witte Huis in Oegstgeest, waar hij een oude bekende was, een verdieping waar de experimenten konden worden uitgevoerd. Toen hij nog op de dependance werkte, hadden familie en vrienden van zijn patiënten in Het Witte Huis overnacht, en toen hij daar vertrokken was, verzorgde het restaurant van het hotel een tijdlang de maaltijden voor het echtpaar Bastiaans. ${ }^{8}$

Tijdens een van de experimenten in hotel Het Witte Huis ging het mis. Een jonge Duitse vrouw kwam's nachts, onder invloed van ibogaïne, te overlijden. Bastiaans noch Lotsof was in het hotel aanwezig toen de politie arriveerde. ${ }^{9} \mathrm{De}$ toedracht van het ongeluk bleef onduidelijk. In het artikel dat Lotsof in 1999 publiceerde over de clandestiene experimenten met Bastiaans, schreef hij dat de patiënte vermoedelijk heroïne had gebruikt. ${ }^{10}$

Er werd sectie verricht maar de directe doodsoorzaak kon niet worden vastgesteld. Of iemand schuld had aan de dood van de Duitse vrouw was daardoor niet te bepalen. Het ongeluk was voor de Inspectie voor de Geestelijke Volksgezondheid wel aanleiding om Bastiaans onder druk te zetten; als hij door zou gaan met behandelen, zou er een tuchtzaak volgen. Bastiaans legde zich neer bij het verbod en staakte zijn behandelingen met pentothal.

Maar helemaal weerstand bieden aan zijn behandeldrift lukte hem niet. De laatste jaren van zijn leven bracht hij, vanwege de steeds ernstiger wordende symptomen van alzheimer, een gedeeltevan zijn tijd door in Psychogeriatrisch Centrum Mariënhaven in Warmond. Op doordeweekse dagen werd hij's ochtends thuis opgehaald en's avonds thuisgebracht. Op Mariënhaven sprak Bastiaans enkele keren met de psycholoog dr. B. Miesen. Uit die gesprekken bleek dat Bastiaans aan het behandelen bleef, ondanks het feit dat de dementie een steeds dikkere mist in zijn geheugen blies. Hij vertelde Miesen dat hij nog steeds patiënten thuis ontving. Als ze hem belden, kon hij geen weerstand bieden en sprak al snel de woorden: 'Kom maar even langs. ${ }^{11}$

Bastiaans stierf op 31 oktober 1997 op tachtigjarige leeftijd. In de necrologieën van de grote dagbladen werd hij gememoreerd als de gedreven 'behandelaar van oorlogssyndromen'. In de stukken werd voorzichtig getwijfeld aan de rol van LSD in de behandelingen; vermoedelijk was het succes van zijn behandeling vooral te danken aan zijn markante persoonlijkheid. Hoewel zijn methode onder collega's omstreden bleef en niet erkend werd, bleef hij bij oud-patiënten én bij verzetsstrijders in hoog aanzien staan. ${ }^{12}$

Dat laatste bleek ook tijdens de afscheidsplechtigheid, die plaatsvond op 6 november 1997 in het Groene Kerkje te Oegstgeest. Namens het voormalig verzet sprak Piet Coumou enkele woorden. Coumou roemde in zijn toespraak, die 
de titel droeg 'Een groot Nederlander is heengegaan', Bastiaans' betrokkenheid bij verzetsstrijders en patiënten. Bastiaans had zich ingezet voor de erkenning van de problemen van zijn patiënten, en daarvoor offers moeten brengen: het directeurschap van Centrum ' 45 , zijn aanstelling bij de universiteit en uiteindelijk zijn LSD-behandelingen. Volgens Coumou was Bastiaans 'geen vechter voor zichzelf, geen politicus of diplomaat' geweest; hij had zijn offers gebracht uit zorg voor zijn patiënten en voor de verzetsstrijders. Coumou spraknamens 'het gehele Voormalige Verzet en de vervolgden' diepe dankbaarheid uit voor die inzet. ${ }^{23}$

Naast de dankbaarheid van patiënten die weer 'door konden' met hun leven, was het belangrijkste resultaat van Bastiaans' inzet de uitzonderingspositie die hij voor oorlogsslachtoffers had gecreëerd. Toen Bastiaans wegviel als bondgenoot, en zijn exclusieve methode verdween, liep die uitzonderingspositie een slag op. Desondanks zou ze nog lang blijven bestaan; de grote compassie met oorlogsslachtoffers, waarop deze uitzonderingspositie was gebaseerd, bleef ook na Bastiaans' vertrek.

Dat bleek in 1987 toen er, tegelijkertijd met de discussie over Bastiaans' vertrek, een publieke strijd losbarstte over een onderdeel van het rapport van de Commissie voor de Vereenvoudiging en Coördinatie van de Wetten voor Oorlogsgetroffenen, onder leiding van mr. P. van Dijke. Die commissie probeerde in opdracht van de regering eenheid te scheppen in de vele regelingen en wetten voor oorlogsslachtoffers. Een paar maanden voordat de commissie haar eindrapport zou publiceren, lekte een belangrijk deelonderzoek uit.

Twee Rotterdamse psychiaters, de hoogleraar klinische en sociale psychiatrie dr. W.J. Schudel en de hoogleraar biologische psychiatrie dr. L. Pepplinkhuizen, hadden in opdracht van de commissie een uitgebreid literatuuronderzoek uitgevoerd naar de vraag of er meer dan veertig jaar na de oorlog nog in redelijkheid' een oordeel kon worden gegeven over het causaal verband tussen 'ziekten en gebreken' en traumatische oorlogservaringen. ${ }^{14}$

Volgens Schudel en Pepplinkhuizen was dat, behoudens enkele uitgesproken gevallen, niet mogelijk. De kwestie was te complex en liet te veel over aan de subjectieve oordelen van zowel beoordelaar als aanvrager. Omdat kwantitatief en epidemiologisch onderzoek ontbrak, kon zelfs niet gezegd worden dat oorlogsslachtoffers vaker of ernstiger ziek waren dan niet-oorlogsslachtoffers; laat staan dat het in individuele gevallen mogelijk was een onderscheid te maken tussen kwalen veroorzaakt door de oorlog, ouderdom, aanleg of andere factoren..$^{15}$ Sinds psychiater De Wind in de jaren zestig het initiatief nam tot de Spätfolge-groep, was daarin niet veel veranderd.

Bastiaans had de hand weten te leggen op het literatuuronderzoek en het, in een poging de publieke opinie in stelling te brengen, in de openbaarheid gebracht. Dat werkte: er barstte een publieke discussie los waarin het onderzoek 
van de Rotterdamse psychiaters werd gehekeld en de redelijkheid verloren ging. Dr. A. Heertje - hoogleraar staathuishoudkunde aan de Universiteit van Amsterdam, en columnist - vergeleek de onderzoekers met 'de kinderen en kleinkinderen van hen, die toen aan de kant van de niet-slachtoffers stonden. Met vertraging menen zij alsnog tot psychische executie te mogen overgaan. ${ }^{16}$ Psychiater Musaph, bekend om zijn goede omgang met oorlogsslachtoffers, zei in een interview:

'Geven de rapporteurs [Schudel en Pepplinkhuizen] de voorkeur aan een beoordelaar die bij het zien van het Auschwitznummer op de arm van de cliënt vraagt: Is dat uw telefoonnummer? ${ }^{17}$

Het literatuuronderzoek van Schudel en Pepplinkhuizen bevatte een boodschap die, hoewel niet per se onjuist, zeer onwelkom was en grote gevolgen kon hebben. Als artsen inderdaad niet konden vaststellen of klachten door de oorlog werden veroorzaakt, wat betekende dat dan voor degenen die al een uitkering ontvingen? Wat betekende dat voor al die patiënten die voor hun oorlogsklachten in behandeling waren of waren geweest? Wat betekende dat voor het voortbestaan van Centrum ' 45 ? Het rapport raakte de uitzonderingspositie van oorlogsslachtoffers aan de basis, en was daardoor veel schadelijker dan het vertrek van Bastiaans.

Schudel zou later in een interview vertellen dat hij Joods was, en dat in zijn familie sprake was van 'concentratiekampervaring'. Hij duidde de kritiek als veroorzaakt door 'gevoelens bij collegae dat ze in technisch-wetenschappelijk opzicht tekort waren geschoten':

'Want iedereen heeft door de jaren heen individueel mensen behandeld, maar nooit nagedacht: wat doe ik eigenlijk. Anderhalf jaar geleden hebben we ze stuk voor stuk gevraagd naar informatie over hun ervaringen met hun beoordelingen. Die hebben ze niet. [...] Ik wil mij niet meten met mensen die al jaren ervaring hebben met individuele begeleiding van vervolgingsslachtoffers. Maar ze hebben het wel altijd gedaan met de natte vinger. ${ }^{18}$

Feitelijk was het literatuuronderzoek, daarin had Schudel gelijk, geen aanval op de oorlogsslachtoffers zelf maar op hun behandelaars. Het was, ook al was het niet zo bedoeld, een aanval op degenen die twintig jaar lang hun patiënten voorhielden dat ze leden aan bijzondere aandoeningen, veroorzaakt door de oorlog, zonder dat verband te onderbouwen met onderzoek. Het literatuuronderzoek legde de kloof bloot die was gegroeid tussen wetenschappelijke inzichten en uitspraken van psychiaters als Bastiaans over het causaal verband. $\mathrm{Al}$ twee decennia lang werd het causaal verband door artsen en patiënten als een vanzelfsprekendheid beschouwd. 
De publieke verontwaardiging liet zien dat er nog steeds veel waarde werd gehecht aan de uitzonderingspositie van oorlogsslachtoffers. De kritische geluiden van de Rotterdamse onderzoekers werden niet getolereerd. Niet door die slachtoffers zelf én niet door hun omgeving.

Gezien de felle reacties die het literatuuronderzoek in 1987 nog had opgeroepen, zal het geen verbazing wekken dat de bijzondere status van oorlogsslachtoffers in de hulpverlening nog lang intact bleef. Zo werd pas in 1995 bij Centrum ' 45 wat ruimte gemaakt voor andere groepen slachtoffers. In de statuten werd toen opgenomen dat het Centrum ook 'de gevolgen van andere extreme menselijke noodsituaties in zijn aandachtsveld' betrok.

Deze voorzichtige formulering werd in 2006, meer dan dertig jaar na de oprichting van het Centrum en meer dan vijftig jaar na het einde van de oorlog, vervangen door een bredere doelstelling: slachtoffers van 'vervolging, oorlog, geweld en andere extreme noodsituaties [...] in de ruimste zin des woords' waren welkom. Pas toen verloor het Centrum definitief zijn categorale doelstelling en waren alle slachtoffers van traumatische gebeurtenissen even welkom. ${ }^{19}$

Inmiddels bestaan veel elementen van de uitzonderingspositie (de speciale diagnose, de speciale kliniek en de speciale behandelmethode) niet meer. Stichting ICODO, naar aanleiding van het wAC-rapport opgericht om de hulpverlening aan oorlogsslachtoffers te coördineren, bestaat nog steeds, maar rekent inmiddels ook andere groepen slachtoffers tot haar doelgroep. Zo lijkt in de hulpverlening een einde te zijn gekomen aan de uitzonderingspositie van oorlogsslachtoffers. Toch zijn de laatste resten ervan nog steeds zichtbaar.

In hoofdstuk 2 van dit boek werd beschreven hoe de Wet Buitengewoon Pensioen vanaf haar inwerkingtreding problemen opleverde voor medici. De WBP eiste een causaal verband als voorwaarde voor het verstrekken van een uitkering. Bastiaans had in zijn proefschrift een oplossing aangedragen, die nog lang in gebruik bleef. Hieraan had hij een groot deel van zijn succes te danken.

De Wet Buitengewoon Pensioen bestaat nog steeds, net als de Wet Uitkering Vervolgingsslachtoffers, en nog steeds wordt er aanspraak op gemaakt. De problemen bij het beoordelen van het causaal verband bestaan ook nog steeds. Dat bleek toen er in 2004, iets meer dan vijftien jaar na het onderzoek van Schudel en Pepplinkhuizen, een rapport verscheen van dr. B.J.N. Schreuder, bijzonder hoogleraar transgenerationele oorlogsgevolgen aan de Radboud Universiteit Nijmegen, eerder directeur van Centrum' 45.

Aan Schreuder was door het Ministerie van vws gevraagd een rapport te schrijven over de vraag of het, bijna zestig jaar na het einde van de oorlog, nog mogelijk was een oordeel te geven over het causaal verband tussen oorlogservaringen en klachten bij patiënten. Bij de uitvoering van de wetten - zoals de Wet Buitengewoon Pensioen en de Wet Uitkering Vervolgingsslachtoffers - 
zijn artsen nog steeds overgeleverd aan hun evidentiegevoelens bij het geven van een oordeel. Dat levert nog steeds onenigheid op onder die artsen.

In zijn rapport beperkte Schreuder zich, net als Schudel en Pepplinkhuizen eerder, tot het verband tussen de oorlog en psychische klachten in de vorm van PTSS. Psychosomatische klachten bleven buiten beschouwing. Door de veranderde ideeën onder wetenschappers over psychosomatiek, was het erg lastig om lichamelijke klachten in verband te brengen met de oorlog. PTss kon nog wel in verband worden gebracht met de oorlog, maar dan alleen als de symptomen zich al kort na de oorlog hadden geopenbaard en sindsdien niet waren verdwenen.

Schreuder merkte op dat er bij de beoordelingen ook andere, naoorlogse invloeden moesten worden betrokken, en dat er rekening moest worden gehouden met vertekeningen in de herinnering bij de aanvrager. Zekerheden in de vaststelling van het verband waren nog steeds niet te geven; het ging om waarschijnlijkheden en aannemelijkheden die waren gebaseerd op het oordeel van de arts en de door hem aangevoerde argumenten. ${ }^{20}$

Uit een reactie hierop van R. Loonstein en A.J. Maas, twee artsen van het medisch bureau van de Pensioen- en Uitkeringsraad (PUR), de instantie die de taken van de Buitengewone Pensioenraad (BPR) heeft overgenomen, bleek dat zij daar heel anders over dachten. In het merendeel van de gevallen boden het feitenonderzoek en het medisch onderzoek volgens hen 'een solide ondergrond' om een 'gedegen medische uitspraak over de causaliteit' te doen. In enkele gevallen werd er een beroep gedaan op de omgekeerde bewijslast. Slechts in enkele gevallen was het lastig een oordeel te vellen en werd, binnen de 'grenzen van de redelijkheid', de 'grootst mogelijke souplesse' betracht in het oordeel over causaliteit. ${ }^{21}$

Volgens Loonstein en Maas waren de beoordelingen niet moeilijker dan voorheen. Deze uitspraak staat in schril contrast met die van hun voormalig directeur eind jaren zeventig. Samen met de directeur van de Stichting 19401945 schreef deze toen aan de verantwoordelijke minister dat het voor medici 'zowel theoretisch als praktisch onmogelijk' was een oordeel te geven over het causaal verband. ${ }^{22}$

Een studie naar de dossiers van de PUR zou een beeld kunnen geven van de totstandkoming van die 'gedegen medische uitspraken'. Welke instrumenten en methoden werden door de jaren heen gebruikt om die oordelen te onderbouwen? Hoe werden de 'grenzen van de redelijkheid' door de jaren heen beïnvloed door ontwikkelingen in wetenschap en maatschappij? En tot wanneer bleef de psychosomatiek zoals Bastiaans die introduceerde in gebruik?

Bastiaans bracht Nederland in 1965 het $\mathrm{KZ}$-syndroom en wist daar lange tijd zijn succes aan te ontlenen. Het KZ-syndroom werd in ieder geval tot 1994 beschreven in een handboek over psychopathologie voor psychologen en psychi- 
aters, als een specifieke vorm van PTss. ${ }^{23}$ Inmiddels behoort de term tot de verplichte historische kennis van psychiaters. Hoogleraar psychiatrie en psychopathologie dr.J.E. Hovens en psychiater dr. G.J. van der Ploeg publiceerden in 2006 een boek met daarin 'sleutelteksten' van de geschiedenis van de psychiatrie. De bedoeling was om vaak aangehaalde klassieke teksten toegankelijk te maken voor de hedendaagse psychiater. Een van die klassieke teksten was een artikel van Bastiaans over het $\mathrm{Kz}$-syndroom, volgens beide auteurs belangrijk om de historische ontwikkeling van het psychisch trauma te kunnen begrijpen. ${ }^{24}$

Bastiaans' bijdrage aan die ontwikkeling was vooral een 'publicitaire bijdrage'; zijn artikelen, toespraken en films lieten een groot publiek kennismaken met het psychisch trauma. Hij maakte het tot een algemeen geaccepteerde aandoening, niet alleen binnen de psychiatrie maar ook daarbuiten. Voor zijn carrière midden jaren zestig een vlucht nam, werd de uitdrukking 'psychisch trauma' slechts spaarzaam onder psychiaters gebruikt. Na zijn carrière was het begrip niet meer weg te denken, noch in de psychiatrie noch in het maatschappelijk leven.

Een nieuwe generatie psychiaters én de maatschappij werden zich bewust van psychische trauma's, en van het feit dat deze zich niet beperkten tot oorlogsslachtoffers alleen. Er ontstond zelfs een nieuwe tak van wetenschap, en ook daar droeg Bastiaans aan bij.

Bastiaans was op bestuurlijk niveau betrokken bij de Centrale Beleids- en Ondersteuningsgroep, een overheidscommissie die wetenschappelijke onderzoeken naar psychotrauma's stimuleerde. Kappeijne van de Coppello, die een initiatief was gestart om het wetenschappelijk werk van Bastiaans voort te zetten, kondigde in de zomer van 1985 de oprichting aan van de Internationale Stichting voor Slachtoffers van Oorlog en Geweld(ISSOG). De IssOG werd deels gefinancierd door de internationale vereniging van verzetsstrijders Fédération Internationale des Déportés et Internés Résistants (FILDIR). De Issog benoemde in 1989 dr. H.M. van der Ploeg, de man die de LSD-behandeling van Bastiaans probeerde te onderzoeken, tot bijzonder hoogleraar met als leeropdracht de psychotraumatologie van slachtoffers van oorlog en geweld. Van der Ploeg was daarmee de eerste hoogleraar in Nederland wiens vakgebied de psychotraumatologie betrof.

In een interview naar aanleiding van zijn aanstelling nuanceerde Van der Ploeg de opvatting van zijn werk als voortzetting van het werk van Bastiaans. Hij zou zich niet met hulpverlening maar met onderwijs en onderzoek bezighouden. ${ }^{25}$ Bovendien richtte hij zich niet alleen op slachtoffers van de Tweede Wereldoorlog, maar ook op slachtoffers van andere oorlogen en andere calamiteiten. De Issog bestaat niet meer, maar inmiddels is er wel een bijzonder hoogleraar psychotraumatologie verbonden aan Centrum ' 45 .

Bastiaans wist niet alleen binnen de psychiatrie, maar ook daarbuiten be- 
grip te kweken voor het psychisch trauma. Tijdens het onderzoek voor zijn proefschrift in de jaren vijftig had hij bij patiënten een zekere schroom waargenomen wanneer het ging over psychische problemen. Ze lieten zich liever behandelen door een somatisch gerichte arts dan door een psychiater. Daarvan was midden jaren tachtig geen sprake meer, integendeel. Toen er op $26 \mathrm{fe}-$ bruari 1988 een symposium plaatsvond ter gelegenheid van Bastiaans' afscheid van Centrum ' 45 , werd die bijdrage ook onder woorden gebracht door een van de sprekers. De toenmalige directeur van Centrum '45, Bas Schreuder, vatte Bastiaans' blijvende bijdrage als volgt samen:

'Een van de grootste verdiensten van prof. Bastiaans, misschien wel de grootste, is dat de publieke opinie in Nederland weet dat traumatische gebeurtenissen die lang geleden hebben plaatsgevonden, iemands actuele leven in ernstige mate kunnen verstoren; dat iemand zich daarvoor niet hoeft te generen; en dat hulp zoeken in zo'n situatie dan ook geen schande is. ${ }^{26}$

Bastiaans' bijdrage aan de behandeling van psychische trauma's - althans de onderdelen die als kenmerkend voor zijn bijdrage werden gezien: het gebruik van pentothal en LSD - verdween met Bastiaans. Omdat hij zijn methode niet wetenschappelijk had onderbouwd, bleef het onduidelijk in hoeverre die methode er, beter dan andere, in slaagde klachten te verminderen. Bovendien bleef onduidelijk wat de methode-Bastiaans precies was; waarin onderscheidde deze methode zich van andere, vergelijkbare behandelingen?

Dat nam niet weg dat de methode-Bastiaans door een enkeling graag behouden werd. Enkele patiënten organiseerden zich in de herfst van 1987 onder de naam 'Vereniging voor Oorlogs- en Geweldsslachtoffers' (VOG) en probeerden de narcoanalyse onderzocht te krijgen. Uiteindelijk staakte de voG haar pogingen in september 1990 wegens gebrek aan interesse bij onderzoekers en psychiaters. ${ }^{27}$

De LSD-behandelingen stimuleerden in 1999 twee Utrechtse onderzoekers, drs. H.C. Ossebaard en drs. N. Maalsté, om een kleine enquête onder voormalig patiënten van Bastiaans te houden. De onderzoekers hadden de bedoeling om met de publicatie van de resultaten van de enquête de interesse van financiers te wekken, zodat vervolgonderzoek naar de methode-Bastiaans kon worden gedaan..$^{28}$ Ook dat vervolgonderzoek kwam er niet meer.

Daarmee is niet gezegd dat de LSD-behandeling voorgoed uit de psychiatrie is verdwenen. Er zijn inmiddels initiatieven ontstaan, los van Bastiaans' werk, die de LSD-therapie nieuw leven willen inblazen. In Amerika bestaan inmiddels vergaande onderzoeksplannen om terminaal zieke patiënten een LSD-sessie aan te bieden, een soort van stervensbegeleiding. De enige overeenkomst met Bastiaans' behandelingen is het gebruik van LSD, de theoretische achtergrond is een heel andere. ${ }^{29}$ 
In de inleiding van dit boek werd de filosoof Ian Hacking aangehaald. Hij beschreef hoe 'tijdelijke psychische aandoeningen' die zich op een bepaald moment en op een bepaalde plaats voordoen, zoals de fugue, een vruchtbaar maatschappelijk en wetenschappelijk klimaat nodig hebben om te kunnen overleven. Het begin van de jaren zestig vormde het ideale klimaat voor het $\mathrm{KZ}$ syndroom.

Het oude paradigma van 'goed' en 'fout' maakte in de jaren zestig plaats voor nieuwe vragen en nieuwe inzichten. Vooral de Jodenvervolging stelde Nederland voor moeilijke en pijnlijke vragen. Dat uitte zich in onrust over de noden van en ontevredenheid onder overlevenden van de kampen. Hoe om te gaan met de gevolgen voor de nog levende slachtoffers? Had Nederland tekortgeschoten, en deed het dat misschien nog steeds? Het leidde tot heftige zelfkritiek en schuldgevoelens.

Deze collectieve onrust vroeg om een oplossing, en die werd gevonden in een psychiatrische aandoening: het $\mathrm{Kz}$-syndroom. Het $\mathrm{kz}$-syndroom vervulde, zoals sociologe Jolande Withuis al eens beschreef, een functie voor patiënten, maatschappij en psychiaters. ${ }^{30}$

Voor de slachtoffers betekende de formulering van het Kz-syndroom de erkenning van hun verleden, die ze zozeer wensten. Dat waar ze altijd over hadden gezwegen, kon nu besproken worden. Eindelijk kregen ze aandacht voor de problemen waar ze al jarenlang mee kampten. De nieuwe diagnose gaf hun toegang tot speciale uitkeringen, speciale behandelingen en een speciale kliniek.

Voor maatschappij en overheid was het $\mathrm{Kz}$-syndroom een manier om de schuldgevoelens over het oorlogsverleden een plaats te geven. Wat kort na de oorlog te weinig was gedaan, kon nu deels worden gecompenseerd. Om die reden bleven de drie van Breda vastzitten, werden de klachten van slachtoffers erkend als een legitieme en bijzondere psychiatrische aandoening, en werd een speciale kliniek opgericht. Door hun een uitzonderingspositie te verlenen en speciale behandelmogelijkheden ter beschikking te stellen, kon een begin worden gemaakt met de inlossing van een 'ereschuld'.

Deze 'medische oplossing' van het maatschappelijke conflict kon alleen ontstaan met de hulp van medici; zij moesten als onafhankelijke derde de noden legitimeren. Bastiaans bleek daarvoor de juiste man op de juiste plaats te zijn. Hij wist, beter dan andere psychiaters, woorden te geven aan de noden van de slachtoffers, en wierp zich op als hun belangenbehartiger. Hij was de man die in 1972, toen de onrust over de gevolgen van de oorlog tot een hoogtepunt was gestegen, in een film figureerde waarin het Kz-syndroom een gezicht kreeg.

Tegelijkertijd presenteerde Bastiaans een uitzonderlijke behandeling, die bekend werd als de methode-Bastiaans. Die methode zette nog eens een uitroepteken achter de ernst en het unieke karakter van de problemen van oorlogsslachtoffers, en bood tegelijkertijd, zo beweerde hij, een manier om ervan 
te genezen. Die belofte op genezing was ook voordelig voor de maatschappij en de overheid; zij konden, door de omstreden behandeling toe te staan en zelfs langer dan gebruikelijk in stand te houden, uiting geven aan een bijzondere compassie met oorlogsslachtoffers. Bastiaans kreeg zo een unieke positie: hij bood zowel op collectief als individueel niveau een manier om met het problematische Nederlandse oorlogsverleden om te gaan.

Dergelijke processen, die al eens uitgebreid werden beschreven door de socioloog Abram de Swaan, kennen dus niet slechts één aanstichter. Medici, patiënten, samenleving en overheid spelen ieder hun eigen rol, worstelen ieder met hun eigenbelang, zonder dat één van hen in staat is boven de materie uit te stijgen. ${ }^{31}$ Niettemin is de verantwoordelijkheid voor het geheel gedeeld. De Swaan benoemde die gedeelde verantwoordelijkheid van de verschillende partijen als een 'verborgen medeplichtigheid', een collusie.

Het kostte moeite die collusie in stand te houden, en er waren ongewenste bijeffecten. De maatschappelijke compassie met oorlogsslachtoffers vereiste bijvoorbeeld een ruimhartige toepassing van de uitkeringswetten. Het Buitengewoon Pensioen werd gezien als een vorm van erkenning; erkenning die slachtoffers graag wilden ontvangen en die de omgeving graag wilde geven. Dat bracht keuringsartsen op den duur in conflict met de wetenschappelijke inzichten van hun vakgebied. Het leidde tot pijnlijke verschillen van inzicht bij het beoordelen van het causaal verband. Pijnlijk voor zowel de artsen als de aanvragers, en uiteindelijk ook voor de overheid en de maatschappij.

De grote aandacht voor de problemen van oorlogsslachtoffers en de compassie met hen, deed ook een sociale fuik ontstaan, waardoor steeds meer klachten werden gezien als een gevolg van de oorlog. Het leidde tot een toename van het aantal aanvragen voor een uitkering en tot groeiende problemen bij de vaststelling van het causaal verband. Het leidde in de behandelingen bij Bastiaans soms tot ernstige vervormingen van de herinnering. De autobiografische reconstructie voldeed in die gevallen wel aan de verwachtingen van patiënt, psychiater en omgeving, maar stond niet of maar zijdelings in verband met authentieke gebeurtenissen. Kritische vragen waren niet goed mogelijk. Zelfs Bastiaans' grote vergissing in het geval-Meester werd, na de openbaarmaking ervan, met de mantel der liefde bedekt.

Om de oplossing in stand te houden, was de hulp van Bastiaans lange tijd van groot belang. Hij genoot het vertrouwen van verzetsstrijders en werd door hen en anderen gezien als dé expert. Hij was de enige die beschikte over een behandelmethode waarmee - zo ging de mythe - zelfs de ernstigste problemen van oorlogsslachtoffers succesvol aangepakt konden worden.

Dat had tot gevolg dat Bastiaans een bijna onaantastbare positie in kon nemen, en zich gedrag kon permitteren dat bij anderen veel eerder sancties of tegenreacties zou hebben opgeroepen: zijn draai in het debat rond de drie van Breda; de lastige start die hij Centrum ' 45 bezorgde; de leugens die hij pers en 
patiënten vertelde over het succes van zijn behandelingen; de gevallen waarbij patiënten een nieuw verleden reconstrueerden; het ontbreken van wetenschappelijk onderzoek naar zijn methode; de bijna-ongelukken met de narcoanalyses; het opjutten van patiënten.

Niemand durfde hem er openlijk op aan te spreken, en als dat tóch gebeurde, zorgden patiënten of sympathisanten ervoor dat de kritiek werd getemperd. Kritiek op Bastiaans kon de collusie in gevaar brengen en dat wilde niemand.

Het klimaat dat zo gunstig was voor Bastiaans en het KZ-syndroom verdween begin jaren tachtig. Het KZ-syndroom paste zich aan - het veranderde enigszins van inhoud en naam om beter aan de veranderde omstandigheden te kunnen voldoen: PTSS ontstond. De opkomst van het psychisch trauma, met nieuwe groepen slachtoffers, zette de uitzonderingspositievan oorlogsslachtoffers én van Bastiaans onder druk.

De opkomst van PTSS en het verdwijnen van het Kz-syndroom, verzwakte Bastiaans' positie. Jarenlang had hij met enkele collega's een monopolie op het gebruik van die term gehad, maar met de komst van PTss was dat monopolie doorbroken. Er waren nu ook andere psychiaters met kennis van psychische trauma's.

Toen Bastiaans zijn methode - zijn laatste troef - niet meer exclusief reserveerde voor oorlogsslachtoffers, werd de magie verbroken. Toen de verzetsstrijders moesten kiezen voor de mogelijkheid Bastiaans nog een paar maanden langer te laten doorwerken óf hun eigen kliniek te behouden, kwam er een einde aan de periode-Bastiaans.

Inmiddels is het ontzag voor psychische problemen ten gevolge van traumatische gebeurtenissen zo groot geworden, dat er sprake is van een ware 'traumacultuur'. Jolande Withuis wijst in dit verband op de vergaande inflatie van het begrip 'psychisch trauma'. Doordat de problemen van steeds nieuwe groepen onder dezelfde noemer worden geschaard, komt het onderscheid ertussen te vervallen. Of dat terecht is, is de vraag. Net zomin als het vanzelfsprekend is dat de problemen van een overlevende van de vernietigingskampen vergeleken worden met die van iemand die hielp bij de verspreiding van illegale kranten, is het vanzelfsprekend dat de problemen van een gemartelde Irakese vluchteling vergeleken worden met die van een slachtoffer van een beroving.

Hoewel het $\mathrm{Kz}$-syndroom inmiddels is verdwenen, spelen de processen die het tot een succes maakten nog steeds. Groepen PTSs-slachtoffers verenigen zich nog steeds, en hebben het idee dat de status van slachtoffer iets is om voor te vechten, dat het iets is waar maatschappelijke, politieke, financiële of andere erkenning voor gewenst of zelfs vereist is. ${ }^{32}$ Die erfenis van de omgang met het Nederlandse oorlogsverleden is in belangrijke mate te danken aan Bastiaans. 


\section{Noten}

\section{Inleiding}

Hacking, 1998.

Zie voor een bespreking van 'shellshock' Shephard, 2001.

Van der Velden, 1989.

Werkgroep Dependance Jelgersmakliniek, 1985.

Gezondheidsraad, 1985.

Zo werd een verzoek aan de gUR, die van vrijwel alle genoemde patiënten over een dossier beschikt, geweigerd.

7 Het citaat van De Swaan is afkomstig uit een essay getiteld 'De maatschappelijke verwerking van oorlogsverledens' en is onder andere te vinden in: De Swaan, 1999, p. 42.

8 Zie daarvoor bijvoorbeeld: Crombag \& Merckelbach, 1996; Merckelbach \& Jelicic, 2005; Wagenaar \& Groeneweg, 1990.

9 Blom, 1989b; De Haan, 1997; De Swaan, 1983a; De Swaan, 1983b; De Swaan, 1999; Mooij, 2002; Van Vree, 1995; Withuis, 2002; Withuis, 2005.

\section{Vormingsjaren}

\section{Interview Frenkel.}

2 Jan Bastiaans sr. werd geboren op 30 april 1879 en stierf op 20 juni 1944. Cornelie Carolina Henriette Nina Tengbergen werd geboren op 22 juli 1883 en stierf op 16 juni 1955 . Gegevens afkomstig van CBG.

3 Leerlingkaart J. Bastiaans. Vindplaats: Archief Kennemer Lyceum. Met dank aan archivaris Van Rijn van het Kennemer Lyceum en L. van Gasteren.

Leerlingkaart J. Bastiaans. Vindplaats: Archief Kennemer Lyceum.

Inschrijvingsregister Universiteit van Amsterdam (1936). Vindplaats: Archief UvA/Drv, nr. TY6. Hagendijk, 1980, p. 71 .

Interview Prenkel.

Ledenlijst BRP. Vindplaats: Archief BRP, $\mathrm{nr}, 64$.

Oud-leden BRP. Vindplaats: Archief BRP, nr. 67

Welke hoogleraar Bastiaans heeft voorgedragen is onduidelijk. In de archieven van BRP is daar geen materiaal over te vinden. Zie daarvoor: Archief BRP, nr. $64 \mathrm{t} / \mathrm{m} 67$.

11 Bastiaans, 1986, p. 7-8; Van Proosdij, S. (1 januari 1984). 'Hoe werk ik hun eruit'. Interview met prof.dr. J. Bastiaans. Arts en Wereld; Willems, M. (31 oktober 1987). 'Ik wil nog zoveel mogelijk traumaslachtoffers helpen'. De Telegraaf; Piët, $S$. (4 mei 1985). Wezenlijk met mensen bezig zijn daar gaat het om. Elsevier. 
Verburgh, H.S. (27 januari 1983). Prof. Bastiaans in conflict met Leidse universiteit. 'Ik heb een symbolische functie'. NRC Handelsblad.

13 Vergelijk: Radio programma Een leven lang, 23 november 1989 en Meijer, 1. (19 januari 1985). De geheimsfeer. Vrij Nederland.

14 Piët, S. (4 mei 1985). Wezenlijk met mensen bezig zijn daar gaat het om. Elsevier.

15 Oolbekkink, H.J. (21 november 1981). Prof.dr. Jan Bastiaans, de helper: 'We lijden allen aan het ziektebeeld van de hysterie'. Hadgse Courant.

$16 \quad$ Knegtmans, 1998

Knegtmans, 1998, p. 90 .

Knegtmans, 1998, p. 90-91; Dohmen \& Steens, 1995, p. 31-32.

Knegtmans, 1998, p. 89-91.

Bastiaans, J. (3 oktober 1940). Rede. Unitas; Bastiaans, 1946.

Knegtmans, 1998, p. 90.

Hagendijk, 1980, p. 81.

Knegtmans, 1998, p.105; Bastiaans, J. (5 juni 1941). Bij het einde van het studiejaar 1940-1941. Unitas.

De arrestaties waren een reactie op de behandeling van gevangen Duitsers in Nederlands-Indië. Van Daal \& De Knecht-van Eekelen, 1994

Interview Frenkel.

Bastiaans, J. (1 mei 1941). Wij die nog leven brengen een groet aan den dode. Unitas.

Exemplaren van het blad Unitas uit de oorlogsjaren bevinden zich in Archief USA.

Bastiaans, J. (5 juni 1941). Bij het einde van het studiejaar 1940-1941. Unitas.

Notulen R\&A, 28 juni 1941. Vindplaats: Archief UVA/R\&A, nr.17.

Notulen R\&A, 28 juni 1941. Vindplaats: Archief UvA/R\&A, nr.17.

Notulen R\&A, 28 juni 1941. Vindplaats: Archief UvA/R\&A, nr.17.

Knegtmans, 1998, p. 120.

Notulen R\&A, 7 juli 1941. Vindplaats: Archief UvA/R\&A (281), nr. 17.

Knegtmans, 1998, p. 119

Hagendijk, 1980, p. 73 .

Hagendijk, 1980, p. 85 en p. 290; Zie ook radio-uitzending Een leven lang, 23 november 1989.

Brief J. Feitsma aan J. van Dam, 20 april 1943. Vindplaats: DocII, 790, map B.

Knegtmans, 1998

Examenregister UvA. Vindplaats: Archief UvA/Drv.

Piët, S. (4 mei 1985). Wezenlijk met mensen bezig zijn daar gaat het om. Elsevier.

Bibeb ( 5 september 1970). Prof.dr. J. Bastiaans: 'Verslaafden liggen me minder dan

verzetsmensen'. Hoe haal je de mens uit de beklemming van zijn persoonlijk concentratiekampsyndroom? Vrij Nederland; Oolbekkink, H.J. (21 november 1981). Prof.dr. Jan Bastiaans, de helper: 'We lijden allen aan het ziektebeeld van de hysterie'. Haagse Courant; Verburgh, H.S. (27 januari 1983). Prof. Bastiaans in conflict met Leidse universiteit. 'Ik heb een symbolische functie'. NRC Handelsblad; Van Proosdij, S. (1 januari 1984). 'Hoe werk ik hun eruit'. Interview met prof.dr. J. Bastiaans. Arts en Wereld; Piët, S. (4 mei 1985). Wezenlijk met mensen bezig zijn daar gaat het om. Elsevier; Bastiaans, 1986.

43 Van Lieburg, 1990

44 Register Zusters Diaconessen. Vindplaats: Collectie Bronovo, nr. 22.

45 Piët, S. (4 mei 1985). Wezenlijk met mensen bezig zijn daar gaat het om. Elsevier; Interview Gaaikema.

46 Interview Gaaikema; Curriculum vitae Jan Bastiaans uit 1963. Vindplaats: Collectie UvA/Drv, Personeelsdossier Jan Bastiaans.

47 Interview Bastiaans-Visser

48 Meer dan vijftig jaar na de oorlog kregen Bastiaans' ouders postuum een erkenning van het Israëlische Yad Vashem. Net als diens zus overigens die het Joodse gezin het huis had ingehaald. Zie daarvoor: Gutman, Bender, Michman, \& Flim, 2005, p. 105-106.

49 Gutman et al, 2005, p. 105-106.

50 Brief Bastiaans aan CRvB, 11 november 1993. Kopie in bezit auteur. 
Provinciaal Electriciteitsbedrijf Noord-Holland, 1945.

Brief Bastiaans aan CRvB, 11 novernber 1993. Kopie in bezit auteur.

Zie bijvoorbeeld: Van der Leeuw, 1950.

Knegtmans, 1998, p. 290.

55 Verslag gesprek Bastiaans en J. Knegtmans. Vindplaats: Privécollectie J. Knegtmans. Kopie in bezit auteur.

56 Zie daarvoor de geschiedenis van het artsenverzet in De Vries, 1949

57 Bastiaans, 1951.

58 Van Proosdij, S. (2 januari 1984). 'Hoe werk ik hun eruit'. Interview met prof.dr. J. Bastiaans. Arts en Wereld; Piët, S. (4 mei 1985). Wezenlijk met mensen bezig zijn daar gaat het om. Elsevier.

59 Bibeb (5 september 1970). Prof.dr. J. Bastiaans: 'Verslaafden liggen me minder dan verzetsmensen'. Hoe haal je de mens uit de beklemming van zijn persoonlijk concentratiekampsyndroom? Vrij Nederland.

6o Brief van Geneesheer Directeur Wilhelmina Gasthuis aan de wethouder voor Openbare Gezondheid en het Ziekenhuiswezen, 21 juli 1953. Vindplaats: Collectie UvA/prv, Personeelsdossier Bastiaans.

61 Bastiaans was overigens geen uitzondering. Tijdens de oorlog hadden meer studenten geneeskunde kans gezien hun onderwijs op de een of andere manier voort te zetten. Zie daarvoor: Woerdeman, 1945.

62 Brief van Van der Horst aan College van B\&W, 20 oktober 1952. Vindplaats: Collectie UvA/Drv, Personeelsdossier Bastiaans.

63 De leeranalyse is een cruciaal onderdeel van de opleiding tot psychoanalyticus. De leerlingpsychoanalyticus ondergaat een analyse bij een ervaren psychoanalyticus, om zo de techniek van het analyseren onder de knie te krijgen en zijn eigen verborgen emotionele motieven te doorgronden.

64 Van Daal \& De Knecht-Van Eekelen, 1994 .

65 De begrippen 'stress' en 'psychisch trauma' werden door de Psychosomatische Werkgroep in ieder geval vanaf 1951 gebruikt. Zie bijv: Groen, Van der Horst, \& Bastiaans, 1951. Het 'psychisch trauma' werd daarvoor in de psychiatrie ook al gebruikt. Zie bijvoorbeeld: Rümke, 1940.

66 Olthuis, 1973

67 Van Daal \& De Knecht-Van Eekelen, 1994.

68 Groen et al., 1951, p. 40-41.

69 Groen et al., 1951, p. 52.

70 Interview Pelser.

71 Groen et al., 1951.

72 Volgens de ledenkaart van de Nederlandse Vereniging voor Psychiatrie werd Bastiaans op 25 januari 1950 ingeschreven in het register. Vindplaats: Archief NVP.

Eysenck als geciteerd in Dehue, 1990, p.132.

Zie voor een recente bespreking ook Gomperts, 2004.

Patiënten gaven met een cijfer van 1 tot 10 'hun gevoel van welbevinden' aan, de Wechsler Bellevue intelligentietest (de opvolger hiervan, de waIs, is nog steeds een van de meest gebruikte intelligentietests) werd afgenomen, een aantal schalen uit de MMO de Maudsley Medical Questionnaire (een oorspronkelijk door Eysenck gemaakte vragenlijst bestaande uit een aantal verschillende schalen die tezamen een maat voor neuroticisme opleverden) en de Rorschachtest (de inktvlekkentest) werden afgenomen.

76 Barendregt, Bastiaans, \& Vermeul-van Mullem, 1960.

77 Gomperts, 2004; Interview Thiel.

78 Barendregt, Bastiaans, \& Vermeul-van Mullem, 1961.

79 Bibeb (5 september 1970). Prof.dr. J. Bastiaans: 'Verslaafden liggen me minder dan verzetsmensen'. Hoe haal je de mens uit de beklemming van zijn persoonlijk concentratiekampsyndroom? Vrij Nederland.

80 Interview Frenkel; Interview Van Ree; Interview Thiel. 


\section{Het proefschrift - psychosomatische gevolgen van onderdrukking en}

\section{verzet}

$1 \quad$ NRC (28 februari 1957). Psychosomatische gevolgen van onderdrukking en verzet. Een

belangwekkend proefschrift.

$2 \quad$ Website Stichting 1940-1945

3 Wals, 1993. Nabestaanden van gevallen verzetsstrijders, de zogenaamde 'nagelaten betrekkingen', kwamen ook in aanmerking voor een uitkering.

\section{Rümke, 1951}

5 Mooij, (2002) noemt de volgende: Kopenhagen (1954), Parijs (1954), Brussel (1955), Moskou (1956), Oslo (1960), Den Haag (1961) en Keulen (1967).

6 Michel, 1955, p. 334-335. Overigens ontstonden in Frankrijk wel weer andere problemen. Wanneer iemand vanwege verzetsdaden was gedeporteerd dan leverde dat een hogere uitkering op. De beoordeling van het causaal verband tussen verzet en deportatie bleek volgens Fichez niet altijd even makkelijk.

Hermann \& Thygesen, 1954.

De afkorting ' $\mathrm{kz}$ 'werd uitgesproken als 'ka-tzet'.

Thygesen in Michel, 1955, p. 22.

10 Voor Frankrijk zie Richet \& Mons, 1956, p. 185; Voor Noorwegen zie Eitinger, 1969; Voor Denemarken zie Michel, 1955, p. 66.

11 Gilbert Dreyfus, Fichez, \& Frank, 1954

12 Dit voordeel van de Deense benadering werd eerder al opgemerkt door Mooij (2002).

13 Volgens het proefschrift van historicus Futselaar (Futselaar, 2007) bleek Noordhoek Hegt inderdaad gelijk te hebben. Futselaar onderzocht de voedingspatronen gedurende de oorlog in verschillende Europese landen. In vergelijking met andere bezette landen, had Denemarken gedurende de oorlog de beschikking over meer en betere voeding dan de rest van Europa. In andere landen was de ondervoeding meer te vergelijken met die in Nederland. Niet Nederland, maar Denemarken was de uitzondering.

14 Michel, 1955, p. 332.

Noordhoek Hegt in het voorwoord op: Barnhoorn, 1954, p. 4.

Bastiaans, 1957, p. 22.

Bastiaans, 1957, p. 65.

Mooij, 2002.

Mooij, 2002, p. 270.

Bastiaans, 1957, p. 2-3.

Het ging om Keys, Brožek, Henschel, Mickelsen, \& Taylor, 1950.

Bastiaans, 1957, p. 85.

Zie bijvoorbeeld: Groen, Van der Horst, Bastiaans, Van der Valk, \& Vles, 1950.

Goldstein \& Kopin, 2007

Bastiaans, 1957, p. 97.

De kunstschilder staat beschreven op p. 218 en de kapper op p. 274 van Bastiaans' proefschrift. Zie Bastiaans, 1957.

Bastiaans noemde dat in zijn proefschrift 'syndroomverschuiving'.

Volgens Bastiaans ging het om meer dan 300 observaties. Bastiaans, 1957, p. 112.

Zie bijvoorbeeld: Bastiaans, 1957, p. 244.

Bastiaans, 1957, p. 113.

De cijfers in Bastiaans' proefschrift bevatten slordigheden en onduidelijkheden. Hij sprak steevast van 'de 210 bestudeerde observatierapporten', waarmee hij doelde op zijn eigen én de Utrechtse rapporten. Hij gebruikte 167 Utrechtse en 40 eigen dossiers, dus het zouden er niet 210 maar 207 moeten zijn. Bovendien waren volgens Bastiaans 62 van de 167 Utrechtse dossiers en 10 van zijn 40 eigen dossiers 'riet-psychosomatisch', waardoor feitelijk maar 135 dossiers interessant waren voor zijn onderzoek. Uiteindelijk gebruikte hij er, in de zes hoofdstukken over de psychosomatische aandoeningen, maar 95.

32 Het ging om bijna honderd korte gevalsbeschrijvingen van drie tot vier alinea's en drie uitgebreide gevalsbeschrijvingen van enkele pagina's: p. 147-194, p. 280-295, p. 123-135, p. 246- 
254 , p. $274-279$, p. $317-326$, p. 331-335, p. 357-36o, p. 365-376, p. 396-399, p. 402-406

Mourer werd in Bastiaans' proefschrift (Bastiaans, 1957) anoniem opgevoerd als Geval I op de

pagina's 147 tot en met 176 .

Bastiaans, 1986, p. 93 .

Interview Mourer.

Dankaart, Flinterman, Groot, \& Vuurmans, 1986.

Mourer, N.A. (17 november 1946.) Spaanse Burgeroorlog. De Waarheid.

Mourer, N.A. (17 november 1946.) Spaanse Burgeroorlog. De Waarheid.

Dankaart et al., 1986.

Verklaring van N.A. Mourer aan A. Treurniet van RIOD, 11 maart 1948. Vindplaats: NIOD,

Kampen en gevangenissen, nr, 709.

41 Verklaring van N.A. Mourer aan A. Treurniet van RIOD, 11 maart 1948. Vindplaats: NIOD,

Kampen en gevangenissen, nr. 709

42 Verklaring van N.A. Mourer aan A. Treurniet van RIOD, 11 maart 1948. Vindplaats: NIOD,

Kampen en gevangenissen, $\mathrm{nr} .709$

43 Broekema, Cnossen, Niemeijer, \& Mulder, 1986.

44 Brief van Van der Molen aan Mourer-van der Horst, 9 oktober 1941. Vindplaats: Privécollectie Mourer.

$45 \quad$ Kaienburg, 2006.

46 Fritsch, Kurth, \& Schultz, 1974; Naujoks, 1987.

47 Verklaring van N.A. Mourer aan A. Treurniet van RIOD, 11 maart 1948. Vindplaats: NIOD,

Kampen en gevangenissen, $\mathrm{nr} .709$.

48 Trouvé, 2006

49 Fritsch et al., 1974.

50 Brief Mourer aan zijn vrouw, to juli 1945 . Vindplaats: Collectie Mourer.

51 Overzicht Nederlandse gevangenen in Sachsenhausen door N.A. Mourer, maart 1945.

Vindplaats: NIOD, Verslagen en verhoren, $\mathrm{nr} .27$.

52 Hemelrijk, 1969.

53 Mourer, N.A. (8 november 1947). Rode Kruis in Sachsenhausen. De Waarheid.

54 Op het Nron bevinden zich 69 brieven verzonden door Nico Mourer ten tijde van zijn gevangenschap in Sachsenhausen aan zijn vrouw. De eerste brief is verzonden op 16 november 1941 de laatste is verzonden op 3 september 1944. Vindplaats: Collectie Mourer.

55 Brief Mourer aan zijn vrouw, 19 december 1943. Vindplaats: Collectie Mourer.

56 Verklaring J. Zwart aan RIOD, 21 december 1946. Vindplaats: NIOD, Verslagen en verhoren, doos 28, nr. 3 .

Brief Mourer aan zijn vrouw, 10 juli 1945. Vindplaats: Collectie Mourer.

Van der Molen, 1987.

Van der Molen, 1987; Mededeling Withuis-van Ringen, toenmalig medewerkster van Mourex.

Van der Molen, 1987, p. 44.

Zie daarvoor bijvoorbeeld knipsels in Privécollectie Mourer.

62 Mourer, N.A. (17 november 1946). Spaanse Burgeroorlog. De Waarheid; Mourer, N.A. (21 juli 1947) Bassano. De Waarheid; Mourer, N.A. (z.d., 1954). Gestampte muisjes. De Stem van het Verzet; Mourer, N.A. (2 november 1947) Gevallen kameraden. De Waarheid.

63 Van der Molen, 1987.

64 Aantreden (januari 1949). Verblijdende berichten.

65 Brief Mourer aan M.W. Mourer-van der Horst, 26 mei 1955. Vindplaats: Privécollectie Mourer; Interview Mourer.

66 Withuis, 2005.

67 Brief Mourer aan mr. E.W. Catz, 1 juni 1955. Vindplaats: Privécollectie Mourer; Bastiaans, 1957. Interview Van Reemst-de Vries; Bastiaans, 1957.

Aantreden (januari 1949). Verblijdende berichten.

Brief Mourer aan M.W. Mourer-van der Horst, 5 november 1949. Vindplaats: Privécollectie Mourer. Brief Mourer aan M.W. Mourer-van der Horst, 5 november 1949. Vindplaats: Privécollectie Mourer.

72 Bastiaans, 1957, p. 160

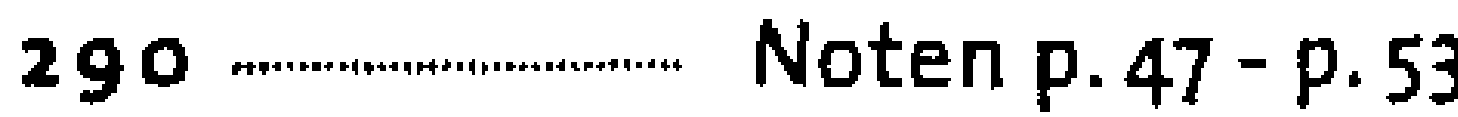


3 Bastiaans, 1957, p. 152

Bastiaans, 1957 , p. 150

Bastiaans, 1957, p. 167

Zie bijvoorbeeld: Bastiaans, 1957, p. 174-176.

Bastiaans, 1957, p. 154 en p. 159.

Bastiaans, 1957, p. 154.

Bastiaans, 1957, p. 160

Bastiaans, 1957, p. 169.

Bastiaans, 1957, p. 155

Bastiaans, 1957, p. 161 .

83 Zie voor een recente bespreking van dat onderscheid het rapport van Schreuder (Schreuder, 2005). Interessant is ook de reactie van twee medici van de Pensioen- en Uitkeringsraad (PUR) die het werk van de Buitengewone Pensioenraad heeft overgenomen (Loonstein \& Maas, 2005) Schreuder legde in zijn rapport de nadruk op het falende geheugen. Volgens de medici van de PUR is beoordeling van de causaliteit mogelijk, ook als er geen herinnering aan de gebeurtenissen bestaat.

84 Bastiaans, 1957, p. 412.

85 Bastiaans, 1957, p. 431.

86 Met uitzondering van twee gevallen waarbij nog geen uitspraak was gedaan.

87 Bastiaans gaf bij ieder van de zes aandoeningen korte gevalsbeschrijvingen en gaf daarbij aan of een verband tussen invaliditeit en oorlogsstress werd aangenomen. Bij 51 van de 62 gevalsbeschrijvingen was dat het geval.

88 Zie bijvoorbeeld: Barnhoorn, 1954.

89 Het had misschien ook anders gekund, al was dat revolutionair geweest. Bastiaans had bijvoorbeeld iemand de somatische diagnosen uit de dossiers kunnen laten verwijderen. Op basis van de resterende informatie had hij een diagnose kunnen stellen; wat was gezien de voorgeschiedenis van de patiënt, gezien de wetten van de psychosomatiek, de meest waarschijnlijke somatische klacht geweest. De mate van overeenkomst in de daadwerkelijke en de 'geschatte' diagnose vertelde iets over de bruikbaarheid van de psychosomatiek.

go Van der Molen, 1987. Van der Molen vermeldde niet voor welke aandoening Mourer behandeld werd, wel dat hij bewusteloos werd binnengebracht in het ziekenhuis en het een tijd duurde voordat hij weer op de been was.

Bastiaans, 1957, p. 153.

Bastiaans, 1957, p. 153.

Een andere voor de hand liggende verklaring was de mishandeling in Sachsenhausen geweest. De opspuiting zelf had blijvende schade aan Mourers darmen kunnen toebrengen.

Bastiaans, 1957, p. 153.

Withuis, 2005.

Verklaring van N.A. Mourer aan RIOD, 11 maart 1948. Vindplaats: NIOD, Kampen en gevangenissen, nr. 709 .

Bastiaans, 1957, p. 154 .

Bastiaans, 1957, p. 167.

Kaienburg, 2006, p. 65 .

Hrdlicka, 1992, p. 132-133.

Kogon, Langbein, \& Rückerl, 1983, p. 254-257.

Bastiaans, 1957, p. 162.

Van Dam \& Giordano, 1962, p. 188.

Bracher et al., 1998, Band XVII, zaak 504.

104 In de 'Collectie Concentratiekampen buiten

korte verklaringen van Mourer die hij afgeeft in het kader van de opsporing van

oorlogsmisdadigers en vermiste Nederlanders (d.d. 15 september 1947, d.d. 10 november 1947,

d.d. 6 april 1948, d.d. 18 december 1950, d.d. 9 februari 1962). Daarnaast bevindt zich in de collectie 'Kampen en gevangenissen' een lang interview met een medewerker van het NIOD (Verklaring van N.A. Mourer aan RIOD, 11 maart 1948. Vindplaats: Kampen en gevangenissen, nr. 709.) 
Bastiaans, 1957 , p. 168

107 Van Dam \& Giordano, 1962; Fritsch et al., 1974; Naujoks, 1987; Hrdlicka, 1992; Kaienburg, 2006. Wel werd een mishandeling beschreven waarbij een Joodse gevangene een waterslang de keel in werd geduwd waarna de kraan werd opengezet. Zie daarvoor Van Dam \& Giordano, 1962, p. 189 en p. 216. Zie ook Bracher et al., 1998, Band XV, Zaak 473. Van der Molen, 1987.

109 Interview Mourer.

no Dr. J. Withuis en T. de Ridder interviewden Bischoff van Heemskerck in 2006 en legden hem, op mijn verzoek, de mishandeling van Mourer voor.

u1 Het gaat om Geval il beschreven op p. 176-194 van Bastiaans' proefschrift. Zie Bastiaans, 1957.

112 Bastiaans, 1957, p. 187.

113 Bastiaans, 1957, p. 442.

114 Het beschikbaar komen voor wetenschappelijk onderzoek van de archieven van de BPR (wiens taken door de PUR zijn overgenomen) zou daar verandering in kunnen brengen.

115 Crombag \& Merckelbach, 1996; Merckelbach \& Jelicic, 2005; Wagenaar \& Groeneweg, 1990.

116 NRC (28 februari 1957). Psychosomatische gevolgen van onderdrukking en verzet. Een belangwekkend proefschrift.

117 Westerman Holstijn, A.J. (23 maart 1957). Ziekte en verzet. Het Parool.

118 De Wind, E. (3o maart 1957). Het verband tussen oorlog en ziekte. Vrij Nederland.

119 Musaph, H. (29 maart 1957) Late reacties op oorlogsleed. NIw.

120 Van Daal \& De Knecht-Van Eekelen, 1994.

121 Van Daal \& De Knecht-Van Eekelen, 1994.

122 Beunderman, 2003.

123 Kaptein, 2006.

124 Lønnum, 1969; Herberg, 1971; Ritter von Baeyer, Häfner, \& Kisker, 1964.

\section{De methode-Bastiaans}

Booij, 1968, p. 7 .

Bastiaans, 1957, p. 452.

Bastiaans, 1957, p. 455.

Ledenkaart J. Bastiaans NVP. Vindplaats: Archief NVP, Ledenadministratie.

Bastiaans, 1979d.

Jackson, 1994

Breuer \& Freud als geciteerd in Kihlstrom, 1998. Mijn cursivering.

Shephard, 2001; Kihlstrom, 1998; Feigon, 1998.

Jackson, 1994.

Miller, 2005.

Poslavsky, 1953, p. 6.

Horsley, 1943.

Sargant, 1959, p. 17.

Bastiaans, 1986.

Poslavsky, 1953.

Poslavsky, 1953. Ook Bastiaans kampte met dergelijke complicaties. Zie de noot in Bastiaans' proefschrift, op p. 260.

Poslavsky, 1953, p. 212.

Poslavsky, 1953.

Poslavsky, 1953, p. 142.

20 Het gaat om het geval dat op de pagina's 365 tot en met 369 van Bastiaans' proefschrift wordt beschreven.

21. Interview Pelser.

22 Bill Rawling, Directorate of History and Heritage, Canada. Persoonlijke communicatie aan auteur, 26 september 2006.

23 Bastiaans, 1957, p. 453 
Zie voor een historisch overzicht: Shorter, 1998.

Patrick \& Howells, 1990.

Stoll \& Hofmann, 1943.

Hofmann, 1979.

Stoll \& Hofmann, 1943 .

Snelders, 2000

Marks, 1979.

Crocket, Sandison, \& Walk, 1963.

Snelders, 2000.

Spencer, 1963 .

Spencer, 1963.

Snelders, 2000; Interview Van Ree.

Snelders, 2000.

'Freudian symbols come out of the mouths of patients with Freudian analysts. Those who have Jungian therapists deal with the collective unconscious and with archetypal images.' S. Cohen als geciteerd in: Booij, 1968.

$38 \quad$ Piper, 1993.

39 Piper, 1993, p.462.

$40 \quad$ Sargant, 1959, p.17-18.

41 Shorvon, in Crocket, Sandison \& Walk, 1963, p.75

42. Flothuis, T. (31 december 1966). Concentratiekampsyndroom. HP-gesprek met prof. Bastiaans en prof. Speijer. Haagse Post.

43 Bastiaans, 1957, p. 453.

44 De Joodse Yehiel de-Nur had een heel oeuvre, ontleend aan zijn ervaringen in Auschwitz, op zijn naam staan voor hij zich bij Bastiaans meldde. G.L. Durlacher, M. Bueno de Mesquita, J. Kopinsky en E. Meester traden na hun behandeling met boeken en kunstwerken naar buiten met hun oorlogsverleden.

45 Durlacher, 1985, p. 13.

46 Durlacher, 1985, p. 45.

47 Durlacher, 1985, p. 69.

$48 \quad$ Laqueur, 1980; Gilbert, 1981.

49 Als geciteerd in: Durlacher, 1985, p. 12.

50 Vermoedelijk ging het om Allemaal rottigheid, allemaal ellende van Wim Wennekes.

51 Interview Durlacher-Sasburg.

52 Abrahams, F. (22 april 1991). De zoektocht van Gerard Durlacher: 'Op het nulpunt van elke beschaving blijft nog een residu van fatsoen over'. NRC Handelsblad.

53 Durlacher, 1985, p. 89.

54 Interview Durlacher-Sasburg.

55 Ligtvoet, F. (22 mei 1987). Er begint begrip te komen maar nu is het bijna te laat. De Volkskrant.

56 Holtrop, A. (maart 1995). Spreken over het onuitsprekelijke. Boekenweekmagazine.

57 Holtrop, A. (maart 1995). Spreken over het onuitsprekelijke. Boekenweekmagazine.

58 Durlacher, 1991.

59 Durlacher, 1991, p. 45.

6o Abrahams, E. (22 april 1991). De zoektocht van Gerard Durlacher: 'Op het nulpunt van elke beschaving blijft nog een residu van fatsoen over'. NRC Handelsblad.

61 Voor dit portret is, naast de hierboven genoemde bronnen, gebruikgemaakt van de knipselmap op het NIOD (KBI-11684) en een interview met A. Durlacher-Sasburg.

62 Huxley, 1954.

63 Novak, 1997, p. 99

64 Cohen \& Ditman, 1962.

65 Zie daarvoor bijv. de discussie in NTuG van 1968; Cohen, 1960; Sankar, 1975.

66 Marks, 1979; Lee \& Shlain, 1985.

67 Snelders \& Kaplan, 2002; Snelders, 2000.

68 Zie bijvoorbeeld de knipselcollectie van schrijver en dichter Simon Vinkenoog over LSD die 
zich bevindt in het archief van Vinkenoog dat berust bij het IISG. Daarin zit bijvoorbeeld: Callcott, J.A. (3 februari 1967). uno tegen LSD. De Volkskrant; Woltz, W. ( 7 juni 1969). Trip naar '42. Algemeen Handelsblad; De Vaal, O.M. (17 mei 1969). LSD als helper van de psychiater. Het Parool.

69 Snelders, 2000.

70 Nota dr. P. Siderius (hoofdinspecteur van de Inspectie voor de Volksgezondheid voor de Geneesmiddelen), 3 februari 1966. Vindplaats: Archief Inspectie, nr. 390.

71 Snelders, 2000

72 De documentaire Begrijpt u nu wadrom ik huil... van Louis van Gasteren werd deels gefinancierd met overheidsgelden.

73 Zie diverse rapporten van RIVG in archief Inspectie. Vindplaats: Archief Inspectie, nr. 345. Snelders, 2000, p. 125.

Snelders, 2000.

Het is onduidelijk wanneer Bastiaans zijn eerste ervaringen met LSD-behandelingen opdeed. In een artikel uit 1974 schreef hij dat hij in 1961 startte met LSD (Bastiaans, 1974c). Maar in een brief aan het Ministerie van CMw uit 1968 schreef hij dat hij pas 'vanaf 1964 ' regelmatig met LSD werkte (brief J. Bastiaans aan Ministerie van CMW, 16 april 1968. Vindplaats: Archief CVB RUL, nr 3609). Bovendien was in het script voor film van At van Praag uit 1964 over de gevolgen van de oorlog, sprake van narcoanalyses met behulp van pentothal. In de opnames die daarna werden gemaakt, werd gebruikgemaakt van LSD. Dat duidt erop dat Bastiaans in die periode een omslag maakte (brief RVD aan Lou de Jong, 1 mei 1964. Vindplaats: Correspondentiearchief NIOD, 1964). In de jaarverslagen van de Faculteit der Geneeskunde van de RUL kwam LSD pas voor in het verslag over het collegejaar 1969-1970. Op een congres in 1969 presenteerde Bastiaans de resultaten van LSD-behandelingen van 36 patiënten uit de periode 1964-1968 (Bastiaans, 1969b).

77 Bastiaans, 1970d.

78 Bastiaans, $1970 \mathrm{~d}$

79 Bastiaans, 1986, p. 88.

80 Flothuis, T. (31 december 1966). Concentratiekampsyndroom. HP-gesprek met prof. Bastiaans en prof. Speijer. Haagse Post.

81 Cohen, 1966.

82 Vos, 1995.

83 Het Vrije Volk (8 november 1966). De aangrijpende LSD-film van prof. Bastiaans: 'Duitse tvmensen werden er verlegen onder'.

84 Flothuis, T. (31 december 1966). Concentratiekampsyndroom. HP-gesprek met prof. Bastiaans en prof. Speijer. Haagse Post.

85 Flothuis, T. (31 december 1966). Concentratiekampsyndroom. HP-gesprek met prof. Bastiaans en prof. Speijer. Haagse Post.

86 Booij, 1968.

87 Booij, 1968, p. 7 .

88 Ladee, 1968

$89 \quad$ Kuijper, 1968.

go Van Praag, 1968.

91 Snelders (2000) haalde de voordracht aan en beschikte over de tekst (inmiddels niet meer). Het archief van de British Psychological Association bevat wel de aankondiging van Bastiaans' voordracht, maar niet de voordracht zelf (met dank aan M. Maskill, archivaris van de BPA, die zo vriendelijk was mij op afstand te helpen). Bastiaans haalde in een artikel uit $198_{3}$ (Bastiaans, 1983, p. 144) de voordracht uit 1969 aan. 
5 De paradox van het $k z$-syndroom

Bastiaans, 1970 d.

Cohen, 1969, p. 2053.

Brief prof.dr. P.C. Kuiper aan Presidium van de UvA, 5 juli 1962. Vindplaats: Archief UvA/DIv, Personeelsdossier Bastiaans.

4 Brief bestuur Faculteit der Geneeskunde aan CvC, 14 februari 1963. Vindplaats: Archief UvA/ DIV, Personeelsdossier Bastiaans.

Rooijmans, 1989 , p. 96.

Plan toekomst Psychiatrie Leiden, Bastiaans, 20 juli 1963. Vindplaats: Archief CvB RUL, nr. 3605.

Plan toekomst Psychiatrie Leiden, Bastiaans, 20 juli 1963. Vindplaats: Archief CvB RUL, nr. 3605. Conclusies bespreking Bastiaans en CvC, 24 juli 1963. Vindplaats: Archief CvB RUL, nr. 3605. Memorandum betreffende ontwikkeling van de universitaire psychiatrie te Leiden, Bastiaans, 25 juli 1970. Vindplaats: Collectie RUL/Rooijmans.

Wibaut, 1961.

De afkorting ' $\mathrm{KZ}$ ' staat voor het Duitse woord voor 'concentratiekamp', 'Konzentrationslager'.

Withuis, 2001; Mooij, 2002.

Cohen, 1952; Kaas, 1946; Tas, 1946; Van Dantzig, 1946; De Wind, 1946; De Wind, 1949; De Wind, 1966; De Wind, 1968.

14 Mooij, 2002 noemt de volgende: Kopenhagen (1954), Parijs (1954), Brussel (1955), Moskou (1956), Oslo (1960), Den Haag (1961) en Keulen (1967).

Ritter von Baeyer et al., 1964; Paul \& Herberg, 1963 .

Brief De Wind aan Polak, 3 juni 1964. Vindplaats: Collectie Polak.

Notulen Spätfolge-groep, 1964. Vindplaats: Collectie Polak.

'Spätfolge' is Duits voor 'verlate gevolgen'.

De Wind, 1966.

Brief De Wind aan JMW, 21 januari 1965. Vindplaats: NIOD, Correspondentiearchief, 1965.

CADSU, 1966.

Brief De Wind aan JMW, 21 januari 1965. Vindplaats: NIOD, Correspondentiearchief, 1965; Waarschijnlijk kreeg De Wind geen toegang tot de adresgegevens van het CADSU. Dat valt op te maken uit: Brief E. de Wind aan L. de Jong, 21 januari 1966. Vindplaats: NIOD,

Correspondentiearchief, 1966.

23 Van de werkzaamheden van de Spätfolge-groep zijn de notulen van de eerste drie bijeenkomsten bewaard gebleven (Notulen Spätfolge-groep van 31 januari 1964, 20 maart 1964, 15 mei 1964. Vindplaats: Collectie Polak). Daarnaast is correspondentie tussen De Wind en De Jong bewaard gebleven (Brief De Wind aan De Jong, 30 november 1964; Brief De Jong aan De Wind, 3 december 1964; Brief De Wind aan JMW, 21 januari 1965; Brief De Wind aan De Jong, 7 januari 1966; Brief De Jong aan De Wind, 11 januari 1966; Brief De Jong aan De Wind, 21 januari 1966. Vindplaats: NIOD, Correspondentiearchief, 1964, 1965, 1966.).

24 Uiteindelijk gingen de psychologen overstag en stelden een enquête op

25 Brief De Wind aan De Jong, 21 januari 1966. Vindplaats: NIOD, Correspondentiearchief, 1964, $1965,1966$.

26 Bijvoorbeeld: Cohen, 1969; Cohen, 1972; Bastiaans, 197od; Bastiaans, 1973d; Bastiaans, 1974a; Bastiaans, 1974C; Hugenholtz, 1970; Hustinx, 1973; Musaph, 1973.

Eitinger, 1964 .

Eitinger, 1969 .

Eitinger, 1964.

Cohen, 1969 .

Bastiaans, 1970d; Musaph, 1973; Hustinx, 1973.

Van Ravesteijn, 1976.

De Wind, 1966; De Wind, 1968; Noordhoek Hegt, 1967; Meerloo, 1969.

Musaph, 1973 .

Cohen, 1969; Cohen, 1972; Bastiaans, 1970b; Bastiaans, 1973; Bastiaans, 1974a; Hugenholtz, 1970; Hustinx, 1973; Musaph, 1973.

Hugenholtz, 1970. 
Cohen, 1972, p. 1684 .

Cohen, 1969. Dat deed overigens ook Musaph (in: Musaph, 1973).

Noordhoek Hegt, 1967.

Dasberg, Davidson, Durlacher, Filet, \& De Wind, 1987.

Hugenholtz, 1970, p. 13.

Cohen, 1972.

43 De omgekeerde bewijslast gold voor een uitkering in het kader van de WBP wanneer de invaliditeit hoger was dan zestig procent en iemand intensief verzet had gepleegd dan wel minstens drie maanden gevangen had gezeten. De omgekeerde bewijslast werd voor het eerst gebruikt bij de uitbreiding van de Rijksgroepsregeling Oorlogsslachtoffers in 1968. De latere wUv hanteerde ook de omgekeerde bewijslast, ongeacht het invaliditeitspercentage. De WUBO kende deze regeling niet. Zie daarvoor: Engelsman, 1989; Van Dijke, 1987; HTK, Zitting 19701971,10958 , Memorie van toelichting.

44 Cohen, 1969, p. 2053.

Bastiaans, $1973 \mathrm{e}$.

Bastiaans, 1973d.

Bastiaans, $1973 \mathrm{~d}$.

Bibeb (5 september 1970). Prof.dr. J. Bastiaans: 'Verslaafden liggen me minder dan

verzetsmensen'. Hoe haal je de mens uit de beklemming van zijn persoonlijk concentratiekampsyndroom? Vrij Nederland.

Bastiaans, 1973d.

Bastiaans, 1974a, p. 1174.

Cohen, 1972.

CBS, 1976 .

Bastiaans, J. (1976). Wat kan de psychiater de verzetsman bieden? Kontakt NPR vVN, 4, 23.

Withuis, 2002.

Bloch, 1971, p. 166.

Hustinx, 1973 .

Hugenholtz, 1980; Bastiaans, 197od.

D. de Loos zoals geciteerd in: Withuis, 2005, p. 292.

D. de Loos zoals geciteerd in: Withuis, 2005, p. 292.

Als geciteerd in: Koedijk, 1995, p. 19.

De Telegrauf (8 april 1972). Hoe een kliniek tot stand kwam.

De Werkgroep Post-concentratiekampsyndroom bestond uit: Noordhoek Hegt, Bastiaans, dr.

E.A. Cohen (overlevende van Auschwitz en huisarts die publiceerde over het Kz-syndroom), dr. A. Querido (lid Eerste Kamer en Amsterdamse hoogleraar sociale geneeskunde), A.D.A. van Overeem (generaal-majoor-arts en Inspecteur Militair Geneeskundige Dienst), dr. C. Buis (Geneeskundig hoofdinspecteur van de Volksgezondheid), dr. K. Modderaar en W.H.J. Bosman (beiden arts voor de Rijksgeneeskundige dienst) en C.E. de Leeuw, secretaris. Gegevens afkomstig uit 'Instellingsbesluit Werkgroep Postconcentratiekampsyndroom van de staatssecretaris van Sociale Zaken en Volksgezondheid, 21 december 1970'. Instellingsbesluit. Vindplaats: Collectie Le Poole, nr. 28.

63 'Instellingsbesluit Werkgroep Postconcentratiekampsyndroom van de staatssecretaris van Sociale Zaken en Volksgezondheid, 21 december 1970'. Instellingsbesluit. Vindplaats: Collectie Le Poole, nr. 28.

64 Interim-advies Werkgroep Post-concentratiekampsyndroom, z.d.. Vindplaats: Collectie Le Poole, nr. 28.

65 Notulen RvA Centrum '45, 16 december 1974. Vindplaats: Archief Centrum '45, map Bestuursaangelegenheden.

66 De Volkskrant (29 juli 1965). Wetenschappelijk onderzoek over de gevolgen van de concentratiekampen.

67 Flothuis, T. (2966, 31 december). Concentratiekampsyndroom. HP-gesprek met prof. Bastiaans en prof. Speijer. Haagse Post. 
6 Begrijpt u nu waarom ik huil...

1 De Jong tijdens de uitzending van televisiescrie De Bezetting als geciteerd in: Van Vree, 1995, p. 73 .

Righart, 1995; Kennedy, 1995.

Cijfers afkomstig uit: Brinkgreve, Onland \& De Swaan, 1979.

Hutschemaekers \& Oosterhuis, 2004.

Foudraine, 1971

Blok, 2004.

Blom, 1989b.

Van Vree, 1995.

Van Vree, 1995 .

De Jong tijdens de uitzending van televisieserie De Bezetting als geciteerd in: Van Vree, 1995, p. 73. Presser, 1965.

De Haan, 1997, p. 132.

Bank, 1983 .

Withuis, 2005.

Het is onduidelijk wanneer de vks precies ontstond, maar het oudste bewaard gebleven exemplaar van het bulletin Nooit weer! van de vKs stamt uit 1961. Daarin is sprake van een reünie van oud-gevangenen die al in 1960 had plaatsgevonden. Vindplaats: Bibliotheek NIOD. Van Weringh, 197o, p. 2

Van Weringh, 1970.

18 Exemplaren van Nooit weer! zijn te vinden op het NIOD. Vindplaats: Collectie Periodieken, nr. 0160 .

Nooit weer! (z.d.) Redactioneel. Vindplaats: Collectie Periodieken, nr. o16o.

Zie exemplaar Nooit weer! van januari 1961. Vindplaats: Collectie Periodieken, nr. 0160.

Telling, J. (januari 1961). Oproep. Nooit weer! Vindplaats: Collectie Periodieken, nr. o16o. VKs, 1964, p. 1 .

De discussieavond vond plaats op 13 december 1963. Zie voor een verslag: Nooit weer! (februari 1965) Verslag van een debat.

Nooit weer! (januari 1962). Brochure. Vindplaats: Collectie Periodieken, nr. o16o.

De Nederlandse artsen durfden dat niet aan, zie daarvoor: Piersma, 2005, p. 88.

Nooit weer! (januari 1967). Telegram aan Samkalden. Vindplaats: Collectie Periodieken, nr. o16o. Voor een uitvoerige analyse van het oorlogsverleden van Van Gasteren zie: Slot, 2006.

De opnamen van Van Gasteren zouden bekend worden onder de titel Omdat mijn fiets daar stond. Brief RVD aan L. De Jong (met script van Bud Linschoten), 1 mei 1964. Vindplaats: NIOD, Correspondentiearchief, 1964

Brief RVD aan L. de Jong (met script van Bud Linschoten), i mei 1964. Vindplaats: NIOD, Correspondentiearchief, 1964

Brief Bastiaans aan Ministerie CMW, 16 april 1968.Vindplaats: Archief CVB RUL, 3609 . Vos, 1995.

De reden waarom Milikowski niet mee wilde doen, is onduidelijk. Zijn weduwe vermoedde dat hij afkeurend stond tegenover LSD. Interview Milikowski-De Raat. Een van de overlevenden schreef een boek over zijn tijd in het Bernhard-kommando dat in Die Fälscher 2007 van regisseur Stefan Ruzowitzky werd verfilmd. Zie daarvoor: Burger, 2007. Interview Milikowski-De Raat.

36 Milikowksi, 1973; Ruyter, M. (22 mei 1969). We horen vaak: Je moet niet zeuren. Milikowski: andere kijk op Van Gasterens film. De Volkskrant; Interview Van Gasteren; Brief Bastiaans aan CvB RUL, 26 februari 1968. Vindplaats: Archief CvB RUL, nr. 3609.

37 Verslag J.R. Telling. Vindplaats: NIOD, Collectie Dagboeken en egodocumenten, nr. 702.

38 Brief van J.R. Telling aan Afwikkelingsbureau Concentratiekampen, 17 juli 1945. Vindplaats: NIOD, Correspondentiearchief.

39 Brieven NSM aan Telling. Vindplaats: Privécollectie Telling.

40 Van Gasteren, 1972.

41 Brief Bastiaans aan CvC RUL, 26 februari 1968. Vindplaats: Archief CvB RUL, 3609. 
42 Brief Bastiaans aan NFGV, 28 november 1967. Vindplaats: Collectie RUL/Rooijmans.

43 Brief Bastiaans aan NFGV, 28 november 1967. Vindplaats: Collectie RUL/Rooijmans.

44 De archieven van Cogis, NIOD en Filmmuseum bevatten allemaal de versie uit 1972. Het is een aangepaste versie van die van 1969 . In ieder geval werd voor de latere versie Bastiaans' uitleg van het kZ-syndroom opnieuw gefilmd. Hij deed zijn verhaal niet meer in het Nederlands, gezeten achter een bureau met op de achtergrond een boekenkast, maar sprak in het Engels voor een collegezaal met studenten. Ook werden fragmenten toegevoegd van een nagesprek met Telling, enkele jaren na de eerste sessie. Blijkens het script werd het rauwe begin waarin Telling vertelt hoe hij een stervende gevangene op de vloer legt, geschrapt. Zie daarvoor: Van Gasteren, 1972.

45 Uitgewerkte tekst Begrijpt u nu waarom ik huil..., 1969. Vindplaats: Archief Kliest. Kopie in bezit auteur.

46 Uitgewerkte tekst Begrijpt u nu waarom ik huil..., 1969. Vindplaats: Archief Kliest. Kopie in bezit auteur.

47 Opdracht aan L. van Gasteren, 27 september 1968. Vindplaats: Archief CvB RUL, nr. 3609

48 Verslag van gang van zaken rond totstandkoming van Begrijpt u nu waarom ik huil..., J. le Poole, 26 september 1987 . Vindplaats: Collectie RUL/Rooijmans.

49 Verslag van gang van zaken rond tot standkoming van Begrijpt u nu waarom ik huil..., J. le Poole, 26 september 1987. Vindplaats: Collectie RUL/Rooijmans.

50 Brief L. van Gasteren aan Ministerie van CRM, 16 augustus 1968. Vindplaats: Archief CvB RUL, nr. 3609 .

51 Verslag van gang van zaken rond tot standkoming van Begrijpt u nu waarom ik huil..., J. le Poole, 26 september 1987. Vindplaats: Collectie RUL/Rooijmans.

s2 Gvo (december 197o). Enige effekten van de film Begrijpt $u$ nu waarom ik huil, p. 38 . Vindplaats: Archief NFGV, nr. 191.

53 Gvo (december 1970). Enige effekten van de film Begrijpt $u$ nu waarom ik huil. Vindplaats: Archief NFGV, nr. 191.

54 Gvo (december 1970). Enige effekten van de film Begrijpt u nu waarom ik huil, p. 49. Vindplaats: Archief NFGV, nr. 191.

55 Tekst van 'Inleiding tot de vertoning van de film van Louis van Gasteren op 16 december 1969' door J. Bastiaans. Vindplaats: Collectie Van Dedem, nr. 49.

56 Uitnodiging première Begrijpt u nu waarom ik huil.... Vindplaats: Collectie Milikowski.

57 Gooi-en Eemlander (14 mei 1969). Genezing van ex-kz-gevangene werd indringend verfilmd. Medische wetenschap dringt door in de geest van lijdende mens.

58 Van den Emde Boas, C. (17 mei 1969). Van Gasteren filmt Kz-syndroom en velen moeten het zien. $A D$.

59 Peereboom, K. (17 mei 1969). Begrijpt u nu waarom ik huil... Het Parool.

60 Bertina, B.J. (16 mei 1969). Van Gasteren maakte geen objectief drama. Begrijpt u nu waarom ik huil? De Volkskrant

61 Peereboom, K. (17 mei 1969). Begrijpt u nu waarom ik huil... Het Parool; jDQ. (14 mei 1969). Nawerking oorlogsleed aanschouwelijk gemaakt: Met filmcamera en LSD. NRC; Flothuis, T. (24 mei 1969). Begrijpt u nu waarom ik huil... Haagse Post.

62 De Vries, H.R. (30 mei 1969). Bijsmaak. De Volkskrant.

63 Ruyter, M. (22 mei 1969). We horen vaak: Je moet niet zeuren. Milikowski: andere kijk op Van Gasterens film. De Volkskrant.

64 Milikowski, H.Ph. (21 juni 1969). Belangrijke feiten over het 'kz-syndroom'. De Nieuwe Linie.

65 Ruyter, M. (22 mei 1969). We horen vaak: Je moet niet zeuren. Milikowski: andere kijk op Van Gasterens film. De Volkskrant.

66 Van den Emde Boas, C. (17 mei 1969). Van Gasteren filmt KZ-syndroom en velen moeten het zien. $\mathrm{AD}$.

67 De Vaal, O.M. (17 mei 1969). LSD als helper van de psychiater. Het Parool.

68 Brief van CVC RUL aan L. van Gasteren, 17 september 1969. Vindplaats: Archief NFGV, nr. 191.

69 Timmers, 1970.

70 In 1969 had hij in vijf jaar tijd nog geen veertig patiënten met LSD behandeld. Zie daarvoor 
Snelders, p. 208. In een artikel dat in mei 1970 gereedkwam, vermeldde hij dat hij twintig verzetsstrijders had behandeld sinds 1964 , hij reserveerde blijkbaar de LSD-behandeling niet alleen voor verzetsstrijders.

71 Flothuis, T. (31 december 1966). Concentratiekampsyndroom. HP-gesprek met prof. Bastiaans en prof. Speijer. Haagse Post.

Bijvoorbeeld: Bastiaans (1974a) en Bastiaans (1983a). Maar ook in Wennekes (1975).

Een verzoek tot inzage in het dossier van Telling dat berust bij de PUR werd geweigerd.

Bastiaans, 1970a.

Interview Milikowski-de Raat.

Verslag J.R. Telling. Vindplaats: NIOD, Collectie Dagboeken en egodocumenten, nr. 702, p. 126.

Timmers, 1970.

Woltz, W. (7 juni 1969). Trip naar'42. Algemeen Handelsblad.

Verklaring van K. Hofman, opgenomen op 25 januari 1951 in Rotterdam. Vindplaats: NIOD,

Kampen en gevangenissen, $\mathrm{nr} .582$.

Bastiaans, 1973d.

81 Hofman, K. (31 oktober 1969). Slachtoffers van drie oorlogsmisdadigers aan het woord.

Geestelijk Weerbaar/Voormalig Verzet Nederland.

82 Bastiaans, 1986, p. 103.

Bijvoorbeeld in: Bastiaans, 1986.

Von Frijtag Drabbe Künzel, 2003.

Von Frijtag Drabbe Künzel, 2003.

Verklaring van Kornelis Hofman, opgenomen op 25 januari 1951 in Rotterdam. Vindplaats:

NIOD, Kampen en gevangenissen, nr. 582.

87 Woltz, W. (7 juni 1969). Trip naar '42. Algemeen Handelsblad.

88 Hofman, K. (31 oktober 1969). Slachtoffers van drie oorlogsmisdadigers aan het woord. Geestelijk Weerbaar/Voormalig Verzet Nederland.

89 Withuis, 2005.

90 Woltz, W. (7 juni 1969). Trip naar' 42 . Algemeen Handelsblad.

91 Machtiging J. Telling aan Spectrum Film, 27 juli 1967. Vindplaats: Archief CvB RUL, nr. 3609. Mijn cursivering.

92 Het Parool ( 1 november 1969).Film nog vrijwel nergens gedraaid: Kritiek op vertoningsverbod Tweede Kamer.

\section{De drie van Breda}

1 Bastiaans tijdens de openbare hoorzitting op 24 februari 1972, HEK, p. 17.

Piersma, 2005.

Hofman, K. (31 oktober 1969). Slachtoffers van drie oorlogsmisdadigers aan het woord.

Geestelijk Weerbaar/Voormalig Verzet Nederland.

4 Withuis, 2002

$5 \quad$ Het ging om de Hoge Raad der Nederlanden en de bijzondere strafkamer bij de arrondissementsrechtbank te Amsterdam. Zie: Piersma, 2005.

6 G.E. Langemeijer als geciteerd in: Piersma, 2005, p. 99-100.

$7 \quad$ Het Vrije Volk (23 februari 1972). Prof. Bastiaans waarschuwt voor acute ziekteverergering. Steeds meer twijfel over gratie in parlement.

$8 \quad$ Kuin, R. (24 februari 1972). Dilemma: óf de klap ineens óf steeds maar weer wonden openrijten. Trouw.

$9 \quad$ Kat, P.J. (23 februari 1972). Ik ben gebeld door mensen die voor de 'drie van Breda' al vuurpelotons hebben gevormd. NRC Handelsblad.

10 Het Parool (25 februari 1972). Stijgend aantal lijders aan het kampsyndroom.

11 Lumeij, 1972; Korver, H. (18 februari 1972) rk voorzie wrede klopjacht op Drie van Breda. De Telegradf.

12 Van Hoof, J. (19 februari 1972). 'Drie van Breda' roept opnieuw angsten op bij slachtoffers. De Tijd 13 De Telegraaf (23 februari 1972). Hoogleraren voor en tegen gratie. Het Vrije Volk (23 februari 1972). 
Prof. Bastiaans waarschuwt voor acute ziekteverergering. Steeds meer twijfel over gratie in parlement.

14 Tekst uitzending Achter het Nieuws van 26 februari 1972. Vindplaats: Collectie Milikowski.

15 Kuin, R. (24 februari 1972). Dilemma: óf de klap ineens óf steeds maar weer wonden openrijten. Trouw.

16 Kuin, R. (24 februari 1972). Dilemma: óf de klap ineens óf steeds maar weer wonden openrijten. Trouw; de Volkskrant (24 februari 1974). Emoties maken veel indruk op Van Agt.

17 Hadgsche Courant (24 februari 1972). Er zijin 30 à 40000 slachtoffers met kampervaringen; Het Vrije Volk (24 februari 1972). Van Agt ziet 'Begrijpt u nu waarom ik huil. Tienduizenden uit kampen nog geteisterd door verschrikkingen.

18 NRC Handelsblad (24 februari 1972). Minister ziet film over syndroom. Haagsche Courant (24 februari 1972). Er zijn 30 à 40000 slachtoffers met kampervaringen Het Vrije Volk (24 februari 1972). Van Agt ziet 'Begrijpt u nu waarom ik huil'. Tienduizenden uit kampen nog geteisterd door verschrikkingen; de Volkskrant (24 februari 1972). Emoties maken veel indruk op Van Agt. W. Kicken van de Landelijke Organisatie Oud-Illegale Strijders had dit dreigement voor de hoorzitting ook al eens geuit.

20 Milikowski verwees naar een door Kamerlid Voogd ingediende motie.

21 Van Merriënboer, Bootsma, \& Griensven, 2008.

22 Piersma, 2005, p. 120.

23 De Telegraaf (26 februari 1972). Toch gratie.

24 Tekst uitzending Achter het Nieuws van 26 februari 1972. Vindplaats: Collectie Milikowski.

25 Tekst uitzending Achter het Nieuws van 26 februari 1972. Vindplaats: Collectie Milikowski.

26 In de notulen van de varA staat dat de film aan Jacobs was 'aangeboden'. Bastiaans zou tijdens de inleiding op de uitzending zeggen dat hem door het bestuur van de VARA was 'gevraagd' de film voor uitzending beschikbaar te stellen.

27 Besluitenlijst stafvergadering VARA, 24 februari 1972. Vindplaats: Archief VARA.

28 Bericht aan afdelingschefs varA, Medezeggenschapscommissie, 3 maart 1972. Vindplaats: Archief VARA.

29 Besluitenlijst stafvergadering VARA, 2 maart 1972. Vindplaats: Archief varA.

30 Het Parool (26 februari 1972). Uitzending over oorlogsslachtoffer gaat toch door.

31 Musaph, 1972.

32 Musaph, 1972, p. 141.

33 Lumeij, 1972.

34 Vos, 1995, p.159.

35 Vos, 1995, p. 159; Het Parool (28 februari 1972), Minister Engels was tegen uitzending.

36 Brief M.H. Cohen Stuart aan bestuur NG Fv, 6 maart 1972. Vindplaats: Collectie Le Poole, nr. 43 37 Vos, 1995; Hofhuizen, H. (28 februari 1972). Huiveringwekkend. De Tija.

38 Tekst uitzending Achter het Nieuws van 26 februari 1972. Vindplaats: Collectie Milikowski. 39 Tekst uitzending Achter het Nieuws van 26 februari 1972. Vindplaats: Collectie Milikowski. 40 Tekst uitzending Achter het Nieuws van 26 februari 1972. Vindplaats: Collectie Milikowski.

41 Psychiaters werkzaam op de Jelgersmakliniek konden onder verantwoordelijkheid van Bastiaans LSD-sessies uitvoeren,

42 Bank, J. (28 februari 1972). Begrijpt u nu waarom ik huil... De Volkskrant.

43 Savenije, A. (1972). Resultaten onderzoek schriftelijke reakties ' 3 van Breda'. Amsterdam; Secretariaat Louis van Gasteren. Vindplaats: Privécollectie Van Gasteren. Kopie in bezit auteur

44 Vos,1995, p.160.

45 Musaph, 1972

46 Piersma, 2005.

47 Algemeen Dagblad (24 februari 1972). De Ruiter: 'Ik weet het werkelijk niet'.

48 Piersma, 2005.

49 Regeringsverklaring als geciteerd in: Piersma, 2005, p. 137.

50 De Haan, 1997.

51 De Volkskrant (29 juli 1965). Wetenschappelijk onderzoek over de gevolgen van de concentratiekampen. 


\section{De strijd om Centrum ' 45}

1 Brief Noordhoek Hegt aan leden van bestuur Centrum '45, 28 mei 1973. Vindplaats: Archief Centrum '45, map Bestuursaangelegenheden.

2 Interim-advies Werkgroep Post-concentratiekampsyndroom, z.d.. Vindplaats: Collectic Le Poole, nr. 28.

3 Bespreking inzake de taakstelling van het Centrum ' 45,3 oktober 1972. Vindplaats: Collectie Le Poole, nr. 37.

4 Het voorlopige bestuur bestond uit: prof.dr. P. Muntendam, oud-gevangene van kamp Vught, voormalig directeur-generaal van het Ministerie van wvc en op dat moment curator van de RUL, vicevoorzitter werd Hans Teengs Gerritsen, die al vanaf het allereerste initiatief met Maliepaard betrokken was bij de kliniek. Verder hadden zitting in het voorlopige bestuur: $\mathrm{mr}$. A.H. van Namen, voorzitter van de Stichting 1940-1945, mr. K.H. Gaarlandt, Commissaris van de Koningin in Drenthe en oud-gevangene van kamp Vught.

5 Brief van 'Neuropsychiatrische Kliniek voor Oorlogsstress i.o.' ondertekend door Muntendam aan staatssecretaris Kruisinga, 30 maart 1971. Vindplaats: Collectie Le Poole, nr. 28.

6 Nota Bastiaans inzake de werkzaamheden van de medisch-maatschappelijke staf, 21 januari 1972. Vindplaats: Collectie Le Poole, nr. 29.

$7 \quad$ Notulen bestuursvergadering, 4 juni 1971. Vindplaats: Collectie Le Poole, $\mathrm{nr} .29$.

8 Bastiaans, 26 september 1971, reactie op stuk van arts-assistenten. Vindplaats: Archief RUL/ Rooijmans.

9 Brief particulier secretaris prins Bernhard aan P. Muntendam, 8 september 1971. Vindplaats: Archief CvB RUL, nr. 3609

10 Statuten Centrum ' 45 . Vindplaats: Archief CvB RUL, nr. 3927.

11 Aantreden (1972, nr. 4) Spreekuren Hers.

12 Bijvoorbeeld: Het Vaderland (17 april 1972). Kliniek prof. Bastiaans eind dit jaar klaar. Prins start bouw Kz-centrum.

13 Notulen bestuursvergadering Stichting Centrum Post-concentratiekampsyndroom, 6 januari 1972. Vindplaats: Collectie Le Poole, nr. 29.

14 Notulen bestuursvergadering Stichting Centrum Post-concentratiekampsyndroom, 6 januari 1972. Vindplaats: Collectie Le Poole, nr. 29.

15 Conceptnota inzake de relatie van de hoogleraar in de psychiatrie tot het Centrum Post concentratiekamp-syndroom, 8 februari 1972. Vindplaats: Collectie Le Poole, nr. 29. Bestuursaangelegenheden. Snelders (2000), die het rapport inzag, schreef daarover dat Meijering het gebruik van LSD niet afwees. Op basis van wat Meijering op zijn studiereis naar Engeland van de LSD-behandeling had gezien zag hij een beperkt en gecontroleerd gebruik door psychiaters als mogelijk. 
17 Zie voor een bespreking van het rapport van Meijering Snelders (2000).

18 Het boek kwam er overigens nooit. In 1977 schreef Bastiaans aan De Jong dat ze moeite hadden met het vinden van een uitgever.

19 Brief Noordhoek Hegt aan J. Bastiaans, 28 februari 1972. Vindplaats: Archief CvB RUL, nr. 3609

20 Notulen bestuursvergadering Centrum Post-concentratiekampsyndroom, 4 maart 1972. Vindplaats: Collectie Le Poole, nr. 29; Noordhoek Hegt aan J. Bastiaans, 28 februari 1972. Vindplaats: Archief CvB RUL, nr. 3609.

21 Notulen bestuursvergadering Centrum Post-concentratiekampsyndroom, 16 maart 1972. Vindplaats: Collectie Le Poole, nr. 29.

22 De Volkskrant (1 april 1972). Prins gaat eerste paal slaan. Deze maand begint bouw kz-paviljoen.

23 Het Binnenhof (15 april 1927) Dr. Meijering vermoedelijk directeur: Na 27 jaar kliniek voor slachtoffers $\mathrm{kz}$-syndroom.

24 Het congres in Mexico duurde van 25 november tot 4 december 1971. De beslissing dat Meijering directeur werd, werd genomen op de vergadering van 6 januari 1972. Blijkens de notulen was Bastiaans daarbij aanwezig. Notulen bestuursvergadering Centrum Postconcentratiekampsyndroom, 6 januari 1972. Vindplaats: Collectie Le Poole, nr. 29.

25 Notulen bestuursvergadering Centrum Post-concentratiekampsyndroom, 21 april 1972. Vindplaats: Collectie Le Poole, nr. 29.

26 Piersma, 2006.

27 Piersma, 2006, p. 88.

28 Brief Meijering aan bestuur Stichting Centrum Post-concentratiekampsyndroom, 1 juni 1972. Vindplaats: Collectie Le Poole, nr. 32.

29 Statuten Centrum ' 45, 25 oktober 1972. Vindplaats: Archief Centrum ' 45.

30 Notulen bestuursvergadering Centrum Post-concentratiekampsyndroom, 19 mei 1972 en 15 juni 1972. Vindplaats: Collectie Le Poole, nr. 29.

31 Notulen bestuursvergadering Centrum ' 45,15 september 1972 en 20 oktober 1972. Vindplaats: Collectie Le Poole, nr. 30.

32 Notulen bestuursvergadering Centrum '45, 15 september 1972 en 20 oktober 1972. Vindplaats: Collectie Le Poole, nr. 30.

33 Notulen bestuursvergadering Centrum' 45, 20 november 1972, Vindplaats: Collectie Le Poole, nI. 30.

34 Notulen bestuursvergadering Centrum '45, 27 september 1973. Vindplaats: Collectie Le Poole, nr. 30.

35 Toespraak P. Maliepaard, 5 oktober 1972 op Landelijke Kontaktdag in Gouda. Vindplaats: Collectie Le Poole, nr. 37.

36 Brief patiënten Jelgersmakliniek aan W.L. Meijering, 28 december 1972. Vindplaats: Archief Centrum '45, map Correspondentie RvA.

37 Notulen bestuursvergadering Centrum ' 45,15 december 1972. Vindplaats: Collectie Le Poole, nr. 30.

38 Notulen bestuursvergadering Centrum ' 45,4 januari 1973. Vindplaats: Collectie Le Poole, nr, 30. 39 Brief Bastiaans aan bestuur Centrum '45, 17 december 1972. Vindplaats: Archief Centrum '45, map Correspondentie RvA.

40 Notulen bestuursvergadering Stichting Centrum Post-concentratiekampsyndroom, 21 februari 1973. Vindplaats: Archief Centrum '45, map Correspondentie RvA.

41 Wennekes, W. (5 mei 1973). 'Ik zoek al jaren een ss'er die ik LsD kan geven'. Gelderlander.

42 Wennekes, W. ( 5 mei 1973). 'Ik zoek al jaren een ss'er die ik LSD kan geven'. Gelderlander.

43 Het Vrije Volk (17 mei 173). Ruzie bij opening kliniek oorlogsslachtoffers.

44 Brief Meijering aan Kliphuis (Jelgersmakliniek). Vindplaats: Archief Centrum '45, Map Raad van Advies, Correspondentie 1973-1977.

45 HEK, Zitting 1973-1974, P. 87-88.

46 Sinner, L. (17 mei 1973). LSD-kamers van prof. Bastiaans bleven dicht. Centrum ' 45 is geopend. Algemeen Dagblad.

47 Eiselin, F. (19 mei 1973). 'Er zijn in deze zaak nare dingen gebeurd'. Het Parool

48 De Volkskrant (17 mei 1973). Prof. J. Bastiaans: 'Bemanning Centrum ' 45 onvoldoende'. 
49 Eiselin, F. (19 mei 1973). 'Er zijn in deze zaak nare dingen gebeurd'. Het Parool.

so De Volkskrant (17 mei 1973). Prof. J. Bastiaans: 'Bemanning Centrum '45 onvoldoende'; Gonggrijp, E. (17 mei 1973). Incident bij opening van Centrum '45. De Telegraaf.

51 Mulder, J. (26 mei 1973). Conflict over opvang oorlogsslachtoffers. Elsevier; Sinner, L. (17 mei 1973). L.SD-kamers van prof. Bastiaans bleven dicht. Centrum ' 45 is geopend. Algemeen Dagblad. Aantreden $(1973, \mathrm{nr} 6 / 7)$. Congresmotie.

53 Notulen RvA Centrum '45, 30 augustus 1973. Vindplaats: Archief Centrum '45, Map Verslagen Raad van Advies.

54 Het Parool (19 mei 1972). Experts twijfelen aan methode Bastiaans.

55 Terwindt, T. (25 mei 1973). Bastiaans. Het Parool.

56 Notulen bestuursvergadering Centrum ' 45,18 mei 1973 . Vindplaats: Collectie Le Poole, nr. 30.

57 Tussentijds rapport van de Commissie van Advies Centrum '45, dr. P. Th. Hugenholtz, z.d. Vindplaats: Archief Centrum '45, Map Raad van Advies, Correspondentie 1973-1977.

58 Notulen bestuursvergadering Centrum ' 45,7 juni 1973. Vindplaats: Collectie Le Poole, nr. 30.

59 Het bestuur van het Centrum zag niets in dit voorstel.

60 Brief Bastiaans aan P. Muntendam, 24 mei 1973. Vindplaats: Archief Centrum '45, map Correspondentie RvA.

61 Brief Muntendam aan minister van Volksgezondheid, 12 juni 1973. Vindplaats: Archief Centrum '45, Map Bestuursaangelegenheden tot 31 december 1973.

62 Notulen bestuursvergadering Centrum '45, 2 augustus 1973. Vindplaats: Collectie Le Poole, nr. 30 63 Tussentijds rapport van de vicevoorzitter van de Commissie van Advies Centrum ' 45 , dr. P. Th. Hugenholtz, z.d.. Vindplaats: Archief Centrum '45, map Bestuursaangelegenheden.

64 Notulen bestuursvergadering Centrum '45, 2 augustus 1973. Vindplaats: Collectie Le Poole, nr. 30

65 Tussentijds rapport van de vicevoorzitter van de Commissie van Advies Centrum ' $45, \mathrm{dr}$. P. Th. Hugenholtz, z.d.. Vindplaats: Archief Centrum '45, map Bestuursaangelegenheden.

66 Notulen bestuursvergadering Centrum '45, 18 mei 1973. Vindplaats: Collectie Le Poole, nr. 30.

67 Brief A. Sunier (lid RvA) aan voorzitter bestuur Centrum ' 45, 14 oktober 1974. Vindplaats: Archief Centrum '45, Map Bestuursaangelegenheden tot 31 december 1973.

68 Naast Bastiaans zaten prof.dr. W.K. van Dijk, prof.dr. J.J. Dijkhuis, dr. P.Th. Hugenholtz, dr. A. Hustinx, J. Pasman, dr. A. Sunier en dr. W.L. Meijering in de Raad van Advies.

69 Zie ook de studie van Paul Koedijk: Koedijk, 1995.

70 Brief Noordhoek Hegt aan leden van bestuur Centrum '45, 28 mei 1973. Vindplaats: Archief Centrum '45, map Bestuursaangelegenheden.

71 Brief Meijering aan bestuur Centrum '45. Vindplaats: Archief Centrum '45, Klapper Verslagen 1973-1976 RvA.

\section{De reconstructie van oorlogsverledens}

K-Zetnik 135633, 1989, p. 62.

Wennekes, 1975. Voor een uitgebreide beschrijving zie Enning, 2001; Zie tevens: Enning, 2005.

Wennekes, 1975 .

Wennekes, 1975.

Wennekes, W. ( 5 mei 1973). 'Ik zoek al jaren een ss'er die ik LSD kan geven'. De Gelderlander.

Brief Meester aan Wennekes, 6 juni 1973. Vindplaats: Collectie Wennekes.

Brief Meester aan Wennekes, 6 juni 1973. Vindplaats: Collectie Wennekes.

Toespraak Bastiaans bij de presentatie van Allemaal rottigheid, allemadl ellende, 20 maart 1975. Vindplaats: Collectie Wennekes.

Brief A. Meester aan Bastiaans. 20 april 1975. Vindplaats: Collectie Wennekes,

1o Brief A. Meester aan Bastiaans, 20 april 1975. Vindplaats: Collectie Wennekes; Interview Meek.

11 Uitgewerkte tekst Ad Langebent, 20 april 1975. Vindplaats: Privécollectie Vogt. Kopie in bezit auteur.

12 Brief Vogt aan Stichting 1940-1945, januari 1975. Vindplaats: Privécollectie Vogt. Kopie in bezit auteur.

13 Verslag bezoek aan Bastiaans door Vogt, 17 juli 1975. Vindplaats: Privécollectie Vogt

14. Brief Vogt aan Stichting 1940-1945, 27 april 1977. Vindplaats: Privécollectie Vogt. 
Brief Bastiaans aan Wennekes, augustus-september 1976. Vindplaats: Collectie Wennekes. Heerma van Voss, A. J. (25 december 1976). 'Dat Weinreb-achtige zit in velen'. Prof. Bastiaans en het liegen over de oorlog. Haagse Post

17 De Koerierster (juli/augustus 1984). Overzicht van de tien gevallen waarin beslissingen van de Stichting 1940-1945 en de Buitengewone Pensioenraad in twijfel werden getrokken.

18 Interview Van Praag.

19 De term 'sociale fuik' is afkomstig van Vetter, (1998). In een eerder gepubliceerd artikel heb ik de zaak-Meester geanalyseerd als een gevolg van een sociale fuik. Zie daarvoor: Enning, 2005. Zie daarvoor bijvoorbeeld Blom (1989a).

Brief Lubbers aan W. Aantjes, 6 februari 1980. Als geciteerd in Bouwman (2002), p. 354 .

De Haan, 1997, p.85.

Van der Zijl, 2002, p.111-12g.

Van Ree, 2000.

Withuis, 2002.

Withuis, 2002.

Gerardts, 1972. Met bijdragen van: W.F. Geradts, J. Bastiaans, D. Van Tol, J.A. Weijel, C.J. van der Poel.

Brinkgreve, Onland \& De Swaan, 1979.

Interview Thiel.

Van Praag, 1977.

Boucher, 1985 , p. 206.

Boucher, 1985 , p. 206.

Zie Bijlage I: Aantal eerste aanvragen Buitengewoon Pensioen per jaar.

Bastiaans, 1986; Bastiaans, 1974a; Bastiaans, 197od, p. 302.

Bastiaans, 1974C, p. 1177

Bastiaans, 1986, p. 91.

Van Weezel, M. (18 juli 1987). Papa Bas. Professor Bastiaans als Gulliver tussen de vele dwergen in Oegstgeest, Leiden en Den Haag. Vrij Nederland; Bastiaans, 1986.

K-Zetnik 135633,1989 , p. 62 .

39 Notulen Grote vergadering van bewoners Jelgersmakliniek, 27 december 1976. Vindplaats: Privécollectie Kopinsky, doos 1.

40 Brief Bastiaans aan H.G.M. Rooijmans, 4 juni 1985. Vindplaats: Collectie RuL-Rooijmans ; Overzicht behandelingen in de Dependance van de Jelgersmakliniek 1 januari $1984 \mathrm{t} / \mathrm{m} 31$ juli 1984, opgesteld door J. Bastiaans, 3 augustus 1984. Vindplaats: Collectie RUL-Rooijmans. De Koning \& Oosterbaan, 1978.

Website Andere Tijden (http://geschiedenis.vpro.nl).

Brief Bastiaans aan bestuur Faculteit der Geneeskunde, 27 april 1983. Vindplaats: Collectie RuLRooijmans.

44 Veraart, 2002, p. 70. Bastiaans en Groen publiceerden op basis van hun onderzoek in de Psychosomatische Werkgroep eind jaren zestig een boek over Ms. Zie daarvoor Groen, Prick, \& Bastiaans, 1967

45 Veraart, 2002.

46 Interview Coumou

47 Interview Coumou.

48 Bijvoorbeeld Trudl van Reemst, die Bastiaans ontmoette via haar man, de huisarts T. van Reemst, en Dolf Schweizer, overlevende van Buchenwald en lid van het bestuur van de Faculteit der Geneeskunde van de RUL.

49 Crombag \& Merckelbach, 1996; Van der Velden, 1989.

50 Laurens, M.J. (2 mei 1990). Tekeningen van Sjaak Kopinsky over Holocaust in Museum Flehite: 'Iemand riep: Hé maat geen stippeltje teveel hoor!'. Amersfoortse Courant.

51 Notulen grote vergadering van bewoners Jelgersmakliniek, 27 december 1976 . Vindplaats: Privécollectie Kopinsky.

52 Het was een twintig minuten durend portret getiteld Dat nooit weerl Gemaakt door Amersfoortse lokale omroep. 
53 Lucassen, M. (1 mei 1999). Golfen op oorlogsgraven. Focus.

54 Kleinveld wist te ontsnappen uit een cel in kamp Amersfoort doordat hij met een lepel het cement rond de tralies wegwrikte, waardoor de tralies weggenomen konden worden.

55 Uitnodiging voor tentoonstelling 'Oorlogsherinneringen' gewijd aan Etty Hillesum en Jacques Kopinsky, 2 mei 1989. Vindplaats: Privécollectie Kopinsky, doos 2.

56 Lucassen, M. (15 november 1999). Het gekste was gewoon in die tijd: Kampgevangene Kopinsky mengde verf voor muurschilderingen. Amersfoortse Courant.

57 De zoon van Weiss stelde een klein dossier samen, getiteld 'De Roland Courant', waarin de levensloop van zijn vader staat beschreven en kopieën van correspondentie met het Rode Kruis en Stichting 1940-1945 over zijn vader zijn opgenomen. Het bevindt zich in het archief van Monument Kamp Amersfoort.

58 Van Colmjon, G. (14 januari 2003). Kamptekenaar (79) overleden. Amersfoortse Courant.

59 De Vries, H. (12 april 1989). De actuele boodschap van Kopinsky. Terdege.

6o Leusder Courant (29 november 1983). Het Kamp Amersfoort, een aangrijpende expositie.

61 Paspoort Kopinsky in Dossier J. Kopinsky (10274), SDA. Vindplaats: Archief SDA.

62 Brief ITS aan NRK, 2 oktober 1954. Vindplaats: Archief NRK. Zijn vader kwam hem ophalen en nam hem, zonder toestemming, mee naar huis. Dat blijkt uit het paspoort van J. Kopinsky sr., waarin een ontheffing is opgenomen om te reizen naar Duitsland en terug. Gedateerd medio augustus 1943. Vindplaats: Privécollectie Kopinsky.

63 Er waren meer verlofbrekers als Kopinsky, zij kregen net als Kopinsky op hun registratiekaart de afkorting 'v.U.', wat stond voor 'Verspäteter Urlauber'. De kaart is te vinden in de kartotheek van kamp Amersfoort, die deels bewaard is gebleven en zich bevindt in het archief van NRK.

64 Rückkehrschein dd. 15 december 1943. Vindplaats: Privécollectie Kopinsky. Zijn kaart in het Gewestelijk Arbeidsbureau vermeldde dat hij 'gemotiveerd ziek' was, wat erop duidde dat hij met toestemming naar Amsterdam was gereisd. Dossier J. Kopinsky (10274), SDA. Vindplaats: Archief SDA.

65 Telefoon- en Adressengids Amsterdam 1942, 1943 en 1944. Hij voldeed daarmee aan de Arbeidsinzet; Ausweis J. Kopinsky. Vindplaats: Privécollectie Kopinsky.

66 AEF DP Repatriation Record t.n.v. J. Kopinsky. Vindplaats: Privécollectie Kopinsky.

67 Dossier J. Kopinsky (10274), SDA. Vindplaats: Archief SDA.

68 In een brief aan het RIOD vroeg de Stichting 1940-1945 om verificatie van de feiten die Kopinsky op zijn aanvraagformulier had vermeld. De brief aan het RIOD vermeldde dat Kopinsky op 18 juni 1943 samen 'met vele anderen naar Duitsland' was vertrokken. De uitdrukking 'met vele anderen' is een verwijzing naar de andere Nederlandse mannen geboren in 1924 die zich in die periode moesten melden bij de Duitsers om tewerk te worden gesteld in Duitsland. Die brief aan het RIOD maakte geen melding van Buchenwald en Theresienstadt, wat erop duidt dat Kopinsky ze niet noemde op zijn aanvraagformulier. Zie daarvoor: Brief Stichting 1940-1945 aan RIOD, 4 oktober 1954. Vindplaats: Correspondentiearchief RIOD, 1954.

69 Bewijs van inschrijving J. Kopinsky, 1941. Vindplaats: Privécollectie Kopinsky. Hij maakte de opleiding overigens niet af. Hij werkte onder andere bij de Bijenkorf als lampenschilder. Dossier J. Kopinsky (10274), SDA. Vindplaats: Archief SDA.

$70 \quad$ Slot, 2006

71 Bouwman, 2002.

72 Grüter, 1997

73 De-Nur publiceerde onder zijn pseudoniem: K-Zetnik 135633 . Over zijn behandeling bij Bastiaans schreef hij: K-Zetnik 135633, 1989.

Bueno de Mesquita, 1991.

Milikowski, 1973, p. 100-101.

Bastiaans, 1957, p. 280-293.

Concepttekst Deel 8 Het Koninkrijk, Hoofdstuk 5, p. 58. Vindplaats: NIOD, Collectie De Jong.

Stein, 2006.

Bibeb (5 september 1970). Prof.dr. J. Bastiaans: 'Verslaafden liggen me minder dan

verzetsmensen'. Hoe haal je de mens uit de beklemming van zijn persoonlijk concentratiekampsyndroom? Vrij Nederland. 
80 Brief Bastiaans aan L. de Jong, 17 juni 1977. Vindplaats: NIOD Correspondentiearchief, 1977.

81 Heerma van Voss, A. J. (25 december 1976). 'Dat Weinreb-achtige zit in velen' Prof. Bastiaans en het liegen over de oorlog. Haagse Post.

82 Gerritse, P. \& Hagtingius, P. (1 april 1976). Kamerlid of Meesterfantast? Panorama.

83 Het geval werd door Bastiaans beschreven in: Bastiaans, 1983a; Bastiaans, 1985 ; Bastiaans, 1986.

84 Bastiaans, 1986, p. 98.

85 Maser, 2007.

86 Stein, 2006; Smith, 1983.

87 Dat leidde ertoe dat een patiënt van Bastiaans, onwetend van de achtergronden van de zaakMeester, Wennekes benaderde. Hij had eerder wat vertaalwerk voor Bastiaans gedaan en stelde voor Allemaal rottigheid, allemaal ellende in het Engels te vertalen. (Brief Santcross aan Wennekes, 24 september 1979. Vindplaats: Collectie Wennekes.)

88 Brief W. van der Noordaa-van der Veer aan L. de Jong, 28 januari 1977. Vindplaats: Collectie De Jong.

10 Een voordelig bondgenootschap

R. van Dam, ongedateerd. Vindplaats: Archief Kliest.

Withuis, 2002.

Askevold, 1976.

Wijsenbeek, 1977 .

Van Praag, 1977

Van Praag, 1977

Withuis, 2005, p. 320.

Geugjes, Kleijn, Willems, \& IJsennagger, 1990.

Geugjes et al., 1990, p. 131

Van Dijke, 1987, p. 135

In memoriam Berend Blokzijl, z.d. Auteur onbekend. Vindplaats: Collectie Polak.

'Over knelpunten'. Verslag oprichtingsvergadering CVv, 12 september 1980. Vindplaats:

Collectie Polak.

Hugenholtz, 1980 .

Van Dijke, 1987.

Openingstoespraak SDV door Polak, 18 december 1981. Vindplaats: Collectie Polak.

In de stukken van het $\mathrm{CVv}$ in het bezit van Veraart ging het om de pleitnota's behorende bij de uitspraken van het CRvB met kenmerk: 1981/87, 1981/36, 1981/27, 1980/130, 1980/121, 1979/101, 1979/100, 1979/85, 1979/60/20, 1979/47, 1978/135, 1978/120, 1978/106. In de stukken van het CVV die zich bevinden in het Collectie Polak gaat het om de uitspraken van het $\mathrm{CRvB}$ met de volgende kenmerken: $1984 / 38,1983 / 109,1983 / 24,1982 / 68,1981 / 68,1981 / 40,1980 / 80,1980 / 47,1979 / 85$, $1979 / 54,1979 / 32,1978 / 103,1978 / 85,1978 / 59,1977 / 176$.

17 Uitspraak CRvB 1979/54. Vindplaats: Collectie Polak.

18 Pelser had tijdens de oorlog geholpen bij het laten ontsnappen van Joden naar Zwitserland. Zie daarvoor: Pelser, 1996.

19 Rapport Pelser, 18 februari 1978. Uitspraak CRvB 1979/54. Vindplaats: Collectie Polak.

20 Uitspraak CRvB 1979/54. Vindplaats: Collectie Polak.

21 Zie bijvoorbeeld ook: Pleitnota Veraart (zaak BPW 1979/85), 5 september 1980. Vindplaats: Archief Veraart.

22 Pleitnota Veraart (zaak BPW 1981/27), 17 november 1983. Vindplaats: Archief Veraart.

23 Pleitnota Veraart (zaak BPW 1981/27), 17 november 1983. Vindplaats: Archief Veraart.

24 Brief $\mathrm{CrV}$ aan eigen leden, 10 mei 1982. Vindplaats: Collectie Polak.

25 Brief CVV aan BPR, 20 april 1982. Vindplaats: Collectie Polak.

26 Pleitnota Veraart (zaak BPW 1978/106), 19 mei 1983. Vindplaats: Archief Veraart.

27 Pleitnota Veraart (zaak BPW 1978/106), 19 mei 1983. Vindplaats: Archief Veraart.

28 Pleitnota Veraart (zaak BPW 1979/47), 12 maart 1981. Vindplaats: Archief Veraart; Pleitnota Veraart (zaak BPW 1980/121), 17 december 1981. Vindplaats: Archief Veraart. 
Bibeb (5 september 1970). Prof.dr. J. Bastiaans: 'Verslaafden liggen me minder dan verzetsmensen'. Hoe hal je de mens uit de beklemming van zijn persoonlijk concentratiekampsyndroom? Vrij Nederland.

Oolbekkink, H.J. (21 november 1981). Prof.dr. Jan Bastiaans, de helper: 'We lijden allen aan het ziektebeeld van de hysterie'. Haagse Courant.

31 Brief Pelser aan Polak, 4 juli 1980. Vindplaats: Collectie Polak.

32 Rooijmans, 1974.

33 Rooijmans, 1983

34 Van Daal \& De Knecht-Van Eekelen, 1994.

35 Het ging om prof.dr. E. Mandema, hoogleraar inwendige geneeskunde in Groningen, prof.dr. E. Lopes Cardozo, emeritus-hoogleraar inwendige geneeskunde aan de vU in Amsterdam en prof. dr. M. Frenkel, hooglaar in de inwendige geneeskunde aan de Erasmus Universiteit in Rotterdam.

36 Rapport Commissie-Mandema, 18 maart 1981, als geciteerd in Uitspraak CRvB 1978/103. Vindplaats: Collectie Polak.

37 Rapport Commissie-Mandema, 18 maart 1981, als geciteerd in Uitspraak CRvB 1978/103. Vindplaats: Collectie Polak.

38 Bijlage bij brief covvs aan staatssecretaris van wvc, 12 juni 1983, getiteld 'Nota Continuering medische zorg voor voormalige deelnemers aan het verzet.' Vindplaats: Collectie RUL/ Rooijmans.

39 Meijer, I. $(1985,19$ januari). De geheimsfeer. Vrij Nederland.

40 Bouwman, 2002.

41 Bouwman, 2002

42 Nieuws van de Dag (november 1978). Prof. Bastiaans: behandeling Aantjes onmenselijk.

43 Hofstede, P. (18 november 1978). De media \& Aantjes. NRC Handelsblad.

44 Het ging om historicus dr. J. Bank, voormalig hoogleraar staatsrecht dr. P.J. Boukema, strafrechtdeskundige $\mathrm{Ch}$.J. Enschedé.

45 Bank, als geciteerd in Bouwman (2002) p. 339

46 Als geciteerd in Bouwman (2002), p. 353 .

47 De Bok, R. (21 maart 1981). Aantjes. Elsevier

48 De Bok, R. (7 februari 1981). Prof dr. J. Bastiaans: 'Aantjes activeert het Kz-syndroom'. Elsevier

49 De Bok, R. ( 7 februari 1981). Prof dr. J. Bastiaans: 'Aantjes activeert het Kz-syndroom'. Elsevier; Van de Vliet, P. (6 januari 1979). Als je de rechtsstaat in stand wil houden, moet je geen mensen in geestelijke nood laten: Prof. Bastiaans over de schade veroorzaakt door een uitspraak. Utrechts Nieuwsblad.

5o Radio-uitzending Hier en $n u$ (NCRV), 26 maart 1981.

51 Brief Aantjes aan bestuur CDA als geciteerd in Bouwman, 2002, p. 361.

52 Milikowski, H.Ph. (21 juni 1969). Belangrijke feiten over het ' $\mathrm{kz}$-syndroom'. De Nieuwe Linie.

53 Milikowski, H.Ph. (29 april 1975). Het Kz-syndroom wordt nog altijd niet begrepen: Van S. en de schuldgevoelens van de burgerlijke psychiater. De Nieuwe Linie.

54 Gerrit IJzer aan H.Ph. Milikowski, mei 1975. Vindplaats: Collectie Milikowski, nr. 6.

55 R. van Dam, ongedateerd. Vindplaats: Archief Kliest.

56 R. van Dam, ongedateerd. Vindplaats: Archief Kliest.

57 R. van Dam, ongedateerd. Vindplaats: Archief Kliest.

58 Interview Op den Velde.

59 Brief E.A. Cohen aan L. de Jong, 14 februari 1977. Vindplaats: Collectie De Jong. Terzijde is het goed om op te merken dat, hoewel plausibel, Cohens interpretatie van het geval-Meester niet correct was; Meester had zich gemeld bij Bastiaans omdat hij hartklachten had. Pas nadat in de LSD-behandelingen zijn verzets- en kampverleden naar boven was gekomen, vroeg hij, op aanraden van Bastiaans, een Buitengewoon Pensioen aan. Meester leek niet met voorbedachten rade op een uitkering uit te zijn geweest, zoals Cohen suggereerde.

60 Dat deed De Jong, maar pas in Deel 14, dat uitkwam in 1991 toen Bastiaans geen rol van betekenis meer speelde.

61 De Jong, 1991, p. 543-544 
11 'Ik heb een symbolische functie'

Brief Ligtvoet aan minister van vws, 20 februari 1985. Vindplaats: Collectie Polak.

Stichting 1940-1945, 1982.

De Boef, Geugjes, \& Nota, 2002; Bijlage bij brief covvs aan staatssecretaris van wvc, dd.12 juni 1983, getiteld 'Nota Continuering medische zorg voor voormalige deelnemers aan het verzet'. Vindplaats: Collectie RUL-Rooijmans.

4 Hers, J.F.P. (augustus 1984). Dr. Hers bericht ons. Aantreden.

5 Withuis, 2002.

6 Andere gijzelingen in die periode waren: de bezetting op 13 september 1974 van de Franse ambassade in Den Haag door drie Japanners, op 26 oktober 1974 de gijzeling van cipiers en bezoekers door gedetineerden in de strafgevangenis van Scheveningen, op 2 december 1975 de treinkaping door Molukkers bij Wijster, op 4 december 1975 de gijzeling op het Indonesisch consulaat te Amsterdam door Molukkers, op 4 september 1976 kaping van KLM-toestel City of Madrid door Palestijnen en op 23 mei 1977 de treinkaping bij de Punt en de gelijktijdige gijzeling van onderwijzers en leerlingen van een lagere school in Bovensmilde door Molukkers. Bastiaans, Jaspers, Van der Ploeg, Van den Berg-Schaap \& Van den Berg, 1979, p.13.

Bastiaans, Jaspers, Van der Ploeg, Van den Berg-Schaap \& Van den Berg, 1979, p. 23.

Brief prof.dr. P.B. Defares aan leden С BOG, 5 maart 1981. Vindplaats: Archief Inspectie, nr. 879; Brom, Kleber, \& Defares, 1986; Kleber, Brom, \& Defares, 1986.

Van Proosdij, S. (1 januari 1984). 'Hoe werk ik hun eruit'. Interview met prof.dr. J. Bastiaans. Arts en Wereld.

11 Van den Hooff (10 juni 1985). Ook een rotjeugd kan leiden tot een soort Kz-situatie. Jan Bastiaans en het contactisolement. Het Vrije Volk.

12 In 1994 stond in het Handboek psychopathologie deel 1, een standaardwerk voor studenten psychologie, nog het post-concentratiekampsyndroom vermeld als speciale vorm van PTss. Vandereycken, Hoogduin, \& Emmelkamp, 1994

13 Rooijmans, 1989.

14 Oolbekkink, H. J. (21 november 1981). Prof.dr. Jan Bastiaans, de helper: 'We lijden allen aan het ziektebeeld van de hysterie'. Haagse Courant.

15 Brief C.J. Zwarts (voorzitter AFZA-commissie) aan Bastiaans, 29 januari 1982. Vindplaats: Collectie CVV; AFZA-commissie Psychiatrie (november 1981). De toekomst van de Leidse universitaire psychiatrie (rapport Vink). Vindplaats: Collectie crv.

16 Brief Bastiaans aan Vermeer, 15 februari 1982. Vindplaats: Collectie cvv. In een brief aan collegevoorzitter Cath schreef Bastiaans dat hij zich 'met alle beschikbare middelen zou verzetten'. Brief Bastiaans aan Cath, 13 april 1982. Vindplaats: Archief CvB RuL/DIVA, personeelsdossier J. Bastiaans.

17 Brief Cath aan Tammeling en Schweizer, 12 maart 1982: Vindplaats: Archief CvB RUL/DIVA, personeelsdossier J. Bastiaans.

18 Anoniem aan H.G.M. Rooijmans, 24 maart 1982. Vindplaats: Privécollectie Rooijmans. Kopie in bezit auteur.

19 Interview Rooijmans.

20 Uitwerking faciliteiten inzake onderwijs, onderzoek en patiëntenzorg, CvB RUL, bestuur AZL en bestuur Faculteit der Geneeskunde, 25 mei 1982. Vindplaats: Archief CVB RUL/DIVA.

21 GHvGV dr. H.J.A. Verhagen aan CvB RUL, 30 juni 1982. Vindplaats: Archief Archief CvB RUL/DIVA.

22 Verslag gesprek commissie Vink met GHIGV, 7 oktober 1981. Vindplaats: Collectie RUL/ Rooijmans.

23 Brief staf Jelgersmakliniek aan bestuur vakgroep Psychiatrie en Faculteit der Geneeskunde, college van bestuur, bestuur en directie AzL, 20 juli 1982. Vindplaats: Collectie RUL/Rooijmans.

24 Open brief van verpleegkundigen Jelgersmakliniek (Van den Ouweelen, M., De Rijk, B. en Schavemaker, B.), 13 september 1983. Vindplaats: Collectie RUL/Rooijmans.

25 HTK, zitting 1982-1983, Aanhangsel, p. 685.

26 Brief Bastiaans aan CvB, bestuur AZL, 25 mei 1982. Vindplaats: Collectie RUL/Rooijmans.

27 Haagsche Courant (23 september 1982). Professor Bastiaans wil niet weg; de Volkskrant (21 september 1982). Hoogleraar weigert verhuizing patiënten: 'Nieuwbouw niet geschikt'. 
28 Haagsche Courant (23 september 1982). Professor Bastiaans wil niet weg.

29 Verslag van een gesprek met Bastiaans, Cath en Den Os op donderdag 30 december 1982. Vindplaats: Archief CVB RUL/DrVA, personeelsdossier J. Bastiaans.

Verburgh, H.S. (27 januari 1983). Prof. Bastiaans in conflict met Leidse universiteit. 'Ik heb een symbolische functie'. NRC Handelsblad.

31 Verburgh, H.S. (27 januari 1983). Prof. Bastiaans in conflict met Leidse universiteit, 'Ik heb een symbolische functie'. NkC Handelsblad.

32 De Telegraaf (4 mei 1984). Oorlogssyndroom neemt toe.

33 Buyze, R. (28 februari 1985). Bastiaans verliest. Het Parool.

34 Sligter, A. (2 september 2008). Vrijbuiter in het oog van de orkaan. De Volkskrant.

35 Komrij, G. ( 2 februari 1983). Een en ander. NRc Handelsblad.

36 Komrij herinnerde zich desgevraagd 'enige pittige reacties ontvangen te hebben. Reacties van nogal sectarische aard.' Correspondentie aan auteur, 15 mei 2007. In NRC Handelsblad verschenen: Beer-Sieburgh, E. (14 februari 1983). Bastiaans 1. NRC Handelsblad; Lafeber, A.F. (14 februari 1983). Bastiaans 2. NRC Handelsblad; Terwindt, T. (14 februari 1983). Bastiaans 3. NRC Handelsblad.

37 Brave-Maks, M.H. (14 februari 1983). Bastiaans. NRC Handelsblad; Over haar periode als persoonlijk secretaresse schreef ze een boek: Brave-Maks, 1962.

38 Beer-Sieburgh, E. $(1983,14$ februari). Bastiaans 1. NRC Handelsblad. Kritiek op Bastiaans was ontkenning van het leed van oorlogsslachtoffers.

39 Terwindt, 1951.

40 Enquêtecommissie regeringsbeleid 1940-1945, 1950. Deel 4C, p. 237.

41 Neave, 1969.

42 Rep, 1977,

43 Enquêtecommissie regeringsbeleid 1940-1945, 1950, Deel 4A, p. 603.

44 Schreieder, 1949.

45 Enquêtecommissie regeringsbeleid 1940-1945, 1950. Deel 4C, p. 240.

46 Proces verbaal Terwindt in het kader van berechting J. Schreieder, 25 juni 1948. Vindplaats: NIOD, DOC 1-1529 Joseph Schreieder.

47 Rep, 1977, p. 333-339.

48 Enquêtecommissie regeringsbeleid 1940-1945, 1950, deel 4C, p. 240.

49 Terwindt, 1948.

50 Brief Terwindt aan bestuur Expogé, 14 januari 1986. Vindplaats: Archief Kliest.

51 Hofland, D. (4 februari 1986). Ex-patiënte over LSD-therapie: 'Bastiaans verdient Nobelprijs'. Binnenhof.

52 Brief Terwindt aan CVB RUL, 5 mei 1974. Vindplaats: Archief CVB RUL/DIVA, personeelsdossier J. Bastiaans.

53 Piersma, 2005, p. 125.

54 Piersma, 2005.

55 Terwindt, T. (14 februari 1983). Bastiaans 3. NRC Handelsblad.

56 De Volkskrant (4 oktober 1987). Voormalig verzetsstrijdster Trix Terwindt overleden.

57 De Volkskrant (4 oktober 1987). Voormalig verzetsstrijdster Trix Terwindt overleden.

58 Brief Terwindt aan bestuur Expogé, 14 januari 1986. Vindplaats: Archief Kliest.

59 Brief Terwindt aan Bastiaans, 4 april 1984. Vindplaats: Privécollectie Rooijmans. Kopie in bezit auteur.

6o Sligter, A. (9 september 2008). Vrijbuiter in het oog van vele orkanen. De Volkskrant.

61 Trouw (4 september 1987). Trix Terwindt: tot het einde toe een strijdbare vrouw.

62 Brief WDJ aan CVB RUL, 18 april 1983. Vindplaats: Collectie RUL/Rooijmans; Brief covvs aan staatssecretaris WVC, 12 juni 1983. Vindplaats: Collectie RuL/Rooijmans.

63 Brief WDJ aan CvB RUL, 25 januari 1983. Vindplaats: Archief CVB RUL/DrvA, personeelsdossier J. Bastiaans.

64 Brief WDJ aan CVB RUL, 25 januari 1983. Vindplaats: Archief CvB RUL/DIVA, personeelsdossier J. Bastiaans.

65 Bastiaans, 1974a. 
WDJ aan mr. L. Brinkman, minister van wVC, 2 maart 1985 . De brief is te vinden in het door het WDJ uitgegeven 'Witboek': WDJ (1985). Vindplaats; Archief vws.

67 Verslag gesprek met Bastiaans, Cath en Kappeijne van de Coppello, 27 februari 1984. Vindplaats: Collectie RUL/Rooijmans.

68 Bijvoorbeeld: Hagers, J. (4 mei 1984). Oorlogssyndroom neemt toe. De Telegraaf; Mulder, J. (4 augustus 1984). Het trauma van Bastiaans. Conflict rond specialisme rampentherapeut. Elsevier; Molthof, P. (25 augustus 1984). Bastiaans. Elsevier; Kluvers, H. (25 augustus 1984). Bastiaans. Elsevier; van Lith, $M$. (30 augustus 1984). 'Die jonge therapeuten vinden dat je in het hier en nu moet leven en het verleden moet vergeten'. Mare; Brave-Maks, M.H. ( 9 september 1984). Bastiaans. Elsevier; Henk. (29 september 1984). Prof. Bastiaans. Elsevier; Brabants Dagblad (17 november 1984). 'De gevolgen van een oorlog duren lang'. Prof. Bastiaans vecht voor voortzetting van zijn werk.

69 Brief Klompé aan Cath, 18 januari 1983. Vindplaats: Archief CvB RuL/DIvA, personeelsdossier J. Bastiaans.

70 Telex ministerie van wVc, 4 februari 1983. Vindplaats: Collectie RuL/Rooijmans.

71 Advies inzake problemen Jelgersmakliniek door Van Borssum Waalkes, 7 juni 1983. Vindplaats: Collectie RUL/Rooijmans.

72 Advies inzake problemen rond Jelgersmakliniek, Geneeskundige Inspectie voor de Geestelijke Volksgezondheid, 30 mei 1983. Vindplaats: Collectie RuL/Rooijmans.

73 Brief wDJ aan GHvGV, 17 augustus 1983. Vindplaats: Collectie RUL/Rooijmans.

74 Bijlage bij brief covvs aan staatssecretaris van wVC, dd.12 juni 1983, getiteld 'Nota Continuering medische zorg voor voormalige deelnemers aan het verzet'. Vindplaats: Collectie RUL/Rooijmans.

75 Brief Bastiaans aan Tammeling, 31 januari 1983. Vindplaats: Collectie RUL/Rooijmans; Rooijmans, 1989.

76 Brief Bastiaans aan decaan van de Faculteit der Geneeskunde, 31 januari 1983 . Vindplaats: Collectie RUL/Rooijmans.

Interview Op den Velde.

Interview Op den Velde.

Brief Rooijmans aan bestuur FdG, 18 februari 1983. Vindplaats: Collectie RUL/Rooijmans. Verslag gesprek 18 januari 1983 tussen Bastiaans, Rooijmans en Abraham, auteur onbekend, 21 januari 1983. Vindplaats: Collectie RUL/Rooijmans.

81 Brief Bastiaans aan bestuur Faculteit der Geneeskunde, 27 april 1983. Vindplaats: Collectie RuL/ Rooijmans.

82 Verslag gesprek 18 januari 1983 tussen Bastiaans, Rooijmans en Abraham, auteur onbekend, 21 januari 1983. Vindplaats: Collectie RUL/Rooijmans.

83 Brief Bastiaans aan bestuur Faculteit der Geneeskunde, 27 april 1983. Vindplaats: Collectie RUL/ Rooijmans.

84 Brief directeur faculteitsbureau aan patiënten Dependance, 18 april 1983. Vindplaats: Collectie RUL/Rooijmans.

85 Uitspraak twistgeding bij Ambtenarengerecht, 5 januari 1984. Vindplaats: Archief CvB RUL/ DIVA, personeelsdossier J. Bastiaans.

86 Brief patiënten Dependance aan bestuur FdG, 27 januari 1983. Vindplaats: Archief CvB RUL/ DIVA, personeelsdossier J. Bastiaans; Brief van patiënten Dependance aan bestuur Faculteit der Geneeskunde, 17 januari 1983. Vindplaats: Collectie RUL/Rooijmans; Brief van patiënten Dependance aan bestuur Faculteit der Geneeskunde, 27 april 1983. Vindplaats: Collectie RUL/ Rooijmans.

87 Brief van patiënten Dependance aan bestuur Faculteit der Geneeskunde, 27 april 1983. Vindplaats: Collectie RUL/Rooijmans.

88 Piët, S. (4 mei 1985). Wezenlijk met mensen bezig zijn daar gaat het om. Elsevier.

89 Vertrouwelijke brief van Bruens (afdeling juridische zaken) aan Cath, 29 maart 1982. Vindplaats: Archief CVB RUL/DrVA, personeelsdossier J. Bastiaans.

9o Zie de jaarverslagen van de Faculteit der Geneeskunde van de jaren 1975-1983. Vindplaats: Bibliotheek Universiteit Leiden. 
91 Brief H.G.M. Rooijmans en H.A. Favery aan bestuur van de Faculteit der Geneeskunde, 24 januari 1984. Vindplaats: Collectie RUL/Rooijmans.

92 Commentaar Bastiaans op conceptadvies van de vakgroep Psychiatrie met betrekking tot verlenging van de aanstelling, 23 januari 1984. Vindplaats: Collectie RUL/Rooijmans.

93 Verslag vergadering bestuur vakgroep Psychiatrie, 23 januari 1984. Vindplaats: Collectie RUL/ Rooijmans.

94 Verslag vergadering bestuur vakgroep Psychiatrie, 23 januari 1984. Vindplaats: Collectie RUL/ Rooijmans.

95 Verslag bespreking Cath, Kappeijne van de Coppello en Bastiaans, 27 februari 1984. Vindplaats: Archief CvB RUL/DIVA, personeelsdossier J. Bastiaans.

96 HTK, 1984.

97 Speech bij installatie projectgroep Polak door J.P. van der Reijden, 28 september 1984 . Vindplaats: Collectie RUI/Rooijmans.

98 Speech bij installatie projectgroep Polak door J.P. van der Reijden, 28 september 1984. Vindplaats: Collectie Ru L/Rooijmans.

99 Brief Ligtvoet aan minister van vws, 20 februari 1985. Vindplaats: Collectie Polak.

100 WDJ (februari 1984). Het werk van professor Bastiaans. Aantreden; WDJ (1 januari 1983). Werkgroep Dependance Jelgersmakliniek. De Koerierster; De Koerierster (januari/februari 1985). Sluiting bedreigt kliniek Bastiaans.

101 Molthof, P. (25 augustus 1984). Bastiaans. Elsevier.

102 De Koerierster (januari/februari 1985). Sluiting bedreigt kliniek Bastiaans.

103 Brief Bastiaans aan P. Coumou en P.J.G. Molthof, 27 december 1986. Vindplaats: Collectie Polak

104 Brief van verschillende belangenorganisaties voor verzetsmensen en oorlogsslachtoffers aan vaste commissie voor Wvc, december 1984 . Vindplaats: Collectie RUL/Rooijmans.

105 Van den Berg, H. (27 februari 1985). Slachtoffers van oorlog bepleiten bij Kamer voortzetting van therapie-Bastiaans. Het Parool.

106 Brief van verschillende belangenorganisaties voor verzetsmensen en oorlogsslachtoffers aan vaste commissie voor WVc, december 1984. Vindplaats: Collectie RUL/Rooijmans. Mijn cursivering.

107 Brief van verschillende belangenorganisaties voor verzetsmensen en oorlogsslachtoffers aan vaste commissie voor wVC, december 1984 . Vindplaats: Collectie RUL/Rooijmans.

108 Breedt Bruyn, M. (16 december 2006). Verdronken leven. Vrij Nederland.

109 Meijer, 1. $(1985,19$ januari). De geheimsfeer. Vrij Nederland.

110 Heerma van Voss, A. J. (13 april 1985). Tegenspelers. 'Het is haast een soort Griekse tragedie, voor hem maar ook wel voor mij, waarin de mensen hun rol spelen onverschillig of ze dat willen'. Vrij Nederland.

111 Pamflet van WDJ uitgereikt op hoorzitting vaste commissie van vws, 26 februari 1985. Te vinden in WDJ (1985). Vindplaats: Archief vws.

112 Van den Berg, H. (1985, 27 februari). Slachtoffers van oorlog bepleiten bij Kamer voortzetting van therapie-Bastiaans. Het Parool.

113 Brief WDJ aan minister Brinkman, 2 maart 1985. Te vinden in wDJ (1985). Vindplaats: Archief vws.

114 Verslag van de vaste commissie van WVC, 27 februari 1985. Vindplaats: Collectie RUL/ Rooijmans.

115 Verslag van de vaste commissie van wVc, 27 februari 1985 . Vindplaats: Collectie RUL Rooijmans.

116 Verslag gesprek Bastiaans, Polak, Kappeyne van de Coppello, Van Borssum Waalkes, 8 maart 1985. Vindplaats: Collectie Polak.

117 De Vries, P. (5 maart 1988). Goliath tussen de dwergen. Elsevier.

118 Interview Worrell.

119 Verslag vaste commissie voor WVC, 27 maart 1985. Vindplaats: Collectie Polak.

120 De motie werd mede-ondertekend door de Kamerleden A.M. Lucassen-Stauttener (VVD), J.G. Kraaijeveld-Wouters (CDA), M. Ernsting (CPN) en G. Mik (D'66). 
12 Het einde van de methode-Bastiaans.

1 Huijskens, C. (8 februari 1986). Weer aan het werk en nog subsidie ook... Prof.dr. Bastiaans: 'Van der Reijden is de kwaadste niet'. De Telegraaf.

2 Het ging om de Stichting Schroeder van der Kolk. De Stichting was de enige plek in Nederland waar Janovs primal scream-therapie werd gegeven; een behandeling die niet gericht was op het analyseren en doorpraten van psychische problemen, maar op het oproepen van emoties (overigens zonder het gebruik van LSD of pentothal). De bedoeling van de behandeling was dat patiënten voelden, huilden en schreeuwden; het begrip en inzicht in de opgeroepen emoties zouden achteraf vanzelf komen.

Verslag vaste commissie voor wvc, 27 maart 1985 . Vindplaats: Collectie Polak.

Interim-rapport PBOG, 21 mei 1985. Vindplaats: Collectie Polak

Brief staatssecretaris Van der Reijden aan bestuur Centrum '45, 27 maart 1985. Vindplaats: Collectie RuL/Rooijmans.

6 Brief staatssecretaris Van der Reijden aan bestuur Centrum ' 45, 27 maart 1985. Vindplaats: Collectie RUL/Rooijmans.

7 Boomer, A, 12 juni 1985 . Notitie over voortzetting methode Bastiaans bij Centrum ' 45 . Vindplaats: Collectie RuL/Rooijmans.

8 Notitie van Peters aan bestuur, z.d. (vermoedelijk begin 1986). Vindplaats: Archief Centrum ' 45. Klapper Bestuur 1986-1987.

9 Notitie van Peters aan bestuur, z.d. (vermoedelijk begin 1986). Vindplaats: Archief Centrum '45. Klapper Bestuur 1986-1987.

10 Bijlage bij brief covvs aan staatssecretaris van $w v c$, dd.12 juni 1983, getiteld 'Nota Continuering medische zorg voor voormalige deelnemers aan het verzet'. Vindplaats: Collectie RUL/Rooijmans.

11 Brief bestuur Centrum ' 45 aan staatssecretaris wVC, 1 april 1985. Vindplaats: Collectie RUL/ Rooijmans.

12 Koedijk, 1995, p.153.

13 Interim-rapport PBOG, 21 mei 1985. Vindplaats: Collectie Polak.

14 Uitnodiging afscheid Bastiaans, maart 1985. Vindplaats: Collectie RUL/Rooijmans.

15 Aantreden (augustus 1985). Afscheidscollege prof. Bastiaans.

16 Brief staatssecretaris van wVC aan Gezondheidsraad, 22 november 1984. Vindplaats: Collectie RUL/Rooijmans.

17 De buitenlandse experts waren: dr. F.K. Goodwin (directeur National Institute of Mental Health Bethesda, Verenigde Staten), prof.dr. H. Pardes (hoofd afdeling psychiatrie van Columbia University, Verenigde Staten), prof.dr. L. Eitinger (op dat moment emeritus hoogleraar aan de Universiteit Oslo), prof.dr. J. Mendlewicz (werkzaam bij de afdeling psychiatrie van de Vrije Universiteit Brussel), prof.dr. M.H. Lader (hoogleraar klinische psychofarmacologie aan de Universiteit Londen), prof.dr. D.X. Freedman (hoofd afdeling psychiatrie Universiteit van Californië) en twee anonieme bijdragen.

18 Gezondheidsraad, 1985, p. r. Mijn cursivering.

19 Brief Peters aan Hoofdinspecteur Inspectie drs. E.W. Roscam Abbing, 11 december 1985. Vindplaats: Archief Centrum '45; Brief Inspectie aan Bastiaans, 27 oktober 1986. Vindplaats: Collectie Polak.

20 Brief Peters aan Hoofdinspecteur Inspectie drs. E.W. Roscam Abbing, 11 december 1985. Vindplaats: Archief Centrum ' 45; Brief Inspectie aan Bastiaans, 27 oktober 1986. Vindplaats: Collectie Polak.

21 De doseringen schommelden volgens een door Rooijmans opgesteld overzicht aan de hand van verpleegrapporten rond de $700 \mathrm{mg}$. Zie daarvoor: Rapportage aan de hand van Verpleegrapporten door H.G.M. Rooijmans, 25 maart 1985. Vindplaats: Collectie RUL/ Rooijmans.

22 Rooijmans had de verpleegrapporten van drie maanden (december 1984, januari en februari 1985) doorgenomen en daarin één melding gevonden die er op wees dat een patiënt tijdens de narcoanalyse te weinig zuurstof had binnengekregen. Zie daarvoor: Rapportage aan de hand van Verpleegrapporten door H.G.M. Rooijmans, 25 maart 1985. Vindplaats: Collectie RUL/Rooijmans. 

Brief B. van Dijk aan bestuur Centrum ' 45,22 januari 1987. Vindplaats: Archief Centrum ' 45 , Bestuursstukken Correspondentie 1981-1989.

27 Voor een overzicht van de medische screening zie 'Procedure pre-operatieve poliklinische screening' van het Diaconessenhuis Voorburg, november 1984. Vindplaats: Collectie Polak. Brief Inspectie aan Bastiaans, 27 oktober 1986. Vindplaats: Collectie Polak.

Coumou, P. (1986, maart). De zaak Bastiaans. Aantreden.

De Koerierster (januari/februari 1986). Prof. Bastiaans weer aan het werk.

Musaph, H. (7 februari 1986). LSD wordt steeds minder gebruikt. De diepte-psychotherapie van prof.dr. J. Bastiaans. NRC Handelsblad.

Hofland, D. (24 januari 1986). Prof. Bastiaans: 'Nooit ongelukken met LSD-therapie

Anaesthesist zal zich bij mij stierlijk vervelen'. Binnenhof.

33 Huijskens, C. (8 februari 1986). Weer aan het werk en nog subsidie ook... Prof.dr. Bastiaans: 'Van der Reijden is de kwaadste niet'. De Telegraaf.

34 Bastiaans, 1974a; Bastiaans, 1974c; Bastiaans, 1983a; Bastiaans, 1986.

35 Bastiaans, 1970d; Bastiaans, 1973d.

36 Bastiaans, 1979d.

37 Bastiaans, 1983a.

38 Bastiaans, 1983a.

39 Bastiaans, 1986, p. 91.

40 Van sommige patiënten die zich in de pers hadden uitgesproken over hun behandeling waren geen banden te vinden. Van sommige patiënten was op de band aangegeven dat het om de vijfde sessie ging maar de voorgaande vier sessies bevonden zich niet altijd in collectie.

41 Mogelijk werden er geen opnamen gemaakt of zijn de banden meegegeven aan patiënten. Volgens een opgave van Bastiaans werden in 1986 zeventig patiënten behandeld. Zij krijgen in totaal 168 pentothalbehandelingen en zeventien LSD-behandelingen (zie: Brief Bastiaans aan bestuur Centrum '45, 9 september 1987. Vindplaats: Collectie Polak).

42 Zie voor een overzicht van de resultaten van de inventarisatie Bijlage Ix: Gegevens ontleend aan collectie banden Cogis.

43 Interview Van der Ploeg.

44 Grossarth-Maticek, Bastiaans, \& Kanazir, 1985.

$45 \quad$ NRC Handelsblad (25 maart 1983). Prof. Bastiaans over voorspellende waarde kankerpersoonlijkheid; Het Parool (25 maart 1983). 'Stress kan oorzaak kanker zijn'; de Volkskrant (2.5 maart 1983). Langdurige stress kan kanker bevorderen. Hoogleraar wijst op onderzoeken.

$46 \quad$ Van der Ploeg, 1991.

47 Verslag van een mondeling overleg, vaste commissie voor wVc, 27 februari 1986. Vindplaats: HTK, 18 994, nr 4.

48 Brief Van der Ploeg aan Polak, 27 april 1987. Vindplaats: Collectie Polak.

49 Van der Ploeg, Reerds, Kleijn, Mook, \& Moormann, 1987.

50 Interview Van der Ploeg.

51 Van den Berg, H. (1987, 14 november). Bastiaans tuimelt van voetstuk. Het Parool.

52 Brief W.S. Duits aan bestuur Centrum '45, 15 januari 1987. Vindplaats: Archief Centrum '45, Bestuursstukken Correspondentie 1981-1989.

53 Brief W.S. Duits aan bestuur Centrum ' 45,15 januari 1987 . Vindplaats: Archief Centrum ' 45 , Bestuursstukken Correspondentie 1981-1989.

54 Brief W.S. Duits aan bestuur Centrum '45, 15 januari 1987. Vindplaats: Archief Centrum '45, Bestuursstukken Correspondentie 1981-1989.

55 Brief Mengelberg aan Bastiaans, 4 januari 1987. Vindplaats: Collectie Polak.

56 Brief Mengelberg aan Bastiaans, 4 januari 1987. Vindplaats: Collectie Polak.

57 Brief Mengelberg aan Bastiaans, 4 januari 1987. Vindplaats: Collectie Polak.

58 Brief Mengelberg aan Bastiaans, 4 januari 1987. Vindplaats: Collectie Polak. 
59 Brief Bastiaans aan ssv, 27 december 1986. Vindplaats: Collectie Polak.

6o Nota 'Gang van zaken Dependance' van Peters aan bestuur Centrum '45, 25 november 1986. Vindplaats: Archief Centrum '45, map Bestuursstukken correspondentie 1981-1989.

61 Nota 'Gang van zaken Dependance' van Peters aan bestuur Centrum '45, 29 december 1986. Vindplaats: Archief Centrum ' 45, map Bestuursstukken correspondentie 1981-1989.

62 Nota 'Gang van zaken Dependance' van Peters aan bestuur Centrum '45, 29 december 1986. Vindplaats: Archief Centrum '45, map Bestuursstukken correspondentie 1981-1989.

63 Brief algemeen coördinator van Dependance aan bestuur Centrum '45, 23 januari 1987. Vindplaats: Archief Centrum ' 45 , map Bestuursstukken correspondentie 1981-1989.

64 Brief verplegend personeel aan bestuur Centrum '45, 21 januari 1987. Vindplaats: Archief Centrum '45, map Bestuursstukken correspondentie 1981-1989.

65 Brief cesartherapeute aan bestuur Centrum ' 45,17 januari 1987. Vindplaats: Archief Centrum '45, map Bestuursstukken correspondentie 1981-1989.

66 Brief psychologen aan bestuur Centrum '45, 22 januari 1987. Vindplaats: Archief Centrum '45, map Bestuursstukken correspondentie 1981-1989.

67 Brief medewerkster aan Peters, 21 januari 1987. Vindplaats: Archief Centrum '45, map Bestuursstukken correspondentie 1981-1989.

68 Brief verpleegkundige aan Peters, 21 januari 1987. Vindplaats: Archief Centrum '45, map Bestuursstukken correspondentie 1981-1989.

69 Brief W.S. Duits aan bestuur Centrum ' 45,21 januari 1987; Brief L. Dommisse-Dalebout aan bestuur Centrum '45, 21 januari 1987; Brief verplegend personeel aan bestuur Centrum ' 45, 21 januari 1987. Vindplaats: Archief Centrum '45, Bestuursstukken Correspondentie 1981-1989.

70 Verslag gesprek met Bastiaans en Melai, Vogelenzang en Schreuder, 23 maart 1987. Vindplaats: Archief Centrum '45, map Bestuur 1986-1987.

De Telegraaf (14 april 1987). Prof. Bastiaans dreigt dakloos te worden.

72 Polak in radio-uitzending van IKON, De andere wereld van zondagmorgen, 12 april 1987. Worrell in radio-uitzending van IKON, De andere wereld van zondagmorgen, 12 april 1987. Brief bestuur Centrum ' 45 aan Bastiaans, 11 juni 1987. Vindplaats: Collectie Polak. De brief was gedateerd op 11 juni maar werd pas op 16 juni overhandigd.

75 Verslag van een mondeling overleg, 17 juni 1987. H EK, 18 994, nr. 5 .

76 Brief Bastiaans aan bestuur Centrum ' 45,12 juli 1987. Vindplaats: Archief Centrum '45, map Bestuursstukken correspondentie 1981-1989.

77 Trouw (21 augustus 1987). Bastiaans (bijna 70) werkt drie opvolgers in.

78 Bruinsma, J. (12 december 1987). 'Buitenwereld maakt van Bastiaans soort goeroe'. Nieuwe therapeut oorlogsslachtoffers bewondert voorganger maar heeft hekel aan mythes. De Volkskrant.

79 Brief Bastiaans aan Brinkman, 19 mei 1987. Vindplaats: Archief Centrum '45, map Bestuur 19861987.

$80 \quad$ Brief patiënten Dependance aan Vaste Kamercommissie voor Volksgezondheid, 13 april 1987. Vindplaats: Centraal Archief Tweede Kamer.

81. Verslag bespreking tussen vertegenwoordigers van de Dependance en bestuur Centrum '45, van 19 juni 1987. Vindplaats: Archief Centrum '45, map Bestuursstukken Correspondentie 19811989.

82 Verslag bespreking tussen vertegenwoordigers van de Dependance en bestuur Centrum " 45 , van 19 juni 1987. Vindplaats: Archief Centrum "45, map Bestuursstukken Correspondentie 1981-1989.

83 Garschagen, A. (31 december 1987). Therapeut: Bastiaans is nooit helemaal te vervangen. NRC Handelsblad.

84 Verslag bespreking tussen vertegenwoordigers van de Dependance en bestuw Centrum '45, van 19 juni 1987. Vindplaats: Archief Centrum '45, map Bestuursstukken Correspondentie 981-1989.

$85 \quad$ Uitzending IKON op 28 juli 1987.

86 De Telegraaf (22 augustus 1987). Ingezonden brief; De Vries, A. (12 november 1987). Bastiaans 5. Het Parool; Memelink, O.W. (14 november 1987). Toen voelde ik dat mijn bevrijding voltooid was. NRC Handelsblad. 
88 Trouw (21 januari 1988). LSD-behandeling in Centrum ' 45 mag nog.

89 Trouw (3 december 1987). Bastiaans laat een onzekere toekomst achter.

90 Fortuin, J. (1987, 31 oktober). 'Wat worden wij daar nou wijzer van, papa Bas?' Het Parool.

91 Coumou, P. (augustus 1987). De opvolging van professor Bastiaans. Aantreden.

92 Brief RvO Stichting 1940-1945 aan minister van wvc, 30 september 1987. Vindplaats: Centraal Archief Tweede Kamer.

93 Van Weezel, M. (18 juli 1987). Papa Bas. Professor Bastiaans als Gulliver tussen de vele dwergen in Oegstgeest, Leiden en Den Haag. Vrï Nederland.

94 Notulen overleg bestuur Centrum ' 45 en Bastiaans, 11 november 1987. Vindplaats: Archief Centrum ' 45, Bestuursstukken Correspondentie 1981-1989.

95 Van den Berg, H. (14 november 1987). Bastiaans tuimelt van voetstuk. Het Parool; de Volkskrant (6 november 1987). Onderzoek naar gevolgen LSD-behandeling Bastiaans mislukt.

96 Van den Berg, H. (14 november 1987). Bastiaans tuimelt van voetstuk. Het Parool; Trouw (6 november 1987). Onderzoek naar methode Bastiaans is mislukking; Het Parool (6 november 1987). Gegevens ontbreken voor onderzoek naar Bastiaans; Willems, $M$. (31 oktober 1987). 'Ik wil nog zoveel mogelijk traumapatiënten helpen'. Prof. Bastiaans (7o) staakt met tegenzin zijn controversiële geneeswijze. De Telegraaf.

97 Brief minister van wVC aan Tweede Kamer ( 5 november 1987). Vindplaats; HEK 18 994, $\mathrm{nr} 8$.

98 Verslag van een mondeling overleg, 24 februari 1988. Vindplaats: HEK 18 994, nr 9.

99 Ter vergelijking is het interessant het verhaal van chirurg F. Sauerbruch te lezen. Deze briljante chirurg kon het opereren tot op hoge leeftijd niet laten, patiënten wilden door hem geholpen worden; ook toen hij dement was. Hij ging er uiteindelijk zelfs toe over op zijn keukentafel patiënten zonder verdoving te opereren. Zie voor een beschrijving: Cherian, Nicks \& Lords, 2001. Gooi-en Eemlander (8 december 1987). 'Niet de LSD helpt, maar begeleiding'. Verguisde en geprezen psychiater Bastiaans over zijn methode.

101 Willems, M. (31 oktober 1987). 'Ik wil nog zoveel mogelijk traumapatiënten helpen'. Prof. Bastiaans (7o) staakt met tegenzin zijn controversiële geneeswijze. De Telegraaf.

\section{Epiloog}

1 Laudy, Y. (8 januari 1994). Bevrijder uit het innerlijke kamp. Prof. Bastiaans (76) helpt wanhopige patiënten zo lang hij kan. De Telegraaf.

2 Laudy, Y. (8 januari 1994). Bevrijder uit het innerlijke kamp. Prof. Bastiaans (76) helpt wanhopige patiënten zo lang hij kan. De Telegraaf.

$3 \quad$ Woltz, W. (7 juni 1969). Trip naar '42. Algemeen Handelsblad.

4 Bijvoorbeeld: Van der Zee, R. (6 mei 2007). 'Dat ene barre jaar beheerst mijn leven'. NRC Handelsblad; Knols, K. (28 juni 2008). Herinneren, niet verwerken. Vrij Nederland.

5 Van Londen deed deze uitspraak in een uitzending van televisieprogramma Andere Tijden op 7 mei 2000.

6 Van der Velde, K. (26 januari 1994). Prof. Bastiaans, de Nieuwe Tijd en het oude zeer. Trouw.

7 In een artikel over de experimenten met ibogaïne waar Bastiaans bij betrokken was, werd het vermoeden uitgesproken dat de dood van de patiënte te wijten was aan heroïnegebruik. De auteurs maakten gebruik van Bastiaans: hij werd opgevoerd als verbonden aan de Universiteit Leiden terwijl hij daar al tien jaar niet meer werkte. Bovendien werd Bastiaans opgevoerd als expert op het gebied van ontwenningsverschijnselen van drugsverslaafden. Iets waar Bastiaans geen enkele ervaring mee had. Zie voor een beschrijving van de experimenten het artikel erover dat na Bastiaans' dood verscheen: Alper, Lotsof, Frenken, Luciano, \& Bastiaans, 1999. Interview Van Ingen Schenau.

Interview Van Ingen Schenau.

Alper et al., 1999.

Miesen zou verslagen van zijn gesprekken met Bastiaans opnemen in de bundel Het Alzheimer Café. Zie daarvoor: Miesen, 2002. 
Trouw (3 november 1997). Gedreven arts van oorlogsgetroffenen; de Volkskrant (s november 1997). Behandelaar van oorlogstrauma's Bastiaans overleden; Het Parool (1 november 1997). Prof, Bastiaans brak het geheugen open; Groeneveld, F. (1 november 1997). Behandelaar oorlogssyndroom. NRC Handelsblad.

13 Coumou, P. (december 1997). Een groot Nederlander is heengegaan. Rede uitgesproken bij afscheidsdienst Bastiaans. Aantreden.

14 Schudel en Pepplinkhuizen bekeken ook welke aanwijzingen er waren voor de tweedegeneratieproblematiek waarbij kinderen van oorlogsslachtoffers lijden onder het verleden van hun ouders.

15 Schudel en Pepplinkhuizen, 1986.

16 Heertje, A. (21 maart 1987). Een rapport dat maar geheim moet blijven. Het Parool.

17 Dekkers, E. (11 april 1987). Een krenkend werkstuk. Haagse Post.

18 Kopuit, M. (24 april 1987). Schudel: Opvoeding geen reden weigering onderzoek. Nieuw Israëlietisch Weekblad.

19 Overzicht wijzigingen in statuten van Stichting Centrum '45. Persoonlijke communicatie van D. Holman aan auteur, 11 september 2008.

20 Een ingekorte versie van het rapport verscheen in Cogiscope. Zie daarvoor: Schreuder, 2005.

21 Loonstcin \& Maas, 2005

22 Van Dijke, 1987, p. 135.

23 Vandereycken et al., 1994.

24 Hovens en Van der Ploeg (2006). Het ging om het artikel waarin Meester werd beschreven als voorbeeld van een succesvolle LSD-behandeling van een lijder aan het KZ-syndroom. Zie:

Bastiaans, 1974.

25 Visser, A. (23 juni 1989). 'Arts mist antenne voor trauma's'. Opvolger Bastiaans richt zich op onderwijs en onderzoek. NRC Handelsblad.

Schreuder in Schreuder \& De Ridder, 1988.

Brief voG aan eigen leden, september 1990. Vindplaats: Archief De Boef. Kopie in bezit auteur. Ossebaard \& Maalsté, 1999.

Zie voor meer informatie: http://www.maps.org

Withuis, 2002.

De Swaan, $1983 \mathrm{~b}$.

Onlangs werd bijvoorbeeld de oprichting van een kliniek voor veteranen voorgesteld omdat de reguliere hulpverlening niet voldoende wordt geacht. 


\title{
Gebruikte afkortingen
}

\author{
AJC Arbeiders Jeugd Centrale \\ Asc Amsterdamsch Studenten Corps \\ AzL Academisch Ziekenhuis Leiden \\ BPR Buitengewone Pensioenraad \\ BRP Bis Repetita Placent \\ CvB College van Bestuur \\ CrC College van Curatoren \\ CADSU Centraal Afwikkelingsbureau Duitse Schadeuitkeringen \\ CBG Centraal Bureau voor Genealogie \\ своG Centrale Beleids- en Ondersteuningsgroep \\ CBS Centraal Bureau voor de Statistiek \\ CMW Cultuur, Maatschappij en Wetenschappen \\ covvs Centraal Orgaan Voormalig Verzet en Slachtoffers \\ CPN Communistische Partij Nederland \\ CRM Cultuur, Recreatie en Maatschappelijk werk \\ CRvB Centrale Raad van Beroep \\ CVv Comité Vervolging en Verzet \\ Expogé Vereniging Ex-Politieke Gevangenen \\ FILDIR Fédération Internationale Libres des Déportés et Internés de \\ la Résistance \\ GHvGV Geneeskundig Hoofdinspecteur voor de Geestelijke Volksgezondheid \\ Gvo Nederlandse Stichting voor Gezondheidsvoorlichting en Opvoeding \\ HEK Handelingen van de Eerste Kamer der Staten Generaal \\ HTK Handelingen van de Tweede Kamer der Staten Generaal \\ IISG Internationaal Instituut voor Sociale Geschiedenis \\ IMP Instituut voor Multidisciplinaire Psychotherapie \\ ISSOG Internationale Stichting voor de Slachtoffers van Oorlog en Geweld
}




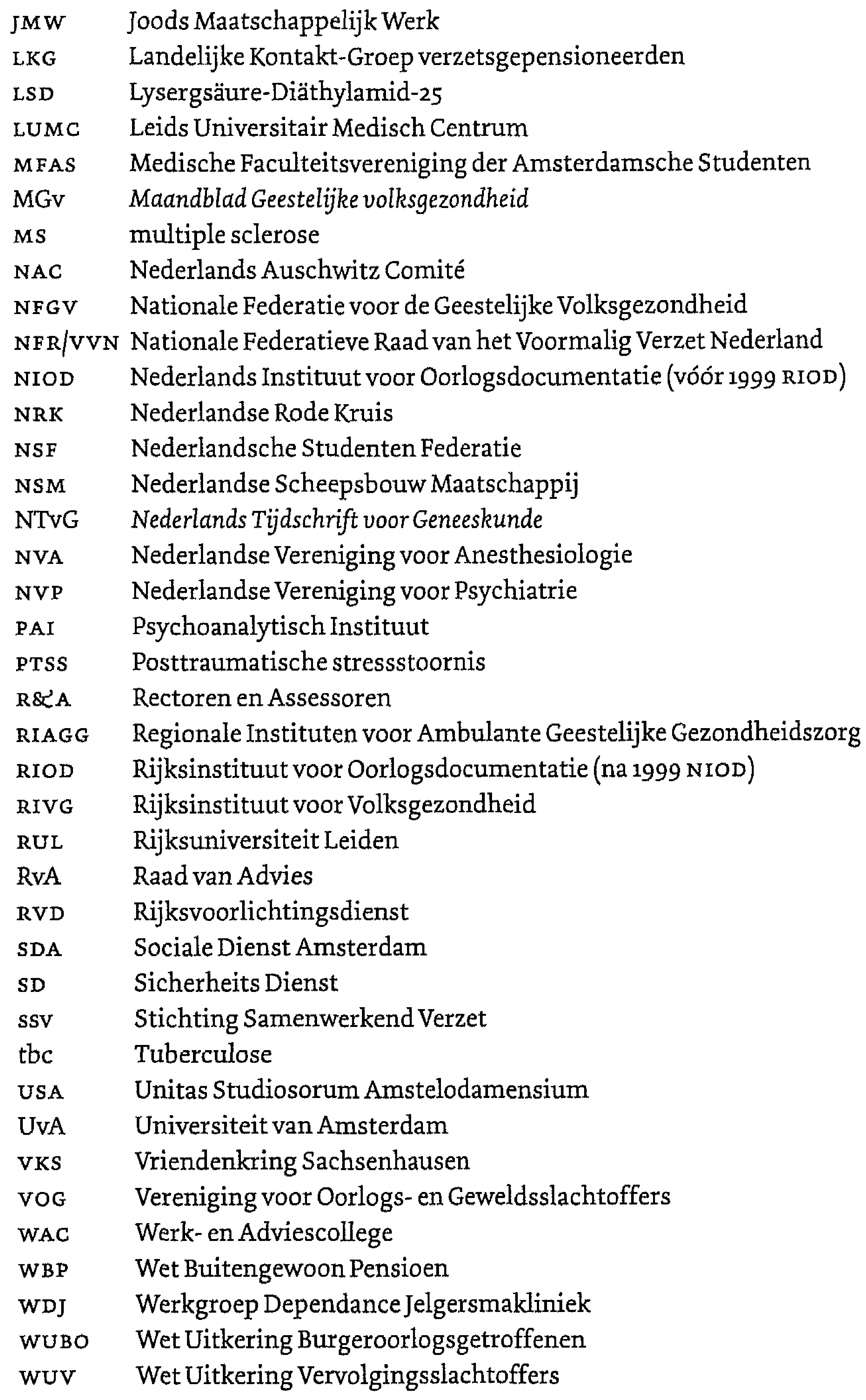




\section{Geraadpleegde archieven en personen}

Centraal Archief Tweede Kamer, Den Haag

Centraal Archief Tweede Kamer. Naast Handelingen ook ingekomen stukken en correspondentie.

Centrum '45, Oegstgeest

Archief Centrum' 45 . Gedeelte bevattende bestuursstukken.

Cogis, Utrecht

Collectie banden Bastiaans.

Bibliotheek Cogis.

Ministerie vws, Den Haag

Bibliotheek Eenheid oorlogsgetroffenen en herinnering woll.

Nederlandse Rode Kruis, Den Haag

Archief NRK. Het NRK beschikt over (gedeeltes van) kampadministratie van PDL Amersfoort.

Gemeentearchief Amsterdam, Amsterdam

Archief SDA. Archief van de Gemeentelijke Sociale Dienst Amsterdam (5256).

ArchiefUUA/R\&A. Archief van College van Rectoren en Assessoren van de Universiteit van Amsterdam (281).

Collectie BRP. Collectie Bis Repetita Placent. Collectie Universiteit van Amsterdam, Fysiologisch

Laboratorium (5298).

Haags Gemeentearchief, Den Haag

Collectie Bronovo. Collectie's-Gravenhaagsche Diakonessen-inrichting en Cornelia-stichting, later

Ziekenhuis Bronovo (BNR 582).

IISG, Amsterdam

Archief Van Gennep. Archief Uitgever Van Gennep, de uitgever van H.Ph. Milikowski met daarin

correspondentie. 
Collectie Vinkenoog. Collectie Simon Vinkenoog met daarin knipselverzameling over LSD.

Knipseldiensten diverse dag- en weekbladen

Knipseldiensten van de Volkskrant, NRC Handelsblad, De Telegraaf, Vrij Nederland, Trouw, Het Parool, en Elsevier.

Nationaal Archief, Den Haag

Archief Inspectie. Archief Staatstoezicht op de Volksgezondheid (5.005.5035).

Archief NFGv. Archief Nationale Federatie Geestelijke Volksgezondheid (2.19.134).

Archief NVP. Archief Nederlandse Vereniging voor Psychiatrie. Archief was in bewerking tijdens raadpleging. Vanaf medio 2009 beschikbaar bij Nationaal Archief.

Collectie Le Poole. Archief mr. J. le Poole (2.21.205.48).

Collectie Van Dedem. Collectie G.W. van Dedem (2.21.267).

NIOD, Amsterdam

Collectie De Jong. Collectie L. de Jong, manuscripten en fiches van De Jong (700).

Collectie Mourer. Correspondentie tussen Nicolaas Mourer en zijn familie, Groningen, Sachsenhausen, 1941-1945. Collectie Aanwinsten NIOD (1906).

Collectie Polak. Collectie prof.dr. B.S. Polak. Collectie Aanwinsten NIOD (2646).

Collectie Wennekes. Collectie journalist W. Wennekes met daarin stukken betreffende de totstandkoming en de nasleep van Allemaal rottigheid, allemaal ellende.

Correspondentiearchief NIOD. Correspondentie van NioD.

Collectie Concentratiekampen buiten Nederland. Verslagen en verhoren over Sachsenhausen (250k).

Collectie Periodieken. Collectie Periodieken met daarin onder meer: Aantreden, De Koerierster en Nooit weer!

Dagboeken en egodocumenten. Collectie dagboeken en egodocumenten (244).

Kampen en gevangenissen. Collectie verhoren, verslagen en divers materiaal over kampen (250d).

Knipselcollectie. Knipselmappen van Aantjes (KBI-10760), Bastiaans (KBI-372), De Bezetting (KBII-1594), drie van Breda (KBII-1419 t/m 1432), Kz-syndroom (KBII-1283), Commissie-Van Dijke (KBII-2410), Terwindt (KBI6696), W.F. Noordhoek Hegt (KBI-5135).

Noord-Hollands Archief, Haarlem

Archief politie Haarlem. Dagrapporten van politie Haarlem gedurende de bezetting.

\section{Privécollecties}

Privécollectie De Boef. D. de Boef voormalig patiënt van Bastiaans. Ondernam pogingen zijn methode te behouden middels de voG.

Privécollectie Knegtmans. Historicus dr. P.J. Knegtmans interviewde Bastiaans ooit voor zijn boek over de geschiedenis van de Universiteit van Amsterdam.

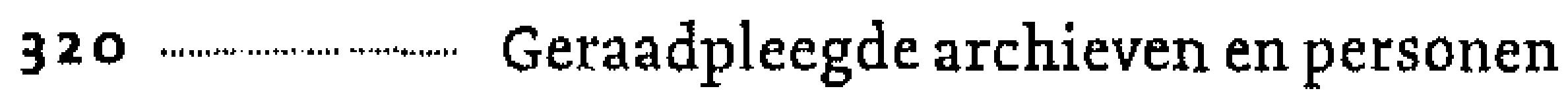


Privécollectie Kliest. Privécollectie A.J. Kliest met daarin onder andere stukken van de LKG. In bezit T. de Ridder.

Privécollectie Kopinsky. S. Kopinsky is in bezit van materiaal van zijn vader J. Kopinsky die ooit in behandeling was bij Bastiaans.

Privécollectie Mourer. N. Mourer jr. is de zoon van N.A. Mourer, die ooit in behandeling was bij Bastiaans. De familie beschikt over enkele brieven van na de oorlog.

Privécollectie Rooijmans. Prof.dr. H.G.M. Rooijmans was vanaf 1982 hoofd van de afdeling Psychiatrie aan de RUL.

Privécollectie Van Gasteren. Cineast L. van Gasteren maakte samen met Bastiaans en Telling de film Begrijpt u nu waarom ik huil....

Collectie CVv. Privécollectie van mr. C. Veraart met daarin stukken betreffende diens werkzaamheden voor de crv.

Privécollectie Vogt. T. Vogt was ooit getrouwd met Eibert Meester, een patiënt van Bastiaans.

Universiteit Leiden, Leiden

Archief CvB RUL. Archief van Curatoren en College van Bestuur (1952-1989). Universiteitsbibliotheek RuL, Bijzondere Collecties: $A C 4$.

Archief CuB RUL/Drva. Personeelsdossier J. Bastiaans (met inbegrip van het vertrouwelijke gedeelte).

Archief RuL/Rooijmans. Collectie H.G.M. Rooijmans betreffende ontslag Bastiaans. In beheer bij bibliotheek Psychiatrie.

Universiteit van Amsterdam, Amsterdam

Archief USA. Archief Unitas Studiosorum Amstelodamensium. Universiteitsbibliotheek UvA Bijzondere Collecties.

ArchiefUvA/Drv. Dienst Informatie Voorziening.

Collectie Milikowski. Collectie H.Ph. Milikowski. Universiteitsbibliotheek, Handschriften (XXXII G21).

VARA, Hilversum

Archief varA. Stukken betreffende uitzending Begrijpt u nu waarom ik huil.... Met dank aan A. van den Berg.

\section{Geraadpleegde personen}

Prof.dr.R.E. Abraham. Chef de clinique van de Jelgersmakliniek toen Bastiaans daar directeur was. Afgenomen op 4 april 2006.

H. Bastiaans-Visser. Weduwe Bastiaans. Enkele korte gesprekken in de herfst van 2005.

G. Bekker. Maatschappelijk werkster voor Stichting 1940-1945 en voorzitter van Werkgroep Dependance Jelgersmakliniek. Afgenomen op 24 juli 2007

A. de Blécourt. Psychoanalyticus die samenwerkte met Bastiaans op het Pal te Amsterdam. Correspondentie juli 2005.

D. de Boef. Zette zich in voor behoud van methode Bastiaans na diens vertrek bij Centrum' 45 via de voG. Afgenomen op 18 april 2005 
Mr. K.J. Cath. Voorzitter van College van Bestuur van de RUL vanaf 1972 tot vertrek van Bastiaans. Afgenomen op is april 2006.

Mr.P. Coumou. Verzetsman met grote betrokkenheid bij oorlogsslachtoffers, was onder andere voorzitter van Rubo en vice-voorzitter van ssv. Afgenomen op 3 maart 2005.

A. Durlacher-Sasburg. Weduwe van Gerhard Durlacher, Afgenomen op 20 september 2006.

Prof.dr. M. Frenkel. Studeerde samen met echtgenote en Bastiaans aan de Gemeentelijke Universiteit van Amsterdam. Werkte na de oorlog op het Wilhelmina Gasthuis in Amsterdam. Afgenomen op 21 april 2005.

P.T. Gaaikema. Verbleef tijdens de oorlog samen met Bastiaans op boerderij 'De Hoogte' in Oldehoven. Telefoongesprekken en correspondentie in zomer 2005.

L. van Gasteren. Cineast die met Bastiaans de film Begrïpt u nu waarom ik huil... maakte. Later bracht Van Gasteren een vervolg uit getiteld De prijs van overleven. Afgenomen op 22 maart 2005.

A.J. Heerma van Voss. Publicist onder andere op het gebied van de geestelijke gezondheidszorg. Interviewde Bastiaans enkele malen. Afgenomen op 3 april 2007.

Dr.J.F.Ph. Hers. Overlevende van concentratiekamp Sachsenhausen, was betrokken bij oprichting Centrum ' 45 en eveneens werkzaam op de Rijksuniversiteit Leiden als internist gespecialiseerd in behandeling oorlogsslachtoffers. Afgenomen op 19 april 2005.

R.F.A. van Ingen Schenau. Eigenaar van hotel Het Witte Huis tegenover de dependance toen Bastiaans daar werkte. In hotel Het Witte Huis vonden de experimenten met ibogaïne plaats. Afgenomen op 9 oktober 2007

A.J. Kliest, Jarenlang voorzitter van de Landelijke Kontakt Groep voor verzetsgepensioneerden. Afgenomen op 13 november $200 \%$

S. Kopinsky. Zoon van J. Kopinsky. Enkele gesprekken in januari 2008.

Prof.dr.J.van Londen. Directeur-generaal van het departement van Volksgezondheid in de periode dat Bastiaans zijn werkzaamheden staakte. Hij was tevens voorzitter van de CBOG. Afgenomen op 10 oktober 2007.

R. Milikowski-de Raat. Weduwe van H.Ph. Milikowski. Afgenomen op 7 maart 2006.

H. van Moock. Zoon van verzetsstrijder H. van Moock sr. die ooit door Bastiaans werd behandeld. Afgenomen op 2 november 2006 .

N. Mourer. Zoon van communist, oud-Spanjestrijder, oud-verzetsman, overlevende van Sachsenhausen en Nico Mourer. Afgenomen op 12 april 2006.

Prof.dr. W. op den Velde. Assistent bij Bastiaans op de Jelgersmakliniek en kwam later te werken bij de Stichting 1940-1945. Afgenomen op 30 maart 2006.

Dr.F.G.P.H. Oyen. Assistent bij Bastiaans op de Jelgersmakliniek. Afgenomen 17 juli 2006.

Dr. H.J.Pelser. Lid van de Psychosomatische Werkgroep en goede bekende van Bastiaans. Afgenomen op 10 oktober 2005. 
Prof.dr.H.M. van der Ploeg. Psycholoog die onderzoek deed naar de effectiviteit van de methodeBastiaans, tevens eerste hoogleraar van de IssoG. Afgenomen op 8 oktober 2007.

Dr.F. van Ree. Schreef eerste (en vermoedelijk enige) Nederlandse proefschrift over LSD. Deed eind jaren vijftig onderzoek op het Wilhelmina Gasthuis in Amsterdam, waar ook Bastiaans toen werkte. Afgenomen op 28 juni 2005.

T. van Reemst-de Vries. Weduwe van huisarts Th. van Reemst. Beiden oud-Spanjestrijders die zich inzetten voor oorlogsslachtoffers en hielpen onder andere bij aanvragen van uitkeringen. Afgenomen op 2 mei 2006.

Prof.dr.H.G.M. Rooijmans. Hoogleraar psychiatrie op de RUL vanaf 1976. Afgenomen op 3 maart 2006.

Prof.dr. A.Th. Schweizer. Lid van bestuur Faculteit der Geneeskunde van de Universiteit Leiden in de periode dat Bastiaans hoogleraar was. Afgenomen op 8 mei 2006.

Prof.dr.J. Thiel. Psychoanalyticus die Bastiaans kende van hun gezamenlijke periode op het Wilhelmina Gasthuis. Afgenomen op 11 augustus 2005.

R. Telling. Zoon van J.R. Telling, die figureerde in Begrïpt u nu wadrom ik huil... Afgenomen op 13 november 2006.

Dr.D. van Tol. Chef de clinique op de Jelgersmakliniek die meewerkte aan de tot standkoming van de film Begrijpt u nu waarom ik huil... Afgenomen op 13 april 2005.

M.J.C. Worrell. Lid van de PvdA-fractie en behartigde daarin de belangen van oorlogsslachtoffers. Diende motie in die leidde tot verlenging van Bastiaans' aanstelling. Afgenomen op 23 augustus 2007. 


\section{Geraadpleegde literatuur}

Alpex, K.R., L.otsof, H.S., Frenken, G.M.N., Luciano, D.J., \& Bastiaans, J. (1999). Treatment of acute opioid withdrawal with ibogaine. American Journal on Addictions, 8(3), 234-242.

Askevold, F. (1976). War sailor syndrome. Psychotherapy and Psychosomatics, 27, 133-138.

Bank, J. (1983). Oorlogsuerleden in Nederland. Baarn: Ambo.

Barnhoorn, J.A.J. (1954). Verhongering als mogelijke oorzaak van nerveuse, psychische en psychosomatische stoornissen.'s-Gravenhage: Buitengewone Pensioenraad.

Beunderman, R. (2003). De man die ontdekkingsreiziger wilde zijn. Nederlands Tijdschrift voor Behavioral Medicine, 14, 4-8.

Bloch, M.B. (1971). Ingezonden: Het post-concentratiekamp-syndroom. Nederlands Militair Geneeskundig Tijdschrift, 24, 165-166.

Blok, G. (2004). Baas in eigen brein. Antipsychiatrie in Nederland 1965-1985. Amsterdam: Uitgeverij Nieuwezijds.

Blom, J.C.H. (1989a). In de ban van goed of fout? Wetenschappelijke geschiedschrijving over de bezettingstijd in Nederland. In J. C. H. Blom, Crisis, bezetting en herstel: tien studies over Nederland 1930-1950. 's-Gravenhage: Nijgh \& Van Ditmar Universitair.

Blom, J.C.H. (1989b). Jaren van tucht en ascese. Enige beschouwingen over de stemming in Herrijzend Nederland (1945-1950). In J.C.H. Blom, Crisis, bezetting en herstel: tien studies over Nederland 2930-1950. 's-Gravenhage: Nijgh \& Van Ditmar Universitair.

Boef, D. de, Geugjes, S., \& Nota, R. (2002). Dertigjaar covvs: 1972-2002. Amsterdam: covvs.

Booij, J. (1968). Farmacotherapie en psychotherapie. LSD als adjuvans bij de psychotherapie? Nederlands Tijdschrift voor Geneeskunde, 112, 2-7.

Boucher, F. (1985). Woord gehouden: Veertigjaar Stichting 1940-1945. 's-Gravenhage: Staatsuitgeverij.

Bouwman, R. (2002). De val van een bergredenaar: Het politieke leven van Willem Aantjes. Amsterdam: Boom.

Bracher, K.D., Brilman, P.M., von der Dunk, H.W., Jescheck, H.-H., Rüter, C.F., \& Dressen, W. (red.). (1998). Justiz und NS-verbrechen: Sammlung Deutscher Strafurteile wegen Nationalsozialistischen Tötungsverbrechen 1945-1966. Amsterdam/Maarssen: Holland University Press.

Brave-Maks, M.H. (1962). Prins Bermhard in oorlogstijd. Amsterdam/Brussel: Elsevier.

Brinkgreve, C., Onland, J.H., \& De Swaan, A. (1979). De opkomst van het psychotherapeutisch bedrijf. De Meern/Antwerpen: Aula/Spectrum.

Broekema, S., Cnossen, P., Niemeijer, J.A., \& Mulder, A.A.J. (1986). Verzet in Groningen. Groningen: Wolters Noordhoff/Forsten.

Brom, D., Kleber, R.J., \& Defares, P.B. (1986). Traumatische ervaringen en psychotherapie. Lisse: Swets \& Zeitlinger.

Bueno de Mesquita, M. (1991). Wat hebben jullie met onze meisjes gedaan? Amsterdam: Vrije Val. 
Burger, A. (2007). Des Teufels Werkstatt: Die grösste Geldfalscheraktion der Weltgeschichte. München: Elisabeth Sandmann Verlag.

CADSU. (1966). Eindverslag betreffende de taken van het CADSU. 's-Gravenhage: Ministerie van Financiën. CBS. (1976). Onderzoek naar de sterfte onder overlevenden uit de concentratiekampen 1945-1968. 's-Gravenhage: Staatsuitgeverij.

Cherian, S.M., Nicks, R. \& Lords, R.S.A. (2001). Ernst Ferdinand Sauerbruch: Rise and fall of the pioneer of thoracic surgery. World Journal of Surgery, 25, 1012-1020.

Cohen, E.A. (1952). Het Duitse concentratiekamp. Amsterdam: Paris.

Cohen, E.A. (1969). Het post-concentratiekampsyndroom. Nederlands Tijdschrift voor Geneeskunde, 113, 2049-2054.

Cohen, E.A. (1972). Het post-concentratiekampsyndroom: een 'disaster'-syndroom. Nederlands Tijdschrift voor Geneeskunde, 116, 1680--1685.

Cohen, S. (1960). Lysergic Acid Dethylamide: Side effects and complications. Journal of Nervous and Mental Disease, 130(1), 29-40.

Cohen, S. (1966). Het buitenste binnen:Een studie over LSD. Amsterdam: Van Ditmar.

Cohen, S., \& Ditman, K.S. (1962). Complications associated with Lysergic Acid Diethylamide (LSD-25). Journal of the American Medical Association, 181, 161-162.

Crocket, R., Sandison, R., \& Walk, A. (Eds.). (1963). Hallucinogenic Drugs and their Therapeutic Use:Proceedings of the Quarterly Meeting of the Royal Medico-Psychological Association in London, February 1961. London: H.K.Lewis \& Co. Ltd.

Crombag, H.F.M., \& Merckelbach, H. (1996). Hervonden herinneringen en andere misverstanden. Amsterdam: Contact.

Daal, M.J.G.W. van, \& De Knecht-van Eekelen, A. (1994).JoannesJehuda Groen (1903-1990):Een arts op zoek naar het ware welzijn. Rotterdam: Erasmus Publishing.

Dam, H.M. van, \& Giordano, R. (1962). Kz-verbrechen vor Deutschen Gerichten. Dokumente aus den Prozesse gegen Sommer (Buchenwald), Sorge, Schubert (Sachsenhausen), Unkelbach (Ghetto in Czenstochau). Frankfurt am Main: Europäische Verlagsanstalt.

Dankaart, H., Flinterman, J.-J., Groot, F, \& Vuurmans, R. (1986). De oorlog begon in Spanje: Nederlanders in de Spaanse Burgeroorlog 1936-1939. Amsterdam: Van Gennep.

Dantzig, A. van $(1946,29$ juni). De tragedie der Puttenaren. De Baanbreker. Onafhankelijk weekblad voor socialistische politiek en cultuur.

Dasberg, H., Davidson, S., Durlacher, G.L., Filet, B.C., \& De Wind, E. (1987). Society and Trauma of War. Assen/Maastricht: Van Gorcum.

Dehue, T. (1990). De regels van het vak: Nederlandse psychologen en hun methodologie 1900-1985. Amsterdam: Van Gennep.

Dijke, P. van (1987). Rapport van de Commissie Vereenvoudiging en Coördinatie van de Wetten voor Oorlogsgetroffenen.'s-Gravenhage: Distributie Overheidspublicaties.

Dohmen, J., \& Steens, O. (1995). Beurijding en bezetting: Vijftigjaar Algemene Studenten Vereniging Amsterdam. Amsterdam: Vossiuspers AuP.

Durlacher, G.L. (1985). Strepen adn de hemel. Amsterdam: Meulenhoff.

Durlacher, G.L. (1991). De zoektocht. Amsterdam: Meulenhoff.

Eitinger, L. (1964). Concentration Camp Survivors in Norway and Israel. Den Haag: Martinus Nijhoff.

Eitinger, L. (1969). Psychosomatic problems in concentration camp survivors. Journal of Psychosomatic Research, 13, 183-189.

Engelsman, A. (red.). (1989). Oorlogstrauma's na 45 jaar? Politiek en psychiatrisch ongeduld. Amsterdam: Van Gennep.

Enning, B. (2005). Een geval van een verzonnen $\mathrm{kz}$-syndroom. Maandblad Geestelijke volksgezondheid, $5(60), 502-514$.

Enquêtecommissie regeringsbeleid 1940-1945. (1950). Verslag houdende de uitkomsten van het onderzoek. 'sGravenhage: Staatsdrukkerij- en Uitgeverijbedrijf.

Feigon, E.A. (1998). 'Recovered-memory' therapy: Profession at a turning point. Comprehensive Psychiatry, 39(6), 338-344.

Foudraine, J. (1971). Wie is van hout... Een gang door de psychiatrie. Bilthoven: Ambo.

Frijtag Drabbe Künzel, G. von (2003). Kamp Amersfoort. Amsterdam: Mets \& Schilt.

Fritsch, C., Kurth, G., \& Schultz, P. (1974). Sachsenhausen:Dokumente, Aussagen, Forschungsergebnisse und 
Erlebnisberichte über das ehemalige Konzentrationslager Sachsenhausen. Berlijn: Deutscher Verlag der Wissenschaften.

Futselaar, R.D. (2007). Lard, Lice and Longevity:A Comparative Study of the Standard of Living in Occupied Denmark and the Netherlands 1940-45. Amsterdam: Aksant Academic Publishers.

Gasteren, L. van (1972). Now do you get it why I am crying? Complete script. Amsterdam: Euro-Television productions.

Gerardts, W.F. (red.) (1972). Leven na een oorlog. Een bundel informatie over het verwerken van ervaringen uit de oorlog 1940-1945. Amsterdam: Nationaal Centrum voor Geestelijke Volksgezondheid.

Geugjes, S., Kleijn, J., Willems, M.A.M., \& IJsennagger, A. (1990). Vijfentwintigjaar LKG: Een kwart eeuw inzet voor belangen en idealen. Uitgeest: Landelijke Kontakt-Groep Verzetsgepensioneerden.

Gezondheidsraad. (1985). Advies inzake de toediening van hallucinogenen bij de behandeling van slachtoffers van oorlog en geweld. 's-Gravenhage: Gezondheidsraad.

Gilbert Dreyfus, H., Fichez, L.F., \& Frank, L.J. (1954). Günstige Wirkungen der Schlafkur bei ehemalige Deportierten mit Asthenischer Abmagerung, auch zusammen mit Lungentuberkulose. In M. Michel (Ed.), Gesundheitsschäden durch Verfolgung und Gefangenschaft und ihre Spätfolgen: Zusammenstellung der Referate und Ergebnisse der Internationale Sozialmedizinischen Konferenz über die Pathologie der ehemalige Deportierten und Internierten, 5-7juni 1954 in Kopenhagen (pp. 317-323). Frankfurt am Main: Röderberg Verlag.

Gilbert, M. (1981). Auschwitz and the Allies. Londen: Joseph/Rainbird.

Goldstein, D.S., \& Kopin, I.J. (2007). Evolution of concepts of stress. Stress, 20(2), 109-120.

Gomperts, W. (2004). Effectonderzoek en de moeizame relatie tussen psychoanalyse en empirische wetenschap. Deles van een historische gevalsbeschrijving. Maandblad Geestelijke volksgezondheid, 1, 1039.

Grüter, R. (1997). Een fantast schrijft geschiedenis. De affaires rond Friedrich Weinreb. Amsterdam: Balans, Gutman, I., Bender, S., Michman, J., \& Flim, B.J. (2005). Rechtvaardigen onder de Volkeren: Nederlanders met een Yad Vashem-onderscheiding voor hulp aan Joden. Amsterdam/Antwerpen: Uitgeverij L.J. Veen/ NIOD.

Haan, I. de (1997). Na de ondergang. De herinnering aan de Jodenvervolging in Nederland 1945-1995. Den Haag: sDU Uitgeverij.

Hacking, I. (1998). Mad Travelers. Reflections on the Reality of Transient Mental Illnesses. Cambridge: Harvard University Press.

Hagendijk, R. (1980). Het studentenleven. Amsterdam: suA.

Hemelrijk, J. (1969). Er is een weg naar de urijheid. Zeven maanden concentratiekamp. Amsterdam; FibulaVan Dishoeck.

Herberg, H.J. (Ed.). (1971). Spätschaden nach Extrembelastungen. Herford: Nicolaische Verlagsbuchhandlung.

Hermann, K., \& Thygesen, P. (1954). kz-syndromet. Hungerdystrofiens følgestildstand 8 àr efter. Ugeskrift for Lager, $116(22), 825-837$.

Hiddema, F. (1985). Bruine terreur door zwarte pedagogie. Psychoanaly tische aspecten van Hitlers racistische nazidom. Rotterdam: Ad. Donker.

Hofmann, A. (1979). How LSD originated. Journal of Psychedelic Drugs, 11, 53-60.

Horsley, J.S. (1943), Narco-analysis, a New Technique in Short-Cut Psychotherapy: A Comparison with other Methods and Notes on the Barbiturates. London: Oxford University Press.

Hovens, J.E., \& Ploeg, G.J. van der (2006). De grote psychiatrie in klassieke teksten. Utrecht: De Tijdstroom. Hrdlicka, M.R. (1992). Alltag im Kz. Das Lager Sachsenhausen bei Berlin. Opladen: Leske/Budrich.

Hugenholtz, P.Th. (1970). Onvoltooid verleden tijd. Maandblad Geestelijke volksgezondheid, 25(5), 3-13.

Hugenholtz, P.Th. (1980). Hoe buitengewoon is 'buitengewoon'? Over de maatschappelijke erkenning van de term 'verzetsslachtoffer'. Maandblad Geestelijke valksgezondheid, 35, 1055-1063.

Hustinx, A. (1973). Het existentieel emotioneel stresssyndroom. Sociale aspecten in de genese en bij de behandeling. Maandblad Geestelijke volksgezondheid, 28, 197-206.

Hutschemaekers, G.J.M., \& Oosterhuis, H. (2004). Psychotherapy in The Netherlands after the Second World War. Medical History, $48,429-448$.

Huxley, A. (1954). The Doors of Perception. London: Chatto \& Windus Ltd.

Jackson, S.W. (1994). Catharsis and abreaction in the history of psychological healing. Psychiatric Clinics of North America, 17(3), 471-491.

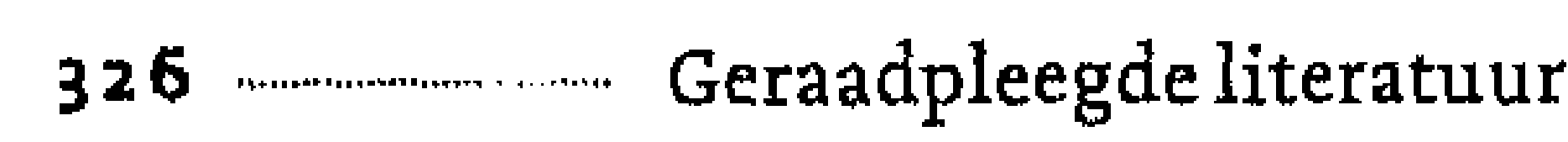


Jong, L. de (1978a). Het Koninkrijk der Nederlanden in de Tweede Wereldoorlog. Deel 8, Eerste deel, Gevangenen en gedeporteerden. 's Gravenhage: Martinus Nijhoff.

Jong, L. de (1978b). Het Koninkrijk der Nederlanden in de Tweede Wereldoorlog. Deel 8, Tweede deel, Gevangenen en gedeporteerden. 's Gravenhage: Martinus Nijhoff.

Jong, L. de (1991). Het Koninkrijk der Nederlanden in de Tweede Wereldoorlog: Deel 14, Reacties. 's-Gravenhage: SDU Uitgeverij.

Kaas, A.J.W. (1946). Over de psychologie der politieke gevangenen in het concentratiekamp. De Nieuwe Stem, $\mathrm{I}, 409-422$.

Kaienburg, H. (2006). Sachsenhausen Stammlager. In W. Benz, B. Distel \& A. Königseder (Eds.), Der Ort des Terrors (pp. 17-72). München: C.H. Beck.

Kaptein, A.A. (2006). Lucht. Leiden: Universiteit Leiden.

Kennedy, J.C. (1995). Nieuw Babylon in aanbouw. Nederland in de jaren zestig. Amsterdam: Boom.

Keys, A., Brožek, A., Henschel, O., Mickelsen, O., \& Taylor, H.L. (1950). The Biology of Human Staruation III. Minnesota: University of Minnesota Press.

Kihlstrom, J.F. (1998). Exhumed memory. In S.J. Lynn \& K.M. McConkey (Eds.), Truth in Memory (pp. 3-31). New York: Guilford Press.

Kleber, R.J., Brom, D., \& Defares, P.B. (1986). Traumatische ervaringen, gevolgen en venverking. Lisse: Swets \& Zeitlinger.

Knegtmans, P.J. (1998). Een kwetsbadr centrum van de geest. De Universiteit van Amsterdam tussen 1935 en 1950. Amsterdam: Amsterdam University Press.

Koedijk, P. (1995). Centrum' '45. Ongepubliceerd manuscript. Kopie in bezit auteur.

Kogon, E., Langbein, H., \& Rückerl, A. (Eds.) (1983). Nationalsozialistische Massentötungen durch Giftgas: Eine Dokumentation. Frankfurt am Main: S. Fischer Verlag.

Koning, P. de, \& Oosterbaan, M. (1978). Problemen in de categorale zorg. Maandblad Geestelijke volksgezondheid, 33(9), 591-595.

Kuijper, P.C. (1968). Psychedelica. Nederlands Tijdschrift voor Geneeskunde, 112(41), 1867-1869.

K-Zetnik 135633. (1989). Bestendig voor ogen: De paddestoel-wolk van Auschwitz. Kampen: Uitgeversmaatschappij J.H. Kok.

Ladee, G.A. (1968). Gebruik en misbruik van LSD. Nederlands Tijdschrift voor Geneeskunde, 112(18), 879-884.

Laqueur, W.Z. (1980). The Terrible Secret: An Investigation into the Suppression of Information about Hitler's 'Final Solution'. London: Weidenfeld and Nicolson.

Lee, M., \& Shlain, B. (1985). Acid Dreams: The CIA, LSD and the Sixties Rebellion. New York: Grove Press.

Leeuw, A.J. van der (1950). De universiteiten en hogescholen. In J.J. van Bolhuis, C.D.J. Brandt, H.M. van Randwijk \& B.C. Slotemaker (red.), Onderdrukking en verzet. Nederland in oorlogstijd. (Vol. III). Arnhem:Van Loghem Slaterus.

Lieburg, M.J.van (1990). Bronovo 1865-1990. Van 's-Gravenhaagsche Diakonessen-Inrichting tot Ziekenhuis Bronovo. Kampen: UitgeversmaatschappijJ.H. Kok.

Lønnum, A. (1969). Delayed Disease and Ill-health: A sequelae of Extreme Stresses During War and Disaster. Oslo: The Norwegian Association of Disabled Veterans.

Loonstein, R., \& Maas, A.J. (2005). De causaliteitsbeoordeling bij oorlogsgetroffenen. Cogiscope, 3, 5960.

Lumeij, J.L.J. (1972), De Drie en de geestelijke volksgezondheid. Maandblad Geestelijke volksgezondheid, 27, 205-212.

Marks, J. (1979). The Search for the 'Manchurian Candidate': The cIA and Mind Control. New York: Times Books.

Maser, W. (2007). Hitler-Stalin. Mythen, leugens en legenden. Soesterberg: Aspekt.

Meerloo, J.A.M. (1969). Persecution trauma and the reconditioning of emotional life: A brief survey. American Joumal of Psychiatry, 125, 1187-1191.

Merckelbach, H., \& Jelicic, M. (2005). Hoe een CIA-agent zijn geheugen hervond. Amsterdam: Uitgeveri] Contact.

Merriënboer, J. van, Bootsma, P., \& Van Griensven, P. (2008). Van Agt. Tour de force. Amsterdam: Boom. Michel, M. (Ed.).(1955). Gesundheitsschäden durch Verfolgung und Gefangenschaft und ihre Spätfolgen: Zusammenstellung der Referate und Ergebnisse der Internationale Sozialmedizinischen Konferenz über die Pathologie der ehemalige Deportierten und Internierten, 5-7juni 1954 in Kopenhagen. Frankfurt am Main: Röderberg Verlag. 
Miesen, B. (2002). Het Alzheimer Café. Utrecht/Antwerpen: Kosmos-Z\&K.

Milikowski, H.Ph. (1973). Sociologie als verzet: Over Kz-syndroom, gezinsproblemen, sociale en seksuele relaties en agressie. Amsterdam: Van Gennep.

Miller, R.D. (Ed.). (2005). Anesthesia. Philadelphia:Churchill Livingstone.

Molen, G. van der (1987, augustus). Nico Mourer (1900-1965). Bulletin van de Nederlandse Arbeidersbeweging, pp. 20-48.

Mooij, A. (2002). De langste schaduw: Het denken over psychische oorlogsgevolgen. In C. Kristel (red.) Binnenskamers. Terugkeer en opvang na de Tweede Wereldoorlog (pp. 261-291). Amsterdam: Bert Bakker. Musaph, H. (1972). Psychische Eerste Hulppost. Maandblad Geestelijke volksgezondheid, 27, 141-145.

Musaph, H. (1973). Het post-concentratiekampsyndroom. Maandblad Geestelijke volksgezondheid, 28(5), 207-217.

Naujoks, H. (1987). Mein Leben im KZ Sachsenhausen:1936-1942. Erinnerungen des ehemaligen Lagerältesten. Räderberg: Pahl-Rugenstein Verlag.

Neave, A. (1969). Saturday at M.I.9. Londen: Hodder and Stoughton.

Noordhoek Hegt, W.G. (1967). Die Situation in den Niederlanden. In H.J. Herberg (Ed.), Die Beurteilung von Gesundheitsschäden nach Gefangenschaft und Verfolgung. Referate eines internationalen medizinischjuristischen Symposiums in Köln. Herford: Nicolaische Verlagsbuchhandlung.

Novak, S.J. (1997). LSD before Leary: Sidney Cohen's critique of 1950 psychedelic drug research. Isis, 88 , 87-110.

Olthuis, F.H. (red.). (1973). Psychosomatiek: Het Groen-boek. Meppel: Boom.

Ossebaard, H.C., \& Maalstê, N. (1999). The Bastiaans method of drug-assisted therapy. MAPS, IX(2), 3-9.

Pannekoek, Y.K, pseudoniem voor F. Dekking (1982). Memoires van Yvo Pannekoek. Amsterdam: Van Oirschot.

Patrick, M., \& Howells, R. (1990). Barbitural-assisted interviews in modern clinical practice. Psychological Medicine, 20, $763-765$.

Paul, H., \& Herberg, H.J. (Eds.). (1963). Psychische Spätschäden nach politischer Verfolgung. Basel/New York: S. Karger.

Pelser, H.E. (1996). Vluchtweg Zwitserland:Verhalen uit een ondergronds verleden. Amsterdam: Bert Bakker.

Piersma, H. (2005). De drie van Breda. Amsterdam: Balans.

Piersma, H. (2006). Op oorlogspad:Jaap le Poole, verzetsman voor het leven. Amsterdam: Boom.

Piper, A. (1993). 'Truth serum' and 'recovered memories' of sexual abuse: A review of evidence. The Journal of Psychiatry and Law, $21(4), 447-471$

Ploeg, H.M. van der (1991). What a wonderfull world it would be: A reanalysis of some of the work of Grossarth-Maticek. Psychological Inquiry, 2(3), 280-285.

Ploeg, H.M. van der, Reerds, J.W., Kleijn, W.C., Mook, J., \& Moormann, P.P. (1987). Onderzoek naar behandeling van oorlogsslachtoffers met LSD-psychotherapie: Een verslag van een vooronderzoek: Rijksuniversiteit Leiden, vakgroep Psychiatrie, Kinder-en Jeugdpsychiatrie en Medische Psychologie.

Poslavsky, A. (1953). Over het gebruik van Pentothal in de psychiatrische kliniek. Amsterdam: Paris.

Praag, H.M. van (1968). Hallucinogenen, het paard van Troje? Nederlands Tijdschrift voor Geneeskunde, $112(44), 1986-1989$.

Praag, H.M. van (1977). Interim-rapport Werk-en Adviescollege. Leidschendam: Ministerie van welzijn, Volksgezondheid en Cultuur.

Presser, J. (1965). Ondergang: De vervolging en verdelging van het Nederlandse Jodendom, 1940-1945.'sGravenhage: Staatsuitgeverij Nijhoff.

Provinciaal Elektriciteitsbedrijf Noord-Holland (1945). Zeven magere maanden:Terherinnering aan een moeizaam doonworstelden oorlogswinter. Speciale uitgave voor het personeel van het Provinciaal Electriciteitsbedrïf van Noord-Holland. Haarlem: Boom-Ruygrok.

Ravesteijn, L. van (1976). De arts geconfronteerd met lijders aan het $\mathrm{KZ}$-syndroom. Nederlands Tijdschrift voor Geneeskunde, 120, 316-318.

Ree, F. van (2000). Vrijheidsstrijd, verzet, terrorisme versldg van een RAF vertrouwensarts. Lisse: Swets \& Zeitlinger.

Rep, J. (1977). Englandspiel: Spionagetragedie in bezet Nederland 1942-1944. Bussum: Van Holkema \& Warendorf.

Richet, C., \& Mons, A. (1956). Pathologie de la déportation. Parijs: Plon.

Righart, J.A. (1995). De eindeloze jaren zestig. Amsterdam: Arbeiderspers.

328 Geraadpleegde literatuur 
Ritter von Baeyer, W., Häfner, H., \& Kisker, K.P. (1964). Psychiatrie der Verfolgten: Psychopathologische und Gutachtlichen Erfahrungen an Opfern der Nationalsozialistischen Verfolgung und vergleichbare Extrembelastungen. Berlin/Göttingen/Heidelberg: Springer Verlag.

Rooijmans, H.G.M. (1974). Het begrip 'specificiteit' in de psychosomatische geneeskunde. Nederlands Tijdschrift voor Geneeskunde, $118(4), 121+127$.

Rooijmans, H.G.M. (1983). Psychosomatosen en psychosomatiek. Nederlands Tyjdschrift voor Geneeskunde, $127,2337-2338$.

Rooijmans, H.G.M. (1989). 99 jaar tussen wal en schip: Geschiedenis van de Leidse Universitaire Psychiatrie (1899-1998). Houten/Diegem: Bohn Stafleu Van Loghum.

Rümke, H.C. (1940). Over psycho-traumatische desintegratietoestanden: Psychogene psychoses. Nederlands Tijdschrift voor Geneeskunde, 84, 5102-5109.

Rümke, H.C. (1951). Late werkingen van psychotraumata: Bijdrage tot kennis der psychogenie. Nederlands Tijdschrift voor Geneeskunde, 95(Iv), 2928-2937.

Sankar, S.D.V. (1975). LSD: A Total Study. Westbury: PJD Publications.

Sargant, W. (1959). Battle for the Mind. London: Pan Books.

Schreieder, J. (1949). Het Englandspiel. Amsterdam: Van Holkema \& Warendorf.

Schreuder, B.J.N. (2005). Het causale verband na meer dan zestig jaar. Cogiscope, 2, 16-22.

Schreuder, B.J.N. Afscheidsrede. In B.J.N. Schreuder \& A.J. de Ridder (1988). Veraf en dichtbij: de actualiteit van het traumatisch verleden. Symposium bij het afscheid van prof.dr.J. Bastiaans. Oegstgeest: Centrum '45.

Schudel, W.J., \& Pepplinkhuizen, L. (1986). Medische causaliteit bij oorlogsgetroffenen 1940-1945. Rotterdam: Erasmus Universiteit Rotterdam, Instituut Psychiatrie.

Shephard, B. (2001). A War of Nerves: Soldiers and Psychiatrists in the Twentieth Century. Cambridge: Harvard University Press.

Shorter, E. (1998). Een geschiedenis van de psychiatrie: Van gesticht tot Prozac. Amsterdam: Ambo.

Slot, E. (2006). De dood van een onderduiker: Louis van Gasteren en de waarheid. Amsterdam: Mouria.

Smith, A.L. (1983). Die Hexe von Buchenwald. Der Fall Ilse Koch. Köln: Böhlau.

Snelders, S.A.M. (2000). LSD-therapie in Nederland:De experimenteel-psychiatrische benadering vanJ. Bastiaans, G.W.Arendsen Hein en C.H. van Rhijn. Amsterdam; Candide/Wrede Veldt.

Snelders, S.A.M., \& Kaplan, C. (2002). LsD therapy in Dutch psychiatry: Changing socio-political settings and medical sets. Medical History, 46, 221-240.

Spencer, A.M. (1963). Permissive group therapy with LSD. In R. Crocket, R.A. Sandison \& A. Walk (Eds.), Hallucinogenic Drugs and their Therapeutic Use. Proceedings of the Quarterly Meeting of the Royal MedicoPsychological Association in London, February 1961. London: H.K.Lewis \& Co. Ltd.

Stein, H. (2006). Buchenwald Stammlager. In W. Benz, B. Distel \& A. Königseder (Eds.), Der Ort des Terrors (pp. 301-356), München: C.H. Beck.

Stichting 1940-1945 (red.).(1982). Toespraken ter gelegenheid van het afscheid van dr. P.Th. Hugenholtzals medisch adviseurvan de Stichting 1940-1945. Amsterdam: Stichting 1940-1945.

Stoll, W.A., \& Hofmann, A. (1943). Partialsynthese von Alkaloiden vom Typus des Ergobasins: Mitteilung uber Mutterkorn-alkaloide. Helvetica Chimica Acta, 26, 933.

Swaan, A. de (1983a). Het postconcentratiekampsyndroom als sociaal probleem. In A. de Swaan(red.), De mens is de mens een zorg (p. 140-151). Amsterdam: Meulenhoff.

Swaan, A. de (1983b). Het medisch regiem (III): uitbreiding en begrenzing van het medisch toezicht. In A. de Swaan (red.), De mens is de mens een zorg (p. 203-219). Amsterdam: Meulenhoff.

Swaan, A. de (1999). De maatschappelijke verwerking van oorlogsverledens. In A. de Swaan (red.), De draagbare De Swaan (pp. 42-54). Amsterdam: Prometheus.

Tas, J. (1946). Psychische stoornissen in concentratiekampen en bij teruggekeerden. Maandblad Geestelijke volksgezondheid, 1(6), 143-150.

Terwindt, T. (1951). Een vrouw vloog mee: Herinneringen van een stewardess. Amsterdam/Antwerpen: Kosmos.

Timmers, S. (1970). Vraagtekens bij de film 'Begrijpt u nu waarom ik huil?'. Nederlands Tijdschrift voor Geneeskunde, $114(7), 73$.

Trouvé, C. (2006). Oranienburg (Klinkerwerk). In W. Benz, B. Distel \& A. Königseder (Eds.), Der Ort des Terrors (pp. 248-253). München: C.H. Beck.

Vandereycken, W., Hoogduin, C.A.L., \& Emmelkamp, P.M.G. (1994). Handboek psychopathologie, deel 1. Houten/Zaventum: Bohn Stafleu Van Loghem. 
Velden, K. van der (1989). Directieve therapie 3. Deventer: Van Loghem Slaterus.

Veraart, C. (2002). Ja kunje krijgen! Optimistische fragmenten uit een advocatenleven met Ms. 's-Gravenhage: BZZTOH.

Vetter, I. (1998). Musik aus dem Jenseits: Der Fall Rosemary Brown und seine soziokulturellen und psychologischen Bedingungen. In Festschrift Helga de la Motte-Haber zum 6o. Geburtstag, Musikwissenschaft zwischen Kunst, Ästhetik und Experiment. Würzburg: Königshausen \& Neumann.

vks. (1964). Homo homini lupus. Amsterdam: Eikelenboom.

Vos, C. (1995). Televisie en bezetting: Een onderzoek naar de documentaire verbeelding van de Tweede Wereldoorlog in Nederland. Hilversum: Uitgeverij Verloren.

Vree, F. van (1995). In de schaduw van Auschwitz. Groningen: Historische Uitgeverij Groningen.

Vries, P. de (1949). Geschiedenis van het verzet der artsen in Nederland. Haarlem: H.D. Tjeenk Willink \& Zoon.

Wagenaar, W.A., \& Groeneweg, J. (1990). The memory of concentration camp survivors. Applied Cognitive Psychology, 4(2), 77-87.

Wals, A.A.G. (red.). (1993). Wetgeving Buitengewone Pensioenen: Wet Buitengewoon Pensioen 1940-1945, Wet Buitengewoon Pensioen Zeelieden-oorlogsslachtoffers, Wet Buitengewoon Pensioen Indisch verzet. Zwolle: W.E.J. Tjeenk Willink.

Wennekes, W. (1975). Allemaal rottigheid, allemaal ellende:Het $\mathrm{kz}$-syndroom van Willem van Salland. Amsterdam: Wetenschappelijke Uitgeverij.

Weringh, K. van (1970). We nemen 't wéér niet: Onderdrukking, verzet 1933-19nu. Amsterdam: Stichting We nemen't wéér niet.

Werkgroep Dependance Jelgersmakliniek (red.). (1985). Levend verleden, op weg naar beleid. Witbriefbehandeling gewelds-en oorlogsgetroffenen. Oegstgeest: Werkgroep Dependance Jelgersmakliniek.

Wibaut, F. (1961). Diseases and disorders resulting from resistance work and imprisonment. In Intemational conference on the later effects of imprisonment and deportation, The Hague, November 20-25, 1961. Den Haag: World Veterans Federation.

Wibaut-Guilonard, T. (1991). Kamp Vught 1943-1944: Bunker en krematorium. Amsterdam: Stichting Vriendenkring Nationaal Monument Kamp Vught.

Wijsenbeek, H. (1977). Is there a hiding syndrome? In Israel-Netherlands Symposium on the Impact of Persecution, 16-24 oktober 1977 (pp. 68-73). Rijswijk: Ministerie van Cultuur, Recreatie en Maatschappelijk werk.

Wind, E. de (1946). Eindstation... Auschwitz. Amsterdam: Republiek der Letteren.

Wind, E. de (1949). Confrontatie met de dood. Folia Psychiatrica, Neurologica et Neurochirugica Neerlandica, 52, 459-466.

Wind, E. de (1966). Directe en late gevolgen van extreme belastingssituaties - het concentratiekamp. Maandblad Geestelijke volksgezondheid, 21(9), 287-300.

Wind, E. de (1968). The confrontation with death. International Journal of Psycho-analysis, 49, 302-305.

Withuis, J. (2001). Geestelijke oorlogsschade. De oorlog in het Maandblad, 1945-2000. Maandblad Geestelijke volksgezondheid, 5, 394-451.

Withuis, J. (2002). Erkenning. Van oorlogstrauma naarklaagcultuur. Amsterdam: De Bezige Bij.

Withuis, J. (2005). Na het kamp. Vriendschap en politieke strijd. Amsterdam: De Bezige Bij.

Woerdeman, M.W. (1945). 'Clandestien' onderwijs in de geneeskunde te Amsterdam 1943-1945. Nederlands Tijdschrift voor Geneeskunde, 89, 348-351.

Zijl, A. van der (2002). Anna. Het leven van Annie M.G. Schmidt. Amsterdann: Nijgh \& Van Ditmar. 


\section{Bibliografie prof.dr. J. Bastiaans}

\section{Totstandkoming}

In het boekje Isolement en bevrijding, dat Bastiaans in 1986 publiceerde en dat was bedoeld als neerslag van zijn carrière, werd een 'Lijst van publicaties van prof.dr. J. Bastiaans' opgenomen. In het archief van de bibliotheek van stichting Cogis bevindt zich een lijst met publicaties van Bastiaans en in het personeelsdossier van de UvA bevindt zich ook een lijst met publicaties. Alle drie de lijsten zijn gebruikt om onderstaande bibliografie samen te stellen. Tevens zijn de publicaties opgenomen die een zoekopdracht naar 'Bastiaans, J.' opleverde in de wetenschappelijke literatuurdatabases Psycinfo en PubMed.

De drie genoemde lijsten bevatten, behalve artikelen die in wetenschappelijke tijdschriften zijn gepubliceerd, ook gelegenheidsteksten (als inleidingen bij een boek) en voordrachten, gehouden voor een academisch of lekenpubliek. Ook bevatten ze interviews met Bastiaans door journalisten. De verwijzingen waren soms onvolledig. Daardoor was het niet altijd duidelijk wat de verwijzing inhield.

Hieronder zijn alleen verwijzingen opgenomen waar Bastiaans als auteur werd genoemd; teksten geschreven door anderen over Bastiaans zijn niet opgenomen. Dubbelingen (bijvoorbeeld wanneer een tekst twee keer opnieuw werd gebruikt in de herdruk van een boek) zijn niet opgenomen, alleen de eerste vermelding is dan opgenomen.

Geprobeerd is om in de wetenschappelijke databases (PubMed en PsycInfo) óf via de internetzoekmachine Google bevestiging te vinden van het bestaan van een tekst (boek, artikel of congres). Soms werd de publicatie gevonden die werd bedoeld, soms moest genoegen worden genomen met de verwijzing naar een publicatie van Bastiaans in het werk van iemand anders. Wanneer geen van beide wegen tot bevestiging leidden, wordt dat met een ${ }^{*}$ aangegeven. Voordrachten zijn aangegeven met een $\$$.

Alper, K.R., Lotsof, H.S., Frenken, G.M.N., Luciano, D.J., \& Bastiaans, J. (1999). Treatment of acute opioid withdrawal with ibogaine. American Journal on Addictions, 8(3), 234-242.

Barendregt, J.T., Bastiaans, J., \& Vermeul-van Mullem, A.W. $(1960)$. Prognose en effect van psychotherapie en psychoanalyse. Een psychologisch-psychiatrische studie van het PAI te Amsterdam. Ongepubliceerd manuscript. Kopie in bezit auteur.

Barendregt, J.T., Bastiaans, J., \& Vermeul-van Mullem, A.W. (1961). A psychological study of the effect of psychoanalysis and psychotherapy. In J.T. Barendregt (Ed.), Research in psychodiagnostics (pp. 157-183). Den Haag: Mouton \& Co.

Bastiaans, J. (1946). Rectoraal jaarverslag. In USA (red.), Lustrumalmanak USA 1946 (pp. 60-65). Amsterdam: USA.

Bastiaans, J. (1951). Zorgvolle tijden. In H. Houtgraaf (red.), 40 jaren USA. Gedenkboek der Unitas Studiosorum Amstelodamensium (pp. 178-18z). Amsterdam; USA.

Bastiaans, J. (1954a). Problemen bij de psychotherapie en psychosomatische ziekten. Nederlands Tijdschrift voorGeneeskunde, $98,1730-1736$. 
Bastiaans, J. (1954b). Psychosomatiek en sexualiteit. Voordracht gehouden tijdens: De plaats van de sexualiteit in het leven van de mens. Intern studie congres NvsH (Amsterdam, 1953). *\$

Bastiaans, J. (1955a). Enkele psychiatrische aspecten van de psychosomatische specificiteit. Nederlands Tijdschrift van de Psychologie en haar Grensgebieden, $\mathrm{x}(3)$, onbekend. *

Bastiaans, J. (1955b). Some problems of the transference in the treatment of psychosomatic patients. Acta Psychotherapeutica, Psychosomatica et Orthopaedagogica, 3, 14-18.

Bastiaans, J. (1957). Psychosomatische gevolgen van onderdrukking en verzet. Amsterdam: N.v. Noord-Hollandsche Uitgevers Maatschappij.

Bastiaans, J. (1958a). Grenzen en mogelijkheden van de psychoanalyse. Voordracht gehouden tijdens: Vergadering van de afdeling Amsterdam van de Koninklijke Nederlandse Maatschappij ter Bevordering der Geneeskunde (Amsterdam, z.d.). *\$

Bastiaans, J. (1958b). Peptic ulcer as a psychosomatic reaction after war stress. Voordracht gehouden voor: Society of Psychosomatic research (Londen, 1958). *\$

Bastiaans, J. (1959). Psychodynamische verhoudingen in de psychosomatiek. Nijmeegs Tijdschrift voor Psychologie (Gawein), vin (2), 33-48.

Bastiaans, J.(1960a). Het transitional object in theorie en praktijk. Lezing gehouden voor: Psychoanalytische Werkgroep en staf Universiteitskliniek Amsterdam (Amsterdam, z.d.). *\$

Bastiaans, J. (1960b). Psychiatric training problems in psychosomatic medicine. Advances in Psychosomatic Medicin, $x, 179-189$.

Bastiaans, J. (1961). The role of the man in family planning. In R.D. Connolly, C. van Emde Boas, C. van Emde Boas-Barkenstein, J.L. Griep, R.E. Polak-Eldering \& L.I. Swaab (Eds.), Proceedings of the 2nd conference of the International Planned Parenthood Federation Region for Europe, Near East and Africa (Den Haag, 11-17 mei 1960). Amsterdam: Excerpta Medica. *

Bastiaans, J. (1961). Wat kan de psychiater-psychotherapeut de huisarts bieden? Nederlands Tijdschrift voor Geneeskunde, 105, 347-352. *

Bastiaans, J. (1962). Psychiatrische Bemerkungen zu Problemen der Fettsucht und Magersucht. Psyche, Zeitschrift fur Psychologische und Medizinische Menschenkunde, 10, 615-630.*

Bastiaans, J. (1963a). De eeuwige concurrent. In J.A. Weijel, J.M. van der Valk \& J. Bastiaans, Storend gedrag: Irrationele achtergronden van bedrijfssituaties: Lezingen en verslag van de Nederlandse Vereniging voor Bedrijfspsychologie (z.p., 7 november 1963). Leiden: Stenfert Kroese.

Bastiaans, J. (1963b). Emotiogene Aspekte der Essentiellen Hypertonie. Voordracht gehouden tijdens: Der 69. Tagung der Deutsche Gesellschaft fur innere Medezin (Wiesbaden, 23 april 1964 ). *\$

Bastiaans, J. (1964a). Combined treatment of two cases of erythrodermia exfoliativa with ACTH and psychotherapy. In H. Musaph (Ed.), Itching and scratching: Psychodynamics in dermatology (pp. 139-154). Basel: Karger.

Bastiaans, J. (1964b). Die manuelle Therapie im Rahmen der Psychomotischen Betrachtung der Menschen. In Physikalisch-Diätische Therapie. Hamburg: Verlag Dr. Blume \& Co. *\$

Bastiaans, J. (1965a). Ontstoren van contact. Rede uitgesproken bij de aanvaarding van het ambt van gewoon hoogleraar in de psychiatrie aan de Rijksuniversiteit te Leiden, op 23 oktober 1964. Amsterdam: N.v. Noord-Hollandsche Uitgevers Maatschappij.

Bastiaans, J. (1965b). The place of personality traits in specific syndromes: Cause or effect? In J.0. Wisdom \& H.H. Wolff (Eds.), The role of psychosomatic disorder in adult life. Londen: Pergamon Press.

Bastiaans, J. (1965c). Over de spanning van ideaal en werkelijkheid. In Weg Wijs (pp. 14-28). Leiden:Universitaire Pers. *

Bastiaans, J. (1965a), Het belang van psychosomatiek in de moderne geneeskunde. Voordracht gehouden tijdens: Nationaal Congres van het Nationaal Verbond der Katholieke Vlaamse Verplegenden. Brussel (Brussel, z.d.). *\$

Bastiaans, J. (1965b). Het begrip organisatie in de dynamische psychiatrie. Wijsgerig Perspectief, 5(5), onbekend.*

Bastiaans, J. (1966a). De mens in zijn dynamisch evenwicht. Voordracht gehouden tijdens: Bijeenkomst van de Koninklijke Nederlandse Toeristenbond ANWB en de Nederlandse Sport Federatie (Amsterdam, 30 november 1966$){ }^{*} \$$

Bastiaans, J. (1966b). De verhouding van psychiatrische en psychosomatische ziektebeelden. Voordracht gehouden tijdens: Vergadering van de Afdeling Amsterdam van de Koninklijke Nederlandse Maatschappij ter Bevordering der Geneeskunde (Amsterdam, 25 oktober 1966). ${ }^{*}$ 
Bastiaans, J. (1966c). Psychiatrische beschouwingen over homosexualiteit en homofilie. Maandblad Geestelijke volksgezondheid, $21(4), 119-134$.

Bastiaans, J. (1966d). The training for specialization in psychiatry in Holland, in Proceedings of the rv World Congress of Psychiatry (Madrid, 5 september 1966). Madrid: Excerpta Medica. ${ }^{{ }_{\$}}$

Bastiaans, J. (1967a). La formation des psychiatres aux Pays Bas. L'Evolution Psychiatrique, 32(2), 367-372.

Bastiaans, J. (1967b). Over tweeërlei ervaring. Toespraak gehouden voor: de eerstejaars der Leidse Universiteit. Leiden: Universitaire Pers. ${ }^{*} \mathbf{\$}$

Bastiaans, J. (1968). Onbekend. In H. Musaph (red.), Jeuk. Een multidisciplinaire benadering. Haarlem: Bohn. \$

Bastiaans, J. (1968). Psychoanalytic investigations on the psychic aspects of acute myocardial infarction. Psychotherapie and Psychosomatics, 16, 202-209.

Bastiaans, J. (1969a). 'Drugs' heilzaam en/of gevaarlijk? Pro Novitate, maandblad van studentengezelligheidsvereniging Catena.

Bastiaans, J. (1969b). Experiences with LSD in treatment. Voordracht gehouden tijdens: Symposium New approaches to the treatment of neurotic disorders, British Psychological Society (Londen, 5 juli 1969).\$

Bastiaans, J. (1969c). Psychiatrie, psychosomatiek en manuele therapie. Nederlands Tijdschrift voor Fysiotherapie, 79, 591-596.

Bastiaans, J. (1969d). The role of aggression in the genesis of psychosomatic disease. Journal of Psychosomatic Research, 13, 307-314.

Bastiaans, J. (1969e). Vertaling van de klacht. In F.J.J. Buytendijk (red.), Taal en gezondheid. Utrecht: Het Spectrum.

Bastiaans, J. (1970a). Ingezonden: Begrijpt u nu waarom ik huil.... Nederlands Tijdschrift voor Geneeskunde, $114,302-303$.

Bastiaans, J. (1970b). Childhood determinants in the genesis of psychosomatic disease. Voordracht gehouden tijdens: 7 th Congress of the International Association for Child Psychiatry and Allied Professions (Jerusalem, 2-7 augustus 1970). *\$

Bastiaans, J. (1970c). Introduction of the discussion on essential hypertension. Psychotherapy and Psychosomatics, $18,355-358$.

Bastiaans, J. (1970d). Over de specificiteit en de behandeling van het KZ-syndroom. Nederlands Militair Geneeskundig Tijdschrift, 23, 346-371.

Bastiaans, J. (1970e). Psychische aspecten van hoofdpijn. Huisarts en Wetenschap, 13, 136-143.

Bastiaans, J. (1970f). The present development of psychiatry and its consequences for the training of future psychiatrists. Psychiatrica, Neurologica, Neurochirurgica, 73, 405-411.

Bastiaans, J.(1971a). Die Uebersetzung der Klage. Zeitschnift für Psychotherapie und medizinische Psychologie, $21(5), 167-181$.

Bastiaans, J. (1971b). Lernprozesse in der Psychoanalyse. Praxis der Psychotherapie, 16(5), 221-239.

Bastiaans, J. (1972). General comments on the role of aggression in human psychopathology. Psychotherapie and Psychosomatics, 20, 300-311.

Bastiaans, J. (1973a). De betekenis van het hysterieconcept voor de psychosomatiek. In F.H. Olthuis (red.), Psychosomatiek:Het Groen-boek. Meppel: Boom.

Bastiaans, J. (1973b). Fixation points in the regulation of aggression and their meaning for syndrome formation. In Proceedings of the 5 th World Congress of Psychiatry, (Mexico D.F, 25 november -4 december 1971). Amsterdam: Excerpta Medica.

Bastiaans, J. (1973c). Het spel en de gestoorde verhouding. Ludieke aspecten in de psychotherapie. Tijdschrift van Vrïmetselaren, $\operatorname{xxIV}(4), 152-170$. *

Bastiaans, J. (1973d). Het Kz-syndroom. Ongepubliceerd manuscript. Vindplaats: Bibliotheek Cogis.

Bastiaans, J. (1973e). Vom Menschen im $\mathrm{Kz}$ und vom $\mathrm{xz}$ im Menschen. Ein Beitrag zur Behandlung des kz-Syndroms und dessen Spätfolgen. In B.A. Sijes en S. Wiesenthal (red.) Essays über Naziverbrechen. (pp. 177-202). Amsterdam: Simon Wiesenthal Gewidmet.

Bastiaans, J. (1974a). Het Kz-syndroom en de menselijke vrijheid. Nederlands Tijdschrift voor Geneeskunde, $118(31), 1173-1178$.

Bastiaans, J. (1974b). Neue Psychodynamische und Psychobiologische Aspekte der Hysterie. Praxis der Psychotherapie, 50, 159-167.

Bastiaans, J. (1974c). The Kz Syndrome: A thirty year study of the effects on victims of Nazi concentration camps. Revista Medico-Chirurgicata a Societatii de Medici si Naturalis li diuJasi, 78, 573-578. 
Bastiaans, J. (1974). Differences between psychoneurotic and psychosomatic syndromes. Methodology and Science, $7(4)$, onbekend. *

Bastiaans, J. (1975). Psychiatric aspects of migrainous headaches. In P.R. Saxena (Ed.), Migraine and related headaches: report of an international symposium arranged by Institute of Pharmacology \& Capita Selecta Committee, School of Medicine (Rotterdam, 22 mei 1974). Uden: Sandoz. *\$

Bastiaans, J. (1976a). Das Erste Gespräch mit Psychosomatischen Patienten. In A. Jores (Ed.), Praktische Psychosomatik (pp. 76-92). Bern: Hans Huber Verlag.

Bastiaans, J. (1976b). Der Beitrag der Psychoanalyse zur psychosomatischen Medizin. In D. Eicke (Ed.) Die Psychologie der 20.Jahrhunderts, Band Tiefenpsychologie (pp. 960-995). Zürich: Kindler Verlag.

Bastiaans, J. (1976c). Doorbraak van isolement. Voordracht gehouden tijdens: Symposium Raakvlak heel de mens (Nijmegen, 18 oktober 1975). Leiden: Spruyt, Van Mantgem \& De Does. \$

Bastiaans, J. (1977a). Einige bemerkungen zur Balint-Gruppen-Technik. Therapiewoche, 27, 9230-9231. *

Bastiaans, J. (1977b). Psychoanalytic psychotherapy. In E.D. Wittkower \& H. Warnes (Eds.), Psychosomatic medicine, its clinical applications (pp. 86-92). New York/San Fransisco/London: Harper \& Row.

Bastiaans, J. (1977c). The implications of the specificity concept for the treatment of psychosomatic patients. Psychotherapy and Psychosomatics, 28, 285-293.

Bastiaans, J. (1978a). De strijd om het bestaan. In $\mathrm{H}$. Hennephof (red.), Menselijke waardigheid: Visies van Nederlanders in woord en beeld. Bussum: Centripress.

Bastiaans, J.(1978b). Psychodynamische aspecten van het asthmauraagstuk. Voordrachtgehouden op Congres van het Nederlands Astma Fonds (Breda, 2 en 3 juni 1978). Leusden: Nederlands Asthma Fonds. *s

Bastiaans, J. (1978c). The psychosomatic consequences of man-made disasters: Life against life. In C.D. Spielberger \& I.G. Sarason (Eds.), Stress and anxiety (pp. 219-231). Washington: Hemisphere Publication Company.

Bastiaans, J. (1978d). Verslag van The Northern European Symposium on Sleep Research (Basel, 16 februari 1979). Medisch Contact, $7 .{ }^{*} \$$

Bastiaans, J. (1979a). Control of aggression and psychotherapy. Voordracht gehouden tijdens: Israel-Netherlands Symposium on the Impact of Persecution, (Jerusalem, 16-24 oktober 1977). ${ }^{*} \mathbf{\$}$

Bastiaans, J. (1979b). De behandeling van oorlogsslachtoffers. Tijdschrift voor Geneesmiddelenonderzoek, 1, 352-358.

Bastiaans, J. (1979c). Models of teaching psychobiological medicine to medical students. Bibliotheca Psychiatrica, 159, 48-61.

Bastiaans, J. (1979d). Psychotherapy of war victims facilitated by the use of hallucinogenic drugs. Voordracht gehouden tijdens: 5 th World Congress of the International College of Psychosomatic Medicine (Jerusalem, z.d.).

Bastiaans, J. (2980a). Kopfschmerzen in der Psychiatrie. Therapiewoche, 30, 463-467. *

Bastiaans, J. (1980b). Psychoanalyse en psychosomatiek. In E.C.M. Frijling-Schreuder (red.), Psychoanalytici aan het woord:Liber amiconum voor P.J. van der Leeuw (pp. 353-362). Deventer: Van Loghum Slaterus.

Bastiaans, J. (1980c). Psychosomatiek en lage rugklachten. Nederlands Tijdschrift voor Fysiotherapie, $90(3)$, 106-109.

Bastiaans, J. (1981a). Gijzelingen. In J. Bastiaans, D. Mulder, W. K. van Dijk \& H.M. van der Ploeg, Mensen bijgijzelingen. Alphen aan de Rijn: A.W. Sijthof.

Bastiaans, J. (1981b). The psychosomatic approach of sleep disturbances. In W.P. Koella (Ed.), Proceedings of the 5 th European Congress of Sleep Research, (Amsterdam, 2-5 september 1980). Basel: Karger.

Bastiaans, J. (1982a). Consequences of modern terrorism. In L. Goldberger \& S. Breznitz (Eds.), Handbook of stress, theoretical and clinical aspects. New York: The Free Press.

Bastiaans, J. (1982b). On freedom and induction. Psychotherapy and Psychosomatics, 38, 24-31.

Bastiaans, J. (1983a). Mental liberation facilitated by the use of hallucinogenic drugs. In L. Grinspoon \& J. B. Bakalar (Eds.), Psychedelic reflections (pp. 143-152). New York: Human Sciences Press.

Bastiaans, J. (2983b). Psyche, stress en het ontstaan vankanker. In E.J. Boer, E. Verhage \& C.J. deWolff(red.), Stress. Uitdaging en bedreiging. Teksten van het gelijknamige symposium dat op 25 maart 1983 werd gehouden onder auspiciën van de Nederlandse Stress Stichting in het Congrescentrum RAI te Amsterdam (pp. 55-73). Lisse: Swets \& Zeitlinger. \$

Bastiaans, J. (1983c). Verlating en rouw. In J. Bastiaans, H. Keilson, M.A.J M. Nevejan, E. van der MeulenKluvers \& A. Lange, Scheiding en rouw. Utrecht: ICODO. 
Bastiaans, J. (1985a). Le recours des hallucinogèenes en therapie psychosomatique. Psychotropes, III III(3), 43-47.

Bastiaans, J. (1985b). Over het aanraken in de geneeskunde. In Liber Amiconum Frans Veldman. Ceret: International Society for Research and Development of Haptonomie.

Bastiaans, J. (1985c). The role of the family in the facing of cancer. In E. Grundmann (Ed.), The cancer patient. Illness and recovery. New York: Gustav Fischer Verlag.

Bastiaans, J. (1986). Isolement en beurijding. Amsterdam: Balans.

Bastiaans, J., Frenkel, M., Godfried, E.G., Groen, J.J., Hertog, H.A.T., \& Reisel, J.H. (1947). De therapie van trombose en longembolie met dicumarine. Geneeskunde Gids, 25(1), onbekend. *

Bastiaans, J., Frenkel, M., \& Koster, M. (1977). Prof. dr. J.J. Groen - 50 jaar arts. Nederlands Tijdschrift voor Geneeskunde, 118, 1301-1302.

Bastiaans, J., \& Groen, J.J. (1951). Psychotherapy of internal disease. Voordracht gehouden tijdens: The Affective Contact. International Congress for Psychotherapy (Leiden-Oegstgeest, mei 1951). \$

Bastiaans, J., \& Groen, J.J. (1952). Psychosomatische onderzoekingen bij ulcuspatienten vóór en na maagresectie. Nederlands Tijdschnift voor Geneeskunde, 96, 2329-2332.

Bastiaans, J., \& Groen, J.J. (1955). Psychogenesis and psychotherapy of bronchial asthma. In D. O' Neill (Ed.), Modem trends in psychosomatic medicine (pp. 242-268). London: Butterworth \& $\mathrm{Co}$.

Bastiaans, J., Jaspers, J. P. C., Ploeg, H.M. van der, Berg-Schaap, T.E. van den, \& Berg, J.F. van den (1979). Psychologisch onderzoek naar de gevolgen van gijzelingen in Nederland (1974-1977). 's-Gravenhage: Staatsuitgeverij.

Bastiaans, J., \& Ploeg, H.M. van der (1978). Control and Regulation of Aggression. Psychosomatics and Psychotherapy, 29, 40-48.

Groen, J.J., \& Bastiaans, J. (1951). Psychotherapy of ulcerative colitis. Gastroenterology, 17(3), 344-352.

Groen, J.J., \& Bastiaans, J. (1953). Psychosomatische en allergische opvattingen over de ontstaanswijze van het asthma bronchiale: Een poging tot synthese. In A. ten Bokkel Huinink \& W.J.Q. van Ufford (red.) Psyche en allergische ziekten (pp. 43-71). Leiden: Stenfert Kroese. \$

Groen, J.J., \& Bastiaans, J. (1975). Psychosocial stress, interhuman communication and psychosomatic disease. In C.D. Spielberger \& I.G. Sarason (Eds.), Stress and anxiety. New York: John Wiley \& Sons.

Groen, J.J., Bastiaans, J., Barendregt, J.T., Dekker, E., Pelser, H.E., \& Valk, J.M. van der (1964). Psychosomatic research: $A$ collection of papers. Oxford: Pergamon Press.

Groen, J.J., Bastiaans, J., Groen, A.S., Groen-van Beverwijk, M., \& Vles, S.J. (1952). De invloed van psychische factoren op het ontstaan en het beloop van de longtuberculose. Een medisch-psychiatrische en -psychologische studie. Amsterdam: Scheltema \& Holkema.

Groen, J.J., Bastiaans, J., Hellinga, G., \& Valk, J.M. van der (1952). Psychosomatische onderzoekingen tijdens de behandeling met ACTH. In J. W.R. Everse, J.J. Groen \& A. Querido (red.), ACTH en cortison. Amsterdam: Scheltema \& Holkema.

Groen, J.J., Bastiaans, J., \& Valk, J.M. van der (1957). Psychosomatic aspects of syndrome shift and syndrome suppression. Folia Psychiatrica, Neurologica et Neurochirugica Neerlandica, 10(3), $33-59$.

Groen, J.J., Bastiaans, J., \& Valk, J.M. van der (1958). Syndroomverschuiving en -onderdrukking. Nederlands Tijdschrift voor Geneeskunde, 102, 616-625.

Groen, J.J., Bastiaans, J., \& Vles, S.J. (1950). Personnalités et conflits émotionnels comme facteurs étiologiques dans la colite ulcéreuse grave. Acta Gastro-Enterologica Belgica, XuII, 793-805.

Groen, J.J., Bastiaans, J., \& Vles, S. J. (1951). De betekenis van persoonlijkheidsstructuur en emotionele conflictsituatie voor de aetiologie van colitis ulcerosa. Nederlands Tijdschrift voor Geneeskunde, 95(14), 1043-1056.

Groen, J.J., Hoogland, P. L., Willebrands, A. F., Bastiaans, J., \& Godfried, E. G. (1947). Onderzoekingen over de vitamine- en stikstofhuishouding bij lijders aan febris typhoïdea. Voeding, 8(1), onbekend. *

Groen, J.J., Horst, L. van der , \& Bastiaans, J. (1951). Grondslagen der klinische psychosomatiek. Haarlem: De Erven Bohn.

Groen, J.J., Horst, L. van der, Bastiaans, J., Valk, J.M. van der, \& Vles, S. J. (1950). Organisatie werkterrein en enkele uitkomsten van de Werkgroep voor Psychosomatisch onderzoek in het Wilhelmina-Gasthuis te Amsterdam. Nederlands Tijdschrift voor Geneeskunde, $94(39), 2816 " 2833$.

Groen, J.J., Orie, N.G.M., Jonxis, G.J., Huët, G.J., Schook, J.E.C., Bastiaans, J., et al. (x957). Enkele beschouwingen over de tegenwoordige stand van het asthmavraagstuk. Nederlands Tijdschrift voor Geneeskunde, 101, 114-124. 
Groen, J.J., Prick, J.J. G., \& Bastiaans, J. (1967). De betekenis van persoonlijkheid en conflictsituaties voor het ontstaan, het beloop en de behandeling van multiple sclerose. Haarlem: De Erven Bohn.

Groen, J.J., Valk, J.M. van der, \& Bastiaans, J. (1957). A case of malignant hypertension, treated with prefrontal leucotomy and psychotherapy, followed for over eight years. Journal of Psychosomatic Research, 2(2), 120-133.

Grossarth-Maticek, R., Bastiaans, J., \& Kanazir, D. T. (1985). Psychosocial factors as strong predictors of mortality from cancer, ischaemic heart disease and stroke: The Yugoslav prospective study.Joumal of Psychosomatic Research, 29(2), 167-176. 


\section{Bijlagen}

Bijlage I: Aantal eerste aanvragen Buitengewoon Pensioen per jaar

Gegevens zijn ontleend aan het rapport van de commissie-Van Dijke (Van Dijke, 1987).

\begin{tabular}{|c|c|c|c|}
\hline Jaar & Aantal aanvragen & Jaar & Aantal aanvragen \\
\hline $195^{\circ}$ & 280 & 1970 & 506 \\
\hline 1951 & 342 & 1971 & 676 \\
\hline 1952 & 574 & 1972 & 699 \\
\hline 1953 & 736 & 1973 & 746 \\
\hline 1954 & 519 & 1974 & 888 \\
\hline 1955 & 349 & 1975 & 1059 \\
\hline 1956 & 470 & 1976 & 1161 \\
\hline 1957 & 262 & 1977 & 1292 \\
\hline $195^{8}$ & 193 & 1978 & 881 \\
\hline 1959 & 218 & 1979 & 759 \\
\hline 1960 & 224 & 1980 & 758 \\
\hline 1961 & 214 & 1981 & 823 \\
\hline 1962 & 191 & 1982 & 776 \\
\hline 1963 & 208 & 1983 & 650 \\
\hline 1964 & 179 & 1984 & 677 \\
\hline 1965 & 223 & 1985 & 552 \\
\hline 1966 & 234 & 1986 & 535 \\
\hline 1967 & 239 & 1987 & 407 \\
\hline 1968 & 315 & 1988 & 370 \\
\hline 1969 & 410 & & \\
\hline
\end{tabular}


Beschrijving collectie

Na zijn vertrek bij Centrum ' 45 in januari 1988 werd Bastiaans' archiefmateriaal betreffende zijn patiënten gesplitst in twee delen. Het papieren gedeelte werd ondergebracht bij Centrum ' 45 , waar Bastiaans tot kort daarvoor bestuurlijk onder viel. De geluidsbanden werden overgebracht naar het toenmalige ICODO, de huidige Stichting Cogis. De redenen hiervoor zijn onduidelijk maar waarschijnlijk van praktische aard. Het papieren gedeelte is inmiddels vernietigd.

De collectie van Cogis bestaat voornamelijk uit geluidsbanden die op spoelen zijn gewikkeld, een klein deel bestaat uit cassettebandjes. In totaal liggen er 809 geluidsdragers opgeslagen in 15 lades. Behalve wat er op de banden zelf en op de hoezen staat is er niets over het materiaal vastgelegd. Op de hoezen staat de meeste informatie. Die is niet altijd goed te lezen, soms erg summier en soms ontbreekt die in z'n geheel. Het beperkt zich doorgaans tot de achternaam van de patiënt (soms met vermelding van dhr. of mevr., soms met initialen), de datum van de sessie(s) en in sommige gevallen het gebruikte middel en welke sessie het is (in volgorde).

Voordat deze inventarisatie werd gedaan was er niet meer over het materiaal bekend dan dat er 15 lades met banden waren. Onduidelijk was om hoeveel banden het ging en welke banden. Daarom is een inventarisatie gemaakt waarbij alle informatie die van een band beschikbaar is, werd ingevoerd in een database. Op basis van die database zijn onderstaande overzichten gemaakt.

Aantal sessies per middel per jaar

\begin{tabular}{|c|c|c|c|c|c|c|}
\hline Jaar & LSD & psilocybine & pentothal & nesdonal & onbekend & Totaal \\
\hline onbekend & 4 & 0 & 10 & 0 & 26 & 40 \\
\hline 1972 & 2 & 0 & 0 & 0 & 1 & 3 \\
\hline 1973 & 12. & 0 & 0 & 0 & 15 & 27 \\
\hline 1974 & 10 & 3 & 1 & 0 & 34 & 48 \\
\hline 1975 & 17 & 1 & 1 & 0 & 31 & 50 \\
\hline 1976 & 22 & 7 & 1 & 0 & 17 & 47 \\
\hline 1977 & 39 & 4 & 3 & 0 & 2 & 48 \\
\hline 1978 & 54 & 9 & 15 & 0 & 4 & 82 \\
\hline 1979 & 44 & 1 & 84 & 0 & 2 & 131 \\
\hline 1980 & 52 & 3 & 71 & 0 & 1 & 127 \\
\hline 1981 & 50 & 0 & 86 & 0 & 5 & 141 \\
\hline 1982 & 47 & 0 & 109 & 0 & 1 & 157 \\
\hline 1983 & 20 & 5 & 161 & 0 & 6 & 192 \\
\hline 1984 & 12 & 2 & 170 & 1 & 3 & 188 \\
\hline 1985 & 3 & 2 & 113 & 0 & 1 & 119 \\
\hline 1986 & 0 & 0 & 0 & 0 & 0 & 0 \\
\hline 1987 & 0 & 0 & 0 & 0 & 0 & 0 \\
\hline 1988 & 0 & 0 & 15 & 0 & 0 & 15 \\
\hline \multirow[t]{2}{*}{1989} & 1 & 0 & 4 & 0 & 0 & 5 \\
\hline & $3^{89}$ & 37 & 844 & $\mathbf{1}$ & 149 & 1420 \\
\hline
\end{tabular}


Aantal personen per middel per jaar

\begin{tabular}{|c|c|c|c|c|c|c|}
\hline Jaar & LSD & pentothal & psilocybine & nesdonal & onbekend & totaal \\
\hline onbekend & 3 & 8 & 0 & 0 & 15 & 26 \\
\hline 1972 & 2 & 0 & 0 & 0 & 1 & 3 \\
\hline 1973 & 7 & 0 & 0 & 0 & 11 & 18 \\
\hline 1974 & 7 & 1 & 3 & 0 & 18 & 29 \\
\hline 1975 & 10 & 1 & 1 & 0 & 18 & 30 \\
\hline 1976 & 12 & 1 & 7 & 0 & 13 & 33 \\
\hline 1977 & 24 & 3 & 3 & 0 & $\mathbf{1}$ & 31 \\
\hline 1978 & 28 & 8 & 3 & 0 & 3 & 42 \\
\hline 1979 & 23 & 37 & 1 & 0 & 2 & 63 \\
\hline 1980 & 19 & 42 & 3 & 0 & 1 & 65 \\
\hline 1981 & 29 & 48 & 0 & 0 & 3 & 80 \\
\hline 1982 & 23 & 57 & 0 & 0 & 1 & 81 \\
\hline 1983 & 16 & 88 & 4 & 0 & 4 & 112 \\
\hline 1984 & II & 88 & 2 & 1 & 2 & 104 \\
\hline 1985 & 3 & 55 & 2 & 0 & 1 & 61 \\
\hline 1986 & 0 & 0 & 0 & 0 & 0 & 0 \\
\hline 1987 & 0 & 0 & 0 & 0 & 0 & 0 \\
\hline 1988 & 0 & 1 & 0 & 0 & 0 & 1 \\
\hline 1989 & 1 & 1 & 0 & 0 & 0 & 2 \\
\hline $\begin{array}{l}\text { Aantal } \\
\text { personen } \\
\text { per middel }\end{array}$ & 132 & 274 & 21 & 1 & 67 & $3^{88}$ \\
\hline
\end{tabular}

Opmerkingen

In totaal zijn van ongeveer 388 personen een of meerdere sessies (met LSD, pentothal of beide) bewaard gebleven. Op basis van de opschriften op de banden werd een lijst met namen gemaakt. De opschriften waren niet altijd duidelijk, soms ontbraken ze in het geheel. Het aantal van 388 is dus een benadering.

Wanneer een persoon verspreid over meerdere jaren een behandeling kreeg is deze ook meerdere keren geteld (als iemand in 1972 én in 1973 een behandeling kreeg is hij in beide jaren meegeteld).

Wanneer een persoon in een jaar zowel een LSD-als een pentothalsessies kreeg is deze in dat jaar ook dubbel geteld (e.g. wordt zowel in de kolom LSD als de kolom pentothal geteld). 
Aantal sessies per persoon

\begin{tabular}{|c|c|c|c|c|}
\hline $\begin{array}{l}\text { Aantal } \\
\text { sessies }\end{array}$ & $\begin{array}{l}\text { Aantal personen } \\
\text { (L5D) }\end{array}$ & $\begin{array}{l}\text { Aantal personen } \\
\text { (pentothal) }\end{array}$ & $\begin{array}{l}\text { Aantal personen } \\
\text { (psilocybine) }\end{array}$ & Aantal personen \\
\hline $\mathbf{1}$ & 54 & 108 & 14 & 141 \\
\hline 2 & 29 & 63 & 4 & 73 \\
\hline 3 & 13 & 32 & 1 & 47 \\
\hline 4 & 10 & 18 & 1 & 35 \\
\hline 5 & 7 & 7 & & 11 \\
\hline 6 & 6 & 16 & & 17 \\
\hline 7 & 2 & 10 & & 18 \\
\hline 8 & 4 & 2 & 1 & 7 \\
\hline 9 & 3 & 2 & & 8 \\
\hline 10 & & 4 & & 5 \\
\hline $\mathbf{1 1}$ & & 4 & & 6 \\
\hline 12 & 2 & 1 & & 6 \\
\hline 13 & & 1 & & 1 \\
\hline 14 & 1 & 1 & & 2 \\
\hline 15 & & 1 & & 3 \\
\hline 16 & 1 & 2 & & 2 \\
\hline 17 & & & & 1 \\
\hline 18 & & 1 & & 2 \\
\hline 19 & & 1 & & 1 \\
\hline 20 & & & & 1 \\
\hline 43 & & & & 1 \\
\hline
\end{tabular}

Opmerkingen:

Bovenstaande tabel moet als volgt worden gelezen:

- 54 personen kregen één keer een behandeling met LSD;

- 108 personen kregen één keer een behandeling met pentothal;

- 14 personen kregen één keer een behandeling met psylocybine;

- 141 personen kregen één behandeling (of met pentothal óf met LSD).

Nesdonal (een barbituraat) werd maar in één sessie gebruikt en is daarom niet opgenomen in bovenstaande tabel. 


\section{Register}

Aalders, mr. G., 140

Aantjes, mr. W., 176, 189, 211-213, 217

Academisch Ziekenhuis Leiden (AZL), 92, 93, 221, 255

Achter het Nieuws, 135, 139, 140

Agt, mr. A.A.M., van, 133, 134, 135, 136, 138, 154, 233 Amerika, 13, 33, 73, 224, 276, 282

Amersfoort, kamp, 117, 128, 129, 174, 186-189, 191

Amsterdamsch Studenten Corps (AsC), 23

Arbeiders Jeugd Centrale (AJC), 173

arbeidsinzet, 188,189

Arendsen Hein, dr. G.W., 84

Auschwitz, $17,64,77,78,80,81,96,115,117,144$, 190, 222

autobiografische reconstructie, $17,18,189$

Baan, dr. P.A.H., 150, 151, 152, 155

Baeyer, prof.dr. W. Rittervon, 94

Balintgroepen, 20

Bank, prof.dr. J.T.M., 113, 141, 211

barbituraat, 55, 68, 69, 72, 73, 254, 258

Barendregt, prof.dr. J.T., 34, 36, 37, 74, 82, 87, 258, 259

Bärth, kamp, 117

Beckman, J.F., 244, 268, 269

Begrijpt u nu waarom ik huil..., 11, 110, 120, 121, 127,

$129,134,135,139,143,145,146,154,162,167,169$, $170,178,189,190,214,252,262$

behandeldrift, $267,273,275,276$

Bekker, G., 234, 266

België, 40

Berg, J. van de, 245

Bergen Belsen, kamp, 117, 118, 126, 187

Bergh, mr. J. van den, 140

Bernhard, prins, 106, 117, 151, 152, 155, 165, 170, 172, 230
Bertina, B.J., 122, 123, 124, 131

Beurkens, L., 180

Bibeb, 29, 32, 101, 192, 208

Biesheuvel, 133, 138

biografische anamnese, 34

biologische psychiatrie, 72, 87, 277

Bis Repetita Placent (BRP), 24, 26, 302

Bisschoff van Heemskerck, W.R.K., 51, 52, 62, 165

Bloch, kolonel M.B., 105

Bloemendaal, 23

Blokziil, B., 201

Blom, prof.dr.J.C.H., 18, 111, 176, 287

Boellaard, W.A.H.C., 244

boerderij 'de Hoogte', 30

Bont, J. de, 118

Booij, prof.dr. J., 66, 86

Boomer, A., 267

Bordeaux, 13

Borssum Waalkes, dr. J.B. van, $236,237,243,246$,

$250,251,260,268,272$

Borst-Eilers, dr. E., 253

Bouwman, dr. R., 211, 213

Braun, dr. A., 165

Brave-Maks, M.H., 230

Breuer, J., 67

Brinkman, mr.drs. L.C., 235, 267, 271

Brom, dr. D., 223

Bronovo Ziekenhuis, 29

Brouwer, J., 183

Brouwer, prof.dr. B., 26, 27, 28

Bruens, mr. C.B.M., 243

Buchenwald, kamp, 26, 27, 59, 60, 96, 113, 117, 187,

189, 191-194, 216, 222

Bueno de Mesquita, M., 190

Buis, dr.C., 151, 153 
Buitengewone Pensioenraad (BPR), 39, 40, 42, 45, $46,66,103,118,154,174,180,189,201,203,-207$, $210,251,280$

Buitengewoon Pensioen, $38,39,42,45,53,55,58$, $60,63,69,93,94,98-100,108,117,125,172,173$ $174,175,180,183,189,190,199-202,205-207$ $209,210,215,216,234,279,284$

Burroughs, W.S., 82

Carp, prof.dr. E.A.D.E, 91

Cath, mr. J.K., 225, 228, 236, 241

Ceha, K.M.J., 202

Centraal Afwikkelingsbureau Duitse Schadeuitkeringen (CADSU), 95

Centraal Bureau voor de Statistiek (CBS), 103

Centraal Orgaan Voormalig Verzet en Slachtoffers (covvs), 210, 222, 234, 237, 244, 251, 273

Centrale Beleids-en Ondersteuningsgroep ( 223, 259

Centrale Raad van Beroep (CRvB), 63, 204-207, 209

Centrum ' $45,18,149,157,158,160,166-168,170,171$, $178,180,182,183,190,202,221,222,229,236$, $237,243,250,251,255,266,267,270,277-279$, $281,282,284$

Charcot, 185

Cleveringa, prof.dr. R.P., 26

Cogis, 19, 257

Cohen Stuart, dr. M.H., 140

Cohen, dr. E.A., 91, 93, 96, 98, 100, 103, 105, 107, $136,140,143,144,179,216$

Cohen, prof.dr. S., 75, 82, 85

Comité Stichting Oranje Hotel, 136

Commissie voor de Vereenvoudiging en Coördinatie van de Wetten voor Oorlogsgetroffenen (commissie Van Dijke), 277

Comité Vervolging en Verzet (cvv), 202-204, 206, $207,217,225,243$

Communistische Partij Nederland (CPN), 51, 52, 201

contactcommissie, 26,28

Contactcommissie Verzetsgepensioneerden van de noordkop van Noord-Holland, 137

Coornhertliga, 138

Cornelissen, G.M.P., 246

Coumou, mr. P., 184, 245, 256, 270, 276, 277

Crombag, prof.dr. H.F.M., 18, 63, 185, 287

Daal, M.J.G.W. van, 64

Dachau, kamp, 105, 106, 116, 143, 163

Dallinga, dr. G., 242

Dam, prof.dr. J. van, 26-29

Dam, R. van, 197, 214, 215

Dantzig, dr. A.A. van, 93, 202

Dees, D.J.D., 242

Defares, prof.dr. P.B., 223

Delysid, 73
Den Haag, 28-30, 70, 93, 156, 250

Denemarken, 40-42, 96

De-Nur, Y., 190

Diakonessenziekenhuis, 30, 31

Dijke, mr. P. van, 277

Dis, A. van, 80

Dreyfus, 41

drie van Breda, 11, 19, 132, 133, 136, 143-145, 167, 169,

$186,190,197,210,212,216,217,233,283,284$

Duinkerken, 71

Duitsland, 13, 20, 30, 31, 40, 77, 115, 187-189, 212, 231

Durlacher, G.L., 17, 77-81, 190

Eerste Kamer, 52, 161, 171, 174

Eerste Wereldoorlog, 14, 68, 101

Eichmann, A., 112

Eiselin, F., 162

Eitinger, prof.dr. L., 96, 97, 161, 253

Emde Boas, $C$. van den, 122, 123

emeritaat, $12,20,225,240,272$

Engels, P.J., 140

Englandspiel, 231, 232

Erasmus Universiteit Rotterdam, 34, 86

existentieel emotioneel stress-syndroom, 105

Expogé, 52-54, 59, 140, 163, 165, 166, 172, 174, 214,

$234,236,243,244,268,273$

Eysenck, prof.dr. H.J., 35-37, 260

Februaristaking, 27

Fédération Internationale Libres des Déportés et Internés de la Résistance (FILDIR), 236, 281

Feitsma, dr. J., 29

Fentener van Vlissingen, 135

Fichez, 41,161

First Canadian Army, 71, 72

Fischer, E., 132, 233

Flehite, museum, 187

Fortuin, J., 270

Foudraine, J., 111

Frankrijk, 13, 40, 41, 100

Frenkel, prof.dr. M., 23, 27, 34, 287

Frequin, L., 17x, 244

Freud, S., 33, 63, 67, 68

fugue, $13,14,283$

Fünten, F.H. aus der, 106, 132

Gaaikema, familie, 30

Gaarlandt, mr. K.H., 151

Gasteren, L. van, 11, 79, 86, 116-118, 120, 121, 125, $127,130,131,139,140,189,190,287$

Gerritse, P., 174

Geurtsen, mr. A., 142

Gezondheidsraad, 242, 246, 247, 252-256, 258, 287

gijzelingen, 31, 223, 259

Gilbert, M., 78

Ginsberg, I.A., 82

Glastra van Loon-Boon, mr. J.E., 136 
Goedewaagen, dr. T., 27, 28

Goudsmit, mr. A.M., 134, 165

Groen, prof.dr.J.J., 26, 33-35, 37, 64, 65, 205, 207, 208

Grootegast (Groningen), 30

Grossarth-Maticek, dr. R., 259, 260

Haan, prof.dr. I. de, 19, 113, 177, 287

Haarlem, 30, 31, 187

Hacking, prof.dr. I.M., 13-15, 283, 287

Häfner, prof.dr. H., 94

Heard, G., 82

Heel de mens, 172

Heerma van Voss, A.J., 175, 192, 193, 245

Heertje, prof,dr. A., 278

Heijden, H.A.M. van der, 25

Hemert, E.W. van, 162

Hendriks, J.P.M., 223, 226

Herberg, H.J., 94

Hermann, K, 41

Hers, dr. H.F.Ph., 94, 151, 167, 210, 221, 222, 251

Heuvel, C.C. van den, 137

Heydrich, $\mathrm{H}, 6 \mathrm{O}$

hiding-syndrome, 198

Hillesum, E., 187

Hilversum, 23, 139

hindsight bias, 58

Hofman, K., 127-130, 133

Hofmann, dr. A., 72, 73

Hongerwinter, 30, 42, 197

hoorzitting, 11, 132, 134, 136-139, 142-145, 154, 199 , 246

Horsley, dr.J.S., 69

Horst, prof.dr. L.M. van der, 33, 35

Het Witte Huis, hotel, 276

Hovens, prof.dr.J.E., 281

Hr.Ms. De Ruyter, kruiser, 71

Hugenholtz, dr. P.Th., 98, 99, 105, 140, 141, 164, $165,166,167,179,202,204,205,210,22$

Hulsman, prof.dr. L., 138

Hustinx, A., 96, 105

Hutte, H., 25

Huxley, A.L., 82

hypnose, 68

Inspectie voor de Geestelijke Volksgezondheid, $83,152,226,236,237,243,250,252,254-256$, $261,262,264,265,270,272,273,276$

Instituut voor Multidisciplinaire Psychotherapie (IMP), 111

Instituut voor Psychiatrische Wetenschappen, 92 Internationale Stichting voor Slachtoffers van Oorlog en Geweld (ISSOG), 281

Italië, 13, 40

Jacobs, H., 139, 140

Jelgersma, prof.dr. G., 24

Jelgersmakliniek, 11, 12, 20, 79, 92, 95, 106, 108, 118,
$140,149-153,155-161,165-167,171,176,182-184$, $186,190,195,214,215,221,225-228,234,236$, $238-241,244,248,251,259,261,266,287$

Joannes Judah Groen Stichting voor Interdisciplinair Gedragswetenschappelijk Onderzoek, 64

Jong, dr. L. de, 94, 95, 110, 112, 191, 192, 194, 211, 213 $215,216,244$

Jong, P.J.S. de, 121

Juliana, koningin, 121

Kaas, A.J.W., 93

kampsyndroom, 12, 96

Kappeijne van de Coppello, mr. N.J.C.M., 236, 244, 246,281

Kennemer Lyceum, 23, 287

Ketwich Verschuur, H.P.J. van, 165

keuringsarts, $40-42,58,98,203,206,284$

Kicken, W., 136

Kisker, K.P., 94

Kleber, prof.dr. R.J., 223

Kleinveld, G., 187

Kliest, A.J., 137, 214, 215

Klompé, dr. M.A.M., 121, 236

Kloos, A.H., 139

Knecht-van Eekelen, A. de, 64

Knegtmans, dr. J., 29, 32

Knigge, dr. V., 194

Koch, I., 191, 192, 193, 194, 216

Koerierster, De, 175, 243, 256

Kogon, E., 60

Komrij, G., 230, 233

Koning, P. de, 183

Kooyman, M., 267

Kopenhagen, 40-42, 44

Kopinsky, J., 17, 185-190, 196

Kotälla, J.J., 132, 233

Koude Oorlog, 110, 113, 130

Kraaijeveld-Wouters. J.G., 201, 246

Kruisinga, dr. R.J.H., 106

Krumperman, A., 267

Kuiper, prof.dr. P.C., 87, 91

KZ-syndroomarchitectuur, 152

Ladee, prof.dr. G.A., 34, 86, 202, 244

Lader, prof.dr. M.H., 253

Lages, W., 115

Lampl-de Groot, A., 33, 64

Landelijke Kontakt-Groep

verzetsgepensioneerden (LKG), 158, 159, 175 $200,214,243,256$

Landelijke Organisatie Oud-Illegale Strijders, 136 Langebent, A., 172, 174

Langemeijer, G.E., 134, 142

Lanschot, W.Ch.J.M. van, 244

Laqueur, W., 78 
Laudy, Y., 274, 275

Leary, dr. T.F., 82,84

Lidice, 59

Ligtvoet, L., 221, 234

Linschoten, B., 116

Londen, dr. J.van, 74, 87, 230, 236, 275

Londo, G., 180

Loonstein, R., 280

Loos, D. de, 105, 106

Loos, dr. W.J. de, 222

Lotsof, H.S., 275, 276

loyaliteitsverklaring, $29,31,32$

LSD, $11,13,15,19,76,82-88,111,116,117,119,120-122$, $124,125,127,128,130,153,154,162,167,168,170$, $182,183,193,229,233,235,242,246,249,252$, $253,256-258,260,261,270-276,282$

Lubbers, dr. R.F.M., 176

Lucassen-Stauttener, A.M., 242, 247, 249

Lumeij, J.L.J., 139

Luxemburg, 40

Maalsté, N., 282

Maandblad Geestelijke volksgezondheid (MGU), 183, 202

Maas, A.J., 280

Maliepaard, P., 106, 151, 158-160, 167, 182

Mariënhaven, 276

Mauthausen, kamp, 163, 222, 231, 232

medisch adviseur, 40, 42, 45, 65, 66, 98, 103, 140, $154,201,203,210,215,221,238,251$

Medische Faculteitsvereniging der Amsterdamsche Studenten (MFAS), 24, 26

Meerendonk, mr. H.J.P. van den, 202

Meerloo, prof.dr. J.A.M., 93, 97

Meester, E., 17, 161, 165, 166, 168, 170-178, 180-182, $185,191-196,214,216$

Meijer, I., 245

Meijer, W., 174

Meijering, dr. W.L., 152-157, 159-164, 166-168

Melai, prof.mr. A.L., 268

Mengelberg, K., 262, 263, 266

Mengele, J., 77

Menten, P.N., 213

Merckelbach, prof.dr. H.L.G.J., 18, 63, 185, 287

Mërzer Bruyns, M., 26

mescaline, 74

methode-Bastiaans, 12, 15, 16, 20, 66, 67, 88, 161, $163,170,181,229,230,237,243,245-250,252$, $254,255,259,260,267,269,270-272,282,283$ Middelburg, B., 189

Miesen, dr. B., 276

Milikowski, dr. H., 117, 123, 125, 137, 190, 214, 217

Ministerie van Cultuur, Recreatie en

Maatschappelijkwerk (CRM), 118, 120, 121, 140,

$174,180,198,201$
Minnesota-experiment, 44

Molen, G. van der, 51

Molthof, P., 243

Mourer, N.A., 17, 39, 47-63

Mourits, drs. H.A.A., 202, 229

Müller-van Ast, M.A., 227

Muntendam, prof.dr. P., 150, 157, 158, 164

Musaph, prof.dr. H., 96-98, 135, 137, 139, 141, 179, $202,210,256,278$

Myers, dr. C.S., 14

Nagasaki, 71

Namen, mr. A.H. van, 151, 157, 158

narcoanalyse, $55,56,62,63,69,70-75,84,85,88$, $116,183-185,191,192,195,196,231,233,251,254^{-}$ $257,263,265,270,274,282$

Nationale Federatieve Raad van het Voormalig Verzet Nederland (NFR/VVN), 133

Natzweiler, kamp, 105, 106, 163, 215, 222

Natzweiler Berichten, 215

naweesyndroom, 105

near accidents, 262, 265

Nederlands Auschwitz Comité, 134, 198

Nederlands Instituut voor Oorlogsdocumentatie (NIOD), 16, 117

Nederlands Ravensbrück Comité, 136

Nederlands Tijdschrift voor Geneeskunde (NTVG), 86, $87,102,208,258$

Nederlandsche Studenten Federatie (NSF), 25

Nederlandse Federatie voor de Geestelijke Volksgezondheid (NFGV), 118, 120, 121, 140, 156

Nederlandse Scheepsbouw Maatschappij (NSM), 117

Nederlandse Stichting voor

Gezondheidsvoorlichting en Opvoeding (Gvo), 120, 121

Nederlandse Unie, 25

Nederlandse Vereniging voor Anesthesiologie (NVA), 255

Nederlandse Zionistenbond, 136

Neijenhuis, H., 234

niet-Joodverklaring, 26

Noach, dr. W.M.E., 94

Nooit weer!, 114

Noordaa-van der Veer, W. van der, 194, 195

Noordenbos, prof.dr. W., 27

Noorderlicht, 48, 51

Noordhoek Hegt, dr. W.F., 40, 42, 43, 97, 103, 104, $107,108,149,151,153,154,167$

Noorwegen, 41,96

norm van verzet, $111,176-178,212$

NSP, 25

Oldehove (Groningen), 30

omgekeerde bewijslast, 100, 149, 178, 180, 190, 203, 246,280 
oorlogstrauma, 17, 97, 229

Oostenrijk, 40

Oosterbaan, M., 183

Op den Velde, dr. W., 215

Opiumlijst, $83,85,117$

Ossebaard, H.C., 282

Overeem, generaal-majoor A.D.A. van, 151

Overveen, 23

Pannekoek, Y. (pseud. van F. Dekking), I43

Pasman, J., 202

Paul, H., 94

Pelita, stichting, 162

Pelser, dr. H.E., 34, 71, 72, 204, 205, 208, 210 pentothal, 15, 55, 69, 70, 72-75, 85, 193, 229, 246, $252,254-256,258,262,263,265,270,275,276$, 282

Pepplinkhuizen, prof.dr. L., 277-280

Peters, drs. J.H.M., 243, 251, 263-265, 269

Piper, dr. A., 75

Ploeg, dr. G.J. van der, 281

Ploeg, prof.dr. H.M. van der, 259-262, 271-273

Polak, mr. C.H.F, 132, 133

Polak, prof. B.S., 18, 94, 201, 202, 204, 206, 208, $243,246,250,251,266$

Polen, 40

Pölitz, kamp, 117

Poole, mr. J. le, 120, 121, 156, 157, 163

Poslavsky, A., 70, 71, 192

post-stresssyndroom, 105

posttraumatische stress-stoornis (PTSS), 5, 222, $224,240,248,280,281,285$

Powick Hospital, 74

Praag, A. van, 116, 124, 131

Praag, prof.dr. H.M. van, 87

Praag, prof.dr. J.P, van, 198

Pree, dr. W.A. de, 227

Presser, J., 112

Prins Bernhard Claltuurfonds, 172

Propria Cures, 27, 28, 32

proto-professionalisering, 179,180

psilocybine, 74

psychoanalyse, $20,33-36,46,54,63,65,67,68,72$, $74,80,208,257,258$

Psychoanalytisch Instituut Amsterdam (PAI), 20, $35-37,64,91$

psycholyse, 68, 74, 85, 87, 88

psychosomatiek, $33,35,37,47,65,91,96,97,101$, $102,193,203,205-210,225,238,257,259,280$

psychosomatische specificiteit, 34, 65, 193, 208

Psychosomatische Werkgroep, $3,5,17,18,33-36$,

$45,53,60,64,71,97,98,106,107,136,149,154$, $198,204,208,209,221,222,234-236,243,248$, 266,287

Querido, prof.dr, A., 151, 153
Ravensbrück, kamp, 117, 231

Ravesteijn, L. van, 97

Ree, dr. F. van, 74, 86, 177

Reemst, Th. van, 53, 201, 221

Regionale Instituten voor Ambulante Geestelijke Gezondheidszorg (RIAGG), 111

Reijden, drs. J.P. van der, 221, 227, 236, 242, 246, $249,250,251,256,265,267$

Reijntjes, P., 163

Rhijn, C.H. van, 84

Rijksinstituut voor Oorlogsdocumentatie (RIOD, na 1999 NIOD), $48,59,94,128,129,211$

Rijksinstituut voor Volksgezondheid (RIVG), 83

Rijksuniversiteit Leiden (RUL), 12, 18, 20, 24, 46,

$84,87,91,92,118,150,152,183,208,233,255$

Ringers, dr. J.A., 52

Rockefeller Foundation, 33

Rode Kruis, 50, 52, 77, 103, 194

Rooijmans, prof.dr. H.G.M., 18, 208, 225, 226, 234, $238-241,243,245,248$

Rotterdam, 23, 34, 77, 86, 127

Ruiter, drs. P.A., 142

Rümke, prof.dr. H.C., 24, 39, 40, 46

Rusland, 13, 40

Sachsenhausen, kamp, $16,48,49,50,52,55,56$, $60-62,94,113,114,117,119,126,137,151,152,155$, 214

Samkalden, prof.dr. I., 115

Sandoz, 72, 73, 74

Sargant, dr. W.W., 69, 75, 76

Schelvis, J., 143

Schmidt, A.M.G., 177

Scholten, Y., 26

School der Universele Wijsheid, 275

Schreuder, prof.dr. B.J.N., 269, 271, 279, 280, 282

Schudel, prof.dr. W.J., 277, 278, 279, 280

Schweizer, prof.dr. D, 242

Selye, prof.dr. H.H.B., 44

shellshock, 14, 68, 287

Sicherheits Dienst (SD), 48, 59, 117, 174, 212

Siderius, dr. P., 83

Sijes, B.A., 94

Sinner, L., 161

Slagter, J., 134

Slot, E., 189

Snelders, dr. S., 75,83

sociale fuik, $175,176,178,180,181,195,201,284$

Soestdijk, Paleis, 106, 165

Soeteman, G.W.D., 180, 187

Soetendorp, A., 135

Spaanse Burgeroorlog, $47,48,59,116$

Spanje, 48, 49, 52, 59

Spätfolge-groep, 93-96, 103, 277

Speijer, prof.dr. N., 85, 106, 124, 152, 155, 157 
Spierdijk, prof.dr. J., 254, 255

spuitsituatie, 56, 57, 61, 62

Staatstoezicht op de Volksgezondheid, 84, 260

Stapel, K., 25

Stichting $1940-1945,38,39,45,53,57,65,66,98$, $118,120,140,151,167,173,174,180,198,201-203$, $206,215,221,234,238,244,251,267,269,270$,

273,280

Stoll, W.A., 72

Sunier, A., 137, 163, 166

survivor-syndrome, 96

Swaan, prof.dr. A. de, 17-19, 78, 169, 179, 284, 287

Tas, prof.dr. J., 93

tbc, $40,41,45,97,104,117$

Teengs Gerritsen, H., 106, 150, 152, 153, 157, 159, $161,163-166,222$

Telling, J.R., 114, 115, 117-119, 122-128, 130, 131, 137, $139-142,165,190$

Terwindt, B.A.W.M., 17, 163, 165, 230-236, 245, 247

Theresienstadt, 77

Thiel, J., 179

Thygesen, P., 41

Timmers, S., 124, 125, 127, 146

Tissié, R., 13

Tol, dr. D. van, 118, 121, 126, 140, 141

Toom, W. den, 106

Treblinka, kamp, 8

Treurniet, A., 59

Tweede Kamer, 19, 136, 139, 212, 242, 244, 247-249 $255,268,271$

Udink, drs. B.J., 121

Unitas, 23, 27, 28, 32

Unitas Studiosorum Amstelodamensium (USA), $23,24,25,26,27,29,31,32$

Universiteit van Amsterdam, 18-20, 23, 25, 29, 32 $33,53,64,78,87,91,278,287,302$

Uyl, dr.J.M. den, 165

Vaal, O.M. de, 124

Valk, J.M. van der, 34

Velden, K. van der, 15, 185, 287

Veraart, mr. C., 183, 184, 201, 204, 206, 207, 225

Vereniging Oorlogs- en Geweldsslachtoffers

(vOG), 270,282

verhongering, $41,42,43,44,96$

Veringa, dr. G.H., 144

verlate gevolgen, 39, 93-97, 102, 103, 206

Vietnam-syndroom, 198

Vink, prof.dr. M., 225
Vinkenoog, S., 82

Visser, H., 30

Vles, dr. S.J., 34

Vogt, T., 173, 174

Voogd, J.J., 139

Vorrink, mr. I., 161

Vos, dr. C., 116,145

Voûte, E.J., 27, 28

Vree, prof.dr. F. van, 19, 111, 112, 287

Vriendenkring Sachsenhausen (vKs), 113-117, 123, 126,130

Vries, H.R. de, 123

Vught, kamp, 106, 117, 128, 129, 150, 151, 187

Waarheid, De, 51, 52, 117

WAC-rapport, 198-200, 228, 279

Wagenaar, prof.dr. W.A., 18, 63, 287

war-sailor syndrome, 198

Weezel, M. van, 271

Weijel, prof.dr. J.A., 140, 141

Weinreb, F, 189

Weiss, L., 187

Wennekes, W., 160, 170, 171, 172, 175

Werkgroep Dependance Jelgersmakliniek (WDJ), 234-237, 241-245

Werkgroep Post-concentratiekampsyndroom,

$149,154,222$

Werkgroep Stichting '40-'45, 136

Westerman Holstijn, prof.dr. A.J., 64

Wet Buitengewoon Pensioen (WBP), 38, 39, 100, 200, 201, 205, 209, 279

Wet Uitkering Burgeroorlogsgetroffenen (WUBO), 267

Wet Uitkering Vervolgingsslachtoffers (wuv), 267

Wibaut, dr. F., 93

Wijnen, H.P., 29

Wijnen, N., 215, 244

Wilhelmina Gasthuis, 20, 33, 35, 37, 43, 53, 55, 61, $71,74,86,91,139,141,157,191$

Wind, dr. E. de, 64, 80, 93-97, 103, 108, 143, 179, 277

Withuis, dr. J., 19, 93, 104, 113, 115, 130, 133, 145, 149, $178,198,216,222,224,283,285,287$

Woltz, W., 128-130

Worrell, M.J.C., 246, 247, 249, 266, 267, 272

Zadoks, I., 136

Zeegers, prof.dr. M., 202, 244

Zijl, A. van der, 177

Zwolle, 173, 174Zijl, A. van der, 177

Zwolle, 173, 174 


\section{Summary}

\section{Bastiaans's war}

The LSD-treatment of the concentration camp syndrome

Dr.J. Bastiaans (1917-1997) was a professor of psychiatry at the Rijksuniversiteit Leiden from 1964 until 1986. For a long time, he was the only professional in the Netherlands who was legally permitted to use the hallucinogen LSD in his treatments. With his 'Bastiaans-method', which sometimes involved the use of LSD or the barbiturate pentothal to gain access to repressed memories and re-live them, he claimed great therapeutic successes in treating a largely therapy-resistant group: survivors of the German concentration and extermination camps.

Already in the 196os, Bastiaans's colleagues regarded these claims as unproven and saw great risks in the use of his method. Despite his controversial status, Bastiaans was granted a cardinal role in certain important political and social issues in which the Second World War and its consequences played a prominent part.

By analysing psychiatric literature on the history of drug-assisted therapies and concentration camp syndrome, primary sources, portraits of patients, government documents, articles from newspapers and magazines and interviews with some of those involved, this research attempts to explain the reasons behind Bastiaans' success.

After the liberation, Dutch Resistance fighters and survivors of the German concentration and extermination camps who had returned to the Netherlands got organised in pressure groups. They demanded that war criminals be tried or serve longer prison sentences, they wanted to inform younger generations about what happened under the Nazis and they fought for better support for 
their sick or invalid comrades. During the 1960 s the way in which they attempted to achieve these goals changed.

The Netherlands also changed during those years: long-standing social structures collapsed and the country 'opened up'; for the first time, it was possible to voice criticism. The Second World War gained increasing public attention due to international developments such as the Eichmann trial. The newly found openness, combined with the renewed focus on the war, channelled public opinion to focus on the Netherlands as a 'nation of resistance'. How was this self-image to be reconciled with the Jewish catastrophe that had happened? Nowhere else in Europe was the Jewish community so decimated. This failure of Dutch society as a whole during the War led to collective feelings of guilt.

The concentration camp syndrome became the symbol of this social failure. Psychiatrists, especially Bastiaans, presented the concentration camp syndrome as a specific problem caused by wartime experiences and the failure to help after the War. It was viewed as a severe illness (sometimes fatal) that in some cases could only be relieved by the use of the Bastiaans-method; severe problems called for severe measures. The Bastiaans-method underlined the severity of the suffering.

Pressure groups used this medical standpoint as an argument in their struggle for recognition - and they were successful. This was caused on the one part by the fact that Bastiaans, and other psychiatrists, were seen as objective scientists who knew what they were talking about. They had, so it seemed, nothing to gain. On the other hand, relieving suffering by allowing the Bastiaansmethod could appease feelings of guilt for society as a whole.

For more than twenty years, this collusion between society, the medical profession and the victims of war proved beneficial for all. The existence of the diagnosis 'concentration camp syndrome', originally meant to facilitate communication between professionals, became a means of acknowledging the past and present suffering of the survivors. By allowing the Bastiaans-method, society could show their compassion and assuage their feelings of guilt towards their fellow citizens. The Bastiaans-method became a symbol of their compassion; it was a medical solution to a social problem.

As a consequence, the obvious risks involved in the Bastiaans-method were ignored or marginalized, while contradictions and unclearness in the definition of the diagnosis were brushed aside. The present research shows that Bastiaans's success and that of his method were a result of this specific social context. Only when Bastiaans undermined the exclusive position of Resistance fighters did he lose their support. It meant the end of the Bastiaans's era of success, and the end of his method. 


\section{Over de auteur}

Bram Enning werd geboren op 16 juni 1974 in Winssen. Na het behalen van zijn vwo-diploma aan het Pax Christi College te Druten in 1992 studeerde hij twee jaar aan de Technische Universiteit Eindhoven. Daar behaalde hij in 1994 zijn propedeuse Techniek en Maatschappij (variant Bouwkunde). In datzelfde jaar begon hij aan de Universiteit van Amsterdam aan een studie psychologie. Daar behaalde hij in 2001 zijn doctorandustitel (met genoegen) in de Algemene Psychologie.

In 2004 begon hij zijn promotieonderzoek naar Jan Bastiaans aan de Faculteit der Psychologie van de Universiteit Maastricht bij de sectie Theorie en Geschiedenis. Inmiddels is hij werkzaam als onderzoeker bij het Nederlands Instituut voor Oorlogsdocumentatie. 